\title{
Archaeologists
}

in Print

Publishing for the People

Amara Thornton 
Archaeologists in Print 



\section{Archaeologists in Print}

Publishing for the People

Amara Thornton

¿UCLPRESS 
First published in 2018 by

UCL Press

University College London

Gower Street

London WC1E 6BT

Available to download free: www.ucl.ac.uk/ucl-press

Text (C) Amara Thornton, 2018

Images (C) Copyright holders named in captions, 2018

Amara Thornton has asserted her right under the Copyright, Designs and Patents Act 1988 to be identified as author of this work.

This book is published under a Creative Commons Attribution Non-Commercial 4.0 International license (CC BY-NC 4.0). This license allows you to share and adapt the work for non-commercial use providing attribution is made to the author and publisher (but not in any way that suggests that they endorse you or your use of the work) and any changes are indicated. Attribution should include the following information:

Thornton, A. 2018. Archaeologists in Print: Publishing for the People. London, UCL Press. https://doi.org/10.14324/111.9781787352575

Further details about Creative Commons licenses are available at http://creativecommons.org/licenses/

ISBN: 978-1-78735-259-9 (Hbk)

ISBN: 978-1-78735-258-2 (Pbk)

ISBN: 978-1-78735-257-5 (PDF)

ISBN: 978-1-78735-260-5 (epub)

ISBN: 978-1-78735-261-2 (mobi)

ISBN: 978-1-78735-262-9 (html)

DOI: https://doi.org/10.14324/111. 9781787352575 


\section{Acknowledgements}

The research for this book would not have been possible without a number of organisations and people. The British Academy funded my postdoctoral project 'Popular Publishing and the Construction of a British Archaeological Identity in the $19^{\text {th }}$ and $20^{\text {th }}$ centuries', enabling me to spend three years researching and writing this book, and provided me with support to attend conferences and to obtain key reference texts, some of which appear in images in the following pages. Joanna Prior at Penguin Random House gave me permission to access the Penguin archive, and Hannah Lowery and Michael Richardson at Bristol University Special Collections helped me get to grips with the Penguin material. Helen Symington and David McClay at the National Library of Scotland helped me with the John Murray archive. The Macmillan papers were also a key collection; my thanks go to Alysoun Sanders and Elizabeth James for their help. I also thank Macmillan Publishers Ltd for the use of extracts in The Macmillan Archive in the British Library. Further useful material was obtained from The Religious Tract Society archives at the School for Oriental and African Studies (SOAS). Alex Fisher, Danni Corfield and Adam Lines from the University of Reading helped me with the publishing archive there, and Natalie Ford gave me permission to access the Chatto \& Windus and John Lane/Bodley Head archives held at Reading. I am grateful to Anthony Smith of Anthony Smith Books for introducing me to John Murray VII, and to John Murray VII for giving me an impromptu tour of 50 Albemarle Street. I am also immensely grateful for the splendid efforts of the many people who have scanned in and uploaded out of copyright texts to the Internet Archive and Hathi Trust, and to the British Library, the Library of Congress, National Library of Israel and the National Library of Australia for providing books and periodicals for digitisation.

Archaeological archives were also critical to this study. I am grateful to Alice Stevenson and Anna Garnett for giving me access to the Petrie correspondence and archives, UCL Special Collections for 
Gardner correspondence and the Horsfield archives, the British Library for the Gardner family archive, the UCL Institute of Archaeology, Robert Winckworth at UCL Records for his valuable help with the session fees books, Stephen Snape at the University of Liverpool for access to the Garstang archive, Richard Temple and Charles Harrowell at Senate House for access to the Mary Brodrick material held in College Hall archives, the Syndics of Cambridge University Library for access to the Agnes Conway papers and Francesca Hillier for access to, and help with. the British Museum Reading Room Admissions records. Felicity Cobbing at the Palestine Exploration Fund allowed me to reproduce a photograph of Duncan Mackenzie's travel ephemera, and Martina and Caroline Collingridge provided valuable assistance on Margaret Wheeler's archive. Thanks to Colin Harris and Oliver House for their assistance, and permission granted on behalf of the Bodleian Library, University of Oxford in relation to the O. G. S. Crawford archive.

I am also grateful to the following people for their help and support in my research and writing: Neal Ascherson, Jo Dullaghan, Tim Schadla-Hall, Gabe Moshenska, Clare Lewis, Ian Carroll, Terry Elkiss, Flore Janssen, Lisa Robertson, Adam Fraser, Martyn Barber, Helen Pike, Debbie Challis, Simon Guerrier, Alice Coote-Cowling, Jamie Larkin, Jennifer Baird, Brigitte Balanda, Carl Graves, Martin Millett, Mike ParkerPearson, Karen Attar, Anne Thomson, David Bindman, John Crowfoot, Tanya Lipovskaia, Elizabeth Hodgkin, Felicity Cobbing, Jonathan Tubb, Sally Fletcher, Nancy Charley, Ed Weech, Michael McCluskey, Elizabeth Jane Ehlers, Katie Jost, Duncan Bolt and Michael Berkowitz. Thanks are also due to the staff at UCL Press, and to the two peer-reviewers of this book. My family, and particularly my parents Linda Heywood and John Thornton and sister Amanda Thornton, have, as always, been there for me. 


\section{Contents}

List of figures ix

1. Scripting Spadework 1

2. Defining the Archaeologist 20

3. The Women Who Did 48

4. Marketing the Archaeologist 75

5. Scripting and Selling Archaeology 103

6. John Murray 128

7. Macmillan \& Co 149

$\begin{array}{ll}\text { 8. Penguin } & 169\end{array}$

9. Archaeological Fictions 188

10. Epilogue 210

Appendix: Archaeologist-Authors 214

$\begin{array}{ll}\text { Notes } & 222\end{array}$

Bibliography 269

Index 289 



\section{List of figures}

Fig. 2.1 Graph showing the numbers of students, broken down by gender, attending Archaeology courses at UCL between 1891 and 1914 (Session Fee book for 1910-11 not accessible at time of research). No data on Archaeology was given in the Session Fees books for $1894 / 95$ or $1895 / 96$. (Copyright the author)

Fig. 2.2 Graph showing the numbers of students, broken down by gender, attending Egyptology courses at UCL between 1891 and 1914 (Session Fee book for 1910-11 not accessible at time of research). (Copyright the author)

Figs 2.3a Exterior and interior shots of a Thomas Cook \& Son and 2.3b travel wallet owned by the archaeologist Duncan Mackenzie and now held in the Palestine Exploration Fund archive. Between 1911 and 1912 Mackenzie was employed as a PEF excavator, conducting excavations at the site of Beth Shemesh. He used Thomas Cook's services for international travel and banking; the wallet contains various business cards and receipts he collected during his travels. (Courtesy of the Palestine Exploration Fund)

Fig. 2.4 A handwritten inscription inside a copy of Murray's Handbook to Egypt \& The Sudan (11th edition, 1907), revealing that it was originally owned by New Yorker Kate Sawyer and probably used on a trip with the 'Paine Party'. (Author's collection)

Fig. 2.5 Diagram showing the cycle of publicity for Leonard Woolley's 1929-30 excavations. (Copyright the author)

Fig. 3.1 Agnes Conway's inscription 'from a kindred soul in travel' in a copy of her Ride to the Balkans. (Author's collection) 
Fig. 3.2 Back cover of the dust jacket for Ellen Bosanquet's The Tale of Athens, showing the list of volumes published in Methuen's 'Wayfarer Series', including Quibell's Wayfarer in Egypt. (Author's collection)

Fig. 4.1 Total number of references to Petrie (out of 779 articles) in the 19th Century British Library Newspapers database, arranged by paper and region. (Copyright the author)

Fig. 4.2 Graph showing the number of Petrie references in the 19th Century British Library Newspapers database between 1883 and 1900. (Copyright the author)

Fig. 4.3 References to Flinders Petrie in the 19th Century British Library Newspapers database in 1886. (Copyright the author)

Fig. 4.4 References to Flinders Petrie in the 19th Century British Library Newspapers database in 1892. (Copyright the author)

Fig. 4.5 References to Flinders Petrie in the 19th Century British Library Newspapers database in 1895. (Copyright the author)

Fig 4.6 The first two parts of Hutchinson's History of the Nations. (Author's collection)

Fig 4.7 Parts 3, 6 and 8 of Harmsworth's Universal History of the World. (Author's collection)

Fig. 5.1 Book plate in a copy of the second edition of Days Before History (1908) indicating that it was given to a young student at St Paul's Preparatory School in London as a prize for Freehand Drawing. By the end of 1907 10,000 copies of the first edition of Days had been printed; the second edition had a printing of 3,000 copies. (Author's collection)

Fig. 5.2 Stanley Casson's Archaeology and Jane Harrison's Myths of Greece \& Rome in Benn's Sixpenny Library. (Author's collection)

Fig. 5.3 Detail from the Saqqara chapter of Quibell's Wayfarer in Egypt. It shows underlined passages and annotations in the margin and includes what appears to be the date of a visit (12 March 1927). (Author's collection) 
Fig. 6.1 Front covers of Murray's Handbooks. (Author's collection)

Fig. 9.1 Reginald Campbell Thompson's inscription to 'Dr. Weston', a colleague in the I. E. F. D. in a first edition of Digger's Fancy. (Author's collection) 



\section{Scripting Spadework}

October 2016. Various news outlets report that archaeology is one of 20 subjects to be removed from the lists of the last examination board in Britain to offer it. The reasons: that it is too specialised to be examined and graded in the time period allotted and that not enough students take the option. There is an immediate backlash from the archaeological community. Agonised statements are later published from celebrities Tony Robinson, host of the popular archaeology TV show Time Team, and classicist and broadcaster Professor Mary Beard. ${ }^{1}$ A petition circulates to debate the matter in Parliament; it accumulates over 13,000 signatures. Only 10,000 are needed to make the debate a reality, so in December 2016 it is held in a House of Commons meeting room. Member of Parliament Tim Loughton, Fellow of the Society of Antiquaries and cochair of the All Party Parliamentary Archaeology Group, stands up to deliver a speech in defence of Archaeology. Among the many positive attributes of archaeology he highlights in his statement is its impact on the creative arts: 'the stories, films'; the fascination of the adventures and discoveries of Howard Carter in the Valley of the Kings, Leonard Woolley at Ur, Hiram Bingham at Macchu Picchu. ${ }^{2}$ All men, all working outside their countries of origin during the early twentieth century. Loughton's speech reflects the emotive nature of archaeology and its history, as well as the continuing role of this history in how we understand archaeology and archaeologists today. How is it that in the twenty-first century the legacies of early twentieth-century archaeologists are still being evoked to represent archaeology's cultural value?

There is one answer to this question. Those historic archaeologists, still so relevant today, cultivated personal visibility. They were committed to bringing the results of their research to the attention of the wider public, where it was - and continues to be - boiled down and built up, cut and recast. ${ }^{3}$ In other words, they were adept at 'scripting spadework'. 
These archaeological authors are a bridge between the 'gentlemanly' model of research of the late nineteenth- and early twentiethcenturies, and what has recently been identified as publishers' commercialisation of academic research after the Second World War. ${ }^{4}$ This book highlights late nineteenth- and early twentieth-century archaeologistauthors as commerce-minded, working in collaboration with commercial publishers, in opposition to the now prevailing idea of humanities academics largely operating within a non-commercial context. It reveals the history of these archaeologists in public, exploring how they scripted spadework, fashioning and curating depictions of archaeological activities and experiences. These images were produced and reproduced in newspaper reports, exhibitions, lectures, radio broadcasts and - the main focus of this book - in books.

Investigating scripting spadework is necessarily a historical endeavour. The term 'spadework' was often used as a byword for archaeology in the late nineteenth and early twentieth centuries; it served as the title of archaeologist Leonard Woolley's 1953 memoir, dedicated to his chief foreman Mohammed Ibn Sheikh Ibrahim, known as Hamoudi, his 'lifelong helper and friend'. ${ }^{5}$ In its allusion to a ubiquitous garden tool, 'spadework' signals the outdoor physicality of digging, with the products of this spadework being not (necessarily) botanical but material evidence of the past. No wonder, then, that in his introduction to Spadework Woolley sought to emphasise archaeology as a living 'science', to highlight 'the all-roundedness' of the archaeological experience. ${ }^{6}$ Scripting, with its dramatic, theatrical, Hollywood overtones, references the overt creation of a representation for commercial purposes - an active, continual process of literary performance. Thus the scripting of 'spadework' - its technologies and knowledges, its foreignness, its seasonality, its seriality, even its illustrations and maps - made it a successful commercial vehicle. Various spadework personas - the wanderer, the student, the antiquary, the photographer, the linguist, the excavator and even the spy - are stock characters performing on the page.

Here I chart the construction, production, distribution and reception of these books. I explore how archaeologist-authors sought to shape through print the public perception of the human past and present, the methods for obtaining that knowledge and the people who sought it. I also examine the range of archaeological experiences and how these fit into diverse genres, from memoirs and guidebooks to popular histories, children's books and fiction. The cultural perception of archaeologists today stems directly from how these late nineteenthand early twentieth-century archaeologists framed themselves, and 
consequently were framed, during and after their lifetimes. ${ }^{7}$ This perception emphasises the archaeologist as a free-spirited international traveller, adaptable, adventurous and scientific, but at times threateningly, dangerously exotic and semi-foreign (even quasi-anarchistic). Here is a person attuned to the whisperings of a past long since gone, yet possessing a skilled and practical knowledge of contemporary societies and cultures that can be harnessed when necessary. ${ }^{8}$

Archaeologists in Print will not analyse the archaeological content of the books referenced for accuracy, nor examine in detail the evolution and reception of archaeological theories and ideas in wider culture. ${ }^{9}$ Rather it considers the ways in which archaeologists captured and promoted archaeological life and work, scripting spadework, sketching themselves in words. In taking more of what Amanda Wrigley has termed an 'in the round' approach, it also illuminates the wider contexts of promotion, consumption and reception that enabled the scripts to become public. ${ }^{10}$ The cyclical nature of archaeology at this period, its excavation seasons, lent itself well to popular publication. To the Amalgamated Press's influential editor John Alexander Hammerton it was 'a perpetually continuing and perennially interesting serial story'. ${ }^{11}$ For commercial publishers archaeology was a renewable resource, the gift that kept on giving.

These historic archaeologists have endured because of a process of literary memorialisation that began in the early twentieth century. A. \& C. Black first published The Story of the Pharaohs, the Rev. James Baikie's popular history of Egyptian archaeology, in 1908, bringing the scientific discoveries of then-active archaeologists such as Flinders Petrie, Gaston Maspero and James Henry Breasted to 'the general reader. ${ }^{12}$ Two years later Baikie's The Sea-Kings of Crete drew on and credited Heinrich Schliemann's excavations at Hissarlik (ancient Troy) and Arthur Evans's continuing excavations of the palace complex at Knossos on Crete. ${ }^{13}$ Over the following two decades Baikie wrote a series of short, clothbound popular archaeologies for 'young men and maidens' called 'Peeps at Ancient Civilisations'; these began with Egypt and eventually covered Assyria, Crete, Rome, Palestine, Jerusalem and Greece. The 'Peeps' sold at 2 shillings and sixpence and featured dramatic, interpretive colour illustrations alongside images of excavated sites and artefacts. ${ }^{14}$ They also briefly referenced key archaeologists. But it was after the spectacular discovery of Tutankhamun's tomb in late 1922 that the appeal of 'the archaeologist' had a significant boost. Three of Baikie's books during this period focused specifically on excavators and excavation: A Century 
of Excavation in the Land of the Pharaohs (1924), Egyptian Papyri and Papyrus Hunting (1925) and The Glamour of Near Eastern Excavation (1927). In the last of these Baikie emphasised the contemporary allure of the archaeologist:

There is no more romantic story than that of the resurrection of the great historic past which has been and is being accomplished by the excavators of the present ... stress all through [the book] has been laid upon the excavator's methods, constantly developing and improving in refinement, his adventures, his triumphs and his disappointments ....' 15

After the end of the Second World War other popularisers followed. Under the pen name 'C. W. Ceram', German journalist Kurt Marek wrote a number of archaeology books. The most famous of these, Gotter, Gräber und Gelehrte ('Gods, Graves and Scholars'), was first published in Hamburg in 1949. Over the following decades it became an international bestseller, available in over 20 languages and read by millions of people. ${ }^{16}$ The many popular histories of the 1950s BBC journalist Leonard Cottrell, sold in paperback through Pan Books, retold the exploits of archaeologists such as Evans on Knossos (The Bull of Minos, The Lion Gate), Carter and Tut's tomb (The Lost Pharaohs), Leonard Woolley at Ur (The Land of Shinar). Cottrell's Digs and Diggers re-emphasised the role of the romantic, adventurous (travelling) excavator. These were collective and selective biographies and histories, the excavators examined within the context of key sites and discoveries. Subsequently in the 1970s and 1980s journalist Harry Victor Frederick Winstone began publishing biographies and histories of exploration (and intelligence gathering) in the Middle East, commencing with a biography of Gertrude Bell in 1978, and following that with The Illicit Adventure. The latter, an overview of intelligence activities in the First World War, featured (among others) the exploits of archaeologists Thomas Edward Lawrence, David George Hogarth, Gertrude Bell, Reginald Campbell Thompson and Leonard Woolley. Winstone later published stand-alone biographies of Leonard Woolley (1990) and Howard Carter (1991). ${ }^{17}$

Underlying all these popular histories and biographies are the publications that archaeologists produced about themselves, and the initial response to these publications and the lives and work captured in them. The essence of these stories of romance, adventure and danger on and off site have been distilled in popular fiction by countless authors - from Sir Arthur Conan Doyle and M. R. James in the late 
nineteenth century to Elizabeth Peters in the late twentieth. I wanted to explore the wider landscape of archaeological publications - to see how archaeologists crafted their own image in print for non-scholarly audiences. Was it as romantic and adventurous as the popular histories and novels depicted? The short answer is yes. The longer answer is that it is a rich, diverse history, detailed in the following pages. It is a progression from what Debbie Challis has charted as the mid nineteenthcentury archaeologist as heroic adventurer/traveller to the archaeologist as interpreter-moderator, losing none of the adventure and maintaining (if not enhancing) the romance and exotic allure through extended and serial contact with the East. ${ }^{18}$

\section{Developing scripting spadework}

ArchaeologistsinPrint is based on myBritishAcademy-funded research project 'Popular Publishing and the Construction of a British Archaeological Identity in the nineteenth and twentieth centuries'. I began this research with the British archaeological network that I had examined during my $\mathrm{PhD}$ : those people who spent time exploring, excavating, researching, preserving and exhibiting the archaeology of the Eastern Mediterranean and Middle East. ${ }^{19}$ My definition of archaeologist here is deliberately loose (albeit confined to the British) - anyone studying or operating within archaeological contexts or working with remains of the human past. I chose to investigate the diversity of archaeological experience as part of that archaeological identity, rather than assessing apparent expertise solely through the accumulation of academic qualifications: this was a time when degrees in archaeology were not the norm, and those working in archaeological contexts had varied routes into (and sometimes out of) the developing discipline. ${ }^{20}$ As Margarita Diaz-Andreu and Mary Louise Stig Sørenson have argued, 'histories of archaeology have been written with total disregard for the various structures through which archaeological knowledge is disseminated'; excluding popular publishing from this history effectively renders a significant number of archaeology's historical contributors invisible. ${ }^{21}$

There was, and still is, a strong 'amateur' element in archaeology. ${ }^{22}$ Many of the best-known British excavators of the early twentieth century - Evans, Hogarth, Carter, Woolley - did not have permanent positions in university departments. They worked under the aegis of excavation societies, antiquities departments, funds, private patrons and museums. Flinders Petrie, who did (eventually) obtain a permanent 
position at University College London, effectively spent the preceding 20 years as a freelance excavator. Once he had obtained a secure post, Petrie remained open to those who had 'real-world' experience. In 1926, for example, he wrote to one hopeful prospective archaeologist that his experience in business, which entailed working with other people, was more suited than 'academic training' to archaeological work. ${ }^{23}$ Equally, specialist knowledge and skill sets were highly valued. Several well-known archaeologists began life as architects, employed on sites specifically to draw plans, survey landscapes, interpret ancient architectural remains and (on a more practical level) construct site buildings. A number of artists (including Howard Carter and Annie Pirie Quibell) spent their professional careers devoted to archaeological illustration, excavation and interpretation.

All of the archaeological authors profiled in this book were affiliated either formally or informally with emerging research centres for archaeology in the UK and abroad - learned societies such as the Egypt Exploration Fund, British Schools of archaeology in key international cities, the British Museum and the Universities - principally University College in London and the Universities of Liverpool, Oxford and Cambridge. Although the popular histories of Baikie, Cottrell and Ceram might lead readers to believe that the landscape of romantic, adventurous archaeological discovery is almost entirely peopled by men, this was - and is - emphatically not the case.

Histories of women in archaeology continue to focus mainly on those excavating in the field and developing reputations within the academy. In relation to popular publishing, however, women with archaeological experience established a public presence through travels, lectures and tours that spurred their scripting of spadework. ${ }^{24}$ Marriage could also provide a useful boost to maintaining a successful public career. A number of women involved in archaeology before marriage, such as Annie Pirie Quibell and Agnes Conway Horsfield, continued to work in archaeology (with archaeological spouses) after it. ${ }^{25}$ Others, such as Ellen Bosanquet and Mary Gardner, were able to access an archaeological network on marriage to an archaeologist-spouse - a network that they turned to their own advantage in publishing terms. Still others, including Jane Harrison, Mary Brodrick and Mary Chubb, successfully navigated the choppy waters of personal professional development within or outside the academy without spousal support.

Women studied, lectured, excavated, travelled, researched and published alongside their male peers. Archaeology was seen from the late nineteenth century as a viable opportunity for British women, a 
situation that Margaret Cool Root has evaluated as part of a wider phenomenon of a crisis of singledom among the British female population. ${ }^{26}$ The Englishwoman's Year-Book and Directory provided information on educational institutions offering courses open to women. This included professional development for women, particularly lecturing both independently and as part of the university extension movement - opportunities taken up by some of the women discussed in this book. The Year-Book included archaeology in its list of 'Lectures and Classes in London' from the 1880s, and provided tips for women travelling abroad. ${ }^{27}$ In addition its editor aimed to 'arouse Englishwomen to a sense of their own powers' by celebrating distinguished women who had made a name for themselves in disciplines and professions. ${ }^{28}$

The Year-Book for 1900, for example, listed the names and addresses of these distinguished individuals. Included among the champions of the suffrage movement, actresses, writers and artists are some women active in archaeology: Jane Harrison, Maria Millington Lathbury Evans, Mary Brodrick. ${ }^{29}$ Furthermore, the Year-Book's 'Notes on Women's Work in Science' reveal women giving lectures at various institutions on archaeological topics. Its 'Literature' section listed women's publications, and works on archaeology and archaeological travel can be found there too. ${ }^{30}$ The women authors featured were interested in cultivating female audiences for their work, and in providing information of use, relevance and interest to other women as active engaged readers, students and tourists. Most of these women dropped fairly quickly out of the historical record, perhaps, as Stig Sørensen suggests, because increasing professionalism brought increasing masculinisation. This 'erasure', as Root describes it, is due to increased attention to specific forms of visibility, and in the post-suffrage, post-Second World War era to a decrease in a perceived need for visible women role models - The Englishwoman's Year-Book and Directory, for example, ceased publication in $1916 .{ }^{31}$ Their male counterparts, in contrast, had a longer lasting legacy.

As scholars and authors men were more broadly visible during their lifetimes, even to the point of caricature. In 1910 Punch lampooned the Who's Who entry for the British Museum Keeper of Oriental Antiquities, Wallis Budge, which included all his publications but none of his pastimes. A year later, Budge was included in Punch's humorous guide to the Museum, as one of its public facing curiosities. ${ }^{32}$ Flinders Petrie was referenced in Punch issues between the 1890s and 1930s. One 1904 Punch piece dubbed Petrie's exhibition in London 'the Flinderies', highlighting (through satire) the power of his name in the public presentation of the past. ${ }^{33}$ Leonard Woolley's Ur of the Chaldees (1929), which chronicled his 
excavations at this ancient site in Iraq, was also the subject of a Punch parody, as were his Ur radio broadcasts. In 1930 Punch published a poetic imagining of a scene in antiquity, based on Woolley's discoveries in the Royal Tomb at Ur; the scene ends with the imagined excavator reaching out to touch the remnants of the ancient world. ${ }^{34}$ The archaeologist as what P. David Marshall has called a 'celebrity-commodity' fed into their commercial viability as authors, giving them authority when dealing with publishers in contract negotiations and marketing. ${ }^{35}$ It also fed into their publication strategies through the production of memoirs and autobiographical works, shaping popular perceptions and ensuring their own future visibility (at least, for some).

In order to structure the research presented here, I made a list of over 50 British archaeologists active during the late nineteenth and early twentieth centuries, and then used a combination of internet searches and library listings to construct bibliographies for each of them. ${ }^{36}$ The bibliographies revealed the range of publishing houses accepting and producing archaeological material. My focus was on solo-authored books issued by 'trade' publishing houses rather than academic (university) presses. This focus revealed over 70 firms that published archaeologists' books aimed at non-scholarly readers in one form or another. The firms were mostly, though not exclusively, London-based, and consisted of what the Writers' and Artists' Year Book mainly classified as 'general' or 'general and educational' publishers. ${ }^{37}$ These firms represent a diversity of interests, from 'trade' publishers large and small, long-lived and short-lived, to publishers with an overtly ideological remit such as the Religious Tract Society and the Society for Promoting Christian Knowledge. ${ }^{38}$

Looking across the bibliographies that I had compiled, some trends began to emerge. A few publishing houses stood out for the number of books published by archaeologists on archaeological topics. Series produced by the Religious Tract Society and the Society for Promoting Christian Knowledge, for instance, enabled archaeologists to reach readers interested in the Bible and the lands and peoples described therein. Macmillan's 'Handbooks on Archaeology and Antiquities' provided a similar venue for classical archaeologists to reach those who were familiar with and interested in the classical world. Kegan Paul's 'Books on Egypt and Chaldea' series was particularly popular with British Museum curators Wallis Budge and Leonard William King. The house of Algernon Methuen published books in various genres, including travel, popular histories and overviews, and books of reference, by authors including Flinders Petrie, Wallis Budge, Arthur Weigall, Annie Quibell, 
Ellen Bosanquet, Mary Brodrick and Harry Hall. Some archaeologists remained with a few regular publishers: Mary Brodrick's main publisher was John Murray, while all of Mary Chubb's books were published by Geoffrey Bles. Other archaeologists had a wider scope. David George Hogarth published with John Murray, Lawrence and Bullen, William Heinemann, Williams \& Norgate and Macmillan. Arthur Weigall began publishing with William Blackwood \& Sons before the First World War, but afterwards published both novels and nonfiction with Hodder \& Stoughton, Hutchinson \& Co, T. Fisher Unwin and Thornton Butterworth. Wallis Budge published with Thomas Cook \& Sons, Chatto \& Windus, J. M. Dent \& Co, Gowans \& Gray, Kegan Paul, Martin Hopkinson, the Medici Society, Methuen, John Murray and the Religious Tract Society.

The nineteenth century was a period of immense growth for publishing endeavours, enabling an ever increasing number of readers in Britain and beyond to access literary material. ${ }^{39}$ Leslie Howsam has shown that in this period the boundaries between 'scientific' and 'popular' could be fluid, demonstrating the active role of publishers in maintaining that fluidity. Peter Bowler, among others, has noted that there are several ways to interpet 'popularity'. ${ }^{40}$ There are the intentions of the authors themselves. The prefaces and introductions to the works featured here demonstrate that archaeologists had specific audiences in mind. Often 'students' were identified as the prospective readers; sometimes archaeologist-authors addressed 'the man on the street' or the 'general reader'. Texts could also be 'popular', 'handy' or 'less technical'. Some identified a specific need or 'demand' that the book would be meeting.

A survey of prices for the books I identified revealed a wide range. Simon Eliot's 1994 study of book pricing sets out three main price categories for books produced between the 1840s and 1915: low ( 1 pence (d) to 3 shillings (s) and $6 \mathrm{~d}$ ); medium (3s 7d to 10s) and high (10s 1d and above). ${ }^{41}$ Archaeologists publishing volumes in the Religious Tract Society's 'By Paths of Bible Knowledge' series in the 1880s and 1890s saw their books being retailed for between $2 \mathrm{~s}$ and $3 \mathrm{~s}$ each, whereas the books of Wallis Budge and Leonard King for Kegan Paul in the 1890s, aimed at beginners in ancient languages, retailed for 15s apiece. Once Kegan Paul began publishing the 'Books on Egypt and Chaldea' series in the 1890s and early 1900s, introductory language texts became available for 3s 6d each. Macmillan's 'Handbooks of Archaeology and Antiquities', also published from the 1890s, sold from 5s. Books of travel and memoir, such as David George Hogarth's Wandering Scholar in the Levant (1896), Ellen Bosanquet's Days in Attica (1914) or Agnes Conway's A Ride Through the Balkans (1917), also fell in this middle price range, retailing for between 
5s and 7s 6d. After the war, archaeologists publishing in Benn's Sixpenny Library and in Penguin's Pelican imprint saw retail prices for their work placed firmly in the low price range, ensuring they would be within the purchasing power of readers with lower incomes and less money to spend on leisure reading. Leonard Woolley's Ur of the Chaldees, published in 1930 by Ernest Benn and retailing for 7s, was republished by Penguin as one of the first 10 Pelican titles in 1937, retailing for 6d. Arthur Weigall's Life and Times of Akhnaton, originally published by William Blackwood in 1911 and retailing at 10s 6d, was in the 1930s republished in Thornton Butterworth's Keystone Library, priced at $5 \mathrm{~s}$.

Some of the books archaeologists produced contained chapters based on articles previously published in newspapers and periodicals, meaning that a version of some texts would have been available in less expensive formats. Gertrude Bell's 1911 travelogue Amurath to Amurath, retailing for $16 \mathrm{~s}$ on publication, for example, was partly based on articles previously published in The Times, the Quarterly Review and Blackwood's Magazine. David George Hogarth's Accidents of an Antiquary's Life (1910) used parts of pieces previously published in Monthly, Cornhill and Macmillan magazines. Arthur Weigall's History of Events in Egypt was formed from his writings published in Fortnightly Review and Blackwood's Magazine, while his biography of Akhenaten used other pieces from Quarterly Review, Blackwood's and Century magazines.

There were some surprises in this research. Arthur Evans, celebrated in later popular histories for his excavations at Knossos, published relatively little in book form on his Knossos excavations for a general readership, though he did contribute articles on the work to The Times. ${ }^{42}$ Over 20 years after the excavations had initially begun, Macmillan \& Co published Evans's multi-volume analysis of the Knossos excavations, The Palace of Minos, starting in 1921; it retailed for a whopping $£ 6$ 6s per volume. ${ }^{43}$ However, Evans himself was aware of the need to publish Knossos for a wider audience. Correspondence in the Macmillan archive shows that he granted permission for a plan of Knossos to be included in Macmillan's Guide to Greece (1908), which also contained his revisions to the text on Knossos. ${ }^{44}$

In the years leading up to the First World War Evans continued to feel pressure to publish a 'popular' book on the Knossos discoveries and the history of the site. He suggested to Macmillan that an 'Album of the discoveries of Knossos' be produced - partly also, he claimed, to undercut local photographers who were secretly taking and selling photographs of the excavated site. ${ }^{45}$ In the end, other authors contributed to the popular publishing of Knossos. James Baikie's Sea-Kings of Crete (1910), retailing 
for 7s 6d, included a detailed, pull-out plan of the Knossos Palace that Evans was excavating, as well as a bibliography with references to Evans's scholarly publications on Knossos and the Minoans. The archaeologist John Pendlebury, the curator of Knossos, eventually met Evans's desire for a popular guide to the site in 1933. As he put it, 'the fortunate possessors of the Palace of Minos have hesitated before hiring the pack animal necessary for the transport of that monumental work round the site'. ${ }^{46}$

The archaeologist John Linton Myres commented that after the discovery of Tutankhamun's tomb in late 1922 newspapers realised that stories on archaeology made 'good copy'. ${ }^{47}$ Howard Carter's The Tomb of Tut-ankh-amen was published by Cassell \& Co, the first of three volumes appearing in 1923, at the close of the first full season's excavation. Subsequent volumes appeared in 1927 and 1931; each was heavily illustrated, with Carter's text giving a first-person, sequential account of the discoveries. The volumes were fairly expensive, priced at $31 \mathrm{~s}$ for the first two volumes and 18s for the final one. However, Carter's discoveries instigated a surge in archaeological publishing as his colleagues quickly produced a range of studies on archaeology and Egyptology, along with histories of Tutankhamun and his family, to meet a perceived public thirst for more information.

Arthur Weigall's books Tutankhamen and Other Essays and Glory of the Pharaohs were both published in 1923 to meet renewed and increased interest in Egyptian archaeology. He followed these five years later with Flights into Antiquity, in which he used the popularity of archaeology in the wake of Tut to '[extend] the range of the general reader's travels in the huge field of Antiquity'. ${ }^{48}$ Egyptologist and anatomist Grafton Elliot Smith's Tutankhamen and the discovery of his tomb (Kegan Paul, 1923) republished in book form his Tut articles for the Daily Telegraph. Wallis Budge's Tutankhamen Amenism, Atenism and Egyptian Monotheism for Macmillan (1923) was a popular guide to Tut facts and an overview of Tut-related religious groups. At the time of the discovery of Tutankhamen's tomb, Annie Quibell's Egyptian History and Art (1923) was too far along in the Society for Promoting Christian Knowledge's production process to do more than allude to its significance. As she put it, 'This tomb has aroused such extraordinary interest that I regret very much the impossibility of giving any detailed descriptions of the objects'. ${ }^{49}$ The following year Lina Eckenstein's Tutankh-aten: A Story of the Past for Jonathan Cape presented a semi-fictional view of 'the conditions of life and the trend of thought at the period which witnessed the construction of [Tut's] tomb'. ${ }^{50}$ 
The Tut phenomenon also highlights the ephemeral nature of archaeology, a phenomenon that Donald Reid has explored in an analysis of Tut reporting in The Times. ${ }^{51}$ Archaeology is fleeting, with old interpretations discarded as new ones are created; artefacts once excavated are separated from their original context; sites, once excavation is begun, are transformed; tour routes and stops once popular are later abandoned or avoided with changing political and economic circumstances. ${ }^{52}$ In assessing scripting spadework, Archaeologists in Print charts that ephemerality, and in so doing illustrates the value of some items that are themselves part of the ephemera canon - newspapers, illustrated magazines, serials, guidebooks and other 'ephemera of empire'. ${ }^{53}$ Ephemera has also been a useful tool for evaluating scripting spadework - book labels, library issue stamps, publishers' lists and catalogues, dust jackets and travel accoutrements all have value to understanding archaeology's promotion, popularity and readership..$^{54}$

\section{A wider context}

As many scholars have noted, the British Empire should not be considered a static, monolithic, bounded entity, but rather a constantly evolving one. During the period covered in this book the Empire was embedded in daily experience and popular imagination, both in Britain and in 'Greater Britain' - its imperial zone. ${ }^{55}$ This book deals directly with developments at the intersection of two empires, British and Ottoman, bringing several countries and their inhabitants into the British sphere of what Christina Riggs has called "'our" exotic'. ${ }^{56}$ These developments had a major impact on archaeologists because of the international, regional and local systems (economic, political and social) critical to enabling excavations and explorations to be conducted and collections, knowledge and experience to be garnered, exported and shared.

In the 1870s, where this book begins, the British Empire was concentrated mainly though not exclusively in the Americas, 'Australasia', in Africa and India; in the last a form of British rule (the 'Raj') had been established after the 1857 rebellion of Indian sepoys at Lucknow and other sites associated with the British East India Company. ${ }^{57}$ Over the course of the next century British possessions increased through occupations, wars and treaties, only to decrease again as former colonies, protectorates and mandated territories gained independence. Many of the countries relevant for this book - Egypt, Sudan, Palestine, Transjordan and Iraq - were 
under British administration in one form or another for at least part of this period.

For example, Egypt had been an independently ruled part of the Ottoman Empire from the 1820s; the Egyptian khedives in Cairo were autonomous from the Ottoman sultans based in Constantinople. In the 1860s British investment, in addition to French, helped to push development of a canal in Egypt's Suez area connecting the Mediterranean and Red Seas, enabling ships to pass through Egypt en route to India. The Suez Canal opened in 1869 to great fanfare in the British press; just over a decade later, in 1882, British forces occupied Egypt in an effort to quash a nationalist revolt, establishing a shadow-hold over the Egyptian government. A British civil service infrastructure was put in place and the British Consul-General in Egypt gained significant authority over government matters. ${ }^{58}$

Following Egyptian conquest in the 1820s, Sudan was occupied Egyptian territory until revolts under a religious leader, the Mahdi Muhammad Ahmad, commenced in the early 1880s. A joint AngloEgyptian force was sent to fight against the Mahdi's army, with the resulting siege in Khartoum leading to the dramatic and much publicised death of General Charles Gordon. During the 1880s and 1890s the AngloEgyptian army continued to fight against the Madhi and his successor, the Khalifa, Abdullah al Taaishi (as well as French forces, hoping to gain control over territory in Sudan), until a battle at the Sudanese city of Omdurman saw the Khalifa defeated and control of Sudan pass equally to Britain and British-occupied Egypt under a treaty (Condominium) in 1899. A British-controlled government was established, based in Khartoum. ${ }^{59}$ Egypt remained an occupied country until the end of 1914, when it was annexed as a British protectorate as a wartime measure. It gained nominal independence from Britain in 1922, but Sudan remained British-controlled until its independence in 1956.

The Ottoman Empire extended across a significant portion of the Eastern Mediterranean and Middle East until the early twentieth century. It encompassed a wide range of peoples with various traditions, ethnicities and religions, all existing within an Ottoman Turkish Islamic administrative system. In contemporary British cartography and reference the Ottoman Empire was divided into two main parts: Turkey in Europe and Turkey in Asia. Turkey in Europe extended across much of the southeastern half of the geographical region known as the Balkans, and included the mainland Europe portion of modern Turkey. Turkey in Asia encompassed the region known as Asia Minor or Anatolia, as well as 
the vilayets (Ottoman administrative region) in Syria (modern Syria and Lebanon), Palestine (modern Israel and the Palestinian Territories and Jordan) and Mesopotamia (modern Iraq). A portion of modern mainland Greece and the nearby Cyclades islands had gained its independence in 1829, and its borders extended with subsequent wars and treaties.

War between Russia and the Ottoman Empire erupted in 1877; following the Congress in Berlin a year later, the Ottoman Empire lost much territory. The island of Cyprus, which had been part of Greece, was ceded to Britain in 1878 and remained under British administration until 1960. The island of Crete was under Ottoman control until the late nineteenth century, after which it came temporarily under the administration of the Great Powers before being incorporated into Greece in the early twentieth century. The borders of the Ottoman Empire shifted again (first reduced, then slightly increased) with the Balkan Wars of 1912 and 1913. Following the outbreak of war in 1914, Ottoman forces allied with the Central Powers (Germany and Austria-Hungary) against the Allies (Britain, France, Italy and the United States).

Allied troops were duly sent across the Balkans and the Ottoman Empire to fight the Central Powers in a series of theatres and campaigns. Soldiers stationed in these ancient landscapes consumed information about archaeology, and several British archaeologists served in military intelligence operations in the Eastern Mediterranean and Middle East. At the end of the conflict the Ottoman Empire was no more - modern Turkey was born, and former Ottoman Empire territories in the Middle East parcelled out among the victors. Britain was granted Mandatory powers from the newly created League of Nations to 'assist' in the administration of Palestine, Transjordan and Iraq. ${ }^{60}$

The Ottoman Empire had come into conflict with the interests of the European Great Powers (Britain, France, Germany, the AustroHungarian Hapsburg Empire and Russia) in the nineteenth century, as the Great Powers exercised themselves in the interests of non-Muslim communities, the 'Eastern Question', supporting the creation of individual nation states in the Balkans. The Great Powers were also heavily involved in the finance and infrastructural development in the emerging Balkan states and Ottoman Empire; banking, steamships and railways, as part of these developments, were all vital for travel, tourism and archaeology. Spiralling debts in the Ottoman Empire during the mid-nineteenth century led to the Great Powers having an increasingly powerful role within the Empire. ${ }^{61}$

Britain had by this point long-standing commercial interests in the Balkans through its Levant Company, which had been trading with 
the Ottoman Empire for several centuries. In 1825 the Levant Company was taken over by the Foreign Office, and in the years that followed the Eastern Mediterranean region became increasingly important to British strategies to protect routes to India. British consular offices had long been established in important cities throughout the Ottoman Empire, including Salonika (Thessaloniki), Constantinople (Istanbul), Smyrna (Izmir), Alexandria and Aleppo (in Baghdad a British Residency was affiliated with the East India Company). These evolved further in the nineteenth century. As Lucia Gunning has shown, these offices - and the consuls, vice-consuls, consular agents and other staff working in them played an important role in facilitating archaeological exploration and movement of antiquities. Several British excavators of the early to midnineteenth century, including Charles Newton and Austen Henry Layard, spent part of their careers in the diplomatic-consular service. ${ }^{62}$

Geographical and political developments in both the British and the Ottoman Empires had an important impact on the ways in which British archaeologists were able to travel and excavate. Archaeologists used a combination of internationally owned steam and rail transport to travel to sites. They harnessed international communications and media networks to publicise their work and required local and international banks and banking systems in order to buy or lease land for excavation and to pay their workforce, mainly recruited locally. Furthermore, archaeologists were beholden to political officials to give them permission to excavate and to enable them, through antiquities legislation, to export a portion of artefacts discovered back to Britain.

Archaeology is therefore integrally linked to imperial systems. Nowhere is this more evident than in African World, a weekly publication established in 1902 to promote commercial developments and financial investment opportunities in Britain's imperial holdings in Africa. The weekly periodical was swiftly succeeded by a lengthy Annual, published at Christmas, which devoted a section to each colonial region in Africa. Annuals for individual countries were also produced - Egypt (later Egypt and Sudan), for example, had its own annual from 1906. As will be seen, archaeologists wrote articles for African World both to promote archaeology as part of Egypt's tourism offer and to appeal to those who might have extra income to invest in archaeological research. It was for these imperial and tourist markets, as well as for a domestic one, that spadework was successfully scripted. ${ }^{63}$

The professionalisation of the discipline, and of its technologies and practices, has been described as a product of the West. However, scholars have more recently begun to explore the formal and informal 
role of local populations in the Eastern Mediterranean and Middle East in the examination of their archaeological heritage. Alongside charting the development of tourism and museums in Egypt, Donald Reid's work highlights Egyptians' contributions to, and difficulties in, archaeology and the management of archaeological heritage from the late eighteenth century to the Egyptian revolution of 1952. Rachel Mairs' discovery of the testimonial book of Palestinian dragoman Solomon Negima presents the history of archaeological tourism in the Middle East through one man's active engagement in giving Western visitors a view of the East. Stephen Quirke has detailed the contributions of the Egyptian workforce on Flinders Petrie's excavations during the late nineteenth and early twentieth centuries, harvesting their names from the pages of Petrie's archived notebooks. Research on the late nineteenth- and early twentieth-century Ottoman Director of Antiquities Osman Hamdi Bey likewise offers a less Western Europe-focused vision of the management of antiquities in the Middle East. Magnus Bernhardsson and James Goode have both discussed Iraqi involvement in, and responses to, archaeology and antiquities management in Iraq during and after the end of the British Mandate. ${ }^{64}$

While British archaeologists regularly discussed their workforce in popular publications in terms of their skill level (referring to them as 'pickmen' or 'basketboys'), some archaeologists publicly named, acknowledged and revealed the histories and interests of those they employed on site, some of whom became close companions. They are mainly presented in ways that echo 'imperial' attitudes, but they are not absent from archaeologists' scripts; in fact, their presence indirectly helped to promote archaeologists' foreignness. In 'Digging Up Bible History', a four part series of articles for Britannia and Eve about the joint British Museum/University of Pennsylvania Museum excavations at Ur, Katharine Woolley described how she and husband Leonard met their foreman Hamoudi and his sons at Aleppo en route to Ur. Over coffee the Woolleys learned what they felt about the past season's discoveries. Reginald Campbell Thompson's 1915 memoir A Pilgrim's Scrip provided a potted biography of his servant, assistant and former digger Mejid Shaiya who, after working with Thompson at Nineveh in 1904, joined him on explorations in Sudan a few years later. Shaiya was again credited for his assistance in Thompson's reports from Nineveh in the 1930s, even though he was then working for the Ottoman Bank. ${ }^{65}$

The archaeologist as scripted moves between the domestic empire 'at home' and a foreign empire abroad. ${ }^{66}$ Barry Crosbie and Mark Hampton have noted an ongoing 'integration of domestic and imperial cultures' in 
contemporary scholarship on empire, and archaeology (though not explicitly explored in such analyses) is part of what scholars are interpreting as the 'cultural British world', incorporating the 'ideas, practices, habits and assumptions' of 'imperial culture' and the 'hybridities' of empire. ${ }^{67}$ Kent Fedorowich and Andrew Thompson have described imperial migrations (and consequently the creation of new identities) as fundamental to the British Empire. ${ }^{68}$ As Tillman Nechtmann has noted, physical objects can be used to chart these 'imperial biographies' ${ }^{69}$ In creating new objects through scripting spadework for commercial publishing houses archaeologists could project a (transnational) archaeological identity, and so feed into what Nechtmann has termed a 'hybrid model of Britishness'. ${ }^{70}$ Archaeologists could identify strongly with their countries of temporary (foreign) residence. ${ }^{71}$ Arthur Weigall's final book, Laura Was My Camel, was a memoir of his time as an Antiquities Inspector in Egypt. In it he revealed the indelible mark his time in Egypt left on him ending Laura with a Proust-like moment as he meets a reminder of Egypt on a country road in England:

'Camels!" I gasped, pointing to the roadway ... it was no delusion. A bend in the road brought us suddenly in sight of a travelling circus, and at the tail of the procession, sure enough, walked three gloomy camels... ${ }^{72}$

The relationship between archaeologists and their publishers also contributed to a wider culture of 'exhibiting the Empire in print'. ${ }^{73}$ British publishers had branches, offices or agents for distribution of their books within and outside the Empire. Macmillan, who published archaeologist D. G. Hogarth's Accidents of an Antiquary's Life in 1910, for example, had offices in the United States, Canada, Australia and India. Amalgamated Press's archaeological serial Wonders of the Past could be obtained from the company's agents in Canada, 'Australiasia' and South Africa. Through them archaeologists fed into 'imperialism in print', shaping images of foreign lands past (and present) in the minds of imperial readers 'at home' and abroad, a 'multi-sited' audience. ${ }^{74}$

It was the personal visibility of archaeologists that enabled them to script spadework successfully during their lifetimes; later histories incorporated these scripts. An important part of that visibility was the allure of the exotic. At their deaths, several of these archaeologists had a public profile that would be the envy of many scholars today - particularly given the current debates on the role and value of experts and expertise in society. Archaeological travel established local reading publics among 
expats and tourists, and therefore local economies overseas are bound up in this history. Archaeologists were, in essence, part of the landscape of foreign lands, mapped out in the guidebooks they helped to shape and the travelogues they published, situating themselves as bridges between home and abroad; they were part of a system of what Keighren et al. call '(unequal) global exchange. ${ }^{75}$ Through them, Britain was linked to Greece and Turkey, Egypt and Sudan, Palestine, Jordan, Iraq. The resulting personal ambiguity of the archaeologist as a figure in culture is reflected both in public and private personas; archaeologist George Horsfield, an Antiquities Inspector in British Mandate Transjordan, noted to his fiancée that he felt he was a stranger everywhere. ${ }^{76}$ While the archaeologists presented here might seem to be bastions of British imperialism to the readers of today, one important aim of this book is to complicate this picture by showing how they were viewed by the wider public 'at home' in Britain as semi-foreign individuals - thus echoing what Susanne Duesterberg has presented as the 'familiar strangeness' of archaeology. ${ }^{77}$

Archaeologists in Print examines archaeologists 'scripts' in three ways. It explores first how archaeology fitted within education, tourism, women's experiences, marketing and publishing. Chapter 2 provides the framework for the study, defining the archaeologist through tracing the evolution of archaeological education, training and practice, and the role of overseas schools and travel in shaping the archaeological experience. Chapter 3 focuses on women in archaeology, revealing how they made a name for themselves through lecturing and publishing and how their books illustrate women's experiences for a presumed female readership. Chapter 4 examines how archaeologists marketed themselves in print, contributing to their visibility through publicity and promotional cycles; it also explores the role of large-scale compendiums in enhancing their 'celebrity' status. These compendiums, issued in weekly or fortnightly parts, fed into book publishing; and served to remind readers serially of archaeological work and archaeological visibility. Chapter 5 introduces the dissemination of popular archaeology through publishers' series and libraries, as books were organised into interdisciplinary lists to spread consumption of the discipline to new audiences. This examination of dissemination continues with an analysis of local, national and international libraries' catalogues, of bookshops at home and abroad, and of readership.

In the second part of the book I draw on detailed archival research in the archives of three key publishing houses to show how in various ways archaeologist-authors and publishers of these houses produced 
spadework scripts. My analysis centres on evidence of the relationship between archaeologists and publishers, and how this relationship influenced the final product - part of what Keighren et al. have called a manuscript's 'travels into print'. ${ }^{78}$ My search for publishers' archives was determined by what is currently extant. ${ }^{79}$ Fortunately fairly extensive records are available for a few of the publishers relevant to this history, namely John Murray, Macmillan \& Co and Penguin, profiled in Chapters 6, 7 and 8 respectively.

Each of these three chapters is shaped around the material available in the individual publishing archive. This compelling body of material contains correspondence from archaeologists about the writing and publishing of manuscripts, as well as documentation on sales, marketing and distribution, that exposes the intricacies of individual archaeologists' career trajectories and reveals in finer detail the production processes leading to the final product. The book concludes with an analysis of fiction by and about archaeologists, capturing the essence of 'scripting spadework' and regurgitating it in a new form. 


\section{2 \\ Defining the Archaeologist}

There is only one name for the study of the material objects of the human past, and that is 'archaeology'. Those who devote their main interests and capacities to this study are archaeologists. ${ }^{1}$

These are the opening sentences of archaeologist Stanley Casson's 1930 book Archaeology. It was Volume 149 of Benn's Sixpenny Library - a series of slim octavo paperbacks that brought the knowledge of experts within the scope (and price range) of all readers. ${ }^{2}$ Casson's clear and concise definition of archaeology, refreshingly gender neutral, outlines its basic principle - the examination of humanity's history through artefacts. The discipline of archaeology featured in this cheap, accessible series as a result of decades of public promotion by archaeologists intimately involved in its formation, adoption, training and practice.

When Casson wrote these lines archaeologists were successfully moving beyond the wholly 'amateur' tradition of an earlier age. ${ }^{3}$ A growing number of institutions offered archaeological training in higher education. There were opportunities for salaried positions in archaeology in universities and training institutions, antiquities services and funded excavations. These developments yielded an increasing number of archaeologists who worked their subject-specific education and personal experience into accessible nonfiction aimed at a broad range of readers. This process was over half a century in the making, as specialist societies and training schools emerged in the mid- to late nineteenth century. These organisations were the crucible for the archaeological authors who produced non-specialist and popular works in the decades that followed.

By the mid-nineteenth century a network of local antiquarian societies existed in Britain, with the Society of Antiquaries in London, the British Archaeological Association and the Royal Archaeological Institute 
providing national centres for investigations into Britain's ancient past. British archaeology was not only concerned with the material remains of the United Kingdom, however. It was the societies, organisations and schemes that facilitated British research abroad that strongly influenced the creation and promotion of an archaeological identity. In so doing, they continued to shift the perception of archaeology from a largely desk-bound, antiquarian, 'dryasdust' [sic] pursuit (despite the 'heroic' archaeologist-diplomats of the mid-nineteenth century) to an alluring, dangerous, exotic adventure. ${ }^{4}$ The archaeologist as explorer and traveller was, and remains, a critical feature in the popular conception of the discipline.

The archaeological authors, men and women, discussed in the following chapters all benefited from the expanded opportunities for archaeological education, training and research. The books they published catered to an audience with expanding literacy and educational opportunities, as well as increasing leisure time and money. In this chapter I examine how the foundation of training schemes and institutions produced a large cadre of archaeological authors who emerged from, and fed back into, public interest in archaeology. The organisations formed to train and educate archaeologists were dependent on a growing ease of access to the East. Tourism was both the product and the means of archaeological work, and thus archaeologists both shaped and were shaped by the evolution of the tourism industry. It allowed them to feed into an increasing tourist market, beneficial for the promotion, reception and sustainability of their own research.

The allure of the travelling archaeologist, the romance and adventure of life and excavation in foreign lands as marketed through scripting spadework, was a critical factor in these developments. These archaeological authors built on their individual experiences in the field to shape the characteristics we now associate with archaeologists.

\section{Educating and training archaeologists}

In 1870 the Society of Biblical Archaeology (SBA) was formed to provide a platform for the presentation, promotion and publication of archaeological research in 'Egypt, Palestine, and Western Asia'. It acted as something of an umbrella organisation for members of societies with more distinct geographical or topical interests such as the Palestine Exploration Fund and the Royal Asiatic Society. ${ }^{5}$ In an address read to the Society a few months after its first meeting SBA founding member Samuel Birch, 
Keeper of the Department of Oriental Antiquities at the British Museum, declared that while interest in the history of biblical lands was nothing new, 'At the present day, owing to researches and excavations which have brought to light a buried world, we are able to ascend into the remotest times of antiquity.... ${ }^{6}$ From the outset, members exploited the potency of the Bible as a marketing tool. Assyriologist Archibald Henry Sayce commented in his memoir that at its foundation, in order to garner subscribers, Birch had 'insisted' that 'Biblical' be part of the Society's name. ${ }^{7}$

Three years later the International Oriental Congress came to London. During the course of the meetings an important resolution was approved: to begin organising lessons in 'Egyptology and Oriental Archaeology generally'. ${ }^{8}$ Out of this decision the SBA initiated a series of 'Archaic Classes'. The classes were small, with the reading matter provided for by private munificence. Wallis Budge, later Keeper of the Department of Egyptology and Assyriology at the British Museum, recalled that as a student of Egyptology in the 1870s a key text such as Egypt's Place in Universal History would cost 'several pounds'. ${ }^{9}$ Within a short time it was apparent that the classes could no longer continue without proper investment and provision of elementary handbooks for students at affordable prices. And so the 'Archaic Classics' series was born.

The brainchild of SBA Secretary W. R. Cooper, the series was issued by noted Bible publishers Samuel Bagster \& Sons. The SBA and the British Museum were closely linked; British Museum keepers and assistant keepers were among the early members, presenting papers at the Society's meetings. This relationship fed into the Society's 'Archaic Classics' as British Museum staff contributed books to the series. ${ }^{10}$

The provision of a series of affordable handbooks of ancient literature and history was a step towards the consolidation of archaeological education. In England's two oldest universities, Oxford and Cambridge, archaeology was slowly introduced into the traditional curricula structure. In the 1870s Oxford offered no formal 'archaeological' option, but its literae humaniores course (comprising two parts, Honour Moderations, or 'Mods', and Greats) encompassed historical topics, and eventually archaeology was included in $1890 .{ }^{11}$ There were also provisions for ancient languages at Oxford, which traditionally placed attention on philosophy. ${ }^{12}$ In the late nineteenth century Professorships and Readerships were founded in Assyriology, Classical Archaeology and Egyptology; holders of these posts contributed to the research and teaching of the Universities through lectures. ${ }^{13}$ Percy Gardner, Professor of Classical Archaeology in Oxford from 1887 to 1925, recorded in his 
autobiography that over the course of his career he had personally taught '757 men and 129 women', and his lectures in addition had attracted many more. ${ }^{14}$ One of Gardner's students, Max Mallowan, recalled the positive impact that Gardner's archaeology lectures had on his choice of career. ${ }^{15}$

The Disney Chair in Archaeology at Cambridge had been extant since the 1850s, but the University's Classical Tripos, transformed in 1854, began to feature archaeology as a subject for study from 1879.16 An optional examination in Part II of the Tripos extended the traditional classical studies into new fields, including archaeology. ${ }^{17}$ Section D (Archaeology) of the Classical Tripos owed its origins in part, as Mary Beard has charted, to art historian Sidney Colvin. ${ }^{18}$ Archaeology was also one of the subjects open to women at Cambridge..$^{19}$ The classical scholar Jane Harrison was an early student at Newnham College, one of two women's colleges at Cambridge which had been established in 1871. She used archaeological knowledge and objects emerging from excavations in Greece to augment her own classical scholarship..$^{20}$ From 1899, through her position as Lecturer in Classical Archaeology at Newnham, she also inspired some of her students to turn to archaeological subjects. ${ }^{21}$ In 1904 the Board of Anthropological Studies at Cambridge, which included archaeology, was established, with the then Disney Professor William Ridgeway and the Lecturer in Ethnology A. C. Haddon among its members. ${ }^{22}$

At London's University College (UCL) there was from the 1870 s explicit provision for archaeology - first through the Slade Professorship in Fine Art and then, with more overt links to the British Museum, through a separate 'Archaeology' Department from 1880. The Department was led by Charles Newton, the College's first Yates Professor of Classical Archaeology and the British Museum's Keeper of Classical Antiquities. Reginald Stuart Poole, Keeper of Coins at the British Museum, succeeded him in the post of Yates Professor in 1887. ${ }^{23}$ In 1892 a bequest from the journalist and travel writer Amelia Edwards established the Edwards Chair in Egyptian Archaeology, implicitly created for William Matthew Flinders Petrie, by then a well-known excavator. ${ }^{24}$ Teaching comprised of lectures for students, 'demonstrations' in collections and practical, hands-on lessons for Archaeology, as well as tutoring in language for Egyptology. ${ }^{25}$ UCL proclaimed that its Chairs in Archaeology and Egyptology would make the College 'a chief centre of archaeological studies in London'. ${ }^{26}$

UCL's session fees books can be used to chart the evolving interest in archaeology and the network of students who were introduced to 
archaeology there. Listing fee-paying students to these courses per academic year, the archive yields a unique insight into both the writers and potential readers or projected audience of popular archaeology books. As the College offered both Archaeology and Egyptology as taught courses to its middle-class constituency, the number of students taking classes in these subjects - and the proportions of men and women students are significant in understanding the impact of popular archaeology publishing. ${ }^{27}$ Among these students were men and women who later wrote books on archaeology for non-scholarly audiences, some of whom I will discuss in greater detail through the course of this book.

In addition, a further tranche of men and women gained archaeological experience through Flinders Petrie's training schemes, the Egyptian Research Account and the British School of Archaeology in Egypt. Petrie's role as sometime excavator for the Egypt Exploration Fund further cemented UCL's critical role as an institution with which many key archaeologists were associated.

The College began admitting women students in the 1870s. By 1891, the last year of Poole's professorship, over half the students in the Archaeology Department at UCL were women, a trend that continued for the next 20 years (Figs 2.1 and 2.2). Under Flinders Petrie's leadership, the new Egyptology Department also attracted a majority of women students. ${ }^{28}$ These students, male and female, were not necessarily studying towards a degree - although unlike Oxford and Cambridge at this time women could be awarded degrees if they passed the necessary examinations. At this point teaching did not inevitably lead to degree assessment. ${ }^{29}$ However, opportunities were opened for travel and practical experience. Soon after his appointment the third Yates Professor, Ernest Gardner, began offering a special trip to Greece for interested students that was programmed to overlap with the Easter break period. ${ }^{30}$ Flinders Petrie, meanwhile, offered interested students the opportunity to travel to Egypt to gain practical experience in excavation. He set up the Egyptian Research Account as a fund to support one student to work in Egypt in 1894; other students, formally and informally supported through this scheme over time, went out also. ${ }^{31}$ Petrie's 'British School of Archaeology in Egypt', another training scheme for students to gain experience in excavation overseas, was established in 1905. The School was associated with UCL, but drew on public subscription for its financial support. ${ }^{32}$ These measures ensured that travel and archaeology were closely intertwined. Archaeologists were to exploit this connection between tourism and the material remains of the past to establish their personal marketability as authors and experts. 
UCL Archaeology Students

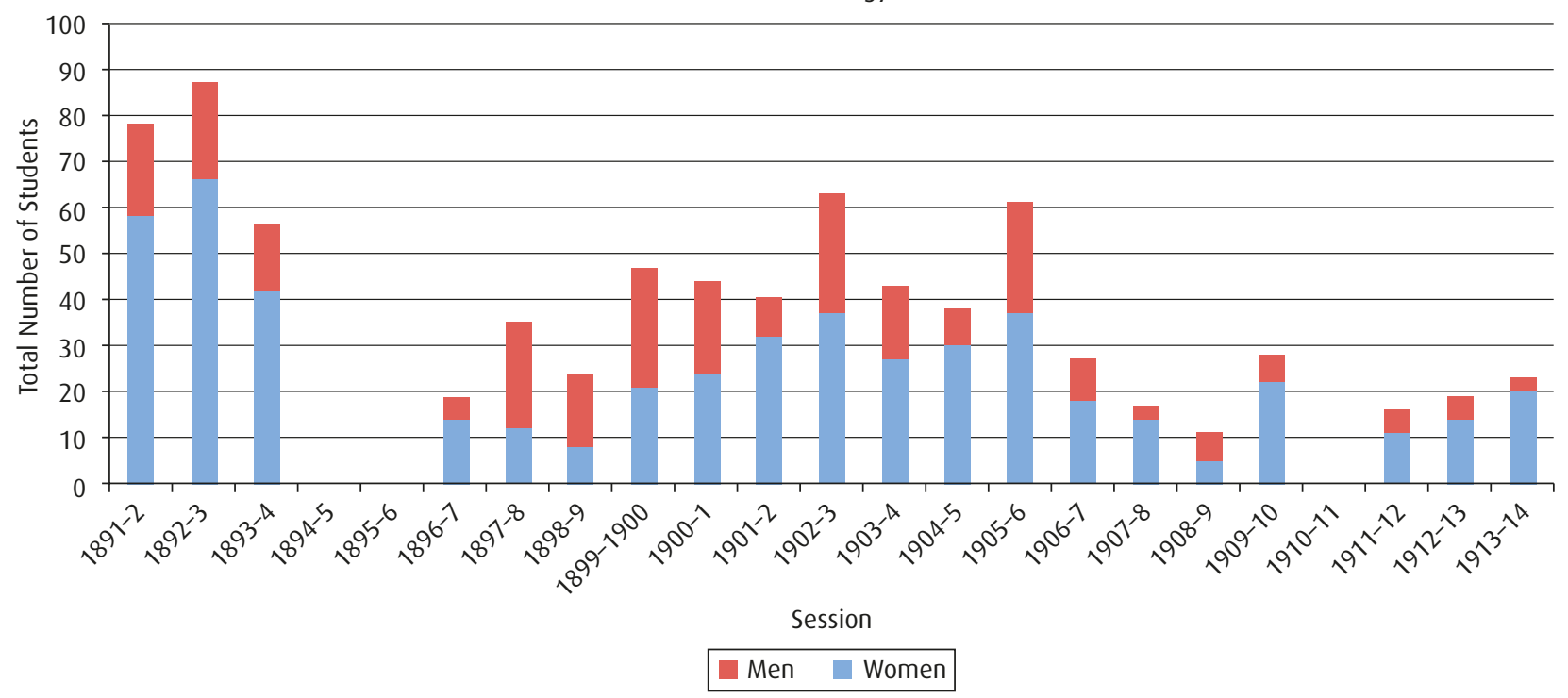

Fig. 2.1 Graph showing the numbers of students, broken down by gender, attending Archaeology courses at UCL between 1891 and 1914 (Session Fee book for 1910-11 not accessible at time of research). No data on Archaeology was given in the Session Fees books for 1894/95 or 1895/96. (Copyright the author) 


\section{UCL Egyptology Students}

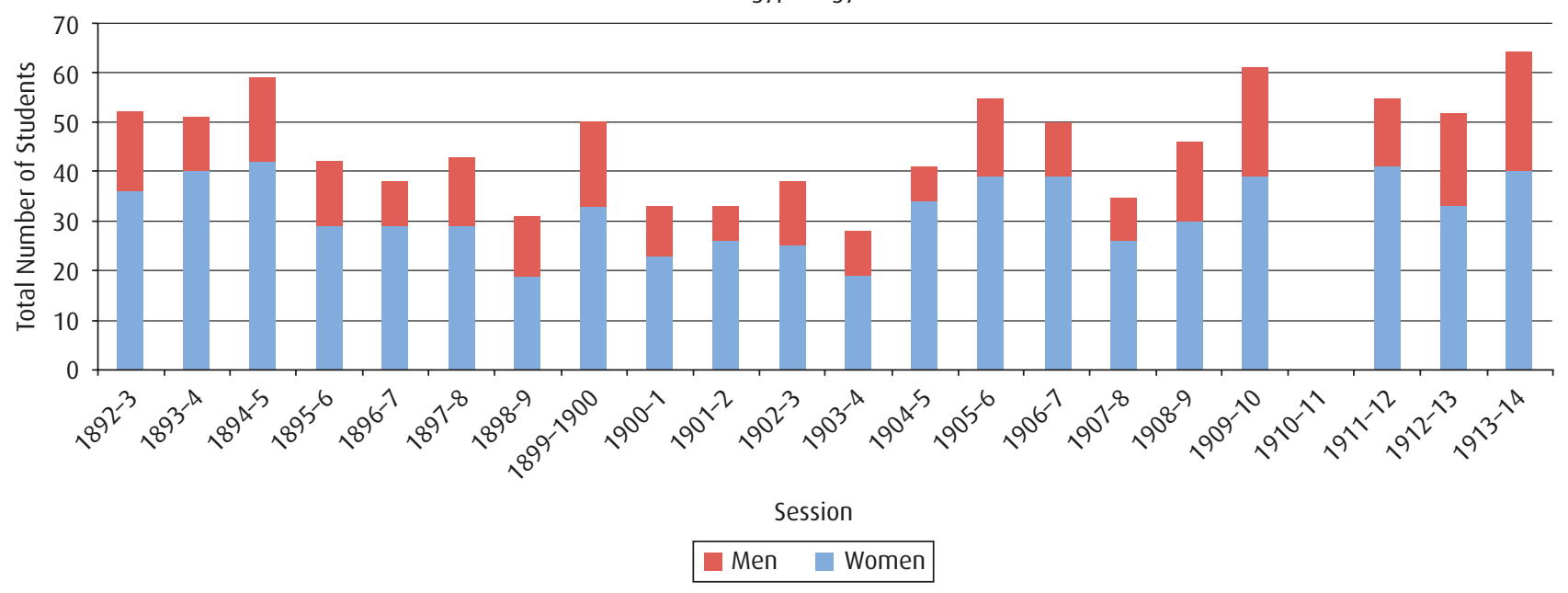

Fig. 2.2 Graph showing the numbers of students, broken down by gender, attending Egyptology courses at UCL between 1891 and 1914 (Session Fee book for 1910-11 not accessible at time of research). (Copyright the author) 
As the century drew to a close new universities, the so-called 'redbricks', had begun to emerge and become more formal institutions. ${ }^{33}$ One of these was the University of Liverpool, which established an Institute of Archaeology in 1904. The archaeologist John Garstang, who had trained with Flinders Petrie in Egypt as an Egyptian Research Account student, became Honorary Reader in Egyptology and then Professor of the Methods and Practice of Archaeology. ${ }^{34}$ Liverpool Professorships were also established in Classical Archaeology and Medieval Archaeology in the following years. ${ }^{35}$ In Scotland a Professorship in History and Archaeology had been established in the University of Aberdeen in 1903, and the Abercromby Chair of Archaeology at the University of Edinburgh was established in 1916.

Another Institute of Archaeology was established in London in 1937 as a training institution affiliated with the University of London by the archaeologists Mortimer Wheeler and his wife Tessa Verney Wheeler, both former UCL students. ${ }^{36}$ Preceding this, as John Evans has shown, Wheeler had been given an unpaid Lectureship in Prehistoric Archaeology through University College, subsequently converted to a part-time post, and a postgraduate diploma option had been instigated. After collecting funds and receiving a significant donation for the creation of the Institute, once it opened courses were to be offered in Palestinian and Mesopotamian archaeology as well as Geochronology. ${ }^{37}$

Alongside the universities, British Schools for archaeological training were established from the late nineteenth century. The first of these was the British School at Athens (BSA), established in 1886. The British School at Rome was established along the same lines in 1901 and the British School of Archaeology in Jerusalem, with John Garstang of Liverpool as its first Director, was established in 1919. ${ }^{38}$ These Schools were closely connected with the universities, offering students field experience during or after the end of their studies. They also facilitated the relationship between tourism and archaeology, serving in part as centres where 'educated' tourists and travellers, including diplomats, could obtain further information about the regions in which the Schools were situated. ${ }^{39}$

The British Schools admitted students on travelling scholarships and encouraged linguistic and cultural explorations alongside the physical activity of travel. The BSA drew its students mainly from Oxford and Cambridge, as both individual colleges and the Universities subscribed to the School. University travelling studentships and fellowships also enabled Oxford and Cambridge students and graduates to support their studies at the School. In its early days the trickle of men (the first 
woman BSA student, Eugénie Sellers, was admitted in 1890) who made their way to Athens gained valuable excavation experience and began building up their local contacts. Two of the first BSA students, Ernest Gardner (Poole's successor as Yates Professor at UCL from 1896) and David George Hogarth, later produced many significant books on archaeology for a non-scholarly audience; these will be discussed in greater detail in subsequent chapters. Two other early students, Montague Rhodes James and Edward Frederic Benson, later published ghost stories featuring archaeologists and antiquaries, a theme I will return to in Chapter $9 .{ }^{40}$ Although many more men passed through the British School at Athens than women, one, Agnes Conway, wrote a popular book on her travels in Greece and the Balkans as a BSA student, discussed further in Chapter $3 .{ }^{41}$

\section{'Professional' aspirations}

As archaeology became embedded in university curricula in Britain, there was an ever-pressing need for salaried employment for those trained students without adequate personal resources to draw upon to support their work. The men and women who studied or contributed to archaeology ended up in a variety of roles. Oxford and Cambridge offered a few Fellowship positions, and some of the archaeological authors featured in this book took these up. There were also an increasing (though still small) number of university posts: professorships, lectureships and readerships, and tutoring. ${ }^{42}$ At Oxford Archibald Henry Sayce, a graduate of the University, became first Deputy-Professor of Comparative Philology in 1876 and then from 1891 Professor of Assyriology. ${ }^{43}$ A Professorship in Classical Archaeology was founded in 1885, held first by the archaeologist and explorer William Ramsay and then by Percy Gardner. In the 1890s Gardner became editor of Macmillan's 'Handbooks on Archaeology and Antiquities' series, discussed further in Chapter 7. Professorships in Ancient History were established in 1907 and 1910, the first post holders being the archaeologists Francis Haverfield and John Linton Myres. Further lectureships emerged in Papyrology and Prehistoric Archaeology in the Edwardian period. ${ }^{44} \mathrm{~A}$ former excavator with the Egypt Exploration Fund, Francis Llewellyn Griffith, became a Reader in Egyptology at Oxford in 1901, and in 1924 Professor. ${ }^{45}$ At Cambridge there was a Readership (later Professorship) in Classical Archaeology from the 1880s, although this was held at first by the art historian Charles Waldstein, and Jane Harrison, as mentioned above, 
had a position as Newnham College's Lecturer in Classical Archaeology from $1899 .{ }^{46}$

Museum curator positions were another important professional role for archaeologists. Wallis Budge had begun Cambridge University's recently established Semitic Languages Tripos in the 1870s, but was told that there were no future prospects in the field professionally. Through Assyriology, however, he could at least have a chance at obtaining payment for work; by the late 1870s, he recalled, 'things happened which proved that ... there was some money to be made out of a knowledge of Assyrian'. Budge therefore began to write on commission, and in 1883 he joined the British Museum's Oriental Antiquities Department. ${ }^{47}$ As David Wilson has shown, during the latter half of the nineteenth century the British Museum evolved into a much more complex institution. In the 1860s its Antiquities Department was divided into three sections: Oriental Antiquities; Greek and Roman Antiquities; and Coins and Medals. The Oriental Antiquities Department was subsequently further subdivided into British and Medieval Antiquities and Ethnography, and Egyptian and Assyrian Antiquities. ${ }^{48}$ Within these Departments was a range of salaried posts, with a Keeper in charge of each Department and between three and four Assistants beneath him. These posts attracted a number of archaeologists. ${ }^{49}$ An expanding museum sector in the nineteenth and early twentieth centuries also yielded professional development opportunities to women, as Kate Sheppard has shown. Women were critical to the development of museums; several women collectors, including Amelia Edwards, helped to found, fund and develop British Egyptology collections. ${ }^{50}$

The Ashmolean Museum in Oxford and the Fitzwilliam Museum, the Museum of Archaeology and Anthropology and Museum of Classical Archaeology in Cambridge also provided positions for archaeologists. ${ }^{51}$ The Ashmolean Museum, originally established in the seventeenth century, underwent a radical reorganisation in the late nineteenth century through Percy Gardner, who intended the museum to bolster his work in introducing archaeology and artefact studies to Oxford. Gardner worked in conjunction with the excavator of Knossos, Arthur Evans, as Keeper; former BSA student David George Hogarth succeeded him; Hogarth's assistant was Leonard Woolley. ${ }^{52}$ Hogarth and Woolley both contributed greatly to the public perception of archaeology through their books, as will be seen in the following pages.

Overseas there were further opportunities for paid employment. The evolution and expansion of Britain's imperial interests in the nineteenth century created new posts for archaeologists, as Antiquities 
Departments or services were established (or re-established) in key countries with a strong Western presence - namely India, Egypt and Sudan before the First World War and in British Mandated Palestine, Transjordan and Iraq after it. From the mid-nineteenth century to the early twentieth century British men gained positions as Directors or Antiquities Inspectors in these Departments. ${ }^{53}$ The British Schools abroad also offered a limited number of salaried positions as Directors, Assistant Directors, Curators or Librarians, although these were occasionally also held in conjunction with other roles. ${ }^{54}$

Archaeologists could also be employed on a freelance basis as excavators working on behalf of - or in conjunction with - excavation funds, learned societies, museums or patrons on specific sites or research agendas. The Hellenic Society (established in 1879) was an early funder of classical archaeological excavation, and the Royal Geographical Society also gave funding for archaeological exploration and travel. ${ }^{55}$ For excavation work in the Middle East the two most important funds were the Palestine Exploration Fund and the Egypt Exploration Fund.

The PEF was established in 1865 for the exploration, survey and publication of research relating to the Levant; its first major projects were excavations in Jerusalem in the late 1860s and a multi-year Survey of Western Palestine in the early 1870s. The Egypt Exploration Fund (later Egypt Exploration Society) was established in 1882, through the efforts of the journalist and traveller Amelia Edwards, for the exploration and excavation of ancient sites in Egypt. ${ }^{56}$ Britain's influence in Egypt had increased with its occupation of the country in 1882 and British officials infiltrated Egypt's government departments. Both the PEF and the EEF collected money from the public and obtained support for research and excavation through a combination of high-level connections and low-level subscription. Other smaller excavation funds for the exploration of Greece and Asia Minor were associated with the British School at Athens. ${ }^{57}$ Archaeologists also shifted roles regularly, moving over the course of their work in the field between work in a freelance capacity and more stable positions in museums or universities.

Excavations run through the auspices of funds, learned societies and museums employed varying numbers of archaeologists - a Director in charge, followed by assistants and others performing particular duties if budget allowed. Dig accounts and interim field reports offer insights into the terms of employment, revealing the myriad levels of participation on site. Flinders Petrie was one of the early EEF excavators, working on the Fund's behalf between 1883 and 1886, and again from 1896 to 1905. Ernest Gardner and David George Hogarth were also employed as 
Fund 'staff explorers' in the 1880s and 1890s. ${ }^{58}$ EEF excavations included women as well; Petrie's excavation accounts for work at Abydos in Egypt on behalf of the EEF during the 1902-3 season included payments to two women, Freda Hansard and Lina Eckenstein, both of them his Egyptology students. ${ }^{59}$ Excavation teams were made up of a number of different people, each fulfilling a task or tasks. Some of them were paid, including excavation artists, architects, photographers and anatomical or geological specialists. Some tasks were unpaid or voluntary, depending on the funding of the dig and the nature of the commitment. The wives of dig directors may not always have been formally trained in archaeology (though a number were), but they were often put in charge of managing the domestic arrangements and accounts, giving tours of the site to visitors, conserving and mending artefacts, and digging, thus picking up invaluable expertise and knowledge over the course of multiple seasons. ${ }^{60}$ Occasionally women acted as secretaries and/or pottery menders, or recorded and drew the objects. These more ephemeral members of the dig team are no less important in the production of popular and nonspecialist archaeology books, with a number of them recording their experiences in archaeology in memoirs and travel accounts.

The emerging centres for archaeological training and education in universities and British schools placed value on experience in the field (abroad). This experience was brought home and presented in the lecture hall and exhibitions, with reports of the work and archaeologists' promotion of it featured in newspapers. With courses at higher education level mainly offered in the archaeology of Bible lands (Egypt, Palestine, Mesopotamia) and the classical world (Greece and Rome), the archaeologists scripting spadework focused on their experience in, and knowledge of, these distant lands.

The myriad ways in which archaeologists captured and promoted themselves to a wider audience reflects this variety of activities and contexts within archaeological practice - travel, language acquisition, cultural knowledge and awareness, translation, photography, conservation and management. Thus in many of archaeologists' popular publications a persona is implicitly or explicitly created, revealing a characteristic or characteristics of archaeological experience. Amelia Edwards chose 'the Explorer' for Pharaohs, Fellahs and Explorers, her account of excavations in Egypt (Osgood McIlvaine, 1891). D. G. Hogarth chose 'the Scholar' and 'the Antiquary' for the titles of two of his popular travelogues, $A$ Wandering Scholar in the Levant (John Murray, 1896) and Accidents of an Antiquary's Life (Macmillan, 1910). Petrie preferred 'the Excavator' in his 1904 manual Methods and Aims in Archaeology (Macmillan), while Annie 
Quibell chose 'the Stranger' for her memoir-travel guide, A Wayfarer in Egypt (Methuen, 1925). Other personas emerge too from these narratives: the photographer, the interpreter, the linguist, the inspector, the tour guide, the curator, the student.

\section{Going abroad}

One of the most important developments to affect archaeology and its visibility in the nineteenth century was the increasing ease of international travel (Figs 2.3a and 2.3b). It fed into and linked together many of the facets of the archaeological experience. The Grand Tour had been an important part of the aristocrat's education in the eighteenth century, but the Napoleonic Wars in the beginning of the nineteenth century disrupted British travel in the region considerably. ${ }^{61}$ When peace returned, as Mullen and Munson describe, middle-class travellers began to appear on the Continent, and further afield. ${ }^{62}$ From the 1850 s railways crisscrossed the Continent, enabling people to travel to the Eastern Mediterranean and Middle East much more efficiently through a combination of railway and steamship. ${ }^{63}$

Competition duly arose between publishers to capture the evolving market, consisting of middle- and upper-class men and women tourists, in increasing numbers as the century progressed, alongside administrators, businessmen and other professionals working in imperial services plus their wives, families and staff (including servants), as well as soldiers and sailors. ${ }^{64}$ As John Pemble has shown, comments on the ubiquity of the Eastern travel narrative began to appear from the mid-1840s, and yet more were published. Archaeologists' popular publications further increased the number of these narratives, but their distinct and continually renewing engagement with landscapes, peoples and pasts also contributed something new. In 1914 the historian James Bryce commented that '...nothing now remains to be said about Palestine except by archaeologists'. ${ }^{65}$

Information relating to archaeological sites and museums made up a significant proportion of the guidebooks published for the Eastern Mediterranean and Middle East. ${ }^{66}$ Publishers collaborated with archaeologists to obtain the latest information on excavations and discoveries, as well as practical information on the logistics of travel based on their own experience. As Martin Anderson observed, publishing was an essential tool in facilitating a tourism cycle. ${ }^{67}$ The Leipzig-based publisher Karl Baedeker has achieved enduring status in the histories 

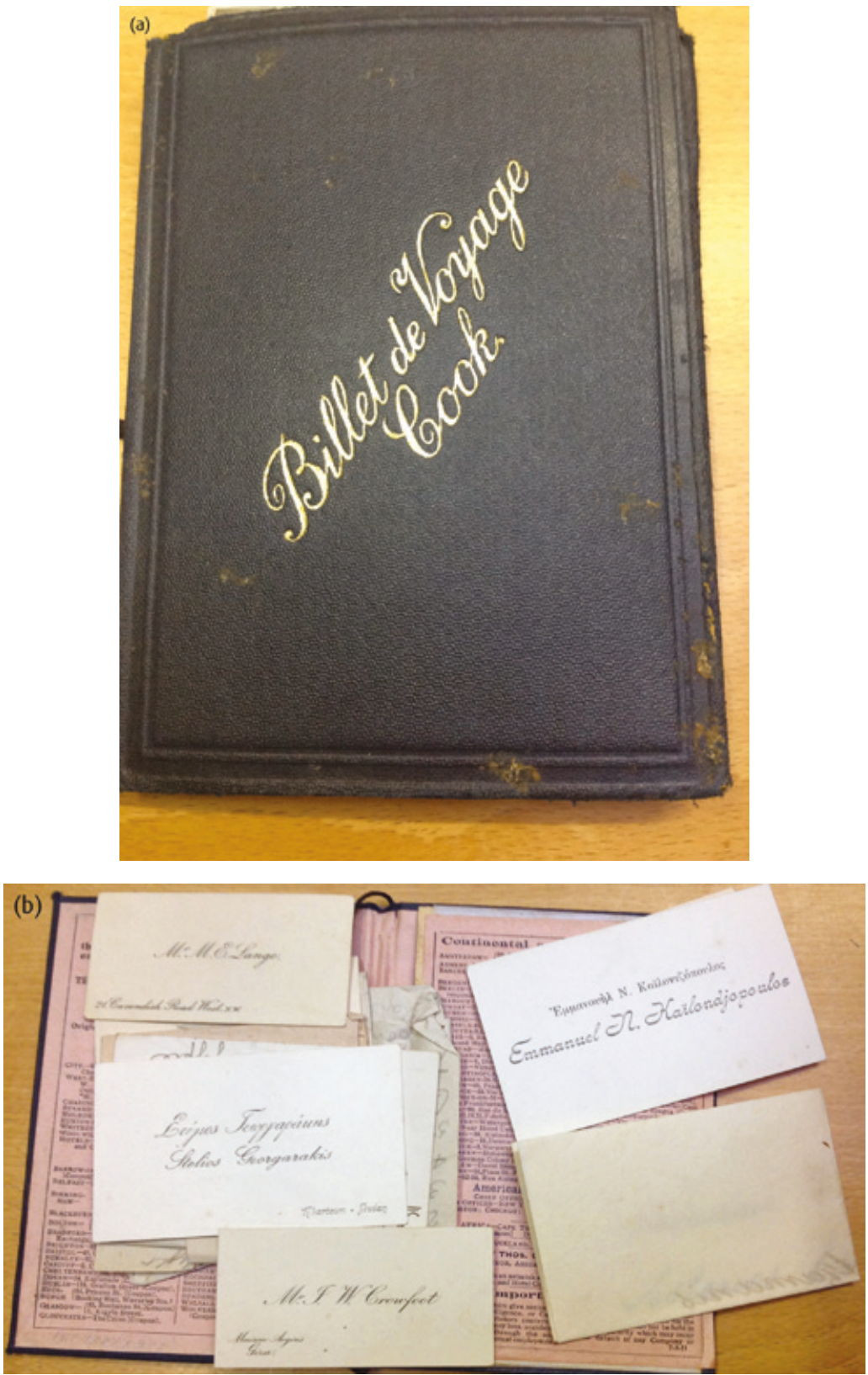

Figs. 2.3a and 2.3b Exterior and interior shots of a Thomas Cook \& Son travel wallet owned by the archaeologist Duncan Mackenzie and now held in the Palestine Exploration Fund archive. Between 1911 and 1912 Mackenzie was employed as a PEF excavator, conducting excavations at the site of Beth Shemesh. He used Thomas Cook's services for international travel and banking; the wallet contains various business cards and receipts he collected during his travels. (Courtesy of the Palestine Exploration Fund) 
of tourism, and many British tourists relied on Baedeker during their travels. However, British publishers produced their own guidebook series to counteract and combat Baedeker's dominance. British guidebooks for these tourists were published to meet their needs, and archaeologists were active contributors and editors for these books. ${ }^{68}$

John Gretton has charted the development of one of the most important brands, the Murray Handbooks, from their origin in John Murray III's 1836 guidebook to the Continent. Murray's book contained information he had collected during his own travels, and it served as the basic concept for Baedeker's guides. Later on other expert travellers compiled or revised individual Murray Handbooks to John Murray's personal specifications regarding practicality and accuracy. The works became more focused and regionally specific as time progressed. ${ }^{69}$ Murray's first Handbook to the East, covering 'Greece, Turkey and Malta', was published in 1840. It was followed by separate handbooks for Greece (1854), Constantinople (1893) and Asia Minor (1895) - the latter two of these written by Royal Engineer Charles Wilson, who had worked as a surveyor for the Palestine Exploration Fund. ${ }^{70}$ Italy was first covered over three handbooks between 1842 and 1853, with a separate Handbook for Rome appearing later. Murray's first Handbook for Egypt, an abridged version of the Egyptologist John Gardner Wilkinson's Modern Egypt and Thebes, appeared in $1847 .{ }^{71}$ By the mid-1890s the handbook had been reissued many times. Mary Brodrick, one of Flinders Petrie's Egyptology students at UCL, extensively revised the ninth (1896) and tenth (1900) editions of Murray's Egypt Handbook, which eventually included Sudan under Anglo-Egyptian administration. Murray's Handbook to Syria and Palestine appeared in 1858 (also later revised by Mary Brodrick), and a Handbook to the Mediterranean was published in $1881 .{ }^{72}$

These handbooks were aimed at the educated English-speaking tourist. One advertisement in the John Murray archive quotes a Times review describing the books as 'scholarly companions', trustworthy because they were 'English and reliable' (Fig. 2.4). ${ }^{73}$ Murray's dealt directly with sellers such as Chapman \& Hall's Book Department on London's Strand to stock and display their guidebooks; they also sent presentation copies to key British consular offices overseas where they might be recommended to British tourists en route. ${ }^{74}$

Like Baedeker, Murray's handbooks became part of the background for real and fictional tours. Baron Schlippenbeck's 1869 short story, 'A Night with King Pharaoh', features a group of English tourists to Egypt for whom Murray's Handbook is the only trusted guide: the 'masculine' Misses Shepherd use it for practical information while fellow travellers 


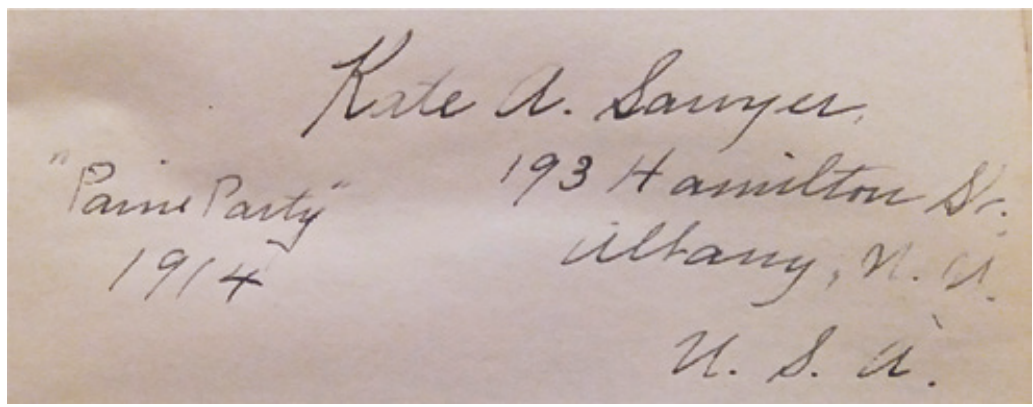

Fig. 2.4 A handwritten inscription inside a copy of Murray's Handbook to Egypt \& The Sudan (11th edition, 1907), revealing that it was originally owned by New Yorker Kate Sawyer and probably used on a trip with the 'Paine Party'. (Author's collection)

Masters and the anonymous narrator use it on site to understand details of ancient Egyptian tombs. ${ }^{75}$ Similarly Daisy Hugh Pryce's Love's Mirage (1902), a romance set during the Cairo Season, sees wealthy, middleaged Miss Tankerville embark upon a Nile steamer voyage with her young companion Evelyn. To avoid answering Evelyn's queries about the weather, she instructs her to 'read up your Murray, my dear'. A veteran of the winter Season in Egypt, Miss Tankerville reads both Baedeker and Murray together to ensure that she can speak intelligently on matters Egyptian. ${ }^{76}$

These guidebooks were not static accounts, but rather needed continual updating with the latest archaeological developments. These did not relate only to excavations, but also to improvements in physical accessibility to sites - and to the increasing visibility and promotion of 'cultural tourism' through the work of Antiquities Departments in opening sites and museums to visitor traffic. Included among these, for example, were the schemes for illuminating ancient tombs with electricity, as was done in Luxor at the Valley of the Kings. ${ }^{77}$ Murray's printed special addenda on coloured paper, bound into copies of the guidebook in order to keep their information up to date between official revised editions.

As 'scientific' archaeology became a fixed entity in the tourism experience, so archaeologists and their works became a more visible part of the landscape of knowledge and experience. Unlike the guidebooks of today, individual sites and discoveries listed in 'routes' explicitly included excavators' names or organisations. They also gave dates of key excavation seasons where relevant, making them effectively modern installations in the ancient landscapes tourists wanted to see. Archaeologists' popular and scientific works were listed in a section for books of reference, or 
were recommended for the traveller wanting to find out more about a region's history, culture and landscape. These were in some cases broken down into categories to enable readers to discover works of particular interest - whether archaeology and ancient history, art, modern culture or travel accounts. ${ }^{78}$ While the inclusion of these readings was not a new feature, the books listed were updated to include the latest publications and translations.

It was not only guidebooks aimed at wealthy educated tourists that included references to archaeology. Eustace Reynolds-Ball's Cairo of To-Day, published by A. \& C. Black, cost 2 shillings and sixpence as opposed to Murray's 15 shilling volume. Reynolds-Ball was a popular and prolific guidebook writer. His Cairo, in its sixth edition by 1912, had a lengthy list of the latest publications on Egypt, including numerous works by male and female archaeologists. ${ }^{79}$ In addition his chapter on 'Recent Archaeological Research' discussed the work of Petrie, the Egypt Exploration Fund and the Egyptian Antiquities service in the excavation and conservation of Egypt's ancient monuments. Similarly, from 1907, African World issued a paperback guidebook called Fascinating Egypt (later including Sudan) for the price of one shilling; it was printed annually to coincide with Egypt's winter Season. Originally published with text in both English and French, its first edition had a print run of 50,000 copies. Archaeologists including Flinders Petrie and John Garstang contributed photographs and text to draw tourists to ancient sites, and to highlight the need for financial support for excavations. ${ }^{80}$

Guidebook production and tour operators were closely entwined. The most famous tour operator facilitating travel to these regions was Thomas Cook, who took his first tour group to Egypt and Palestine in $1869 .{ }^{81}$ The following year a Help-Book for Travellers to the East was issued, featuring Cook's as the provider of practical arrangements. ${ }^{82}$ From 1872 Up the Nile By Steam, a printed pamphlet with practical hints and tips, was issued including maps and details of individual stops en route..$^{83}$ By the 1880 s Cook \& Son had signed a 10-year contract to run Nile steamers (building its own fleet after war damage in the Sudan campaigns), and the winter Season in Egypt was a critical factor in the company's success in the region. In a bid to expand coverage to the Eastern Mediterranean and beyond, Cook's offices opened in Athens and Constantinople to facilitate tourist traffic to Greece and Asia Minor. ${ }^{84}$

In 1886 a young Wallis Budge, then an Assistant in the Department of Oriental Antiquities, made his first journey to Egypt to excavate tombs at Aswan and purchase antiquities for the British Museum. It was on Cook's steamer Prince Abbas that Budge first met Thomas Cook's son and 
partner John Cook. ${ }^{85}$ As Piers Brendon has shown, John Cook was particularly interested in Egypt. ${ }^{86}$ Budge claimed that it was on this trip that Cook asked him to write a guidebook for the main archaeological sites on the Nile as far south as Wadi Halfa at the Second Cataract, usually visited on a Cook's tour. His subsequent guide, The Nile: Notes for Travellers in Egypt, appeared in 1890.

The book was not placed on general sale. Instead it was specifically intended for Cook's passengers in order to enhance their interest in the sites and counter what Cook's determined was the lack of detailed information given to tourists by local dragomans. ${ }^{87}$ One such tourist, an American woman travelling on Cook's steamer S. S. Ramses, described how, on their departure up the Nile in December 1907:

The manager of the steamship company was at the boat to see us off, and presented each passenger with a permit for which the ordinary tourist pays a pound, and which secures the entrée to all the monuments of Egypt ... He also gave to each a copy of Dr Wallis Budge's book on Egypt, which contains chapters on both ancient and modern Egypt and answers many questions. ${ }^{88}$

The text charts sites as encountered on a voyage up the Nile, from Alexandria at the river's mouth to (by 1905) Khartoum. In addition, early editions of The Nile had included a chapter profiling 'Recent Excavations'. ${ }^{89}$ In its ninth edition (1905), The Nile had so many archaeological enhancements that the volume was over 800 pages long. In an attempt both to cater to his perception of Cook's tourists' interests in Egypt and to showcase his own knowledge, Budge kept the most fulsome descriptions for the ancient Egyptians, while truncating details of Egypt under 'foreign rulers'.$^{90}$ Acknowledging contemporary contexts, he added sections on the religious practices of Coptic Christianity and Islam, as well as chapters on 'Egypt under British Influence' and 'Progress in Egypt' during British administration. These additions were particularly relevant as Egypt and Britain joined together in the administration of Sudan; the establishment of the Anglo-Egyptian Condominium agreement in 1899 brought the region more firmly into the Egypt tourist's purview. ${ }^{91}$ Budge also revised Cook's Tourist's Handbook for Egypt and the Sudan, published the same year. ${ }^{92}$ Unlike his Nile, Budge's Handbook included the details of Cook's practical information for travellers, which Budge praised enthusiastically. ${ }^{93}$

Cook's has also been credited with opening Palestine to Western tourists during this time, issuing a Tourist's Handbook to Palestine and 
Syria in 1876 , with a second edition in $1886 .{ }^{94}$ Just over a decade later John Cook and his son Frank brought Kaiser Wilhelm and his retinue to the Holy Land in a heavily publicised and extremely expensive 'pilgrimage', ensuring Cook's supremacy over European tourism in Palestine. ${ }^{95}$ A new, revised edition of Cook's Handbook was issued in 1907; one of its editors was the physician and Palestine Exploration Fund secretary Ernest Masterman. A special section on 'Palestine Exploration' in the introductory information to the 1907 Cook's Handbook highlighted the Fund's explorers and excavations in the region. ${ }^{96}$

Macmillan \& Co began publishing its own guidebooks to the Eastern Mediterranean and Middle East at the turn of the twentieth century; the first editions of its 'Guides' to Palestine and Egypt, Italy, Eastern Mediterranean and Western Mediterranean were issued between 1901 and 1903. ${ }^{97}$ In 1905 separate Guides were published for Palestine and Syria and Egypt and the Sudan. Three years later the Guide to the Eastern Mediterranean had become Guide to Greece, the Archipelago, Constantinople, the Coasts of Asia Minor, Crete and Cyprus. George Macmillan's position as Secretary to the British School at Athens enabled him to secure the services of several archaeologists linked to the BSA to bring this book up to date: D. G. Hogarth, Arthur Evans and Ernest Gardner, as well as Ernest Gardner's wife Mary. Each was responsible for revising or rewriting sections, transforming Guide to the Eastern Mediterranean into Guide to Greece. ${ }^{98}$ Macmillan \& Co hoped to set their guidebooks apart in what had become a moderately saturated market by decreasing their weight and price. As the publisher observed, 'Modern guidebooks have grown so large, that to use them with intelligence and advantage ... requires more time than the average traveller has at his disposal. 99

The relationship of archaeology to tourism and travel was also based on a cycle of journeying from Britain to the East and back again - a cycle replicated on a broader scale in the phenomenon of the winter 'Season'. ${ }^{100}$ As John Pemble noted in his history of Victorian and Edwardian travel, 'the superior classes were travelling classes'. ${ }^{101}$ The author Douglas Sladen claimed that 'to winter in Egypt is to winter in Paradise'. ${ }^{102}$ A number of people followed this seasonal pattern, spending summers in England and winters abroad. Murray's 1900 Handbook to Egypt referred to the Europeans in the country as a 'floating population'; scholars have noted 11,000 tourists to Cairo for the 1889-90 season, and by 1900 there were an estimated 50,000 tourists in Egypt. ${ }^{103}$ ReynoldsBall dated the evolution of 'Social Cairo' to the opening of the Suez Canal in 1869 and declared that those staying in the city's chief hotels created 
a formidable group of their own; outside of the 'official' British community, they were a potent driving force in social life. ${ }^{104}$ These elite visitors were joined by health tourists as well as 'a leaven of artists, literary people, Egyptologists, students, etc.' ${ }^{105}$

Eventually Cook's expanded tours into Sudan as far as Khartoum, which by 1912 had its own winter social season. ${ }^{106}$ The Egyptian Gazette, a daily English-language paper published in Alexandria, regularly listed prominent guests in Egyptian hotels during the season and announced passengers on Cook's steamers. ${ }^{107}$ Other destinations were not quite as popular as Egypt, which Pemble considers one of the dominant Mediterranean tourist destinations in the Victorian and Edwardian eras. However, as Gunning has shown, the British consular community in the Eastern Mediterranean and Asia Minor had a long-standing public and private relationship with key excavators, facilitating the exploration of sites and acquisition of artefacts. ${ }^{108}$ In tourism terms, Pemble argues that both Greece and Palestine grew in popularity, particularly for 'culture' (in the case of Greece) and 'pilgrimage' in the case of Palestine. ${ }^{109}$ The physical presence of British Schools in Athens, Rome and - after the First World War - in Jerusalem facilitated an international scholarly-diplomatictraveller nexus, with other nations' Schools, staff and students close at hand for working collaborations and socialising. ${ }^{110}$

There was also an established expat community living in Egypt in the late nineteenth century. The 1900 Whitaker's Almanack gives a figure of 6,116 English people living in Egypt in 1882, the year that Britain occupied Egypt. By 1897 this number had increased to 14,000 British civilians and 5,000 soldiers, and by 1907 to 21,000. ${ }^{111}$ These long-standing communities developed a 'hybrid' Anglo-Egyptian identity. In his first memoir, A Wandering Scholar in the Levant, the archaeologist David George Hogarth recorded a European maxim: 'Stay in Egypt seven years at a stretch and become an Egyptian.' ${ }^{112}$ On arrival in a major capital city such as Athens, Cairo or Jerusalem, archaeologists were enmeshed in the social scene of expatriate life. They spent time in these capitals at the start and end of an excavation to organise official permissions, gather supplies, meet friends, visit collections and witness the division of objects. ${ }^{113}$

In Seventy Years in Archaeology, Petrie describes the significance of some of these British expats - Professor Sheldon Amos, legal advisor to the Egyptian government, and his wife Sarah Bunting Amos, a women's rights campaigner; Dr James Grant ('Grant Bey'), the Khedive's physician, and Florence Sabina Gibson Grant. He acknowledges their importance in shaping his experience of Cairo during his initial years of travelling in the 
city. Through them he also met other important British Cairenes. The British official Ronald Storrs similarly captures expat life and archaeological interests in Egypt and Palestine in his memoir Orientations. ${ }^{114}$

What was true of Cairo also applied to other cities and towns in Egypt - Alexandria, for instance, and, on a smaller scale, to Luxor and Saqqara. ${ }^{115}$ Most archaeological travel roughly coincided with the seasonal pattern of tourism, but Antiquities Inspectors and Directors of the British Schools abroad were essentially foreign residents. However, there was in most cases one key difference - expense. Ellen Sophia Bosanquet, who married BSA Assistant Director Robert Carr Bosanquet in 1902, recorded that archaeological travel meant keeping costs down and travelling as rapidly as possible, while ensuring the route included visits to sites and museums of interest. ${ }^{116}$

After the end of the First World War, interest in archaeological tourism was re-energised with the discovery of Tutankhamun's tomb in Egypt in the early 1920s (to which Cook's ferried tourists in hordes) and the new emphasis in 'heritage' tourism to Palestine, Transjordan and Iraq. ${ }^{117}$ In the 1920 s these latter countries were in essence governed by Britain with the authority of a League of Nations Mandate agreement, and cultural (archaeological) tourism was one element of the Mandate government's stewardship agenda. ${ }^{118}$

The 1924 and 1925 British Empire Exhibitions at Wembley included a Palestine Pavilion where British audiences could view Palestine with a new, more imperial gloss. The Palestine Pavilion Committee's related handbook included information on tourist destinations and archaeological sites. ${ }^{119}$ The following year, delegates from the international archaeological community were made welcome by both the British and French administrations for a 1926 International Archaeological Congress-sponsored tour through Syria, Palestine and Transjordan. ${ }^{120}$ This well publicised event, with a provisional programme published in The Times, was intended to jump-start international exploration in the region and to develop subsequent knock-on effects for tourism (despite the still ongoing issues of 'security'). Scottish travel writer Norah RowanHamilton, whose obsession with visiting Petra saw her talk her way onto this archaeologist-only tour, recorded her experiences of seeing the Holy Land with special archaeological access in her 1928 travelogue Both Sides of the Jordan. Reviews of the work praised the value of Hamilton's observations because she benefited from, and passed on to her readers, the privileges afforded to the archaeologists and their families on tour. ${ }^{121}$

The Palestine Mandate government's own guidebook/manual The Handbook of Palestine emerged from wartime and immediate post-war 
guides to the antiquities of Palestine. The guides had been developed for soldiers and administrators overseeing affairs during the British military occupation of the region following the British 'capture' of Jerusalem in December 1917. The Handbook, published in 1922, later became The Handbook of Palestine and Transjordan. It included the information deemed necessary for the cohort of British administrative officials, staff and their families who settled in Palestine and Transjordan in the 1920s and 1930s. Like other guidebooks, it included a section on archaeological research and antiquities provided by Antiquities Department archaeologists. ${ }^{122}$

Cook's Traveller's Handbook for Palestine and Syria (which also included Iraq), published in 1924, reflected Palestine's change in governance. Renewed excavations began in Palestine from the early 1920s and John Garstang, then Director of the British School of Archaeology in Jerusalem and Director of the Palestine Department of Antiquities Service, contributed an 'Archaeological Appendix' for the Cook's Handbook. The 1934 edition featured the Palestine Exploration Fund's new map of excavated sites in Palestine. ${ }^{123}$ The map was the manifestation of the Fund's aims to improve the visibility of its work through a closer alliance with tourism. ${ }^{124}$

A new series of high-profile excavations also began or were resumed in Iraq, under a British Mandate administration until 1932. These became part of tourists' itineraries, and archaeologists hoped to capture the attention of this new market. ${ }^{125}$ Reginald Campbell Thompson, an archaeologist and former assistant in Budge's Department of Egyptian and Assyrian Antiquities, compiled a pocket-sized guidebook to the country's antiquities and sites for troops stationed in Iraq during the war. Another guidebook followed in 1926, this time by Dorothy Mackay, wife of the British excavator Ernest Mackay; the couple were then working at the site of Kish, south of Baghdad and near Babylon. Both guidebooks were locally published. ${ }^{126}$

\section{Returning home}

At 'home' in Britain, from the nineteenth century onwards, conversaziones, lectures, exhibitions of artefacts, periodicals and books were the bread and butter of archaeological publicity. Through text, objects and images, they brought interested audiences face to face with the past. Complementing these narratives were artwork and lantern-slides, an early form of archaeological projection, emphasising both the exoticism 
and the science of research. In the early twentieth century the emerging technologies of cinema and radio expanded the opportunities for archaeologists to project their disciplinary identity in conjunction with and beyond the printed page. In the 1920s and 1930s excavation films made on site were brought back to Britain, to be shown alongside the traditional lecture and slide presentations. The adventurous lifestyles of British archaeologists overseas were thus transported to people at 'home' via a dynamic new medium. ${ }^{127}$

The development of radio technology provided another important venue for promoting and projecting archaeology and archaeological experiences. The creation of the British Broadcasting Company (later British Broadcasting Corporation) in the 1920s facilitated a raft of educational radio programming. ${ }^{128}$ With transmitted sound came new scope for communicating directly to (eventually) millions of listeners across the country and the world, and archaeologists were among the early speakers featured. Flinders Petrie's wife and co-excavator Hilda Petrie and one of Petrie's many students, Arthur Weigall, as well as Stanley Casson and Leonard Woolley - by then an experienced excavator - all gave educational radio talks for adults in London. Some of these were simultaneously broadcast to other major cities in Britain in the mid-late 1920s. ${ }^{129}$ Their talks synthesised research and publicised their discoveries, reinforcing a key message of the archaeologist as a cross-cultural and international communicator.

These broadcasting activities fed back into publishing. The BBC began issuing its weekly magazine The Listener in January 1929 to provide printed material that both supplemented and complemented the radio talks it broadcasted. This new venture did not please everyone. The BBC's 1930 annual report noted opposition to The Listener from newspaper and print publishers, who felt that the BBC was encroaching into their territory and undercutting the market for educational works. ${ }^{130}$ Stanley Casson waded into the debate in support of The Listener, arguing that the periodical would enable ephemeral radio broadcasts to be permanently recorded. ${ }^{131}$ He had already benefited from the BBC's new platform, having given a talk in 1927 on his excavations of the Hippodrome in Constantinople. ${ }^{132}$

Despite the opposition The Listener first appeared on 16 January 1929. ${ }^{133}$ It offered archaeologists publicity both for their broadcasts and their books in separate sections of the magazine. In 'The Listener's Choice for Next Week', programmes of interest for the coming week were selected, and some given brief explanatory descriptions. Related illustrations complementing particular talks were also included in this 
section. Individual radio talks became two- to three-page illustrated articles; written by the presenter, they included a reference to the original broadcast date. The articles occasionally drew attention to relevant publications, while another section, 'The Listener's Book Chronicle', also featured reviews of relevant works.

Stanley Casson was the first archaeologist to be featured in The Listener; his six-part survey series 'New Light on Ancient Greece' examined the history of research and recent discoveries. Covering the sites of Sparta, Troy, Delphi, Mycenae, Corinth and Olympia, it ran between early March and early April 1929. Each 'episode' in Casson's series was selected as a 'Choice of Next Week' and in the following issue featured as a full illustrated article complete with newsy, eye-catching title - his Corinth broadcast, for instance, became a piece titled 'The New York of the Ancient World'. ${ }^{134}$ These articles tied in with archaeologists' other publicity activities. Leonard Woolley began a fruitful relationship with BBC radio in 1924, with two broadcasts in July 1924 on archaeology and excavations in Babylonia. The following month he gave a broadcast on the first season of his excavations at Ur, a now-famous archaeological site south of Baghdad. The objects uncovered were at that point still on display at the British Museum in the first of a series of exhibitions organised to publicise the work. ${ }^{135}$

For the next four years Woolley delivered a radio broadcast every summer as the annual exhibition of his finds was ongoing at the British Museum. Essentially he was building a regular slot for publicising his activities and establishing himself as a BBC radio regular. In 1929 he gave two broadcasts in August and September; the first, 'The Royal Tombs and the Flood', enticed audiences with tales of the spectacular golden treasure in the royal burials or 'death pits' at Ur, then still on display at the British Museum. ${ }^{136}$ The tombs were built on top of a deep layer of mud, which Woolley claimed was evidence of a great flood as recounted in the biblical story of Noah and the Ark. ${ }^{137}$ His second broadcast laid out his plans for the next season at Ur. A few months later, Ernest Benn published Woolley's Ur of the Chaldees, the summary of seven seasons' work at the site, and Woolley was mentioned along with other key experts and cultural figures who had given talks in the BBC's annual report. ${ }^{138}$

In 1930 Woolley's successful publicity cycle continued. The objects from Ur were exhibited in July; among the displays was a skeleton said to be of the same age as biblical Noah. ${ }^{139}$ Another review noted the care Woolley took to explain the methods and practices of archaeology in the context of the display, using a sectional drawing of archaeological stratification to emphasise that excavation exposed the layering of historical 


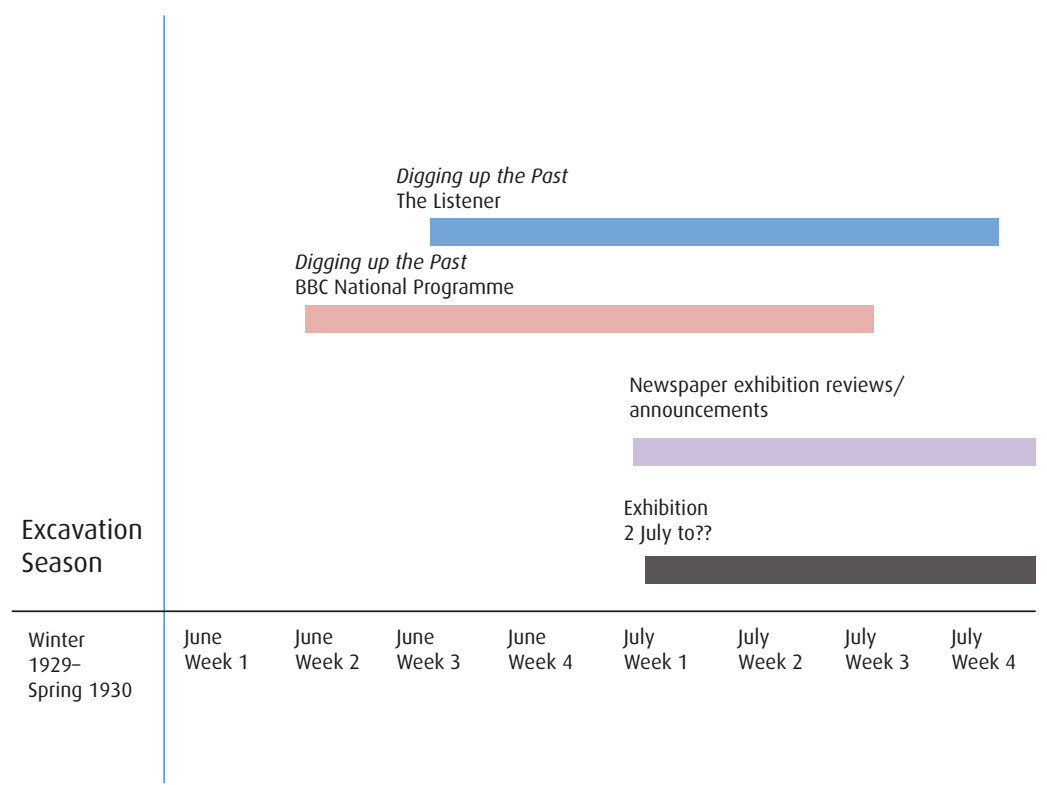

Fig. 2.5 Diagram showing the cycle of publicity for Leonard Woolley's 1929-30 excavations. (Copyright the author)

levels. Short catalogues, costing sixpence, were produced to help illuminate these displays for visitors. Woolley's 1930 catalogue included a reproduction of the sectional drawing as an illustration. The objects on display were explained by reference to this drawing, section by section. ${ }^{140}$ At the same time Woolley was giving a six-part series of talks about archaeology entitled 'Digging up the Past', in which he outlined the practices and processes of archaeology; these were subsequently published in weekly instalments in The Listener (Fig. 2.5). By drawing mainly on excavations outside of Britain, reflecting in detail on his own experiences, Woolley focused audiences' attention on the travel associated with archaeology as well as its place as a subject of scientific study; he defined its practices and methods and identified the characteristics of its chief practitioners. His book of the same title was based on these broadcasts; Ernest Benn published it in November 1930. ${ }^{141}$

\section{Looking back}

The archaeologists who began their researches in the 1880s and 1890s were the basis for popular archaeology histories of the 1920s and 
1930s. These later decades were a time of increasing memoir-isation and memorialisation, through which archaeologists constructed a more distinct identity for the discipline and its practitioners. Archaeologists' travelogues and memoirs of archaeological work had previously generally been published as what Debbie Challis has called 'travel journals', charting recently completed journeys and excavations. ${ }^{142}$ As the first generation of 'scientific' (trained) archaeologists approached middle to old age, however, they began to look back on their experiences and to record them in print for posterity as the reflection of a period of great evolution in which the discipline was transformed and formally constructed.

When Flinders Petrie reached his 50th anniversary of life in archaeology in 1930, it was duly celebrated as a momentous occasion. A programme of events included a fundraising performance to an audience of 1,400 people at the Hippodrome Theatre in London. Samson Low published his autobiography, Seventy Years in Archaeology, the following year. ${ }^{143}$ Recounting his own contributions to the field, Wallis Budge published a two-volume memoir, By Nile and Tigris, with John Murray in 1920. In 1923 Macmillan published Archibald Henry Sayce's wideranging Reminiscences, in which the author detailed his extensive network of contacts in scholarly and political circles that stretched across Britain, the Continent and the Middle East. Percy Gardner likewise published his Autobiographica with Oxford publisher Basil Blackwell in 1933, recording his contributions to the discipline and the influence that he had had on younger generations of archaeologists. Arthur Weigall's 1933 memoir mentioned in the previous chapter, Laura Was My Camel, featured highlights of his life as an Antiquities Inspector in Egypt, and archaeological artist Annie Quibell's Wayfarer in Egypt was both a memoir and a travel guide.

Archaeologists also produced reflections on the progress of archaeology and the evolution of the field. With the highly publicised excavation of Tutankhamun's tomb in the early 1920s as a flash point, they strove to capture the heightened public interest by providing a solid yet adventurous foundation of scientific pursuit out of which could flower further excavation work in future. Budge's The Rise and Progress of Assyriology, published by Martin Hopkinson in 1925, emphasised the critical leading role of the British Museum in the discipline's formation and gave potted biographies of key archaeologists in the field. Former Palestine Exploration Fund excavator Robert A. S. Macalister's Century of Excavations in Palestine (Religious Tract Society, 1925) charted the Fund's history of excavation in the region. The author also introduced some of the key methods of 'scientific' excavation, examining the connection 
between archaeology and topography and political and cultural history. Another archaeologist, Reginald Campbell Thompson, used past triumphs as a marketing tool. He and his assistant Richard Hutchinson published A Century of Exploration at Nineveh in 1929 to captivate interest in (and attract funding for) the recently renewed excavations at the site. ${ }^{144}$

The archaeologist as traveller had now become one of the most visible characteristics of the discipline. At the end of the Edwardian era Arthur Weigall commented on the transformation of the archaeologist from antiquarian scholar to adventurous explorer. In 1911 he noted that:

...the archaeologist is generally considered to be a kind of ragand-bone man; one who, sitting all his life in a dusty room, shuns the touch of the wind and takes no pleasure in the vanities under the sun. ... The ease with which long journeys are now undertaken ... [has] made it possible for the archaeologist to seek his information at its source .... ${ }^{145}$

Weigall, a former student of Flinders Petrie, was at that point one of three British Inspectors in the Egyptian Antiquities Service. His comments were made in the closing chapter of another of his books, The Treasury of Ancient Egypt. Entitled 'Archaeology in the Open', the chapter offers pointed argument against what Weigall deemed to be the prevailing image of the archaeologist-as-antiquary, a dust-covered hermit entombed in a library or museum surrounded by paper. In Weigall's opinion, travel had irrevocably changed archaeology. It heralded the era of the new archaeologist a virile young 'Anglo-Saxon' go-getter, ready to take on and surmount any intellectual or physical problem. He takes the argument even further by implying archaeology could be a route through which fears about the weakening of British masculinity, so potent after the Boer War and with escalating suffrage campaigns, might be addressed. ${ }^{146}$ Significantly, this chapter was reproduced almost word for word as the first chapter of Weigall's The Glory of the Pharaohs, first published over a decade later in 1923 as Tut-mania was growing and reissued in a cheaper edition in the mid-1930s. A canny title change to 'Egyptology in the Open' referenced the popular interest in the archaeology of ancient Egypt. Popular works by archaeologists such as Leonard Woolley published in this interwar period echoed Weigall's sentiments and reinforced the connections between archaeology, travel, exploration and (masculine) adventure.

The formalisation of archaeological education and training and improvements in travel in the late nineteenth century were intimately 
connected. These two developments have a lasting legacy on the ways in which the archaeological identity evolved. The educational structures for archaeology caused and enabled intra-continental movement as experience in the field became associated with excavations overseas. The men and women involved in archaeology during this period travelled extensively. They recorded their work and lives abroad in popular books aimed at those readers most likely to support their work financially and through engagement in lectures, exhibitions, broadcasts, classes or volunteering. They took advantage of imperial expansion and social structures and cycles to become visible both at home and abroad. By catering to audiences in Britain and in the various foreign or imperial capitals that were centres for British expat and tourist society, they cultivated an international readership. The archaeological identity therefore became intimately associated with international work and exploration: learning new languages, gaining new cultural experiences, infiltrating with spade, camera and pencil into 'remote' regions and distant pasts, and translating these experiences through scripting spadework in print, in radio and in the physical recreation of an exhibition space or lecture hall to educate British audiences about ancient histories and the modern 'science' of archaeology. 


\section{3 \\ The Women Who Did}

The students gave me a bad time; they were rough and rude and they smelt. ... in the end we became great friends ... ${ }^{1}$

Mary Brodrick's life in archaeology is charted in a slim volume called Egypt. ${ }^{2}$ Published in 1937, it is a compilation of her lectures, papers and biographical and autobiographical notes. The daughter of a solicitor who described herself as 'a gregarious wanderer and lover of men and things', Brodrick's interest in ancient Egypt began in childhood with the gift of a book - a history of Egypt in French. ${ }^{3}$ In the late 1880s she built up a reputation for herself as an expert in Egyptology through her lectures at the British Museum, and in 1892 began attending lectures in archaeology at University College London. She was among many women students attending the College, and in the years that followed she and several of her classmates would have a wide-ranging impact in archaeology. They were the 'women who did' - celebrated in the title of this chapter, which references Grant Allen's novel of 1895. This was the age of the 'real New Woman', a time when opportunities - educational, professional, personal - flowered amid a backlash against these developments, from men and women alike. These were promoted in the pages of periodicals for women and girls, and listed in the pages of The Englishwoman's YearBook and Directory. ${ }^{4}$

This chapter charts the evolution of women in archaeology during a critical period over which women fought for, and eventually won, greater political representation and professional and personal opportunities. It examines the ways in which these archaeological women developed a public and commercial expertise through taking part in a broader movement of 'lady guides' and lecturing in the 1880s and 1890s. ${ }^{5}$ Publishers facilitated the promotion of this expertise through women's writing, which in some cases was specifically designed for a female 
audience. The women carved out a niche for themselves outside the salaried or official positions of their male counterparts, and largely outside what Sheppard has called 'the domestic space' of university lectures. ${ }^{6}$

Of course, there were women who came before. ${ }^{7}$ One of those women was Sophia Lane Poole, who died in 1891. Poole's letters from residence in Egypt had been published in the 1840s as The Englishwoman in Egypt: Letters from Cairo. Credited with being a pioneering travel writer of Egypt, Poole was noted at her death particularly for her observations on the life of Egyptian women and her status as their 'privileged friend'. ${ }^{8}$ In the 1860s she and her son Reginald Stuart Poole, later the Yates Professor at UCL and a key member of the Egypt Exploration Fund's Committee, provided descriptions for a series of the photographer Francis Frith's 'views' of sites and activities in Egypt, Palestine and Sinai, available in sets of three for 10 shillings. ${ }^{9}$ Presumably both drew on their own experience of seven years living and travelling in Egypt to contribute context for the photographs.

In 1892 Amelia Edwards died. She was a celebrated writer and traveller by the time she took her first trip to Egypt in 1873, in the company of her friend Lucy Renshaw. One of the main results of their trip was her travelogue A Thousand Miles Up the Nile. Published in 1877 to positive reviews, it was eventually reprinted many times. A. L. Burt's 1888 American edition included it as one of 'Burt's Library of the World's Best Books. ${ }^{10}$ Fifty years later, in the 1930s, it was still being mentioned in travel publicity. For example, Imperial Airways passenger pamphlets for the Empire Flying Boats' Africa service directly referenced $A$ Thousand Miles up the Nile in the text accompanying the outbound Alexandria to Khartoum route. ${ }^{11}$ The other significant result of Edwards' trip was her role in establishing an organisation key to driving British archaeological interest in Egypt: the Egypt Exploration Fund. The EEF was critical to archaeology - not only for its work in conserving, excavating and publishing research on Egypt's monuments and artefacts, but also, significantly, as the means by which several of the early Archaeology and Egyptology students at UCL made a name for themselves through lecturing and publishing.

Edwards' efforts began in 1880 when she approached Reginald Stuart Poole and Samuel Birch, among others, about the possibility of setting up a subscription fund for supporting excavations in Egypt. ${ }^{12}$ Formally established in 1882, she campaigned, lectured and fundraised on behalf of the Fund both in Britain and in the United States over the next decade. Her second book on explorations in Egypt, Pharaohs, Fellahs and Explorers, was published in 1891; it featured the work of one of the 
Fund's star archaeologists, Flinders Petrie. When Edwards died in 1892, she left a bequest establishing a Chair in Egyptian archaeology at UCL a position implicitly designed for Flinders Petrie and to which he was duly appointed. Clause B of Edwards' will made clear that her bequest to UCL was contingent on the College fulfilling (among other specificities) her desire to ensure gender equality would be promoted in Egyptology studies:

the bequest to U. C. is subject to the following conditions wh shall be provided for - in such rules + regulations as aforesaid...(b) that the classes, scholarships, + exhibitions - if any - be open to students of both sexes. ${ }^{13}$

\section{Perambulating lady lecturers}

In 1892 Reginald Stuart Poole was in his last years as Yates Professor of Classical Archaeology. His course included Egyptian subjects, and alongside Mary Brodrick, mentioned above, were Anna Anderson Morton, Helen Beloe Tirard and Emily Paterson (later EEF Secretary and promoter of Fund interests in Britain). ${ }^{14}$ Each of them would have a significant role in promoting archaeology and particularly the study of ancient Egypt. ${ }^{15}$ Although she had entered UCL as a student in 1889, Helen Tirard was by that point already an experienced lecturer in Egyptology. ${ }^{16}$ A vicar's daughter from Suffolk, she joined the British Museum's Reading Room in 1883. Two years later she began lecturing on 'Ancient Egypt' at the British Museum, using illustrative materials to enhance her presentation as well as leading a tour through the antiquities on display, moving through the museum. ${ }^{17}$ She aimed her course particularly at 'ladies', thus building a female audience for her expertise. Her students paid for the course, and Tirard donated her proceeds to the Egypt Exploration Fund, raising $£ 10$ for the Fund in the first year. ${ }^{18}$

These lectures continued for several years, and were advertised in periodicals targeted towards the literary and scientific elite such as the Academy and the Athenaeum, as well as ordinary newspapers and women's periodicals. In 1887 Tirard's new course, entitled 'Life in Ancient Egypt - at Home - at Work - at Play', suggests that she sought to connect directly to her audience using concepts that would have been familiar to them. ${ }^{19}$

The following year Tirard expanded her offer to students: two courses and a formal syllabus on Ancient Egypt. In addition, the Academy 
noted, her lectures would be enhanced by her own direct observations of excavations following a visit to Egypt earlier in the year. ${ }^{20}$ Tirard began lecturing during the week at the King's College Ladies Department in 1889. Although this institution was based in Kensington, the course still included tours at the British Museum - a way for her to maximise and publicise the benefit of maintaining a link to the collections and expertise there. ${ }^{21}$

At this point Mary Brodrick began lecturing at the British Museum on Saturdays. Having trained with Gaston Maspero and other French Egyptologists at the Sorbonne, she became an 'occasional student' at the British Museum, receiving further training with Egyptian Antiquities Keeper Philip LePage Renouf. In 1888 Brodrick was accepted to College Hall, the only residence for women university students in London..$^{22}$ Established in the early 1880s, College Hall fostered an international community of students embarking on courses mainly at University College London and the London School of Medicine for Women. It gave women a separate space outside their family homes within which they could develop their own social and scholarly networks. ${ }^{23}$ Brodrick received very little family support to pay for her residence at College Hall; the British Museum lectures provided her with much needed income and enabled her to remain based there. The Hall also served as her professional address where tickets for her lectures could be purchased. Like Helen Tirard, Mary Brodrick charged for her course on 'Ancient Egyptian History and Antiquities', asking 21 shillings for the series and 4 shillings for a single lecture. Unlike Tirard's lectures, Brodrick's were open to both men and women (though predominately attended by women), and were aimed particularly at those who had spent or anticipated spending time in Egypt.

The visibility of these women was increasing in the press. In November the Sheffield Daily Telegraph's 'Lady Correspondent' highlighted the number of women writing and lecturing about Egypt, mentioning Tirard and Brodrick's efforts specifically. Brodrick, an open supporter of women's education, was clearly interested not only in the history of ancient Egypt, but particularly in women's experience in the ancient world. The 'Lady Correspondent' noted Brodrick's conclusion: that women's rights campaigns were unnecessary in ancient Egypt because laws relating to marriage, divorce and other issues favoured them. ${ }^{24}$

By the time Kegan Paul published Helen Tirard's (guide)book Sketches from a Nile Steamer in 1891, she was, according to the Athenaeum, a noted lecturer. ${ }^{25}$ Her Preface explains her qualifications - 'some years of 
study in the British Museum' - and her role as a teacher who had 'help[ed] many students ... to realize the interest of the study of Egyptology'. At 275 pages it was a slightly more compact and more female-oriented alternative to Budge's Nile. The first sentences of Tirard's first chapter address 'ladies', offering advice on an appropriate wardrobe for a Nile cruise. ${ }^{26}$ Thereafter, in the guise of her own diary, she formed the text as a narrative of her own experience as a tourist on the Cook's steamer Ramses, giving dates and times for arriving at sites and noting that the number of women on board was double that of men. A long folding map of the Nile was bound in to the back of the book for easy reference.

Readers could follow Tirard on and off board, wandering through or passing by archaeological sites that were explained or described with added contextual information, including short definitions of basic terms such as hieroglyphics and stelae. Tirard also noted the crafts and activities of the Egyptians in their villages, introducing readers to modern transliterated Egyptian terms such as 'goolahs' (water pots). Her narrative incorporates reflections on modern and ancient Egyptian women. A drawing of a girl carrying a water jar on her head at Thebes gave readers a glimpse of modern Egypt. On reaching Queen Hatshepsut's temple at Deir el Bahri, readers were told about 'the wonderful woman of her time' who dressed in men's clothes, commanded an army, funded exploration and commemorated herself 'with a daring spirit of innovation'. ${ }^{27}$

Tirard continued giving lecture courses at King's College Ladies Department in the 1890s, expanding her repertoire into Egyptian religious life and death practices and in particular the Book of the Dead. By 1894 the institution was advertising courses with Tirard and the classicist Jane Harrison that were aimed at women aged 16 and over. Her student Jessie Stewart noted the popularity of her 'perambulating lectures' at the British Museum, and so inspired the subtitle for this part of Chapter $3 .^{28}$ The substance of these 'Book of the Dead' lectures later appeared as a book in 1910. Swiss Egyptologist Edouard Naville, who had been one of the EEF's excavators, provided an introduction for the book. He praised her 'profound knowledge' and ability to present the complexities of ancient Egyptian religious life and ceremonies clearly as the product of extensive study, but rather dismissively characterised her as 'not an Egyptologist by profession'. ${ }^{29}$

Mary Brodrick increased her intellectual influence as well, publishing in 1891 through John Murray a condensed and edited English translation of the German Egyptologist Heinrich Brugsch's Geschichte Aegypten's unter den Pharaonen, which had first appeared in 1877 . In order to produce 'a cheaper and more convenient' edition 
of a book highly esteemed by the public, Murray engaged Mary Brodrick to make Brugsch's original work reflect 'the most recent discoveries in Egyptological science'. ${ }^{30}$ She also added sections on recent excavations to ensure the work included the most up-to-date discoveries. Brodrick's correspondence with John Murray during this time reveals the pressure she was under to complete the work in amongst her lecturing, which, along with other work, contributed to her income. ${ }^{31}$ She initially was offered $£ 50$ from Murray's for the book, published as Egypt under the pharaohs. ${ }^{32}$ The John Murray archive also indicates the number of copies of Brodrick's Brugsch acquired in the first year of publication: of the 1,500 produced, 973 were sold and another 49 presented..$^{33}$

Shortly after submitting the manuscript of Egypt under the pharaohs, Mary Brodrick began contributing revisions to the eighth edition of Murray's Handbook to Egypt. Her correspondence in the John Murray archive indicates that she was asked to look over the text generally rather than taking on a detailed revision, as J. C. Chapman was officially editing the Handbook. Brodrick had been in Egypt the year before on a trip down the Nile. Her recent experience there led her to suggest a few practical amendments to the text, including a change of proprietor at the d'Angleterre Hotel (popular with English tourists) and the restriction of dahabiya travel (a form of houseboat used on the Nile) above the First Cataract at Aswan. ${ }^{34}$ She also recommended that Murray's add the services of Henry Gaze, a competitor of Cook's, to the information given. ${ }^{35}$ Brodrick applied her Egyptological knowledge in assessing site plans and cartouche illustrations and sought to confirm the latest archaeological identifications. ${ }^{36}$ Her amendments turned out to be more extensive than initially expected, and she was offered 100 guineas for her work on the Brugsch translation and the Handbook, representing about 10 months work in total. ${ }^{37}$

Brodrick subsequently began work on another edited translation this time of French Egyptologist Auguste Mariette's 1867 work, Aperçu de l'histoire ancienne egypte. As she stated in her Preface, this was a book that she routinely recommended for those interested in learning about ancient Egypt. ${ }^{38}$ Outlines of Ancient Egyptian History, Brodrick's English translation of this important general text, had international appeal. William Copley Winslow, the secretary of the American branch of the Egypt Exploration Fund, was eager to see it in an American edition. Winslow's enthusiasm rendered Brodrick more visible specifically as a female scholar when he requested that, rather than the usual 'M. Brodrick', her full name be included on the frontispiece in order that her gender be clearly acknowledged and 'recognised'. And so it 
was; when Charles Scribner's edition of the work was published, 'Mary Brodrick' appeared on the title page. ${ }^{39}$ Despite this international publicity coup, Brodrick's work and expertise were called into question, particularly the decisions she made in the translation that varied at points with other editions available. Brodrick stubbornly stuck by her work, drafting a letter in response to her critics and referring Murray to letters of approval sent by Mariette's daughter Sophie and her former tutor Gaston Maspero. ${ }^{40}$

Regardless of such criticisms, the American edition of Outlines contributed to Brodrick's increasing visibility there. During the production process she was named the Egypt Exploration Fund American branch's Honorary Secretary. ${ }^{41}$ Within a year the University of Kansas granted her a PhD degree, as she put it, 'on the strength of Brugsch + the Outlines .... ${ }^{42}$ Her association with Murray was also benefiting Brodrick professionally in England: she used a letter of recommendation from John Murray to enhance her appeal for attracting lecturing jobs. ${ }^{43}$

She retained an interest in Murray's Handbook to Egypt, and her editing of the ninth and tenth editions is discussed in detail in Chapter 6 . Enabling access to Egypt was in the forefront of Brodrick's mind; in 1893 she submitted a manuscript to Murray for a short, inexpensive book of 'useful hints for those going to Egypt', which outlined some basic travel logistics - updated railway ticket prices, projected expenses of travel, telegram and postal information. She believed such a book would be valuable to those travellers who might not want to invest 18 shillings in a Murray's guidebook..$^{44}$ Her professional relationship with John Murray was also growing - it is clear that she became a reader of submitted manuscripts for the firm as well as providing information to contribute to the Handbook. ${ }^{45}$ Four years later, ordered to spend the winter in a warmer climate, she and her colleague Anna Anderson Morton planned to conduct a party of women to Egypt. In a telling demonstration of her personal relationship with the firm, a circular advertising for 'A Winter on the Nile in a Dahabiyeh' with 'Miss BRODRICK, Ph.D', laying out Brodrick's full credentials, was sent to Mr Murray for further distribution to interested people of his acquaintance. ${ }^{46}$ She and Morton repeated this tour several times.

The tours were a way for Brodrick both to reinforce her own expertise and to draw on the authority of the Murray name to sell through personal networks her own brand of archaeological expertise to female audiences. Brodrick's Handbook for Murray was listed in the 1899 Englishwoman's Year-Book as one of the 'Works of Women Writers, Published 1898', a list dependent on publishers giving information to 
the Year-Book editors. ${ }^{47}$ In 1902 Brodrick's desire to produce a low-cost text came to fruition, but not with Murray. ${ }^{48}$ Methuen \& Co published Brodrick and Morton's A Concise Dictionary of Egyptian Archaeology, priced at 3 shillings and sixpence. Catering to students and tourists, they drew on the experiences of these tours to shape the work. ${ }^{49}$

While Tirard and Brodrick were publishing and lecturing on Egypt, other women were becoming known for lectures on classical archaeology. Jane Harrison, her near-contemporary Eugénie Sellers and her student Maria Millington Lathbury were named as a triumvirate of knowledgeable women in the field. ${ }^{50}$ Harrison began lecturing at the British Museum in the early 1880s, publishing in 1882 her first book, Myths of the Odyssey in Art and Literature, in which she promoted the value of archaeology to the study of Greek myths. Three years later came Introductory Studies in Greek Art, which drew on several years' worth of her British Museum lectures. At this time Harrison was also one of the candidates for the Yates Professorship at UCL, but she was not ultimately selected for the position. Her lecturing expanded to the South Kensington Museum (now the Victoria \& Albert Museum), where her talks were illuminated with electric lantern slide photographs. She also visited Greece and saw archaeological excavations there at first hand. ${ }^{51}$

With this new, personal experience of the country and its archaeology Harrison continued to publish, producing, like Mary Brodrick, edited and enhanced translations of art historical works. Pierre Paris's A Manual of Ancient Sculpture, in which she credited Mary Brodrick for help with Egyptian material, and Maxime Collignon's Manual of Mythology in relation to Greek Art through H. Grevel \& Co were both published in 1890. Such works demonstrate the power of translation for increasing women's public presence.

The following year, an article interviewing Harrison about the then-current debate on retaining ancient Greek studies at university level was published in the Pall Mall Gazette. It provides both a literal image of Harrison herself (an illustration from a photograph) and a textual one in which Harrison, joined by Maria Millington Lathbury, is interviewed in a space surrounded by echoes of the ancient world, complete with an artfully draped swatch of 'mummy cloth' in pride of place, where 'The very air ... breathed antiquity'. Harrison's intriguing interview yields an important insight into the 'public' attracted to these women's archaeological lectures. She divided her audience (mainly though not exclusively women) into three groups: educated women who were particularly interested in supporting and engaging in the intellectual welfare of their children; wealthy women of leisure who wanted a light touch 
introduction to the subject; and women for whom the lectures inspired further academic work. With non-working-class women expected to remain at home, the public lectures of Harrison and her contemporaries may have been a welcome escape for those women interested in expanding their intellectual horizons, however briefly. When asked the size of her largest audience, Harrison reported that a lecture on funerary art in Dundee had attracted 1,600 people. ${ }^{52}$ Through this interview Harrison and Lathbury are portrayed as living embodiments of a new kind of (female) public intellectual.

\section{Women abroad}

Brodrick, Tirard and Harrison all made names for themselves at home before beginning to publish. Other women who had lived abroad within an emerging 'professional' archaeological context drew on their personal experiences of foreign countries to establish and solidify their own archaeological expertise, targeting a mobile, seasonal audience more specifically. ${ }^{53}$ Mary Wilson Gardner was one of these women. She married the archaeologist Ernest Gardner in 1887, when he was a Fellow of Gonville and Caius College, Cambridge. ${ }^{54}$ Having been one of the first students at the British School at Athens, Ernest Gardner became the School's second Director in the year of his marriage. Mary Wilson, a soldier's daughter, had been brought up partly in Ireland and Scotland. Her educational background is less clear, but she and Gardner certainly met in Cambridge. ${ }^{55}$ When Ernest Gardner took up his post at the British School, the Gardners spent a substantial part of the year in Athens. They remained based there for eight years, over the course of which 33 students were admitted to the School. ${ }^{56}$ Ernest Gardner's diary from his first year as Director yields a glimpse of the kind of work he was doing - visiting ancient sites and museums in Athens and surrounding districts, paying social calls and visits, learning Modern Greek and networking with staff of the other archaeological Schools in Athens. ${ }^{57}$

There is currently little archival evidence of Mary Gardner's experience in Athens - what survives of her incomplete typewritten memoir 'The Gates of Life' unfortunately does not include the section on Athens. However, the extant chapters hint at the strength of the Gardners' connection to the city and to Greece. In the beginning of her chapter on their return to Britain, Mary Gardner states that they had been away so long they felt they were 'out of things'. ${ }^{58}$ It was during this period that 
Mary Gardner published her first book. A Short and Easy Modern Greek Grammar was an edited translation of Carl Wied's textbook of the Modern Greek language. This was no straightforward translation, however, as Mary Gardner apologised for 'the amount of alteration and rearrangement of his text which I have found it impossible to avoid'. ${ }^{9}$

Gardner's Modern Greek Grammar set out the basics of a language that was at that moment at the centre of an ongoing debate. In brief, one camp advocated a return to a 'classical' or ancient/ 'pure' form of Greek. The other was in favour of learning and using the form of Greek that 'ordinary' people spoke, which incorporated the transmutations and 'foreign' elements that had accumulated over the centuries. Mary's Grammar was placed firmly in the latter camp, boosted by her husband's introduction outlining the debate. Gardner's translation of this text is significant to understanding her experiences in Greece. It suggests that her appreciation, knowledge and promotion of Greek was based on the language of the 'people' - or, as one Athenaeum reviewer put it, 'out-and-out vulgar Greek'. ${ }^{60}$ These were the people who would have been employed on the British School's excavations, or who worked as servants in the Gardners' Athens home, or were encountered in everyday interactions and local travels. This book went into a second edition in 1910. In her Preface to this edition Mary Gardner noted her pleasure at 'the widespread use of this little grammar', describing Modern Greek as 'the connecting link between east and west'. ${ }^{61}$ It was included as an 'indispensable' volume for travellers to Greece in Murray's Handbook to Greece (seventh edition). ${ }^{62}$

By all accounts Mary Gardner was an ambitious woman who hoped to become a writer and cultivated relationships with the literary elite. ${ }^{63}$ Her unpublished autobiography references some of these names, illuminating the circle in which she and her husband moved. It included H. G. Wells and E. F. Benson, the latter of whom had studied at the British School under Gardner. ${ }^{64}$ Letters from Mary Gardner to Macmillan \& Co further illuminate her literary ambitions and her experiences as an archaeological expat in Greece. The correspondence begins with her submission of four 'sketches' to Temple Bar, a magazine for a 'middle-class readership' with a mix of fiction, biography, history and geography essays owned and published by Macmillan \& Co. ${ }^{65}$ Her ambition was to capture the excitement of living in Greece, although she was not completely satisfied with her attempt. ${ }^{66}$ These short pieces of semi-autobiographical fiction appeared in Temple Bar in January 1905 as 'Samian Wine: Some Greek Sketches', illuminating local travel and interactions, cultural knowledge and the relationship 'between East and West'. 
Each sketch features a British woman protagonist in Greece; Gardner obviously drew on her own experiences in these short stories. In 'An Attic Night', Gardner's nameless protagonist is on board a small Greek schooner enjoying the scenery from the deck when the Greek captain approaches her and strikes up a conversation. Rather than being annoyed by the intrusion Gardner's lady is charmed, glad of the opportunity to converse and improve her Greek. It is clear that she already knows the landscape - when a local earthquake forces her to change her planned route, she remembers the unpleasant facilities available at her new destination. But that hotel too has been affected, and instead she takes shelter at the home of a local steamer agent while waiting for her husband, a student of antiquities, to arrive. The home of this Greek family is a far more pleasant space than any hotel could have been; but the story concludes with the lady committing a faux pas by offering payment for the hospitality. It is refused, with the insinuation that despite her familiarity with Greece she is still a stranger. ${ }^{67}$

When Mary Gardner lived in Athens, the BSA did not have its own student residence; instead, students were expected to take lodgings in the city. ${ }^{68}$ In her final sketch, 'Wrecking a Plot', Gardner explores the role of the BSA Director's wife as surrogate mother to the (then) all male BSA students in Greece. The story involves one such young man. Attempting to learn Greek from the daughter of the local Greek family where he is staying, it becomes clear that he is a novice in the customs of the 'East'. In speaking to the girl alone, she and the rest of her family think that the young man is courting and will marry her. The 'hostess' (the fictionalised Director's wife), aware of the trouble he is heading for, warns him that customs in Greece differ from those in Britain. ${ }^{69}$ In this case, the 'hostess' is literally the translator of Eastern customs to Western students.

The Gardners continued their engagement with Greece through taking student tours there after Ernest Gardner became Yates Professor in 1896. Alongside taking classes in Archaeology at UCL, Mary Gardner achieved press notices through her active participation in organising and taking part in UCL's Greek Plays, and in 1908 she contributed her knowledge in revisions to Macmillan's guide to Greece, further discussed in Chapter 7. ${ }^{70}$ By the First World War Mary Gardner's language skills and knowledge of Greece had a new, more urgent relevance. In October 1915 she offered her services to King's College London as Honorary Lecturer in Modern Greek, intending to teach nurses heading for the front at Salonica. ${ }^{71}$ Her husband was also on his way there, having departed England in the same month to take up a post in military intelligence where he, too, used his linguistic knowledge and local contacts to interpret local 
newspaper reports for military use. ${ }^{72}$ Towards the end of her life in the 1930s Mary Gardner's ambitions had not dimmed; she hoped to publish her memoirs with Macmillan, citing the value of her extensive network and the popular appeal of archaeological memoirs at the time. She also drew on her archaeological experience to craft a book of antiquarian ghost stories, taking inspiration from M. R. James. She planned for her work to be introduced by her friend of many years, Edward Frederic Benson - who in this instance, as the author of antiquarian ghost stories, was her ticket to authenticity. Unfortunately neither Gardner's memoir nor her ghost stories were published. ${ }^{73}$

The concept of the Director's wife as hostess and interpreter is further highlighted in Ellen Sophia Bosanquet's Days in Attica. Published in 1914 by Methuen in the UK and Macmillan New York in the US, it reflected Bosanquet's experiences in Greece in the previous decade. Ellen Sophia Hodgkin had studied history at Somerville College, Oxford before her marriage to Robert Carr Bosanquet, the then Director of the British School at Athens, in 1902. During the four years that the Bosanquets were based in Greece, Ellen Bosanquet became integrated into Athenian social life, in addition to gaining knowledge of Greek culture, history, archaeology and archaeological sites, and improving her own knowledge of Modern Greek. ${ }^{74}$ Her book is a travel guide to the city in which she acts as a tour guide to her Athens. Its ancient and modern landscapes mingle with myths, (pre)histories and lived experiences, simultaneously incorporating elements of archaeological life - knowledge of artefacts, excavators, people and places, routes and byways. The first chapter of Days in Attica actively mirrors a Murray, Baedeker or Cook's handbook, with distinct sections on travel, hotels, climate and supplies. Then readers are presented first to the island of Crete, then to Attica, the region en route to and incorporating Athens. The narrative progresses chronologically through Byzantine to contemporary Athens. The contemporary perspective reflects Bosanquet's personal experience as an expat in Greece, and it was this context that reviewers of the work felt was the most valuable. ${ }^{75}$

In her own memoir, Late Harvest, Bosanquet described the experiences she had on arriving in Greece for the first time as a young and pregnant wife. As the wife of the BSA Director, she was not only part of the British expat community in Athens, which centred around the British Legation, but also the intellectual community of all the other international archaeological schools in the city - Austrian, German, French and American. During Bosanquet's time in Athens Sir Edwin Egerton, British Minister to Greece, was at the head of the British Legation, and 
there were numerous British Consuls or Vice Consuls spread through the country and its islands. The close ties between the British archaeological community and the Legation was reflected in the fact that the Bosanquets dined with the Egertons 'twice a week'. ${ }^{76}$

Furthermore, on an international level there was collaboration between archaeologists of different nations. The Bosanquets, at the British School, were next door to their counterparts at the American School at Athens, and the association with other international archaeological schools and local archaeological societies was strong. Ellen Bosanquet's relations with archaeologists are reflected in her book as she describes the various personalities and excavations key to understanding the ancient and modern context of the region. The first chapter, on Crete, contains Bosanquet's discussion of the evolving separation of Crete from Ottoman Turkey. Alongside a brief reference to the work of British archaeologists Arthur Evans and David George Hogarth at Knossos, she introduces one local scholar whose role in Crete is of particular relevance to the tourist and the student's experience of the island's archaeology: Joseph Hazzidakis, Keeper of the Museum in Candia (modern Heraklion). Hazzidakis, readers are told, in addition to directing excavations himself, is at the heart of the archaeological network on the island. He has a thorough knowledge of the latest scholarship and artefacts discovered, and guides those students who come to the Museum in their research. ${ }^{77}$

Bosanquet's intended readership is evident in the inclusion of information of direct relevance to women. The most obvious is her chapter 'Home Life in Attica', which charts her own experiences as an 'Athenian' housewife, signals her personal affiliation to the city and gives her an Anglo-Hellenic identity. She provides her readers with detailed information on the range and characteristics of her servants, rather like an expat Mrs Beeton. ${ }^{78}$ Yet she also used Days in Attica to draw parallels between the lives of women in the ancient and modern world, and in so doing offered her modern (female) readers alternative narratives for ancient buildings and battles. As Mary Brodrick did in her lecture on ancient Egypt, Bosanquet drew parallels with the ancient world to air her own feelings on contemporary women's issues. Minoan frescoes showing the women of Knossos in the Candia Museum are brought to life in Bosanquet's prose. Guiding readers through the exhibits in sequence, on reaching the frescoes she declares that 'These Minoan ladies are well educated.... they often, Ariadne like, took the law into their own hands and interfered successfully in affairs of state... ${ }^{79}$

Bosanquet's chapter 'Legends of the Acropolis' likewise draws on ancient sources to give the history of Athens a gendered twist, with 
reference to the ongoing suffrage campaigns of her own period. She includes an excerpt from the Roman historian Varro on the vote to decide between Athena and Poseidon as the 'spiritual patron' of Athens. Attic women, who outnumbered men and were politically active, decided in favour of Athena, 'But the men had superior strength and punished the suffragatrices by the loss of the vote and otherwise.' This potent reference to suffrage was picked up by a Newcastle Journal reviewer as evidence of Bosanquet's skill in making a classical story relevant to contemporary issues. ${ }^{80}$

Her own experience of Greece is framed as a transformational one, in which she sheds her British identity and becomes enmeshed in the local community. The tourist - Bosanquet's 'bird of passage' - does not appreciate the intricacies, annoyances and delights of modern Greek life, and instead is buried in the ancient world. ${ }^{81}$ But as a resident Bosanquet can enjoy the 'pleasures to be had for nothing ... the exhilarating atmosphere that sends us Athenians about our day's work with a singing heart'. ${ }^{82}$ As a resident, she explores an Attica not open to the tourist passing through, who is dependent on the routes mapped out in guidebooks. She distances herself from the British tourist in Athens, cloaking herself in an identity that is both alluring, and, to outsiders, unknowable. Only she can reveal a hidden world to us - one informed not just by prolonged residence, but also by a special relationship to the landscape and the people that archaeological life brings, drawing on the explorations of the staff and students at the British School at Athens.

Days in Attica was published in March 1914. The positive reviews heralded it both as a record of a past age and a glimpse of Greece in the midst of great change, as its borders extended as a result of the Balkan Wars against Ottoman rule. ${ }^{83}$ In her Preface, Bosanquet described the political context as a 'new phase' for Greece. ${ }^{84}$ But the change that was just around the corner with the declaration of war in August was even greater than expected. The Preface to Bosanquet's 1932 travel guide $A$ Tale of Athens begins with a reflection on her earlier work, and it provides a fitting evaluation of Days' history: that it was intended for 'leisurely people' visiting Athens who would walk around the city and use the text to enhance their experience. But with war came the total cessation of such tourism. Instead, in a postwar context, Bosanquet observes a change in seasonal visiting patterns and audiences. Her new book is aimed not at the 'winter resident' of prewar days but 'the yachting visitor with little time for studying monuments on the spot, and with interests wide rather than deep. ${ }^{85}$ Luckily, in the few months preceding the declaration of war in 
1914 Days was enthusiastically read, particularly in Liverpool where the Bosanquets resided at the time. In March 1914 the Liverpool Daily Post reported the results of a survey of the six most sought-after books; two of the city's main libraries and bookshops listed Days among their six. ${ }^{86}$

Three years later another work appeared that shed light on the experience of a BSA student in the Balkans on the eve of world war. Agnes Conway's A Ride Through the Balkans: On Classic Ground with a Camera brings a unique perspective on the context of the British School at Athens, providing an example of how the School acted as a key focal point for facilitating regional travel, scholarly networks and cultural exchange - particularly relating to and relevant for women. As a student at Newnham College between 1903 and 1907, Conway studied ancient history with Alice Gardner (sister of Ernest Gardner and Percy Gardner) and Greek with Jane Harrison. She continued her archaeological studies abroad, first under Eugénie Sellers Strong at the British School at Rome and then as a student at the British School at Athens. ${ }^{87}$ During this period she was also writing; in 1909 she and her father, noted art historian and mountaineer Martin Conway, co-authored The Children's Book of Art, published by A. \& C. Black. She also wrote reviews, notes and articles under her own name for (among other periodicals) the Law Quarterly Review, Archaeologia Cantiana and the Burlington Magazine for Connoisseurs. ${ }^{88}$

Conway and a Newnham friend, Evelyn Radford, were admitted as students at the British School at Athens for the 1913/14 session. They arrived in Greece in February 1914, staying in Athens initially to do preliminary research. The proximity of, and strong connections with, the other international schools of archaeology in the city meant that BSA students could take advantage of their libraries and meet an international set of scholars. Conway recorded in her diary that at the beginning of the trip in Athens she and Radford attended a party at the German Institute hosted by its Director, Georg Karo. While there they met many American students and also chatted to Wilhelm Wilberg from the Austrian Institute. ${ }^{89}$ After spending a short time the city, Conway and Radford embarked on an unofficial 'tour' in Greece and the Peloponnese, Asia Minor, Albania and Montenegro. A Ride therefore centres on their experiences as British School students and Western travellers in the East.

The Balkans had significance particularly for British women, who had been involved in travelling and educational work there for decades and had published books on their observations and experiences. ${ }^{90}$ Conway's text examines and presents the many peoples they encountered en route, which Martha Klironomos has highlighted 
as a factor of 'sociological-anthropological travel'. ${ }^{91}$ It also explicitly ties their journey to the archaeological network of researchers in the Eastern Mediterranean, and to their own roles as prospective excavators, highlighting the presence of women in the field. The women's visit to the excavations of the American archaeologist Alice Walker at Corinth illuminates this presence. ${ }^{92}$ Although no full names are used, it is clear that the excavator is female and integrated into the local community. In the passages relating to Walker readers are introduced to a woman who, with her local foreman 'George', had travelled round the Peloponnese during the Balkan Wars, blending into the community in disguise in local costume and giving 'relief' to soldiers' families. They allowed her in because she looked like one of them. Once inside their homes, Conway adds, Walker and George 'in the course of talk heard of the needs of the poor people without the purpose of their visit being suspected. ${ }^{93}$ The melding of excavation life with local modern context in this passage is a critical element in the value of $A$ Ride as a form of scripting spadework.

This melding is further emphasised as the book progresses. Although both Conway and Radford had interests in classical sites, 'New Greece', as they called it, claimed an equal amount of interest, particularly at a time when political tensions were building to a fever pitch of conflict. Their journey to Corfu was interrupted by a Greek revolt against the Albanian state, which had been created just a few months before Conway and Radford's arrival. After successfully bargaining with reluctant drivers prepared to charge extortionate prices to take them to Corfu during the revolt, Conway and Radford encountered numerous refugee camps. These were packed with men, women and children who, according to Conway, wanted nothing more than to be incorporated into Greece rather than into the new Albania.

Conway was fascinated by the situation; she and Radford, in their efforts to see all aspects of local life, took it all in. A priest working with refugees conducted them round a camp, hoping Conway and Radford would make public their plight. ${ }^{94}$ Once in Corfu and comfortably ensconced in the Pension Suisse, they returned to their classical interests and a more acquisitive scholarly attitude towards the region. Kaiser Wilhelm II, who had a residence, Achilleion, on Corfu, had been involved in excavations on the island's Temple of Artemis. Conway noted in A Ride: 'There are splendid possibilities for excavation in Corfu, and we envied the Kaiser his facilities. ${ }^{95}$

On returning from the Balkans in late June 1914, Conway almost immediately began drafting a new book recounting her experiences on her 'tour'. She continued working on the chapters, arranged 
geographically, over the following weeks as the political situation in the Balkans worsened. On 29 July, the day war was declared between Austria and Serbia, she finished the first chapter. Five days later, as the British government was on the verge of declaring war, she was writing the 'Salonica' and 'Athens Regained' chapters. The next day, 5 August, she had completed her work. The British government had declared war, and she acknowledged her sense of impending anxiety, a pressing need to finish the book. It was eventually dedicated to Jane Harrison, who Conway asked to look over the draft (Fig. 3.1). ${ }^{96}$

A Ride is based primarily on Conway's personal diary and the letters she and Radford wrote home during the course of their trip. She worked hard to convert these resources into readable and informative text, editing and revising the chapters over a number of months and seeking expert advice on the region and its history. By early 1915 it was finished, and she deposited the manuscript at John Murray, but after a week it was returned to her. She offered it next to Robert Scott, who accepted it in July 1916, along with numerous photographs. With the delay between submission and acceptance, Conway had to bring the text up to date, and the war is explicitly referenced at several points in the text. Her network of friends, all of them women, helped her edit and polish the manuscript to meet the tight deadline: Robert Scott's manager was in a rush to publish. The Gallipoli campaign in the Dardanelles, an area Conway and Radford had travelled through en route to Constantinople (Istanbul) and

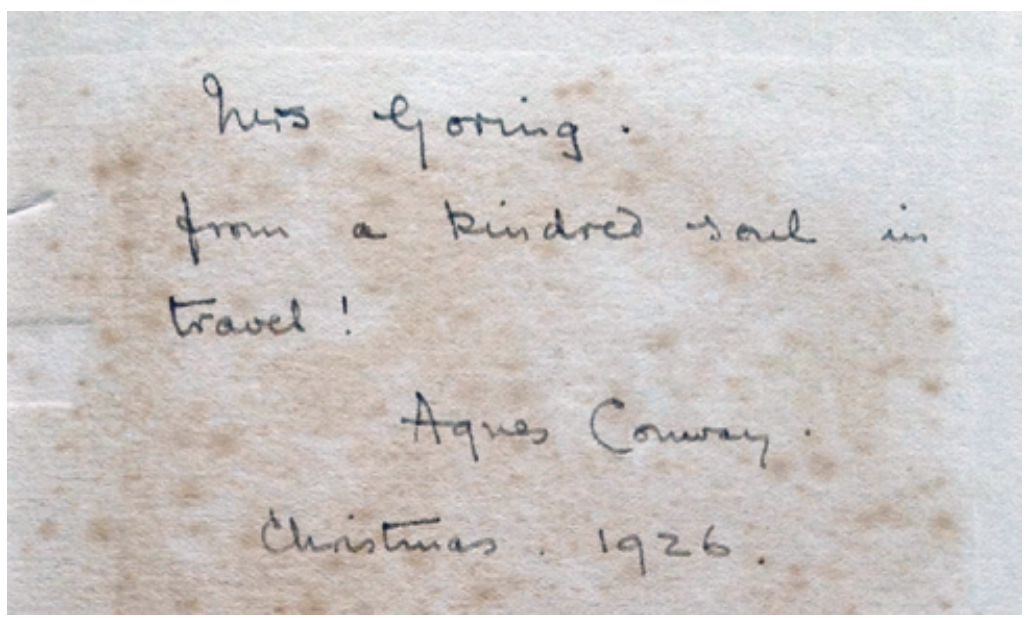

Fig. 3.1 Agnes Conway's inscription 'from a kindred soul in travel' in a copy of her Ride to the Balkans. (Author's collection) 
Brusa (Bursa), had only ended at the beginning of the year. Forces were concentrating on the Macedonian front. Conway's observations - and particularly the images she and Radford had taken - would thus have been a marketable commodity, one which (she surmised) was the main reason for the manuscript being accepted. ${ }^{97}$ It was Conway's scripted identity as a knowledgeable and observant photographer and informal foreign correspondent, ready to go where the action was happening, following the stories picked up on the way, that gave the book its contemporary relevance.

To illustrate this point further, a simple 'sketch map' was bound into the book to accompany the Epilogue. It showed Conway and Radford's meandering, circuitous route, with lines jutting out here and there and loops where they had gone back over ground already covered. In the final sentences of $A$ Ride Conway reflects the destiny of the archaeological wanderer, caught between the ancient world and the modern one: 'That year we seemed fated to be in the vicinity of wars, past and present, little as we suspected that each place as we left it would become more deeply embroiled. ${ }^{98}$ When the book eventually appeared, in March 1917, it was advertised along with other works relating to the war, adding an archaeological perspective to Robert Scott's list. Conway's 'unconventional journey' reported in a 'bright and easy style' was, Scott's marketing pitch noted, valuable for its description of 'scenes which now hold the world's attention'. ${ }^{99}$ Her hard work paid off in positive reviews. ${ }^{100}$

Women continued to produce archaeological travel guides and narratives after the war. The Scottish artist and archaeologist Annie Pirie Quibell had been an Egyptology student at University College London in the 1890s. She was among the first women students who travelled to Egypt as part of Flinders Petrie's Egyptian Research Account to copy tomb paintings at Saqqara and Thebes in 1895, and her work there with fellow artist Rosalind Paget was noted in UCL's 1896 annual report. ${ }^{101}$ She continued to work as an artist and excavator at Egyptian sites Hierakonpolis/El Kab before her marriage to fellow Egyptologist James Edward Quibell in 1900. At that time J. E. Quibell was a recently appointed Inspector in the Egyptian Antiquities Service, and the Quibells continued to be based in Egypt for the following decades. ${ }^{102}$ During that time she published two short site guides through the Church Missionary Society, The Pyramids of Giza and The Tombs of Saqqara, as well as a short guide to the Cairo Museum - all of which (it was stated at her death) were greatly appreciated by soldiers stationed in Cairo during the war. ${ }^{103}$

Annie Quibell's memoir and travel guide A Wayfarer in Egypt was published by Methuen in 1925, three years after Egypt became an 


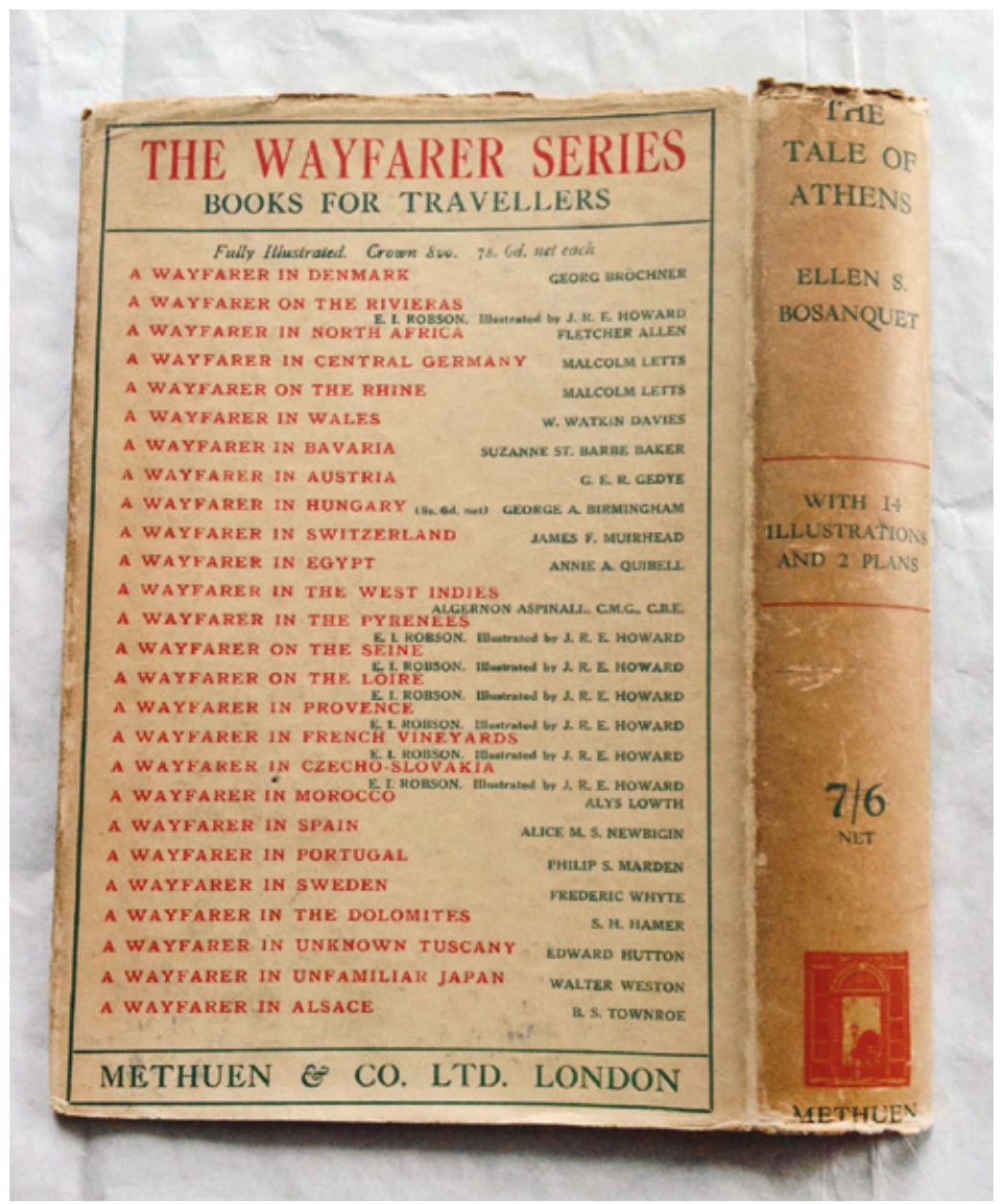

Fig. 3.2 Back cover of the dust jacket for Ellen Bosanquet's The Tale of Athens, showing the list of volumes published in Methuen's 'Wayfarer Series', including Quibell's Wayfarer in Egypt. (Author's collection)

independent nation. It was part of Methuen's 'Wayfarer Series of Books for Travellers', with titles eventually covering regions and countries in Europe, the Americas and the Far East (Fig. 3.2). The series was part of what Maureen Duffy has characterised as 'a new wave of enthusiasm for armchair travel' in the mid-1920s that helped keep Methuen financially viable; it drew on both republished older titles and newly written work. ${ }^{104}$ Quibell's Wayfarer reflects the wide range of her experiences as an archaeological artist, tour guide and the wife of an Antiquities Inspector 
and later Director of the Egyptian Museum in Cairo. Her husband's positions in the Egyptian government meant a considerable amount of travel within the country, as well as personal knowledge of the scholarly network actively investigating Egypt's ancient past, which she acknowledged in her Preface. ${ }^{105}$ A reproduced photograph of the bust of Nefertiti serves as the book's frontispiece image, emphasising the underlying thrust of Quibell's narrative: that it is written by a woman, for women readers and describing a female experience in and of Egypt. As Ellen Bosanquet had proclaimed herself an 'Athenian' in Days in Attica, through A Wayfarer Quibell could define her own Anglo-Egyptian identity.

The opening words of her Preface emphasise the 'otherness' of archaeological experience, setting Quibell-as-archaeologist in the position of outsider as she begins 'We are all wayfarers and strangers in an Eastern land.... This is the uncertainty of an Anglo-Egyptian existence, and of expat life in general. Quibell's words are particularly relevant when considering that she arrived in Egypt just over a decade after its occupation by British forces and she was there as it was ending in the early 1920s. Throughout the text Quibell highlights the nature and intensity of her interactions with local communities as a long-term resident in the country, and her relations with these communities on their terms developing her language skills in Arabic. Like many other books by British women travelling to Egypt, Quibell's book references access to the 'hidden' world of the Eastern 'harem' - a genre that has been dubbed 'harem literature'. ${ }^{106}$ Quibell's experience is located in the context of her role accompanying her husband on calls to local notables, part of the life of Antiquities Inspectors.

In one of the most illuminating passages of A Wayfarer, Quibell describes the wedding of a village notable (Bey)'s daughter. Rather than approaching the scene from a position of superiority, as Billie Melman notes occurred in some harem literature, Quibell's recollections of this event set her firmly on the back foot. Feeling as though she ought to do so, she asked to see the 'harem', and she immediately sensed that she had stepped out of place: 'I was a little surprised to see a shade of embarrassment pass over the Bey's countenance ... that night I ... felt more uncomfortable than has often been my lot.... Once she was shown into the women's dominion, she felt once again that she had intruded: 'I longed to speak to the two trembling things in the corner, but there, too I felt tongue-tied and could only ask to be allowed to come again...'. Her hesitancy is particularly meaningful - here is a more nuanced and complex experience of British imperial life, in circumstances in which 
Quibell feels that she is the intruder. As it turned out the relationship between Quibell and the young Egyptian bride eventually blossomed, so that, through repeated attempts to communicate, Quibell-as-stranger and 'other' became Quibell-as-friend - a person with whom (when she was alone) the nameless Egyptian bride could have 'real human conversation'. The women discussed household matters, customs and visitors, and even 'in rare bursts of confidence ... family feuds and scandals' ${ }^{107}$

While A Wayfarer is an intriguing memoir of Quibell's experiences, it is also a practical travel guide. Like others in this genre Quibell offers a short list of recommended reading, but, in what I have interpreted as a gesture towards her intended (female) audience, her list of authors includes Henriette Caroline Vulliamy Devonshire ('Mrs R. L. Devonshire') and Eugénie Le Brun ('Niya Salima'). Both born in France, these women were, like Quibell, long-term residents in Egypt. ${ }^{108}$ A Wayfarer in Egypt was published only two years before her death, but it enjoyed a healthy success posthumously, being sold in the US through Houghton Mifflin. By the outbreak of war in 1939 the work had been reissued four times. ${ }^{109}$ It reached the notice of imperial readers too; a lengthy review in the Melbourne newspaper The Age praised Quibell's knowledge of both ancient and modern Egypt, her ability to penetrate 'far below the surface of things' to find the humanity in her surroundings. ${ }^{110}$

Dorothy Simmons Mackay's writings highlighted travel, excavations and antiquities during this period. Little information is currently available about her early life, but by the mid-1920s she began publishing on archaeology, drawing on her experiences on site with her husband Ernest Mackay. He had been one of Flinders Petrie's many students and worked on excavations in Egypt before the First World War. Mackay became part of the small team of archaeologists who undertook initial survey and custodian tasks in British-administered Palestine between 1919 and 1922, subsequently taking a role on the University of Pennsylvania excavation at Beth Shan, or Beisan, a site south of the Sea of Galilee. ${ }^{111}$ He then moved on to excavations in Iraq at the ancient city of Kish, southwest of Baghdad near Babylon.

It was while the Mackays were at Kish that Dorothy Mackay became more publicly visible as a communicator of archaeology, voicing the perspective of, as the Western Daily Press put it, 'an unofficial member' of the excavation. Her article 'Housekeeping in the Desert', published in the Western Daily Press in 1925, outlined her domestic arrangements of camp life - a side which remained hidden in most other popular publishing on the subject. ${ }^{112}$ The following year, she published a short guidebook, Ancient Cities of Iraq, giving short histories of excavation and key findings 
for sites across a country that she noted, unlike Egypt or Palestine or Lebanon, was an 'uncompromisingly flat, greyish, dusty plain'. But, Mackay emphasised, the region had both allure and potential, particularly for the imaginative archaeological enthusiast: "For him who has vision... it speedily acquires a subtle and mysterious attraction. ${ }^{113}$

Mackay superimposes ancient cities on a modern landscape - giving railway and road directions for each site included and featuring a map of the country whose title, 'Assyria and Babylonia Iraq Railways', echoes this multi-period context. Her choice of sites incorporated the feasibility of visiting and proximity to a local railway station and was generally ordered according to the Iraq railway system. ${ }^{114}$ Readers are brought straight into the domestic day to day in the beginning; Mackay trusts that through her words readers will animate excavated remains with imagined scenes of everyday activities undertaken in them in the past, as 'some slight knowledge of the daily life and difficulties of the ancients adds so much to the interest of their ruined cities.... ${ }^{115} \mathrm{~A}$ few years later the Mackays had moved to India to work the site of Mohenjo-daro on behalf of Sir John Marshall, the Director of the Archaeological Survey of India. Continuing her interest in improving the intellectual accessibility of sites to visitors, Dorothy Mackay produced a short guide to this prehistoric Indus Valley metropolis, located eight miles from Dokri station in the Sindh province (now in Pakistan), for the Indian State Railways Publicity Department. ${ }^{116}$

\section{Women's site stories}

Women also published focused excavation and site histories for a wider readership. One of the earliest examples of such a publication is Margaret Benson and Janet Gourlay's 1899 book The Temple of Mut in Asher, covering Benson and Gourlay's excavations between 1893 and 1897 at an ancient temple in Luxor. Gourlay was a student in Egyptology at UCL in the early 1890s, while Benson (sister of E. F. Benson) was a writer and philosopher who had studied at Lady Margaret Hall, Oxford. ${ }^{117}$ For these two authors, the field work presented was particularly significant, as they acknowledged in their Preface thanks to then Director of the Egyptian Antiquities Service Jacques de Morgan 'for the first permission to excavate given to women in Egypt'. ${ }^{118}$

The book, published by John Murray, came about on Mary Brodrick's recommendation, highlighting the efficacy of women's networks for publishing. ${ }^{119}$ Because Brodrick suggested to Murray that Benson's work 
would be a significant contribution to Egyptology, Murray asked to see a manuscript. Benson submitted writing samples to Murray showcasing three main parts of the book: a description of the site, the history of the eighteenth dynasty and a description of their dig work. ${ }^{120}$ In Temple, Benson and Gourlay combined investigations of the site, its history and the interpretation of ancient religious beliefs with the surrounding contemporary context of Luxor, the relationships - economic, social and cultural - with those employed to dig, and the field of archaeology, which they infiltrated both as 'amateurs' and as women.

The medieval historian Lina Eckenstein, a contemporary of Janet Gourlay's at UCL, published her experiences on excavation with Flinders and Hilda Petrie in Sinai. Eckenstein's pioneering work of women's history, Women under Monasticism (1896), was published the year that she became a student in Egyptology at UCL. ${ }^{121}$ She joined Flinders and Hilda Petrie in Egypt for the 1902/3 and 1904/5 seasons, contributing to the Petries' work at Abydos and Saqqara, where she copied tomb-paintings alongside artists Winifred 'Freda' Hansard and Kate Kingsford. ${ }^{122}$ Eckenstein and Hilda Petrie subsequently travelled with a small group of Bedouin men to Flinders Petrie's camp in Sinai a journey Hilda Petrie later described for the woman's magazine The Queen. ${ }^{123}$ Eckenstein joined the Petries as a member of the excavation party at a temple at Serabit, copying inscriptions and organising fragments. This work, as she later recorded in her book A History of Sinai, inspired her to reflect on 'the site which meant so much in the history of religion', as she had a general interest in the peninsula's 'hermit life'. ${ }^{124}$ The book was published by the Society for Promoting Christian Knowledge, to whose audience its analysis of the history of religious life at the site would appeal.

One of the best known of Flinders Petrie's female Egyptology students, Margaret Murray, started her studies at UCL in $1893 .{ }^{125}$ She gained her first taste of excavation on Petrie's excavations at Abydos in Egypt in the first decade of the twentieth century; over the course of her early career in archaeology she was a successful University Extension Lecturer and undertook a well publicised public mummy unwrapping in Manchester. ${ }^{126}$ Mainly recognised for her scholarly works on Egyptology and witchcraft, and for her (at that time) unusual academic status as an Assistant Professor in Egyptology at UCL, by the 1920s she expanded her field experience to Malta and Minorca. As Kathleen Sheppard has noted, this field work enabled her to train a number of her female students from UCL. ${ }^{127}$ Following her 1937 excavations at the famous ancient city of Petra, Blackie and Son published her guidebook and excavation memoir 
Petra: the Rock City of Edom in 1939. Murray wrote the book for the increasing number of visitors to Petra, which was then being promoted, as it is today, as one of (Trans)Jordan's main tourist attractions. It was aimed specifically at "the "man in the street", or ... for the "visitor to Petra"'. ${ }^{128}$

Murray's text set out the early history of Petra, but she also used the book to make the case for a more intensive excavation of the site, which before Murray's work had only been excavated for a few months in the spring of 1929 and very briefly in $1934 .{ }^{129}$ Her interest in folklore, customs and women's experiences is incorporated into the text. In introducing Petra and the Bduls who (then) lived in the site, she notes that 'The women struck me as more intelligent than the men, but that may have been because they talked to me more . . . ${ }^{130}$ Her own time on site is couched explicitly in terms of the exotic. 'Every excavation, no matter where it is,' she wrote in the Preface, 'is always somewhat of an adventure.' Yet she simultaneously tames the exotic with more prosaic observations: 'I have always found that the more adventurous the work the more uncomfortable is the life....

There are glimpses of the difficulties that she had on site as a woman, too, and the annoyance of this reality. She highlights particularly 'the know-all' who thinks he knows better without having the benefit of Murray's experience, and those who fail to follow her carefully thoughtout instructions. ${ }^{131}$ She does not mince her words. The final chapter of Murray's book is the account of her dig. Entitled 'The Trials and Troubles of an Excavator', Murray concentrates mainly on the logistical difficulties of her 'short and intensive excavation', outlining not the romance but the monotony of field work. For her, the intellectual thrill of post-excavation analysis was the real joy of archaeology. ${ }^{132}$

As much as Margaret Murray disliked uncomfortable adventures in the field, so Mary Chubb revelled in them - to her field work was a joy. Chubb's two memoirs of life on the sites of Tell el-Amarna in Egypt and Eshnunna in Iraq in the 1930s did not appear in print until the 1950s. Chubb had no archaeological background when she had her first experience in the field. As a young art student in London in the early 1930s, she had taken the job of secretary/accountant with the Egypt Exploration Society, providing her with useful income to fund evening classes in sculpture. Chubb's initial foray in archaeology occurred at Tell el-Amarna, as she described in her 1954 memoir Nefertiti Lived Here. Officially she was 'Secretary to the Field Director', but in Nefertiti she clarifies in no uncertain terms the duties additional to this role on site: 'plasterer, 
chemist, sick-nurse, draughtsman, painter, excavator, antiquity-cleaner, carpenter, and above all - diplomat. ${ }^{133}$

Chubb's work makes clear the diverse community of an archaeological excavation, drawing distinctions not just between 'professional' archaeologists and the rest, but outlining all the different contributors: locally recruited men and children, highly experienced Quftis from Qift, a village to the north of Luxor, and those representing more specialised roles. Among the British members of the Amarna excavation team charted in Nefertiti, beyond Chubb, the Director John Pendlebury and his wife Hilda Pendlebury, there were two architects, Hilary Waddington and Ralph Lavers. ${ }^{134}$ As Chubb was the excavation accountant as well as Secretary, she describes the systems she employed to manage 'pay day' in some detail. ${ }^{135}$

Her work has been placed alongside others produced by women in the field as examples of accessible narratives of excavation life with 'sensitive and lucid insights into the academic contexts of the field projects. ${ }^{136}$ Chubb's accounts are more than this, however, as she presents the view from the dig support staff whose contributions are often as invisible in published excavation reports as (in the case of Amarna) the Egyptian workforce. Hilda Pendlebury, for example, is introduced to readers as 'the right wife for an archaeologist, for as well as running the domestic side of the dig she was a classical scholar in her own right .... ${ }^{137} \mathrm{~A}$ former student at Newnham College, Cambridge, Hilda White had married John Pendlebury after meeting him at the British School at Athens, where both were students. ${ }^{138}$ At Amarna, Hilda Pendlebury was Chubb's informal mentor on the dig. She is certainly the one with whom Chubb spent the most time, both in the field and in the dig house.

Chubb also puts into words an intangible element of archaeological life to reveal the archaeologist-as-time traveller. She frames her observation in the context of her insider-yet-outsider status (as an amateur) on site. However, her feelings on the mysterious magic of archaeological life in which through the archaeological process temporal boundaries become meaningless are no less important:

There was no padding, no insulation, made up of familiarity, to deaden the shoot of delight that I felt at touching even the poorest of the little everyday things we found...that made me feel as if I had not only travelled to Akhenaten's capital across space, but through time as well. ... this odd feeling of time folding up into nothing... ${ }^{139}$ 
Margaret Collingridge Wheeler presented archaeological processes, practices and interpretations alongside her experience of life on site in her first book, Walls of Jericho, published by Chatto \& Windus in 1956. Born in Australia, Margaret Collingridge was among several women archaeology students working on Mortimer Wheeler's excavations in Britain and France in the 1930s. She married Wheeler in the mid 1940s when he was Director-General of the Archaeological Survey of India. ${ }^{140}$ While Mortimer Wheeler was a Professor at the Institute of Archaeology in London, Margaret Wheeler joined her former colleague Kathleen Kenyon's excavations at Jericho, where Wheeler was a Field Supervisor for several seasons. In contrast to Chubb, Wheeler's years of archaeological knowledge and field work experience are evident. She explains the site through both its chronology and the scientific techniques employed to understand the layer or level of history, including a brief but detailed introduction to the relatively new techniques of radiocarbon dating. Kenyon is 'the Great Sitt', whose God-like presence is felt throughout. ${ }^{141}$

Like Chubb, Wheeler wore many hats on site. She had a position of 'archaeological' responsibility for drawing, measuring and recording bodies in situ as a designated 'bone person', as well as directing some parts of the excavation herself. In her chapter 'Wandering Tribes', she discusses the excavation and recording of Jericho's 'Dagger tombs' where the skeletons of ancient nomads were found. Wheeler deconstructs the deconstruction of the archaeological context through her own recording of one such body, the so-called 'Sultan' found beneath the surface of the modern refugee camp near the ancient Jericho tell. After she had finished recording and the body had been photographed, removed and packed she recounts her sense of loss, but also records her own role in the Sultan's eventual resurrection in Amman Museum:

One moment he was a personality and the next but a box of bones labelled Tomb L 2, right femur, left tibia, mandible and so on ... from the photographs and my scale drawing he is to be reconstructed as he was. You will see him . . . with his crown and his dagger, and his dignity. ${ }^{142}$

Similarly to Chubb, Wheeler takes us not only to the sites of excavation, but shares the more informal moments, 'at home' inside the dig house. Her insider view of the dig space reveals it to be one in the process of cultural transformation. She records the excavation artist's attempts to capture the colour of the local landscape, so that in his decorative scheme a bland hallway becomes 'a gay Arab sitting-room' through the addition 
of blue and red tiles and 'reed mats' to make the floor more comfortable to sit on. Eventually the tiles, at first considered 'garish', became less foreign as familiarity grew. ${ }^{143}$

In 1892 Flinders Petrie recorded the association between women and archaeology in Ten Years' Digging in Egypt: 'Probably most people have somewhat the ideas of a worthy lady who asked me how to begin to excavate a ruined town - should she begin to dig at the top or at the side?'144 Women were as involved as men at promoting archaeology in print - travel and tourism, photography, linguistics, translation and excavation are all key archaeological practices and elements coming through in these works. Beyond this, however, it reveals the transformational power of archaeology for women's personal lives, enabling them to construct, use and enhance their own works to build visibility for themselves both within and outside the 'professional' sphere, and to communicate their expertise to other women. Women's efforts to script spadework made archaeology both physically and intellectually accessible. By presenting this information and experience in palatable form they demonstrated their command of the field in both projects and products. As they walked through the past in the present, whether in the museum, lecture theatre or foreign country and archaeological site, they were walking towards a new future. 


\section{4 Marketing the Archaeologist}

We ought to have had good accounts in all the dailies + a page of sketches in the Graphic, $+c \ldots . .1$

In a letter to Amelia Edwards, the young Egyptian Exploration Fund excavator William Matthew Flinders Petrie noted the value of marketing for archaeology. Without building a public profile and constructing a nonspecialist audience for their work, archaeologist-authors would have little appeal for commercial publishers. This chapter will investigate the varied routes for marketing archaeology, drawing on evidence of periodical publication and advertisement, and exhibitions as sites of celebrity and identity creation. It will examine how the cycle of archaeological work, as briefly introduced in Chapter 2 , fostered a continual renewal of archaeological visibility. This seasonality fed into and enhanced the value of archaeologists' popular publications. Finally, this chapter will focus on the role of compendiums in drawing upon - and spreading the visibility of - archaeologists and archaeological knowledge. Through newspapers and periodicals 'serial' archaeology developed into a potent commercial package for archaeologists, as they maintained and increased a steady flow of 'copy' on site and off. Such actions helped to situate archaeology and archaeologists within the context of expanding international and imperial infrastructures, from communication, transport and tourism to knowledge production and publication.

\section{Archaeology in the news}

Alan Lee described the nineteenth-century press as 'the most important single medium of the communication of ideas'. ${ }^{2}$ Thus for archaeologists newspapers were a significant platform for promoting disciplinary 
identity and sharing knowledge. Archaeological reports had been appearing in newspapers since at least the eighteenth century. However, in the mid-nineteenth century the abolition of stamp duty on newspapers and periodicals, increasing literacy rates and technological innovations affecting printing, communications and travel transformed newspaper and periodical production, circulation and readership in Britain. ${ }^{3}$ The range of newspapers and periodicals featuring archaeologists and archaeological research was wide, from cheap daily papers in London and 'the provinces' to elite learned or specialist weekly or monthly periodicals to those aimed primarily at women and younger readers or family audiences. ${ }^{4}$

In order to investigate this phenomenon more closely, I used the British Library's 19th Century Newspapers database to chart how the early career of Flinders Petrie was evident in the newspapers of late nineteenth-century Britain. The 19th Century Newspapers database can be used to pull together digitised articles from regional newspapers across Britain that include the search terms entered. Although this dataset only includes a portion of the papers published in Britain, it serves to indicate the spread of news in both key industrial centres and local communities. I searched for the word 'Petrie', and limited my search to the years he was most active in Egypt during the period represented in the database: namely from 1883, when Petrie first began as an excavator for the Egypt Exploration Fund (and the year in which he published Pyramids and Temples of Gizeh) to $1900 .^{5}$

The first graph (Fig. 4.1) represents the geographical distribution and number of articles referencing Flinders Petrie across Britain including England, Scotland, Wales and the whole of Ireland. London is represented in red, Scotland in blue, Ireland in green and Wales in yellow. Different regions of England are represented in various shades of purple. ${ }^{6}$ The data also reveals that there were key cities with papers that included a significant number of articles referencing Petrie. Over 350 articles in my dataset - nearly half - were from London-based newspapers. ${ }^{7}$ This fact is reflected in both the number of London papers represented and the number of articles published in these London papers. The Leeds Mercury in Yorkshire, Glasgow Herald in Scotland, Birmingham Daily Post in the West Midlands and Liverpool Mercury in the North West have the highest numbers. Andrew Hobbs has argued that these regional papers were critical to the dissemination of news, having larger circulation figures than the London press. ${ }^{8}$

By investigating these numbers more closely a more nuanced picture emerges. The second graph (Fig. 4.2) plots the number of articles 


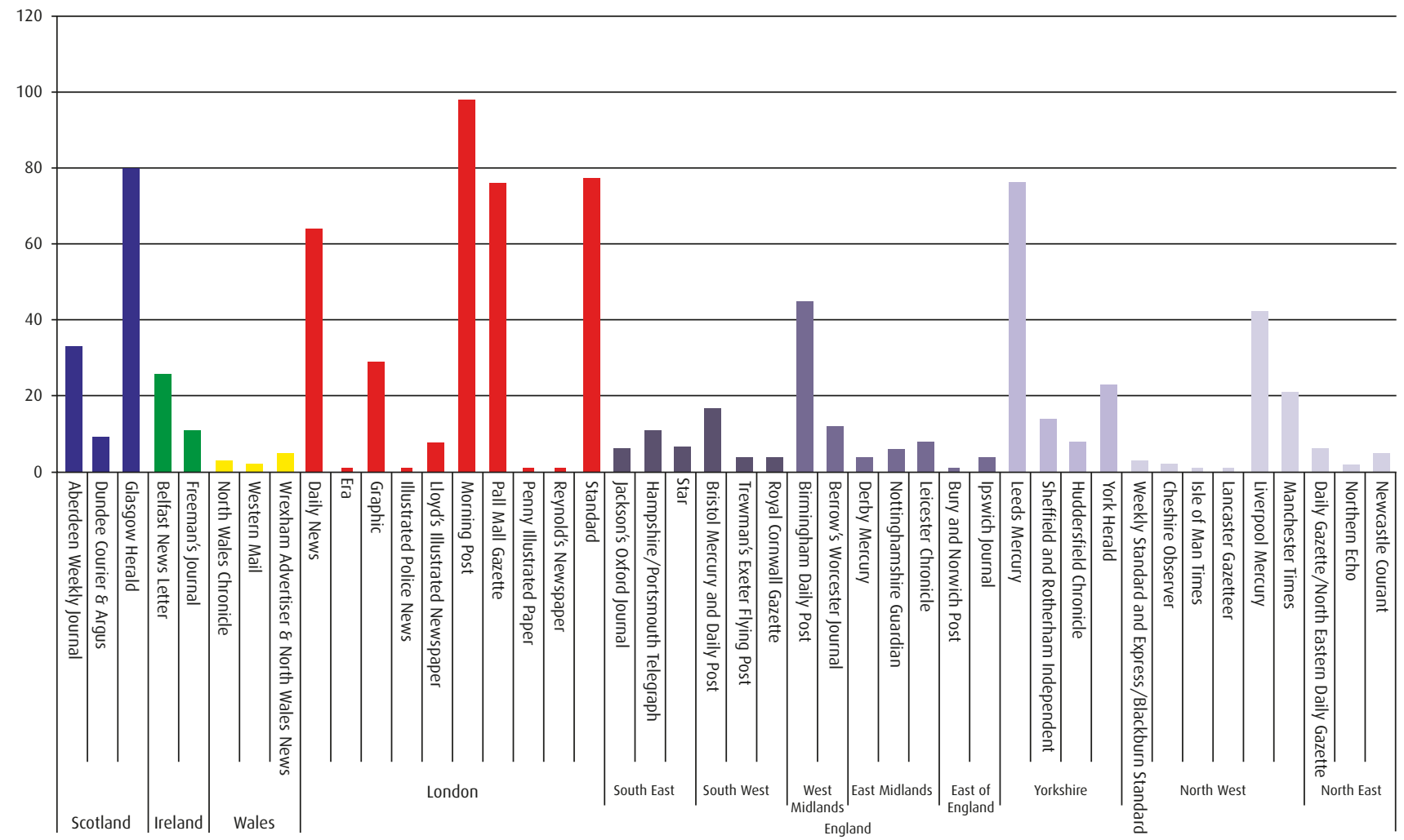

Fig. 4.1 Total number of references to Petrie (out of 779 articles) in the 19th Century British Library Newspapers database, arranged by paper and region. (Copyright the author) 


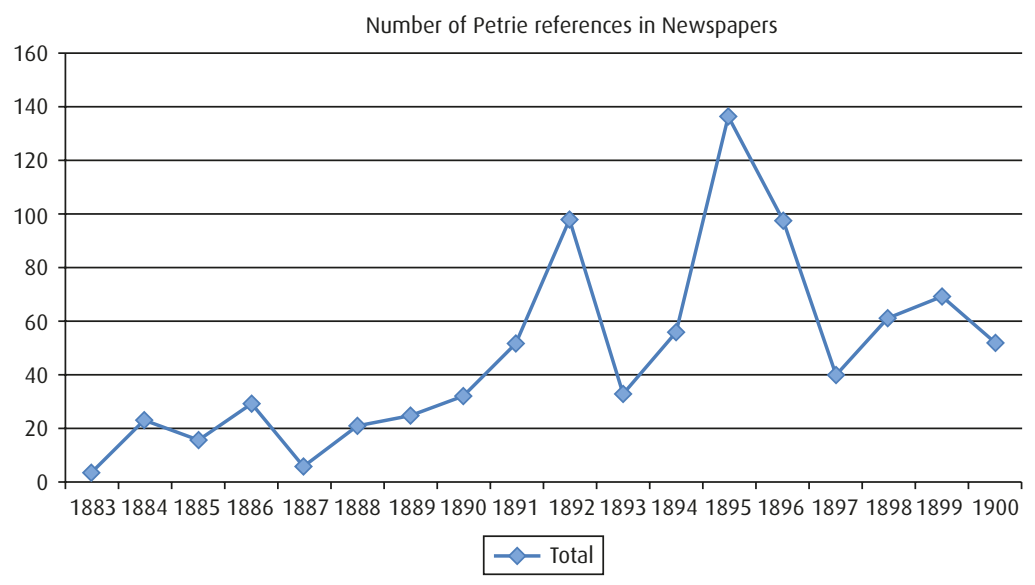

Fig. 4.2 Graph showing the number of Petrie references in the 19th Century British Library Newspapers database between 1883 and 1900 . (Copyright the author)

referencing Petrie by year. In so doing it highlights Petrie's personal visibility in newspapers as he continued to conduct archaeological research.

There are two main conclusions to highlight. First the numbers gradually increase over time and second there are some obvious peaks and troughs. An analysis of individual years indicates some of the reasons for these trends, and reveals the role of notices and publisher's announcements in putting archaeologists' names into the public sphere. In 1886 Petrie published 'A Digger's Life' in the English Illustrated Magazine, a 'shilling monthly'. This nine-page article introduced Petrie's view of the value of excavation to building up a picture of the ancient past, and emphasised the importance of ordinary finds over treasure. Beyond that, the article provided a template for the proper way to conduct archaeology - finding a site, hiring, instructing, managing and paying labourers, deciding the main aim of the research and the plan of the work to be done and dividing the finds for further funds. It also noted the fascination of the archaeologist on site: 'There will be all sorts of strange tales floating about, as to your object, and your personality. ${ }^{10}$ The article is essentially a skeletal version of Petrie's 1892 book Ten Years' Digging in Egypt, and his 1904 manual Methods and Aims in Archaeology.

The references to Petrie in 1886 (Fig. 4.3) show the effect that the publication of 'A Digger's Life' had on his visibility. The article appeared in the March issue of the magazine, and notices listing contents and 


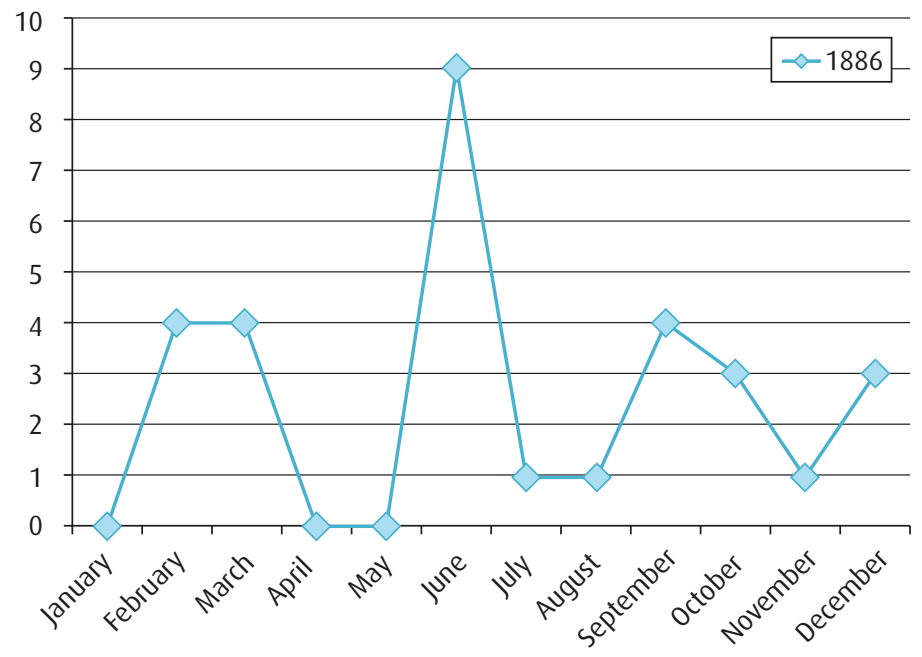

Fig. 4.3 References to Flinders Petrie in the 19th Century British Library Newspapers database in 1886. (Copyright the author)

referencing Petrie began to appear in February. A short extract from the end of the piece subsequently appeared in the Manchester Times Weekly Supplement. ${ }^{11}$ In June reports began to appear on Petrie's find of a palace, dubbed 'The Castle of the Jew's Daughter', at Tahpanhes (Tell Defenneh) near Kantara, on the opposite side of the Suez Canal in the eastern Delta. The biblical Book of Jeremiah featured a story about princesses having fled there with other refugees from the Kingdom of Judah. ${ }^{12}$ The report was published in The Times on 18 June 1886, prefaced by a lengthy editorial statement in the same issue encouraging support of Petrie's work for the Egypt Exploration Fund. ${ }^{13}$ The Times article was reprinted in part the following day in the Leeds Mercury, the Bristol Mercury and Daily Post and the Glasgow Herald. The Liverpool Mercury also noted the story on 19 June, providing its own (somewhat 'sceptical') commentary on Petrie's identification of the site. ${ }^{14}$ Other newspapers followed suit later in the month, drawing on The Times story to publish Petrie's discovery. ${ }^{15}$

By September Petrie had arranged an exhibition of the season's discoveries at Oxford Mansions, near Oxford Circus. The Royal Archaeological Institute had rooms in the building, and it was with the RAI Committee's co-operation that Petrie's display was arranged in the space. The exhibition was open three days a week between 2 and 21 September 1886, and the Royal Archaeological Institute's Annual Report for the year noted the exhibition's public appeal. ${ }^{16} \mathrm{~A}$ lengthy review, 
describing key objects and their locations in the space in detail, had been published in The Times the day before it opened. It ended with a comment on the exhibition being a space for showcasing the 'personal influence' of the excavator in the context of the work. ${ }^{17}$ Reviews also appeared in two London papers, the Daily News and the Morning Post. Petrie did not necessarily do all his own publicity. In a letter to Amelia Edwards in July 1889 he begged her to 'describe the collection' for the papers in advance of the opening of that year's exhibition on 16 September. As Moon has shown, Edwards had valuable contacts with newspaper editors which would have made her input invaluable, and she was the author of many reports to The Times on Petrie's progress. ${ }^{18}$

1892 and 1895 were the two years with higher numbers of references to Petrie (Figs 4.4 and 4.5). Petrie had begun publishing a four-part series of articles entitled 'The Romance of Ancient Literature' in the Religious Tract Society's monthly periodical Leisure Hour in late 1891; these continued into early 1892, and announcements for the publication appeared in several papers. ${ }^{19}$ Petrie's article revealed the story of papyri manuscripts, 'the mass of miscellaneous papers' found during his excavations. It framed these ancient textual fragments as both new sources of the literature of the ancient world and evidence of daily life in the past - wills, mortgages, domestic expenses, even correspondence from servants to employers. Amelia Edwards' book Pharaohs, Fellahs and Explorers had been published in late 1891, and reviews of her work, which explicitly named Petrie and featured his excavations in the Delta, were still appearing. ${ }^{20}$ The text was an enhanced version of the

1892

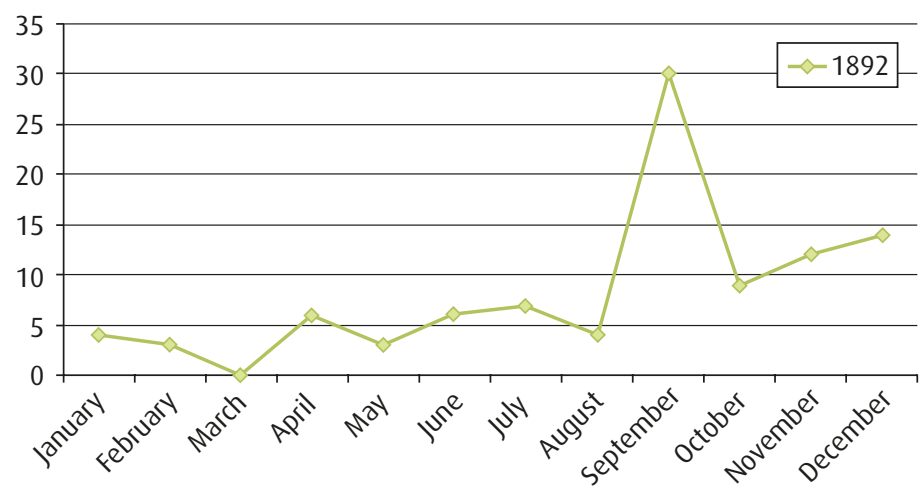

Fig. 4.4 References to Flinders Petrie in the 19th Century British Library Newspapers database in 1892. (Copyright the author) 
1895

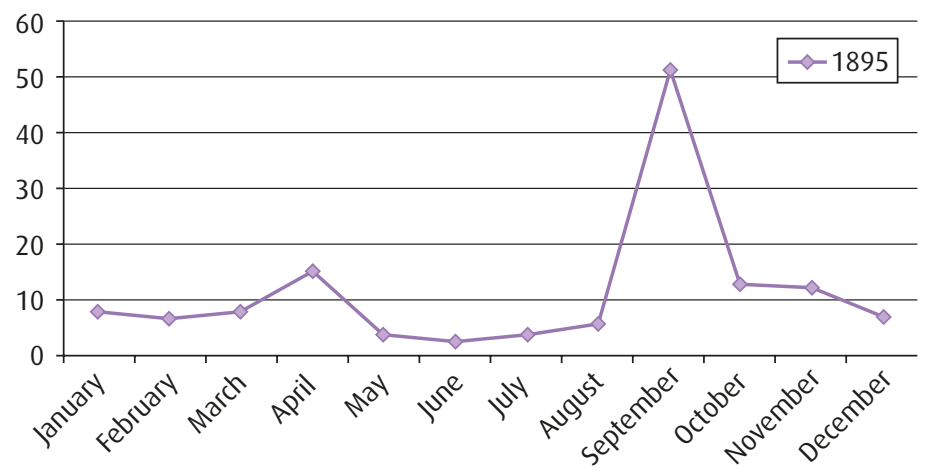

Fig. 4.5 References to Flinders Petrie in the 19th Century British Library Newspapers database in 1895. (Copyright the author)

speeches she had given in support of the Egypt Exploration Fund during a successful tour in the United States, and it helped to establish Petrie as a pre-eminent explorer of Egypt in the public imagination in both Britain and America. ${ }^{21}$ She drew upon a public conception of 'the excavator' to define key elements of the experience of spadework - seasonal travel, discovery, tent life, linguistic and diplomatic skills and physical health referencing Petrie both directly and indirectly:

Few, very few probably, of those who 'sit at home at ease' have any clear notion of the qualifications which go to make an explorer of the right sort - still less of the kind of life he is wont to lead when engaged in the work of excavation. They know that he goes to Egypt just as our November fogs are coming on, and that he thereby escapes the miserable English winter. They also know that he lives in a tent, and that he spends his time in 'discovering things'. ${ }^{22}$

Edwards continues to list the various intellectual abilities necessary for the ideal excavator - a knowledge of ancient history, ancient Greek and ancient Egyptian, a facility in trigonometry (for surveying) and the possession of 'all-round' archaeological knowledge, which she defined as a 'science' of registration and classification of the remnants of human progress towards 'civilization'. ${ }^{23}$

Petrie's memoir Ten Years' Digging in Egypt appeared in the spring of 1892. It was his own attempt to define his way of working and to acquaint audiences with his work in the field. The Religious Tract Society, which also published Leisure Hour and Sunday at Home, was his publisher for 
Ten Years' - obviously the RTS considered Petrie a worthwhile investment. ${ }^{24}$ Reviews of the work again increased references to him. In the summer Petrie's article 'Rahotep and Nefert. The Oldest Sculpture in the World' appeared in Sunday at Home and notices appeared in the press. ${ }^{25}$ A significant increase in references to Petrie came in September 1892. They consisted of reporting on Petrie's paper at the Oriental Congress in London on his work on the site of Tell el-Amarna, nearly 200 miles south of Cairo, his exhibition of objects from his excavations there at the Oxford Mansions and a deposit of mummies at the Royal College of Surgeons from his excavations. The numbers started to increase again at the end of the year when Petrie's appointment as Edwards Professor of Egyptian Archaeology at UCL was announced.

A few years later, in 1895, an increase in references in April was due to the announcement of Petrie's discovery of a 'New Race' in Egypt at his lecture to the Royal Society of Edinburgh. In presenting this he drew on the discovery of prehistoric human remains in a cemetery during his excavations at Ballas and Naqada, north of Luxor. Numerous papers used a review of the lecture in The Times as the basis for their reports on the event. ${ }^{26}$ The origin of the bodies Petrie presumed at that time to be outside of Egypt, and the pottery discovered with them, red at the base and topped with black, was dubbed particularly fine. Ironically, despite the fact that Petrie declared the bodies and their goods had to belong to non-Egyptian invaders, these finds helped to draw Petrie ever closer to Egypt in the public imagination. The Middlesbrough North-Eastern Gazette, reporting on the lecture, noted the discoveries caused a 'sensation' even as Petrie, his tanned skin equated with foreign-ness, was identified with the Egyptians among whom he spent so much time. ${ }^{27}$

Another sharp increase in references, in September of 1895, was the result of publicity around the British Association's annual meeting, at which Petrie discussed his 'New Race' findings. ${ }^{28}$ That year he had been nominated president of Section H (Anthropology) and, as Debbie Challis charts, he used the opportunity of his Presidential address to lay out his theories about race and empire more broadly, inviting personal contributions on the topic from imperial administrators. ${ }^{29}$ Reports on this speech circulated through the newspapers, drawing attention to Petrie's role as a public intellectual who used the strength of his archaeological identity and his intimate knowledge of Egyptian cultural life to justify his expertise in matters of imperial politics.

Events ensured that archaeologists who worked abroad remained visible at home, and annual exhibitions of archaeological material 
helped to enhance this visibility. Petrie's exhibition of objects from Hawara, a site in Egypt's Fayum oasis, including strikingly realistic and well-preserved Roman mummy portraits, gave him the most references in $1888 .{ }^{30}$ His name was mentioned in exhibition reviews in the London Daily News and the Glasgow Herald, as well as The Times, under the headline 'Mr Flinders Petrie's Egyptian Antiquities'. A listing with his name appeared twice in the events section of the Morning Post. ${ }^{31}$ The exhibition was held at Egyptian Hall on Piccadilly, well known by that point as an entertainment venue with a long history of performances and displays. ${ }^{32}$ Although at this stage Petrie had broken away from the Egypt Exploration Fund to establish himself as an independent excavator, with financing from two industrialists (Jesse Haworth and Martyn Kennard), he kept in touch with Amelia Edwards, who continued her association with the Fund. His letters to Edwards during the course of the exhibition reveal the importance Petrie placed on newspaper coverage during its run at Egyptian Hall - not merely for his own visibility, but also for the financial success of the venture in recouping the expense laid out and raising money for further excavations. Articles appeared two weeks into the exhibition in the Illustrated London News and the Lady's Pictorial. Both papers had sent their own artists to the display, and the articles featured sketches of objects and the Egyptian Hall space. Petrie wrote to Amelia Edwards that

The Illustrated L. N. sketches will give a great lift I hope, + may save us from loss perhaps. The Ladies Pictorial will have drawings also, + the Sat. Rev. + Daily T. will have articles. We have advertised moderately about 20 times in all. ${ }^{33}$

It was particularly important to Petrie at this stage to distance himself from the Fund. In 1889 he confided in Amelia Edwards that 'I find that many people do not at all realise that my work is independent of the Fund. So please do not relax in proclaiming that neither party has aught to do with the other'. ${ }^{34}$ This confusion affected Petrie's own scholarly publications, as some EEF members expected to have copies of Petrie's volumes, produced at his own expense, for free on subscription to the Fund. ${ }^{35}$ After a lecture in Manchester in 1891 Petrie fumed that two members of the audience were "both claiming attention for the Fund on the ground of my work! ${ }^{36}$

The locations and timing of these exhibitions contributed to generating publicity for excavations and excavators. ${ }^{37}$ Petrie's correspondence reveals that he chose the sites carefully. Although he had exhibited 
objects from his excavations annually, his earlier exhibitions had been in the autumn, after the end of the London Season - a time when the political, financial and social elite gathered in the capital to visit, network, entertain and debut. Post-Season was not a particularly suitable time for capturing public attention as many from the higher social echelons left London in early August. As Charles Pascoe put it, 'The people with the money have gone away'. ${ }^{38}$

In 1889 Petrie could not finish up his excavations in time to hit the London Season. However, he reasoned that the discoveries of his archaeological season would only be of interest to specialists, who would make the effort to view them regardless. Egyptian Hall was out too expensive for featuring finds of only specialist interest. The South Kensington Museum was similarly rejected as that season's finds were considered 'too antiquarian + unartistic', while the Burlington Fine Arts Club, open only to members and their guests, was dismissed as 'too private'. In the end Petrie returned to Oxford Mansion, which had a 'good position, not dear (10 gs a month on the ground floor?) + people know the way from going to exhibs at the Institute', demonstrating the value of a consistent location for encouraging visitors. ${ }^{39}$ Once arranged, Petrie remained in the space to insert his presence into the display, his personal visibility being an important factor. During his first exhibition at Oxford Mansions in 1884, he wrote to Amelia Edwards that responding to visitor interest was a demanding task, but necessary as 'it is just a scrap of personal attention to each who comes which may keep them in better humour'. ${ }^{40}$

Petrie's presence in the space also meant that he was aware of his audience, and of how many visitors there were to the displays - some known to him, some not. In 1884 he observed 'The numbers run up rapidly 16th [September] 5, 18th- 9, 23rd- 14, 25th, 30.... ${ }^{41}$ As the exhibition continued, he reported 'We have lots of people (say 30 a day average coming to see the things). I am sure 200 or 300 have been' ${ }^{42} \mathrm{~A}$ week and a half into the 1888 exhibition he wrote that 'The show draws fairly well, quite as well as I expected; 30 to 50 on rainy days +40 to 50 in fine weather'. ${ }^{43}$ By the final week he concluded that

Things are going on very fairly at the hall, in spite of the miserable weather we have had all the time. I expect we shall take about $£ 100$ (2000) people... So that is far better than I had hoped for. Several solid folks have been ... all more than once. We have got hold of the right vein of folks, + not had any nasty boors or 'arrys about. $^{44}$ 
Attracting these audiences as readers was a crucial factor in the commercial appeal of archaeology. The market for news changed radically in the nineteenth century as the governmentreleased control over publishers and their products. ${ }^{45}$ Alan Lee declared that 'the Victorian newspaper ... was for those who ran it first and foremost as a business.... ${ }^{46}$ Tied into this were improvements in circulation - international telegraphy systems played a crucial role in the ability to relay news quickly, and an exclusive contract between news associations helped to spread international news across Britain. ${ }^{47}$ Bob Nicholson has presented reprinted and modified newspaper articles as elements of 'cultural transfer', erasing 'national boundaries' ${ }^{48}$ This erasure, drawing home and abroad closer together, is particularly relevant for publicising in Britain archaeological research conducted overseas. Newspapers and the circulation and dissemination of news enabled archaeologists to present themselves and their work in transnational terms, and brought the foreign field of research much closer to readers at home.

In this system of circulation and dissemination, communication between archaeologist and newspaper editor was of paramount importance. News of excavations and discoveries was an important part of archaeological publicity; reports from the field relied on an international system of telegraphs and a good postal service, enabling news of discoveries to be communicated quickly. The London-based company Reuters was one of the most important companies in this history of communications. Established in 1851, it has been dubbed 'the news agency of the British Empire'. ${ }^{49}$ Reuters sent and received reports via an increasingly integral and broad-ranging telegraph system, feeding international news to British newspapers subscribing to its service. It opened an office in Alexandria, Egypt (the first beyond Europe) in 1865; by 1879 Reuters' base in Egypt had been moved to Cairo. From the 1880s news from abroad could be received in London in a day. ${ }^{50}$

The archive of archaeologist John Garstang offers a valuable insight into how archaeological news was sought and created, and the relationship between the press and archaeologists. Garstang, who had trained under Flinders Petrie in Egypt, was an experienced excavator by the time he began working at Meroe, an important ancient city on the Nile in what was then British-administered Sudan. He had just started his second season at Meroe in December 1910 when a well-preserved bronze statue head was uncovered, buried outside the entrance to a chamber in the Royal City. ${ }^{51}$ A news report on the discovery was telegraphed from Reuters agents in Khartoum on 21 December. The Reuters report announced Garstang's return to the Sudan to continue 
his excavations, and listed his discoveries: the head and the remains of a city water-front and royal dwelling mapped in the sparse words of the article. ${ }^{52}$ This report appeared, only slightly modified, in newspapers from 22 December in England, Scotland and Ireland. Headlines included 'Excavation Work in the Sudan' (The Times), 'Discoveries in Egypt' (Daily News), 'Buried Nile City Unearthed' (Gloucestershire Echo), 'Buried City of Meroe. Important Discoveries' (Dublin Daily Express) and 'Exhuming a City' (Dundee Courier). ${ }^{53}$

On the day that the Reuters report was printed, the Illustrated London News offices on the Strand sent a telegram to Liverpool asking for photographs of all the discoveries mentioned in the report. ${ }^{54}$ The immediacy of their request highlights the importance of visual evidence of the finds, critical for an illustrated newspaper, and the need to be the first to obtain that evidence. Further Reuters telegraph reports followed in January, when Lord Kitchener, soon to be Consul General in Cairo, visited the excavation site in person on a tour of Sudan in the company of Sudan Governor General Reginald Wingate and his wife Catherine. Garstang arrived back in England in May and promptly replied to the ILN's request, supplying photographs and text to inform the article that appeared in the paper on 10 June. The article explicitly referred to the role Reuters telegrams had played in notifying the public (and the press) about the discoveries made during the season, and in reinforcing the value of communication technology. ${ }^{55}$

The ILN had been drawing on Garstang and his team's expertise, experiences, artwork and photographs for illustrations since at least 1904, when a full-page montage of images was published to promote Garstang's exhibition of objects from his excavations of Beni Hasan on behalf of Liverpool University's newly established Institute of Archaeology. Alongside the sketches of artefacts featured, this article included a sketch of Garstang's foreman Saleh abd el Nebi, who had had the unenviable responsibility of lowering Queen Victoria's daughter Princess Beatrice (Princess Henry of Battenburg) down a shaft to see one of the tombs during her visit to the site. ${ }^{56}$

Garstang's relationship with the ILN was thus well developed by the time of the Meroe publicity campaign. On the request of ILN chief editor Bruce Ingram, the ILN featured Garstang's images of the bronze Head of Augustus in August 1911, following the British Museum's acquisition of the artefact. ${ }^{57}$ Liverpool's Sudan Excavations Committee, which was financing Garstang's work, was then selling sets of three reproduced photographs of the Head, and it was these three images Ingram wanted to feature..$^{58}$ One of these images was included in John 
Stobart's The Grandeur that was Rome, published by Sidgwick \& Jackson the following year, so demonstrating the object's translation into different commodities - from news item to reproduced photograph to book. ${ }^{59}$ The head became the signature object - an unofficial trademark - for Garstang's excavations that year and in subsequent years at Meroe.

Garstang also corresponded with the editorial staff of a number of other papers about the discoveries on his return from Meroe in May 1911. His letter to the Editor of The Times referred to the Reuters telegrams on Meroe published in The Times as evidence of the value of a longer report on the excavation, encapsulating Garstang's desire to strengthen the relationship between archaeologist and newspaper editor. It also promoted his forthcoming exhibition of the objects discovered there, due to be opened at the Society of Antiquaries, Burlington House the following month. The next week he sent a letter from Kitchener supporting the exhibition, which was fully reproduced in The Times. On 13 June Garstang's article, a draft of which is in his archive, appeared in The Times. The actual article as printed in the newspaper appeared without an author, but the draft indicates that Garstang's words were only very slightly changed in the final piece, revealing information taken directly from the source without much alteration. ${ }^{60}$

Other papers were keen to follow suit. The Evening Standard, eager to promote Garstang explicitly, wrote to arrange an interview about the Meroe discoveries. ${ }^{61}$ The correspondence relating to this Special Interview, printed in the Standard on 3 June 1911, highlights the specific interest taken by the press in archaeology overseas. The Editor, G. Westgarth Heslam, sent a list of questions for Garstang to answer that Heslam felt addressed in more detail themes brought to light in the initial reporting. The questions reveal something of the Editor's (one might say the public's) assumptions about archaeology and archaeologists working in a place such as Sudan, and particularly in the potential desecration of the dead that excavation involved. They included how the Meroe excavations contributed to Egyptology, clarification on ceremonial and religious activity at Meroe and whether workers found opening tombs problematic. To the last question Garstang replied his workforce only objected when the excavation plan went too close to a cemetery in use, but he included his own misgivings about opening tombs. Significantly, information omitted from the final printed version of the interview relates to the excavation's organisation and number of workers employed, along with an explicit mention of Garstang's chief foreman Saleh Abd el Nebi. While this omission suggests that such details were not editorial 
priorities, they were nevertheless part of Garstang's original narrative of his archaeological experience. ${ }^{62}$

The Garstang archive reveals the opportunities for further publishing and visibility that resulted from the broader exposure of Garstang's excavations at Meroe. The Editor of Nature invited Garstang to submit an article on the excavations, indicating the sizable, sciencefocused audience who would be interested in reading such a piece. ${ }^{63}$ It also reflects Garstang's impact in Sudan and the commercial appeal of Garstang's discoveries for marketing tourism. Arthur Bull, Chief Passenger Agent for the Sudan Government Railways, was eager to enter into a negotiation with Garstang to promote tourism to the Sudan, harnessing the excavations as an additional attraction for visitors to the country. Bull organised 'Combined Circular Tours', offering tourists allinclusive travel from Cairo to Khartoum, with an overnight stay at a camp at Kabushia railway station. He hoped to advertise the tours at Garstang's 1911 exhibition in London, and eventually produced a leaflet for circulation at the display.

Garstang had already submitted text on Meroe and Kabushia with photographs to Bull for the Government Railway handbook, and Bull was interested in offering a special guidebook to Meroe. This bespoke guidebook Garstang offered to write and illustrate, suggesting that it could be sold at between 10 and 20 piastres, the local currency in Sudan. Bull's interest in incorporating archaeological elements into the Government Railways material extended to menu design for both the Port Sudan Hotel on the Red Sea coast and Railway dining cars on which he sought Garstang's opinion, enquiring whether the drawing drafted was suitably representative. ${ }^{64}$ Bull's request brings the railway and the site together as part of the same imperial context, two elements of imperial display. To capture this tourist market further, Garstang contributed a special article on the site for the African World's 'Egypt and Sudan Annual' for 1914; the site had also been briefly highlighted in Fascinating Egypt and Sudan for the 1913-14 season. ${ }^{65}$ Garstang's excavations closed after the end of the 1914 season and were not renewed after the war, though Meroe itself remained visible in imperial tourist ephemera. ${ }^{66}$

Photographs in the Garstang archive show a dig building clearly marked 'Meroe Camp' in large letters, which would be visible from the passing railway carriages. Garstang's catalogue for the 1911 exhibition in Burlington House credits the government for investing in the site, noting that trains bringing supplies already stopped at the camp en route to Khartoum. Plans to build a special station at Meroe to help visitors access the site were also promoted. ${ }^{67}$ In fact, the excavations and 
camp were noted in travelogues on Sudan, demonstrating the efficacy of Garstang/Meroe marketing and Arthur Bull's efforts to incorporate the site into Railway ephemera. At the beginning of My Sudan Year (Mills \& Boon, 1912), the journalist Ethel Stefana Stevens travelled to Khartoum by train and saw both Garstang's camp and the Meroe pyramids from her carriage window. ${ }^{68}$ Similarly, in her 1914 book $A$ White Woman in a Black Man's Country, American tourist Nettie Fowler Dietz noted that en route to Khartoum on the train, 'In passing Kabushiyeh we could plainly see the pyramids and the excavating camp of Meroe where some recent interesting finds have been made'. ${ }^{69}$

The discovery of the Meroe Head had brought a new visibility and commercial standing to Garstang's excavations. Publishers responded to this - in June 1912, Sidgwick \& Jackson urged Garstang to consider submitting a 'popular' book detailing his Meroe excavations and findings. ${ }^{70}$ Flinders Petrie had a similar visibility in Egypt, although this manifested itself in a slightly different way. In 1891 the Minister of Education in Egypt, Yacoub Artin, asked him to write 'an elementary geography for the fellah boys!' - an idea that Petrie himself had suggested. Petrie hoped to address a lack of educational texts written in accessible language and phrasing that would be familiar to them, a skill for which he thought himself uniquely qualified. He boasted to his friend Flaxman Spurrell that 'I doubt if there are any English here who know the fellah understandings more than I do.....$^{71}$

Archaeologists gained a valuable visual organ for reporting the results of their research to British readers and a platform for being profiled as experts when the Illustrated London News was established in 1842. The first illustrated archaeological article appeared in that paper on 11 February 1843, reporting a British Museum exhibition of socalled 'Xanthian marbles' shipped from Turkey by the traveller Charles Fellowes. ${ }^{72}$ Regular contributions to the paper, as highlighted above, helped to maintain archaeological visibility. This was achieved not only through individual articles publicising key discoveries or exhibitions, but also in themed serials.

In 1911, while Garstang was actively promoting his Meroe excavations, David George Hogarth was contributing a regular series on active excavations and sites of interest to the $I L N .^{73}$ Amounting to 20 articles published between February 1911 and November 1913, Hogarth's series 'The Remodelling of History and the Realisation of Legend' highlighted previous, ongoing and new work of British and international archaeological teams and excavators across the Eastern Mediterranean and Middle East - Italy, Greece, Asia Minor, Turkey, Mesopotamia, 
Libya. The first article in the 'Remodelling of History' series included at its centre a circular profile portrait photograph of Hogarth from the renowned 'society' photographic firm Elliot \& Fry, noted for commercial reproductions of its photographs of famous figures. The image marks Hogarth's piece as emanating from his personal brand. ${ }^{74}$

Through the series he was able to expose his knowledge of work stretching across thousands of miles, directly and indirectly emphasising his own experience as an explorer and excavator and drawing on an extensive network of contacts to obtain illustrative material for each article. ${ }^{75}$ Hogarth's narrative of these sites establishes him as the ILN's archaeological reporter. He weaves a story of international imperial expansion (both ancient and modern) through literal and metaphorical 'snapshots', offering an overview of the key teams and sites undergoing excavation in the years just before the outbreak of the First World War. The value placed on visual evidence for archaeological work was high; illustrations were copyrighted to the excavators and societies providing them to the paper. Thus, when Hogarth's 'Remodelling of History' article on the Hittite Empire featured photographs from John Garstang's explorations of Hittite sites in Asia Minor without crediting him, Garstang immediately contacted his publisher Constable \& Co - who had produced his book The Land of the Hittites - and wrote a stern note to the Illustrated London News Editor on the damage this negligence had caused to his friendly relationship with the paper. ${ }^{76}$ The $I L N$ printed an apologetic note in the following issue. ${ }^{77}$

The ILN published a double-page spread in March 1923 (following Howard Carter's sensational and well publicised discovery of Tutankhamun's tomb), acknowledging the strength of archaeologists' relationship to the $I L N$. It proclaimed its role in increasing general interest in the discipline and featured photographic portraits of the 'famous British archaeologists' who regularly contributed articles and information. ${ }^{78}$ Among the 15 archaeologists included were Petrie, Garstang, Leonard Woolley, Howard Carter, A. H. Sayce and David George Hogarth.

Over a decade later, in 1935, a special 'Record Number' of the ILN was produced to celebrate the Silver Jubilee of George V and Queen Mary. A series of articles outlined 'twenty-five years' of achievements in imperial politics, military prowess, exploration, science, literature, aviation, art and archaeology. The double columns of archaeologist Alan J. B. Wace's text 'Twenty-Five Years of Archaeology' were lined with the images of 'Prominent Persons in Archaeology and Anthropology'; the Record Number's 'Explanatory Index' gave brief details of their achievements. 
Arthur Evans, Leonard Woolley, Flinders Petrie, John Garstang, D. G. Hogarth and A. H. Sayce, as well as Gertrude Bell and Dorothy Garrod, were all visible as thumbnail photographs, while the portraits of Howard Carter and his patron Lord Carnarvon sat in the middle of the first page. ${ }^{79}$ Both the 1923 and 1935 articles reflect the value of scripting spadework for news outlets during the early twentieth century in promoting archaeologists' visibility.

\section{Archaeology as a serial}

Serialised compendiums, a halfway house between periodicals and books, helped to raise archaeologists' public profiles still further. These works provided archaeologists with the opportunity to define - and in some cases lavishly illustrate - their expertise, dividing the world and its human history into easily digestible chunks, with the potential for incremental acquisition through subscription. Compendiums broke knowledge down while packaging it into bound volumes, heavy with authority and based on lived experience.

Between 1910 and 1911 the eleventh edition of the Encyclopaedia Britannica (EB11) was published. This edition has recently been assessed as a publication reflecting the zenith of prewar imperialism, yet it continues to have relevance today as the foundation for many Wikipedia articles. ${ }^{80}$ Gillian Thomas has noted that the Encyclopaedia's 'cultural authority' was due in large part to its contributors' 'prestige and celebrity'. ${ }^{81}$ EB11 presented information in a new format from previous editions, providing shorter, more specific articles rather than 'the comprehensive general, or "omnibus" articles, so characteristic of the earlier editions'. ${ }^{82}$ Its 'Prefatory Note' identified The Times's republication of the ninth edition in 1898 (a strategy masterminded by its future owner, Horace Hooper) and subsequent publication of a supplemented ninth edition as the tenth edition in 1902-3 as being the point when 'The great possibilities of popularity for the Encyclopaedia Britannica in Great Britain were... realized'. ${ }^{83}$ The Editor of the eleventh edition promised 'a fresh survey of the whole field of human thought and achievement', drawing on over a thousand international experts - each contributing articles that represented the latest knowledge. ${ }^{84}$

The Editor of EB11 claimed it was the most modern general survey available. It was made possible through improvements in the production process, financial investment and management strategies which enabled all the volumes of the encyclopaedia to be published simultaneously; 
formerly, volumes had been issued consecutively in alphabetical order. Published by Cambridge University Press, the latest of a number of different publishers to produce the work, it was now owned by American businessman Horace Hooper and edited in both London and New York, ensuring both a British and American market. Its editorial team included Janet Hogarth, sister of D. G. Hogarth.$^{85}$ EB11 introduced changes to make the text more accessible, such as listing famous individuals by names recognisable to a wider public - giving the example of listing the author George Eliot by her pseudonym instead of her given name Mary Ann Evans Cross. Members of the peerage were mainly listed by their titles rather than family names as titles had wider recognition - peers featured in newspapers, for example, would have been called by their titles. Its introduction outlined the innovations and characteristics that set $E B 11$ apart from competitors. In incorporating biographies of notable figures in the text, the Encyclopaedia Britannica claimed to outstrip the Dictionary of National Biography, a compendium providing brief profiles of deceased Britons, in two senses: first in including notable people alive in 1910, among whom were a number of archaeologists, and second in including eminent non-Britons. The Introduction also specifically referred to the progress made in the late nineteenth century by 'modern archaeology', which enabled knowledge of human history to be 'thrown farther and farther back'. It vowed that the contributions it included represented the most current information available as a permanent record of the 'triumphs' achieved up to autumn $1910 .{ }^{86}$

The eleventh edition and its index provide a unique insight into the arrangement and authorship of this important compendium, and the visibility of the scholars who contributed to it as authors and editors. General Editor Hugh Chisholm's approach to contributors emphasised what Thomas describes as 'direct participants' - he sought those actively engaged in a practice rather than 'objective' academics, at a time when universities were not necessarily the centre of the intellectual sector. ${ }^{87}$ Hogarth, Percy and Ernest Gardner and Petrie were among the archaeological contributors to EB11, authoring articles on geographical locations (ancient and modern) as well as thematic overviews. Gertrude Bell was one of a few female contributors included in the 'List of Contributors', writing an article on 'Druses' which drew on her personal explorations and experience. ${ }^{88}$ Among the articles that Hogarth contributed was 'Aegean Civilization', which alongside his text featured numerous illustrations from the Hellenic Society. ${ }^{89}$ Percy Gardner contributed a lengthy illustrated outline of 
'Greek Art' incorporating brief histories of excavations and excavators for sites mentioned in the overview. ${ }^{90}$

The entry on Egypt contained a substantial section on 'Ancient Egypt' with contributions from several Egyptologists, including Flinders Petrie on 'Art and Archaeology'. The 'Ancient Egypt' section began with 'Exploration and Research', outlining the work of generations of explorers and excavators and placing Western scholars front and centre in the elucidation of this ancient civilisation. The work of the Egypt Exploration Fund - especially the papyri excavators Bernard Grenfell and Arthur Hunt and Petrie's Egyptian Research Account and British School of Archaeology in Egypt - were also directly referenced in this section. Petrie was credited with instigating 'The era of scientific excavation', during which 'the general level of research has gradually risen'. ${ }^{91}$

Contributors were further credited in each volume in which their pieces appeared as a list of initials identifying individual authors, with a short biographical article (where one was not already included in the Encyclopaedia) and the entries credited to them in that volume forming part of the opening section. Thus Gertrude Bell ('G. Be.') is listed in Vol.8 as 'Author of Desert and the Sown \&c.' for her work on the 'Druses' entry. ${ }^{92}$ In addition to authoring articles, D. G. Hogarth and Ernest Gardner were both credited for advising the editors on 'Hellenic Archaeology', while other archaeologists or former students of the British Schools at Athens and Rome advised on classical archaeology and art. ${ }^{93}$

The organisation of the new edition featured a new scheme of classification for articles, outlined in great detail in the Editorial Introduction and the Introduction to the Index. Janet Hogarth was in charge of a team of women indexers who arranged EB11 articles into clear topics and subtopics to provide better access to the information within, as well as fact checking and cross-checking entries for inconsistency. ${ }^{94}$ Beyond an alphabetical list of all the eleventh edition articles, the index also featured a 'Classified Table of Contents'. In this Table disciplines provided the overarching structure and biographies of key individuals within each discipline were included in the classification. Therefore, its editors proposed, the index comprised 'what we believe to be the first attempt in any general work of reference at a systematic subject catalogue or analysis of the material contained in it'. ${ }^{95}$

'Archaeology and Antiquities' was one of the disciplinary categories. Subjects listed included ancient civilisations such as 'Hittites' and 'Mound Builders', archaeological features such as 'cist' and 'cliff dwellings', periods such as 'Mousterian' and 'Neolithic' and objects such 
as 'chariot' and 'scarab'. Individual sites were listed under the discipline 'Geography', while elements of ancient culture were listed under the disciplinary categories 'Art', 'Philology' or 'Religion'. A list of biographical entries within the Archaeology and Antiquities categories comprised a roster of past and current contributors to the discipline. As EB11 claimed to reach beyond the remit of the Dictionary of National Biography in its inclusion of biographies of living scholars, these biographies represent a list of some of the best known intellectuals of the day. Petrie, Percy Gardner and Ernest Gardner and the archaeologist and explorer William Mitchell Ramsay were included among them. ${ }^{96}$

Each biographical entry provided an outline of educational and professional status, as well as a list of important publications and the years in which these appeared. Petrie's biographical entry defined him as an 'English egyptologist' [sic] whose reputation had been established since 1891. Alongside referencing key sites Petrie had excavated, the entry noted his work in establishing the Egyptian Research Account and the British School of Archaeology in Egypt. His memoir Ten Years' Digging is referred to twice in the context of the entry, evidence of its popular appeal. ${ }^{77}$

When EB11 was published in January 1911, it was hailed as a 'work of the greatest magnitude', and the decrease in weight and shelf space in comparison to previous editions was noted and praised. ${ }^{98}$ Horace Hooper's forceful marketing and sales strategies had caused consternation in the British press when The Times EB had appeared in 1898. But, as Thomas notes, Hooper's commitment to making knowledge accessible to the widest number of people possible, and explicitly targeting middle- and lower middle-class self-improvers, underpinned these techniques. By 1911 the qualms over Hooper's marketing drives largely disappeared - helped, Thomas suggests, by the collaboration with Cambridge University Press as publisher. ${ }^{99}$

Hooper's marketing strategies appeared in full force in newspapers. One advertisement in the London Daily News a few months following the eleventh edition's publication released the names of 160 eminent purchasers of the work out of a total of 20,000, bishops, peers and MPs, men and women. Early subscribers to EB11 were offered a discount, and payment could also be made after delivery in instalments. ${ }^{100}$ It was offered in both leathers and hard paper bindings, and the availability of India paper printing ensured that each volume could be as light as possible. There were also other options for purchasing the work. By 1912 the London Daily News offered potential purchasers the opportunity to acquire the work in parts, priced at 3 shillings and sixpence, issued fortnightly. 
Coupons were included in newspapers for use at vendors from whom the 3/6 parts could be purchased; these coupons also enabled purchasers of part 1 to obtain subsequent parts fortnightly thereafter. ${ }^{101}$

Expert author visibility was incorporated into this marketing. Contributors were named in advertising, drawing on the public awareness of, and thereby increasing, their public presence - a strategy that stemmed from the previous edition. ${ }^{102}$ One London Daily News article listing '100 among 1,500' contributors had a section on 'Greece and Rome' that highlighted Percy and Ernest Gardner and D. G. Hogarth. ${ }^{103}$ Advertising for the fortnightly 3/6 EB11 parts appearing in the London Daily News in 1912 took this concept further: it included reproduced photograph portraits of key contributors with their positions featured. Hogarth and Petrie's portraits appeared in an EB advertisement for the first serialised part in February 1912. Within it were articles on archaeological topics from Petrie, Hogarth, Ernest Gardner, Francis Llewellyn Griffith, Robert Alexander Stuart Macalister (a Palestine Exploration Fund excavator) and William Ridgeway (a former Disney Professor of Archaeology). ${ }^{104}$

Subject-specific serialised compendiums were also published in the early part of the twentieth century. ${ }^{105}$ Pictorial history compendiums created for general readership placed 'modern' archaeological work in the context of the history of the world, its regions, civilisations and peoples. Like the Encyclopaedia Britannica, these compendiums could be purchased in parts for a lower price, spreading out the total cost of the volume. They featured archaeological authors alongside scholars and others with regional and subject expertise, complementing the periodical press in the market for archaeological knowledge and visibility of archaeologists.

The newspaper baron Alfred Harmsworth (Lord Northcliffe) played a critical role in facilitating the production of these cheap, accessible serial publications, dubbed 'fortnightlies'. ${ }^{106}$ Harmsworth employed John Alexander Hammerton, an experienced newspaperman, to edit these works under a specific imprint, the Amalgamated Press's Educational Book Company. ${ }^{107}$ Parts were published every two weeks at a cost of six or seven pence per part; these could then be bound into large, encyclopaedic volumes when all the parts had been acquired. Each part was generally split in such a way as to encourage continued reading. 'Chapters' (articles) could end almost mid-sentence, leaving readers poised on a veritable cliff-edge - a serial much like archaeology itself, with its lingering, unanswered questions at the end of a season. In the 1920s Hammerton explained this design method to a complaining reader. His response was 
printed in his editorials on the inside front cover of the magazine in order to ensure it reached a wider audience:

The single Part must be regarded as a divisor of the whole, and not as a complete unto itself, so that it will often happen that articles are broken...I have urged upon my readers to remember that the fortnightly issue should be regarded merely as a contribution to a concerted whole ... ${ }^{108}$

Harmsworth's History of the World first appeared in 40 fortnightly parts from October 1907. ${ }^{109}$ Based on Hans Helmolt's History of the World, a scholarly German compendium, it bore the hallmarks of Harmsworthian 'popular journalism', including a significant number of illustrations, and drew on 'eminent English writers' to contribute bespoke pieces for the work. ${ }^{110}$ These authors included archaeologists Flinders Petrie, Archibald Henry Sayce, Harry Hall and Leonard King. Hammerton was particularly surprised at the 'tradesmen'-like manner of attaché-case carrying Hall and King, Assistant Keepers under Wallis Budge at the British Museum. On arrival at the Harmsworth offices of Carmelite House, they immediately began negotiating 'the money value' of their contributions with unexpected savviness. ${ }^{111}$

Hammerton, along with Arthur Mee, the editor of Harmsworth's Self-Educator, and A. D. Innes were the Harmsworth History's general editors. With its chronological and anthropological framework, contributors to History of the World used geography and racial theories to underpin the formation of the text. Its expanded version, The Book of History: A History of All Nations, was co-published with the American Grolier Society from 1915. According to Hammerton, the 'immense circulation' of this kind of serialised publication took book publishers completely by surprise. ${ }^{112}$

The intellectual prowess, 'scientific' methods and personal involvement of the contributing authors in 'the field', rather than the academy alone, were front and centre in the first volume of Harmsworth's History of the World. It began with lists of Contributing Authors and Editorial and Contributing Staff, who were mainly British, American and German. In their introduction to the work, its editors declared it to be 'the product of experience ... a book of history by writers and makers of history; it is a book of action by men of action; it is a book, that is, by men who know intimately the real life of the world' (original emphasis). ${ }^{113}$ Petrie, as one of the key contributors, was valuable not only for his knowledge 
of ancient Egypt through study, but also for his lived experience in the country.

Each of the volumes had a specific plan, adding up to eight 'Grand Divisions'. The first division, 'Man and the Universe', contained an outline of geological and human history from the beginning of the universe to modern times. The following divisions were geographical: The Far East, the Middle East, the Near East, Africa, Europe (a history in seven parts) and America. To 'Man and the Universe' Petrie contributed two significant chapters on the emergence of 'civilization' in Egypt and Mesopotamia, while D. G. Hogarth contributed a chapter on the same theme in Europe. The Near East division included contributions from Archibald Henry Sayce on 'Ancient Civilizations and their Vanished Glories' and Hall and King on the history of 'Western Asia' to the modern period. Petrie returned to explore 'The Continuity of Civilization' at the beginning of the Sixth Division (European History), pontificating on Europe's role in leading the investigation into the history of ancient civilisations through archaeological research. As with the Encyclopaedia Britannica, advertising for the serial included the names of key contributors, including Petrie and Sayce.

Hutchinson \& Co's lavishly illustrated History of the Nations (Fig. 4.6) was a rival to Harmsworth's History. First published in January 1914, it totalled 50 seven pence parts issued fortnightly, available for purchase from newsagents and booksellers. ${ }^{114}$ It featured narratives of the history of various countries and civilisations, from the earliest times to the modern era, and claimed to feature all the latest research. In his introduction to the work, general editor Walter Hutchinson described how progress in historical research had moved beyond classical and oral historical sources, stating '...there are older and more reliable historical records which, though not literary, are not the less eloquent. The geologist and the archaeologist are the chief coadjutors of the modern history of early man'. ${ }^{115}$ As in Harmsworth's History, Hutchinson's compendium featured imaginative reconstructions of key scenes and sites referred to in the text. ${ }^{116}$ In addition to these, reproductions of works in museums and galleries and photographs credited to archaeologists or archaeological societies of cleared sites and excavations in progress made up the over 2,000 images included in the series. The combination of reconstruction, excavation and artefact reinforced the connection between past and present in archaeological life.

Advertisements emphasised the expense laid out to bring this 'sumptuous work' and its 'popular, concise, pictorial, and authoritative' 


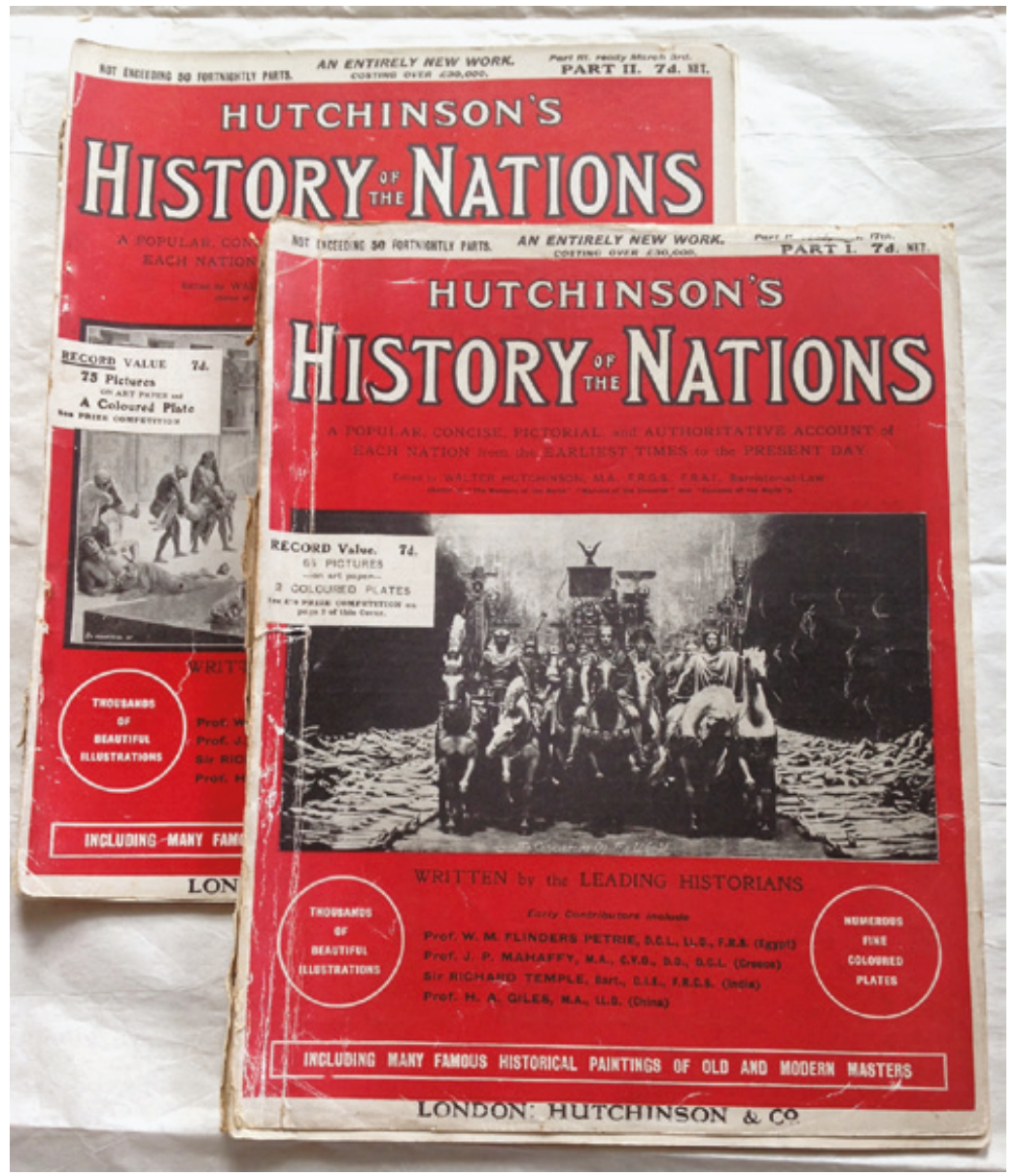

Fig. 4.6 The first two parts of Hutchinson's History of the Nations. (Author's collection)

articles to the hands of a general readership. ${ }^{117}$ The first part began with Egypt, and featured Flinders Petrie's contribution on its ancient history, which the Daily Mirror announced had never been published before. His words were further enhanced by the reconstruction drawings of scenes in ancient Egyptian life, some of which were the work of artist Winifred Newberry Brunton. She had studied Egyptology with Petrie and worked on archaeological sites with her husband Guy Brunton. ${ }^{118}$ Within a month Hutchinson \& Co's advertising declared History of the Nations a success, with a single firm purchasing 40,000 copies of the first instalment. ${ }^{119}$ The names of 'celebrity' contributors were used to 
boost advertising and were seen as a guarantee for the quality of the publication as a whole - a celebration, indeed, of British scholarship at a 'high point' in imperial history. ${ }^{120}$

In the early 1920s Harmsworth's Amalgamated Press released the illustrated Peoples of All Nations, a Hammerton-edited weekly in 60 parts, available for purchase for 1 shilling and threepence (later reduced to sixpence) per part. It was a global survey of the world's inhabitants, released in alphabetical order. Like Harmsworth's History of the World, Peoples of All Nations offered the British public a carefully constructed image of countries and peoples that most readers would never see in the flesh, while emphasising the need, since the First World War, for a new recognition of a 'global' rather than 'nationalistic' civilisation. Therefore it drew on the knowledge of those people (mainly though not exclusively men) who had personal experience of a world beyond Britain's borders - particularly regular travel writers. ${ }^{121}$ Proclaiming it 'a condition of our plan' that only writers with the proper authority could be contributors, a number of now-familiar archaeologists were included. A 'representative group' of 'explorers, travellers and historians', with photographs and short notes on their expertise, were featured in a Gallery of Contributors. ${ }^{122}$ D. G. Hogarth was among the contributors profiled. Fresh from his war service running the Arab Bureau (a Cairo-based intelligence network) and playing a role in the Arab Revolt alongside T. E. Lawrence, he wrote about the history of Hejaz and Arabia. Petrie contributed an analysis of the history of Egypt, while Arthur Weigall, an Antiquities Inspector in Egypt for over a decade, wrote about the 'life of Egypt' - modern Egyptians and their culture, religion, costumes and practices.

Reflecting on the work years later, Hammerton judged it to be one of his 'winners'. ${ }^{123}$ Although acknowledging the potential detrimental effect the Harmsworth brand might have on the scholarly reception of its educational publications, Hammerton thought it worthwhile because of the vast readership, 'boldness of publishing' and generosity in remuneration for contributors a Harmsworth imprint brought with it. ${ }^{124}$ His list of eminent contributors, which he figured to be in the hundreds, obviously felt the same way. ${ }^{125}$ Harmsworth's Universal History of the World was published soon afterwards (Fig. 4.7). Each part was less than 100 pages with 200 illustrations and four colour plates. The front cover of each paperback part advertised the brand; for Part 3, Harmsworth boldly declared: 'You need a History - this is the History You Need.'

Hammerton noted that although the Universal History represented 'a new and elaborate (and extremely costly) method of illustrating 


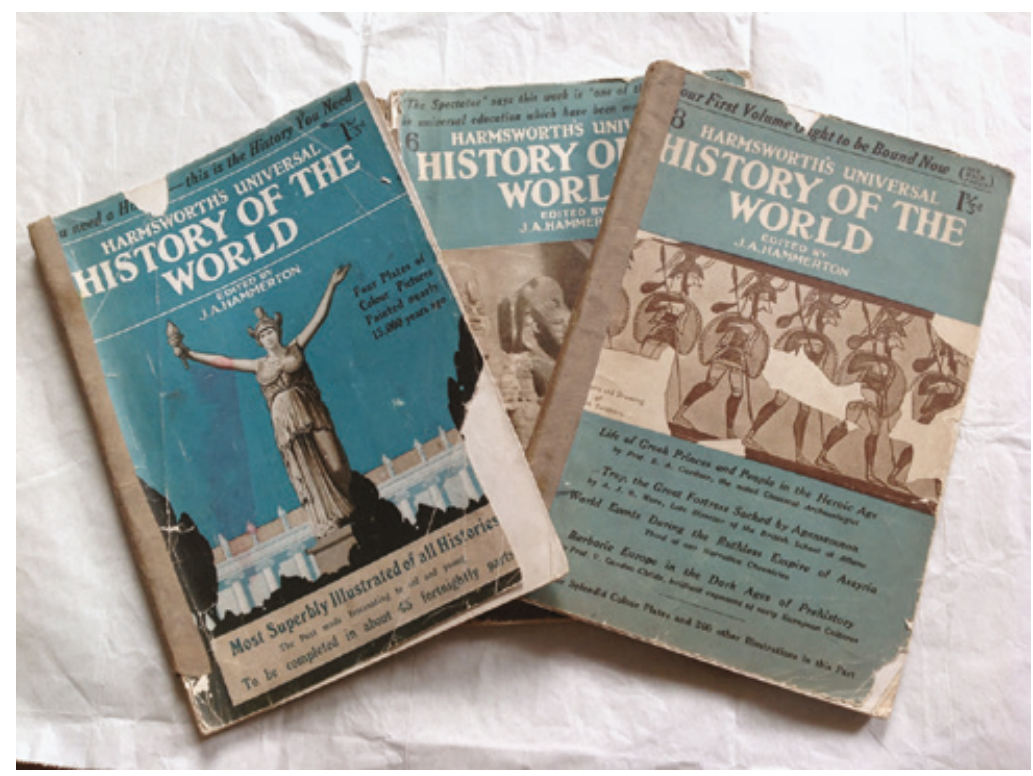

Fig. 4.7 Parts 3, 6 and 8 of Harmsworth's Universal History of the World. (Author's collection)

history', its authoritative articles found favour with scholars and students worldwide. ${ }^{126}$ It showcased the work of younger scholars alongside older ones, signalling a fresh start at the beginning of a new era of peace. Photographs now dominated the illustrations featured, showing artefacts from a range of museums and collections alongside excavators' own photographs and illustrations taken from publications, with captions providing reference information. On the inside back cover of each part brief biographical profiles accompanied thumbnail photographs of the authors included.

Chasing the popularity of archaeology after Tut, in 1923-4 Harmsworth issued Wonders of the Past, a fortnightly devoted exclusively to the results of archaeological work. With Wonders, Hammerton produced what he considered to be 'the first attempt' to bring the insular and specialist discipline to a 'general reading public'. ${ }^{127}$ He drew on longstanding friendships with archaeologists William Mitchell Ramsay and Archibald Henry Sayce in the initial stages of the work. ${ }^{128}$ In his introduction to the series, Hammerton emphasised the recent shift in public awareness of archaeology, and the move away from a view of archaeology as a dull, dusty, museum-bound study to an innovative, romantic science. Framing the postwar period as an age of renewed 
support for archaeological expeditions (and international AngloAmerican collaborations), Hammerton declared it was the time of the 'new archaeologist'. ${ }^{129}$

When put together, the serialised parts of Wonders of the Past explored archaeology through a series of eight key topics: ancient cities, tombs, palaces, monuments, temples, construction, arts and crafts and the seven wonders of the ancient world. ${ }^{130}$ In arranging the parts in this way, actively breaking down the systematised, scholarly, chronological approach, Hammerton sought to make the work accessible and 'popular' while retaining the value of the contributor's expertise. While contributors were a mix of archaeologists and writers, the majority were archaeologists, a fact that meant the work won favour with the scholarly community. ${ }^{131}$

As an extra enticement for prospective purchasers, the Amalgamated Press offered a 'free gift' with all officially bound volumes (done through the company, not with an unauthorised binder): large photographs of three key contributors, bound into the front of each volume. The first three-volume edition of the compendium features Petrie, artefact in hand, leaning almost seductively against a case full of ancient objects in the museum he established at UCL, showing it off to the camera. The caption under the photograph begins 'Sir W. M. Flinders Petrie: Doyen of British Archaeologists'. ${ }^{132}$ Among the contributors were some, such as Petrie and Arthur Weigall, who had written for Harmsworth's previous publications. However, Wonders also included many other active archaeologists, a number of whom, such as Leonard Woolley, Rex Engelbach and John Garstang, had been Petrie's students. It also included women among the contributors, specifically Margaret Murray, Eugénie Sellers (under her married name Mrs Arthur Strong) and Jessie Mothersole. Murray was among the most prolific contributors to the series, while Mothersole was an artist who had worked with Murray copying tomb paintings at Saqqara 20 years earlier. ${ }^{133}$ At the time of publication Mothersole had just produced her own illustrated travel guide to Hadrian's Wall; it was this monument of the Roman era that formed her Wonders contribution.

Wonders was also published in the United States and sold widely there. In the 1930s it was reissued, the chapters revised and a new topic, 'The Study of the Past', added to the eight originally included. In all Hammerton assessed the work's popularity to be slightly below that of his other serialised works, but nonetheless a 'substantial success'. ${ }^{134}$ Wonders of the Past reached Britain's imperial outposts too - parts were available through Amalgamated Press agents in Canada, South Africa 
and 'Australasia', as well as G. P. Putnam's Sons in New York. In his editorial commentary of 13 November 1923 Hammerton was pleased to announce the possibility of an Arabic edition on receipt of a letter from 'the Education Department of a Government in the distant East'. ${ }^{135}$

In 1933 Flinders Petrie took his first flight, leaving London's Croydon airport on Imperial Airways liner Horatius for a short jaunt to the 'Riviera' of Northern France, in advance of Imperial Airways' launch of a special weekend service to the bright lights of Le Touquet's casinos. ${ }^{136}$ On alighting from the plane in London on his return, he gave an interview on the experience to an Associated Press journalist. The story of Petrie's flight, taken in his eightieth year, circulated round the country the following day. ${ }^{137}$ Petrie was by this point a famous travelling excavator, and his interview effectively endorsed commercial air travel as the latest development in modern technology and convenience. Gaza was now a stop on the Imperial Airways route - another line on the map for imperial travel and travellers. This incident emphasises the celebrity that Petrie had built up over the decades, facilitated by a good relationship with the newspapers, additional promotion in serial publications and compendiums and his own efforts to market himself as a regular traveller and expert on foreign cultures. Petrie, in his way, had helped to kick-start serial (imperial) archaeology in the 1880s - how fitting that by the end of his career he was syndicated. 


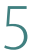 \\ Scripting and Selling Archaeology}

You have often been telling me to write for the public .... ${ }^{1}$

In 1890 Flinders Petrie began to write his first memoir, Ten Years' Digging in Egypt. He was in Palestine, finishing up his excavations at Tell Hesy for the Palestine Exploration Fund. The chapters he outlined while 'delayed in Jerusalem' were pitched at those who might be subscribers to excavation funds: 'interested but ignorant in general'. The chapters were to be written in a lecture style - a lecture being the ideal medium for translating 'scientific matters' into publicly accessible print, and one at which Petrie was by this point adept. Of his manuscript he declared, 'there is not a single measurement or exact statement of quantity in the whole of it'. The title was of his own making. Sensing that timing was important and could make the book more marketable, he planned to finish the manuscript the following season in order that it could be 'Ten Years' Digging in Egypt'. ${ }^{2}$ The bulk of his chapters roughly followed a chronological arrangement, focusing on one site per chapter.

Although his correspondence suggests that Petrie forced himself to write Ten Years', ultimately he felt it was worth his time. ${ }^{3}$ In his Preface to the finished work, he drew on the topographical imagery of the field to outline the projected audience of the book: 'the large number of readers who feed in the intermediate regions between the arid highlands and mountain ascents of scientific memoirs, and the lush - not to say rank - marsh-meadows of the novel and literature of amusement'. ${ }^{4}$ Within the first few pages of the work readers encountered Petrie's field literally mapped out on the page, with the sites on which he worked in the decade covered in the book plotted on a basic sketch map of Egypt. At the end of the book Petrie endeavoured to make the field more accessible for 'active trippers', as he called them, rather than passive tourists. He provided an addendum of Arabic words to add to those already 
covered by popular guidebooks, as well as a guide to 'The Fellah', which he planned to be 'a careful estimate of the Egyptian's character; with a view to enlightening home-folks as to the real nature of the people + state of the country'.

In this chapter Petrie thus situated himself as translator of Egypt (ancient and modern) to his British readers, emphasising his linguistic competence and ability to give them access to knowledge beyond the ordinary. At the same time he attempted to distance himself from a perception of being 'Egyptianised' himself - rejecting an accusation, as he stated in Ten Years', of 'having gone some way towards them'. ${ }^{6}$ Petrie also used Ten Years' to begin to codify his approach to the field; although it was not in his original outline of the book, he eventually added a chapter on 'The Art of Excavation'. In it Petrie outlined what basic changes in the landscape might signify for excavation. It was well illustrated with his own drawings, prepared by a new process of his own creation. Some of the objects represented, so he claimed in the Preface, were being published for the first time. ${ }^{7}$

Petrie drafted the manuscript for Ten Years' while growing increasingly concerned about the expense of publishing his scientific works. The copious illustrations he included in his excavation memoirs (some of which were in colour) were costly to produce, making the books in turn costly to purchase. He was also publishing them at his own risk, investing his own funds with a publisher to produce the books and negotiating directly with booksellers who would take a cut of the sale. Fortunately for Petrie, the Religious Tract Society (RTS) took on the publication of Ten Years', offering him the choice of a royalty of one pence per shilling or a $£ 50$ advance. When published, the cloth-bound volume cost 6 shillings and was available from the RTS's offices at Paternoster-row, and in other booksellers. ${ }^{8}$

Archaeologists scripted spadework into books to package archaeological knowledge for a variety of publics. Through publishers' series and universal libraries, archaeology was connected to other disciplines and situated within the larger sphere of knowledge. The production and consumption economics of archaeological titles, gleaned through publishers' advertisements, authors' contracts and print sales, as well as from library catalogues and booksellers' lists, reveal how these books were promoted, circulated and received, both at home and abroad. Traces of personal readership and reception through marginalia and other sources offer glimpses into the effect these books had on those who used and enjoyed them. 


\section{Book series and archaeology}

The previous chapters have introduced some forms of popular publishing in archaeology - travel guides and travelogues, memoirs and compendiums. The production of 'book series', which Aileen Fyfe defines as 'the genre... where each published unit has the form of book, but is issued as part of a larger, periodic project', also helped archaeologists strengthen their relationship with publishers. ${ }^{9}$ The RTS published several archaeological series in the late nineteenth and early twentieth centuries. By the late Victorian period, the Religious Tract Society had a long history of publishing 'popular' science generally and archaeology specifically. Founded in the last year of the eighteenth century, it was an evangelical society dedicated to spreading its missionary message at home in Britain and eventually further afield. Fyfe has explored the role of the early to mid-Victorian Religious Tract Society in popular science publishing in interpreting science for a Christian public, with their books and tracts aimed at readers of all levels. She cites both the industrialisation of publishing and distribution processes and the evangelicals' value of literacy as causes for the RTS's success. ${ }^{10}$

For the RTS, with Christianity at its heart, the archaeology of the Bible lands was a particularly relevant topic for publication. Wallis Budge outlined the origin of the RTS's engagement with archaeology in Cleopatra's Needles and other Egyptian Obelisks (1926), dating it to 1848 when the Society's Committee became aware that the excavations of Austen Henry Layard, John Gardner Wilkinson and others in Assyria and Egypt would contribute to 'the study and right understanding of the historical and other books of the Bible'. ${ }^{11}$ This resulted in the publication of Ancient Egypt: its monuments and history in the Society's 'Monthly Series' of sixpenny volumes in the 1850s, advertised as 'SCRIPTURAL... POPULAR...PORTABLE .... and ECONOMICAL. ${ }^{12}$ The Monthly Series included a number of books on archaeological or ancient history subjects. Although these were not explicitly identified as archaeological, as Fyfe has shown the RTS used advertising to group books into subject 'series' in an overarching Christian framework. ${ }^{13}$

While Ancient Egypt and a number of other books relevant to archaeology in the series were published anonymously, Budge particularly singled out the work of biblical scholar John Kitto, who had contributed volumes on ancient and modern Persia and Jerusalem. Thirty-odd years later, according to Budge, the 1877 removal of Cleopatra's Needle from Egypt to London and Britain's occupation of Egypt in 1882 were 
significant events in the history of RTS's archaeological publications. The Society took advantage of the renewed interest in Egypt to formulate a new series, 'By-Paths of Bible Knowledge', which would focus on the archaeology of Palestine, 'Western Asia' and Egypt. ${ }^{14}$

Rev. James King, author of the first 'By-Paths' book Cleopatra's Needle, was credited with encouraging the RTS to start this new archaeological series. King had a long association with the Palestine Exploration Fund; he was himself a Fund authorised lecturer and had collaborated with Samuel Birch on the compilation of the book. Series advertisements proclaimed the books were for 'general readers': those who were seeking concise and stimulating summaries of the latest research in 'so many departments of Biblical study'. ${ }^{15}$ By this point, as Budge put it, 'the progress of Egyptology and Assyriology had advanced by leaps and bounds'. The 'By-Paths' volumes were 'warmly received' and successful in the long-term. ${ }^{16}$

Fyfe gives a detailed description of the editorial processes of the RTS in the 1840s and 1850s during the production of their Monthly Series. This process was in the hands of the RTS's Copyright Committee, whose minutes for this early period are still extant. The Copyright Committee evaluated incoming manuscripts for 'Christian tone', while relying on external readers for critical assessment of the text. ${ }^{17}$ Gaps in the RTS archive mean that the Copyright Committee's work in the late nineteenth and early twentieth centuries is much less visible, although they did report to the RTS Executive Committee on the manuscripts they recommended for publication. In the 1880s the Copyright Committee members are still listed as readers, but no external readers are listed, which suggests editing was now done in-house, privileging both authorship and content. ${ }^{18}$ While the RTS's mid-Victorian Monthly Series included a number of anonymously written works, by contrast in 'ByPaths' the RTS took full advantage of the authority of an author's name and scholarly credentials, which were included in advertising.

Among the Executive Committee minutes for the early 1880s are notices of manuscripts accepted that were destined to become the first tranche of the 'By-Paths' series. These include the socialist reformer and British Museum lecturer Margaret Harkness's Assyrian Life and History (By-Path II) and Egyptian Life and History (By-Path VII), Wallis Budge's book Babylonian Life (By-Path V) and Archibald Henry Sayce's Fresh Light fromtheAncientMonuments (By-PathIII). TheRTSadvertised theirauthors as subject specialists who had 'special' access to the latest discoveries and research. ${ }^{19}$ An introduction from the British Museum's Reginald Stuart Poole boosted the authority of Harkness's text, but Cambridge-educated 
Budge, then an Assistant in the Oriental Antiquities Department of the British Museum, and Sayce, Deputy Professor of Comparative Philology at Oxford, could rest on their own laurels.

The process of compilation and editing of this series is not evident in the archive, but in his memoir Sayce recorded that he wrote Fresh Light from the Ancient Monuments over the course of three weeks at the Society's request. It was, he wrote, an attempt 'to take stock of our present knowledge, and to see how far it bears out that "old story" which has been familiar to us from our childhood' - in other words a 'fresh' look at recently discovered monuments that seemed to reflect the biblical narrative. ${ }^{20}$ For this three-week investment of his time producing a work of 'quasi-theology' Sayce received what he considered an 'excessive' sum. His book was a success, however. He noted that it went into multiple editions (a 1900 edition of the work lists reprinting dates in 1885, 1886, 1889, 1890, 1891, 1893 and 1895), was translated into other languages and widely imitated. ${ }^{21}$ Sayce wrote a number of titles in the series, making him one of its most regular contributors. There were over 20 'By-Paths' volumes in all. Each was less than 200 pages and priced between 2 and 3 shillings in cloth covers, making them among the most affordable of the 'popular' archaeology books published before the First World War. Challis notes that they were popular with Sunday Schools as presenting material evidence of the Bible. ${ }^{22}$

Sayce also wrote for another RTS series, 'Present Day Primers'. These handbooks published in the 1890s were aimed at 'ministers, teachers of Bible classes, and ... all general readers' interested in biblical research and religion. His Primer of Assyriology introduced this readership to the geography, literature, history and daily life of Assyria and Assyrians, as well as the chronology of excavators and discoveries relating to its ancient peoples and places. ${ }^{23}$ Although the high point for the RTS's engagement with 'popular' archaeology publishing was before the First World War, the RTS continued to publish such books after the war. These were advertised together rather than being included in a specific series.

The Society for Promoting Christian Knowledge, which had an even longer history of printing educational Christian texts than the RTS, instigated the 'Ancient History from the Monuments' series in the 1870s to provide regional histories based on archaeological remains in the lands of the Bible. Regions covered included Egypt, Assyria and Persia. Authored by scholars from the Society of Biblical Archaeology and the British Museum, including Samuel Birch, George Smith and A. H. Sayce, these two-shilling volumes were written in clear, accessible English and 
aimed at a wide readership who without them would be unable to access information on the latest findings and developments in knowledge. They were successful in doing so. By 1890 Birch was dead, but his book, Egypt from the earliest times to $B C 300$, was on its 'tenth thousand' printing. ${ }^{24}$

Kegan Paul's affordable series 'Books on Egypt and Chaldea', issued in the first decade of the twentieth century, provided the British Museum's Department of Egyptian and Assyrian Antiquities with an opportunity to publish the research of its staff in a 'popular' format. ${ }^{25}$ By this period Kegan Paul, Trench, Trubner \& Co represented the amalgamated publishing houses of Kegan Paul, King and Trubner \& Co, with Trench as Kegan Paul's partner. ${ }^{26}$ King had established the 'International Scientific Series' and Trubner had its 'Oriental Series', so Kegan Paul, Trench, Trubner \& Co's 'Books on Egypt and Chaldea' could be said to combine the ethos of 'Oriental Series', with its focus on 'Eastern' cultures, with the latest in 'scientific' archaeology. The 'series of short popular handbooks ... at moderate prices' had been commissioned as a wide-ranging introduction to the culture, religion and language of the ancient Egyptians, Babylonians and Assyrians. ${ }^{27}$ Wallis Budge, at that time Director of the Department, was the series editor, and wrote most of the volumes in the series; a few were authored by his assistant Leonard King. ${ }^{28}$ These drew on the work that Budge and King had published in scholarly volumes, but - at under 200 pages per book and priced at 3 shillings and sixpence - this series was accessible to the interested amateur. Eventually volumes on more specific topics were included in 'Books on Egypt and Chaldea', particularly Budge's History of Egypt mini-series (post-dating by a few years a series on the same topic edited by Petrie for Methuen) and his handy volumes of the 'Book of the Dead', which Budge biographer Matthew Ismail notes became popular with those with an interest in the occult. Budge had previously published a transliteration, translation and vocabulary of the Book of the Dead with Kegan Paul, but the volumes first published in 'Books on Egypt and Chaldea' were only the English translation of the text based on papyri in several collections. ${ }^{29}$

From the turn of the twentieth century, archaeologists' popular archaeology books were also incorporated into a number of other disciplinary series. While the RTS, SPCK and Kegan Paul's series focused on the literary and historical elements of the Bible and other ancient texts as well as archaeological research, archaeologists were able to fit their work into other subject-specific and general series to ensure their expertise reached diverse audiences. Under Orientalist scholar Arthur Strong's editorship Duckworth's 'Library of Art' was established; on his death his archaeologist-wife Eugénie Sellers (Strong) took on the series. She 
published two volumes on Roman art in the Library in 1907, followed a few years later by Ernest Gardner's book Six Greek Sculptors; these volumes provided an ancient context to the series. Sellers based her books on a 'series of lectures' outlining her approach to the study of Roman art, while Gardner's aim was to provide an introduction (for 7 shillings and sixpence) to key artists in ancient Greece, without overburdening readers with a lengthy discussion of the history of art. Each volume contained references and copious photographic reproductions. ${ }^{30}$

Known for their exacting and aesthetic production standards, and taking a more materials-centred route, the Edinburgh and London publishers T. N. Foulis's 'Arts and Crafts of the Nations' series included works on Old Japan and Older Spain, to which a lavishly illustrated five shilling volume from Petrie, The Arts and Crafts of Ancient Egypt, was added. ${ }^{31}$ Its chapters laid out ancient Egyptian art by medium and type wood, ivory, stone, pottery, textiles, painting, sculpture and architecture were all covered. Originally published in 1909, Petrie's book went into a second edition in 1910 with an additional chapter on Egyptian art in a 'global' context. His goal with this new addition was to combat what he considered to be England's misguided love of ancient Greek art, and to inspire a new appreciation for ancient Egyptian art. ${ }^{32}$

Similarly the Medici Society, initially a subscription society established in 1908 by publishers Philip Lee Warner and Eustace Gurney, produced many high quality aesthetic archaeological works. Lee Warner was noted at his death for his persistence in bringing books on archaeology and art to a wider audience. These included Wallis Budge's five illustrated, contextualised translations of ancient texts in the British Museum that appeared both before and after the First World War. In addition, between 1912 and 1916 Lee Warner issued the 'Handbooks to Ancient Civilisations' series under the general umbrella of the Medici Society. Produced as English-language introductions to the field and the history of excavations for a 'general reader', the series bore the hallmark of a Medici Society production with numerous high quality illustrations, including a few in colour. All the authors were connected to the British Museum and, judging from the prefaces in each book, Wallis Budge played an instrumental role in the series' production by soliciting manuscripts. Thomas Athol Joyce for instance, an Assistant in the Department of British and Medieval Antiquities and Ethnology who was excavating Central and South American sites, contributed three books on South American, Mexican and Central American, and West Indian archaeology respectively. Percy Handcock and Harry Hall from Budge's Department of 
Egyptian and Assyrian Antiquities produced books on Mesopotamian Archaeology (Handcock) and Aegean Archaeology (Hall). Budge noted that Handcock's Mesopotamian Archaeology was popular during the First World War, as thousands of Indian Expeditionary Force soldiers, stationed in what would become Iraq during the Mesopotamia campaign, progressed through the ancient landscapes of Assyria and Babylonia. From the pen of Lionel Barnett, Keeper of the Department of Oriental Printed Books, came a book on Indian antiquities. Priced at 12 shillings and sixpence, the series was on the expensive end of the 'popular' scale. However, the intention was to reach a non-specialist audience with the money to invest and who would appreciate the high quality production. ${ }^{33}$

Geographical series offered another venue for archaeologists who could exploit their travels and exposure to other cultures for these works. At the start of the twentieth century from William Heinemann's publishing house came the 'Regions of the World' series; its editor Halford John Mackinder was an eminent geographer and champion of the University Extension movement. Each volume explored a designated region through both its physical and cultural elements - descriptions of the physical landscapes complement descriptions of the lives of the people. In writing The Nearer East (1902) for this series, D. G. Hogarth aligned himself with the new 'scientific' geography. The 7 shillings and sixpence book was meant to make geography 'generally intelligible' to a wide audience, and Hogarth's visible knowledge of the East gave his words authority. ${ }^{34}$ Significantly the series enabled Hogarth to define a geographical boundary around the 'Nearer East' at a time when the power of the Ottoman Empire would soon be challenged and nationalist movements were emerging in the Balkans.

Two years after The Nearer East was published Hogarth contributed to pioneering geographer-educator John Scott Keltie's 'Story of Exploration' series for the publisher Lawrence and Bullen. This series used the story of travel to highlight geographical themes, setting out the history of human-geographical interaction by land and sea and using the extant records to examine and promote adventurous (male) explorers. This approach formed, as Keltie put it, 'a biographical history of exploration', written by those 'who are recognised as authorities on the particular subjects with which they deal'. ${ }^{35}$

In contributing The Penetration of Arabia to the series, Hogarth's analysis of the exploration of the Middle East sat alongside similar narratives relating to India, North America, the Nile and the South Pole. He traced the history of exploration to the Arabian peninsula, emphasising Western 
scholars' long engagement with the region while commenting on its mystery - its lands still to be examined. Although he had no direct personal experience there, Hogarth claimed his authority sprang from a thorough knowledge of relevant travel accounts. Just as with his Nearer East, reviews picked up on the political relevance of Hogarth's work. The area was of increasing importance in international relations and for British interests in Suez, the Levant and India. ${ }^{36}$

Archaeological authors also contributed to philosophical series. Editors Shaporji Kapadia and Launcelot Cranmer-Byng sought to give British readers access to the insights of 'Eastern' philosophy and religion through the 'Wisdom of the East'. The series, originally published by Orient Press and subsequently acquired by John Murray, eventually totalled around 50 volumes, representing translations and extracts from Chinese, Japanese, Indian, Hebrew, Arabic, Persian and Egyptian sources. For the editors, the series was an effort to promote 'good-will and understanding between East and West' by providing the knowledge of the 'old world of Thought' to 'the new of Action'. They wished the volumes of philosophy and literature to help resuscitate 'that true spirit of Charity which neither despises nor fears the nations of another creed or colour' ${ }^{37}$ The series presented English translations of ancient philosophical and literary texts to modern readers at the affordable price of between 1 and 2 shillings each.

Margaret Murray's volume Ancient Egyptian Legends appeared in 1913. The translated tales she presented were written 'according to the English method', but without, she claimed, losing 'the expressions and metaphors of the Egyptian', thus emphasising her role as intermediary between the two cultures. Her intended readership was wide and she drew on popular themes as outlined in many horror stories of the day. Her introduction referenced the contemporary transfixion with ambulatory and 'unlucky mummies'; as she put it, 'the general public, who are increasingly interested in the religion and civilisation of ancient Egypt, but whose only means of obtaining knowledge of that country is apparently through magazine stories in which a mummy is the principal character'. ${ }^{38}$ This was the era of what Roger Luckhurst has called 'Egyptian Gothic' - a time when the popular tales of authors such as Algernon Blackwood, Bram Stoker and Sax Rohmer, whose Fu-Manchu stories included a supporting character called 'Dr Petrie', focused on ancient Egyptian bodies, religious practices and objects. Ancient Egyptian Legends, Murray emphasised, contained no mummies, but rather the gods of Egypt as represented in Egyptian literature with references to the texts from which the legends had been taken (for the benefit of students). Her 
goal was to demystify ancient Egypt, to make its religion less 'other' and more domestically acceptable. The Egyptologist Battiscombe Gunn, then dabbling in the occult and an associate of the occultist Aleister Crowley, also published Egyptian translations in this series. Years later Murray published her Ancient Egyptian Religious Poetry in the same series. ${ }^{39}$

Several archaeologists contributed to Constable's 'Religions Ancient and Modern Series', also published in this period. These books likewise offered basic introductions and histories of world religions, from the pens of publicly known experts. Each slim volume was no more than 100 pages; sold for a shilling, they covered diverse subjects from Anamism, Pantheism and Fetishism and Magic to Zoroastrianism, Hinduism and Shintoism, alongside historical studies of religion in ancient Greece (by Jane Harrison) and ancient Egypt (by Flinders Petrie). Theophilus Pinches, a former Assistant in the Department of Egyptian and Assyrian Antiquities, contributed a volume on Babylonian and Assyrian religion. References were again included to add to the value of these introductory texts for students. ${ }^{40}$

Finally Harper's 'Library of Living Thought' sought to bring together intellectuals' responses to the progress of modern life, enabling them to publish their 'philosophies' and analyses of the latest research in an accessible format, less than 200 pages, for 2 shillings and sixpence. ${ }^{41}$ As Bowler has noted, for science this meant discussion of 'evolutionary themes'. For archaeologists, the series enabled them to take comparative and interdisciplinary approaches. Ernest Gardner's contribution was Religion and Art in Ancient Greece (1910). Flinders Petrie sought to combine psychology and archaeology in his Personal Religion in Egypt before Christianity, and compared developments in ancient Egypt and Europe in The Revolutions of Civilisation. The anatomist and Egyptologist Grafton Elliot Smith provided an insight into the origins of ancient Egypt (1911), while the Eastern Mediterranean was the territory of husband and wife team Charles Hawes and Harriet Boyd Hawes. Their book Crete, the Forerunner of Greece (1909) presented an analysis of the state of archaeological research on the island, setting it within a modern historical context. This 'modern' context included references to measuring the heads of modern Cretans, a practice with racial anthropological overtones used at the time, to gain insights on ancient Cretans. ${ }^{42}$

Although most of the books discussed here relate to adult readers, archaeologists also sought to bring their expertise to younger audiences. The publisher George Harrap had only recently started his business when his series 'Books on Primitive Times' first appeared. Harry Hall, an Egyptologist by profession, contributed two books to this series: Days 
before History and Threshold of History. Harrap was known for his educational literary output - a list of recommended books in The Practical Teacher in 1910 includes a number of works on English and European history and legend published by Harrap, including Hall's. Hall used fiction to explore life in the British Stone and Bronze Ages through a child's eyes for children, 'present[ing] . . . the facts in a vesture of imagination, put together with as much verisimilitude as the writer can achieve, but with but the minimum of embroidery'. ${ }^{43}$

Days before History, the story of a young boy called Tig, was the means by which the tools and domestic settings of prehistoric periods could be placed in context, with a parallel narrative of Dick, a young boy 'of today', and his antiquarian uncle John looking for traces of prehistoric Britain (and in a later edition excavating a barrow). Many of the illustrations of objects were based on the British Museum's collections. Educationalist Joseph John Findlay's introduction explained Hall's efforts to write accessible, direct, hands-on history for children, relating the experience of ancient Britons (men, women and children) to the experience of modern Edwardian children. Though Hall is now primarily known for his excavations overseas in Egypt, Days and Threshold enabled him to spark interest in archaeology among the young at home. Days encouraged readers to engage actively in the process of reconstruction, with practical information on how to weave cloth, make pots and become self-sufficient; it predated Robert Baden Powell's Scouting for Boys by two years and experimental archaeology by several decades. Using Days, children could re-enact being an archaeologist on their own terms; Hall defined archaeology just for them. By 1927 the book had been reprinted 12 times, and revised and enlarged twice (Fig. 5.1). In his second children's book, The Threshold of History, Hall presented a narrative for the trade, religion, community and administration of the ancient peoples of Britain based on contemporary archaeological knowledge. It was explicitly designed for use in schools, and included reconstruction illustrations in both black and white and colour by artists Nancy Smith and Hilda Booth. ${ }^{44}$

Following Margaret Wheeler's successful memoir Walls of Jericho (1956), discussed in Chapter 3, she began compiling A Book of Archaeology. Here she brought together published and unpublished reports on archaeological excavations from around the world and edited them for younger audiences, providing some basic contextual information for each site and emphasising the adventurous side of excavation to appeal particularly to boys. ${ }^{45}$ By the 1950 s the public promotion of archaeology occurred in print, radio and the new medium of television, 


\section{St. paul's preparatory Srljorl, \\ COLET COURT, LONDON. \\ Inidsummer Torm, 1909 .

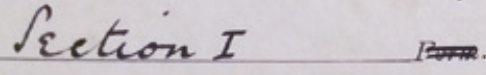 \\ Freekand Arawing Prise.}

Awarded to
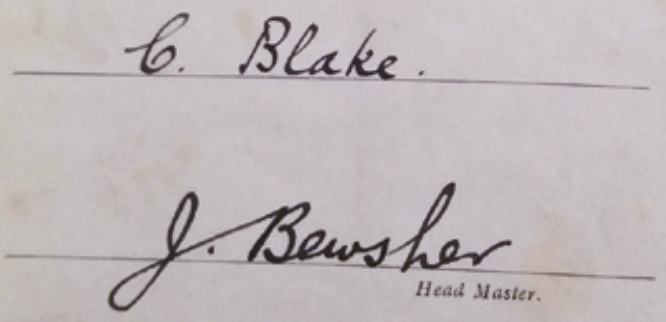

Fig. 5.1 Book plate in a copy of the second edition of Days Before History (1908) indicating that it was given to a young student at St Paul's Preparatory School in London as a prize for Freehand Drawing. By the end of 1907 10,000 copies of the first edition of Days had been printed; the second edition had a printing of 3,000 copies. (Author's collection)

via the archaeology-themed game show Animal, Vegetable, Mineral? in the early 1950s and subsequent television programmes Buried Treasure and Chronicle. ${ }^{46}$ Advertisements for Wheeler's Book of Archaeology indicates that her publisher Cassell hoped to capitalise on the enthusiasm for archaeology that these programmes inspired. ${ }^{47}$ The chapters of A Book of Archaeology were grouped geographically, representing Britain 
and Continental Europe, Scandinavia, the Middle East, South America, Africa and Russia.

Wheeler's correspondence with the archaeologist Osbert Guy Stanhope ('Ogs') Crawford in the summer of 1956, as she was gathering material for the book, reveals her desire to make the subject appealing to young people and to emphasise a 'can do' attitude. She found obtaining content that hit the right tone a difficult task, especially as she was working mainly from previously published specialist reports and books. She explained to Crawford her difficulty in sourcing accessible, exciting text. ${ }^{48}$ She wanted to showcase the variety of archaeological work, including not only field excavations, but also underwater archaeology through the story of the salvage of a 2,000-year old ship near Tunis and a specially written chapter on 'Archaeology from the Air' by Crawford. Wheeler commissioned it directly from him, asking Crawford to compose a piece that would be suitably dramatic and offering suggestions on elements to include. ${ }^{49}$

She drew on Crawford's knowledge to enhance the book, asking for recommendations on reports that might be suitable for her purposes. She also sent him a list of those she had already selected and those she had excluded because they lacked the necessary verve. ${ }^{50} \mathrm{He}$ advised that she include the American Egyptologist Herbert Winlock's discovery of a hidden vault containing a cachet of ancient Egyptian model scenes at Thebes, and this duly became A Book's opening chapter. She featured both the latest research and earlier publications: $A$ Book ranged from the mid-nineteenth-century excavations of Austen Henry Layard at Nimrud and Henry Creswicke Rawlinson at Behistun to Kathleen Kenyon's manuscript report on her continuing excavations at Jericho. Significantly, although Wheeler's book was aimed at boys and featured mainly the archaeological narratives of men, she included the work of two women in archaeology - her Jericho director Kathleen Kenyon and the AustrianChilean archaeologist Grete Mostny, investigating an Inca mummy. A Book of Archaeology went into at least three editions (1957, 1959, 1963), and its success enabled a follow-up Second Book of Archaeology in 1959. As with A Book, Wheeler took a broad geographical and chronological approach in her Second Book, drawing on published material for the extracts. $^{51}$

In the 1960s Mary Chubb began publishing a series of archaeology works for children with Geoffrey Bles, a London-based publisher who had brought out five of C. S. Lewis's Narnia books. ${ }^{52}$ Chubb used the alphabet to give her books an accessible structure. Her first children's book, An Alphabet of Ancient Egypt (1966), drew on the experiences she had in 
Egypt at Amarna, discussed in Chapter 3. Each letter of the alphabet represented a piece of the archaeological puzzle, covering archaeological methods, finds, historical figures (both ancient and modern) and activities. The striking design of the book, a page of text opposite a full-page illustration, some based on ancient paintings, helped to cement these concepts in readers' minds. The author and journalist Jessica Mitford recalled that on the recommendation of her grandchild Mary Chubb's Alphabet of Ancient Egypt was one of three books she read in preparation for her first trip to Egypt in 1977. Chubb's text in 'Cartouches' demystified that word for Mitford, defining the oval framing for hieroglyphics that was graphically interpreted in Jill Watts's accompanying artwork. Meanwhile 'Excavating' enabled Chubb to describe the processes of work on site - recording, subsequent destruction of layers, and publication - as well as the workforce carrying out most of the physical labour. In 'Flinders Petrie' Chubb continued her discussion of archaeological activity, describing Petrie's careful conservation of a painted pavement at Amarna with tapioca and water in the 1890s, while the final destination of excavated artefacts was revealed in 'Museums'. ${ }^{53}$

Chubb's subsequent Alphabets also represented a marriage of aspects of ancient life and legend and modern archaeological techniques and contexts - effectively scripting spadework for her readers (both young and old). In An Alphabet of Assyria and Babylonia (1969) she drew on her experience of working in the late 1930s at the Oriental Institute's excavations at the ancient city of Eshnunna in Iraq, something which she had already chronicled for adults in her 1957 memoir City in the Sand. 'Digs' in this Alphabet explores how and where archaeologists excavate sites to discover ancient people and their history. In An Alphabet of Ancient Greece (part 1), several of Jill Watts's illustrations show the intersection of tourism and archaeology. Tourists are depicted viewing the ancient remains of 'Corinth', 'Knossos' on Crete, where Chubb's text highlights Arthur Evans's work on the excavation and restoration of the site, and 'Mycenae'. The German excavator Heinrich Schliemann's dreams of Troy and (with his Greek wife Sophia at his side) discoveries of unique gold and ivory objects there and at Mycenae are revealed through 'Schliemann' and 'Treasure Hunter'. ${ }^{54}$

\section{Archaeology in universal libraries}

Similar to series, as part of an effort to bring subject specialism to a largely self-educating (extra university) audience, the cheap 'libraries' 
that flourished in the late nineteenth and into the twentieth century enabled archaeological works to sit within a system of 'universal' knowledge that these libraries sought to curate. ${ }^{55}$ Volumes of Williams \& Norgate's popular 'Home University Library' began appearing in the spring of 1911. Touted in newspaper reports as 'Books for the People', the Library's publisher Geoffrey Williams announced that it was a response to the increasing number of readers in the wake of successive Education Acts. Williams aimed to provide an intellectually and financially accessible university education in a book-shaped 'new sort of periodical' by releasing ' 10 new volumes' quarterly. ${ }^{56}$ These shilling volumes would be under the intellectual management of an editorial board consisting of classicist Gilbert Murray, historian Herbert Fisher and J. Arthur Thompson, a biologist, and the American literature scholar William Tenney Brewster. Their credentials, and the credentials of the authors they commissioned, were an important part of the marketing of the Library. Bowler has shown the terms on which Home University Library books were commissioned and published through a discussion of Thompson and Patrick Geddes' book Evolution: $£ 50$ advances and provision made for royalties. By 1936 the Library had reached nearly 200 volumes (having been taken over by the publisher Thornton Butterworth), and was issued in Britain, America (through Henry Holt \& Co) and the Empire. ${ }^{57}$

Number 26 in the Library was archaeologist John Linton Myres' volume Dawn of History, in which he explained archaeology as the study of the history of humans in the early stages of social development and subsequent changes over time. He focused on issues drawn from archaeological, anthropological and ethnographic evidence to support his historical narrative. A volume on Rome's ancient past (No. 30, by William Warde Fowler) followed. In 1913 Jane Harrison's Ancient Art and Ritual became No. 70 in the Library. The New York Times, according to the Library catalogue, called Harrison's work 'One of the 100 most important books of 1913'. David Hogarth's The Ancient East (No. 92, published in September 1914) was a follow on from Myres' volume. The Library catalogue's September 1914 edition alluded to upcoming volumes by archaeologists, including Francis Llewellyn Griffith on ancient Egypt, and another Hogarth volume on 'Modern Turkey'. Hogarth's Turkey volume seems never to have appeared, but the Egypt volume did - the work of Wallis Budge rather than Griffith (No. 114, 1925). ${ }^{58}$

In the first decade of the twentieth century the small, thin volumes of 'Gowan's International Library' brought a transnational flavour to readers. For a shilling each they could acquire a finely produced 
parchment paperback collection of more than 50 volumes by the early 1920s. The works provided a feast of world literature, both translated and in original languages. Wallis Budge's Egyptian Fairy Tales (1923), English translations of stories from British Museum papyri, was volume $48 .^{59}$

A new, 'universal' multi-disciplinary library came along in the 1920s - Benn's 'Sixpenny Library' (Fig. 5.2). Now considered a precursor to Allan Lane's Pelicans of the late 1930s, the Library began life in 1926 one of Ernest Benn's attempts to capture the education market with an affordable, accessible series covering a wide range of topics. ${ }^{60}$ It was issued through a subsidiary company, Ernest Benn Limited, with Ernest

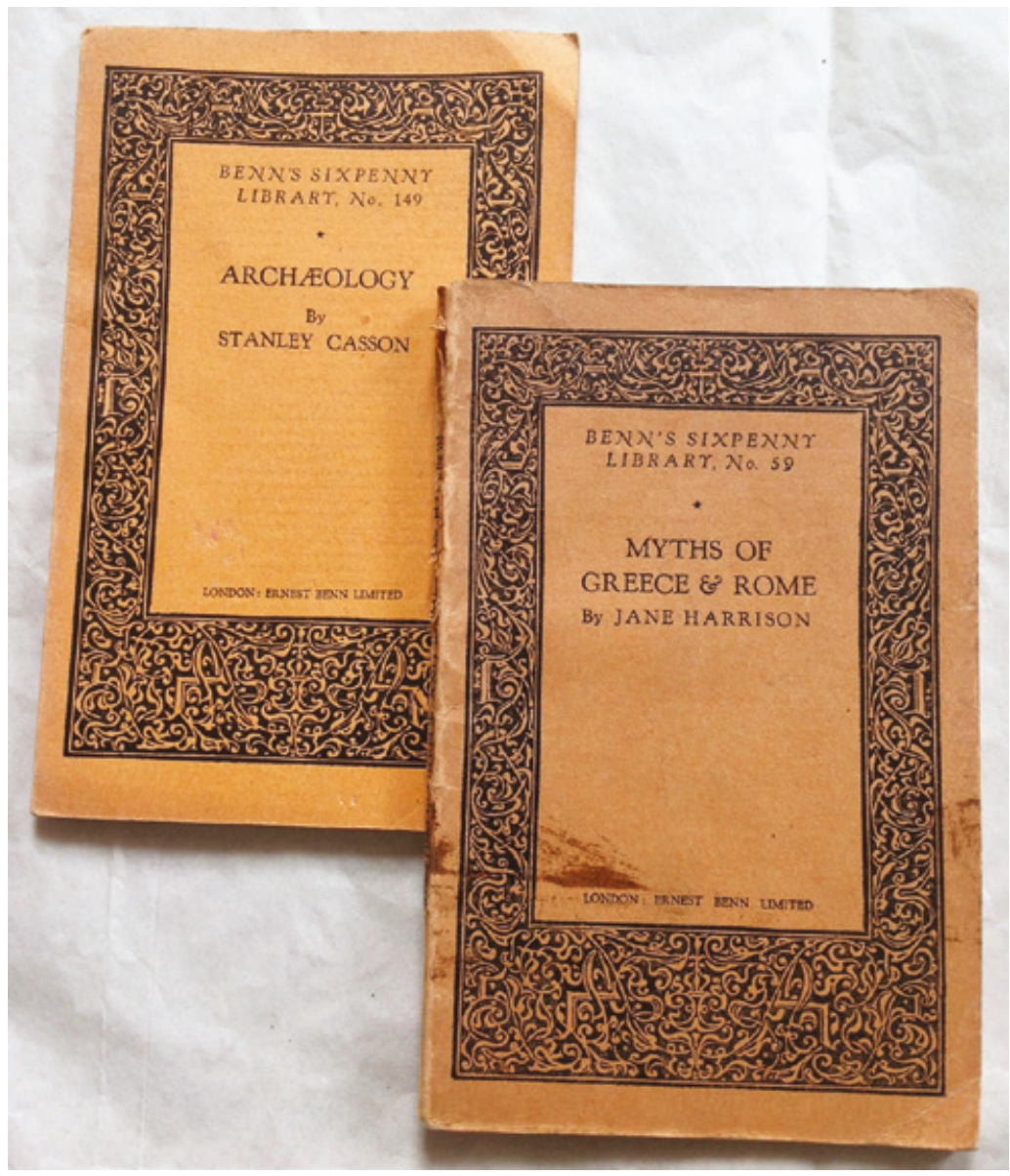

Fig. 5.2 Stanley Casson's Archaeology and Jane Harrison's Myths of Greece \& Rome in Benn's Sixpenny Library. (Author's collection) 
Benn as Chairman and a young Victor Gollancz (later to have his own successful publishing company) as Managing Director. It was Gollancz and another Benn employee, Douglas Jerrold, who created the Library and oversaw the contractual negotiations with authors. ${ }^{61}$ These paperback volumes, less than 100 pages in extent and slightly larger than a postcard, included books on world history, geography, literature, politics, the sciences, technology, economics, biography and religion. The literary scholar William Rose edited the Sixpenny Library for Benn, under Victor Gollancz's management.

A series of Ernest Benn's Memoranda of Agreement (authors' contracts) yields insights into the business arrangements underpinning the scheme in terms of royalties and print runs. ${ }^{62}$ In the first phase of the Library's publication (1926-7), authors signed a contract with Benn for an initial advance with a royalty of a halfpenny per copy. Benn Ltd reviewed the success of the venture in early 1928. A letter to the classicist James Thomson (due to write a volume on Plato and Aristotle) outlines a change in the terms following the review. In order to make the series financially viable more copies would be provided to booksellers and newsagents; authors would be given a lower initial royalty based on the print run quantities rather than sales, with Benn Ltd taking on the risk of copies given away or unsold. Authors of books published in 1928 and thereafter would have at least 10,000 copies of their books printed, and would be paid $£ 15$ outright for this first printing. Additional royalty on sales in the United States would be given. A vigorous advertising push would accompany the new arrangements from $1928 .^{63}$

The Ernest Benn catalogue of 1928 boldly declared the Library to be 'the finest publishing venture of modern times', comprising 'an original piece of work' directly from experts. ${ }^{64}$ A number of archaeological volumes were included in the series, written by publicly known figures, including Arthur Weigall's Ancient Egypt (No.17, 1928) and Jane Harrison's Myths of Greece \& Rome (No.59, 1927). Stanley Casson's Archaeology (No.149) appeared in 1930 (Fig. 5.2). At that point Casson was Reader in Classical Archaeology at Oxford and the recent director of excavations in Constantinople for the British Academy. As discussed in Chapter 2, he had also become a general reporter on archaeology in the Eastern Mediterranean for the BBC, with his 1929 radio broadcast series subsequently published in The Listener. Casson's name would therefore have been familiar to Library readers, a fitting author to outline archaeological practice for a wide audience.

After defining the scope and methods of archaeology, quoted at the beginning of Chapter 2, Casson gave a brief history of the study of 
archaeology and key excavations and events in the progression of the discipline as a science (with a focus on the Eastern Mediterranean and Middle East). He discussed the contributions of archaeological research to diverse fields, introduced archaeological techniques and made clear distinctions between the 'professional' and the 'amateur'. He concluded with a summary of the state of archaeology and projections for future directions. ${ }^{65}$

In 1928 Benn's catalogue advertised the Library's sales 'in the second million', with '100,000 regular readers' placing a 'standing order' for the volumes. Despite this apparent success, subsequent paperback nonfiction publishing efforts (namely Penguin's Pelicans) meant that by the 1950s Benn's Sixpenny Library had been supplanted and nearly forgotten - it was indeed completely ignored by a supplement in The Times dedicated to the 'Paperback Revolution'. In response to his father's omission from this history, John Benn wrote a letter to The Times in 1960, recording sales of the 'little orange-covered books' of the Sixpenny Library in the 'millions' and inferring that the contributor-authors had been among the best known of their day. ${ }^{66}$

\section{Circulation and readership}

Thornton Butterworth's Keystone Library, begun in the 1930s, enabled republication of earlier works in 'popular' (cheaper) format. Although it did not quite emulate Benn's inexpensive price model, the Keystone Library proved valuable as a marketing package - five of Arthur Weigall's books were posthumously published in cloth through the Keystone Library for 5 shillings, a decrease on their original price. ${ }^{67}$ Weigall had begun to publish 'popular' books on Egyptology in the first decade of the twentieth century. In these works he chronicled his travels, posed questions on the nature of the discipline and proposed solutions to the problems he saw in his position as Inspector of Antiquities in the Egyptian Antiquities Service. ${ }^{68}$

His first book, Travels in the Upper Egyptian Deserts (1909), was based in part on articles he had published in Blackwood's Magazine. Although priced at 7 shillings and sixpence, his biographer and granddaughter Julia Hankey declared that with this book Weigall began his relationship with 'a large, educated general public' and met with 'instant success'. ${ }^{69}$

Two years later The Treasury of Ancient Egypt, Weigall's third book with Blackwood, was also based on enhanced articles previously 
published in magazines. One Blackwood advertisement declared it '... so fascinating as to arouse the enthusiasm of patrons of the circulating libraries'. ${ }^{70}$ For Weigall as an author, popular writing represented a significant and valuable contribution to his personal finances. Hankey noted that for his 'popular' biography of the ancient Egyptian king Akhenaten, whose body had been discovered by a British-led team a few years earlier, he received $£ 100$ in advance. This book went into three editions before 1914; it was revised and reissued a further eight times by the early 1930s. ${ }^{71}$ The biography was based in part on previously published magazine articles; writing for magazines was an important part of his annual income of $£ 600 .{ }^{72}$ Weigall followed this up with a biography of Cleopatra, in which he defended his interpretation of ancient Egypt by drawing on the effects of his own experience of the country - something that he felt was crucial to understanding its history and the detritus of its ancient past:

I would only plead for my views that a residence in Egypt of many years, a close association with Alexandria, Cleopatra's capital, and a daily familiarity with Greek and Egyptian antiquities, have caused me almost unconsciously to form opinions which may not be at once acceptable to the scholar at home. ${ }^{73}$

As an archaeologist resident in Egypt, therefore, Weigall was a cultural and historical translator. This experience of Egypt was reflected also in his history of European interaction with the country - his fifth Blackwell publication. These books, Hankey demonstrates, brought Weigall international recognition, despite criticism from some reviewers for his imaginative reconstruction. His rising notoriety put him in a difficult position in the Antiquities Service, as wealthy and influential tourists to Egypt were eager to meet him and be guided round sites. One of these was the American former president, Theodore Roosevelt, whose assessment of Weigall's potency as a popular communicator '... seeing the living body through the dry bones and then making others see it also' was a powerful advertisement. By the early 1920s Weigall had progressed from the theatre to novels and even film. ${ }^{74}$

On the resumption of excavation activity in Egypt in the early 1920s, and the subsequent discovery of Tutankhamun's tomb at the end of 1922, a new resurgence of interest in Egyptology led to the republication of some of Weigall's earlier work. This included his Akhnaton biography with the renewal of Egypt Exploration Society excavations at Tell el-Amarna, Akhenaten's city. Hankey charts the boost in sales that the 
new interest in Egypt and Weigall's coverage of Tut for the Daily Mail had brought: 3,000 copies of Akhnaton sold over a few weeks in early 1923. New books (with some older content) were also published, namely The Glory of the Pharaohs and Tutankhamun and other Essays; Glory sold 1,500 copies before being put into bookshops. In his Tutankhamun Preface Weigall declared that Carter's discovery 'has revealed an almost universal love of ancient things' and that, in opening society's 'inheritance in the regions of the Past', the archaeologist 'will have to labour under the eyes of an ever increasing public who will follow him into those regions, and will continuously demand to know what he has found'. Weigall's success as a writer continued after the first flush of Tutankhamun excitement as he expanded into travel writing on Roman, Anglo Saxon and Norman Britain based on Daily Mail articles which attracted a new audience. The publishers Thornton Butterworth were releasing and reissuing his Egyptological titles. ${ }^{75}$

Hankey's biography reveals the size of audience that a popular writer such as Weigall could command from sales, even after his death. Yet his readers were also library users. The importance of booksellers and libraries is crucial to the analysis of circulation and readership. Increasing literacy rates, communication and technological developments and even improvements in lighting, Joseph McAleer argues, helped to foster a growing reading public from the mid-nineteenth century. This public satisfied their literary desires by acquiring books from a network of book stalls and book shops such as W. H. Smith, subscription circulating libraries (aimed at middle-class readers) - of which W. H. Smith's Library and Mudie's were among the best known - and Mechanics Institutes and public libraries provided for by town councils. Begun in 1843, Mudie's Library contained thousands of books, with over a hundred branches throughout Britain by the end of the nineteenth century. ${ }^{76}$ Mudie's and the other circulating libraries were characterised in the early twentieth century as attracting a mainly female clientele. In her book of London life, Emily Cook declared that:

A morning spent at Smith's or Mudie's is curiously instructive as to the methods pursued by them in the search for light literature. The library counters then usually exhibit a double or treble row of women, with a very faint sprinkling of elderly men, all waiting, in varying degrees of patience, for their turn. ${ }^{77}$

Mudie's did provide some more intellectual fare, however; Simon Eliot has argued that nonfiction made up a significant and predominant part 
of Mudie's offer. He has noted that prospective readers would browse the catalogue, not the shelves, in order to select their reading material, making the catalogues more significant as finding aids than might be expected today. ${ }^{78}$ In the 1890s Mudie's catalogue included Amelia Edwards' A Thousand Miles Up the Nile, Petrie's Ten Years' Digging, Percy Gardner's New Chapters in Greek History, Jane Harrison's Introductory Studies in Greek Art and Myths of the Odyssey and Wallis Budge's Babylonian Life and History and Dwellers on the Nile (both 'By-Paths' books). A. H. Sayce had a total of 10 books included in the catalogues - among them his 'By-Paths' volumes Fresh Light from the Ancient Monuments, The Hittites and The Races of the Old Testament. Helen Tirard's guidebook Sketches from a Nile Steamer was also featured. By 1910 Mudie's was stocking new archaeological authors, among them D. G. Hogarth with four books listed - including A Wandering Scholar in the Levant, The Nearer East and The Penetration of Arabia - and Arthur Weigall with his guidebook, Travels in the Upper Egyptian Deserts. In the 1910 catalogue books were classified into subjects as well as being listed by author's name. Thus archaeologists' books could be found either under 'Archaeology' or in geographical categories such as 'Egypt' or 'Palestine'. Mudie's also offered juvenile fiction and nonfiction; Hall's Days Before History was listed in the juvenile section of its 1914 catalogue. $^{79}$

Other experiments in circulation include The Times Book Club, begun in 1905, where Janet Hogarth worked for a time as librarian. The brainchild of Encyclopaedia Britannica's Horace Hooper, it offered annual subscribers to The Times a circulating library of their own, at no extra cost. The Book Club announcement promised subscribers a 'practically unlimited' choice of books published in Britain, with a large selection of foreign-published books as well. All sorts of books were represented, from the latest novels to works of travel, biography, art history, medicine and theology. It also offered readers a chance to purchase the books they had acquired through the library at a discounted price. ${ }^{80}$ Book Club librarians were expected to advise readers on selection and provide excellent customer service. In her memoir Janet Hogarth described the characteristics of the Book Club librarian as '... someone conversant with current literature, able to talk about books without revealing too deep a depth of ignorance'. ${ }^{81}$ She worked with Hooper's assistant Oswald Sickert to develop strategies for promoting books to the public through careful placement and a 'note' - a tactic still used in bookshops today. ${ }^{82}$

The Preface to The Times Book Club catalogue of 1908 gives a flavour of the Book Club's philosophy, claiming that it was 'comprehensive 
and suggestive' rather than 'exhaustive' and therefore it is 'A guide ... to what the most intellectual class of English society has been reading during the last three years'. ${ }^{83}$ While there was a substantial 'Archaeology' section in the catalogue, archaeological authors were, as in Mudie's catalogues, also listed in geographical and cultural categories: 'Egypt', 'Near East', 'Greece and Rome' and 'Oriental'. Books by Mary Brodrick and Anna Anderson Morton, Amelia Edwards, Wallis Budge, David George Hogarth, Flinders Petrie, Ernest and Percy Gardner and A. H. Sayce were all listed. A later catalogue for The Times Book Club, representing the best books added to the Club lists between 1915 and 1936, includes Budge, Petrie and Margaret Murray, as well as the younger archaeologists John Garstang, Stanley Casson, Arthur Weigall (with an impressive 25 of his nonfiction and fiction works included) and Leonard Woolley. All these authors appeared under 'Archaeology', but a smattering of other categories, books and archaeological authors were also represented Budge's Egyptian Tales under 'Literature', Lina Eckenstein's History of Sinai and Ellen Sophia Bosanquet's The Tale of Athens under 'History', Ernest Gardner's Greece and the Aegean and D. G. Hogarth's Wandering Scholar under 'Travel' and Petrie's Seventy Years in Archaeology under 'Biography'. ${ }^{84}$

Founded in 1899 and incorporated into Boots' pharmacies across the UK, Boots Book-lovers' Libraries were an important venue for accessing fiction and nonfiction works. Nicola Wilson has shown the significance of Boots' Libraries to fiction publishing in the early twentieth century. Like Mudie's and the Times Book Club, Boots' libraries offered subscribers the opportunity to access new and older publications based on their subscription criteria, offering readers a range of options. Catalogues offered a carefully selected range of material, and by 1920 readers came from both the lower middle and working classes. ${ }^{85}$

The Boots' Library catalogue was searchable by author and subject. Archaeological authors featured in its 1912 catalogue included Wallis Budge, with a few of his 'Books on Egypt and Chaldea' volumes; Amelia Edwards' A Thousand Miles Up the Nile and Arthur Weigall's Akhnaton biography and Travels in the Upper Egyptian Deserts (all cross-listed under 'Egypt - Ancient and Modern'); Ernest Gardner's Handbook of Greek Sculpture and Ancient Athens (cross-listed under 'Greece - History, Ancient and Modern') and Religion and Art in Ancient Greece; Percy Gardner's Grammar of Greek Art; Jane Harrison's Introduction to Greek Art and Religion in Ancient Greece; D. G. Hogarth's Penetration of Arabia, The Nearer East and Accidents of an Antiquary's Life. Ten of Petrie's books were featured in the 1912 Boots' catalogue, including Ten Years' Digging and Personal Religion. ${ }^{86}$ 
The Libraries Act was passed in 1850, and the number of public libraries in Britain increased significantly from the 1890s. As with Mudie's Libraries, rather than allowing access to books directly many public libraries made catalogues available for readers, who would use them to place orders with a library assistant. ${ }^{87}$ Public libraries also advertised their latest acquisitions in local newspapers. Archaeologists' popular works featured in these lists: in 1899 York Library listed Petrie's Ten Years' Digging among its recent acquisitions; in 1926 Annie Quibell's Wayfarer in Egypt was advertised in the lists for the Beveridge Central Library; and in 1939 the Sunderland Public Library acquired Margaret Murray's recently published Petra. ${ }^{88}$ These library advertisements were by no means limited to Britain: US newspapers also included them. The Honolulu Library in Hawaii (under provisional US administration, and not yet a state) acquired Petrie's Ten Years' Digging in January $1894 .^{89}$

As discussed in Chapter 2, British men, women and children headed to the Eastern Mediterranean and Middle East for work and pleasure each year. Large co-operative stores such as the Civil Service Stores and the Army and Navy Stores provided and shipped many household goods to the far-flung corners of Empire, as Alison Adburgham has noted. The Army and Navy Stores catalogue reflects the needs of this mobile population, with the book department on the third floor of its London premises offering a wide selection of guidebooks and language dictionaries. In the 1907 catalogue alongside the Baedekers are Macmillan's Guides and Murray's Handbooks. ${ }^{90}$

In foreign cities, English language bookshops and libraries served tourists and expats. The Church Missionary Society (CMS) Bookshop in Cairo was on the Sharia Kasr el Nil, a street leading to the National Museum of Egyptian Antiquities in the Ismailiya quarter of Cairo. This was an area that contemporary travel guides dubbed 'European' Cairo, and a main residential district for wealthy Europeans. ${ }^{91}$ Annie Quibell's books, some of which were published in Cairo by the CMS, were available from this shop, which claimed to offer 'the largest selection of English and Arabic literature'. ${ }^{92}$ There were providers outside the Egyptian metropolis too; in a letter to Amelia Edwards in 1890, Flinders Petrie mentioned a Luxor-based missionary whose bookshop supplied interested tourists with books on Egyptology. ${ }^{93}$

Similarly, to Kenneth Mackenzie's Baghdad Book Shop on Al-Rashid Street's Ras El Karya flocked British and American tourists, soldiers, sailors and residents, as well as Iraqi, Kurdish and Indian customers. Established in conjunction with the instigation of the British administration of Iraq in the early 1920s, Kenneth Mackenzie began by supplying 
local Iraq schools and soon expanded his business to cater to a wider variety of readers. Unsurprisingly he carried books relating specifically to the history and archaeology of the region, and was known for specialising in 'Eastern' literature. ${ }^{94}$ In 1923 Gertrude Bell, then Director of the Baghdad Museum, wrote to her mother on the popularity of Mackenzie's recently established shop, and noted that he was interested in stocking her 1911 travelogue Amurath to Amurath. ${ }^{95}$ Dorothy Mackay's guidebook Ancient Cities of Iraq was actually published through Mackenzie's shop. For the benefit of her readers, she included in her bibliography relevant books available for purchase there. Alongside Bell's books Amurath to Amurath and The Desert and the Sown, books by Budge, Hogarth, Hall and Sayce were also listed..$^{96}$

Evidence of a more personal engagement with archaeologists' 'popular' books can be difficult to source, but some traces survive in annotations, letters and library issue stamps. Early modern studies has benefited from analysis of annotations on manuscripts to evaluate readership, and the same principle applies to late nineteenth- and early twentieth-century texts. ${ }^{97}$ A second-hand copy of Annie Quibell's Wayfarer in Egypt, for example, still has visible traces of use (Fig. 5.3). A previous reader underlined in pencil key archaeological sites in the text, including Saqqara (Sakkara), where Quibell herself spent many years working. Dates were jotted in the margin, presumably the dates on which he or she visited the sites in person.

Over a decade later, R. B. Sarjeant at the BBC read Margaret Murray's Petra. He was impressed and wanted to have Murray speak on the BBC's Near Eastern programme. Although there is no published

As to the other Old Empire tombs at Sakkara, which are among the most interesting things in Egypt, I feel it less necessary to write at any length, as some accounts of them are to be found in all guide-books. But, again, they are not easy to see.

I have sometimes thought, that if one could imagine a general destruction of the monuments of Egypt, out of which it was possible to save one thing only, that one thing would be the large room in the tomb of Ti. But for years I was in ravel 12.27 the habit of taking friends and friends of friends round to show them this tomb, and I can solemnly say that the majority

Fig. 5.3 Detail from the Saqqara chapter of Quibell's Wayfarer in Egypt. It shows underlined passages and annotations in the margin and includes what appears to be the date of a visit (12 March 1927). (Author's collection) 
evidence to suggest that she discussed Petra in this capacity, she did deliver several radio programmes between the 1920s and 1960s. ${ }^{98}$ However, Sarjeant's reaction does show that Murray's Petra made a personal impact on one reader who had the potential for public professional development for Murray. There is physical evidence of Murray's readership too: my second-hand copy of the book, formerly belonging to the Dumfriesshire Libraries service, still retains its issue stamp, showing dates of issue stretching into the 1970s.

Archaeologists scripted spadework for many reasons, both personal and professional, and targeted both children and adults in their desire to communicate the latest archaeological research. Publishers helped to shape these texts by marketing them as specialised series, defining disciplinary boundaries and sub-fields, and subsequently distributing archaeology into broader social science and humanities series and 'universal' libraries. As archaeologists developed new interpretations, techniques and processes, and promoted a new rigour in their research, publishers offered commercially valuable contracts, in some cases providing archaeologists with much needed financial rewards. Libraries and booksellers in Britain and beyond ensured the circulation of these texts, while books that have survived the ravages of time show us a glimpse of the effect of the cycle of scripting, selling and consuming on individual readers. 


\section{John Murray}

Now to say 'Travels' to a Murray was like saying 'Rats' to a terrier. ${ }^{1}$

John Murray I founded the business that would become a major publishing house in 1768. It was to John Murray III that Austen Henry Layard turned to publish the volumes relating his excavations at the ancient cities of Nineveh and Nimrud. The two-volume first edition of Layard's Nineveh and its Remains was released in 1848, followed by an abridged version, A Popular Account of Discoveries at Nineveh, two years later. Nineveh and its Remains was a success for Murray's; John Murray had taken on the risk of an unknown author, and the book sales eventually generated Layard profits of $£ 1,500$ per year. In the 1870s Murray's began publishing the works of German excavator Heinrich Schliemann, whose excavations at Troy uncovered a hoard of ancient gold jewellery and other artefacts. ${ }^{2}$

Under the helm of John Murray IV (1851-1928) and his brother Alexander Henry Hallam Murray (1854-1934), the 1890s were also an important decade for publishing accessible archaeology titles, with an emphasis on those associated with foreign travels for which the house of Murray was known. ${ }^{3}$ This chapter examines in detail the correspondence from some of the archaeologist-authors the Murray brothers fostered, drawing out the relationship between publisher and author during this period. It will focus particularly on letters to the Murray brothers from Mary Brodrick and David George Hogarth.

\section{Mary Brodrick}

Humphrey Carpenter contends that although the house of John Murray published books that were 'uncommercial' compared to other commercial publishing houses, the business nonetheless had a formidable reputation 
by the late nineteenth century. In the hands of John Murray IV the company became more financially solvent and better managed - largely, it has been argued, due to John Murray IV's detailed approach. He took over the firm on his own account on the death of John Murray III in 1892, but he had been working there since the mid 1870s, becoming a partner in 1878. ${ }^{4}$ British Museum keeper Alexander Stuart Murray had been associated with the firm since 1880, when John Murray III published his History of Greek Sculpture. ${ }^{5}$ This book was revised and reissued in 1890, and followed two years later by his Handbook of Greek Archaeology. Based on a series of lectures given in Edinburgh at the Society of Antiquaries of Scotland in 1887, Murray drew together what he called the 'accepted truths' of the ancient history of Greece - coalescing in turn a half-century of (mainly German) specialist research for the Handbook. On its publication the work was positively reviewed; A. S. Murray noted in a letter to Murray that the artist Frederick Leighton, notoriously 'hard to please', described the book as 'dainty'. ${ }^{6}$

By this point Murray was advising John Murray IV on future archaeological publications, citing his own knowledge of what would be successful. His situation in the British Museum gave him access to a network of prestigious and emerging scholars upon which he drew in his correspondence with Murray. Following a conversation with the Egyptologist Peter Le Page Renouf, a British Museum colleague, he passed on to John Murray Renouf's suggestion that an 'abridged' version of Heinrich Brugsch's Egypt under the pharaohs be published - and that Mary Brodrick, then lecturing on Egyptological subjects at the Museum, should be the one to tackle it (with Le Page Renouf's help). ${ }^{7}$

Mary Brodrick's correspondence with John Murray IV and Hallam Murray reveals her development from an emerging scholar into a more confident author and intellectual. It also serves to locate her chronologically and geographically across the UK, the Continent and Egypt, establishing herself as a traveller with personal authority based on studies of, and experience in, the country. As discussed in Chapter 2, her abridgement of Brugsch and subsequent editing of Mariette's history were her introduction to the firm, and the foundation of her longstanding relationship with the two Murray brothers. The majority of the correspondence between Brodrick and the house of Murray relates to her work on editing Murray's Handbook to Egypt in the 1890s. Through this work she was able to gain both financial and personal support from John Murray IV and Hallam Murray, while in return offering the company valuable commercial insight into the tourist scene in Egypt. Many of the letters are addressed from Brodrick's residence at College Hall in 
London, but others indicate her travels outside of London and outside of Britain.

Brodrick's initial meeting with the house of Murray was a visit to the publisher's offices at 50 Albemarle Street, in Piccadilly, and it is clear from the correspondence that the relationship between author and publisher was maintained both in writing and in personal meetings. ${ }^{8}$ While the correspondence is only from Brodrick to the Murrays, jotted notes at the top of many of her letters are the evidence of publishers' instructions and notes for following up on the contents of the letter. As the letters are addressed simply to 'Mr Murray' it is not always clear to which Murray she is writing, but it seems likely that her initial correspondent may have been Hallam Murray. Reading through the correspondence reveals that she wrote on the same topics to both brothers. Sequential letters contain the same basic facts, but her tone in letters to John Murray, head of the company, is more formal than in letters sent to Hallam Murray.

The summer of 1891 was a busy one for Brodrick; she was revising her Brugsch translation and providing edits to the eighth edition of the Handbook to Egypt at the same time. Conscious of the importance of the timing of publication, she wrote to Murray to enquire whether her Brugsch book and the Handbook would be published in time to catch the seasonal flow of tourists to Egypt. ${ }^{9}$ Once she was engaged to undertake the revision of the Handbook's addenda in preparation for subsequent seasons from the summer of 1892, she began to look in more detail at the main competition in the guidebook market: Cook and Baedeker. In Brodrick's opinion Cook's guidebook contained too much advertising, was decidedly inferior in finish and predominately based on Murray's without credit. ${ }^{10}$ Baedeker was a more formidable competitor, however, especially in its maps and plans. Her scoping exercise completed, Brodrick set about positioning herself as an unofficial 'agent' for Murray's business interests in Cairo. Consequently her letters reveal the local economies of tourism publishing and promotion in Egypt.

Until a new edition was prepared the eighth edition Handbook's addenda pages, located in the front of the volume, and its Directory at the end offered Brodrick an opportunity to showcase her knowledge of both ancient and modern Egypt more regularly. Separately printed, these sections were bound with the loose pages of the pre-printed edition; they could thus be amended annually if necessary, in time for the start of Egypt's winter season. No detail was too minor for Brodrick. Her letters indicate that she kept up to date on changes in hotel proprietors and enhancements to amenities (such as electricity) and providers (English-speaking doctors) in key towns and sites all along the Nile, from 
Alexandria and Cairo in the north to the more southern towns of Luxor and Aswan. ${ }^{11}$

This was a time of substantial infrastructure development in Egypt, encompassing the extension of Egyptian railways and tram services, improvements to access enhancing visitor experience and increasing accommodation facilities. In her time as Murray's Egypt Handbook editor, Brodrick was part of, and reflected, a Europeanised Egypt. Her correspondence charts the developments with a view to the European experience of Egypt and its importance - one that over a century later seems entirely foreign. This was imperial Egypt. Mary Brodrick was committed to the British project in the country, convinced that Britain's role was a force for good. ${ }^{12}$

Among the reports that she shared with the Murrays in the autumn of 1893 was her concern about the practices of the Cairo bookseller Charles Livadas, who acted as Murray's agent in the city. Based across the street from Shepheard's Hotel and Cook's offices on the Sharia Kamel Pasha de L'Opera in central Cairo, Livadas's bookshop 'The Tourist' was located in a prime place to entice the English-speaking visitors. ${ }^{13}$ According to Brodrick, Livadas was promoting Baedeker's Handbooks to his clientele as 'superior', and failing to acquire new Murray's Handbooks when he had run out of stock. ${ }^{14}$ Worried that Livadas was undermining the house of Murray, Brodrick had suggested an alternative agent from whom she had already obtained an expression of interest: the New Hotel proprietor Madame Mayer, who promised to sell not only the Handbook but also Brodrick's other books, Brugsch's Egypt and Mariette's Outlines. She assured Murray that Madame Mayer had a good reputation in Cairo with a growing number of clients and 'the books will get pushed, I think'. ${ }^{15}$

By 1896, however, the situation had not improved and Brodrick suggested another alternative: her own dragoman or tour manager Charles Hornstein, a German from Cairo. She indicated that having made general enquiries about suitable prospective agents, her own long-standing association with Hornstein proved his worth. He was on the brink of establishing himself as an independent tourist agent, which would mean, Brodrick intimated, that he was no longer under the thumb of a tourist manager (for example Cook's). ${ }^{16}$ Hornstein's contacts among Cairo's dragomen and hotel staff was an added bonus - a good sign, Brodrick proposed, of his ability to deliver on the promotion of Murray's Handbooks to visitors. ${ }^{17}$ He was later taken on, but ended up not being able to meet his expected promise - Brodrick later reported that independent dragomen were not able to compete with Cook's tourism management. ${ }^{18}$ 
With a few years' experience working with the Murrays under her belt, Brodrick sought to expand her horizons as a more general archaeology and travel contributor to Murray's Handbook series. A trip to the south of France in sight, during which she planned to go " "prehistoric man" hunting', she offered to check in at the Murray office, 'in case there may be any little thing that I can do out there for you in the guide book way'. ${ }^{19}$ The summer of 1895 brought Mary Brodrick a more involved task: a 'stop gap' update to the Handbook to Egypt, for which she was paid $£ 10$ 10s, the most of all the contributors. ${ }^{20}$ On this she intended to collaborate with Archibald Henry Sayce, then living for part of the year in Egypt, having bought a dahabiya (Nile boat) in $1891 .{ }^{21}$ The work was also supplemented with notes from Flinders Petrie. His notes were quite thorough, and Brodrick queried whether the majority of Petrie's suggestions should be held for a more involved revision, as extra amendments would have added to production costs. As the deadline was approaching, she offered to end her own holiday early to get the proofing done. A firm response that she should not cut her holiday short indicates that 'Mr Murray' was interested in Brodrick's wellbeing as well as her productivity. ${ }^{22}$

Brodrick planned a trip to Egypt for the winter Season of 1895-6, taking on the majority share of editing the Handbook's ninth edition. The correspondence relating to Brodrick's trip shows how much the Murrays were willing to support her in her editorial duties. Having heard rumours that someone had been making enquiries purportedly on Murray's behalf in Egypt, she solicited and received an official letter from the firm in order to aid her efforts. ${ }^{23}$ Travelling with fellow UCL student Anna Anderson Morton as companion, at the outset of her trip Brodrick was based at the Hotel d'Angleterre in Cairo - a 'medium priced' establishment which was described as 'charming', 'well managed' and 'most comfortable'. ${ }^{24}$ While in the city she and Morton attempted to use the Handbook as a guide 'as if we were tourists', but without depending on the services of a dragoman. The results, in Brodrick's opinion, were very unsatisfactory. Her main concern related to the plans and descriptions of the city, and she set about sourcing a 'modern' plan of Cairo suitable for inclusion in a new edition. She recommended the Egyptian Public Works Department's new map of the region between Cairo and Aswan, and some other governmentproduced maps of Cairo and the Delta. The scale of the improvements Brodrick projected meant that she suggested to Murray that she stay longer in Alexandria and Cairo to do both cities justice. To support this work she asked Murray for $£ 50$ 'on account', on which she could draw if needed. Her request was granted. ${ }^{25}$ 
Brodrick and Morton were also finalising their plans for an onward journey up the Nile. Brodrick was to cover the region north of Beni Hasan, 150 miles south of Cairo, for the Handbook, while Sayce was to be responsible for updating information on the region between Beni Hasan and Aswan. Brodrick also took responsibility for the book's Introduction, 'general editing' and fine details such as distances between sites. ${ }^{26}$ She and Morton had rented a dahabiya, the Lotus, enabling them to see the country's sites at a leisured pace and to stop at less well-known sites off the regular tourist track. This mode of transport Brodrick felt particularly enthusiastic about, and she incorporated her feelings into her Handbook section on the Nile valley region. ${ }^{27}$ Where the eighth edition conveyed somewhat apathetically that travel by dahabiya 'as has been said, is the most comfortable', Brodrick's edition advised readers that dahabiya travel was 'the best and most comfortable method of seeing the Nile', despite its expense. ${ }^{28}$

The dahabiya can be read as a symbol of Brodrick and Morton's independence, a reflection of their own archaeological identities; as Brodrick wrote to Murray, 'of course dahabiyehs are always independent'. ${ }^{29}$ Still a slightly transgressive mode of transport (particularly for unchaperoned women), it enabled them to push the boundaries of what was considered seemly and safe behaviour. Unmonitored, mistresses of their own destinies, 37-year-old Brodrick, 29-year-old Morton and their tour guests took to the river, separating themselves from the managed experience of a Cook's steamer. It is perhaps not surprising that in the tenth edition Brodrick edited the text of the Nile River section to note the enticement of the dahabiya:

The River is the highway of Egypt beyond Cairo, and along this highway the traveller can proceed either in a boat of his own, or in a steamer, or by railway.... The great advantage of hiring a dahabiya is that the traveller is absolutely his own master. ${ }^{30}$

Once on the Nile, one of the key sites that Brodrick wanted to explore in more detail was Dashur, 20 miles south of Cairo. For two years French archaeologist Jacques de Morgan had been excavating the site's 'pyramid field'. She and Anna Morton had taken two women with them on an educational tour; despite the trying habits of one of their guests, Brodrick reported to Hallam Murray that 'we enjoy the out of door life thoroughly'. By the time they reached Aswan, 590 miles south of Cairo, they were still collecting details for the Handbook despite being well into Sayce's territory, 'in case we can pick up a scrap of information 
that may have escaped him'. ${ }^{31}$ For Brodrick and Morton the Nile also became a watery network - guests hopped between boats and meetings could be had comfortably on board their dahabiya. Indeed one such meeting was with Sayce, who boarded the Lotus to discuss progress on the Handbook text. ${ }^{32}$

Coming back down the Nile towards Cairo in the spring of 1896, Brodrick aimed to spend time making notes at Beni Hasan, where the Egypt Exploration Society was in their fifth season of work uncovering, copying and interpreting tomb paintings. ${ }^{33}$ From there she and Morton were going to the Fayum region. They planned to abandon their dahabiya temporarily and cover the ground between Dashur and Giza over land, camping 'in order to live among the pyramids'. ${ }^{34}$ This they duly did, and Brodrick reported that she had had 'a splendid time'. She also added with the prospect of another edition of the Handbook in view - that there was much to be amended in the Handbook's presentation of 'temples + tombs. ${ }^{35}$

En route up and down the Nile, Brodrick realised how inadequate the Handbook was for route planning. Good maps were essential to the tourist experience, particularly for those on an independent dahabiya. Responding to a query from Hallam Murray on the subject, Brodrick recommended that detailed maps of a larger scale relating to each section of the country be bound into the Handbook at the start of each subsection. This was a significant change from the eighth edition, which had one long, narrow sheet map of the whole Nile region tucked away in the back pocket. With a new system of smaller yet more detailed maps, Brodrick noted, visitors to Egypt would not miss relevant sites otherwise easily overlooked, given the longer map's small and blurred type.

Brodrick's advice was accepted; the back pocket map was abandoned in favour of a system of separate overlapping maps for the various subsections of the Nile and surrounding countryside. She was adamant that site plans and city maps also needed to be added or improved - particularly, in the case of cities, indicating up-to-date transport. The Survey of Egypt was still unfinished (though nearing conclusion) and Brodrick wanted to obtain the latest information straight from the Royal Engineer surveyors involved. This was Egypt under colonial development; railways and engineering projects were designed to increase the country's productivity. Likewise Brodrick made notes on facilities for Nile travellers particularly those on dahabiyas - such as landing places for obtaining suitable medicines. Ensuring adequate map coverage would bring the Murray Handbook up to the standard set by Baedeker; Brodrick reported 
that Murray's maps were causing some among her acquaintance in Egypt to purchase Baedeker over Murray. However, despite the problem with the maps, Broderick reported, German tourists were recommended Murray Handbooks as an 'exhaustive' guide to the country. She also suggested that Murray consider producing a German language edition of the Handbook as a form of competition with Baedeker's English language handbook. ${ }^{36}$

Having returned to Cairo briefly in April 1896, on arriving in Alexandria she realised the scale of the changes to be made to the description and plan of the city in the Handbook. She was staying with Admiral Richard Massie Blomfield, then Controller of the Port of Alexandria, who had played a key role in the British occupation of Egypt in 1882. ${ }^{37}$ Blomfield was interested in archaeology; he was part of a movement of Alexandria-based Europeans promoting the potential for archaeological research in the city. Alexandria had a significant European population and its 'merchant princes', as Donald Reid terms them, initially drove the city's development, including its cultural development. The Institut Egyptien in Alexandria, established in 1859 and dominated by Europeans, led to the beginnings of a collection of artefacts. An Athenaeum Society took the place of the Institut on its removal to Cairo in the early 1880s, and worked with Alexandria's municipality (also dominated by European members) to form the Greco-Roman Museum and Municipal Library in Alexandria in 1892. A Society for Alexandria Archaeology (Société d'archéologie d'Alexandrie) opened in 1893 with Blomfield playing a prominent role in its founding. ${ }^{38}$

Archaeologists were beginning to recognise the potential for research in the area. D. G. Hogarth and a young E. F. Benson had received the support of the Hellenic Society and the Egypt Exploration Fund to make test excavations in the city in early 1895, receiving logistical support from Blomfield and his wife Rosamond Graves Blomfield, herself active in promoting Alexandria's intellectual and social life. ${ }^{39}$ When Mary Brodrick arrived in Alexandria in April 1896 she unsurprisingly deplored the inaccuracy of the Handbook - not only for Alexandria, but also its suburbs and other port cities on Egypt's Mediterranean coast, including Rosetta and Damietta. She wrote to Murray that 'the information might well belong to another country'. Using the advance from Murray's, she planned to delay her return to England in order to travel across the region to view the situation and gather information personally, thus improving tourists' access to what she termed 'a fresh district'. As for Alexandria, she was 'surprised at the amount of interesting things there are to do + see ... quite enough to keep people for some days'. None of these new 
developments had yet been incorporated into the Handbook, a problem she intended to rectify. ${ }^{40}$

When Mary Brodrick returned to England, she spent the summer sourcing plans for sites and tombs - two of the latter were Anna Morton's work. She was paid $£ 200$ for editing and an additional $£ 5$ for the Directory, a fee that reflected the amount of effort she had put in; Sayce, for his part, received $£ 50 . .^{41}$ Murray's Handbook for Travellers in Lower and Upper Egypt (ninth edition) was published in late 1896, and reviews began to appear in January 1897. The reviewer for the The Times, Brodrick felt, was verging on malicious, having declared that it was not quite up to the standard of Baedeker even with its improvements on previous editions in bringing the latest archaeological and infrastructural developments in Egypt to readers' attention. ${ }^{42}$ Despite this criticism, Brodrick's hard work on the maps was duly noted..$^{43}$ A more positive review in The Times in July, recommending the volume as a valuable introduction to Egypt for those at home as well as tourists, helped to assuage Brodrick's indignation. ${ }^{44}$

She was by then also dealing with criticisms of the Handbook from D. G. Hogarth, who had provided Murray with detailed notes. While conceding that some of his points were correct, on other matters she stood her ground against Hogarth - brusquely defending herself against his comments on her handling of Alexandria, for example, which had been shaped through her conversations with Admiral Blomfield. His intimate knowledge of its history and topography born of long residence in the city, Brodrick declared, she trusted more than Hogarth's brief 'academic' experience. ${ }^{45}$ Meanwhile sales were continuing well: of the initial 2,000 copies printed, by June 1898 nearly 700 had sold. ${ }^{46}$

Brodrick planned another Egyptian tour with Anna Morton for the 1897-8 winter Season. Another dahabiya was secured and, as noted in Chapter 3, advertisements sent out for a small party to accompany the two scholars. On arrival in Cairo in late 1897, Brodrick was again confronted with the scale of change in the city and in Egypt generally. She wrote to Murray to request an interleaved copy of the Handbook a volume bound specially with blank pages inserted - so that she could make notes on each section for the 1897-8 addenda. She also reported a new contact, 'The Chief of the Tanzim', or 'civil works department', who had promised to give her further details on the 'present condition of the country, government business, etc'. ${ }^{47}$ Brodrick continued to keep track of the popularity of guidebooks, reporting her observations to Murray. Having conducted an informal market survey experiment, she told Murray that she "[thought] more "Murrays" are about than formerly'. The 
passengers of one Cook's steamer provided her with further insight: that 'between $50+60$ ' of 72 passengers were carrying Murray's Handbooks, and that the number of Baedekers to Murray's Handbooks was evenly split. Murray's double-columned layout and the position of its Directory (containing the tourist essentials of hotel information and opening times) at the end of the volume was the main reason for a preference for Baedeker. ${ }^{48}$

One of the other major changes was to tourism in Upper Egypt and into Sudan. The Egyptian Army Sirdar, at that time General Horatio Herbert Kitchener, had opened the route to Dongola below the Second Cataract of the Nile. Although Brodrick and Morton were deeply interested in going further south, travel of that distance was prohibitively expensive. As the Alma, their dahabiya, continued on its journey up the Nile she noted the increased potential for tourism in the south of Egypt following the opening of a passenger rail service between Luxor and Aswan. ${ }^{49}$

Brodrick's letters from this trip reveal a country in the midst of political and social upheaval. Having occupied Egypt in 1882, the British army turned their sights to the south and Sudan, a region historically of great interest to Egypt and its expansion. The AngloEgyptian army attempted to quell the rise of the Sudanese Mahdi, whose army of followers - termed 'dervishes' - were fomenting revolution against Egypt. This had resulted in a failed relief attempt to save General Charles Gordon in Khartoum in 1885. In the 1890s the situation in Sudan was still unresolved, and Egypt's southern border with Sudan was a hotspot. In 1895 Brodrick had reported that a 'dervish raid' in the south meant that travel to Abu Simbel, one of Egypt's southernmost archaeological sites, had been restricted..$^{50}$ As the Alma approached Luxor in late January 1898 she spotted troops being transported further south; eight months later the battle of Omdurman between the Egyptian army and the Mahdi's successor, the Khalifa, would take place, an event leading to Sudan coming under AngloEgyptian administration.

The ports along the Nile were in chaos as the military transport operations were in full swing. These operations had an effect on tourist travel - the Alma was delayed at the Nag Hamadi bridge, about 70 miles from Luxor, to make way for troops. Camels, essential for desert tourism, were being seized for military use. Brodrick's enthusiastic recording of these military details for Murray's benefit reflects the relish she took in the enterprise. ${ }^{51}$ On finding that her cousin, a Lancer, would be marching close by, she and her companions were planning to 
'wave towels (being more visible than handkerchiefs) + cheer vigorously'. A sense of expectancy and excitement was in the air, and on the lips of everyone to whom she spoke. She communicated to Murray her eager anticipation that lines of communication and transport would be established deeper into Sudan, so that the 'rush for Khartoum' could be accomplished. ${ }^{52}$

The military situation was not so serious as to affect archaeological research, however; despite her observation that " "soldier shop" seems more in the ascendant this year than Egyptology', Brodrick made note of the excavators and work she was passing on her way south: Flinders and Hilda Petrie at Dendara, James Edward Quibell, his sister Kate Quibell and Somers Clarke near El Kab..$^{53}$ The intermingling of archaeology, infrastructure and troop movements continued in Brodrick's correspondence as the Alma came back down the Nile. She and her party had managed to get as far south as Shellal, south of Aswan, close to the border of Sudan, where she declared that the 'Arab tribes' loyalty to the Khalifa was 'wavering' and that 'Everyone is in good spirits at the prospect of really smashing that horrible Khalifa this time'. The prospect of a dam at Aswan had the Egyptological community worried - the ancient temples of Philae would be subjected to major water damage if the plans went through ${ }^{54}$ Alongside these developments she noted new archaeological discoveries, including a gold hawk's head with obsidian eyes, found at $\mathrm{El} \mathrm{Kab}$ and destined for the Egyptian Museum at Giza (across the Nile from the isle of Roda), as well as a report that 'natives' had discovered 'a king's tomb'. ${ }^{55}$

Brodrick's frustration with, and dislike of, Thomas Cook \& Co is apparent throughout her correspondence. While in Egypt she gathered information from either personal experience or reports from others on the company's provision for tourists. ${ }^{56}$ Certain reports she would not put on paper, and she mainly referred to the company instead as 'the enemy' or 'the Culinary Department'. Much of her frustration with Cook's relates to the company's dominance over Nile traffic, pricing and what she considered the aggressive nature of their policies concerning dragomen and dahibiya procurement. The tourism industry was interconnected, however, and the firm of Murray's was keen to be included as recommended books for tourists to Egypt, so on the surface cordialities had to be maintained. It is clear that the Murrays were concerned about Brodrick's contempt for Cook's, as she had to reassure them that 'I shall neither do nor say anything in connection with our "friends" that will lead to any unfriendliness with them'. ${ }^{57}$ Cook's similarly were eager to secure Brodrick's attention, both as a noted Egyptologist and for her association with Murray's, but 
did not like the fact that she used and promoted independent (i.e. nonCook's) dragomen and dahabiya rental.

Cook's power in Egypt caused trouble for independent dragomen, and Brodrick was worried. ${ }^{58}$ In one letter she noted an example of a Cook's dragoman behaving badly - the Austrian Archduke, on board a Cook's dahabiya, had been prevented from going on board the Lotus as it was not associated with Cook's. ${ }^{59}$ As the end of the century approached Cook's was supplying steamers on military service, but trouble ensued when things went wrong. Brodrick reported almost triumphantly that 'his [Cook's] day here is fast waning... The Sirdar now is dead against him'. ${ }^{60}$ Soon afterwards John Cook's own dahabiya passed theirs on the Nile, and Brodrick observed Cook's displeasure at the fact there was 'no "C + Son" flag on our mast'. ${ }^{61}$

Brodrick continued to contribute addenda pages for the ninth edition in 1898 and 1899 with her eye on current events. With the war for Sudan coming to a close in 1898 , there would be political changes and the renewal of tourism to the country. Brodrick advised first that the map of Sudan ought to be extended to include Fashoda (a region over which Britain and France were then actively fighting) as 'We ought to have it, don't you think?' Subsequently she advised that the Handbook needed information on Khartoum, the new administrative capital of Anglo-Egyptian Sudan. ${ }^{62}$

Brodrick had also offered to make notes for Murray on a trip to Syria and Palestine, added at the last minute to the end of her 1897-8 trip to Egypt. In a letter to Murray she noted that the then-current edition of the Syria Handbook (1892) lacked information on the likely expenses of travel, 'so that any one wishing to visit Palestine cannot form any estimate of what their trip will cost'. In addition she drew Murray's attention to the fact that the new railway in Palestine 'has changed expenses + methods of travelling'. She was on the ground, planning to go to the country anyway, and would 'collect information carefully'. ${ }^{63}$ In her revised Handbook for Travellers in Syria and Palestine (1903) the significance of the improvements in access was made abundantly clear; with the completion of new roads and railways the region would be 'opened up ... to many travellers who have until now been unable to visit these countries. ${ }^{64}$

John Murray IV divested the house of Murray of its interest in all but two of the Murray Handbooks entirely in 1901 (Fig. 6.1), selling the copyright, copies and stocks to Edward Stanford for $£ 2,000 .{ }^{65}$ Brodrick was not happy with the change in her publishing relationship. Stanford was a well-known mapmaker and printer who had supplied Murray's with 


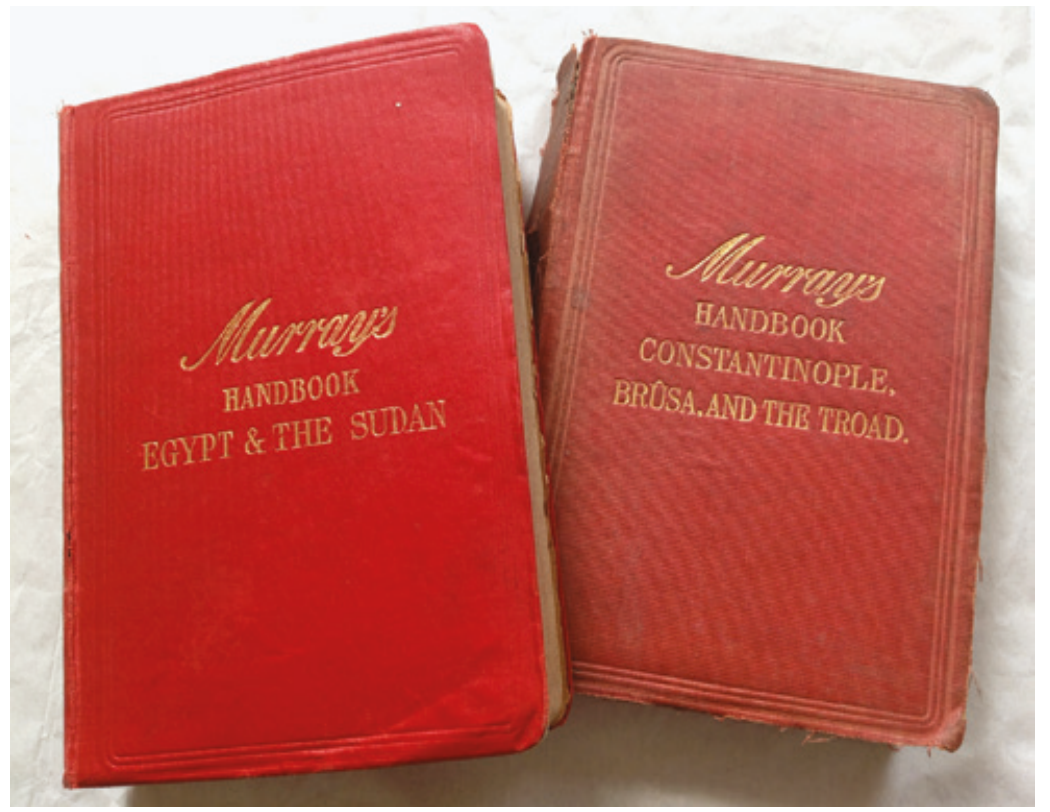

Fig. 6.1 Front covers of Murray's Handbooks. (Author's collection)

copies of maps for the Handbooks for many years. For Brodrick, however, the editing process under Stanford's management was far from ideal. The distant, almost mechanical attitude they took towards the Handbook editors was completely different from what she had experienced with the Murray brothers. She wrote despairingly to Murray in December 1903 that 'I can't go on with Stanford any longer. I can never see him personally, + the letters are all sent through Mason his manager - + they have been so annoying and tiresome that I can't go on with the worry of it'. ${ }^{66}$ She was working on corrections to the Handbook to Egypt and ultimately gave up. The eleventh edition (1907) was edited by the British Museum's Harry Hall, who emphasised in his Preface the scale of changes he had made to the text and organisation. These, like Brodrick's, were based on 'my own observation and the consultation of the latest archaeological and other works'. ${ }^{67}$ In another significant change to the Handbook, for the first time, Hall's specially compiled Notes on the Arabic Language were included as a separate pamphlet fitted into the back pocket.

Brodrick combined the work on the Handbook with a gruelling public lecture schedule. In the late 1890s she was suffering with ill health, and as the new century dawned she was also struggling financially. A poignant letter in the John Murray archive reflects the lengths to which the Murrays were prepared to go to support her. In 1902 Anna Anderson 
Morton was preparing an application to the Royal Literary Fund on Brodrick's behalf; the Fund offered support to authors struggling financially. Even though she declared herself able to 'scrub along', Brodrick admitted, 'I do get dreadfully hampered now I am in such bad health'. ${ }^{68}$

Her health increasingly forced her to give up valuable work opportunities. Following the publication of her and Morton's Concise Dictionary with Methuen \& Co, Algernon Methuen had asked Brodrick to write another book on Egyptology, but she had turned down the project. She explained to Murray that she was physically unable to 'chase out in all weathers to read at the museum', and could not afford to buy 'essential' reference works or arrange trips to museums abroad for other necessary information. She outlined her financial circumstances as an independent author and lecturer - added to her $£ 70$ a year of money through the Brodrick family were her literary earnings of about $£ 100$ a year, 'according to luck + health'. ${ }^{69}$ A later letter reveals that the Murray brothers worked behind the scenes to ensure that she received a grant of $£ 50$ from the Fund in 1903. She recalled in this letter that, despite her outlined earnings, "there were several years where "ends" would hardly meet'. When Brodrick later came into money she made a donation back to the Fund, in order to ensure other authors might receive help at difficult times; the Fund wrote a specific note detailing the donation was for its 'help in a time of misfortune'. ${ }^{70}$

Throughout the correspondence it is clear that as an author Mary Brodrick acted on her own initiative; she took on her critics and used the benefit of her experience and contacts to improve Murray's offer for tourists. Brodrick's correspondence shows the strength of the relationship between archaeologist and publisher during this period - one that was quite personal, as evident in the Murray brothers' financial support during and after her work on the Handbook. While they did not support her every publishing effort, the brothers, particularly Hallam Murray, worked to cultivate Brodrick as an author and lecturer, offering her opportunities, promotion and funding when she requested them and when she did not.

\section{David George Hogarth}

While Brodrick was sometimes timid and deferential in her dealings with the Murray brothers (as opposed to the more forthright stance she took with her critics), D. G. Hogarth was significantly more confident. His letters mainly date to the mid-1890s, overlapping chronologically with Brodrick's correspondence. Hogarth was at the beginning of this 
period a freelance archaeologist and traveller, conducting excavations and explorations with university and learned society supported grants. As Peter Lock has noted, he did this with no access to family money; his father was a vicar in Lincolnshire, and his sister Janet remarked on the Hogarths' restricted finances.

Hogarth finished his degree at Oxford in 1885, but as his sister recorded, he had no great affinity for the routine of academic life. He toyed with the idea of writing a historical novel, which never materialised, and obtained paid work as a tutor and lecturer at Magdalen College, where he had been a student. The direction of his life changed dramatically when the Craven Fellowships were established to support classical studies, including travel to the 'classical' lands of the Eastern Mediterranean and Levant. ${ }^{71}$ Hogarth was one of the first recipients. With the Fellowship he was able to leave Britain's shores, becoming with Ernest Gardner one of the first students at the newly opened British School at Athens in 1886. While there he copied inscriptions in Salonika (Thessaloniki) and travelled in Asia Minor with the classical scholar and geographer William Mitchell Ramsay. ${ }^{72}$

Hogarth was re-admitted to the School for the next session, undertaking work in Cyprus for the Cyprus Exploration Fund. Established in 1887 and associated with the BSA and the British Museum, among other bodies, the Cyprus Exploration Fund provided financial support for Hogarth's archaeological research on the island in 1887-8, where he met his friend and longtime foreman Gregori Antoniou. ${ }^{73} \mathrm{He}$ continued exploring and excavating in Asia Minor under the auspices of the Asia Minor Excavation Fund, both in the company of Ramsay and on his own. He worked in Egypt at Deir el-Bahri from late 1893 and, as mentioned previously, in Alexandria for the Egypt Exploration Fund in 1895. Two years later he became the Director of the British School at Athens. ${ }^{74}$

The first letter in the John Murray archive from Hogarth dates to 1889, when he was 27. He wrote to John Murray IV, who had been at Magdalen before joining the firm, as one Magdalen student to another, seeking to establish a productive relationship with the publisher. Hogarth was editing the college magazine and sought books to review. He promised that Murray's books, 'invariably the most interesting of the year', would under his editorship be 'prominently' noted. ${ }^{75} \mathrm{He}$ also offered his services in the editing of the Murray 'Levant guide-book', based on his recent experiences in Cyprus and Asia Minor. ${ }^{76} \mathrm{He}$ commented that the description of Asia Minor was rather out of date, but felt it was probably not worth Murray's attention. Although he ends on this modest note, the letter reveals the value Hogarth put on his knowledge of the region. ${ }^{77}$ 
In the early 1890s, with the increased British archaeological presence and active exploration in the region through the British School at Athens, Murray's brought the coverage of the region up to date. The previous edition of the Handbook for Travellers in Turkey in Asia, including Constantinople, the Bosphorous, Plain of Troy, Isles of Cyprus, Rhodes, \&c, Smyrna, Ephesus and the routes to Persia, Baghdad, Moosool, \&c. had appeared in 1878. Under the helm of a new editor, Charles Wilson - who after his surveys for the Palestine Exploration Fund had been British Consul-General in Anatolia - the Turkey in Asia handbook was split into two: Handbook for Travellers in Constantinople, Brusa and the Troad and Handbook for Travellers in Asia Minor, Transcaucasia, Persia etc. Wilson drew on the knowledge of several other experts for the work, among them Hogarth and Ramsay. Based on his own experience, Hogarth ultimately provided Wilson's Asia Minor with 'most of the introductory notes on climate, accommodation, travelling \&c'. for Asia Minor, making 'many hints and suggestions' on the routes, as well as furnishing more specialist details on the history of Asia Minor, and information on specific objects and monuments. ${ }^{78}$

Hogarth's next letter to Murray in the archive is dated 1895. Having worked between Oxford and the Eastern Mediterranean in the intervening period, Hogarth enquired whether Murray would be interested in publishing a series of 'sketches' he had written about his travels. These sketches would become A Wandering Scholar in the Levant, published by John Murray the following year. Hogarth had already offered the manuscript to George Macmillan of Macmillan \& Co, discussed in more detail in Chapter 7. It had been sent to readers, but Hogarth objected to both the readers' comments and the terms offered and pulled the manuscript. Hogarth ended his submission letter to Murray with the admission that a 'leading publisher' had already considered the work, but explained that he had considered Macmillan's terms unsatisfactory. Murray's proclivity for - and long history of - publishing travel writing was an additional attraction for Hogarth. As he had in 1889, he noted the value of his personal experience of travel and foreign peoples recorded in the pages of his manuscript. As added inducement he remarked on his own increased public visibility, stating 'a good many people know me and would give my book a start, I believe'. ${ }^{79}$

The emphasis Hogarth placed on his name recognition returned on the book's acceptance, when he requested a number of presentation copies to be supplied for dispersal among his circle. This circle was not only in England but also abroad; Hogarth's travelling had enabled him to build up an international network of contacts. As he put it, 'a good 
many people have come across me in the sort of wandering life or know me in connection with it'. ${ }^{80}$ He hoped that an advance press notice from the publisher would help to stoke anticipation for the book, but deferred to Murray's commercial instincts on the matter. This Murray did - a note giving a short description of the contents of Hogarth's book appeared in the Athenaeum and was circulated in regional newspapers. ${ }^{81}$

Hogarth had definite ideas about how his work should be produced and sold. Among his main concerns in the initial Wandering Scholar correspondence was the book's length, format and price. Pitched as a series of 'sketches' of no more than 200 pages, he concluded that without illustrations it should be sold for a 'reasonable' 6 shillings. ${ }^{82}$ He entreated Murray to assess the book not as an academic contribution but 'from a trade point of view'. ${ }^{83}$ This notion of commerce was important to Hogarth at this stage in his career. The term 'trade' infused his work, reflecting his views of archaeology; Hogarth originally presented the first chapter ('A Scholar's Calling' in the published book) as 'A sketch of the trade of a wandering scholar in Asia Minor'. ${ }^{84}$

It is clear that Murray himself looked over the manuscript, as Hogarth removed repetitive phrases and other stylistic errors on Murray's advice. Hogarth was indifferent on the question of illustrations, offering at first only a map and then later (after negotiating with Murray) adding photographs and other illustrations to enhance the text. The map, Hogarth suggested, should have his route marked in red, enabling the reader to locate him within the landscape. ${ }^{85}$ That red-lined map was duly included in the book. Another formatting issue arose when Murray suggested Hogarth add chapter descriptions to the table of contents; although he was aware of commercial concerns, for Hogarth this suggestion was overthe-top American style marketing, akin to 'a hawker crying his wares'. He lost that battle, however, and the content descriptions were published. ${ }^{86}$

The chapters he outlined in his initial letter to Murray were more or less the same as those eventually published in A Wandering Scholar, covering his travels in Asia Minor, Cyprus and Egypt. He used his first chapter to define the archaeological field as 'catholic' - by all accounts reflecting his own personal approach. All subjects, from politics to botany, are of interest to Hogarth-as-Scholar and both interrupt and enrich his archaeological investigations. For Hogarth, arrival in the Ottoman East, having been separated from the West for centuries, was like landing on the Moon, so that 'in many parts [the Scholar] will find himself a pioneer, breaking new ground for every science. ${ }^{87}$ Exploration was not to be done with rigid discipline, but rather a wide scope, taking into account both the vestiges of the ancient world as discovered and recovered and its 
modern context: 'maps and political reports, customs and types and folklore, eggs and bulbs and butterflies and rocks - all these fill his day with amateur occupations for which his professional interest is probably not the worse...88

Hogarth's Scholar proved relatively successful in the first year of its publication and had a lasting effect on his career, being judged one of the most memorable of his books. ${ }^{89} \mathrm{~A}$ thousand copies were prepared for sale in December 1895 and 939 sold within the first half of 1896. Hogarth, who had agreed a royalty of 10 per cent on the sales of the book, was paid $£ 35 .{ }^{90}$ Hoping for a second edition, he sent a letter to Murray in April 1896 on the progress of sales. The book had been reviewed favourably; Hogarth hoped that this positive reception would lead to his desired new edition, thereby enabling him to make adjustments and revisions to the text. The book had been dedicated to his fellow traveller William Mitchell Ramsay, who in 1897 published Impressions of Turkey, which Hogarth deemed to be a 'counterblast' to A Wandering Scholar. ${ }^{91}$ Among the changes Hogarth wanted to make was to name publicly all the others who had accompanied him on his wanderings. The second edition materialised, his fellow-travellers were named and dates given for each journey, comprising a chronology of Hogarth's career as archaeological explorer. ${ }^{92}$ A further 500 copies of the book were produced, of which 219 were sold within a year. ${ }^{93}$ Hogarth also enjoyed sales in the United States through Charles Scribner from 1897.94

The success of A Wandering Scholar brought Hogarth to the attention of other more 'popular' publishers who, Hogarth wrote to Murray, 'were beginning to sue'. He asked Murray, with Murray's valuable 'literary experience', to advise him on whether he should take up their offers of writing work..$^{95}$ One of the offers was for a volume of 'The Library of Useful Stories', instigated by the publisher George Newnes, founder of the popular magazine Tit-Bits, a few years earlier. Despite the series of shilling volumes being advertised as featuring contributions from the pens of 'distinguished scientists' and representing a wide range of subjects, Hogarth was reluctant to take it on. Newnes' reputation as a populariser was clearly not to his taste. ${ }^{96}$ It was not to Murray's taste either, and he advised Hogarth against embarking on such a project. Hogarth, perhaps with an eye towards a more 'academic' career, commented that producing a 'Useful Story ... would have been sheer pot boiling + that I really think I need not begin to do now'. ${ }^{97}$

In fact, Murray had in mind a new project for Hogarth to undertake. He proposed that Hogarth write a book on archaeology, a general introduction to the subject's varied branches. Hogarth seized on the 
prospect, identifying it as a route by which to cement his archaeological legacy, even if he was forced to move away from it into another walk of life'. Concerned over his precarious employment in archaeology but wanting to make his mark, Hogarth felt the book for Murray, 'the first firm of publishers who are noted for archaeological works', should 'be really sound + thorough, however readably put. ${ }^{98}$ In the midst of preliminary planning for the proposed work he submitted another manuscript, a double biography of Philip of Macedon and his son Alexander (the Great), essentially the main output of his Oxford fellowship. He considered it 'the best piece of work I have done'. ${ }^{99}$

By the time he submitted Philip and Alexander (published by John Murray in 1897), Hogarth had also received an important professional boost, having been offered the Directorship of the British School at Athens. ${ }^{100}$ With 'a year out of work' before he was due to begin at the BSA, he was searching for paid projects. Although planning some exploration work, he hoped to use this time productively in contributing to Murray's Handbook to Egypt (the edition on which Mary Brodrick was then at work). He was particularly interested in the coverage of Sudan and its imminent accessibility for tourism, suggesting to Murray that 'it might be well to be the first in that field' and that he should be the author to take it on. Hogarth boldly coupled this proposition with a reference to the commercial value of his expertise and ability to travel with ease, a reflection of his self-confidence: 'it would, I suppose, be worth a certain sum to you to be the first in this new field, and you might tell me what you think that sum is. ${ }^{101}$ In the end, prevented from going very far into Sudan, he submitted only notes. ${ }^{102}$

Although he did not end up making Hogarth an official editor for the Handbook, Murray was clearly interested in cultivating him as an archaeological author. He suggested Hogarth submit articles on Egypt and Greece to Murray's magazine Quarterly Review. Hogarth was also working on the proposed archaeology 'handbook' - which was proving complex. Originally conceived of as part of a series, the general overview Murray had proposed was left up to Hogarth to define and he was struggling to find the right scope, wavering between geographical and broadly thematic. By June 1897 he wrote to Murray with some anxiety, proposing a change of tack. Instead of one book in a larger series, he suggested that the book become instead a bespoke archaeology series, enabling him to find new authors to contribute 'some half-dozen vols' to cover a variety of archaeologies - prehistoric, Egyptian and Assyrian, classical, 'Hebrew', 'North Europe', Far Eastern and American. Murray noted on the top of this letter that the proposal 'shall be most caref[ully] 
cons [idered]'. ${ }^{103}$ Ultimately it was not taken up, and Hogarth again faced the problem of being out of his depth. He wrote somewhat despondently, 'I do not say that it is in any ways impossible, but it is very difficult to see exactly how to do it. The field is so vast and the knowledge required is so catholic'. Even with his own 'catholic' approach to exploration he was at an impasse, not wanting to overstretch his capabilities and produce a poorly researched book that could damage his reputation on the brink of taking up his new position in Athens. Again he showed his commercial acumen, insisting that Murray propose a financial arrangement that would match the 'time and labour' necessary. With the prospect of 'demand' for a book of this kind, Hogarth declared, 'I think you ought to give me an interest in its sale besides a sum for the copyright'. ${ }^{104}$

While working on a solution to the problem, Hogarth started writing what sections of the book he could. He opted to produce short articles on key topics - 'Aegean + Mycenaen Discoveries', 'historic Greece' and 'Greek Literature' for the Quarterly Review, proposing to republish them in a book. These, he surmised, would also enhance his visibility in the arena in which he would be circling as British School Director, based in Athens. With these beginnings in hand, Hogarth proposed to approach a collaborator who could use his text as a template. In this proposal lay the kernel of the solution to the problem: an edited text with a range of contributors. This was published in 1899 as Authority and Archaeology: Sacred and Profane. ${ }^{105}$ The book in its final form was heavier than initially conceived, both in tone and price. As Hogarth put it, it rather indicates the right methods of using archaeological evidence, + the legitimate possibilities of that evidence, than gives practical information'. It was not a how-to manual, such as the one that Petrie would produce in $1904 .{ }^{106}$ By the time it was published, Hogarth was established in Athens and able to report on the popularity of $A$ Wandering Scholar in the city, where 'there seems to be a small steady demand' through the 'local agent' for the British in Athens, Arthur Hill. ${ }^{107}$

After the publication of Authority and Archaeology, Hogarth began to work with other publishers as noted in Chapter 4, and the extant correspondence in the John Murray archive becomes less frequent. His term as BSA director came to an end in 1900 (during this time he had also acted as a correspondent for The Times on conflict on Crete). Excavations on an internationally administrated Crete, begun with Arthur Evans in 1899 as BSA Director, remained an ongoing salaried project; under his directorship a new Cretan Exploration Fund was established. ${ }^{108}$ Authority and Archaeology did well enough to warrant a second printing, but this did not match the strength of the first. ${ }^{109}$ 
In 1905 he suggested to Murray the possibility of publishing a collaborative work with his sister Mary, a former Slade School student and practising artist and later art teacher. ${ }^{110}$ She had shown her work to Hallam Murray, an artist as well as a publisher, and Hogarth wrote on her behalf to see if these could be made up into a book comprising her illustrations and with brief 'accompanying text' from him. Mary had been with him during his first year in Athens and produced sketches of 'modern' Athenian life. ${ }^{111}$ Hogarth's proposed text, 'devoid of learning or any archaeology', would 'make the drawings intelligible'. Murray did not accept the idea and the book was eventually published elsewhere. ${ }^{112}$ What Murray wanted, and Hogarth resolutely refused to produce, was 'a new Wandering S.', drawing on Hogarth's talents for conjuring up the experience of foreign lands. Hogarth was indeed planning another foray into travel writing, but he would not offer this work to Murray. It was destined for Macmillan, the subject of the following chapter. ${ }^{113}$ 


\section{7 \\ Macmillan \& Co}

I want if possible to have the imprimateur of your firm... ${ }^{1}$

The 'House of Macmillan' began with Daniel and Alexander Macmillan, brothers who came from Arran, an island off the west coast of Scotland. Daniel Macmillan, the eldest, had joined a Cambridge publishing house and built up contacts there before moving to another in London in the early 1830s. His brother joined him there and subsequently they set up their own bookshop and publishing house. From the beginning the brothers were committed to educational publishing, but with a commercial eye. London proved expensive and the brothers relocated to Cambridge, where they were able once more to lock into the intellectual and cultural networks of the University. The location of their Cambridge bookshop made it an informal salon. They began to cultivate authors from the university to provide them with marketable nonfiction. ${ }^{2}$

Daniel Macmillan died in 1857, and Alexander Macmillan opened an outpost of the Cambridge bookshop and publishing house in London's Henrietta Street in Covent Garden. Here, as in Cambridge, an informal salon developed, drawing in writers, artists and scholars. ${ }^{3}$ The business expanded during the 1860s and 1870s, identified as a key period in the development of Macmillan \& Co, as new periodicals Macmillan's Magazine and Nature were established. Educational publishing remained a priority, providing a steady stream of income, particularly after the 1870 Education Act. Expansion continued abroad as branch offices were set up in India and the United States. The New York branch, discussed in more detail below, was to prove a particularly fruitful relationship for archaeology, bringing the work of British archaeologists to the attention of students and universities across the Atlantic. Formed in 1869 under the helm of Englishman George Brett, it was the result of Alexander Macmillan's deep interest in the United States and the North American market. ${ }^{4}$ 
In the 1870 s and 1880 s control of the company was transferred from the first to the second generation of Macmillans - the children of Alexander and Daniel. Three second-generation Macmillans, Frederick Orridge and Maurice Crawford Macmillan (sons of Daniel) and George Augustin Macmillan (son of Alexander), began working for the firm at this time. John Kajinski has shown that the Macmillan firm of the 1870s and 1880s believed it more important that their nonfiction authors should be publicly visible intellectuals than academics attached to a particular institution or discipline, with the publisher, rather than any other scholarly body, serving as the authoritative mediator between a respectable, middle-class reading public and their authors. ${ }^{5}$ Charles Morgan noted that this new generation placed more emphasis on readers' reports, rather than resting the decision-making powers entirely on the shoulders of the Macmillans themselves. However, the incoming manuscript books and correspondence held in the Macmillan archive show that the Macmillan family remained actively engaged in the process of accepting and producing books and facilitating relationships with authors. ${ }^{6}$

George Macmillan helped to found the Hellenic Society in the 1870s and served as its Honorary Secretary for decades. He also had a long association with the British School at Athens, serving as its Honorary Secretary for over a decade in the 1880s and 1890s. These two roles brought him a strong network of classicists and classical archaeologists to draw on for publishing, and he is credited with overseeing and strengthening the company's archaeology list. ${ }^{7}$ Macmillan \& Co's strong relationship with classical archaeologists and commitment to education resulted in the production of the Handbooks of Archaeology and Antiquities series, with Percy Gardner as its English editor. These works, written by known scholars, helped to define the field in setting out key themes, principles and specialisms in archaeology, and were destined for use in teaching. The archaeologists Macmillan cultivated through the series were committed to expanding both archaeological education in general and the authority and identity of archaeologists in particular. Macmillan's guidebook to Greece drew on and highlighted the experiences of Ernest and Mary Gardner in the country, while D. G. Hogarth, a long-term friend of George Macmillan, contributed his second memoir, Accidents of an Antiquary's Life, to the Macmillan lists at an important stage in his professional life.

The correspondence of archaeological 'men of letters' - as Kajinski has termed professional (male) authors of “'serious" writing to ... a general, middle-class readership' - has been gathered together and classified in the Macmillan archive at the British Library. ${ }^{8}$ Thus under 
'K: Archaeologists' can be found correspondence from D. G. Hogarth and Percy, Ernest and Mary Gardner (among others) with George or Maurice Macmillan. ${ }^{9}$ In practical terms, initial stamps (for example, 'GAM') on some of the Macmillan correspondence occasionally indicates which Macmillan received the letters referenced in this chapter, but the universal formality of addressing letters to 'Dear Macmillan' often makes it difficult to distinguish between the three Macmillans working for the firm at the time. Relevant material related to archaeological publications is also found in the ' $\mathrm{U}$ : Letter Books' containing delicate triplicate copies of correspondence from Macmillan \& Co in London to Macmillan \& Co in New York.

The value of this particular part of the archive lies in its insight into the nature of Anglo-American scholarship and publishing. This relationship was particularly productive for the compilation of Macmillan's Handbooks on Archaeology and Antiquities, co-edited in the 1890s by Percy Gardner and Francis Kelsey, the American classical archaeologist of the University of Michigan. Many of the books and authors discussed throughout this book were published in both Britain and America, but through the Macmillan archive letter books this relationship can be examined in detail, allowing an image of the late nineteenth- and early twentieth-century American and British educational nonfiction markets to emerge. ${ }^{10}$

\section{The Gardners and the House of Macmillan}

In the early 1890s Percy Gardner was Lincoln Professor of Classical Archaeology at Oxford, working towards developing the classical collection at the Ashmolean Museum. He was also editing the Hellenic Society's Journal of Hellenic Studies - a core part of his involvement with Macmillan - and acting as a reader advising on the potential for publication of archaeological works. ${ }^{11}$ One of these works was the 'projected primer' on ancient Greek dress by the archaeologist and classicist Maria Millington Lathbury. Having completed examinations in the 'Literae Humaniores' course at Somerville College in the late 1880s, Lathbury was subsequently appointed an Extension Lecturer for Oxford University - an appointment, her daughter later noted, that enabled her to concentrate on 'making herself a recognised intellectual personality'. ${ }^{12}$ As noted in Chapter 3, Lathbury was one of the British Museum's cohort of 'lady lecturers'; her classes there focused on ancient Greek costume and daily life. ${ }^{13}$ Her lectures included demonstrations of Greek dress, 
using a wooden artist's lay model and pieces of fabric, expertly pinned to create draping effects.

Gardner was generally in favour of publication, recognising and promoting to Macmillan the book's value to various strata of society. In his vision, amateur and professional theatrical companies and country house parties, enthusiastic during the 1890s for plays and tableaux vivants set or containing scenes in ancient Greece, would turn to the primer for hints. Artists such as Frederick Leighton, renowned for painting classical scenes, would be able to represent these scenes correctly in dress terms with such a reference work to guide them. ${ }^{14}$ Macmillan \& Co subsequently published Maria Millington Lathbury Evans's illustrated Chapters on Greek Dress, priced at 5 shillings, in 1893, the year after her marriage to antiquary John Evans. ${ }^{15}$ Dedicated to the Oxford University Dramatic Society, reflecting the book's value (as Gardner had predicted) to similar theatrical productions, Evans echoed the book's relevance for theatrical and artistic pursuits in her brief introduction:

... having noticed in pictures of classical scenes and in Greek costume when exhibited on the stage, some ignorance of the elements of the subject, I venture to make public the following pages in the hope that they may be of service to those who, from archaeological or artistic causes, wish to obtain a correct insight into the character of the Greek dress in classical times. ${ }^{16}$

She also thanked 'Professor Gardner' for reading the proofs.

In another 1892 letter Percy Gardner presented Macmillan with his own prospective archaeological publication - a general 'handbook of Greek Antiquities' that he was in the process of planning. Two years later he offered a work on 'Greek sculptural reliefs', promoting the 'wider public' who he proposed would use them as the inspiration for tombstones. ${ }^{17}$ The publication resulting from this suggestion, Gardner's Sculptured Tombs of Hellas (Macmillan, 1896), priced at 25 shillings, was certainly aimed at wealthier mourners. Gardner's expertise was called upon again in the following year for a project that ended up consuming a good deal of his time - the 'Handbooks on Archaeology and Antiquities' series.

Francis Kelsey's suggestion that a series of handbooks on 'Roman life' be compiled first landed on Frederick Macmillan's desk in early 1895, via George Brett in Macmillan's New York office. ${ }^{18}$ A more detailed outline of the scheme was called for, and Macmillan questioned whether the series should include both Greek and Roman topics. Asked for his 
advice on the details of the scheme, Gardner replied favourably but urged caution, particularly on the selection of authors. For him the quality and visible expertise of the authors was paramount, and in his opinion Kelsey's projected contributors were not internationally significant.

Percy Gardner's comments on the value of the scheme reveal both his unexpected astuteness and his willingness to encroach on Macmillan's knowledge of the market. He advised that the most important points in evaluating the success of the scheme would be the careful selection of topics, the quality of the illustrations and the price. ${ }^{19}$ In fact, he was talking himself into a job. Frederick Macmillan took Gardner's advice wholly on board, a step that reflected his value as an advisor and his role as knowledge broker for the company. Macmillan wrote to George Brett that as Kelsey was not a well known figure in either America or Britain, it would be difficult to obtain the public experts that the series required to be financially viable. On the other hand, having suggested the scheme, it would be discourteous to disconnect Kelsey and replace him with a better known scholar. He also suggested an amended scope for the scheme, with works focused on the classical world featuring 'new' illustrations at an affordable price. The series would cover themes including domestic and public life, architecture, theatre, religion and money. Authors, he proposed, should be offered a substantial lump sum ( $£ 100$ ) for the copyright of their work outright, or a smaller $£ 20$ advance and 10 per cent royalty. Overseeing the series would be two editors, one responsible for organising the American collaborators (Kelsey) and the other responsible for the British ones. ${ }^{20}$ It would be an Anglo-American production, through the London and New York branches of the firm. Macmillan of London, however, reserved the right to reject authors or titles from those Kelsey identified. Further, some topics were kept for British authors. $^{21}$

The Macmillans wanted to secure Percy Gardner as British editor of the series. He was approached with the proposal and sent a prospectus outlining further details. Initially he demurred on account of a heavy workload, offering instead to write 'a volume or two' and act as 'amicus curiae' (impartial advisor) for the series, suggesting a few other potential contributors from among his network. On the prospectus to be sent out to prospective authors, he advised that its phrasing be 'toned down' in order not to repel English scholars; in his opinion they would be put off by its slightly more aggressive marketing. ${ }^{22}$

By August 1895, however, Gardner was beginning to change his mind. Kelsey had been actively recruiting authors in America, and in response to news of Kelsey's progress Gardner's patriotic instincts kicked 
in. His letter to the firm communicates his belief that the organisation of the English volumes lacked energy: 'We ought to do our share of the work in England, and we should do it better than the Americans. ${ }^{23}$ Therefore in October 1895 he accepted the role of English editor of the series, for a salary of $£ 20$ for each book he worked on, and immediately set about formalising his role and recruiting authors. He aimed for a wide and comprehensive scope, proposing works on 'Jewish Private Life', 'Ancient Slaves' and 'Ancient Commerce', enabling his prospective authors to set out their literary and intellectual wares in an Anglo-American marketplace. ${ }^{24}$ Although the series was primarily focused on the Greco-Roman world, there were initial proposals to widen the scheme to other ancient civilisations. In one letter Frederick Macmillan indicated that an 'agreement' with Flinders Petrie had existed since 1893 for an Egyptology Handbook. ${ }^{25}$

The scheme was beginning to take shape over the summer of 1895 . Discussions over what it was to be called signalled the growing importance and visibility of archaeology as a discipline. A clear and meaningful title was crucial to ensuring sales, and while Frederick Macmillan was not opposed to the proposed title 'Ancient Life and Art', he was worried that it might not adequately reflect the themes and mission of the series. Instead he proposed 'Archaeological Handbooks', archaeology being, in his opinion, 'an accepted subject ... understood to embrace both art + antiquities'. The word 'Handbooks', for Macmillan, conveyed the twin ideals of commerce and academic rigour that Macmillan \& Co (in London) wanted the scheme to embody. ${ }^{26}$ Kelsey meanwhile was pushing for 'Archaeology and Antiquities' to be part of the title. When asked for advice on the matter, Gardner wrote to George Macmillan that he agreed with Kelsey, as the two words together signified the breadth of the subject and would be meaningful in an international context. Without archaeology attached, antiquities sounded too specialist; yet without antiquities, archaeology might be understood only as 'the treatment of existing remains. ${ }^{27}$

The series title was eventually settled as 'Handbooks of Archaeology and Antiquities'. ${ }^{28}$ Volumes, varying in length and price (from 5 shillings upwards), were advertised as 'the work of a thoroughly competent author', covering different themes in the ancient world in a way that would interest both students and 'the educated general reader'. As a whole, the scheme offered its readers a 'handy encyclopaedia'. ${ }^{29}$ Percy Gardner and Francis Kelsey (in that order) were jointly named as editors in the advertising; in Macmillan's opinion, the use of two editors to represent both England and America meant that there would be no 
opportunity for 'prejudice' from readers of either nation to compromise book sales. ${ }^{30}$

The first volume, A Handbook of Greek Sculpture, was published in January 1896. Its author was Ernest Gardner, brother of Percy. He had been working on a manuscript on the subject while in Athens as Director of the British School in the autumn of 1894, by which point he was already receiving enquiries from teachers on both sides of the Atlantic on the publication status of his book. ${ }^{31}$ It was published in two parts; Gardner's progress on finishing the manuscript was slow, but he was anxious not to hold up publication. He proposed to Macmillan that the first part of the manuscript, which was then finished, be published so that he could 'at once [occupy] the field' and satisfy the need for a handbook on sculpture that he saw reflected in teachers' letters. This proposal was accepted, and Gardner was given a 10 per cent royalty on the price of the book in Britain and America. ${ }^{32}$

Gardner's Greek Sculpture Part 1 was favourably reviewed; Macmillan's advertisement for the series included a quote from the Guardian that 'confidently recommended' Gardner's handbook. ${ }^{33}$ While finishing Part 2, Gardner wrote to Macmillan with a new idea for marketing and reported on the audience for his book. According to Gardner, the Teacher's Guild of Great Britain and Ireland, who were assembling 'an extensive series of slides for lecturing purposes', proposed to create a special sequence of slides on 'Greek sculpture', using his book as a basis for their selection. Gardner wanted to write a special notice in the Preface for Part 2, publicly tying his books to the scheme and providing further marketing for the title among teachers. He would also provide the Teacher's Guild with an advance copy of the Part II illustrations. ${ }^{34}$ Gardner's amended Preface was duly published, and the illustrations in his Handbook corresponded with the Teacher's Guild slides. Readers were referred to the collection held in the Teacher's Guild's 'Educational Museum' on Gower Street - close to Gardner's new office at University College London, where he had just begun his tenure as Yates Professor. ${ }^{35}$

The Handbook to Sculpture remained one of the most popular of Ernest Gardner's many books, particularly drawing readers in the United States. It was reprinted several times and Gardner received regular statements on its progress from Macmillan's. These revealed what Gardner considered to be his 'practical monopoly' over the subject in both Britain and America. ${ }^{36} \mathrm{~A}$ revised edition combining the two volumes was issued in 1915, enabling Gardner to bring the artworks considered into 
chronological order, something previously impossible to address. With the rapid pace of archaeological discovery in Greece during the early twentieth century, a new edition bringing the text thoroughly up to date with current excavations and interpretations was a priority. ${ }^{37}$

Over 10 Handbooks eventually appeared in the series, but Percy Gardner began to struggle to find contributors who could finish the works they had promised. He wrote an anxious letter to George Macmillan in November 1899, asking for information on the fate of the English volumes in the series. ${ }^{38}$ Sales were steady in America, but by the end of the century in England they were beginning to stagnate. In 1902 George Macmillan wrote to Brett in New York that he was considering ceasing to commission new English volumes, stating: 'the series has so far proved very disappointing, and our English sales have been considerably below those on your side' ${ }^{39}$

Despite his gloomy outlook, two years later he included Percy Gardner's Grammar of Greek Art as a new volume in the series. In the intervening period Gardner and fellow Oxford archaeologist John Linton Myres had published a short pamphlet, 'Classical Archaeology in Schools', with the Clarendon Press; it had inspired teachers in the United States to seek further resources for their classrooms. ${ }^{40}$ One reader, a Massachusetts teacher called Anna Boynton Thompson, spent six weeks studying Greek art with Gardner in Oxford. Her goal was to promote the study of the subject in America. It was working directly with Thompson that inspired Gardner to construct his 'rationale of sculpture vases $+c$.' in the Grammar. ${ }^{41}$ He later credited Thompson and her enthusiasm for Greek art and its value to education, noting the Grammar's 'larger circulation in the United States than in Britain'. ${ }^{42}$

Both Percy and Ernest Gardner saw teachers and schools as a productive market for their work, and focused from the mid-late 1890s on developing their personal relationships with them. Following an 'Archaeological Conference' for 'schoolmasters + others' organised by the Gardner brothers at University College London in January 1898, Percy Gardner notified Macmillan of teachers' positive responses to the presentations he and his brother had made during the day. He also noted their suggestion for the publication of a cheap edition of selected plates from the Atlas of Classical antiquities, which provided descriptive text to accompany illustrations of classical art. ${ }^{43}$ Although Macmillan chose not to embark on such a scheme, the episode reveals the Gardners' dedication to providing up-to-date archaeological information for secondary-school students and teachers, as well as their active engagement in curricula frameworks and willingness to pursue opportunities for this market. 


\section{Touring Greece}

While Percy Gardner's correspondence is mainly focused on the editing of the Handbooks series, Ernest Gardner's correspondence with Macmillan highlights his role in London- and Athens-based networks. He served as the Director of the British School at Athens for seven years (188795) before becoming Yates Professor of Classical Archaeology at UCL in 1896. While at UCL he maintained his link with Greece by conducting bespoke tours there on a regular basis; Mary Gardner often accompanied him on these trips. Educational yachting cruises in the Aegean were a relatively new phenomenon; in 1892 a group of Athens-based dragomen organised a 10-day cruise for 14 passengers to the islands, including Ernest Gardner. ${ }^{44}$ During the steamer Aegina's maiden voyage Thomas Jex-Blake, Dean of Wells, wrote a letter published in The Times outlining the benefits of the new scheme and naming Gardner, then British School Director, as one of the passengers on board. Jex-Blake celebrated the opportunity to engage with ancient and modern Greece, noting among the tour activities visits to sites well-known through Greek myths and legends, and those undergoing excavation. Modern Greece was sampled too, as the tourists took part in the annual Festival of the Annunciation doubly significant as the date of Greek independence from Ottoman Turkey.

An editorial in The Times, published the day after Jex-Blake's letter, promoted Gardner's presence as a symbol of the cruise's intellectual legitimacy. It hailed the enterprise of 'courriers' (dragomen) John Weale, Apostolos Apostolis and Angelos Melissinos in offering the experience of a privately conducted tour at a moderate price, opening up the Aegean islands to tourist traffic. ${ }^{45}$ After Gardner became Yates Professor, bringing what the College promoted as a 'European' reputation, he offered the possibility of lectures on site in Greece during the final term of the session. ${ }^{46}$ By 1902 these Greece-based lectures were given annually, attracting not only students, but also history and classics teachers, university lecturers and others. ${ }^{47}$ Among those who joined the Gardners on board was Robert Carr Bosanquet during his tenure as Director of the British School at Athens. ${ }^{48}$ Gardner was later hailed as a 'pioneer' of archaeological tourism to Greece during this period. ${ }^{49}$

One of the works that helped draw out the potential for tourism in Athens in particular was Gardner's Ancient Athens. Macmillan's New York office published Ancient Athens in 1902 as an accompanying volume to the work of August Mau, whose Pompeii: its Life and Art had been published in 1899. Ancient Athens was a thorough guide to the city's sites and monuments, generously illustrated with photographs and plans 
intended to serve a broad readership of both travellers and students. In this work Gardner combined current scholarship and ancient sources to produce a chronological and topographical survey. The illustrations were carefully inserted into the text in positions where they might be easily found in relation to the description and analysis Gardner intended them to illustrate. He had drawn on contacts both in Athens and London for his illustrations; his Preface acknowledged the debt he owed to local photographers. ${ }^{50}$ Macmillan New York revealed and promoted Gardner's expertise and personal experience of the city, on publication declaring the book to be among its 'New Books of Importance.. ${ }^{51}$ A lengthy illustrated review appeared in the New York Tribune in December 1902, praising the work as 'clear, practical and vivid, and altogether a sound guide'.52

As the twentieth century dawned, Ernest Gardner became more heavily involved in tourists' intellectual and physical access to Greece and the Aegean through his work on the revision of Macmillan's guide to Greece. As noted in Chapter 2, Macmillan \& Co had instigated a series of handy 'Guides' for tourists to the Mediterranean and Near East from 1901. The Guide to the Eastern Mediterranean originally covered the area between Italy and the western part of Asia Minor, and went through two editions in its original format. By 1908, however, Macmillan had decided to cover Greece and Asia Minor in a separate guidebook. The third edition guide was renamed Guide to Greece, Constantinople, Asia Minor etc, and entirely 'revised and re-arranged'.$^{53}$ Macmillan's Mediterranean guides included scholarly essays on thematic topics of relevance to the tourist, and George Macmillan approached Ernest Gardner to write a short article on 'Greek Art' for the new edition. Murray's Handbook for Travellers in Greece had incorporated a much earlier work of Gardner's but, as Gardner told Macmillan, by that point the information was very out of date. He began to draft the article using Macmillan's Guide to Italy for reference, writing to Macmillan to ascertain the projected scope of the piece and whether (as in the Italy guide) he should include architecture as well as sculpture and other artworks. He modelled his final draft on Roger Fry's article on 'Italian Art' in Macmillan's Guide to Italy, including guiding headings to make the text easier for readers to follow. ${ }^{54}$

The Macmillan Guide to Greece offered specific yachting notes alongside essays on archaeology, history and art garnered from experts. When he received the proofs of his Greek Art article back from Macmillan, Gardner noticed a portion of the yachting notes had been included. In his acknowledgement letter for the proofs he told Macmillan that the information for yachts 'seem[s] to me curiously selected + scrappy', leaving out many of the spots relevant to ancient 
history that (in his opinion) would be of interest to tourists in Greece. Drawing on his own experience touring sites of archaeological significance on small steamers, Gardner offered his own emendations to the yachting notes in which he would detail the best landing spots for some key ancient important sites: Miletus, Troy and Pergamum on the eastern coast of Asia Minor, and the Aegean islands - Naxos, Melos, Ios, Paros, among others.

In setting this information out, Gardner highlighted his own contacts in Greece's evolving tourist industry - the Greek sailors responsible for tourist access to ancient sites with whom he would have dealt both as a traveller and as an archaeologist based in Athens. ${ }^{55}$ It is clear that Macmillan was interested in the information that Gardner was offering, and asked him to send notes. A 'practical sailor' had originally contributed the yachting notes, and Gardner was anxious that his suggestions should not be taken without due care being given to precise directions for sailing. Rather, Gardner's knowledge would enhance these practical details - he was interested in enabling access to sites omitted from the original list of landings that would be popular among those tourists interested in ancient Greek history and archaeology. It was this personal experience of sailing in small, 500-tonne vessels (rather than large steamships), of going to ports that were off the beaten track and of having personal contacts with local sailors that he promoted to Macmillan. ${ }^{56}$

When it was published, the Macmillan Guide to Greece acknowledged the debt owed to Ernest Gardner for his work on 'Greek Art'. The Preface to the volume also highlighted the contributions of Mary Gardner, David Hogarth and Arthur Evans, the excavator of Knossos (who revised the guidebook's coverage of the site). Mary Gardner had been involved in contributing to the guide since 1904, when one of the Macmillans had contacted her about revisions. Having accumulated knowledge of Greece through her personal studies and experiences there, she wrote confidently in response, suggesting that new regional maps and site plans should be added. She also noted that a newly opened Museum at Delphi might be worth highlighting in the text. ${ }^{57}$ For the 1908 edition, she was credited with revising the sections on Greece and the Greek islands.

Alongside her work on tourism, the relationship with the Macmillan family was one Mary Gardner sought to cultivate. The letters in the Macmillan archive show both her regular submission of manuscript short stories for publication in Temple Bar and her desire to include the Macmillans in social gatherings she organised. She was not always successful in her publishing efforts, but the range of her submissions 
illustrates her desire to use and record her archaeological experiences to the greatest extent possible.

\section{Hogarth and the House of Macmillan}

David George Hogarth's relationship with Macmillan \& Co, and particularly with George Macmillan, was an important part of his writing career. It was to Macmillan he turned with the original manuscript of A Wandering Scholar (later published by John Murray as described in the previous chapter). For Hogarth as an emerging archaeologist in the 1890s, George Macmillan's position as Secretary to the Hellenic Society and the British School at Athens made him an important figure in the support for archaeological research in the Eastern Mediterranean and Middle East.

George Macmillan's first serious engagement with Greece came in 1877 when, aged 22, he accompanied the classical scholar John Pentland Mahaffy and Oscar Wilde on an extended trip to the country. His letters to his family from this trip, preserved in the Hellenic Society archives, show his enthusiasm for the country and its people, and what he saw as the melding of ancient and modern Greek culture in the interactions he had. His first trip to the Acropolis was a particular highlight. This experience led him to become one of the founding members of the Hellenic Society in 1879, a role that he used to make studies of the Greek world more visible and to encourage financial support for research. Among the list of initial members was his father, Alexander Macmillan, and Percy Gardner, whom he had met in Greece. ${ }^{58}$

By 1894, the date of the first letter from Hogarth in the Macmillan archive, George Macmillan had been Hellenic Society Secretary for 15 years. He sat on a council that was directly responsible for financing excavations, employing archaeologists such as Hogarth. This first letter concerns Hogarth's explorations in Alexandria, partly supported by Hellenic Society funds. The submission of five draft chapters of 'A Wandering Scholar' came in May $1895 .{ }^{59}$ At this early stage in the development of the manuscript Hogarth already aimed for the five 'essay sketches' submitted to be 'more than mere narrative' - suggesting that his goal was, in a sense, to set out his personal scope for the archaeological identity. The draft was still taking shape, however. Having originally suggested chapters on 'The Scholar's Calling', his experiences in Egypt, seeing the Euphrates River and observations of 'The Anatolian' and 'The Modern Greek', he quickly added a new chapter, 
and took one away, observing to Macmillan that his thoughts on the people of Greece should not be published if he intended to have any further dealings in the country. As he was to do later with Murray, he promoted his own visibility as a scholar to Macmillan as proof that the manuscript, if published, would draw purchasers. The sketches were officially submitted in July, under the title 'The Great River Euphrates, $+c^{\prime} \cdot{ }^{60}$

Macmillan sent the manuscript to readers, and offered Hogarth terms. Readers' reports were sent to Hogarth, and his response to Macmillan illustrates his confidence in the manuscript and in his projected audience. The readers objected to Hogarth's use of 'foreign words' in the manuscript; Hogarth was mildly affronted, inferring that with the popularity of Eastern travel and Eastern travel narratives among certain sections of English society some terms - tell (for hill), khan (for market or resting place) and pasha (an Ottoman title) - were so familiar that they did not need translation. ${ }^{61}$ It was these seasoned transnational tourists, whether armchair or not, to whom Hogarth wished to appeal. Hogarth was also unhappy about the terms Macmillan offered. Judging from Hogarth's response to the contract, the terms were designed to minimise the risk of publishing a relatively untested author (a fact that he later recognised himself). Despite his novice status, Hogarth outlined his views in no uncertain terms: royalties of 10 per cent on the book's price (which he suggested should be set at 6 shillings), beginning after a certain number had already been sold (he suggested 250 copies) and rising to 15 per cent after the sale of 1,500 copies, would be a more appropriate deal. ${ }^{62}$

In his opinion, the essays he presented for publication would be just as financially valuable as individual magazine articles for which he could expect more satisfactory remuneration. In addition, and more relevant to Macmillan as a book publisher, Hogarth believed that the public who already knew him as a scholar and writer would be eager to purchase his work. ${ }^{63}$ It seems, however, that Macmillan was not quite as enthusiastic in his response to Hogarth's letter as Hogarth had hoped. In his next letter Hogarth's sensitivities became apparent. Viewing Macmillan's hesitancy over the shape of the book (particularly in his reliance on readers' reports) as a sign that he was only accepting the manuscript because of their prior friendship, Hogarth decided to withdraw the manuscript altogether. He again complained about the readers' aversion to non-English terms - in Hogarth's view it was these words that set his manuscript apart, a signal 'to the very large public' with a growing interest in the East that the book was written for them 
by someone with experience. Such terms belonged in a book about the East; no English words would convey the same meaning. ${ }^{64}$

Despite the difficulties over the Wandering Scholar manuscript, Macmillan and Hogarth kept up their correspondence. As British School at Athens Director, Hogarth began working with Arthur Evans at Knossos on Crete in 1900 under the auspices of the Cretan Exploration Fund. His personal visibility increased with the post and with the spectacular finds made during the excavation, which laid bare the Mycenean palace of King Minos - he of the Labyrinth where the princess Ariadne helped hero Theseus pursue and defeat the Minotaur. Hogarth gave up the post of BSA Director to devote more time to the Cretan Exploration Fund excavations, and George Macmillan was the Fund's treasurer, making personal appeals in the press to gather money to continue excavations. ${ }^{65}$ In 1903 a room full of three seasons' worth of Knossos finds was arranged as part of the Royal Academy's annual Winter Exhibition. A note indicating Macmillan's role as treasurer receiving subscriptions was included at the end of the 'Short Account of the Excavations' in the Winter Exhibition catalogue. Hogarth was briefly profiled for the contributions he made to the display from his own excavations on Crete. ${ }^{66}$

As noted in Chapter 6, in the following years Hogarth began publishing with a focus on his geographical knowledge of the 'Near East', while at the same time gaining further excavation experience. He collaborated with Macmillan on an article on the excavations in Crete that appeared in the Illustrated London News in September 1906. Macmillan provided the images on behalf of the Cretan Exploration Fund, while Hogarth wrote the accompanying text. ${ }^{67}$ At the same time he had returned to his earlier focus on Asia Minor, conducting excavations on behalf of the British Museum at the coastal site of Ephesus, where the remains of a large ancient city were located. With the new knowledge and insights into ancient Greek culture and life gained from the dig, and fresh experience of the landscape, Macmillan asked Hogarth to contribute to the revision of the Asia Minor section of Macmillan's Guide to Greece in 1907.

Asia Minor was increasingly connected by railway, and at Macmillan's request Hogarth added information on sites accessible by railway from Smyrna (Izmir) - an important, populous port and commercial centre with links to other key ports in the Mediterranean and beyond: from Marseilles, Brindisi, Genoa, Athens, Constantinople, Alexandria and Tripoli to London and Liverpool. ${ }^{68}$ These sites had visible ancient remains, and Hogarth's brief historical and topographical descriptions were meant to give prospective tourists an idea of the 
importance of the archaeology as well as highlighting accessibility by rail. His suggestion that the section title be changed further reflected this opening of Asia Minor to more conventional tourist traffic: the original title of 'Smyrna and Ephesus' became 'Smyrna and District'. ${ }^{69}$ Ephesus, Hogarth's particular area of expertise, was revised, and a new plan of the site included with Hogarth's emendations. Unlike the previous plan, it included the area immediately surrounding the site.

This additional information gave readers a visual representation of the ancient city within its modern context - both the nearest railway station at Ayasoluk (which also offered hotel accommodation) and the main road were shown. Hogarth was explicit in his instructions that the railway line should be shown continuing on past the station, suggesting that he was keen to show Ephesus not as an end point, but rather a stop en route: there was more of Asia Minor to see..$^{70}$ The information on Ephesus was brought up to date, with a section including Hogarth's own excavations at the Artemesium, site of successive temples, during which ivory objects, jewellery and coins had been discovered. ${ }^{71}$

In the autumn of 1907 Hogarth travelled across the Atlantic to embark on a lecture tour in North America. His work was already available there, the American publishers Charles Scribner and Sons having acquired the rights from John Murray to publish A Wandering Scholar and Philip and Alexander. His invitation came from the Archaeological Institute of America (AIA), which had branches in many states. The focus of Hogarth's tour was on the West Coast, beginning in Washington State and moving south, then east. His trip was financially supported with a $\$ 1,000$ honorarium from the philanthropist and classical studies enthusiast James Loeb, who established the Loeb Classical Library series a few years later. ${ }^{72}$ Hogarth delivered dozens of lectures, covering all three of the AIA's 'circuits' (Western, Eastern and Central). His lectures featured the results of excavations in Crete and Asia Minor, and he was advertised in the American press as a noted expert in the field, and the author of $A$ Wandering Scholar.

The events were mainly open to the public without charge and featured Hogarth's own specially selected photographs, illuminated on a projection screen. ${ }^{73}$ Hogarth clearly sought to appeal to his US audience and simultaneously to highlight his archaeological connections by expressing his opinion, the San Francisco Call reported, that the Ottoman Sultan would look on new American excavations in Asia Minor with approval. ${ }^{74}$ By early January Hogarth was in the nation's capital as the keynote speaker at the eighth anniversary celebrations of the George Washington University's Classical Club, established to promote the study 
of the classical world both at the University and to Washington DC's 'cultured' set. ${ }^{75}$ He moved on to Chicago for the AIA Annual Meeting. Here, The Salt Lake Herald noted, Hogarth, as 'one of the most able students of archaeology and history engaged in the active work of exploration today', discussed the results of the British Museum's excavations at Ephesus, keeping his audience rapt 'from start to finish'. ${ }^{76}$

On his return to England in early 1908 Hogarth embarked for the East once more. He began an initial survey of the ancient city of Carchemish, on a hill overlooking the Euphrates river near the village of Jerablus on the border between what is now Turkey and Syria. ${ }^{77}$ This site allowed him to continue working on his interest in the Hittite civilisation, about which there were brief references in the Bible and ancient inscriptions. Carchemish had been one of the Hittites' chief capital cities, and Jerablus was also then on the route of the Baghdad Railway line, still under construction. The vision for the railway was to provide a new overland route between Europe and the East, opening up traffic to parts of Asia Minor and Mesopotamia that were at that time considered remote except for the most hardened and experienced travellers. ${ }^{78}$ The plans advanced over the first few years of the twentieth century - the cities of Constantinople, Aleppo, Mosul, Baghdad and Basra were to be joined in a projected railway route, under the control of the German-owned Baghdad Railway Company. ${ }^{79}$

When Hogarth was surveying the area the railway had not yet reached Jerablus, but a station was due to be constructed as a stop en route to Mosul; eventually tourists would follow. Therefore, Carchemish/ Jerablus was a key site for Hogarth's visibility both as an excavator and a geographical expert, in a region of increasing political importance. This importance Hogarth himself emphasised a few years later in his article on the plans for the Baghdad Railway for the Illustrated London News, juxtaposing his archaeological expertise with political astuteness. ${ }^{80}$ His professional life turned in a new direction at the end of 1908, when he was appointed to a prominent (and salaried) university position - Keeper of the Ashmolean Museum in Oxford, nominated by the Trustees as the successor to his friend and colleague Arthur Evans. He wrote to Macmillan to acknowledge his note of congratulations, expressing some relief at being given the job. Although Hogarth did not have the same freedom as Evans had enjoyed in the role, he declared to Macmillan that it still put him in a better position than would be possible in a similar role at the British Museum. He also suggested that Macmillan consider publishing a book on the Hittites, as 'The importance of the subject is expanding vastly'. ${ }^{81}$ 
In early 1909 Hogarth submitted another manuscript to Macmillan. Originally entitled 'Diversions of an Antiquary', it was a continuation of the narrative of his adventures in the field begun in A Wandering Scholar. The Scholar of youth, with another decade of experience under his belt, had grown into the Antiquary of middle-age in Accidents of an Antiquary's Life. Hogarth had already published parts of the main text in other venues, such as Macmillan's, Cornhill and Monthly magazines, but, he promised Macmillan, the published text had been edited in such a way 'that these chapters are well nigh new, ${ }^{82}$ With an introductory chapter prefacing his experiences up to becoming Director of the British School at Athens in 1896, he began his book recounting his role as The Times correspondent during conflict in Crete - then managed by international representatives of the Great Powers, but still officially under Ottoman rule. Hogarth had journeyed to the island as hostilities were commencing. On being asked to cover the role of correspondent, he recalled later in Accidents that he agreed almost without hesitation: 'I had never been in Crete and a scholar may rarely watch a war. ${ }^{93}$ With this statement Hogarth put himself directly in the heart of the action. Continuing chronologically, he discussed his explorations in the southern part of Asia Minor (ancient Lycia) in the late 1890s, his work on Crete with Arthur Evans at Knossos and his own excavations in the eastern part of the island, at a cave where Greek god Zeus, 'the Father God of Crete', was thought to have been born. ${ }^{84}$ One part of the cave was deep and dark; Hogarth described a dank archaeological underworld where centuries' worth of religious offerings and other items had accumulated. It was probed and (eventually) laid bare by the nimble fingers of the men and women in his employ. ${ }^{85}$

The final chapters of Accidents cover his work at Ephesus, Assuit in Egypt and Carchemish, bringing the book in line with the latest events in his life. He began 'Digging' (the Ephesus/Assuit chapter) with a note on the excitement his excavating life elicited, particularly from women. While he implies the digging life is a relatively remote prospect for them (though, as evident in this book, not unknown), he indirectly also signals a female audience for his work. In 'Digging' Hogarth chronicled the practicalities and monotonies of excavation, deliberately removing the rose-tinted spectacles of romantic adventure so firmly attached to the perception of archaeological life. He charted the rewards of patience - when, after two months of unproductive work, a decision to dig below the altar of the 'earliest temple' yielded a hoard of jewellery and coins. The excitement attached to the discovery was severely tested when winter storms flooded the site, resulting in a programme of 
emergency pumping and channelling, while Hogarth and many of his men came down with fevers. In Hogarth's memory, 'I have never struck such a vein of luck, and never liked my luck less'. ${ }^{96}$

He moved from the overwhelming plethora of treasure at Ephesus to Assuit, where he dealt with two other factors in archaeological life: antiquities dealers and the perils of excavating human remains. Having led readers down into an ancient burial pit, crawling through mummified bodies to reach the bottom of what turned out to be a 'thrice plundered charnel house', Hogarth-as-Digger 'crawled back by the same grisly path to the sunlight, choked with mummy dust'. With the grime of that image still fresh in readers' minds, he appealed to a hypothetical (female) enthusiast: 'Partner of the scented dinner table, is that the trade you desire? ${ }^{\text {'87 }}$

Accidents ends at Carchemish with Hogarth's exploration of the land surrounding the site. He details his quest for the remnants of the Hittites that still lingered there, both in the ground and in the daily life of the locals - women used Hittite cylinders and seals as talismans against the dangers of childbirth. ${ }^{88}$ The Hittite language had not yet been deciphered, and in his explorations of the area Hogarth found yet more evidence of Hittite life. It is no wonder, then, that he ended the book with a description of a fever-induced dream in which, floating on the Euphrates, he kept 'a strange company of mitred men with square, curled beards, and stunt, long-nosed folk with tiptilted shoes', subsequently passing 'between winged lions scanning elusive shifting symbols'. ${ }^{89}$ This, for Hogarth, was the digger's lot: caught between past and present, far away in a foreign land, finding evidence that only generates further questions in a never-ending search for truth.

Four days after its submission, Macmillan provisionally accepted Hogarth's manuscript and offered him a contract for the book. Hogarth was generally happy with the terms, but would not sign the contract unless Macmillan increased his royalty offer to 25 per cent on the sale of 2,000 books. He assured Macmillan, 'I rather think that, in your hands, and for other reasons, the "Diversions" will sell better'. Hogarth's American tour had also added value to his status as an author. Part of Hogarth's confidence in his potential sales stemmed from the fact that, as he told Macmillan 'I have become known in America'. ${ }^{90}$ Aside from the manuscript itself, Hogarth wanted to shape how Accidents would look and feel to readers, offering suggestions on the number and size of illustrations to be included and the book's binding, page weight and price. This time Macmillan accepted his royalty increase request, a sign 
of his confidence in Hogarth as an author. ${ }^{91}$ The final manuscript was submitted in September 1909, as Hogarth was preparing to embark on his second North American tour. ${ }^{92}$

Francis Kelsey, who had worked with Percy Gardner on Macmillan's Handbooks of Archaeology and Antiquities, was now President of the Archaeological Institute of America. Using James Loeb's \$20,000 endowment fund to create a lecture series bringing eminent European scholars to America, Kelsey had arranged for Hogarth to be the first recipient of this new funding. ${ }^{93}$ Hogarth's tour began in Nova Scotia, Canada and continued on to several major US cities: Buffalo, New York; Philadelphia, Pennsylvania; Baltimore, Maryland; and Washington DC. ${ }^{94}$ George Macmillan wrote to George Brett in the New York office about the publication of Accidents and Hogarth's imminent arrival in North America, describing the work as 'scattered papers of a popular kind'. ${ }^{95} \mathrm{He}$ arranged to send the proofs to Brett in New York, as Hogarth planned to correct them on the journey back to England. There was one final change to the book: its title. Just before he sailed, Hogarth wrote to Macmillan that he had begun to dislike the 'Diversions' he had originally proposed. 'Accidents', he felt, would 'describe the whole book better' - perfectly summing up the unexpected nature of archaeological life. ${ }^{96}$

At less than 200 pages, the published volume arrived on the bookshop shelves in March of 1910, containing over 40 reproduced photographs on individual plates; it sold in Britain for 7 shillings and sixpence. Through Macmillan New York the book reached American readers, and in an advance notice of Accidents' imminent publication the New York Tribune emphasised Hogarth's renown. ${ }^{97}$ A longer review of Accidents, published in the same paper in May 1910, noted his 'enkindling ardor' for archaeology and his success in communicating 'the romantic appeal made by the soil of antiquity'. ${ }^{98}$ Hogarth's Accidents leads readers behind the curtains of archaeology, exposing some of the adventure that the public found so appealing.

Hogarth attained further acclaim (and much added inscrutability) during the First World War, serving as an Intelligence Officer in the Royal Naval Reserve. His sister Janet recalled that he declared, 'I can't sit here in Oxford writing about Hittite Seals ... with all the world in upheaval'. 99 Based in Cairo from 1915, he was tasked with organising the Arab Bureau, bringing in fellow archaeologists and explorers T. E. Lawrence and Gertrude Bell to work there; Hogarth and Lawrence took part in negotiations for the the Arab Revolt. ${ }^{100}$ However, the success of his prewar publications was fading; his postwar correspondence with Macmillan 
indicates that the firm were ready to close the account on Accidents in 1922. Hogarth wanted to negotiate the purchase of all remaining stock and Macmillan's rights over the title. ${ }^{101}$ Canny to the end, and ensuring his legacy in capturing the romance of archaeological life in print, elements of A Wandering Scholar and Accidents of an Antiquary's Life were combined and reissued by Oxford University Press in 1925. Hogarth died two years later, aged 66. 


\section{8 \\ Penguin}

... the earnest Pelican joined the cheerful Penguin. ${ }^{1}$

In 1935 Allen Lane, Managing Director of The Bodley Head, created one of the most iconic publishing enterprises of the twentieth century: Penguin Books. These paperback publications, marketed with bold striped covers and the simple Penguin logo, were sold for sixpence (a price later recorded as equivalent to a pack of cigarettes), making fiction accessible to a wide range of budgets. ${ }^{2}$ Lane intended the series to help boost book purchasing among readers used to borrowing books from a library. ${ }^{3}$ Two years later he launched the nonfiction 'Pelican' series as a 'companion' to his fiction list. The first title was George Bernard Shaw's two volume The Intelligent Woman's Guide to Socialism, Capitalism, Sovietism and Fascism, published in May 1937 as Pelicans A1 and A2. ${ }^{4}$ Pelican A4 was Leonard Woolley's Digging up the Past.

These early Pelicans were a combination of original works and paperback editions of previously published works, in some cases with additional text. Shaw's Guide was based on his 1928 work The Intelligent Woman's Guide to Socialism and Capitalism (originally published by Constable), but with new, enhanced material. ${ }^{5}$ As discussed in Chapter 2, Woolley's Digging, based on his BBC radio series of July 1930, originally appeared in articles for the Listener; it was subsequently published in book form by Ernest Benn in the autumn of the same year. Benn's Sixpenny Library, discussed in Chapter 5, has been presented as the antecedent to the Pelican series, and Allen Lane continued to draw both inspiration and titles from Ernest Benn's publishing house.

Benn had been publishing since 1900, issuing Benn's Sixpenny Library through his book publishing enterprise Ernest Benn Limited in the 1920s. Alongside the myriad archaeology titles in the Library, Benn Ltd had published two volumes of archaeologist, traveller and diplomat 
Gertrude Bell's Letters in 1927; these were destined to be Pelicans A46 and A55, published in 1939. Woolley's Ur of the Chaldees, published by Benn in 1939, became Pelican A27 in 1938. At the time of her death in 1926 Bell had already achieved a near-mythical status that has only grown in strength since. ${ }^{6}$ As a younger woman her books chronicling her travels in the East received great acclaim; the first, Safar Nameh; Persian Pictures, was published anonymously by Richard Bentley and Sons in 1894. Further books of travel and archaeology appeared through William Heinemann, The Desert and the Sown in 1907 and Amurath to Amurath in $1911 .^{7}$ Recruited into intelligence by D. G. Hogarth during the First World War, at its end Bell became Political Advisor to the British Mandate government in Iraq and took responsibility for leading the Iraq Department of Antiquities and creating the Baghdad Museum.

Benn later recalled that Bell's Letters were nearly never published at all. Rejected by Benn's numerous manuscript readers, it was only at the behest of Bell's father Hugh, a personal friend of Ernest Benn, that the volumes were eventually published on Benn's insistence. The first edition, Benn remembered, was badly printed and expensive at over $£ 2$ for the two volumes: destined to fail. Instead it became one of the firm's 'outstanding successes'; 'many thousands' of the first edition were sold, followed by a single-volume edition that sold thousands more. ${ }^{8}$

Benn Ltd had also introduced innovative marketing for the books published - echoed later in Lane's Penguins Progress magazine catalogue. Benn's Samplers were positively reviewed as a pioneering alternative to regular advertising - a literary anthology perfect for light reading on the train. ${ }^{9}$ Priced at 1 shilling and sixpence, the first Sampler was a paperback 250-page 'miscellany' and 'Popular Bookfinder' containing extracts from some of the chief books published out of Benn Ltd's Fleet Street address. Extracts were chosen to give a flavour of the variety of subjects and genres material Benn Ltd published, highlighting 'much of the best in the literature of our day' and containing the very latest copyrighted material. As an added bonus, Benn Ltd offered purchasers of the Sampler a discount equal to its cost on their next Benn Ltd book purchase. ${ }^{10}$ Benn's first Sampler appeared in September 1930, and included extracts from Bell's Letters and Woolley's Ur. Bell's entry was a short passage playing on the translation and (mis) understanding of Democracy, while Woolley's was a longer sample chronicling the discovery of the biblical flood clay level at Ur. ${ }^{11}$

Benn's Samplers were later judged to be an unqualified success, reaching sales of over 10,000 at publication and a continued popularity 
subsequently. The work was marketed in Benn's regular catalogue of books as a stand-alone anthology, with Leonard Woolley's name featured as one of the key contributors. ${ }^{12}$ Riding high on the popularity of the experimental Sampler, Benn Ltd published a Second Sampler in 1931. This also included an extract of Woolley's work, this time from Digging up the Past. The Second Sampler had fewer authors but lengthier extracts; the one chosen from Digging was taken from the Introductory chapter, in which Woolley addresses the question 'Why does anyone dig?'13

\section{The first archaeological Pelicans}

Four years later, when Allen Lane started Penguin Books, he depended on agreements with other publishers to provide the books needed for repackaging and republication as a Penguin paperback. For fiction, he began with a list from the publisher Jonathan Cape, settling on an agreement in which Lane paid Cape an advance and royalties from sales. ${ }^{14}$ By 1936 Lane had expanded into other genres, each with its own colour: green striped Crime, cerise Travel and Adventure, dark blue Memoirs and Biography. There was also 'Penguin Shakespeare'. Unlike other publishing houses, Penguin did not depend on newspaper advertisements for its books; rather, J. M. Morpurgo argued, readers bought on the strength of the Penguin brand directly from the booksellers, with the bold design of Penguin paperbacks proving a strong visual attraction. The small team of editors working alongside Lane at the beginning of the company's history were responsible for selecting published books that would make suitable Penguins. ${ }^{15}$

Once established, Penguin began producing a catalogue/magazine, Penguins Progress, containing reviews of published works alongside its publication listings and advertisements for bespoke reader's services. These included a 'subscription scheme' through booksellers, enabling readers to receive the latest publications for quarterly payments of 5 shillings. They could also acquire 'limp-cloth'-covered editions of their books to prevent cover damage through use. ${ }^{16}$ With a short article titled 'Enter Pelicans', Penguins Progress introduced the new series in its May 1937 issue. Aspirational Penguin readers were now offered a chance to expand their intellectual horizons past their daily routines of work and leisure, by owning rather than borrowing the books that would enable them to accomplish that expansion. This knowledge, coming direct from eminent scholars and hitherto accessible only to the wealthy, was being laid at their fingertips. ${ }^{17}$ 
Perceived public knowledge of authorial expertise drove the selection of the first 10 titles published as Pelicans - it was imperative not to put off the reading public with indigestible writing. ${ }^{18}$ Penguins Progress gave Woolley's Digging a brief profile, highlighting both its presentation of an ancient past as revealed through excavation and the scientific methods used on site. ${ }^{19}$ A short article on Bell's Letters appeared in Penguins Progress in Spring 1939, drawing readers' attention to Bell's edited correspondence as a fitting representation of her remarkable life. ${ }^{20}$

For authors, getting their book into Penguin was a desirable outcome. Although initially authors did not benefit financially from a Penguin contract, ultimately the firm's visibility and availability were worth it - Penguin books were stocked in bookshops, Woolworth's Stores and railway stations across the UK and beyond. ${ }^{21}$ As the success of Lane's experiment in paperback publishing became more established, publishers began to open their lists to Lane, ensuring their authors had full advantage of the wide readership reached by Penguin/ Pelican, as well as the potential for increased sales of their hardback editions. Sales figures for Penguins were estimated at around 40,000 books per year for most titles. ${ }^{22}$ When Woolley's Digging was published a committee of four were responsible for selecting Pelican books: Vengalil Krishna Menon, who had worked for The Bodley Head, was head of the Editorial group, assisted by zoologist Lancelot Hogben, historian Hugh Lancelot Beales and champion of adult education William Emrys 'Bill' Williams. ${ }^{23}$ The imprint proved immediately popular, and Pelican reading clubs were started. Hundreds of books were eventually published as Pelican paperbacks but the method of selection, Hare notes, was often arbitrary. Former Penguin employee Tatyana (Tanya) Kent Schmoller's personal recollections further highlight the haphazard nature of Pelicans. Authors for Pelican books were sought from the editorial network to cover a particular subject felt to be insufficiently represented in existing lists. ${ }^{24}$

The archival evidence for Pelican's archaeology offerings comes chiefly from Editorial files covering the books published in the imprint. These are comprised of memos and correspondence between authors, rights holders and Penguin staff members relating to a particular title. Files can be thick or thin, depending on the circumstances of the book's history with Penguin. As Benn Ltd originally published Woolley's Digging, its Editorial file in the Penguin archive does not reflect the writing or editing of the manuscript. Rather, it reveals the breadth of Penguin's reach and the popularity this book enjoyed. Thirty years after it was first produced as a Pelican book it had been reprinted 11 times; a copy of each 
newly reprinted edition was sent back to Benn and related correspondence generated. ${ }^{25}$

The first Pelican edition of Digging gave the work the subtitle 'Romance of Archaeology', emphasising Woolley's own adventurous experiences in the field. In later editions this was changed to the more prosaic and detailed 'introduction to archaeology showing how excavation has grown from a treasure hunt to a science', suggesting that there was a change of attitude about the construction of archaeology in a postwar context. ${ }^{26}$ Fifty Pelicans had been published by the outbreak of war in September 1939 - Woolley's Ur had been added as A28 in February 1938 and the first volume of Bell's Letters as A46 in March 1939.

Archaeology was one of the subjects Lane was eager to include in Pelicans. Peter Gathercole noted that during the early years of the war Lane was corresponding with Gordon Childe, the University of Edinburgh's Abercromby Professor of Archaeology, about the possibility of other titles and authors even as Childe was composing What Happened in History as Pelican A108. ${ }^{27}$ During the war paper rationing was extremely restrictive. A wartime edition of Woolley's Digging was half the length of the postwar edition, featuring the smaller, densely packed type and flimsy binding that characterised Penguin's wartime production. ${ }^{28}$

However, Morpurgo argued, war brought a new 'seriousness' to readers; the desire for self-education rose as war work brought expanded horizons to many. The size and shape of Penguin books made them easy to pack, ship and read on the move - Penguin histories mention military readers carrying Penguins with them in their uniform or equipment pockets. Penguin's offer expanded with the introduction of new series and a special service, the Penguin 'Forces Book Club', was instituted for the armed forces. The Club sought to address a shortage of reading material for these groups and was considered a way to increase morale. Pelican editor Bill Williams, Army Bureau of Current Affairs Director, was busy organising educational opportunities for the troops and took charge of the scheme. The Book Club ran from 1942 to 1943, issuing 10 books per month in a range of genres, chosen by a bespoke committee. ${ }^{29}$ Leonard Woolley's Ur was among the 10 chosen for the first group, published in October 1942. Eunice Frost, a key member of the Penguin team, sent him a copy, which Woolley acknowledged with pleasure. ${ }^{30}$ Other archaeological titles were also released in the scheme before it closed in September 1943. Childe's What Happened in History appeared in December 1942, with amateur archaeologist Samuel Edward Winbolt's Britain BC and Stanley Casson's archaeological murder mystery Murder by Burial becoming Book Club titles in February $1943 .{ }^{31}$ 
The Editorial files for Woolley's Digging and Ur help to contextualise the diversification of Woolley's writing. The correspondence relating to the Pelican editions of these books shows that many readers believed Penguin to be the original publisher, highlighting the effectiveness of the Pelican brand for bringing archaeological books to a wider readership. Penguin's Editorial Department, particularly the tattooed polymath known as Alan Samuel Boots Glover, who had joined Penguin during the war, and Eunice Frost acted as intermediaries between the correspondents and the authors. ${ }^{32}$ Correspondents wishing to reproduce excerpts of the text or plates were referred to Benn or Woolley as the original rights holders.

The content of these reproduction requests highlight the work's reception, revealing frequency of translation and the various media using the text and images that were aimed at different audiences. One 1955 letter was a from representative of the US-based Volunteer Service for the Blind wishing to make an audio version of Digging $U p$ the Past for the visually impaired. Permission was sought from Woolley and granted..$^{33}$ Another letter came from the Civil Service Commission, hoping to include an extract from the Introduction to Digging in its exam papers (with full reference to the book's Pelican edition). ${ }^{34}$ Woolley revised Digging for Benn in 1954, and Pelican subsequently used the revised text in reissuing the paperback. ${ }^{35} \mathrm{Ur}$ was also updated and reprinted in Pelican.

In 1947 Woolley's new book for Penguin's King Penguin series, Ur: the first phases, was published. Launched in 1939, King Penguins were short, heavily illustrated art books, covering specific rather than general subjects. They were aimed at book collectors and encapsulated innovative printing practices to reconstruct illustrations that in previous years would have meant a high purchase price. By the end of the war Nikolaus Pevsner (who also edited Penguin's Buildings of England books) was leading the way on King Penguins, broadening the original concept of works on natural history to include art and archaeology. ${ }^{36}$ Woolley dedicated his King Penguin title to his wife Katharine Woolley, who had died in 1945. She had worked with him on site for years, a vital contributor to the excavation and its publicity, and Woolley openly acknowledged her role in the creation of the book. ${ }^{37}$ Ur: the first phases contained numerous colour plates, showing off some of the excavation's unique and exciting discoveries that were captivating evidence of daily life in the ancient world. Some of these images had featured in black and white in other publications, but Woolley's King Penguin, priced at 2 shillings and sixpence, put the colour reproductions into the hands of a wider readership. 
Penguins Progress declared that these reproductions enabled readers to appreciate the artefacts discovered more than ever before. ${ }^{38}$ As a King Penguin, Woolley's book contributed an archaeological element to a series highlighting the natural, architectural and cultural landscape of Britain; it also added a rare non-Western topic to the list.

In the aftermath of war Penguins Progress resumed publication, promoting the latest Penguins and Pelicans. At a time when affairs in the Middle East were considered politically relevant, Penguins Progress sought to capture readers with titles which would improve their knowledge of the regions - one of which was a specially written Pelican from Egyptologist Iowerth Eiddon Stephen Edwards, The Pyramids of Egypt. ${ }^{39}$ Morpurgo characterised the late 1940s to early 1950s at Penguin as a 'golden epoch' for the company - a time in which new subject-specific series were instigated that had a major impact on education at upper secondary school and university level throughout Britain. As the education system expanded in Britain during this postwar period, Pelican books were used as textbooks. Morpurgo cites the medium of television as another major influence on public interest in archaeology which Pelicans addressed, with, from the early 1950s, the presence of archaeology game show Animal, Vegetable, Mineral? Robert Eric Mortimer Wheeler was one emerging archaeological 'celebrity' who AVM helped bring to prominence. The 'Pelican Archaeologies' series met a demand that the programme stoked. ${ }^{40}$

\section{'Pelican Archaeologies'}

By the late 1940s Penguin editor Bill Williams declared in Penguins Progress that Penguin was now publishing a majority of original works, and that publishers were now seeking out Penguin paperbacks to reissue in hardback editions. He also announced a special subseries, 'Pelican Archaeologies', with Max Mallowan as editor. ${ }^{41}$ It was a series, Allen Lane later claimed, in which he had a special interest. ${ }^{42}$ Mallowan had originally worked as an assistant to Leonard Woolley at Ur. He met Agatha Christie on site at Ur and married her in 1930. Mallowan was working with Penguin from the mid-1940s as archaeological advisor, and by the time his editorship was formally announced he was Professor of Asiatic Archaeology at the Institute of Archaeology in London as well as Director of the British School of Archaeology in Iraq. ${ }^{43}$

In reminiscing about Allen Lane and working at Penguin, Tanya Schmoller recalled the close friendship between Allen Lane, Max 
Mallowan and Agatha Christie. Lane had originally met Christie in the 1920s when he was working as a Director at The Bodley Head, the publisher of Christie's first five novels. Christie also served as godmother for one of Lane's daughters. The Lanes and the Mallowans visited each other, and Lane had even provided funding for Mallowan's archaeological activities. In fact Lane's biographer Jack Morpurgo has suggested that it was on the journey back from visiting the Mallowans that the idea behind Penguin books solidified. ${ }^{44}$

As new Penguin editor, Mallowan set about finding books to add to the archaeology titles that Penguin had already published. Four titles were announced in the new series in 1948: Oxford Reader in Assyriology (and John Garstang's nephew) Oliver Gurney's 'The Hittites', Edinburgh's Abercromby Chair of Archaeology holder Stuart Piggott's 'Early Indian Civilisation', American archaeologist William Foxwell Albright's 'The Archaeology of Palestine' and a book on 'Ancient Asia' by Mallowan himself. ${ }^{45}$ The Editorial file for Gurney's Hittites shows the process of publishing a Penguin archaeology book in some detail. First commissioned in 1946, The Hittites manuscript was not submitted until 1950; Gurney wrote to Glover with some anxiety on submission because his finished text had arrived just before another author's book draft on the same topic. ${ }^{46}$ Gurney consulted Mallowan as series editor on the construction of the book - in one letter he outlined his plans for a reference bibliography to add to the text. He took care to create it specifically for readers without specialist knowledge, featuring books mainly in English and those that would have been most accessible to a general readership. ${ }^{47}$ This bibliography A. S. B. Glover was happy to approve for publication; Albright's Archaeology of Palestine had been published the year before without a reference list, causing some reader dissatisfaction. ${ }^{48}$ Gurney was very pleased with the final product, priced at 3 shillings and sixpence. He wrote to Allen Lane of his excitement at seeing the volumes disappearing from bookshop tables. ${ }^{49}$ The Editorial file on Gurney's book shows that Danish, Hebrew and German translations rights were sought within three years of its first publication. ${ }^{50}$

Alongside commissioning original research for 'Pelican Archaeologies', another early Mallowan project was an abridged new edition of Gertrude Bell's Letters, in which he acted as Lane's initial intermediary. In 1948, having asked Gertrude Bell's sister Elsa Lady Richmond about republication on Lane's behalf, Mallowan reported to Lane that Ernest Benn had commissioned a new book on Bell with never-before-seen additional material - a trunkful of letters that had been left out of the 
original volume. Mallowan hypothesised that the omission was due to some of them containing sensitive information. Lane wrote to Benn to follow up the lead. Benn cautiously suggested to Lane that Penguin publish a new edition of the original two-volume Letters as a singlevolume Penguin, and eventually later on another volume including the additional letters could be produced. Lane, sensing the opportunity to capitalise on Bell's celebrity and the new material, immediately proposed to Benn that Penguin publish a new edition of Bell's Letters that incorporated both old and new material. In the end Elsa Richmond's Selected Letters of Gertrude Bell, published in August 1953, was Pelican A275. ${ }^{51}$

Woolley's third Pelican book, A Forgotten Kingdom, was specially written for the series and its acquisition involved both Lane and Mallowan. Mallowan had been negotiating with Woolley to acquire for Penguin the unfinished manuscript that Woolley was still working on. Allen Lane wrote to Woolley in September 1951. Full of enthusiasm for the book and in potentially being its publisher, he indicated his expectation that the book would be particularly appealing to American readers to whom Penguin's newly established American branch would cater. Although there was an editorial team in place to facilitate the book's publication, Allen Lane was still involved - his letter to Woolley outlined Penguin's royalty terms of 7.5 per cent rising to 10 per cent for clothbound books, with an advance of $£ 750$; by contrast, Gurney, as a first time author, received simply a $£ 100$ advance. $^{52}$

Woolley replied to him three days later expressing his pleasure at the possibility of his manuscript's publication with Pelican. His response reflects the level of success he had achieved as a popular author and demonstrates his assessment of the commercial value of his work. He expressed his surprise at Lane's offer of 7.5 per cent when he normally expected royalties of 15 per cent. Nevertheless, given Penguin's reputation Woolley was willing to accept the terms offered, only suggesting a higher royalty rate on cloth-bound books..$^{53}$

In a further demonstration of his experience in publishing and level of commercial nous Woolley noted to Lane that, while he was used to ceding English rights of his works to publishers, he claimed all rights for translated editions of his work. ${ }^{54}$ This latter clause Lane acceded to, but he repeated his original offer of 10 per cent on higher priced cloth volumes, explaining that the offer was designed to maintain the lower purchase price of the book, which he promoted as an advantage for authors in the longer term. As a token of his esteem for 
Woolley, and to demonstrate his commitment to publishing Woolley's book, Lane offered an increased advance, and suggested that the two meet in person at his home, Silverbeck. He also asked to read the manuscript. ${ }^{55}$ Having had the terms fully explained, Woolley refused an increase in advance and accepted Lane's invitation to meet. ${ }^{56}$ Once the manuscript was submitted Glover acted as reader. His report was glowing, comparing the work favourably to Woolley's previous Pelicans, Digging and Ur. As for the archaeological details, Woolley's status was such that, as long as Mallowan approved, the book should proceed to production. ${ }^{57}$

In A Forgotten Kingdom Woolley chronicled his excavations in the province of Hatay - a disputed border region between modern Syria and modern Turkey where the sites of Tell Atchana and al Mina are located. The shifting geopolitics of the region were an underlying theme; one which echoed the international character of the site in antiquity. Woolley noted in his introduction to the book that when excavations began in 1937 the site was part of 'North Syria'. The Hatay region then became an independent entity and was finally subsumed into Turkey. ${ }^{58}$ Woolley begins Kingdom by locating the site in the landscape and justifying his selection of Atchana, 'the Thirsty Mound'. After the introductory chapter explaining the beginnings of history there through pottery finds, each chapter is subtitled with stratigraphic layers, emphasising archaeological method through the structure of the book itself - the gradual accumulation of knowledge as the spades dig deeper. The aim of the excavation, which took place over seven seasons between 1936 and 1949 (with a break during the Second World War), was to find evidence of the links between the civilisations of the Levant and the Aegean through trade routes. $^{59}$

A Forgotten Kingdom was published in 1953. At this point, it appears, Penguin editors were beginning to take stock of the company's success in archaeology publications - an intriguing undated note in the Editorial file contains figures showing the total copies printed and the frequency with which titles had been produced for many of the key archaeology Pelicans published to that date. Woolley's good fortune in allying himself with Penguin from such an early period is obvious. Digging's initial printing of 55,000 copies had swollen to 196,000 with 4,500 left in stock by June 1951; five reprintings had occurred between 1938 and 1951. Ur had done nearly as well, with a total of 149,000 copies printed and 500 in stock by June 1951, with three reprintings in between. Production levels were steady for the other 'Archaeologies' on the list: 75,000 copies printed of Albright's Archaeology of Palestine, 
40,000 copies printed of Piggott's newly published Prehistoric India and 95,000 copies (with none left in stock) of Edwards' Pyramids of Egypt. ${ }^{60}$

When Mortimer Wheeler began his relationship with Penguin in the mid-1950s he was already a noted television star, a regular panellist on Animal, Vegetable, Mineral? AVM adapted University of Pennsylvania Museum Director Froelich Rainey's original concept for his Columbia Broadcasting Service show What in the World. This concept was to have a panel of experts identifying 'mystery' objects from archaeological and ethnographic collections. Mary Adams, one of the BBC's Executives, added a new spin - that different museums would be responsible for each week's challenge. ${ }^{61}$ Wheeler had appeared on the show 18 times by autumn 1954, when he was named Guild of Television Producers and Directors' 'TV Personality of the Year'. ${ }^{62}$ His television appearances brought him considerable public visibility and celebrity status.

During this period Wheeler was also forming a relationship with Penguin. He was in touch with Penguin editor Eunice Frost about the prospect of the book that would become Rome Beyond the Imperial Frontiers, which he was writing for the publishers George Bell \& Sons, being included in the Pelican list. It is clear that Wheeler was eager to see his work published with Penguin, but George Bell \& Sons were less enthusiastic about the prospect. Allen Lane had produced a proposal for terms on which the book would be published in paperback as a Pelican, but Bell \& Sons clearly did not see what advantage would be gained by Lane's terms. ${ }^{63}$

Though Wheeler wanted to move forward with Penguin, he also wanted to keep Bell on side. He pleaded with Frost, whose experience with the book trade he deferred to, to come up with a plan that would appease Bell \& Sons while continuing with the Pelican edition. ${ }^{64}$ Eventually an agreement was reached; the paperback publication would be delayed for six months after the publication of the Bell hardback edition. ${ }^{65}$ Once the deal was set, A. S. B. Glover managed the production of Wheeler's first Pelican. Glover had wanted to publish Wheeler's work in Pelican and, beyond his copyediting queries, Glover sought Wheeler's opinion of an idea to prepare a sourcebook of classical texts on the outposts of empire covered in Wheeler's narrative. Glover wanted to stretch Penguin's coverage to include primary sources to complement the interpretive Pelicans, but it is unclear whether his idea ever came to fruition. ${ }^{66}$

The following year the Clarendon Press approached Penguin to publish a paperback version of Wheeler's Archaeology From the Earth, first issued by them in 1954. The agreement between Penguin and 
Clarendon progressed quickly, and Wheeler wrote to Eunice Frost to urge haste, to take advantage of a surge in Wheeler's celebrity status (probably resulting from his TV appearances) ${ }^{67}$ However, even with Wheeler's public visibility and positive reviews, the book was not as successful as some of the other Pelican archaeologies. Both were out of print by 1960 , neither of them having sold over 40,000 copies. ${ }^{68}$ Archaeology from the Earth remained for some years on Penguin's lists, being reprinted in 1961; Rome had sold too few copies to be worth reprinting. ${ }^{69}$ However, beyond British shores Rome did find success - rights were sought to translate the work into Italian, Polish, German and French. ${ }^{70}$

Oxford University Press originally published Seton Lloyd's history of archaeology in Iraq, Foundations in the Dust, in 1947. Lloyd was an architect, training at the Architectural Association schools in London in the late 1920s, but soon afterwards embarking on his first archaeological expedition to Egypt and the Egypt Exploration Society's excavations at Amarna for the 1929-30 season. He moved on to Iraq, working for the Oriental Institute's excavations in the area north of Baghdad and supervising a number of sites until 1937. Thereafter he moved to Turkey, working initially for John Garstang at Mersin for a few seasons before becoming Advisor to the Iraq Department of Antiquities just before the outbreak of the Second World War. ${ }^{71}$ Lloyd's long experience in archaeology and in diplomacy in Iraq (via his government position in Antiquities) certainly played a part in the construction of his 1947 history. His historical predecessors in the archaeology of Iraq characters he introduced to the public in Foundations - had been even more enmeshed in the permeable borders between archaeology and diplomacy than he was.

The book's concept originated in an article in The Times celebrating the century since the British archaeologist Austen Henry Layard had first begun working at Nimrud. ${ }^{72}$ The interconnection between interest in ancient sites and modern political and diplomatic work was highlighted still further in the fold-out map attached to the back cover of the book, which later became the only illustration in the first Pelican edition of Foundations. On this map both ancient and modern site names were given, modern road and railway lines cutting across ancient borders. Lloyd's OUP Foundations included an introduction by Leonard Woolley, at that time one of a few prewar veterans of excavations in Iraq. Woolley's text makes much of the contribution of British scholars to the excavation and interpretation of Iraq's monuments and inscriptions, and the significance of exporting antiquities to Western museums for continued public interest in and awareness of both archaeology and the context of 
the Ottoman Empire. The OUP edition of Foundations also featured the work of Lloyd's artist-illustrator wife, Ulrica (Hyde) Lloyd. Her intriguing composite illustrations drew on and enhanced the characters and scenes that Lloyd chronicled in its pages. ${ }^{73}$

Foundations had gone out of print by 1953 when Mallowan suggested to Allen Lane that it might be republished as a Pelican. Glover contacted OUP to seek permission for reprinting and a contract was drawn up. ${ }^{74}$ Asked to update the book to ensure its relevance to readers, Lloyd sought Mallowan's advice on how the book should be changed to adapt it for publication with Pelican. Mallowan had by this point begun working in Iraq himself, excavating the site of Nimrud under the auspices of the British School of Archaeology in Iraq, founded in 1927 to commemorate Gertrude Bell's life and work in the country. ${ }^{75}$ In the 1950s things were different. Lloyd's Pelican was to reflect the new era - a change wrought even in the few years since his OUP Foundations had appeared. Mallowan and Lloyd decided that Woolley's introduction was out of date; it was removed from the Pelican version and replaced with Lloyd's new Preface describing the changes that had occurred, both in Iraq and in archaeology more broadly, since the book's initial publication. Better techniques for retrieval meant that more delicate objects were emerging from the excavation relatively unscathed and, while Western archaeological teams continued to have access to Iraq's ancient cities for excavation, Lloyd emphasised the work of (unspecified) Iraqi archaeologists on various sites. $^{76}$

Lloyd's narrative, which Penguin praised enthusiastically, wove together biographies of the early nineteenth-century British diplomatarchaeologists who had travelled to the East to take up posts in administration at Consulates and Residences. It progressed chronologically through the more formal (and 'scientific') explorations in Mesopotamia sanctioned by the British Museum from the mid-nineteenth century onwards. ${ }^{77}$ The exploits of these archaeological men reinforced the sense of masculine romantic adventure pervading public perceptions of archaeology.

The presence of Mary Mackintosh Rich in Lloyd's narrative presents an interesting and significant diversion from this male-dominated history. Married before her twentieth birthday to Claudius James Rich, Baghdad Resident and informal archaeologist during the 1820s, Mary Rich had accompanied her husband on his trips to ancient sites in the region. She outlived him, and in her widowhood edited and published two compilations of his journals in 1836 . One of these contained a fragment of her own journal as an appendix to her husband's words, the other her 
own introduction to the history of Babylon. ${ }^{78}$ Ulrica Lloyd's illustration of Charles and Mary Rich served as the frontispiece to OUP Foundations, but her illustrations (apart from the map) disappeared from the Penguin edition, primarily it seems because of cost. ${ }^{79}$ However, in Foundations' Editorial file, Glover's first draft of text describing the book's contents included Mary Rich's name alongside Rawlinson's and Layard's; this was removed in the later (published) version. The subtle alteration served to reinforce the dominance of great men in the history of archaeology, with reviews like the one published in The Sunday Times (quoted in the draft description) highlighting still further the appeal of Lloyd's narrative for 'schoolboys' as well as 'scholars'. ${ }^{80}$

The Editorial file for Seton Lloyd's second Pelican book, an original work called Early Anatolia, yields further insights into Max Mallowan's editorial role at Penguin and discussions within the company about his editorial remit. A copy of a letter from Allen Lane to Max Mallowan in June of 1953 reveals Lane's continuing involvement in soliciting authors directly to submit manuscripts to Penguin. On a trip to Athens Lane met the American archaeologist Carl Blegen, former Director of the American School of Classical Studies at Athens, who had worked on the site of ancient Troy (Hissarlik, Turkey) in the 1930s. Blegen was eager to write a popular book for Penguin on his discoveries that would enable him to find a new audience. He had also recommended to Lane that Alan Wace, the British archaeologist and former director of the British School at Athens, should be approached to write about Mycenae, an ancient city in Greece associated with Perseus, of Greek myths. ${ }^{81}$

Internal memos from Alan Glover to Lane suggest that both Glover and Lane had been discussing Mallowan's involvement with the company. Lane wanted to bring on another archaeologist to advise on books outside Mallowan's regional interests, although Glover's suggestion that O. G. S. Crawford might be solicited to fulfil this role was rejected. ${ }^{82}$ From an editorial perspective, Glover was beginning to question how the 'Pelican Archaeologies' were to be marketed; whether the series was to include books covering areas and themes from outside Mallowan's focus on ancient Middle Eastern civilisations. Titles such as Wheeler's Rome Beyond Imperial Frontiers and Archaeology From the Earth had not gone through Mallowan's editorship, but if they were classified as 'Pelican Archaeologies' Mallowan's name would be attached to them. ${ }^{83}$

The fact that 'Pelican Archaeologies' largely focused on the area of Max Mallowan's research interests - Middle East and Asia - reflected the historic prominence of these areas in public consciousness. Difficulties arose editorially when attempting to fit European-focused research 
into this model. In his memoir the archaeologist Glyn Daniel, who took over editing the 'Pelican Archaeologies' from Max Mallowan in the 1960s, recorded Lane's dissatisfaction over Mallowan's preference for the Middle East and Asia over a more diverse approach. ${ }^{84}$ Through the decades, because of the company's 'organic' (read haphazard) approach to commissioning, there was no one definitive scheme for the 'Archaeologies'. While Penguin actively sought to publish archaeologists' work as Pelicans between the 1930s and the 1960s, and successfully brought key archaeologists' work to a wide international readership, their attempt to plan 'Pelican Archaeologies' as a whole series largely failed.

However, in books relating to Mallowan's interests, his involvement could be more intensive. Seton Lloyd's Early Anatolia, for instance, Mallowan judged to be both scholarly and accessibly written. Alongside his assessment of the book's importance, and his praise for Lloyd's approach in spreading detailed archaeological matter evenly throughout the text alongside more general insights, he had a number of recommendations. Some of these were academic, others stylistic. Anatolia was a region of special interest to Mallowan; Lloyd's work had piqued his scholarly interest and he had read the text particularly closely. He assured Lloyd that at points where his opinion differed to Lloyd's interpretation his comments were meant to be constructive. ${ }^{85}$ Notwithstanding Mallowan's comments, Lloyd had also asked Winifred Lamb, honorary curator in the Fitzwilliam Museum in Cambridge, whose expertise he felt was unsurpassed in Britain, to comment on his text. The final manuscript incorporated both Mallowan's and Lamb's responses. ${ }^{86}$

Ancient Anatolia eventually appeared in 1956. Its production had been delayed, and Lloyd had written directly to Lane to ask for an update on progress. He was anxious: with each new discovery in the region his material was becoming more and more obsolete. Three years had passed since the work was originally commissioned, and Mallowan had already suggested to Lloyd that an appendix be added to bring the work up to date. Nonetheless, on publication Lloyd noted the positive response the work had received, including an encouraging review from Mortimer Wheeler. ${ }^{87}$

Towards the end of the 1950s Penguin began a more formal accounting of sales figures, highlighting the relative popularity of Pelicans against Penguin's main series titles, particularly fiction. Eunice Frost's papers contain a valuable breakdown of sales by title and series, separated into subsections of monthly rates of sale in the UK. Over half of Penguin fiction published in 1957 sold below 750 copies per month, while 
just under one-third sold over 1,000 copies per month..$^{88}$ In comparison the Pelican (nonfiction) books sold more moderately - 84 per cent sold below 750 copies per month, while a mere seven per cent were in the top rate of sale-between 1,000 and 2,000 copies per month. Pelican archaeology titles hovered mainly between $0-500$ average monthly sales. By the late 1950s Gertrude Bell's Letters were listed at a rate of sale of 30 books per month; Wheeler's Rome averaged 200 copies per month and Lloyd's Foundations averaged 150. Woolley's Digging (still in print 20 years after first publication) continued to do relatively well, with sales of 400 copies per month. One of the most successful Pelican archaeology books at this time was J. M. Allegro's Dead Sea Scrolls, with sales averaging over 1,000 copies per month. ${ }^{89}$ Published in 1956 as Pelican A376, it told the story of the discovery in 1947 of delicate fragments of early biblical texts found in jars in a cave at the edge of the Dead Sea. Allegro was an archaeologist and one of a team working on the Scrolls at the time.

In comparison to top-selling fiction, Pelican sales were modest. The author Evelyn Waugh's novels were among the top rates of sale in fiction, with a combined average rate of sale for Decline and Fall, Scoop and Brideshead Revisited equalling 4,200 volumes per month. ${ }^{90}$ Yet there is one significant bestselling author of fiction whose books helped to situate archaeology within popular culture: Agatha Christie. Her Mysterious Affair at Styles, originally published in hardback by The Bodley Head, was among the first Penguin paperbacks published (No.6). After Allen Lane made a deal with her second publisher William Collins in 1948, Christie's mysteries began to appear in numbers, bringing her even more success. ${ }^{91}$ She had been a best-selling author for decades by the time Penguin's sales data was compiled. She was also intimately familiar with archaeology as a subject. Being married to Mallowan at the time, she incorporated her experiences in a number of 'archaeological' novels produced between the 1930s and the 1950s: Murder in Mesopotamia (1936), Death on the Nile (1937), Appointment with Death (1938), Death Comes as the End (1944) and They Came to Baghdad (1951)..$^{92}$ The data in Eunice Frost's files shows that Christie's books, including Death Comes as the End and Murder in Mesopotamia, were selling at a rate of over 2,000 copies per month. ${ }^{93}$ With her personal experience and observations of archaeologists and archaeological sites Christie's (fictional) scripted spadework reached an audience who might never have picked up a Pelican, a theme explored in more detail in the following chapter.

By the mid-1960s Welsh archaeologist Glyn Daniel began assisting Max Mallowan with the 'Pelican Archaeologies'. Daniel had been the 
main host for Animal, Vegetable, Mineral? in the mid-1950s; he held a Fellowship and taught archaeology at Cambridge. As editor of Antiquity and a new series of specialised archaeology books for Thames \& Hudson called 'Ancient Peoples and Places', he played a critical role in deciding what and who should be published in archaeology at a time when archaeology was becoming more firmly embedded in academia; specialised university departments of archaeology (and therefore positions for 'academic' archaeologists) were increasing. ${ }^{94}$ Papers relating to Daniel's role as 'Pelican Archaeologies' editor reveal that he was feeding authors who published in the 'Ancient Peoples and Places' series to Penguin editors Jim Cochrane and Anthony 'Tony' Godwin as contributors of new Pelicans.

Daniel had a firm view on the quality of work acceptable for Pelican. When Jim Cochrane suggested that Pelican republish an Encyclopaedia of Archaeology edited by BBC scriptwriter Leonard Cottrell, a prolific popular chronicler of archaeology, Daniel was scathing in his response. Instead he suggested a similar yet more scholarly venture, to be edited by an emerging archaeologist who could use the role to boost his personal finances and increase his personal visibility. ${ }^{95}$ Daniel was on the lookout for new talent to cultivate, and he later submitted a memo of those archaeologists who he thought might make good contributors. In a bid to expand the potential reach of archaeology beyond mere narrative text, he also suggested the creation of a new series of Pelican guides to the antiquities and archaeology of Britain. ${ }^{96}$

The 'Pelican Archaeologies' Daniel proposed signalled a shift towards increasing specialism, a move away from a narrative driven (in part) by the popularity and public visibility of the archaeologistauthor. Old titles were revised by new, up-and-coming archaeologists who had not yet made their names in the field, while proposed new titles (and authors) encompassed bold, wide-ranging themes as well as geographical/chronological works. As if to solidify the distinction between the archaeology of the past and the present, Daniel also contributed his own take on the evolution of his discipline. The Origins and Growth of Archaeology was published in 1967 as Pelican A885 (his 150 Years of Archaeology was published by Duckworth in 1950). ${ }^{97}$

The success of Penguin/Pelican paperbacks encouraged other publishing houses to form their own paperback imprints. ${ }^{98}$ Archaeologists' popular writing and new popular histories of archaeology began to appear from the 1950s, rivalling Penguin's dominance. Alan Bott's Pan paperbacks had been established as the Second 
World War was ending. Mandira Sen notes that Pan initially published various genres of 'light fiction', but Pan Books in particular played an important role in promoting popular archaeology. ${ }^{99}$ As a Collins imprint, it produced paperback editions of Agatha Christie's works alongside the Penguin editions: Death on the Nile was Pan Book No. 87 (1949) and Murder in Mesopotamia was Pan Book No. 200 (1952). A version of Mortimer Wheeler's 1955 memoir Still Digging appeared as a Great Pan paperback (No. 94) in 1958, its original subtitle, 'Interleaves from an antiquary's notebook', now replaced with the more exciting 'adventures in archaeology'. ${ }^{100}$ In the summer of 1958 Hutchinson set up Arrow Books as a paperback imprint. 'Grey Arrow' was established as its nonfiction series, aiming to harness the potential market for accessibly written and priced nonfiction direct from experts that Penguin's Pelicans had unleashed. Margaret Wheeler's memoir Walls of Jericho, originally published as a Chatto \& Windus hardback in 1956, appeared as a Grey Arrow paperback three years later, marketed alongside fellow Grey Arrow author Rose Macaulay, a notable novelist and travel writer. ${ }^{101}$

Yet as archaeologist-authors continued to prepare manuscripts for general readers, another source of competition came in the form of Leonard Cottrell, who emerged during this period as one of the most prolific authors of popular archaeology books. In the 1950s and 1960s Cottrell wrote over 20 different nonfiction works on archaeology, with a focus on excavators and excavations in Egypt, Greece and Iraq. Cottrell's work drew on the personal experiences of archaeologists; The Bull of Minos, for example, chronicled Heinrich Schliemann and Arthur Evans's excavations in Greece and Turkey. In a nod to Cottrell's journalistic background it drew on an interview with John Linton Myres, as well as extracts from Schliemann's and Evans's writings and their memories of friends. London publishing houses Evans Brothers and Robert Hale were Cottrell's main publishers. They produced hardback editions of his works, including Evans's 'Cadet editions', specially edited to appeal to younger readers. Pan produced paperback editions of Cottrell's books with both Evans and Hale, including The Lost Pharaohs, The Bull of Minos, Life Under the Pharaohs, Lost Cities and Wonders of Antiquity.

As Benn and Penguin had done in the 1930s, Pan issued a marketing magazine, Pan Record, which was available from the company. Short articles promoted new and recently republished titles and authors. Referencing the success of Cottrell's career at the BBC and his Bull of Minos, already in its second Pan edition, Pan Record No.20 
(September 1956) encouraged readers to buy Cottrell's Lost Pharaohs, a history of archaeology in Egypt. Cottrell's history showcased the exploits of Western archaeologists in Eastern lands. Described as 'a fascinating and romantic story', it reinforced still further these strands of the archaeological experience and their value in scripting spadework. ${ }^{102}$ 


\title{
9 \\ Archaeological Fictions
}

\author{
About myself? Me? My trade is to read \\ The dusty ciphers on the dial which Time \\ Scores on the face of midden-pyramids... \\ To tell the past, each hour a thousand years \\ Mark'd by a layer'd interval of dust... ${ }^{1}$
}

In 1938 the archaeologist Reginald Campbell Thompson published Digger's Fancy, a 70-page romantic verse 'melodrama'. As much as the (foreign) field was a central part of scripting spadework, creating a fictional field allowed the archaeological experience to be reinterpreted, reformed and projected in the cultural imagination. Archaeologists both produced fiction and were themselves fictionalised. Focusing on three, often linked genres of archaeological fiction - romance, horror/fantasy and crime - this chapter will introduce and explore how archaeologistauthors and others have interpreted and presented spadework in fiction through the twentieth century. ${ }^{2}$

\section{Archaeological romance}

Digger's Fancy stars English archaeologist Alan who, settling down for an evening camping with his Arab caravan at 'Tell Jiljilah' in Southern Mesopotamia, is met by travelling English botanist Ann, searching for elusive desert plants. The haunting atmosphere of the landscape and her encounter with thousands of recently unearthed clay frogs of great antiquity along the way has unnerved her. Alone with only her Armenian driver for company, she has lost her way. In wandering they come across Alan's camp, and he offers her a cup of tea by the campfire. As conversation ensues it becomes clear that she has heard his name before. She asks his views on his work - how he defines himself. Alan waxes lyrical, 
not merely about archaeology, but specifically about archaeology in the Middle East.

In Digger's Fancy archaeology is romance and adventure - the exotic allure of biblical names drawing young 'Ulysses' away from British barrows to the East. It is a land, Alan says, of ghosts, of 'soul[s] death free'. ${ }^{3}$ During their conversation Ann offers her own morbidly cynical take on 'the archaeologist': 'you who dig bodies up' only to remove them to London where they can be viewed at the Museum. ${ }^{4}$ She joins Alan's camp for the night, and the next day the conversation continues. Both have been affected during the night, the surrounding landscape inspiring access to ancient pasts. Ann inhabits the spirit of Nefertiti, while Alan channels the spirit of an Assyrian soldier on campaign. Alan's lengthy description of his dream taps into the (un)conscious knowledge of the archaeologist to draw a vivid depiction of ancient daily life. Later on the pair encounter a Sheikh on the road, whom it transpires knows Alan from his wartime exploits. To the Sheikh, Alan 'is my very son'. ${ }^{5}$ Yet with British aerial bombardment campaigns wreaking havoc among the local population, the Sheikh is no longer in a position of power. ${ }^{6}$ When Alan and Ann are captured by the Sheikh's rebellious men he seems unable to help them. Alan hopes that his 'Orientalist' knowledge and past experience in managing local relationships and expectations will see them successfully free themselves from their imprisonment. ${ }^{7}$ Ann despairs, turning to Alan for comfort. All seems bleak, but the Sheikh comes to their rescue; having drugged their captors, he provides the means both for their escape and for his own resurrection of power. The adventure solidifies Alan and Ann's developing romance.

Digger's Fancy was dedicated to Thompson's friends 'Agatha and Max Mallowan' with whom Thompson had worked on his final season at Nineveh. It was on this excavation that Christie wrote Lord Edgware Dies, which she had dedicated to Thompson and his wife Barbara. ${ }^{8}$ Nineveh was the most significant site of Thompson's long career in archaeology. It began in 1899 when, a First from Caius College, Cambridge in hand, he had been appointed a Second Class Assistant in the Department of Egyptian and Assyrian Antiquities at the British Museum. The Department was in the hands of Wallis Budge, whom Campbell Thompson (with an eye on the melodramatic) remembered ensconced in an office guarded by the Museum's own 'sinister mummy lady', impervious to the doom that she (reputedly) caused many others. ${ }^{9}$

Thompson's immediate work colleagues, Leonard King and Harry Hall, were also twenty-somethings. According to Matthew Ismail's biography of Budge, all three were athletic, intelligent and outspoken: they 
worked well together. ${ }^{10}$ The Department was particularly concerned with discovering, translating and publishing cuneiform texts uncovered during excavations, and in shedding further light on the ancient rulers and peoples, among them Sumerians, Assyrians, Hittites and Babylonians, who had populated Nineveh and other cities in Turkey, Syria, Mesopotamia (Iraq) and Iran. Thompson and his colleagues churned out detailed transcriptions and translations of ancient inscriptions, published in successive volumes through nearby Luzac \& Co's 'Semitic Text and Translation' series. Several of Thompson's publications focused on the occult: magic and demons, astrology and alchemy.

Within four years of his appointment he was heading east to join the British Museum's excavations at ancient Nineveh. These were focused on the Mound of Kouyunjik, across the Tigris river from Mosul, in what is now northern Iraq. His colleague Leonard King was already there. Over the year that he spent at Nineveh Reginald Campbell Thompson embedded himself in Mesopotamia, travelling both in that country and in Persia (Iran), where he and Leonard King made copies of the famous trilingual inscription at Behistun. ${ }^{11}$

Thompson enriched himself with experience of a foreign land, taking notes on variations in language and vocabulary, costumes, customs, geography, the changing of the seasons, epidemics, food, pastimes, colours, the biographies and travails of the men who worked with him and for him. ${ }^{12}$ He left the Museum at the end of 1905 and spent six months in northeastern Sudan, then took a post at the University of Chicago for two years. Another spate of travel in Turkey followed. Then, in 1911, Thompson joined the British Museum's excavations at Carchemish, begun under the direction of David George Hogarth with a young Oxford graduate, Thomas Edward Lawrence, and Leonard Woolley making up the team. He stayed one season, but elected to resign after discovering that his fiancée Barbara Brodrick Robinson would not be allowed to accompany him. When war was declared in 1914 Thompson applied for a commission, which he obtained. He was assigned to the Indian Expeditionary Force, section D (I. E. F. D.), for 'special service' in military intelligence (Fig. 9.1). After spending a month in India he returned to Iraq, where he remained for four years. ${ }^{13}$

Before he left for India, Thompson had completed his first 'popular' book. A Pilgrim's Scrip was dedicated to his old British Museum colleagues, Harry Hall and Leonard King. It was published by John Lane/Bodley Head in January 1915, in the lead up to the Gallipoli campaign, and marketed along with the other travelogues emerging from that publishing house as an amusing narrative of Thompson's excavation 


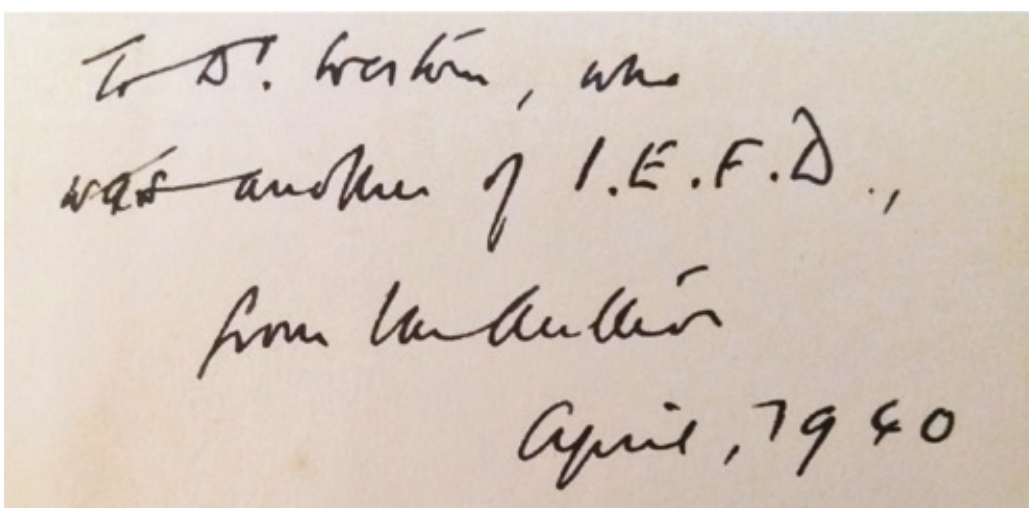

Fig. 9.1 Reginald Campbell Thompson's inscription to 'Dr. Weston', a colleague in the I. E. F. D. in a first edition of Digger's Fancy. (Author's collection)

work. ${ }^{14}$ In A Pilgrim's Scrip Thompson distils his first experiences in archaeology into an autobiographical tale of a border-crossing transnational nomad - a Burton-esque character who seems to slip quite comfortably into life in the East. The prose is notably antique. Thompson, emphasising the wanderings of his excavator-pilgrim, describes the archaeologist's 'trade' as a 'bifurcation of employ' - one in which he spends part of the year on site, 'digging for the pot of gold beneath the rainbow, seeking the peculiar treasure of kings who like chimneysweepers have come to dust', before going back at the end of the season 'to the dullness of steam, electricity, and policemen'. ${ }^{15}$

An anonymous review in the Geographical Journal noted that although the language might not please all readers, the work of archaeologists 'in the NearEast' waslikely to 'acquire anew political importance'. ${ }^{16}$ By the timePilgrim's Scrip appeared, Reginald Campbell Thompson was working as a member of the I. E. F. D. in the Mesopotamia theatre. His guide to Arabic language for the troops, written with his colleagues in the I. E. F. D., was locally published in 1915 . Having been with British troops heading to Kut al Amara (where they were later under siege), in the spring of 1916 he was based in Basra working on intelligence reports; here he crossed paths with Gertrude Bell. She was working for the Arab Bureau, an intelligence agency operating from Cairo and managed by D. G. Hogarth, with T. E. Lawrence and Leonard Woolley also working in intelligence in the Middle Eastern theatre. Bell and Thompson shared an office temporarily, while Bell was organising information collected about various local groups. Thompson's 'normal routine' - so his biographer 
wrote - consisted of 'many hours every day unostentatiously interrogating all sorts and conditions of men'. ${ }^{17}$ As the war drew to a close he took up 'the spade' once more. His military role came to an end in the spring of 1918 and he joined the Political Service in the emerging British administration. ${ }^{18}$ While beginning preliminary excavation and survey work and providing general oversight over archaeology, Thompson wrote A Small Handbook to the History and Antiquities of Mesopotamia. Intended for the benefit of the troops stationed in the region, it included a gazetteer of sites along with references to the chief excavators working on them. ${ }^{19}$

It was Mesopotamia that provided the backdrop for Campbell Thompson's two novels, both published under the pseudonym of John Guisborough. ${ }^{20}$ Both A Song of Araby (1921) and A Mirage of Sheba (1923) were romances, published by Mills \& Boon. Although now almost entirely focused on the romance market, which they have dominated for decades, at the beginning in 1908 Mills \& Boon was a general publisher who published a wide range of nonfiction and fiction. In his history of the firm Joseph McAleer has noted a number of eminent authors of fiction who published books with Mills \& Boon, including Georgette Heyer, Jack London, E. F. Benson and P. G. Wodehouse. ${ }^{21}$ Co-founders Gerald Mills and Charles Boon met and worked together at the successful publishing house Methuen (through which many popular archaeology books appeared). ${ }^{22}$ The firm maintained close links with Methuen in these early years, and was successful in its early ventures. A postwar increase in demand for accessible fiction led Mills \& Boon to focus on specialising in romantic fiction, an area in which they saw the most profit during the postwar period. This was also a time of financial difficulties for the firm; as McAleer has demonstrated, there was a significant decrease in first edition sales figures. However, McAleer notes, the firm was still developing new authors, its target audience the circulating library users. ${ }^{23}$

Thompson, writing as Guisborough, was one of the new authors taken on by Mills \& Boon at this time. A Song of Araby appeared in the autumn of 1921 and was advertised by the firm as a 'brilliant first novel'; its author was identified as a former officer of the Mesopotamian front a nod, perhaps, to the veracity of the fictional narrative. Mills \& Boon praised its 'vivid portray[al]' of Near Eastern peoples and landscapes, noting that the book would be of real value for those interested in the region. ${ }^{24}$ Published reviews were generally favourable. The Scotsman particularly lauded Thompson's heroine, while The Illustrated Sporting and Dramatic News felt that, despite some novice novelist flaws, A Song was 'fascinating'. It went into two editions. ${ }^{25}$ 
Both of Thompson's Mills \& Boon novels featured archaeologists as protagonists, and in them he clearly draws on his own experiences. He had toyed with a lyrical, highly romanticised and dramatic approach in $A$ Pilgrim's Scrip; in his Mills \& Boon books he kept the romance of archaeology intact but toned down the linguistic frolics significantly. Set in wartime Mesopotamia, A Song of Araby is the story of explorer-archaeologist Robert Eliot and his quest to confirm the movements of a stray German gun. The book opens with Eliot at his desk in Bombay in 1914. He had diverted his personal explorations in Arabia at the outbreak of war, intending to return to Britain to join up. But his fluent written and spoken Arabic (which we are told is useless for most paid positions in England) and knowledge of the landscape and peoples of the region had been subpoenaed by the India Office. Itching to get away from his desk-based intelligence work compiling lists of Arab 'tribes', Eliot takes advantage of an opportunity to conduct a secret reconnaissance mission, offering himself as an 'independent' agent:

I'm free, Sir; I am neither soldier nor Government servant, and if I choose to take the risks of going out there to see for myself, no one else is involved. You are not responsible for me. ${ }^{26}$

He goes undercover, disguised as an Arab (from Tripoli to explain his blue eyes) who had formerly been employed as a servant to an archaeologist at Nineveh and had then gone on to work for the oil companies further south. ${ }^{27}$ 'Mohammed' Eliot's ability to blend in is nearly flawless. As an explorer, he is neither fish nor fowl. He can move freely and take all risks on himself as a (semi) independent agent, drawing on his local connections and sources, local linguistic skills and local topographical knowledge to best advantage as an unofficial and highly competent spy. He revels in the necessary physical discomfort as he makes his way north of Basra towards a reservoir that has been the preserve of the German engineer, spy and villain of the piece Herr Blauhammer.

Thompson's narrative fits into the exotic romance/adventure mould that echoed other Mills \& Boon romances being published at that time. ${ }^{28}$ The romance narrative, along with the espionage theme, is one of the most interesting aspects of the book. Its heroine, Katharine Appledor, is a noted explorer and lecturer, Cambridge-educated and prone to giving papers at scientific societies. With her own mission to recover a secret message en route to Herr Blauhammer thwarted, she finds herself under his threat of captivity and implied sexual violence. Events enable her to join Robert in disguise dressed as an Arab boy in a race to dodge 
the Turkish troops on the way to war in support of the Central Powers. Together the pair travel southeast on foot towards Basra and the British Indian Expeditionary Force, due to land in Mesopotamia. They take a night's refuge at 'the dead city of Ur', resting among the city's 'ghosts' in narrow makeshift shelters built of the ancient bricks, safely entombed by the past. ${ }^{29}$ To pass the time Katharine quotes from the Epic of Gilgamesh. Ultimately the explorers reach a British naval vessel and shed their false identities (so convincing that even Katharine's uncle is taken in), allowing their blossoming romance to be fully realised. Thompson's wife Barbara, to whom the book is dedicated, may have served as inspiration for Appledor's character, though (to date) Barbara Campbell Thompson remains an elusive figure in the historical record. At the very least Katharine Appledor's role in the adventure shows Thompson's healthy respect for intelligent women, echoed in the Scotsman review, as well as his awareness of his potential readership. ${ }^{30}$

The sales of $A$ Song clearly encouraged Mills \& Boon to take on Thompson's follow-up novel. In A Mirage of Sheba the exotic adventure of archaeology is again realised. Unlike Song, Mirage focuses in more detail on archaeological life in prewar peacetime. The novel's strength lies in its depiction of archaeological activity as a series of negotiations with antiquities dealers, officials and local residents, and in the dual nature of an excavator's life: one foot in Britain, the other abroad. The allure of the East, present in all Thompson's popular books, is equally visible here.

Mirage opens in northern Mesopotamia, Thompson's old stomping ground, in 1913. Arriving in Mosul hoping to scout out a site for excavation, Cambridge-educated archaeologist Geoffrey Lyndhurst purchases a cuneiform tablet from a local antiquities dealer who claims it has come from a tell (a mound in the landscape indicative of human occupation) near Nineveh. After translating the tablet's inscription, he realises that it refers to another older piece from which the tablet is translated. Thompson illustrates the archaeologist's ability to picture the past as Geoffrey imagines in detail the circumstances of his newly purchased tablet's last moments in antiquity - a scene that echoes Hogarth's feverish dream of Hittite invaders in Accidents of an Antiquary's Life. Determined to find what he believes is a hidden cache of ancient texts, Geoffrey draws on the knowledge of his servant Hajji Abdullah and finds the mound. After purchasing the lease of the land, he is ready for a season of excavation once a firman (permit) has been obtained from Constantinople.

He returns to Norfolk for a summer's holiday on the Broads, where he meets tattooed Felicity Curthoys. Felicity, a young, beautiful, welltravelled novelist and cinema screenwriter, carries a London Library 
copy of Ouida's Under Two Flags (1867) as a badge of 'Character'. ${ }^{31}$ Her satirical articles lampooning academic life had nearly led to her expulsion from an Oxford college. A romance develops and at the end of the holiday the smitten Geoffrey (slightly worried that he might be tying himself to a partner who would want to stay at home and start a family while he went exploring) blurts out a proposal of marriage. Felicity refuses. She does not want to give up her writing and has her own worries that a future with Geoffrey in the desert (before children ensued) would ruin her career.

In describing Geoffrey's internal struggles, Thompson may have been drawing on the memory of his own fears of marriage hampering his life's work. Equally, in creating Felicity Curthoys and Katharine Appledor as independent, educated women, Thompson was certainly reflecting the corps of women archaeologists, explorers and archaeological wives who must have been known to him. Geoffrey and Felicity part - he to his excavation and she to continue her successful writing career. However success, once achieved, is not enough for Felicity. Unable to forget Geoffrey, she travels to Mesopotamia to experience in person the setting for her latest novel and to declare her affection for him. After he dramatically rescues her from the clutches of an insidious Ottoman antiquities inspector, the two declare their love for each other. At the close of the story, Geoffrey describes what Felicity will be taking on upon marriage:

Your life is now here, now there! .... I must spend eight months a year on this mound for five years; this mound which has been so good to me. I won't turn back now. ${ }^{32}$

Through Thompson's scripting spadework in fiction we see the adventurous romance of archaeology in its widest sense; as a 1911 dictionary put it, 'scenes \& incidents remote from everyday life'. ${ }^{33}$ Themes such as exploring/documenting local context, hiring/paying locals and relationships on site - not to mention partnerships between explorers emerge that reflect the archaeological documentary films of the interwar period, created by excavation teams to educate members of the public about their profession. ${ }^{34}$ These are further emphasised in the genre of 'adventure' feature films, such as The Mummy (1932) and particularly strong since the 1980s, with Steven Spielberg's Indiana Jones series, Stephen Sommers' The Mummy (1999) and the Mummy Returns (2001) and Luc Besson's The Extraordinary Adventures of Adele Blanc-Sec (2011). All are set in the early twentieth century. ${ }^{35}$ These narratives also 
demonstrate that (un)conscious awareness of ancient pasts and ancient lives is part of the romantic adventure narrative, linking us to the next genre: horror/fantasy.

\section{Fantastical horror and archaeology}

Dorothy L. Sayers noted the long-standing allure of the occult in the Introduction to her 1928 anthology Great Stories of Detection, Mystery and Horror, declaring that 'The art of self-tormenting is an ancient one, with a long and honourable literary tradition'. ${ }^{36}$ Margaret Murray acknowledged it in her 1963 autobiography with her observation that '... all good archaeologists are expected to have had at least one occult experience...', while she defines herself as '... a bit of a "bodysnatcher" ' - as, she states, are most other archaeologists. ${ }^{37}$ Murray's two observations on archaeological life lend themselves effectively to both 'horrific' and 'fantastical' literature. She neatly encapsulates archaeological characteristics with definite commercial appeal - what Gabriel Moshenska has termed 'the archaeological uncanny', drawing on the interaction of the living and the dead through the act of excavation and the alienation from the norm that results. ${ }^{38}$ In exhuming the dead and buried and interpreting the remnants of human existence, through scripting spadework archaeologists create an image of past worlds for others to consume. Archaeological work involves constructing a channel through time. ${ }^{39}$

Agatha Christie has vividly described her first tour around the Ur excavations with Leonard Woolley, who created through his narrative a vision of the site in ancient times. She experienced the archaeologist tapping into his knowledge and belief in his interpretation of the site and its objects to create an Ur of a past age. ${ }^{40}$ Such a vision, such tapping into the past, can be interpreted as magical, subversive and dangerous archaeological alchemy. In this sense archaeologists and the history they uncover are prime candidates for inclusion in studies of the reception and reuse of fantastical and occult themes. Brian Stableford's Historical Dictionary of Fantasy Literature, for example, includes entries on prehistoric and classical fantasy fiction, mummies and druids, as well as 'timeslip' fantasies in which characters are able to access a past historical period. Margaret Murray is also included in the Dictionary for her work on witchcraft, classified by Stableford as 'scholarly fantasy', and its inspiration for modern Wiccan practices. ${ }^{41}$ Although Murray declared to posterity that she had never personally experienced the occult in her work, 
she nonetheless included a chapter on it as part of her autobiography the exploration of her own carefully scripted identity as an archaeologist. Writing stories that mingle archaeological and antiquarian themes with horror, fantasy and the occult is not new. ${ }^{42}$ Horror/fantasy genres allow us to see most clearly how those outside archaeology have reshaped the spadework scripts, presenting evidence of the reception of the archaeological experience in popular literature. A number of authors' stories featured either ancient artefacts or the people responsible for their discovery and/or collection. These have been anthologised over the decades, with ancient Egypt, and particularly mummies, being a popular and fruitful theme. ${ }^{43}$ One of Arthur Conan Doyle's most famous Egyptological short stories is the much anthologised 'Lot No. 249', with a crazed student-Egyptologist, the 'reptilian' Edward Bellingham, 'reanimating' a mummy to persecute his enemies on the streets of Oxford. Another Conan Doyle horror story, 'Burger's Secret', written for the Sunlight Yearbook of the philanthropic Lever Brothers' soap manufacturing company, featured a young German archaeologist driven mad by jealousy of a rival in love; he uses his discovery and knowledge of Roman catacombs to entomb his enemy. ${ }^{44}$

The archaeologist and medievalist Montague Rhodes James continues to be probably one of the best known authors of archaeologythemed ghost stories. The first compilation of these tales, Ghost Stories of an Antiquary, was published in 1904, and others followed. Edward Frederic Benson, who went on to write the notable Mapp and Lucia books, also wrote ghost stories, drawing on his own experiences in archaeology in Egypt; he and D. G. Hogarth had excavated in Alexandria together in the 1890s. Some of these tales were published in Spook Stories and More Spook Stories. Algernon Blackwood wrote several Egyptian-themed tales and other short stories that feature archaeologists or archaeological themes. In his 1914 short story, 'A Descent into Egypt', the narrator watches her excavator friend George Isley become psychologically buried by interest in the past. One scene describes how both of them are sitting at a table in a restaurant when the narrator notices a mysterious presence, The Third, joining them. Later she reflects on its significance, observing that The Third was, in fact 'the Past'.

The Third consumes the spirit of the archaeologist. Isley pairs up with the fascinating and disturbing 'speculative archaeologist' Moleson to conduct experiments attempting to recreate ancient Egyptian religious practices. The sinewy, mummy-like Moleson uses adaptations of ancient Egyptian music, resurrecting the ancient world through his playing, to wield power over others, dragging them back into Egypt's past. 
His work with Isley brings their mutual absorption into (ancient) Egypt to completion. ${ }^{45}$

Like these authors, Margery Lawrence found the appeal of the archaeologist and the fascination of ancient pasts a fruitful subject for her fiction. A popular author and public figure during her lifetime, she published over 33 novels and short story anthologies between the 1920s and the 1960s, a portion of which drew on fantastical and occult themes. ${ }^{46}$ She used archaeologists as characters and drew on archaeological themes and motifs in her writing, including ancient gods and artefacts, knowledge of the past and past lives and the reconstruction of the past through interpretation. Archaeologists, in Lawrence's fiction, are by turns wise, knowledgeable and, to a certain extent, set apart from the ordinary - though not in the negative sense implied in Hall's 2004 overview of archaeologists' cinematic portrayals, and in Gabriel Moshenska's work on M. R. James. ${ }^{47}$ Her fiction also represents a useful source for exploring the reception of archaeological popular publishing in more detail. In various works she explicitly acknowledged archaeologists and the popular work they produced as an inspiration and a valuable resource.

The earliest representation of the archaeologist in Lawrence's fiction occurs in her short story 'The Curse of the Stillborn', originally published in Hutchinson's Mystery-Story Magazine in June 1925. The Mystery-Story Magazine was a cheap pulp periodical; issued monthly in Britain, it was priced initially at 7 pence and featured male and female authors. Hutchinson advertised Mystery-Story as the ultimate venue for 'romantic mysteries' of 'detection' and 'the weird'. ${ }^{48}$ Tables of contents for the issues published during this period show a number of Egyptianthemed titles - not surprising as newspapers regularly featured Howard Carter's Tutankhamun tomb excavations and the ensuing 'Tutmania' spread its tentacles through art, design, fashion, music and commerce, as well as fiction and nonfiction. ${ }^{49}$

Work published in Mystery-Story and its companion, Hutchinson's Adventure Story Magazine, frequently drew on 'exotic' settings. 'The greatest miscellany of stories of Mystery, Crime and the Supernatural' Mystery-Story was, so Hutchinson's claimed, 'A Magazine the public has taken into its heart'. ${ }^{50}$ The magazine's colourful covers featured an illustration from one story in each issue. Taking full advantage of the popular appeal of Egyptomania and the uncanny, Hutchinson's chose to feature Lawrence's anti-heroine Mrs Bond and the vengeful mummy that terrorised her as the front-cover illustration for the issue in which 'Curse' was published. ${ }^{51}$ 
In 1926 'The Curse of the Stillborn' was published by Hutchinson in book form alongside 11 other Lawrence tales. The magazine version of 'Curse' had been adapted and enhanced to fit Lawrence's framework for her Nights of the Round Table - that it is the product of a monthly dinner party given by one Frank Saunderson. There are 12 guests, each from a different profession, and there is one story per dinner. It is an eclectic group: Saunderson and Lawrence join a policeman, a barrister, a minister, a soldier, an engineer, a golf secretary, a spiritualist, a hypnotist, an Egyptologist and a poet. The Egyptologist is called Frith, and 'The Curse of the Stillborn' is his contribution.

The role of the Egyptologist in this story departs from the excavator/discoverer/scholar in archaeology-themed horror as the victim of forces he or she has disturbed in some way and cannot control. In this case the Egyptologist is the sage, both part of a very small British community in Egypt and apart from it; he has knowledge that his fellow Britons do not. He is able to go places where they dare not go, and to see things they cannot see. The story begins one afternoon in a small settlement called Ikn Nessan where Frith meets his neighbour, local missionary Mrs Peter Bond. Mrs Bond and her husband are forthright, British and, to Frith's mind, very narrow-minded. Mrs Bond is full of the news that the young, heavily pregnant Egyptian girl Mefren, who had arrived in the village with her mother Takkari, had given birth to a still-born child. Mrs Bond was determined to bury the child in a Christian manner, but Takkari had firmly refused to allow her to interfere.

Far from being a foreign invader, Frith is at home in the landscape, living away from Ikn Nessen on the edge of a nearby valley. Having a detailed knowledge of local customs, he warns Mrs Bond not to get involved and to allow Takkari to bury the infant in her own way. Peter Bond then arrives on the scene, announcing his success in persuading Mefren to allow him to bury the baby. Next Takkari appears, joining the Bonds and Frith. She is silent, but her displeasure is clear. She whispers something to Frith and walks away, leaving the village. On enquiring, Mrs Bond discovers from Frith that Takkari has warned against further interference.

Later on the Bonds are closeted up in their small house, curtains closed against the darkness outside. Here they are forced to confront a vengeful ancient Egyptian spirit, determined to make them see their error in interfering with custom. Frith, meanwhile, wanders comfortably alone in the dark through the village streets. The context of Frith's role as Egyptologist becomes clearer at the end of the story, which includes a new section added for book publication. This details Frith's analysis of 
the events, drawing on Egyptological knowledge of the afterlife - specifically on how the Ka (soul), denied its rightful rituals, would return in vengeance, and how long-forgotten ancient practices might still linger deep in the psyche of Egyptian villagers. ${ }^{52}$

Lawrence was interested in spiritualism and the paranormal, and several of her books have overtly spiritualist themes: the closeness of the past to the present, the dead to the living, and the ability to tap into or access past time periods. She communicated with dead relatives and friends through mediums, and claimed to have psychic abilities herself. Lawrence held a deep-seated belief that her spirit had been reincarnated several times in different historical contexts, including Egypt, Persia and Greece. ${ }^{53}$ She spelled out this belief in her spiritualist 'primer' for beginners, Ferry Over Jordan. In defending her beliefs, Lawrence pointed out that eminent authorities and celebrities had spent many years gathering evidence of the possible existence of life after death. ${ }^{54}$ Among those on her list were the Egyptologist Grafton Elliot Smith and Arthur Conan Doyle, whose active promotion of spiritualism in early part of the twentieth century was well known. She also referenced as an example the work of architect-archaeologist Frederick Bligh Bond, whose excavations at Glastonbury Abbey were directed through collaboration with a medium. The automatic writing scripts produced during these sessions suggested the location of a lost chapel in the Glastonbury Abbey complex. ${ }^{55}$

Bligh Bond was part of a broader network of intellectuals exploring the possibilities of pushing the boundaries of the known world. ${ }^{56} \mathrm{He}$ was a member of the Society for Psychical Research (SPR), founded in 1882 by a group of Cambridge classicists, philosophers and scientists. The SPR collected evidence of, examined and classified phenomena. These included mental phenomena, such as hypnotism, thought reading and clairvoyance, and physical phenomena such as ghosts, as well as the varied sounds, smells, sights and feelings produced by mediums. The Society then used the data gathered to test the possibility of scientifically proving the existence of another world or other dimensions. Other aspects of psychical research, more applicable to archaeology, were automatic writing and psychometry, or reading the past associations of material through touch. ${ }^{57}$

Agnes Conway, whose nonfiction travelogue A Ride Through the Balkans was discussed in Chapter 3, explored the potential of psychical connections to the past in the context of her 1929 excavations at the ancient and evocative city of Petra in modern Jordan, home to the Roman-era Nabataean civilisation. Conway's interest in psychical research stemmed from her days at Newnham College, where her mentor 
Jane Harrison had long-established interests in, and links to, some of leaders of the SPR. ${ }^{58}$ In 1929, while on site at Petra, Conway collected some sand, probably from a 'place of sacrifice' excavated under her direction. She sent three samples of the sand to a contact in Surrey, who gave them to the Kent-based medium L. Margery Bazett. Bazett read the packets psychometrically and recorded her visions in short impactful phrases, accompanied occasionally with small line drawings. ${ }^{59}$ The vivid scenes that she reported after holding the packets to her head could have come directly out of a fantasy novel:

Now I see a curious scene here ... it is dancing, girls, dancing ... they are very lightly clad... a ring of girls, all going to the centre and back, to the centre and back... they may be decorated with some flower or leaf... it was a quick movement, a sort of running to the centre and back ....6 ${ }^{60}$

During this period the SPR was collecting evidence of the potential for mediums being able to link into the past. Letters to Conway's close friend and SPR administrator and researcher Helen Verrall in 1924 from SPR member C. Drayton Thomas chart sittings with medium Mrs Osborne Leonard, through whom spirits described ancient Egyptian objects and their uses. ${ }^{61}$

These influences can be seen in some of Lawrence's novels, which draw upon archaeological knowledge mingled with belief in reincarnation and spiritualist undercurrents to inform the creation of past civilisations. Lawrence's 1951 'timeslip' 'spiritualist fantasy' novel The Rent in the Veil takes place in a house on the Sussex Downs. Its new owner, Liz Anderson, discovers that in a past life during the Roman period she lived in the same house as Bronwen, a British chieftain's daughter married to Roman centurion and harbour master Lucius Paulinus. ${ }^{62}$ As the narrative unfolds, she discovers her 'mediumship' is triggered ever more frequently by her domestic surroundings. ${ }^{63}$ She exists in both lives simultaneously, initially drawn in through the discovery of a Roman-era statue base in her garden. Though Liz has had momentary disturbing encounters with her 'past' before the discovery, the revelation of the statue base is the final key to her dawning realisation of this double life. Local archaeologists Professor Cummings and his wife call on Liz to ascertain the authenticity of the discovery. With their authentication of the base, her new reality is also authenticated. She discovers through the course of the book that husband, brother, friends and neighbours also inhabited Liz-Bronwen's Romano-British world with their own past 'doubles'. Eventually her 
Roman-British life absorbs her so thoroughly that she kills herself trying to follow her Roman lover and their child across the sea. In its review of the book the Dundee Courier noted the power of the narrative to inspire readers to reflect on the potential of time travel. ${ }^{64}$

The book also shows that Lawrence drew on published accounts of archaeology to create an atmosphere that would approximate what was known about Roman society at that time, drawing on communications with experts to inform her interpretation. These experts included Cambridge Regius Professor of History George Macaulay Trevelyan and archaeologist William Hugh Clifford Frend. To strengthen the authenticity of her work, Lawrence included five Appendices in The Rent in the Veil, covering aspects of Roman dress, buildings and historical events. She also listed the sources she had consulted, featuring works by Francis Haverfield, a notable archaeologist of Roman Britain, and archaeological artist Jessie Mothersole. Lawrence's voice and interpretation of the archaeological publications with which she constructs her narrative is evident in the text. She uses footnotes to reference the appendices, define terms and in some cases promote her own views on the expert evidence she consults, such as defining 'woad painting' as a tattoo. ${ }^{65}$

The Rent in the Veil can also be read as a work of historical fiction, a genre that had been recognised for over a century. Lawrence's book is among a number of similar works published during the mid-twentieth century that offered a dramatic presentation and interpretation of women's history. ${ }^{66}$ Robert Hale, a regular publisher of Lawrence's work, also published historical fiction by other women during the 1950s. One of the best known Hale authors was Jean Plaidy, whose fictionalised biographies of famous women - including Eleanor of Acquitaine, Elizabeth I and Marie Antoinette, alongside less famous but no less fascinating women - were and continue to be popular, particularly with female readers.

Daughter of the Nile (1956) is Lawrence's fictionalised biography of the ancient Egyptian queen Hatshepsut. In the book's opening pages Lawrence compares Hatshepsut to Elizabeth I to help contextualise a ruler about whom readers might know little. As she did in The Rent in the Veil, in her Foreword to Daughter Lawrence gives insights into her source material - including an acknowledgement to T. G. H. James, then in the Department of Egyptian and Assyrian Antiquities at the British Museum, for his advice on reference books. Lawrence's list of the source material at the end of the novel highlighted the continued relevance of nineteenthand early twentieth-century popular archaeological works: Flinders Petrie, Gaston Maspero, John Gardiner Wilkinson, Arthur Weigall and 
James Henry Breasted are among the authors listed. ${ }^{67}$ In both books, however, she is careful to acknowledge that the narrative has considerably stretched the boundaries of what is actually known about the ancient past. As an author Lawrence takes on an archaeological identity as she interprets and intuits archaeological evidence, creating her own historical fantasy through previously scripted spadework, constructing landscapes and lives of the past and filling in the spaces where archaeological evidence falls short with her own imaginative vision.

\section{Archaeological crime}

An alternative 'dark side' of archaeology can be seen in the ways in which archaeologists have been represented in crime fiction. Since its publication in 1936, Agatha Christie's Murder in Mesopotamia has been reissued countless times, in both hardback and paperback. Various cover illustrations for the book - including those of UK publishers Pan and Fontana and the American paperback publishers Dell - reveal symbolic representations of archaeology: skeletons, pots, a dig, the dig house, the landscape, the exotic East. The original dust jacket for the 1936 first edition, featuring a drawing by archaeological architect Robin Macartney, further emphasised the 'authenticity' of the work through Christie's connections to archaeology as Max Mallowan's wife. ${ }^{68}$ In his memoirs Max Mallowan estimated her readership at '2,000 million' people; the many cheap editions of her work produced facilitated this extensive readership. ${ }^{69}$ Considering her archaeological mystery novels as very simple introductions to the field and projections of archaeological experience makes her role as a populariser of archaeology highly significant. ${ }^{70}$ In this volume Murder in Mesopotamia and They Came to Baghdad will be analysed as spadework scripts.

Christie was born in Torquay, Devon in $1890 .{ }^{71}$ Her Belgian refugee protagonist Hercule Poirot made his premier in The Mysterious Affair at Styles, published by John Lane/Bodley Head in 1920. Four years later one of the stories featuring Poirot was the first in which Christie employed an overtly archaeological narrative. 'The Adventure of the Egyptian Tomb' takes place as Howard Carter's excavations of Tutankhamun are unfolding and explores, among other things, the value of curses as a cover-up for murder. The relative of a supposed victim engages Poirot to go to Egypt and prevent the same fate befalling her son.

In 1928 Christie went to Iraq. It was an escape: her first marriage had ended in divorce and she was travelling independently for the first 
time, via the Orient Express. En route she met the domineering Mrs C., one of what were called the 'Mem-Sahibs' - a term originally used for British women in India, but applied in this case to Iraq. ${ }^{72}$ She made her escape from so-called 'Mem-Sahib Land' by planning a trip to see Leonard and Katharine Woolley's excavations at Ur, which she had read about in London in the Illustrated London News. ${ }^{73}$ When she returned to Ur for another visit during the $1929 / 30$ season she met Max Mallowan, the Woolleys' new assistant; the couple married in September 1930. Five years later she began to draft Murder in Mesopotamia, having become by that point familiar with the rhythms and processes of archaeology. Later, when Christie was writing They Came to Baghdad, Mallowan was Professor at the Institute of Archaeology, with a budget for excavations. They were excavating at Nimrud, in the northern part of Iraq, but their seasons began and ended in Baghdad. ${ }^{74}$

In Murder in Mesopotamia the scene of the action and most of the associated activity is the Expedition House. There are parallels to be drawn between the 'country house murder' of the period and the 'dig house murder' of Murder in Mesopotamia. ${ }^{75}$ Christie used floor plans in both her country house mystery, The Mysterious Affair at Styles, and Murder in Mesopotamia. Just as she introduces her readers to some country house 'types' in the Mysterious Affair at Styles, in Murder in Mesopotamia she introduces archaeological 'types', each with their own distinct role in their own distinct space. Thus Christie's organised world provides a key to understanding archaeology.

Murder in Mesopotamia's narrator, Nurse Leatheran, has these 'types' explained to her before she embarks for the site of Tell Yarimjah. The team is composed of an architect named Mr Carey, an inscription expert Father Lavigny, the bottle-washing Miss Johnson, Mr and Mrs Mercado, photographer Mr Reiter and assorted young volunteers. ${ }^{76}$ The Dig Director is Dr Leidner; his wife Louise, like many archaeological wives, joins her husband on site. Unlike many archaeological wives (and unlike Katharine Woolley, on whom she is reputedly based), Louise Leidner seems to have very little to do. Nevertheless readers are informed she has learned Arabic within two seasons and is no intellectual lightweight, as inspection of her room and its small library during the course of the subsequent investigation demonstrates. Murder in Mesopotamia's dig house is slightly more ordered than the rather haphazard plan of the Ur dig house, but there are obvious similarities to the country house plan, with archaeological elements included. ${ }^{77}$ Thus the dig house is both familiar and unfamiliar - an example of the 'familiar strangeness' of archaeology. ${ }^{78}$ The sense of isolation is pervasive in the book, with a 
key component of the classic detective story in the country house style translated to and enhanced by a flavour of the exotic in an archaeological context.

Christie's 1951 thriller They Came To Baghdad represents archaeology and archaeologists in a different, more nuanced light. Instead of the claustrophobic dig site with its menacing murderer at large, the site of Tell Aswad in They Came to Baghdad is a place of refuge and peace for protagonist Victoria Jones. She leaves dreary London for the bright lights of cosmopolitan capital Baghdad in search of the man she loves. Through a twist of events she finds employment as an undercover agent, assisting the world-weary Mr Dakin to root out the source of an international conspiracy to jettison efforts at global peace. Having been drugged and imprisoned in a small village, Victoria manages to escape her captors. Swathed in an Arab woman's black Aba (robe), she rests on an ancient mound. Archaeologist Richard Baker arrives on the scene to investigate the mound and discovers Victoria. Believing her to be the English anthropologist due to arrive at the Tell Aswad excavation where he too is expected, Baker takes her to the site. His character reinforces what we now expect of archaeologists - broad cultural knowledge and experience of travel, as well as linguistic skills; Victoria assumes he can easily 'pass' as an Arab with his knowledge of Arabic.

Once on site, Victoria becomes ever more captivated by archaeology, using the dig house library to enhance her own knowledge. After a week on site she is capable enough to give a tour of the site to unexpected visitors. Christie describes Victoria's active imagination conjuring up scenes of ancient life the more she handles ancient objects and understands the layers of history at Tell Aswad. Her developing awareness is a reflection of Christie's own gradual immersion in archaeology. The narrative explores the roles of photographer and artefact cleaner that she herself took on, and the dawning perception of the processes and practices of the discipline. ${ }^{79}$

In 1975, under the pseudonym Elizabeth Peters, American Egyptologist Barbara Mertz began publishing her bestselling 'Amelia Peabody' series of mystery novels set in late nineteenth- and early twentieth-century Egypt. Featuring British Egyptologists Amelia Peabody (later Emerson) and Radcliffe Emerson, Peters' first instalment was Crocodile on the Sandbank. Her intimate knowledge of the history of late nineteenth-century Egyptology, and of scripted spadework, shines through the texts. She illuminates key aspects of the archaeological experience with particular relevance to women: education, independence, artistic skill, marriage bordering on equality with an archaeological 
partner, even field 'nursing' skills - as Amelia is eventually given the title of 'Sitt Hakim', or lady doctor. ${ }^{80}$ In later books other aspects of archaeology emerge - the seasonality of excavation demanding homes in both England and Egypt, hybrid personal identities, familiarity with Egypt and Egyptian customs, linguistic facility, relationships with local communities and, though participating in British expat life in Cairo, having (in the novels) more overt than subtle resistance to a British colonial establishment (not perhaps surprising given Mertz/Peters' own postcolonial chronology). Two books in particular help to illuminate these themes: Crocodile, which sets the stage for the series, and the exploration of archaeologists in wartime in the twelfth Amelia Peabody mystery, He Shall Thunder in the Sky.

Crocodile opens in 1884 as well-educated, unmarried Amelia, daughter of a wealthy antiquarian, inherits her father's property on his death and so gains financial independence at the age of 32 . She decides to travel to the ancient sites she had heard about from childhood. In Rome, en route to Egypt, she rescues Evelyn Barton-Forbes, a young aristocratic woman whose elopement and subsequent abandonment leads her to contemplate suicide. Engaging Evelyn as her companion, the women set sail for Egypt. Once in Cairo the Philae, a dahabiya, is secured to enjoy a scenic tour up the Nile (Amelia Peabody's desire for the freedom and independence of the dahabiya echoes Mary Brodrick's thoughts on the subject). Before embarking, however, a run-in with irascible excavator Radcliffe Emerson at the Boulaq Museum provides the clinching archaeological (and romantic) link. Emerson and his philologically-inclined brother Walter have been granted a permission to excavate at Amarna. With Evelyn being pursued by a particularly ardent suitor, the two women take to the Philae, using the freedom of dahabiya travel to defy convention by stopping at sites on the way up the Nile against favourable currents. When the Philae reaches Amarna, they visit the Emersons on site and are swept up in the adventure of excavation, even as they are being 'pursued' by a mysterious and frightening ambulatory mummy who, while terrorising the camp, also murders several people.

As in Thompson's Mirage, Peters in Crocodile draws on the fundamentals of the archaeological experience to provide the context of the action. Relations between excavators and the villagers they employ are soured when rumours of the mummy's presence circulate, for example, nearly forcing the Emersons to abandon the site entirely. Amelia Peabody's growing fascination with ancient Egypt and the adventure of archaeology leads to her abandoning conventional attire and 
behaviours to adapt to the practicalities of site life: a Rational Dressinspired divided skirt, too radical to wear in Society (whether in London or Cairo), becomes her work-day suit as she conserves a fragile painted pavement with a solution of water and tapioca. Her working relationship with Emerson develops into a romance and marriage, and she eventually finds her calling in life - as equal partner with Emerson in archaeological expeditions. Though her characteristics have been described as a feminist revision of the 'New Woman' and a 'spoof', Peabody is in essence a composite of late-Victorian female archaeologists. ${ }^{81}$

Peters' 'Author's Note' in Crocodile reveals that she drew on archaeologists' publications for inspiration. Her comments highlight the long-term commercial and cultural value of late nineteenth- and early twentieth-century archaeological memoirs and travel guides. 'Reallife' archaeologists such as Gaston Maspero, Francis Llewellyn Griffith, Amelia Edwards and Flinders Petrie appear as characters in the novels or are directly referenced in them, and among other sources Peters used nineteenth-century guides to influence her phrasing and reflect the state of knowledge and its practitioners at the time. ${ }^{82}$ Emerson is a fictionalised alter-Petrie. He is given some of Petrie's eccentricities, including his use of pink undergarments in the field and requisition of tombs as camp living quarters, while notable Petrie discoveries, such as the painted pavement at Amarna, are also credited to Emerson. ${ }^{83}$ In order to emphasise still further the 'authenticity' of the Emersons' adventures as the series progressed and the Emerson family expanded, Peters eventually began to frame the books as, in part, an interpreted archive; she assumed the role of semi-omniscient Editor, on occasion revealing lost or hitherto unpublished manuscripts. ${ }^{84}$ Thus by the publication of Thunder in 2000 the novels are a compilation of multiple voices/manuscripts to Peabody's first person narrative is added 'Manuscript H', representing (in third person) the experiences of her son Walter 'Ramses' Peabody Emerson and in 'Letter Collection B' (in first person), the views of her foster daughter Nefret Forth. ${ }^{85}$

In Thunder Peters gives us a glimpse into fictionalised wartime Cairo and surrounds, setting the scene for the city's role in Middle Eastern intelligence operations. The book opens in the city, recently formally annexed by Britain. Twenty-seven-year-old Ramses Emerson has a reputation as a pacifist and Cairo is full of spies. The Emersons, having lived for half the year in Egypt for nearly 30 years, can assume the role of British expats in the city, inhabiting the same social spaces - Shepheard's Hotel, the Turf Club and the Opera House - when necessary. However, they are most comfortable in the company of their Egyptian colleagues, 
either in the city's bazaars in Khan al Khalili (in the 'Arabic' quarter of Muski), where they patronise all the best unhygienic cafes, or at their home in a village nearby. ${ }^{86}$ Their relationship with the Egyptian population has been deemed so valuable that Ramses has been recruited to join the Military Intelligence Department and Emerson offered a position advising the British officials on the latest developments in the Egyptian community. ${ }^{87}$ With due reference to the role of archaeologists Leonard Woolley, T. E. Lawrence, D. G. Hogarth and Gertrude Bell in the intelligence operations of the Arab Bureau during the First World War, in Thunder Peters-through-Peabody acknowledges archaeology's value to espionage. In fact Woolley and Lawrence both appear briefly in the novel in relation to intelligence work. ${ }^{88}$

Ramses, nicknamed after the Egyptian pharaoh because of his 'swarthiness' and arrogance, having spent half his life in Egypt even has an alternate Egyptian nickname. ${ }^{89}$ Through the years he has taken an Egyptian identity so thoroughly that he and his best friend David, grandson of the Emersons' reis (foreman) Abdullah, can with clever costuming and imitation be mistaken for each other. Further, Ramses can confidently represent himself as Wardani, the Egyptian leader of a nationalist cell in Cairo, to the other Egyptian members of the group. His loyalties and his identities are divided.

It is easy for the majority of the British official class in Cairo to believe that Ramses is a pacifist; they may even be suspicious of his motives concerning Egyptians in relation to British interests. Certainly Ramses knows his way around Cairo's byzantine back streets, and uses his knowledge to advance the causes he believes are right. Beyond undercover activities the Emersons' work during the 1914/15 season involves an excavation in the Giza Pyramid fields, allowing Peters (as in the other Peabody books) to offer readers an insight into the details of excavation life and the archaeological network. When a well preserved statue turns up on their dig site, Antiquities Inspector James Quibell and his artist wife Annie Quibell (see Chapter 3), in the same roles held by their reallife counterparts, are invited to see it. ${ }^{90}$

In 2003 Peters further blurred the lines between her fictional and factual worlds with the publication of nonfiction, quarto-size 'compendium' contextualising the nineteenth-century world of Egyptian archaeology and the archaeologists who studied it - the Emersons included. The compendium consists of essays on literature, music, science, travel, chronology, fashion, tourism, religion and society, among other themes. 'The People of the Journals' features photographs or illustrations of real and fictional people who appear in the series. As a whole Amelia 
Peabody's Egypt draws on the visual imagery and style of the nineteenthcentury illustrated newspaper for its aesthetic. Engravings, lithographs and photographic images abound in the book, while 'Pictorial Essays' further enhance its vintage look. Though Peters died in 2013 her legacy and that of the Emersons - lives on in print and digital form. ${ }^{91}$ The latest Amelia Peabody mystery, The Painted Queen, was posthumously published in 2017.

In 2015 the UK-based role-playing game company Cubicle 7 commissioned a stand-alone novella to accompany their 'Cthulu Britannica' series Curse of Nineveh campaign. ${ }^{92}$ The Journal of Reginald Campbell Thompson is premised on a 'lost' journal of the eminent archaeologist covering a secret journey to the site in 1919 to reveal the secrets of the hidden temple of Assyrian god Nabu. The novella is an artefact to be used to create other scenarios and identities in the Curse of Nineveh role-play. In The Journal, as in other forms of archaeological fiction, archaeologists are outsiders; they have local contacts, but work within a broadly supportive imperial network. Being in the East - on site - is both exciting and terrifying; the archaeologists make new discoveries even as they unleash and battle forces beyond their control. The novella allows its readers/users to inhabit elements of the archaeological identity, with the characteristics of expedition teams, exotic destinations and espionage as a background to the 'curse' theme of the game. With The Journal, through play, new spadework fictions can be scripted. 


\section{Epilogue}

A 'Conference on the Future of Archaeology' was held in London at the Institute of Archaeology in 1943. Papers in the session on 'The Future of Discovery: Archaeology Overseas' noted the changing times, with John L. Myres acknowledging that the age of private patronage in archaeology and 'luxury-digging' was over, and that 'the courtesies' allowed to Western archaeologists 'have been grossly abused in the past'. ${ }^{1}$ In that session and one on 'Archaeology and the State Overseas', assembled archaeologists, including Leonard Woolley and Ernest and Dorothy Mackay, debated the advantages and disadvantages of the freedoms (and risks) of the late nineteenth- and early twentieth-century period. The need to have established and stable positions in archaeology in order to ensure its future was clear, but participants were divided on whether more government input would be beneficial. The postwar power of socalled 'nationalist' governments in controlling antiquities and managing sites was also unknown; it would depend, some felt, on the outcome of the war. In 1943 the archaeological establishment was at a turning point; the world of scripting spadework was fading. ${ }^{2}$ British archaeologists' 'foreignness' slowly became a less significant factor in their public archaeological identity. Rather it remained a fixture of historical spadework and its legacy in popular imagination.

It was a gradual process. Independent national governments in the Middle East had begun to manage Western archaeologists' activities in the interwar period. With the end of the Second World War in 1945, imperial infrastructures began to crack publicly. Egypt had been nominally independent from Britain since 1922, but the revolution under Colonel Nasser in the early 1950s ensured that British archaeologists no longer had the freedoms that they had enjoyed in earlier decades. Egyptian archaeologists, who in the late nineteenth and early twentieth centuries had been denied opportunities to take formal positions in the management of antiquities, or to direct excavations, were now able to do so under a fully independent Egyptian government. ${ }^{3}$ The British Mandate 
in Iraq had come to an end in 1932, but British Mandates in Palestine and Transjordan lingered on through the war. In 1948 the Palestine Mandate ended and the state of Israel was created. British officials left Jordan in 1956.

With the end of the imperial systems, direct British involvement in the management of archaeology and antiquities in these countries also ceased. Instead Western archaeologists worked under the supervision of national governments, with antiquities legislation evolving over time to ensure that significant quantities of objects discovered could no longer be exported. ${ }^{4}$ British patterns of tourism shifted too. Ellen Bosanquet had noted the beginnings of this change in the 1930s, but after the Second World War a lengthy winter season abroad was no longer an achievable prospect. The economic models on which these seasons rested no longer existed. ${ }^{5}$

The first generation of spadework histories, largely written by and about men, had been published in the 1910s, 20s and 30s; in the 1950s, thanks to Leonard Cottrell and Pan, Seton Lloyd and Glyn Daniel and Penguin, these histories were making the rounds in paperback. By 1960 archaeology's technologies were developing further, with new media beginning to dominate the old methods of communication. At this moment, archaeology was still so relevant to newspaper publication that Edward Bacon, archaeology editor for the Illustrated London News, could declare in his 1960 book Digging for History that 'Archaeology - like sex now has the freedom of Fleet Street'. ${ }^{6}$ But just over a decade later the Illustrated London News was bowing to market pressure, converting first from a weekly to a monthly and then to an occasional issue publication.?

Archaeologists who had been active in the early part of the twentieth century continued to publish after the end of the war. Spadework scripts were still being produced, but new specialist studies and series were being initiated. At Thames \& Hudson, established in 1949, Glyn Daniel began editing a new series of high quality, well-illustrated archaeology books, 'Ancient Peoples and Places', in 1956. ${ }^{8}$

As more households acquired television sets, the archaeology television stars of the 1950s, Mortimer Wheeler and Glyn Daniel, who had dominated Animal, Vegetable Mineral?, Buried Treasure and other documentaries became the public face of the profession. Although many of the most prominent archaeologists of the 1960s had had overseas experience, they also conducted well-publicised excavations much closer to home in Britain and Europe. The Council for British Archaeology, established in 1944 as a national body for British archaeology, was ensuring that Britain's own sites and antiquities, and those who excavated them, had a 
more prominent place in national consciousness. ${ }^{9}$ As the number of universities in Britain increased, the archaeology of the British Isles became more embedded in academia, with increasing numbers of archaeology students working alongside historic local societies to excavate sites in Britain. The Middle Eastern focus of British spadework scripts was beginning to dissipate. This was beginning to emerge during the early 1960s in the difficulties experienced in organising 'Pelican Archaeologies'.

The Illustrated London News reflected this change. In December 1953 a double-page spread of archaeologist-contributors to the paper was published, a direct reflection of the 'Men Who Perform Spade-Work' article of 1923. Yet the difference between these two double-page spreads is notable. The 'Spade-Work' article consisted entirely of portraits of men, entirely British and almost exclusively working overseas, mainly in the Eastern Mediterranean and Middle East. The 1953 article still privileged excavators working outside of Britain, but the 'Archaeologists' featured represented a number of different countries, including Spain, Turkey, Denmark, France, Greece and Mexico (and three of the 36 archaeologists represented were women). ${ }^{10}$

The framework for publishing research evolved too. A recent report, Untangling Academic Publishing, charts how the academic publishing landscape changed dramatically in the second half of the twentieth century, particularly after the 1960s when (in Britain at least) the higher education sector expanded significantly and emphasis was placed on peer-reviewed research published in reputable venues. Following highlevel mergers and acquisitions in the last 50 years, a few commercial publishing conglomerates dominate now-'traditional' models of commercial academic publishing. ${ }^{11}$

As debates continue about the future of academic publishing, the recently increased pressure on academics, particularly in the UK but also beyond, to make their findings publicly accessible, both in terms of price and content, is beginning to change the academic publishing landscape once more. ${ }^{12}$ Some academics have successfully bridged what is now a gap between academic and commercial publishing, but most continue to publish only with academic presses. However, the recent relaunch of the Pelican nonfiction series (defunct since the 1990s) by Penguin is one example of a renewed energy for scholarly yet popular books. ${ }^{13}$ Likewise digital open access platforms are offering more academics the chance to reach new readers beyond academia. Popular publishing of scholarly work may now be making a comeback.

Archaeology has always relied on scripting spadework to enhance its popular and commercial appeal. As further archives are explored, we 
will understand better how spadework affected, and was interpreted by, the societies and cultures relating to it. We can expose its inequalities and injustices more fully and in finer detail. We can reveal the contributions and experiences of those who had been wiped from the record. With this knowledge, we can generate new spadework scripts that incorporate archaeology's diversity in the past. 


\section{Appendix: Archaeologist-Authors}

A list of the main archaeological authors mentioned in the text. Emphasis has been placed on their popular publishing efforts and issues of relevance to Archaeologists in Print. References for the information presented can be found in the previous chapters and in the source list below.

\section{Abbreviations}

ODNB - Oxford Dictionary of National Biography

Times - The Times obituary

WWW - Who Was Who

WWWinE - Who Was Who in Egyptology ${ }^{1}$

TB - Trowelblazers.com

BGB - Breaking Ground book ${ }^{2}$

BGW - Breaking Ground: Women in Old World Archaeology (online)

DBC - Dictionary of British Classicists ${ }^{3}$

MCA - Makers of Classical Archaeology ${ }^{4}$

*Degree not awarded: women not eligible for degrees until 1920 (Oxford) and 1948 (Cambridge). For a short time at the start of the twentieth century women studying at these universities were able to receive degrees from University College Dublin; they were known as 'steamboat ladies'. Agnes Conway received one of these degrees. ${ }^{5}$

Bell, Gertrude Margaret Lowthian (1868-1926) University of Oxford.* Arabic at University College London. Travelled across Middle East, South East Asia. Surveys and excavations in Asia Minor. Service First World War 
(Arab Bureau). Political Officer in Iraq, Hon. Director of Antiquities and founder of Baghdad Museum. Published with Richard Bentley \& Son, William Heinemann, Hodder \& Stoughton; letters posthumously published by Ernest Benn and Penguin. Contributor to Encyclopedia Britannica eleventh edition. Feat. ODNB, WWW, TB, BGB, Times.

Benson, Margaret (1865-1916) University of Oxford.* Excavations in late 1890s at Temple of Mut in Luxor, Egypt. Published with Murray. Feat. WWWinE, TB, Times.

Bosanquet, Ellen Sophia (née Hodgkin) (1875-1965) University of Oxford.* Lived in Athens and travelled extensively in Greece and Mediterranean islands. Published with Methuen.

Brodrick, Mary (1858-1933) University of Sorbonne, Collège de France. Egyptology at University College London. PhD awarded by University of Kansas. Lectured on Egyptian antiquities and history at the British Museum, South Kensington Museum (later Victoria \& Albert Museum), UK and Italy. Travelled extensively in Egypt, Sudan and Palestine, lived in Egypt during winter Seasons. Edited Murray Handbook to Egypt (ninth/ tenth editions) and Handbook to Syria. Conducted tours in Egypt. Served on the Archaeological Committee in Egypt. Published with Murray and Methuen. Feat. ODNB, WWWinE, Times.

Budge, Eustace Alfred Wallis (1857-1934) University of Cambridge. Assistant then Keeper, Department of Egyptian and Assyrian Antiquities, British Museum. Travelled extensively in Egypt, Sudan, Iraq. Guidebooks for Thomas Cook \& Son. Published with Religious Tract Society, Kegan Paul Trench Trubner \& Co, Gowans \& Gray, Medici Society, John Murray, Methuen, Williams \& Norgate (Home University Library). Feat. ODNB, WWW, WWWinE, Times.

Carter, Howard (1874-1939) Artist/draughtsman in Egypt for the Egypt Exploration Fund; Inspector in Egyptian Antiquities Service; excavations in Egypt, including tomb of Tutankhamun. Published with Cassell \& Co. Feat. ODNB, WWW, WWWinE, Times.

Casson, Stanley (1889-1944) University of Oxford. Student at British School at Athens. Service in First World War including postings in Belgium and Salonica. Travels and excavations in Greece and Turkey. Assistant Director British School at Athens (BSA), Fellow New College and Lecturer in Classical Archaeology, Oxford. BBC radio presenter. ${ }^{6}$ Service in Second World War (Intelligence). Published with Ernest Benn (Sixpenny Library), Methuen, Harrap, Hamish Hamilton and contributor to The Listener, the 
Illustrated London News, Harmsworth's Universal History of the World. Feat. WWW, MCA, DBC, Times.

Christie, Agatha (1890-1976) Writer. Travelled extensively, including in Iraq, worked with husband Max Mallowan at sites in Iraq and Syria. Published with John Lane/Bodley Head, William Collins, paperback editions with Penguin and Pan. Feat. ODNB, WWW, TB, Times.

Chubb, Mary (1903-2003) Art student. Secretary/Accountant to the Egypt Exploration Society, Amarna excavations. Excavations in Egypt and Iraq. BBC radio presenter. Published with Geoffrey Bles. Feat. WWWinE, TB, Times.

Conway, Agnes Ethel (1885-1950) University of Cambridge.* Student at British School at Rome and British School at Athens. Travelled through Balkans. Excavations in Transjordan. Travelled extensively in British Mandate Palestine, Transjordan, Iraq. Published with Robert Scott. Contributor to the Illustrated London News. Feat. TB, Times.

Eckenstein, Lina Dorina Johanna (1857-1931) Egyptology at University College London. Copied tomb paintings in Egypt. Excavations in Egypt and Sinai peninsula. Published with the Society for Promoting Christian Knowledge, Jonathan Cape. Feat. ODNB.

Edwards, Amelia Blanford (1831-92) Writer. Extended trip to Egypt in the 1870s, founded the Egypt Exploration Fund to raise money through public subscription for research, excavation and preservation of ancient Egyptian monuments and sites. Lectured extensively in the UK and US. Published with Longmans, Green; Osgood McIlvaine. Feat. ODNB, WWWinE, TB, BGW.

Evans, Arthur John (1851-1941) University of Oxford. Travelled extensively in the Balkans. Keeper of the Ashmolean Museum. Excavations at Knossos, Crete in association with British School at Athens. Published with Macmillan. Contributed to Macmillan Guide to Greece. Contributor to Encyclopedia Britannica (eleventh edition) and the Illustrated London News. Feat. ODNB, WWW.

Evans, Maria Millington (née Lathbury) (1856-1944) University of Oxford.* Extension Lecturer for Oxford University and lectured in archaeology at the British Museum. Travelled extensively in Greece and Italy. Published with Macmillan.

Gardner, Ernest Arthur (1862-1939) University of Cambridge. Fellow of Gonville and Caius College. Student at and Director of British School at 
Athens. Excavator for the Egypt Exploration Fund. Travelled and excavated in Cyprus, Egypt, Greece. Yates Professor of Classical Archaeology at University College London. Service in First World War (Intelligence). Contributed to Macmillan Guide to Greece. Published with Macmillan, Duckworth, Harper \& Brothers. Contributor to Encyclopedia Britannica (eleventh edition), Harmsworth's Universal History of the World, Wonders of the Past. Feat. ODNB, WWW, WWWinE, MCA, DBC.

Gardner, Mary (née Wilson) (d.1936) Archaeology at University College London. Travelled extensively in Greece, participated in and helped organise Greek plays at University College London. Contributed to Macmillan Guide to Greece. Hon. Lecturer in Modern Greek at King's College London, taught Modern Greek at University College London. Published with David Nutt, Macmillan.

Gardner, Percy (1846-1937) University of Cambridge. Assistant in Department of Coins and Medals, British Museum. Travelled in Greece. Disney Chair of Classical Archaeology, Cambridge. Keeper of Ashmolean Museum, Oxford. Professor of Classical Archaeology, Oxford. Published with Macmillan, Basil Blackwell. Contributor to Encyclopedia Britannica (eleventh edition), Harmsworth's Universal History of the World. Feat. ODNB, WWW, MCA, DBC, Times.

Garstang, John Berges Eustace (1876-1956) University of Oxford. Excavations at Romano-British sites, Egypt, Asia Minor/Turkey, Sudan and Palestine. Training via Egyptian Research Account. Hon. Reader in Egyptology then Professor of the Methods and Practice of Archaeology, University of Liverpool. Hon. Director of Antiquities, Sudan. Director of the British School of Archaeology in Jerusalem and Department of Antiquities in Palestine. Director of the British Institute of Archaeology, Ankara. BBC radio presenter. Published with Constable \& Co, Williams \& Norgate, Hodder \& Stoughton. Contributor to the Illustrated London News, Harmsworth's Universal History of the World, Wonders of the Past. Feat. WWW, ODNB, Times.

Gourlay, Janet(ta) Agnes (1863-1912) Egyptology at University College London. Excavations with Margaret Benson at Temple of Mut, Luxor, Egypt. Published with John Murray. Feat. WWWinE.

Gurney, Oliver (1911-2001) University of Oxford. Excavated in Asia Minor/Turkey. Reader then Professor of Assyriology, Oxford. Published with Penguin. Feat. WWW, Times.

Hall, Harry Reginald Holland (1873-1930) University of Oxford. Assistant and later Keeper, British Museum Department of Egyptian and Assyrian Antiquities. Travels in Greece, Egypt and Iraq, excavations in Egypt 
and Iraq. Service in First World War (Military Section, Press Bureau, Intelligence); Political Service in Mesopotamia. Edited Murray Handbook to Egypt and Sudan (eleventh edition). Published with George Harrap, Society for Promoting Christian Knowledge, Methuen, Medici Society. Contributor to Encyclopedia Britannica (eleventh edition), the Illustrated London News, Harmsworth's History of the World, Universal History of the World, Wonders of the Past. Feat. WWW, WWWinE, ODNB.

Harrison, Jane Ellen (1850-1928) University of Cambridge.* Lectured on Greek Art at British Museum, King's College Women's Department and South Kensington Museum in London and elsewhere in the UK. University Extension Lecturer. Travelled extensively in Europe, including Greece. Fellow and Lecturer in Classical Archaeology at Newnham College, Cambridge. Published with Rivingtons, T. Fisher Unwin, Constable \& Co, Williams \& Norgate (Home University Library), Ernest Benn (Sixpenny Library), Hogarth Press. Feat. ODNB, WWW.

Hogarth, David George (1862-1927) University of Oxford. Excavated and travelled in Crete, Greece, Asia Minor, Egypt. Student at and Director of the British School at Athens. Excavator for the Egypt Exploration Fund. Tutor and Fellow at Magdalen College, Oxford. Keeper of the Ashmolean Museum. Charles Eliot Norton lecturer in the United States. Service in First World War Intelligence (Arab Bureau). Contributed to Murray's Handbook to Asia Minor and Macmillan Guide to Greece. Published with John Murray, Lawrence and Bullen, Williams \& Norgate (Home University Library) and Macmillan. Contributor to Encyclopedia Britannica (eleventh edition), the Illustrated London News, Harmsworth's History of the World, Peoples of All Nations. Feat. ODNB, WWW, WWWinE, MCA, DBC, Times.

Lloyd, Seton Howard Frederick (1902-96) Trained as an architect, Architectural Association Schools. Excavated and travelled in Egypt, excavated and resident in Iraq and Turkey. Archaeological Advisor to the Iraq Government, Director of the British Institute of Archaeology, Ankara. Professor of Western Asiatic Archaeology at University of London. Published with Penguin. BBC radio presenter. Contributor to the Illustrated London News. Feat. WWW, Times.

Mackay, Dorothy (née Simmons) Excavated and travelled in Iraq, Persian Gulf and India. Published guides with Baghdad Book Shop and Indian State Railways Publicity Department.

Mallowan, Maximilian Edgar Lucien (1904-78) University of Oxford. Excavated and travelled in Iraq, Syria. Director of the British School 
of Archaeology in Iraq. Professor of Western Asiatic Archaeology at University of London. Editor of 'Pelican Archaeologies' for Penguin. Contributed to BBC radio and television programmes. Feat. ODNB, WWW, Times.

Mertz, Barbara [Elizabeth Peters] (1927-2013) Writer. PhD, Egyptology, University of Chicago. Travelled in Egypt. Published 'Amelia Peabody' series with William Morrow and Harper Collins.

Murray, Margaret Alice (1863-1963) Egyptology at University College London. Assistant Professor of Egyptology, University College London, University Extension Lecturer. Field training via Egyptian Research Account. Excavated and travelled in Egypt, Malta, Transjordan. Published with Blackie \& Son, William Kimber, John Murray, Sampson Low Marston \& Co, Duckworth, Arthur Stockwell. Contributor to BBC radio and television programmes. Contributor to Harmsworth's Wonders of the Past, Universal History of the World. Feat. ODNB, WWW, WWWinE, BGB, TB, Times.

Petrie, William Matthew Flinders (1853-1942) Excavated and travelled in Egypt and Palestine, resident in Palestine. Excavator for Egypt Exploration Fund. Professor of Egyptian Archaeology at University College London. Founder and Director of the Egyptian Research Account and British School of Egyptian Archaeology. Published with Methuen, Macmillan, Constable \& Co, Religious Tract Society, T. N. Foulis, Harper \& Brothers, Macmillan, Sampson Low. Contributor to Encyclopedia Britannica (eleventh edition), the Illustrated London News, Harmsworth's History of the World, Peoples of All Nations and Wonders of the Past; Hutchinson's History of the Nations. Feat. ODNB, WWW, WWWinE, MCA, Times.

Poole, Sophia Lane (1804-91) Resident in Egypt. Published with Charles Knight, James Virtue. Feat. WWWinE.

Quibell, Annie Abernethie (née Pirie) (1862-1927) Artist. Egyptology at University College London. Field training via Egyptian Research Account. Excavated, travelled and resident in Egypt. Conducted tours of Cairo Museum. Published with Church Missionary Society Bookshop, Society for Promoting Christian Knowledge, Metheun. Feat. WWWinE, TB, Times.

Sayce, Archibald Henry (1845-1933) University of Oxford. Deputy Professor of Comparative Philology then Professor of Assyriology, Oxford. Travels in Europe, excavated and travelled in Egypt and Sudan, resident in Egypt. Published with Samuel Bagster \& Sons, Religious Tract 
Society, Macmillan, Society for Promoting Christian Knowledge. Contributor to Encyclopedia Britannica (eleventh edition), Harmsworth's History of the World and Wonders of the Past.

Strong, Eugénie (née Sellers) (1860-1943) University of Cambridge.* Student at British School at Athens. University Extension Lecturer on archaeology and classics in London at the British Museum and elsewhere. Editor 'Library of Art' series for Duckworth. Travelled in Europe, later resident in Rome, Italy. Assistant Director of the British School at Rome. Fellow of Girton College, Cambridge. Charles Eliot Norton lecturer in the United States. Published with Duckworth, Constable \& Co, William Heinemann. Contributed to the Illustrated London News, Harmsworth's Wonders of the Past. Feat. ODNB, WWW, MCA, Times.

Tirard, Helen Mary (née Beloe) (c.1851-1943) Archaeology and Egyptology at University College London. Lecturer in the British Museum and King's College Women's Department in London. Member of Egypt Exploration Fund Committee. Travelled in Egypt. Published with Kegan Paul, Macmillan and the Society for Promoting Christian Knowledge. Feat. WWWinE, Times.

Thompson, Reginald Campbell (1876-1941) University of Cambridge. Assistant in British Museum Department of Egyptian and Assyrian Antiquities. Excavated at Nineveh for British Museum and in Egypt, Asia Minor. Travelled extensively in Middle East. Service during First World War (Intelligence). Political service in Iraq. Director of British Museum excavations at Nineveh. Fellow of Merton College, Oxford, Shillito Reader in Assyriology, Oxford. Published with John Lane/Bodley Head, Mills \& Boon, Sidgwick \& Jackson. Guidebook for Mesopotamia. Contributed to the Illustrated London News, Harmsworth's Universal History of the World and Wonders of the Past. Feat. ODNB, WWW, Times.

Weigall, Arthur Edward Broome Pearse (1880-1934) University of Oxford. Excavated for Egypt Exploration Fund. Inspector for the Egyptian Antiquities Service. Novelist, film critic and set designer. Published with William Blackwell, Thornton Butterworth, T. Fisher Unwin, Hutchinson \& Co, Hodder \& Stoughton, Ernest Benn (Sixpenny Library). Contributor to Harmsworth's Peoples of All Nations and Wonders of the Past. Contributed to $\mathrm{BBC}$ radio programmes. Feat. WWW, WWWinE, Times.

Wheeler, Margaret (née Collingridge) (1916-90) Trained at Institute of Archaeology, London. Student at the British School at Rome. Excavations in Britain, France, Rome, India and Jordan. Travels in 
Europe, India, Iran, Israel, Jordan, Nepal, Afghanistan. Published with Chatto \& Windus, Cassell \& Co, paperback with Grey Arrow. BBC radio and television presenter. Feat. Times.

Wheeler, Robert Eric Mortimer (1890-1976) University College London. Excavations in Britain, North Africa, India. Travels in Middle East, South East Asia. Director of the Institute of Archaeology, University of London. Director of Archaeological Survey of India. Professor of the Archaeology of the Roman Provinces, University of London. Service in Second World War (North Africa). Published with George Bell \& Co, Michael Joseph, paperbacks with Penguin and Pan. BBC radio and television presenter. Contributor to the Illustrated London News, Harmsworth's Wonders of the Past. Feat. ODB, WWW, MCA, DBC.

Woolley, Charles Leonard (1880-1960) University of Oxford. Excavations and travels in Egypt, Sudan, Asia Minor, Iraq, India, Hatay Province, Turkey. Assistant Keeper of the Ashmolean Museum. Service in First World War (Intelligence and POW, Turkey). Director of Joint British Museum-University of Pennsylvania expedition to Ur. Advisor on archaeology, Government of India. Service in Second World War (Public Relations and Archaeological Advisor). BBC radio presenter. Contributor to The Listener, the Illustrated London News, Harmsworth's Universal History of the World and Wonders of the Past. Published with Ernest Benn and Penguin. Feat. ODNB, WWW, WWWinE, Times. 


\section{Notes}

\section{Chapter 1}

1. See Society of Antiquaries. 'Outrage at A Level Losses', SALON E-Newsletter 373, 18 October 2016. Last modified 29 November 2017: http://us6.campaign-archive2.com/?u=5557b c147d34993782f185bde\&id=ec68e7d8b7; Society of Antiquaries. 'AQA A and AS Level Archaeology', 20 October 2016. Last modified 29 November 2017: https://www.sal.org.uk/ news/2016/10/aqa-a-and-as-level-archaeology-examinations/. See also Graeme Barker, Charlotte Roberts, Christopher Gosden, Audrey Horning, Kate Welham, Reflections on Archaeology (London: British Academy, 2017), 6.

2. Tim Loughton, 'A-Level Archaeology', 14 December 2016, Hansard. Last modified 29 November 2017: https://hansard.parliament.uk/Commons/2016-12-14/debates/16121434000001/ A-LevelArchaeology.

3. On the current fascination with 'the archaeologist' see Marilyn Johnson, Lives in Ruins: Archaeologists and the Seductive Lure of Human Rubble (New York: HarperCollins, 2014). On the importance of nineteenth-century popular literary representations of the 'mad scientist' in the way science (in particular chemistry) is interpreted in popular culture today see Joachim Schummer, "Historical Roots of the "Mad Scientist": Chemists in Nineteenth-Century Literature', Ambix 53 (2) (2006).

4. Aileen Fyfe, Kelly Coate, Stephen Curry, Stuart Lawson, Noah Moxham, Camila Mørk Røstvik, Untangling Academic Publishing: a history of the relationship between commercial interests, academic prestige, and the circulation of research. 2017. DOI: https://doi.org/10.5281/ zenodo. 546100

5. Leonard Woolley, Spadework: Adventures in Archaeology (London: Lutterworth Press, 1953), 9.

6. Woolley, Spadework, 12-13.

7. For a late twentieth-century overview of the popular appeal of archaeology and archaeologists see Cornelius Holtorf, Archaeology is a Brand! (Walnut Creek, CA: Left Coast Press, 2007).

8. On identity creation through travel writing see Susan Bassnett. 'Travel Writing and Gender', in The Cambridge Companion to Travel Writing, ed. Peter Hulme and Tim Youngs (Cambridge: Cambridge University Press, 2002), 233-5.

9. For reception of Egyptology in the nineteenth and early twentieth centuries, see David Gange, Dialogues with the Dead: Egyptology in British Culture and Religion, 1822-1922 (Oxford: Oxford University Press, 2013).

10. Amanda Wrigley examines engagements in classical drama on BBC radio through looking at a variety of factors - including production, policy, publicity and complementary cultural products - which she designates as 'Classical reception studies "in the round"', in Greece on Air: Engagements with Ancient Greece on BBC Radio, 1920s-1960s (Oxford: Oxford University Press, 2015), 25-6.

11. John A. Hammerton, 'From the Editor's Desk: Chats About "Wonders of the Past"', Wonders of the Past Part 8 (21 December 1933).

12. James Baikie, The Story of the Pharaohs (second edn) (London: A. \& C. Black, 1917). 'Dr. James Baikie', Times Digital Archive (7 February 1931), 14.

13. James Baikie, The Sea-Kings of Crete (London: A. \& C. Black,1910).

14. Adam and Charles Black, Prospectus. Peeps at Ancient Civilisations (London: A. \& C. Black, 1927). I discovered a copy of the series prospectus tucked inside the British Library's copy of Baikie's [Peeps at] Ancient Greece (1931). The illustrations for these books were done partly by his wife, the artist Constance Baikie. 
15. James Baikie, The Glamour of Near Eastern Excavation (London: Seeley, Service \& Co Ltd, 1927), 11-12.

16. 'C. W. Ceram of "Gods, Graves and Scholars” Dies', New York Times Archive [Online], 13 April 1972; 'C. W. Ceram', Gods, Graves and Scholars: The Story of Archaeology (second revised and enlarged edition) (New York, NY: Bantam Books, 1980).

17. Tam Daybell, 'H. V. F. Winstone: Writer, Scholar and Authority on the Middle East', The Independent [online], 22 February 2010. Last modified 27 November 2017: http://www.independent.co.uk/news/obituaries/hvf-winstone-writer-scholar-and-authority-on-the-middleeast-1906519.html.

18. See Debbie Challis, From the Harpy Tomb to the Wonders of Ephesus (London: Duckworth, 2008).

19. Amara Thornton, British Archaeologists, Social Networks and the Emergence of a Profession: the social history of British archaeology in the Eastern Mediterranean and Middle East 1870-1939. (Unpublished PhD thesis. University College London, 2011).

20. Mary Louise Stig Sørenson, 'Rescue and Recovery: on historiographies of female archaeologists', in Excavating Women: A History of Women in European Archaeology, eds Margarita Diaz-Andreu and Mary Louise Stig Sørenson (London: Routledge, 1998), 36. She discusses how the historiography of women in archaeology is often modelled on a 'male system', privileging qualities such as full-time professional positions in academia, journal and academic book publishing and degrees.

21. Margarita Diaz-Andreu and Mary Louise Stig Sørenson, 'Excavating Women: Towards an engendered history of archaeology', in Excavating Women, 13.

22. On the amateur contributions to archaeology today see Barker et al., Reflections. Chris Naunton, President of the International Association of Egyptologists, has recently reflected on defining the Egyptologist - see 'How should we define "Egyptologist"?'. Last modified 1 December 2017: https://chrisnaunton.com/2017/05/25/how-should-we-define-egyptologist/.

23. Petrie to G. L. Harding, 18 June 1926. Harding Archive, UCL Institute of Archaeology.

24. See for example Diaz-Andreu and Stig Sørenson, Excavating Women; Getzel M. Cohen and Martha Sharp-Joukowsky, eds, Breaking Ground: pioneering women archaeologists (Ann Arbor, MI: University of Michigan Press, 2004); Martha Sharp-Joukowsky and Barbara S. Lesko, 'Breaking Ground: Women in Old World Archaeology'. Last modified 27 November 2017: https://www.brown.edu/Research/Breaking_Ground/introduction.php. For overviews of women's travel writing see Susan Bassnett, Travel Writing, and Billie Melman, Women's Orients: English Women and the Middle East, 1718-1918 - Sexuality, Religion and Work (Ann Arbor, MI: University of Michigan Press, 1995).

25. Margaret Cool Root, 'Introduction: Women of the Field', in Breaking Ground, 9-10, discusses the complexity of analysing married women's contributions to archaeology. Helena M. Pycior, Nancy Slack and Pnina G. Abir-Am have enumerated and evaluated types of marital collaborations in the history of science in 'Introduction', in Creative Couples in the Sciences, ed. Nancy Slack et al. (New Brunswick, NJ: Rutgers University Press, 1996).

26. Cool Root, 'Introduction', 22-23.

27. For example Louisa Hubbard, The Englishwoman's Year-Book and Directory (London: Hatchards, 1888), 130 and Emily Janes, The Englishwoman's Year-Book and Directory 1899 (London: A. \& C. Black, 1899), 172-3.

28. Janes, Englishwoman's Year-Book 1899, v.

29. Janes, Englishwoman's Year-Book 1900, 329, 331, 333. Although not a central theme in this book, many of the women discussed here supported the suffrage movement to varying degrees, and the debates about suffrage and women's rights in the late nineteenth and early twentieth centuries are certainly undercurrents in the history presented here. On Amelia Edwards' lecture relating the social status of ancient Egyptian women to that of late nineteenth-century women, see Patricia O'Neill and Amelia B. Edwards, 'The Social and Political Position of Women in Ancient Egypt', PMLA 120 (3) 2005: 843-57. Margaret Murray's suffrage activities are discussed in Kate Sheppard, The Life of Margaret Alice Murray (Lanham, MD: Lexington Books, 2013).

30. See 'Women Lecturers in Science', in The Englishwoman's Year-Book, ed. Geraldine M. Mitton (London: A. \& C. Black 1909), 155-7; for 'Literature' see 159-68. Janes, Year-Book 1900, 120-21.

31. Stig Sørenson, 'Rescue and Recovery', 54; Cool Root 'Introduction', 4.

32. 'Lines to Professor Budge', Punch Historical Archive, 21 December 1910, 446; 'Mr Punch's Supplement. VII. - The British Museum', Punch Historical Archive, 31 May 1911, 412.

33. 'At the Flinderies', Punch Historical Archive, 20 July 1904, 46. 
34. 'Charivaria', Punch Historical Archive, 27 March 1929, 337; 'The Silver Ribbon', Punch Historical Archive, 20 August 1930, 215; 'The Ziggurat and Temenos', Punch Historical Archive, 26 April 1933, 455.

35. On 'celebrity-commodity' see Peter Marshall, referenced in Graeme Turner, 'Approaching Celebrity Studies', Celebrity Studies 1 (1) (2010), 14.

36. The British Library's online catalogue was my main source for the bibliographies. A few fairly comprehensive bibliographies have already been published by some archaeologists, including Flinders Petrie, Arthur Weigall, Margaret Murray, D. G. Hogarth. See Eric Uphill, 'A Bibliography of Sir William Matthew Flinders Petrie (1853-1942)', Journal of Near Eastern Studies 31 (4) (1972), 356-79; Julie Hankey, A Passion for Egypt: Arthur Weigall, Tutankhamun and the Curse of the Pharaohs (London: Tauris Parke Paperbacks, 2001); Wilfred Bonser, 'A Bibliography of the Writings of Dr Murray'. Folklore 72 (3) (1961), 560-6; Peter Lock, 'D. G. Hogarth (1862-1927): “...A Specialist in the Science of Archaeology”, Annual of the British School at Athens 85 (1990), 175-200.

37. See A. \& C. Black, Writers' and Artists' Year Book 1906 (London: A. \& C. Black, 1906); A. \& C. Black, Writers' and Artists' Year Book 1933 (London: A. \& C. Black, 1933).

38. Over 30 of these firms are listed in Patricia Anderson and Jonathan Rose, eds, British Literary Publishing Houses 1820-1880 (Detroit, MI: Gale Publishing, 1991) and Jonathan Rose and Patricia Anderson, eds, British Literary Publishing Houses 1881-1965 (Detroit, MI: Gale Publishing, 1991).

39. See James Raven, 'The Promotion and Constraints of Knowledge: The Changing Structure of Publishing in Victorian Britain', in The Organisation of Knowledge in Britain, ed. Martin Daunton (Oxford: Oxford University Press, 2005) for a discussion of Victorian publishing.

40. Peter Bowler, Science for All: The Popularization of Science in Early Twentieth-Century Britain (Chicago: University of Chicago Press, 2009), 8-11; Leslie Howsam, 'Academic Discipline or Literary Genre?: The Establishment of Boundaries in Historical Writing', Victorian Literature and Culture 32 (2): 525-45. For a critical overview of the difficulties of defining popular, and texts shifting between 'popular' and 'serious' in terms of fiction, see Bob Ashley, The Study of Popular Fiction: A Sourcebook (London: Pinter Publishers, 1989), Ch. 1.

41. Simon Eliot, Some Patterns and Trends in British Publishing 1800-1919 (London: Bibliographical Society, 1994), 60.

42. Early on in his life Evans wrote two books of travel based on his experiences in the Balkans: Arthur Evans, Through Bosnia and the Herzigovina on foot... (London: Longmans, Green, 1876) and Arthur Evans, Illyrian letters: a revised selection of correspondence... (London: Longmans, Green 1878). On Evans's life see Joan Evans, Time and Chance: The Story of Arthur Evans and his forebears (London: Longmans, Green, 1943).

43. Arthur Evans, The Palace of Minos .... (London: Macmillan \& Co, 1921-).

44. Macmillan \& Co, Guide to Greece, the Archipelago, Constantinople... (London: Macmillan \& Co, 1910), 207.

45. Evans to George Macmillan, 13 July 1907, 2 December 1909, 27 April 1913. Add MS 55129. Correspondence K: Archaeologists - Arthur Evans, Macmillan Archive, British Library.

46. John D. S. Pendlebury, A Handbook to the Palace of Minos at Knossos and its Dependencies. (London: Macmillan \& Co, 1933), 7.

47. John L. Myres, 'Archaeology: The Middle East and Britain', Times Literary Supplement Historical Archive, 1 May 1937, 341.

48. Arthur Weigall, Flights into Antiquity (London: Hutchinson \& Co, 1928), 13.

49. Annie Quibell, Egyptian History and Art with reference to museum collections (London: Society for Promoting Christian Knowledge, 1923), vi.

50. Lina Eckenstein, Tutankh-aten: A Story of the Past (London: Jonathan Cape, 1924), 5.

51. Donald M. Reid, Contesting Antiquity in Egypt: Archaeologies, Museums \& the Struggle for Identities from World War 1 to Nasser (Cairo: American University in Cairo Press), Ch. 2.

52. A case in point is Meroe, in Sudan. Once highlighted in guidebooks for Egypt and Sudan, the site is now being promoted as a 'forgotten' tourist destination. See 'The "Forgotten" Pyramids of Sudan', BBC News Online. Last modified 29 November 2017: http://www.bbc.co.uk/news/ av/world-africa-38994176/the-forgotten-pyramids-of-sudan.

53. On 'ephemera of empire' see Ashley Jackson and David Tomkins. 'Ephemera in the British Empire', in Exhibiting the Empire: cultures of display and the British Empire, eds John McAleer and John M. Mackenzie (Manchester: Manchester University Press, 2015). 
54. An overview of different types of ephemera can be found in Maurice Rickards and Michael Twyman, The Encyclopedia of Ephemera: a guide to the fragmentary documents of everyday life for the collector, curator and historian (London: The British Library, 2000).

55. See, for example, the volumes of Manchester University Press's 'Studies in Imperialism series'. A good overview can be found in Catherine Hall and Sonya O. Rose, 'Introduction: Being at home with the empire', in At Home with the Empire: Metropolitan Culture and the Imperial World, eds Catherine Hall and Sonya O. Rose (Cambridge: Cambridge University Press, 2006), 2. On daily experience of Empire see in addition, for example, John Mackenzie, ed., Imperialism and Popular Culture (Manchester: Manchester University Press, 1986). Whitaker's Almanack uses the term 'Greater Britain' to refer to the Empire. Published annually, the Almanack provides a chronological assessment of Britain's imperial holdings.

56. Christina Riggs, 'Tutankhamun goes to the fair'. Last modified 29 November 2017: https:// photographingtutankhamun.wordpress.com/2017/08/23/tutankhamun-goes-to-the-fair/.

57. A useful short overview of the different governing arrangements of Britain's Empire and themes in imperial historiography can be found in Catherine Hall, 'Introduction: thinking the postcolonial, thinking the empire', in Cultures of Empire: Colonizers in Britain and the Empire in the $19^{\text {th }}$ and $20^{\text {th }}$ Centuries: A Reader, ed. Catherine Hall (Manchester: Manchester University Press, 2000). See also Gregory Barton, Informal Empire and the Rise of One World Culture (Basingstoke: Palgrave Macmillan, 2014).

58. A useful overview of nineteenth-century Egyptian and Anglo-Egyptian history can be found in Donald Reid, Whose Pharaohs?: archaeology, museums, and Egyptian national identity from Napoleon to World War I (Berkeley, CA: University of California Press, 2002).

59. For a history of Sudan see Peter M. Holt and Martin W. Daly, A History of Sudan from the Coming of Islam to the Present Day (sixth edn) (London: Routledge, 2011).

60. Dennis P. Hupchick, The Balkans: From Constantinople to Communism (New York: Palgrave Macmillan, 2002), Map 9. Zainab Bahrani, Zeynep Çelik and Edhem Eldem, 'Introduction: Archaeology and Empire', in Scramble for the Past: A Story of Archaeology in the Ottoman Empire, 1753-1914, eds Zainab Bahrani, Zeynep Çelik and Edhem Eldem (Istanbul: SALT), 36 discuss infrastructure developments during the reign of Ottoman Sultan Abdulhamid II (1876-1909), including telegraph lines and railways.

61. See Hupchick, The Balkans, 293; see Philip Cottrell, Monica Poehl Fraser and Iain Fraser, eds, East Meets West: banking, commerce and investment in the Ottoman Empire (Aldershot: Ashgate, 2008).

62. See Lucia Gunning, The British Consular Service in the Aegean and the Collection of Antiquities for the British Museum (Farnham, Surrey: Ashgate, 2009), 1-58; Seton Lloyd, Foundations in the Dust (Harmondsworth: Penguin, 1955), 14. Gunning notes some of the former Levant Company consular offices were closed due to perceived lack of commercial relevance, while others were re-opened. See Challis, Harpy Tomb, 14; Michelle Tusan, 'At Home in the Ottoman Empire: humanitarianism and the Victorian diplomat', in The Cultural Construction of the British World, eds Barry Crosbie and Mark Hampton (Manchester: Manchester University Press, 2016).

63. See 'Advertisement', St James's Gazette [British Newspaper Archive], 14 November 1902. The African World Annual was first published in December 1903. See for example Leo Weinthal and C. D. Baynes, 1913, African World's Christmas Annual IX 1913-14 (London: African World). See 'Egypt Past and Present', Cornishman [British Newspaper Archive], 1 November 1906.

64. See Donald Reid, Whose Pharaohs? and Contesting Antiquity; Rachel Mairs, From Khartoum to Jerusalem: The Dragoman Solomon Negima and his Clients (1885-1933) (London: Bloomsbury Academic, 2016); Stephen Quirke, Hidden Hands: Egyptian workforces in Petrie excavation archives, 1880-1924 (London: Duckworth Egyptology, 2010), 9; Zainab Bahrani, Zeynep Çelik and Edhem Eldem, 'Introduction'; on Hamdi Bey see Edhem Eldem, 'An Ottoman Archaeologist Caught Between Two Worlds: Osman Hamdi Bey (1842-1910)', in Archaeology, Anthropology and Heritage in the Balkans and Anatolia: the Life and Times of F. W. Hasluck, 1870-1920, ed. David Shankland (Istanbul: Isis Press, 2004). Magnus Bernhardsson, Reclaiming a Plundered Past: Archaeology and Nation Building in Modern Iraq (Austin, TX: University of Texas Press, 2005). James Goode, Negotiating for the past: archaeology, nationalism, and diplomacy in the Middle East 1919-1941 (Austin, TX: University of Texas Press, 2007). Goode also discusses archaeological matters in Egypt, Iran and Turkey.

65. Katharine Woolley, 'Digging Up Bible History', Britannia and Eve [British Newspaper Archive], 4 January 1929, 24-6. Reginald Campbell Thompson, A Pilgrim's Scrip (London: John Lane/Bodley Head, 1915), 45-51. See also Thompson and Robert W. Hamilton, 'The 
British Museum Excavations on the Temple of Ishtar at Nineveh, 1930-31', Liverpool Annals of Archaeology and Anthropology 19 (1932): 55. Challis discusses early nineteenth-century archaeologists' attitudes to local people in Ottoman Turkey and Greece in Harpy Tomb, 14-18. Innes M. Keighren, Charles W. J. Withers and Bill Bell also discuss this in relation to early and mid-nineteenth-century travellers and explorers in Travels into Print: Exploration, Writing and Publishing with John Murray, 1773-1859 (Chicago, IL: University of Chicago Press, 2015), 2-3.

66. On Britain as the domestic empire or empire 'at home' see Hall and Rose 'Introduction'.

67. Barry Crosbie and Mark Hampton, 'Introduction: the cultural construction of the British world', in Cultural Construction, 3-6.

68. Kent Fedorowich and Andrew S. Thompson, 'Introduction: Mapping the contours of the British World: empire, migration and identity', in Empire, Migration and Identity in the British World, ed. Kent Fedorowich and Andrew S. Thompson (Manchester: Manchester University Press, 2013), 1-2.

69. Tillman Nechtmann, 'Mr Hickey's Pictures: Britons and their collectibles in late eighteenth century India', in Cultural Construction, 181.

70. Nechtmann, 'Mr Hickey', 182.

71. This has been discussed in relation to mid-nineteenth-century archaeologists in Gunning, Consular Service and Challis, Harpy Tomb.

72. See Amara Thornton, 'An Unusual Archaeological Memoir', Reading Room Notes. Last modified 29 November 2017: https://www.readingroomnotes.com/home/an-unusual-archaeologicalmemoir; Arthur Weigall, Laura Was My Camel (London: Eyre \& Spottiswoode, 1941), 126-8.

73. See Berny Sèbe, 'Exhibiting the Empire in print: The press, the publishing world and the promotion of 'Greater Britain', in Exhibiting the Empire, 168-93.

74. On 'imperialism in print' see Berny Sèbe, 'Exhibiting', 188. Fedorowich and Thompson also discuss the effect of migration on publishing in 'Introduction', 8-9. On using 'multi-sited' to interpret the histories of excavated artefacts and collections in archaeology see Alice Stevenson, Emma Libonati and Alice Williams, "A selection of minor antiquities": a multi-sited view on collections from excavations in Egypt', World Archaeology 48 (2) (2016).

75. Keighren et al., Travels, 2.

76. On Horsfield's identities see Amara Thornton, 'The Nobody: Exploring Archaeological Identity with George Horsfield (1882-1956)', Archaeology International 17 (2014), 137-156.

77. Susanne Duesterberg, Popular Receptions of Archaeology: Fictional and Factual Texts in 19th and Early 20th Century Britain (Austria: Transcript, 2015).

78. Keighren et al., Travels. On the value of publishers' archives for literary history see Nicola Wilson, 'Archive fever: the publishers' archive and the history of the novel', in New Directions in the History of the Novel, ed. Patrick Parrinder et al. (Houndmills: Palgrave Macmillan, 2014). For an examination of publishers' and historians' archives in relation to the production of history books see Leslie Howsam, Past Into Print: The Publishing of History in Britain 1850 1950 (London: British Library, 2009). In Science for All Peter Bowler has produced a survey of popular science publishing which looks in part at the relationship between scientists and publishers through correspondence in scientists' archives.

79. A devastating bombing raid in 1940 on Paternoster Row and the subsequent fires destroyed many valuable archives in London's publishing district - see Rose and Anderson, Dictionary, ix.

\section{Chapter 2}

1. Stanley Casson, Archaeology (London: Benn, 1930), 5.

2. Ernest Benn Ltd., The Autumn List Being A Choice of Books to be Published During the Later Months of the Year 1928 (London: Benn, 1928), 31-3.

3. See Phillipa Levine, The Amateur and the Professional: antiquarians, historians and archaeologists in Victorian England 1838-1886 (Cambridge: Cambridge University Press, 1986).

4. On archaeologist-diplomats of the mid-Victorian period see Challis, Harpy Tomb; Gunning, Consular Service. 'Dryasdust' (meaning 'learned scholar') was a description from which some archaeologists sought to disassociate themselves and their discipline - see, for example, Arthur Weigall, The Treasury of Ancient Egypt: Miscellaneous Chapters on Ancient Egyptian History and Archaeology (London: William Blackwood \& Sons, 1911), 56; John Guisborough, A Mirage of Sheba (London: Mills \& Boon, 1923), 10; Godfrey R. Driver, 'Reginald Campbell Thompson, 
1876-1941', Proceedings of the British Academy 30 (1944) 460; Hammerton, 'Editors Desk' (December 1933).

5. Society of Biblical Archaeology, 'Introduction', Transactions of the Society of Biblical Archaeology 1 (1) (1872): i-iv; David Gange has discussed the early history of the Society of Biblical Archaeology and its evolution from earlier societies in Dialogues. See also Theodore Davis, Shifting Sands: the rise and fall of Biblical archaeology (Oxford: Oxford University Press, 2004), 18-20.

6. Samuel Birch, 'The Progress of Biblical Archaeology: An Address', Transactions of the Society of Biblical Archaeology 1 (1) (1872), 1.

7. Archibald H. Sayce, Reminiscences (London: Macmillan \& Co, 1923), 55.

8. Ernest A. Wallis Budge, By Nile and Tigris... vol.1 (London: Murray, 1920), 11.

9. Budge, Nile and Tigris, 12-14.

10. 'Samuel Bagster \& Sons, [Catalogue]', in A Short Hebrew Grammar Without Points (1877). Last modified 29 November 2017: https://archive.org/stream/ ashorthebrewgra00shargoog\#page/n76/mode/2up.

11. Christopher Stray, Classics Transformed: schools, universities and society in England, 18301960 (Oxford: Clarendon Press, 1998), 121-2; Thornton, British Archaeologists, Ch. 2; Percy Gardner, Autobiographica (Oxford: Basil Blackwell, 1933), 60, and see 13 for his views on Oxford and Cambridge.

12. See Stray, Classics Transformed, 121, and for example Gardner, Autobiographica, 13, 60.

13. See Alice Stevenson, 'The Object of Study: Egyptology, Archaeology, and Anthropology at Oxford, 1860-1960', in Histories of Egyptology: Interdisciplinary Measures, ed. William Carruthers (London: Routledge, 2015) on the history of Egyptology at Oxford.

14. Gardner, Autobiographica, 60.

15. Max E. L. Mallowan, Mallowan's Memoirs: Agatha and the Archaeologist (London: HarperCollins Publishers, 2010), 25-6.

16. For the history of the foundation of the Disney chair see David Gill, 'The Collection of John Disney, Antiquarian and University Benefactor', The Museum Archaeologist 36 (2017).

17. See Christopher Stray, 'The First Century of the Classical Tripos (1822-1922): High Culture and the Politics of Curriculum', in Classics in 19th and 20th century Cambridge: Curriculum, Culture and Community, ed. Christopher Stray (Cambridge: Cambridge Philological Society, 1999).

18. See Mary Beard, "The Invention and Reinvention of "Group D": An Archaeology of the Classical Tripos, 1870-1919', in Classics in ... Cambridge.

19. See Claire Breay, 'Women and the Classical Tripos 1869-1914', in Classics in ... Cambridge.

20. Several biographies of Harrison have been produced - namely Jessie Stewart, Jane Harrison: a portrait from letters (London: The Merlin Press, 1959); Anne Robinson, The Life and Work of Jane Harrison (Oxford: Oxford University Press, 2002); Sandra Peacock, Jane Ellen Harrison: the mask and the self (London: Yale University Press, 1988). Harrison also published her own memoir, Reminiscences of a Student's Life, through Leonard and Virginia Woolf's Hogarth Press in 1925. Mary Beard's The Invention of Jane Harrison (Cambridge, MA: Harvard University Press, 2002) traces Harrison's early years in London and her relationship with another notable woman classicist, Eugénie Sellers Strong, subsequently Assistant Director of the British School at Rome.

21. On Jane Harrison's role at Newnham see Breay, 'Women'. On Jane Harrison as mentor in archaeology see Amara Thornton, 'The Allure of Archaeology: Agnes Conway and Jane Harrison at Newnham College, 1903-1907', Bulletin for the History of Archaeology 21 (1) (2011). David Shankland, 'The Life and Times of F. W. Hasluck (1878-1920)', Archaeology, Anthropology and Heritage in the Balkans and Anatolia: the Life and Times of F. W. Hasluck, 1870-1920, ed. David Shankland. (Istanbul: Isis Press, 2004), 39-48 also discusses the role of Harrison as mentor.

22. Pamela Jane Smith, A 'Splendid Idiosyncrasy': Prehistory at Cambridge 1915-50 (Oxford: British Archaeology Reports, 2009), 17.

23. Hugh Hale Bellot, University College London, 1826-1926 (London: University of London Press, 1929), Charts I and II.

24. For a biography of Petrie see Margaret Drower, Flinders Petrie: A Life in Archaeology (London: Victor Gollancz Ltd, 1985).

25. For example University College London, Calendar. Session MDCCCV-MDCCCVI (London: Taylor and Francis, 1905), 33-4, 119-120.

26. University College London, Calendar. Session MDCCCXCVL-XCVII (London: Taylor and Francis, 1896), xliv-xlv. 
27. See Negley Harte, The University of London 1836-1986: an illustrated history (London: Athlone Press, 1986), 64. The closer association between University College and the University of London meant that any students studying at Colleges within the University of London's aegis could be admitted as internal students to UCL, see University College London, Calendar. Session MDCCCCVI-MDCCCCVII (London: Taylor and Francis, 1906), cxix. This association is particularly relevant for the students attending Gardner's Archaeology classes, which from the 1905/1906 session included students from Bedford College, Westfield College, King's College and King's College Women's Department and East London College. Bedford College and Westfield College were both women's colleges. See John Whitaker, An Almanack for the year of our Lord 1911 (London: Whitaker, 1911), 270-1.

28. Kate Sheppard and Rosalind Janssen have written about some of the women Egyptology students at UCL. Sheppard's biography of Murray and chapter on women's networks reveals Margaret Murray's role in shaping women's experience of Egyptology at UCL. See Sheppard, Margaret Murray; Kate Sheppard, 'Margaret Alice Murray and Archaeological Training in the Classroom: Preparing 'Petrie's Pups', in Histories of Egyptology: interdisciplinary measures, ed. William Carruthers (New York: Routledge). Rosalind Janssen, The first hundred years: Egyptology at University College London (London: Petrie Museum, 1992). Rosalind and Jacques Janssen, 'Excavating the Petrie Museum', in Studies on ancient Egypt in honour of H. S. Smith, eds Anthony Leahy and John Tait (London: The Egypt Exploration Society, 1999).

29. The University of London was responsible for examinations leading to the awarding of degrees, as Harte discusses in University of London.

30. See, for example, University College London, Calendar. Session MDCCCXCVII-XCVIII (London: Taylor and Francis, 1897), 52; University College London, Calendar. Session MDCCCCII-MDCCCCIII (London: Taylor and Francis, 1902), 119; 'Dr. E. A. Gardner. Classical Archaeology at London', The Times Digital Archive. 29 November 1939, 4.

31. Drower, Petrie, 202.

32. 'British School of Archaeology in Egypt', The Times Digital Archive, 14 June 1905, 10; see also Rachel Sparks, 'PUBLICISING PETRIE: Financing Fieldwork in British Mandate Palestine (1926-1938)', Present Pasts 5 (1) (2013).

33. Amara Thornton, British Archaeologists; University of Liverpool, Redbrick University: A Portrait of University College, Liverpool and the University of Liverpool 1881-1981 (Liverpool: University of Liverpool, 1981). Liverpool had been a constituent college of the Victoria University (examining body for Owens College Manchester, Yorkshire College Leeds and University College Liverpool). In the early to mid-nineteenth century, university examining boards and university colleges were established outside of the Universities of Oxford, Cambridge and London in the Midlands and North of England (Birmingham, Bristol, Manchester, Yorkshire, Durham and Newcastle), as well as in Wales. By the early twentieth century these institutions were expanding significantly, and university colleges were becoming fully fledged universities. In Scotland the Universities of St Andrews, Glasgow and Aberdeen had been operating since the fifteenth century and Edinburgh since the sixteenth century - see John Whitaker, Whitaker's Almanack 1900 [Facsimile Edition] (London: The Stationery Office 1900); Whitaker, Almanack 1911.

34. Thornton, British Archaeologists; see also Philip Freeman, The Best Training Ground for Archaeologists: Francis Haverfield and the Invention of Romano-British Archaeology (Oxford: Oxbow, 2007).

35. Thornton, British Archaeologists; University of Liverpool, Redbrick.

36. See Lydia Carr, Tessa Verney Wheeler: women and archaeology before World War Two (Oxford: Oxford University Press, 2012).

37. See John Evans, 'The First Half Century - And After', Bulletin of the Institute of Archaeology 24 (1987) for the early history of the Institute of Archaeology at the University of London.

38. Thornton, British Archaeologists; Amara Thornton, 'Archaeologists-in-Training: Students of the British School of Archaeology in Jerusalem, 1920-1936', Journal of Open Archaeology Data, 1 (1) (2012); Amara Thornton, 'Social Networks in the History of Archaeology: Placing Archaeology in its Context', in Historiographical Approaches to past archaeological research, eds Gisela Eberhardt and Fabian Link (Berlin: Edition Topoi, 2015); Shimon Gibson, 'British archaeological institutions in Mandatory Palestine, 1917-1948', Palestine Exploration Quarterly 131 (2) (1999); David Gill, Sifting the Soil of Greece: the early years of the British School at Athens (1886-1919) (London: Institute of Classical Studies, 2011); Andrew Wallace-Hadrill, The British School at Rome: One Hundred Years (Rome: British School at Rome, 2001). 
39. See Thornton, 'Social Networks' for a summary of this. See also political official Ronald Storrs' experiences of the British School at Rome during the First World War, Orientations (London: Nicholson \& Watson, 1949), 263-4.

40. For lists of BSA students see David Gill, Students at the British School at Athens (1886-1914) (Swansea: Ostraka Press, 2008) and Gill, Sifting. On James's archaeological ghost stories see Gabriel Moshenska, 'M. R. James and the archaeological uncanny', Antiquity 86 (334) (2012).

41. On women at the British School at Athens see David Gill, "The passion of hazard': Women at the British School at Athens before the First World War', Annual of the British School at Athens 97 (2002), David Shankland, 'The Life and Times of F. W. Hasluck (1878-1920)', in Archaeology, Anthropology and Heritage in the Balkans and Anatolia: the Life and Times of F. W. Hasluck, 1870-1920, ed. David Shankland (Istanbul: Isis Press, 2004). See Agnes Conway, A Ride Through the Balkans: On Classic Ground with a Camera (London: R. Scott, 1917).

42. For example Whitaker, Almanack 1900, 247-54.

43. Sayce, Reminiscences, 133, 280.

44. John Boardman, '100 Years of Classical Archaeology in Oxford', in Beazley and Oxford: lectures delivered in Wolfson College, Oxford 28 June 1985, ed. Donna Kurtz (Oxford: Oxford University Committee for Archaeology, 1985), 49; Whitaker, Almanack 1911, 265-9.

45. See Robert Simpson, 'Griffith, Francis Llewellyn (1862-1934)', Oxford Dictionary of National Biography [online edn] (Oxford University Press, 2004-8); Alan Gardiner, 'Francis Llewellyn Griffith', Journal of Egyptian Archaeology 20 (1/2) (1934) 71-7.

46. See Beard, 'Invention'.

47. Budge, Nile and Tigris, 15-6, 68.

48. David Wilson, The British Museum: a history (London: British Museum Press, 2002), 379.

49. See for example Whitaker, Almanack 1911, 192.

50. See Sheppard, Margaret Murray, 96-7. Some of these women collectors have been profiled in the digital exhibition 'Gold and Grime', http://www.goldandgrime.co.uk/, last modified 30 November 2017, and the Beyond Beauty exhibition - see Beyond Beauty: Transforming the Body in Ancient Egypt (London: Two Temple Place, 2016). More generally museums were seen as a potential career path for women - The Englishwoman's Year Book listed 'Women Curators and Assistants' in their chapter on 'Science', Year Book 1909, 157. For a recent analysis of this see Kate Hill, Women and Museums 1850-1916: Modernity and the Gendering of Knowledge (Manchester: Manchester University Press, 2016).

51. See Mary Beard, 'Casts and Cast-Offs: the Origins of the Museum of Classical Archaeology', Proceedings of the Cambridge Philological Society 39: 1-29 (1993) for a history of the connection between the Fitzwilliam Museum and the Museum of Classical Archaeology in Cambridge. As Pamela Jane Smith has shown, Cambridge's Museum of Archaeology and Anthropology, established in 1884, played a fundamental role in the foundation of prehistoric archaeology in the University, see Splendid Idiosyncracy. See also Whitaker, Almanack 1900, 252 for M. R. James as Fitzwilliam Keeper; John Whitaker, An Almanack for the year of our Lord 1927 (London: Whitaker, 1927), 301.

52. Gardner, Autobiographica, 58-9; Boardman, '100 Years'.

53. Gertrude Bell was the only woman to hold a post in Antiquities, serving as Honorary Director of Antiquities in Iraq in the early 1920s. See Bernhardsson's Plundered Past for a history of the Iraq Antiquities Department. The formation of the Palestine and Transjordan Antiquities Departments are discussed in Gibson, 'British archaeological institutions' and Thornton, British Archaeologists, Amara Thornton, 'Tents, Tours and Treks: Archaeologists, Antiquities Services and Tourism in British Mandate Palestine and Transjordan', Public Archaeology 11 (4) (2012), Thornton, 'Social Networks'. The nineteenth- and early twentieth-century history of the Egyptian Antiquities Service is presented in Reid's Whose Pharaohs? and Conflicted Antiquities; that of the Sudan Antiquities Section is charted in Thornton, British Archaeologists.

54. Thornton, British Archaeologists; Jocelyn Mary Toynbee and Henry Major, rev. David Gill, 'Gardner, Ernest Arthur (1862-1939)', in Oxford Dictionary of National Biography [online edn] (Oxford University Press, 2004). For example salaries for British School staff can be found in the BSA Annuals.

55. Thornton, British Archaeologists.

56. For a history of the Palestine Exploration Fund see John J. Moscrop, Measuring Jerusalem: the Palestine Exploration Fund and British interests in the Holy Land (London: Leicester University Press, 1999); for Amelia Edwards' role in setting up the EEF see Barbara Moon, More Usefully 
Employed: Amelia B. Edwards, writer, traveller and campaigner for ancient Egypt (London: Egypt Exploration Society, 2006).

57. See Thornton, British Archaeologists, Amara Thornton, ““... a certain faculty for extricating cash": Collective Sponsorship in late $19^{\text {th }}$ and early $20^{\text {th }}$ century archaeology', Present Pasts 5 (1) (2013); Amelia Kakissis, The Byzantine Research Fund Archive: encounters of Arts and Crafts architects in Byzantium (British School at Athens Studies 17, 2009); Gill, Sifting; Davis, Shifting Sands.

58. See Annual Reports of Accounts 1880s and 1890s in the EES Library.

59. See Egypt Exploration Fund, Report of the Seventeenth Ordinary General Meeting, Subscription List and Balance Sheet (London: Kegan Paul, Trench, Trubner \& Co, 1902-3).

60. For a brief introduction to this phenomenon see, for example, Norma Dever, 'They Also Dug! Archaeologists' Wives and Their Stories', Near Eastern Archaeology 67 (3) (2004).

61. On Grand Tours see for example Lynn Withey, Grand tours and Cook's tours: a history of leisure travel, 1750-1915 (London: Aurum, 1997).

62. Richard Mullan and James Munson, The Smell of the Continent: the British Discover Europe (London: Macmillan, 2009), x-xiii, 189; Martin Anderson, 'The development of British tourism in Egypt, 1815-1850', Journal of Tourism History 4 (3): 2012; Reid, Whose Pharaohs?

63. John Pemble, The Mediterranean Passion: Victorians and Edwardians in the South (London: Faber and Faber, 2009), 25-6.

64. John Gretton, 'Introduction', in A Guide to the Microfiche Edition of Murray's Handbooks for travelers, ed. W. B. C. Lister (Bethesda, MD: University Publications of America, 1989), viii-ix; Eitan Bar-Yosef, The Holy Land in English culture 1799-1917: Palestine and the question of Orientalism (Oxford: Clarendon Press, 2005), 64-5; John Mackenzie, 'Empires of Travel: British Guide Books and Cultural Imperialism in the 19th and 20th Centuries', in Histories of Tourism: Representation, Identity and Conflict, ed. John Walton (Clevedon: Channel View Publications, 2005), 19, 26. Servants are an often overlooked travelling population, but families living or travelling overseas brought with them English maids, nannies and governesses. One such travelling maid was Jenny Lane, who accompanied the archaeological author Amelia Edwards and her companion Lucy Renshaw to Egypt. Moon used Lane's diary as a resource for reconstructing Edwards and Renshaw's trip to Egypt (Moon, Amelia Edwards, 112-3). See also Robert Bickers' Settlers and Expatriates: Britons over the Seas (Oxford: Oxford University Press, 2010) for a history of British settlers and expats in the nineteenth and twentieth centuries, and James Whidden, 'Expatriates in Cosmopolitan Egypt: 1864-1956', in Settlers and Expatriates: Britons over the Seas, ed. Robert Bickers (Oxford: Oxford University Press, 2010) for expats in Egypt during the same period.

65. Bryce, quoted in Pemble, Mediterranean, 8. See also David Gange and Michael Ledger Lomas, Cities of God: the Bible and Archaeology in Nineteenth-Century Britain (Cambridge: Cambridge University Press, 2013) for a discussion of biblically-inspired Protestant tourism.

66. John Mackenzie in 'Empires of Travel' has referenced the role of antiquarian and archaeological knowledge in the construction of British guidebooks to imperial destinations in the nineteenth and twentieth centuries.

67. Anderson, 'British tourism': 261-2.

68. Anderson, 'British tourism'; Reid, Whose Pharaohs?, Ch. 2.

69. John Murray (n. d.), 'The Origin and History of Murray's Handbooks for Travellers' [pamphlet]. Miscellaneous papers concerning the 'Murray's Handbooks for Travellers' series, MS 42615, John Murray archive, National Library of Scotland.

70. Gretton 'Introduction', xix-xx; see also Churnjeet Mahn, British women's travel to Greece, 1840-1914: travels in the Palimpsest (Farnham: Ashgate 2012), Ch 1.

71. Gretton, 'Introduction', xxv. See also Reid, Whose Pharaohs?, 69-86.

72. Lister, A Guide, 39-40, 47.

73. 'Murray's Handbooks English and Foreign' [pamphlet advertising], MS 42615, John Murray archive, National Library of Scotland.

74. See [unsigned notes] 20, 26 May 1896; William Kingdon to Hallam Murray, 8 January 1895. 'Letters of various correspondents to John Murray, publishers', MS 42613, John Murray archive.

75. Baedeker's guidebook is famously part of Miss Lucy Honeychurch's experience of Florence in E. M. Forster's 1908 novel A Room With A View. Baron Schlippenback, 'A Night with King Pharaoh', in Lost in a Pyramid \& Other Classic Mummy Stories, ed. Adam Smith (London: British Library, 2016). 
76. Daisy Hugh Pryce, Love's Mirage (London: Greening \& Co Ltd, 1902), 22, 65. Daisy Hugh Pryce published several books in the late 1890s and early 1900s, the most famous of which, Valda Hanem (1899), was set in a harem. She was known for publishing novels with 'Oriental' settings, drawn from her own experience - see 'Reviews: Under Star and Crescent', The Outlook [British Periodicals], 20 January 1900, 816-17; Troy J. Bassett, 'Daisy Hugh Pryce. At the Circulating Library: a database of Victorian fiction 1837-1901'. Last modified 30 November 2017: http://www.victorianresearch.org/atcl/show_author.php?aid=2346.

77. Gretton, 'Introduction', xxi; Mary Brodrick, ed., A Handbook for travellers in Lower and Upper Egypt (tenth edn) (London: John Murray 1900), vi; Harry R. Hall, ed., Handbook for Travellers in Egypt and Sudan (eleventh edn) (London: John Murray, 1907), 380; Reid, Whose Pharaohs?; Amara Thornton, 'Howard Carter Lights Up The Ancients'. Last accessed 30 November 2017: http://www.readingroomnotes.com/home/howard-carter-lights-up-the-ancients.

78. See Reid, Whose Pharaohs?, 81.

79. He also published city guides to Rome and Jerusalem and served as editor of Travel and Exploration magazine. See 'Obituary. Mr. Reynolds-Ball', The Times Digital Archive, 13 April 1928, 16.

80. See Leo Weinthal, ed., Fascinating Egypt and Sudan Guide (London: African World, 1913), 19, 187, 247.

81. See Piers Brendon, Thomas Cook: 150 years of popular tourism (London: Secker \& Warburg, 1991), Ch. 7; Felicity Cobbing, 'Thomas Cook and the Palestine Exploration Fund', Public Archaeology 11 (4) (2012). Although Cook's company is now famous in the history of tourism, during the mid- to late nineteenth century his competitor Henry Gaze was also a popular tourism provider. See also Reid, Whose Pharaohs?, Ch. 2 for an overview of tourism to Egypt.

82. See Brendon, Thomas Cook, 129-31; Burns, Help-Book for Travellers to the East, including Egypt, Palestine, Turkey, Greece and Italy (London: Cook's Tourist Office, 1870).

83. Thomas Cook Ltd, Up the Nile By Steam (new edn) (London: T. Cook \& Son, 1877).

84. Brendon, Thomas Cook, 129, 135-9; 188, 200.

85. Budge, Nile and Tigris, 86-8. See also Matthew Ismail, Wallis Budge: Magic and Mummies in London and Cairo (Kilkerrin, Scotland: Harding Simpole Publishing, 2011), 218.

86. Brendon, Thomas Cook, 223; for an analysis of tourist Egypt see Peter Lyth, 'Carry on up the Nile: The Tourist Gaze and the British Experience of Egypt, 1818-1932', in The British Abroad Since the Eighteenth Century, Volume 1: Travellers and Tourists, eds. Martin Farr and Xavier Guegan (Basingstoke: Palgrave Macmillan, 2013).

87. Ernest A. W. Budge, Cook's Handbook for Egypt and the Sudan (second edn) (London: Thos. Cook \& Son 1906), iii; Ernest A. W. Budge, The Nile: Notes for Travellers in Egypt (London: Thos. Cook \& Son, 1890); Eustace Reynolds-Ball, Cairo of To-Day (sixth edn) (London: A. \& C. Black, 1912), 255. Further editions of Budge's revised Cook's Handbook were published in 1906, 1911 and 1921.

88. Blanche Carson, From Cairo to the Cataract (Boston: L. Page \& Co, 1909), 104.

89. Ernest A. W. Budge, The Nile: Notes for Travellers in Egypt (London: Thomas Cook \& Son, 1905); see The Nile (editions 1895 and 1898).

90. Budge, Nile 1906.

91. Budge, Nile 1906, ix-xii.

92. Budge, Handbook 1905. This book was previously titled Cook's Tourists' Handbook for Egypt, the Nile and the Desert, with editions published in 1876, 1888, 1892 and 1897.

93. Budge, Handbook 1905, iv.

94. Brendon, Thomas Cook, Ch. 7.

95. Brendon, Thomas Cook, 240-2.

96. Brendon, Thomas Cook; Cobbing, 'Thomas Cook'; James Hanauer and Edward Masterman, eds, Cook's Handbook for Palestine and Syria (new edn) (London: Thos. Cook \& Son 1907), 31-3.

97. Guide to Palestine and Egypt (London: Macmillan \& Co, 1901); Guide to Italy (London: Macmillan \& Co, 1901); Guide to the Eastern Mediterranean (London: Macmillan \& Co, 1903); Guide to the Western Mediterranean (London: Macmillan \& Co, 1901). Thomas Ashby, Director of the British School at Rome, was credited with revising the eleventh edition of Macmillan's Guide to Italy.

98. Guide to Greece, the Archipelago, Constantinople... (London: Macmillan \& Co, 1908).

99. See, for example, Macmillan Guide to Italy (1901). 
100. For a brief discussion of 'tourism seasonality' see Rudi Hartmann, 'Tourism, seasonality and social change', Leisure Studies 5 (1986).

101. Pemble, Mediterranean, 1.

102. Douglas Sladen, Queer things about Egypt (London: Hurst \& Blackett, 1910), viii.

103. Brodrick, Handbook to Egypt, 25; Pemble, Passion, 17; Spiro. 'Leading Nineteenth Century Publishers of Travel Guidebooks to Egypt', Openstax CNX. Last modified 30 November 2017: http://cnx.org/contents/Pb1T261b@3/Leading-Nineteenth-Century-Pub.

104. Eustace Reynolds-Ball, Cairo of To-Day (fifth edn) (London: A. \& C. Black, 1907), 35-43.

105. Eustace Reynolds-Ball, Cairo: City of the Caliphs: a popular study of Cairo and its Environs and the Nile and its Antiquities (Boston: Estes and Company, 1897), 129.

106. Ethel S. Stevens, My Sudan Year (London: Mills \& Boon Ltd, 1912), 32.

107. See 'Cook's Nile Service', Egyptian Gazette, 9 January 1895; 'Visitors' List', Egyptian Gazette, 13 January 1900. A December 1895 article in the Gazette noted the increase in numbers of tourists between November 1894 (844) and November 1895 (900). See 'The Day's News', Egyptian Gazette, 9 December 1895.

108. Gunning, Consular Service.

109. Pemble, Mediterranean, 4, 46-50; 54-80.

110. Thornton, 'Social Networks'; on travel to Greece see also Deborah Harlan, 'Travel, Pictures, and Victorian gentlemen in Greece', Hesperia 78 (2009).

111. Whitaker, Almanack 1900, 552. See also Reid, Whose Pharaohs?, 301 for a table of foreign residents in Egypt by nationality. For memoirs of Anglo-Egyptian families in the late nineteenth and early twentieth centuries see Patricia Napier, A Late Beginner (London: Slightly Foxed Ltd, 2013); Mary Rowlatt, A Family in Egypt (London: Robert Hale Ltd, 1956) and Whidden, 'Expatriates'.

112. David G. Hogarth, A Wandering Scholar in the Levant (London: John Murray, 1896), 158.

113. See, for example, Petrie Diary 1894, Petrie Museum collection transcribed via Micropasts; on division see Alice Stevenson et al., 'selection'.

114. William M. F. Petrie, Seventy Years in Archaeology (London: Sampson, Low, Marston \& Co Ltd, 1931), 38; Storrs, Orientations.

115. See Hankey, Passion for details of life at Luxor, also Rowlatt, Family; Napier, Late.

116. Ellen S. Bosanquet, Late harvest: memories, letters and poems (London: Chameleon Press, 1971), 63; Ellen S. Bosanquet, ed., Robert Carr Bosanquet: Letters and Light Verse (Gloucester: John Bellows, 1938), 10-11.

117. Brendon, Thomas Cook, 262-3. For a detailed analysis of tourism in post-First World War Egypt see Reid, Contested Antiquity,137-57.

118. Thornton, 'Tents, Tours'.

119. Palestine Pavilion Committee, Palestine Pavilion Handbook and Tourist Guide etc. (Fleetway Press: London, 1924-5); Amara Thornton, 'Exhibition Season: Annual Archaeological Exhibitions in London, 1880s-1930s', Bulletin of the History of Archaeology 25 (2) (2015).

120. The background to the 1926 International Archaeological Congress, and the Archaeological Congresses that preceded it, are discussed in Thornton, 'Tents'.

121. Norah R. Hamilton, Both Sides of the Jordan: A Woman's Adventures in the Near East (London: Jenkins, 1928); 'Book of the Week. A Scotswoman Travels in the Near East', Aberdeen Press and Journal [British Newspaper Archive], 29 October 1928, 6; 'The Latest Travel Books', The Sphere [British Newspaper Archive], 22 December 1928, 33.

122. See Thornton, 'Tents'; Davd Gill, 'Harry Pirie-Gordon and the Palestine guide-books', Public Archaeology 11 (4) (2012); Luke and Keith Roach, The Handbook of Palestine. London: Macmillan \& Co Ltd, 1922, The Handbook of Palestine and Transjordan (London: Macmillan \& Co Ltd, 1930).

123. A sketch plan of this map was included in the 1929 edition.

124. C. Lumby, Cook's Traveller's Handbook to Palestine, Syria \& Iraq (London: Simkin Marshall Limited, 1934); Executive Committee Meeting 19 October 1933. PEF Minute Book, 20 September 1922-25 July 1935, Palestine Exploration Fund.

125. See Ethel S. Stevens, By Tigris and Euphrates (London: Hurst \& Blackett, 1923).

126. Reginald Campbell Thompson, A Small Handbook to the History and Antiquities of Mesopotamia... (Bombay: Times Press, 1918); Dorothy Mackay, The Ancient Cities of Iraq (Baghdad: Kenneth Mackenzie, 1926).

127. See Chris Naunton, 'The Film Record of the Egypt Exploration Society's Excavations at Tell el-Amarna', KMT 21 (2010); Thornton. 'Exhibition Season'; Sparks, 'Publicising'. 
128. See Asa Briggs, The history of broadcasting in the United Kingdom (Oxford: Oxford University Press, 1995).

129. BBC Genome (Radio Times listings): searches for Arthur Weigall, Lady Petrie and Leonard Woolley. See also Sparks, 'Publicising'.

130. BBC. The British Broadcasting Corporation Third Annual Report 1929 (London: His Majesty's Stationery Office, 1930), 12; 'The 'Listener', The Times Digital Archive, 3 January 1929, 8. Bowler discusses science radio broadcasts and Listener articles in Science, 209-14.

131. Stanley Casson, 'The Listener', The Times Digital Archive, 10 January 1929, 8.

132. BBC Genome. 19 December 1927, 'Digging Up Old Stamboul'.

133. 'Publishing by the B. B. C.', The Times Digital Archive, 5 January 1929, 9.

134. Stanley Casson, 'The New York of the Ancient World', The Listener 1 (12): (1929).

135. BBC Genome: Woolley; for exhibitions see Thornton, 'Exhibition Season', Appendix 2.

136. Lady Correspondent, 'London Diary. Back to Noah', Hartlepool Northern Daily Mail [British Newspaper Archive], 30 September 1929.

137. BBC Genome - Woolley.

138. BBC, Third Annual Report, 6 .

139. 'Sequence of Civilisations. Remarkable Finds at Ur on View in London', Nottingham Evening Post [British Newspaper Archive], 2 July 1930, 4.

140. Janet A. Smith, 'Putting Noah's Flood into a Glass Case', Aberdeen Journal [British Newspaper Archive], 31 July 1930, 6; Leonard Woolley, Antiquities of Ur .... (London: Hazell, Watson \& Viney, 1930).

141. Leonard Woolley, 'Why Dig Up The Past?', The Listener 3 (75) (1930); 'The Archaeologist at Work', The Listener 3 (76) (1930); 'Building up the Past', The Listener 3 (77) (1930); 'The Witness of Bricks and Mortar', The Listener 3 (78); 'Treasures of the Grave', The Listener 4 (79) (1930). Leonard Woolley, Digging Up the Past (London: Benn, 1930).

142. Challis, Harpy Tomb, 2.

143. Drower, Petrie, 1985, 377-8; Petrie, Seventy Years.

144. Ernest Budge, Rise and Progress of Assyriology (London: Martin Hopkinson, 1925); Robert A. S. Macalister, Century of Excavations in Palestine (London: Religious Tract Society, 1929); Reginald Campbell Thompson and Richard Hutchinson, A Century of Exploration at Nineveh (London: Luzac \& Co, 1929).

145. Arthur Weigall, The Treasury of Ancient Egypt: Miscellaneous Chapters on Ancient Egyptian History and Archaeology (London: William Blackwood \& Sons, 1911), 281.

146. Weigall, Treasury, 1911, 284-8; on fears relating to the degeneration of masculinity in Edwardian England see for example Susan Kingsley Kent, Gender and Power in Britain, 1640 1990 (London: Routledge, 1999), 236-7.

\section{Chapter 3}

1. Eversley Robinson, ed., Egypt: Papers \& Lectures by the late May Brodrick (London: Alexander Moring, Limited, 1937), viii.

2. She has also now been included in the Oxford Dictionary of National Biography (David Gill, 'Brodrick, Mary (1858-1933)', in Oxford Dictionary of National Biography [online edn] (Oxford University Press, 2004-6).

3. See Dr Mary Brodrick, PhD, FRGS, Dame of Grace of St John of Jerusalem... a small tribute, 1933 [pamphlet]. CH8/5/5: College Hall Archive, University of London Special Collections.

4. On real v. fictional New Woman, see Ann Ardis, New women, new novels: feminism and early modernism (New Brunswick, NJ: Rutgers University Press, 1990), 12-13. As an example of how archaeology was promoted specifically for girls, between October 1894 and May 1895 the Girls Own Paper published an eight-part series called 'Archaeology for Girls'. On women in the 1890s see David Rubenstein, Before the Suffragettes: Women's Emancipation in the $1890 \mathrm{~s}$ (Brighton: The Harvester Press, 1986).

5. On this wider context see Lady Correspondent, 'Lady Guides and Lecturers', Sheffield Daily Telegraph [British Newspaper Archive], 23 August 1889, 4; Janes, Year-Book 1899, 57-8; Mitton, Year Book 1909, 72. The Lady Guide Association was founded in 1888.

6. Sheppard, Murray, 82. 
7. There are many scholarly works charting women's travel writing on the Eastern Mediterranean and Middle East in particular throughout the eighteenth, nineteenth and twentieth centuries. Those that have been particularly relevant for this chapter include Melman, Women's Orients, Mahn, British women's travel, 2012, Martha Klironomos, 'Early Twentieth-Century British Women Travellers to Greece: Contextualizing the Example of Virginia Woolf', Literature Compass 4 (2) (2007) and Andrew Hammond, 'Memoirs of conflict: British women travellers in the Balkans', Studies in Travel Writing 14 (1) (2010). A particularly relevant and helpful bibliography is John Theakstone's 'An alphabetical bibliography of books by Victorian and Edwardian women travellers published between 1837 and 1910'. Last modified 30 November 2017: www.victorianresearch.org/wtravelbib2003.pdf.

8. 'Obituary. Mrs Sophia Poole', Englishwoman's Review [19th Century British Periodicals - New Readerships], 15 July 1891, 201; Elizabeth Baigent, 'Poole, Sophia Lane (1804-91)', in Oxford Dictionary of National Biography [online edn] (Oxford University Press, 2004-16); 'Mrs Poole's 'Englishwoman in Egypt', Blackwood's Edinburgh Magazine [British Periodicals], 57 (353) (1845).

9. See Baigent, 'Poole'; Sophia Lane Poole, The Englishwoman in Egypt: Letters from Cairo, written during a residence there in 1842, 3, \& 4... (London: Charles Knight \& Co, 1844) and Cairo, Sinai, Jerusalem and the pyramids of Egypt (London: James Virtue, 1860/61).

10. Amelia Edwards, A Thousand Miles Up the Nile (New York: A. L. Burt, 1888); Moon, Edwards, 141.

11. Imperial Airways, Ltd. Through Africa By the Empire Flying Boat [c.1938?] CAS/7/83/3/19 Croydon Airport Archives. Thanks to Debbie Challis for bringing these pamphlets to my attention.

12. Moon, Edwards, 160-71.

13. Amelia Edwards' will transcribed by her friend and secretary Kate Bradbury (later married to Petrie's student Francis Llewellyn Griffiths), 5/BRD/23, Petrie Museum Archives.

14. On Paterson see Carl Graves, 'A Ready Intelligence: Emily Paterson 1861-1947'. Last modified 30 November 2017: http://birminghamegyptology.co.uk/virtual-museum/a-readyintelligence/.

15. University College London, Calendar, Session MDCCCXCIII-XCIV (London: Taylor and Francis, 1893), 46-7.

16. UCL, Calendar 1892.

17. See 'Marriages', John Bull [British Periodicals: New Readerships], 18 April 1885, 259; 'Notes on Art and Archaeology', The Academy [British Newspaper Archive], 16 May 1885, 355; A17728/6293. Helen Mary Beloe, Reading Room Admissions Register 1880 to 1888 (A to D), British Museum Central Archive. At this time there were no official guide-lecturers at the British Museum, although lecturers were guiding tours through the collections by 1881, including one woman who only guided women. Jane Harrison is that first woman giving tours at the British Museum, see 'A Peripatetic Lecturer at the British Museum', The Graphic [19th Century British Periodicals], 5 November 1881, 462. A proposal for 'official guides' was put forward in 1910, and the idea was trialled successfully in 1911. Official tours began in 1912, see Jamie Larkin, Trading on the Past: an examination of the cultural and economic roles of shops at museums and heritage sites (unpublished $\mathrm{PhD}$ thesis: University College London, 2016). Thanks to Jamie Larkin for this information.

18. 'Notes on Art and Archaeology', Academy [British Periodicals], 20 June 1885, 445.

19. 'Notes on Art and Archaeology', Academy [British Periodicals], 30 April 1887, 314.

20. 'Notes on Art and Archaeology', Academy [British Periodicals], 31 March 1888, 228. In these advertisements, various women are listed as main contact and collectors of fees for these courses, indicating a female-centred economy in lectures.

21. 'Notes on Art and Archaeology', Academy [British Periodicals], 5 October 1889, 227.

22. Vacation Committee Minutes 1886-93, 25 September 1888, CH1/3/1 College Hall Archives, University of London Special Collections; 'Dr Mary Brodrick. Work in Egyptology', The Times Digital Archive, 22 July 1933, 14; Robinson Egypt, vii-viii.

23. 'A Visit to College Hall, Byng Place', Women's Herald [19th Century British Periodicals New Readerships], 2 May 1891, 436. For overviews of higher education in Britain see Martha Vicinus, Independent women: work and community for single women 1850-1920 (London: Virago, 1985), Ch. 4, and Carol Dyhouse, No Distinction of Sex? Women in British Universities 1870-1939 (London: Taylor \& Francis, 1995). Brodrick's connection to and appreciation of the Hall lasted her entire life, and at her death she bequeathed the Hall the 
residue of her estate, including royalties on her Dictionary of Egyptian Archaeology. This legacy ensured the Hall would continue to provide a residence for women, and in 1934 the Mary Brodrick Wing was opened in the Hall. The Brodrick Wing was demolished in renovations to the Hall in the 2000s (see CH6/1/34, CH6/1/2, College Hall Archives; pers. comm. Alice Coote-Cowling).

24. On Brodrick's finances see Mary Brodrick to Thyra Alleyne, 29 October 1932, CH 6/1/3 College Hall Archives; 'Miss Brodrick's Lectures at the British Museum', Women's Penny Paper [19th Century Periodicals], 12 October 1889, 3; Lady Correspondent, 'London Between the Seasons', Sheffield Daily Telegraph [British Newspaper Archive], 22 November 1889, 6; 'Current News about Women', Women's Penny Paper [19th Century Periodicals], 26 October 1889. For Brodrick's views on women's education see Mary Brodrick, 'Our Inheritance': University College London 18271927. An Address delivered by Mary Brodrick... (London: University of London Press, 1926).

25. 'Fine Art Gossip', Athenaeum [British Periodicals], 17 January 1891, 95.

26. Helen Tirard and Nestor Tirard, Sketches from a Nile Steamer (London: Kegan Paul, Trench, Trubner \& Co, 1891), viii.

27. Tirard, Sketches, 41-2. Interestingly, Hatshepsut's role as a figurehead for women's suffrage is emphasised in Daisy Pryce's Love's Mirage, 223 (referenced in the preceding chapter). Miss Tankerville forces a small party to look at a granite obelisk that 'recorded the doings of the first known exponent of Women's Rights' who had had 'herself depicted in Rational Dress'.

28. Stewart, Jane Harrison, 10. On the importance of public perambulations for middleclass Victorian women in London moving through theatres, protest sites and department stores see Judith Walkowitz, City of Dreadful Delight: Narratives of Sexual Danger in LateVictorian London (Chicago: University of Chicago Press, 1992), Ch. 2. 'Miscellaneous Items', Leeds Mercury [British Newspaper Archive], 21 March 1892, 8; 'Notes on Art and Archaeology', Academy [British Periodicals], 4 March 1893, 205; 'Advertisements' Morning Post [British Newspaper Archive], 1 October 1894.

29. Edouard Naville, 'Introduction', in Helen M. Tirard, The Book of the Dead (London: Society for Promoting Christian Knowledge, 1910), 12.

30. Mary Brodrick, ed., Egypt under the pharaohs: a history derived entirely from the monuments (London: John Murray, 1891), vii-viii.

31. Brodrick to Murray, 30 January 1891, MS 40142, Incoming Correspondence, John Murray archive, National Library of Scotland (hereafter NLS).

32. Brodrick to Murray, 12 July 1891, MS 40142, Incoming Correspondence, John Murray archive, NLS.

33. Copies Ledger H: 191, MS 42733, John Murray archive, NLS.

34. Brodrick to Murray, 29 July, 5 August 1891, MS 40142, John Murray archive; Jean Capart, ed., Travels in Egypt (December 1880 to May 1891): letters of Charles Edwin Wilbour (Brooklyn: Brooklyn Museum 1936), 564.

35. Brodrick to Murray, 29 July 1891, MS 40142, Incoming Correspondence, John Murray archive, NLS.

36. Brodrick to Murray, 21 August 1891, 25 September 1891, MS 40142, Incoming Correspondence, John Murray archive, NLS.

37. Brodrick to Murray, 6 August 1891, MS 40142, Incoming Correspondence, John Murray archive, NLS. In the Copies Ledger for Brugsch's Outlines, the sum paid to Brodrick was $£ 105$. Copies Ledger H: 191, MS 42733, John Murray archive, NLS.

38. Mariette, Auguste; Brodrick, Mary, ed. and trans., Outlines of Ancient Egyptian History (London: John Murray, 1892): v.

39. Brodrick to Murray, 19 June 1892, MS 40142, Incoming Correspondence, John Murray archive, NLS.

40. Brodrick to Murray, 14, 24, 31 August 1892, MS 40142, Incoming Correspondence, John Murray archive, NLS.

41. Brodrick to Murray, 31 August 1892, MS 40142, Incoming Correspondence, John Murray archive, NLS.

42. Brodrick to Murray, 15 August 1893, MS 40142, Incoming Correspondence, John Murray archive, NLS.

43. Brodrick to Murray, 2 February 1893, MS 40142, Incoming Correspondence, John Murray archive, NLS.

44. Brodrick to Murray, 24 August 1893, 1 September 1893, MS 40142, Incoming Correspondence, John Murray archive, NLS. 
45. Brodrick to Murray, 8 November 1894, MS 40142, Incoming Correspondence, John Murray archive, NLS.

46. Brodrick to Murray, 27 August 1897 and printed circular, MS 40142, Incoming Correspondence, John Murray archive, NLS.

47. See, for example, 'Social and Personal', Glasgow Herald [British Newspaper Archive], 12 August 1899, Janes, Year-Book 1899, 113.

48. Brodrick to Murray, 17 November 1898, MS 40142, Incoming Correspondence, John Murray archive, NLS.

49. Mary Brodrick and Anna Morton, A Concise Dictionary of Egyptian Archaeology: a handbook for students and travellers (London: Methuen \& Co, 1902). In 'Excavating' Janssen and Janssen note the success of this volume, which had five editions.

50. 'From Our Lady Correspondent', Sheffield Daily Telegraph [British Newspaper Archive], 10 October 1891, 5.

51. Jane Harrison, Myths of the Odyssey in Art and Literature (London: Rivingtons, 1882), xii-xiv; see also Robinson, Life, Ch. 3. Her mentor at the British Museum was Keeper (and UCL Yates Professor) Charles Newton. Jane Harrison, Introductory Studies in Greek Art (London: T. Fisher Unwin, 1885), vi. On Harrison's time in London and relationship with Eugénie Sellers in publicising Harrison's lectures, see Beard, Invention, Ch. 5. Harrison was a University Extension Lecturer; the University Extension movement offered lectures, courses and examinations outside of the formal universities. These were organised locally by committees across the UK (Whitaker, Almanack 1900, 249, 268). The appointment was offered to her British Museum associate Reginald Stuart Poole. Penelope, 'Our Ladies' Column', Western Daily Times [British Newspaper Archive], 10 December 1888, 4. On Harrison's experience in Greece see Robinson, Life, Ch. 4.

52. 'A Woman's View of the Greek Question. An Interview with Miss Jane Harrison', Pall Mall Gazette [British Newspaper Archive], 4 November 1891, 1-2. On this debate see Judith Raphaely 'Nothing but gibberish and shibboleths?: The Compulsory Greek Debates, 18701919', in Classics in ... Cambridge.

53. For a recent overview of scholarship on women's travel writing see Short, Emma, 'Women Writing Travel 1890-1939', Journeys: The International Journal of Travel and Travel Writing 16 (1) (2015).

54. Lorna Beckett, The Second I Saw You: the true love story of Rupert Brooke and Phyllis Gardner (London: British Library Publishing, 2015), 2.

55. Beckett, Second, 3 suggests she attended Newnham College, but there is no evidence of her attendance at Newnham (pers. comm. A Thomson). However, a poem in a volume of Ernest Gardner's diaries written 'To Mary' dates from Gardner's time at Cambridge. See MS Add 82/ 1, Gardner Papers, UCL Special Collections.

56. See Gill, Students for a list of the students admitted under Gardner's Directorship. These included novelists M. R. James and E. F. Benson, the noted anthropologist James G. Frazer; the classicist Eugénie Sellers (the first woman to be admitted to the School) and a number of men who became noted archaeologists, including John Linton Myres and Robert Carr Bosanquet.

57. See Gardner Papers, MS 82/8, UCL Special Collections.

58. Mary Gardner (n. d.) 'The Gates of Life', Gardner Papers, Add MS 89076/5, British Library.

59. Mary Gardner, A Short and Easy Modern Greek Grammar with grammatical and conversational exercises, idiomatic, proverbial phrases, and full vocabulary. (London: David Nutt, 1910).

60. 'Philological Books', Athenaeum [British Periodicals], 24 December 1892, 884. On Greek intellectuals and Modern Greek see Richard Clogg, 'Politics and the Academy: Arnold Toynbee and the Koraes Chair', Middle Eastern Studies 21 (4) (1985).

61. Gardner, Modern Greek, 1910: vii-xvi.

62. Handbook for Travellers in Greece.... (seventh edn) (London: John Murray, 1900): 1xi.

63. See Beckett, Second, 12, 32; Donald Sheehy et al., eds, The Letters of Robert Frost, vol.1 (Cambridge, MA/London: Belknap Press, 2014); Lesley L. Francis, Robert Frost: An Adventure in Poetry, 1900-1918 (New Brunswick, NJ/London: Transaction Publishers, 2004).

64. Mary Gardner (n. d.) 'The Gates of Life', Gardner Papers, Add MS 89076/5, British Library.

65. Peter Blake and Barbara Onslow, 'Temple Bar', in Dictionary of Nineteenth-Century Journalism in Great Britain and Ireland, eds Laurel Brake and Marysa Demoor (London: Academia Press/ British Library, 2007).

66. Mary Gardner to Macmillan, 8 March 1904, Records of Macmillan and Co Ltd, fonds MAC, Reading University Publishing Archive. 
67. Mary Gardner, 'Samian wine: some Greek sketches', Temple Bar: a monthly magazine for town and country readers [British Periodicals], 131 (530) (1905).

68. A student residence (for men) was built in 1895 at the end of Gardner's time at the BSA. Women students did not have their own residence and were expected to live in hostels, as Agnes Conway charts in her book A Ride Through the Balkans - see Gill, 'Passion', 501-2.

69. Gardner, 'Sketches'.

70. Session Fees Books 1904-5, 1909-10, UCL Special Collections. See 'The Greek Play at University College', The Times Digital Archive, 11 June 1897, 6; 'University Intelligence', The Times Digital Archive, 24 December 1904, 8; 'University Intelligence', The Times Digital Archive, 27 March 1907, 12. Mary Gardner describes Iphigenia in Aulis, the first Greek play the Gardners produced at UCL, in some detail in her memoir. She took the role of Clytemnestra.

71. Clogg, 'Koraes Chair', 7. Clogg's research on the history of the Koraes Chair of Modern Greek and Byzantine History, Language and Literature at King's (with funding from Anglo-Greek families) briefly discusses the origins of Mary Gardner's lectureship there. Mary Gardner also taught Modern Greek at UCL in the spring of 1916. See 'Law Society Lectures', The Times Digital Archive, 1 May 1916, 13.

72. See Ernest Gardner's letters to his daughter Delphis, in Add MS 89076/1/2, Gardner Papers: British Library.

73. See Mary Gardner to G. A. Macmillan, 30 July 1928, Add MS 55130: 128, Macmillan Archive, British Library; Mary Gardner to Mr Willett at John Lane/Bodley Head, 25 February 1929: John Lane Ltd, letters file 1928-33 - G., Reading University; Mary Gardner to W. E. F. Macmillan, 17 November 1934, Add MS 55130: 139, Macmillan Archive, British Library.

74. Before her marriage she studied Modern Greek with a tutor in Liverpool. See Bosanquet, Harvest, 54.

75. See also Amara Thornton, 'A Book, A Pudding and A Party'. Last modified 30 November 2017: http://www.readingroomnotes.com/home/a-book-a-pudding-and-a-party; 'Days in Attica', The Newcastle Daily Journal [British Newspaper Archive], 8 April 1914, 4; 'The Women of Modern Greece', Wells Journal [British Newspaper Archive], 28 May 1915, 6. 'Keeping House in Greece', Western Liberal [Library of Congress Chronicling America], 12 February 1915.

76. Bosanquet, Harvest, 57, 58. See Whitakers Almanack 1900, 564 for details of British Consuls; for a history of the relationship between the British consular service in the Aegean and archaeology see Gunning, Consular Service.

77. Ellen S. Bosanquet, Days in Attica (London: Methuen, 1914), 19.

78. Bosanquet, Days, Ch. 12.

79. Bosanquet, Days, 23.

80. Bosanquet, Days, 74-5; Newcastle Daily Journal, 'Days'.

81. Bosanquet, Days, 271.

82. Bosanquet, Days, 278-9.

83. See, for example, 'Books to Read and Books to Use', Yorkshire Post and Leeds Intelligencer [British Newspaper Archive], 10 June 1914, 4. On developments in the Balkans see Hupchick, Balkans, Chs. 13-14.

84. Bosanquet, Days, vii.

85. Ellen S. Bosanquet, The Tale of Athens (London: Methuen,1932), v.

86. 'Popular Books. What the Public Are Reading', Liverpool Daily Post [British Newspaper Archive], 1 April 1914, 11.

87. See Thornton, 'Allure'; Amara Thornton, 'Agnes Conway's Rome'. Last modified 30 November 2017: http://www.readingroomnotes.com/home/agnes-conways-rome; and Amara Thornton, 'A Balkan Adventure'. Last modified 4 December 2017: http://www. readingroomnotes.com/home/a-balkan-adventure.

88. Although Martin Conway is listed as a co-author, Agnes Conway's diary shows that most of the work on the book - designing the structure, choosing the pictures to be included and writing the text - was hers. Agnes Conway, Diary, 4 February 1908, MSS Add 7676/Z10; William, Lord Conway of Allington and family: Letters and Papers, Cambridge University Library. A bibliography of Agnes Conway's work can be found in Thornton 2011 (Appendix A).

89. Agnes Conway, Diary, 25 February, 28 June 1914, MS Add. 7676/Z16, Conway Letters and Papers, Cambridge University Library. 
90. See, for example, Hammond, Memoirs; John B. Allcock and Antonia Young, eds, Black Lambs \& Gray Falcons: Women Travellers in the Balkans (second edn) (New York: Berghahn Books, 2000). As her trip through the Balkans was coming to a close, Agnes Conway was reading British traveller Edith Durham's books on Albania. See Agnes Conway, Diary, 29 May 1914, Ms Add. 7676/Z16, Conway Letters and Papers, Cambridge University Library. On Durham see John Hodges, 'Edith Durham: Traveller and Publicist', in Allcock and Young, Lambs.

91. Klironomos, 'British Women', 482-3.

92. Agnes Conway, Diary, 7 March 1914, MS Add 7676/Z16, Conway Letters and Papers, Cambridge University Library.

93. Conway, A Ride, 37-8.

94. Agnes Conway, Diary, 16 May 1914: MS Add 7676/Z16, Conway Letters and Papers, Cambridge University Library.

95. Conway, ARide, 162-3. The excavation was a collaboration between the Greek Archaeological Society and the German Archaeological Institute. See 'Excavations in Corfu. Interesting Discoveries', Northern Whig [British Newspaper Archive], 24 May 1913, 12.

96. Agnes Conway, Diary, 28 June, 29 July; 4, 5 August 1914, MS Add 7676/Z16, 2 August 1916, MS Add 7676/Z18, Conway Letters and Papers, Cambridge University Library.

97. Agnes Conway, Diary, 10, 17 March 1915. MS Add 7676/Z17. Agnes Conway, Diary, 27 July, 6 September 1916: MS Add 7676/Z18, Conway, Letters and Papers, Cambridge University Library.

98. Conway, A Ride, 204.

99. Robert Scott, 'From Robert Scott's List', in Conway, A Ride.

100. 'A Ride Through the Balkans', Gloucester Journal [British Newspaper Archive], 23 June 1917, 3; 'A Ride Through the Balkans', The Times Literary Supplement Historical Archive, 15 March 1917, 130.

101. University College London, Calendar, Session MDCCCXCVL-XCVII (London: Taylor and Francis, 1896), lii.

102. See Lee Young, 'Annie Abernethie Quibell', Ancient Egypt 14 (4) for a summary of Annie Quibell's life and work. While resident in Egypt the Quibells were also responsible for organising and installing the Egyptian government's archaeology displays at the 1904 Worlds Fair. See Amara Thornton, 'I'll Meet You in St. Louis'. Last modified 30 November 2017; http://www.readingroomnotes.com/home/ill-meet-you-in-st-louis.

103. See 'Obituary. Mrs. J. E. Quibell', Aberdeen Press and Journal [British Newspaper Archive], 19 January 1928, 8.

104. British influence continued in Egypt for another 30 years. Maureen Duffy, A Thousand Capricious Chances: A History of the Methuen List 1889-1989 (London: Methuen 1989), 86; 'A Selection of Messrs. Methuen's Publications', in Quibell, Wayfarer.

105. Annie Quibell, A Wayfarer in Egypt (London: Methuen, 1925), v.

106. See Melman, Women's Orients, 16.

107. Quibell, Wayfarer, 133-5.

108. Henriette Caroline Devonshire published many travel books about Egypt during her time in the country. She married an English lawyer, Robert Llewellyn Devonshire, and moved with him to Cairo when he took up a position there. See Israel Katz, Henry George Farmer and the First International Congress of Arab Music (Leiden, Netherlands: Brill, 2015), 157-8 n.65. Eugénie Le Brun married Husayn Rushdy, later Egypt's Prime Minister. She wrote many books on the lives of Egyptian women as a semi-insider, see Mervat Hatem, 'Through Each Other's Eyes: The Impact on the Colonial Encounter of the Images of Egyptian, LevantineEgyptian, and European Women, 1862-1920', in Western Women and Imperialism: Complicity and Resistance, eds Nupur Chaudhuri and Margaret Strobel (pp.35-60) (Bloomington, IN: Indiana University Press,1992): 47-50. I discussed this idea in a blogpost on A Wayfarer, see Thornton, 'The Wayfarer: Annie Pirie Quibell'. Last accessed 30 November 2017: http:// www.readingroomnotes.com/home/the-wayfarer-annie-pirie-quibell.

109. See fourth edition (1939) of Quibell, Wayfarer; 'Books and Bookfolk', Jacksonville Daily Journal [Newspapers.com], 7 August 1928, 5.

110. 'New Books', The Age [Trove], 6 February 1926, 6.

111. See Gregory L. Possehl, 'Ernest J. H. Mackay and the Penn Museum', Expedition 52 (1) (2010).

112. Dorothy Mackay, 'Housekeeping in the Desert', Western Daily Press [British Newspaper Archive], 13 July 1925, 5.

113. Mackay, Ancient Cities, v. Mackay deliberately set her focus in this short guide on pre-Islamic Iraq. 
114. Mackay, Ancient Cities, vii.

115. Mackay, Ancient Cities, 1.

116. 'Local News and Notes - Distinguished Bristolian', Western Daily Press [British Newspaper Archive], 9 August 1929, 5. Dorothy Mackay, Mohenjo-daro (Indian State Railways Publicity Department, 1929). A copy of this short pamphlet, given by the author herself, is held in the Society of Antiquaries Library. It includes hotel and railway station information.

117. See Arthur C. Benson, Life and Letters of Maggie Benson (London: John Murray, 1917).

118. See UCL Session Fees Book 1892-3, UCL Special Collections; Margaret Benson and Janet Gourlay, Temple of Mut in Asher; an account of the excavation of the temple and of the religious representations and objects found therein... (London: John Murray, 1898), viii.

119. Brodrick to Murray, 14 October 1897, MS 40152, Incoming Correspondence, John Murray archive, National Library of Scotland.

120. Benson to Murray, 16 December 1897, MS 40087, Incoming Correspondence, John Murray archive, National Library of Scotland.

121. See UCL Session Fees book 1896-7; Eckenstein is listed as a student of Egyptology almost every year between 1896 and 1914. For further detail on Eckenstein and her membership of the sex and sexuality discussion group 'Men and Women's Club', see Walkowitz, City, Ch. 5.

122. See EEF Report, 9-10; William M. F. Petrie, Catalogue of Egyptian Antiquities...1905 (London: University College, 1905).

123. Originally titled 'On camel-back in Sinai', Hilda Petrie's article appeared in November 1905. It is quoted at length in Margaret Drower, Letters from the Desert: The Correspondence of Flinders and Hilda Petrie (Oxford: Aris \& Phillips, 2004), 168-74.

124. Lina Eckenstein, A History of Sinai (London: Society for Promoting Christian Knowledge, 1921), iii.

125. UCL Session Fees Book 1893-4, University College London Special Collections.

126. See Sheppard, Murray, 121-37 for a detailed description of Murray's Manchester unrolling. The year before she and a colleague, Margaret Sefton Jones, had unwrapped a mummy for the Hastings and St Leonards Museum Association. See 'Museum Prospects', Hastings and St Leonards Observer [British Newspaper Archive], 2 November 1907, 9.

127. Sheppard, Murray, Ch. 8; Sheppard, 'Training'.

128. On Petra tourism see Thornton 'Tents, Tours'; Margaret Murray, Petra: the Rock City of Edom (London: Blackie \& Son Limited, 1939), iii.

129. Agnes Conway and George Horsfield, the Chief Curator of Antiquities in Transjordan, carried out this excavation with a team of locally recruited workers. American archaeologist William Foxwell Albright directed the brief 1934 excavation.

130. Murray, Petra, 30.

131. Murray, Petra, v-vi.

132. Murray, Petra, Ch. 8.

133. Mary Chubb, Nefertiti Lived Here (London: Geoffrey Bles, 1954), 18.

134. Lavers illustrated Nefertiti.

135. Chubb, Nefertiti, 54-5. This important weekly ritual was also represented in excavation films, including the film made by Waddington of the Amarna dig. On the EES film see Naunton 2010.

136. Roger Matthews, The archaeology of Mesopotamia: theories and approaches. (London: Routledge, 2003), 192.

137. Chubb, Nefertiti, 68 .

138. See British School at Athens, 'List of Directors, Honorary Students, Students and Associates', Annual of the British School at Athens 33 (1932/1933), 249.

139. Chubb, Nefertiti, 88.

140. See R. E. Mortimer Wheeler, Maiden Castle, Dorset (Oxford: University Press for Society of Antiquaries of London, 1943); Jacquetta Hawkes, Mortimer Wheeler: adventurer in archaeology (London: Weidenfeld and Nicolson, 1982); 'Lady Wheeler' The Times Digital Archive, 26 December 1990, 10.

141. Margaret C. Wheeler, Walls of Jericho (London: Arrow Books, Ltd, 1959), 84. Ernest Benn published Kenyon's Digging Up Jericho, her own summary of the excavations for a wider readership, in 1957.

142. Wheeler, Walls, 109.

143. See Wheeler, Walls, 95-6.

144. William M. F. Petrie, Ten Years' Digging in Egypt, 1881-1891 (London: Religious Tract Society, 1892), 156. 


\section{Chapter 4}

1. Petrie to Edwards, 7 October 1884, 3/1/PEN/13, Petrie Museum archives.

2. Alan Lee, The Origins of the Popular Press in England 1855-1914 (London: Croom Helm, 1976), 18.

3. See, for example, a letter from Abbe Winklemann on excavations at Herculaneum, published in June 1765 in the Public Ledger, a London newspaper; see for example Henrik Ellegard, The Readership of the Periodical Press in Mid-Victorian Britain (Goteborg: Goteborgs Universitets arsskrift 63 (3) (1957)); Lee, Origins.

4. These include specialist periodicals such as British Architect and The Builder, the Women's Penny Paper, Girls Own Paper and Chums.

5. The 19th Century Newspapers database does not include intellectual cultural review periodicals such as The Academy, The Athenaeum and the Saturday Review, which regularly featured articles on archaeological research. For a detailed discussion of archaeology as presented in these periodicals, see Gange, Dialogues. For example there were no paper(s) from Cambridge represented in the database at all at the time of research. The range of papers available also changes over time - there are no Edinburgh papers, for instance, available in the database after 1867. Nor does it include a number of significant newspapers, i.e. The Times, The Daily Telegraph, The Daily Mail or The Manchester Guardian. The end date of my search was dictated by the availability of articles in the database at the time of research. Using 'Petrie' for a search term meant I needed to discount unrelated hits; in total, I ended with a list of 779 articles relating to the archaeologist Flinders Petrie. I did this search without enhancing the optical character recognition (OCR) in the database search function.

6. These geographical delineations are based on those given in the 19th Century British Library Newspapers database 'Publications by Location' section.

7. $362 / 779$ (46.6 per cent).

8. Andrew Hobbs, 'When the Provincial Press was the National Press (c.1830s-1900)', The International Journal of Regional and Local Studies 5 (1) (2009), 16-7.

9. See Claudia Nelson, 'The English Illustrated Magazine', in Dictionary of NineteenthCentury Journalism in Great Britain and Ireland, eds Laurel Brake and Marysa Demoor (London: Academia Press/British Library, 2007), 201-2.

10. William M. F. Petrie, 'A Digger's Life', English Illustrated Magazine 30 [19th Century British Periodicals] March 1886, 441.

11. William M. F. Petrie, 'Miscellaneous Extracts - The Recovery of Egyptian Antiquities', Manchester Times Weekly Supplement [19th Century British Periodicals], 20 March 1886, 6.

12. Jeremiah 43: 5-9.

13. 'Editorial', The Times Digital Archive, 18 June 1886, 9; 'Pharaoh's House in Tahpanhes', The Times Digital Archive, 18 June 1886, 13.

14. 'Ancient Egypt. Remarkable Discovery', Bristol Mercury and Daily Post [19th Century British Library Newspapers], 19 June 1886, 6.; 'Pharaoh's House in the Tahpanhes', Leeds Mercury [19th Century British Library Newspapers], 19 June 1886, 2; 'Pharaoh's House in the Tahpanhes', Glasgow Herald [19th Century British Library Newspapers], 19 June 1886, 8; 'Our London Correspondence', Liverpool Mercury [19th Century British Library Newspapers], 19 June $1886,5$.

15. For example 'Pharaoh's House in Tahpanhes', Berrow's Worcester Journal [19th Century British Library Newspapers], 26 June 1886, 6.

16. Royal Archaeological Institute, 'Report of the Council for the Year 1884-5', Archaeological Journal 44 (1887), 420; see also Thornton, 'Exhibition Season'.

17. 'Egyptian Antiquities at Oxford Mansion', The Times Digital Archive, 1 September 1886, 13; see also Thornton, 'Exhibition Season'.

18. Petrie to Edwards, 6 July 1889 3/1/PEN/43, Petrie Museum archives; Moon 2006: 160, 193.

19. William M. F. Petrie, 'The Romance of Ancient Literature I' (November 1891); 'The Romance of Ancient Literature II' (December 1891); 'The Romance of Ancient Literature III' (January 1892); 'The Romance of Ancient Literature IV' (February 1892), The Leisure Hour [19th Century British Periodicals].

20. Amelia Edwards, Pharaohs, Fellahs and Explorers (London: Osgood McIlvaine, 1891); for example 'New Books', Birmingham Daily Post [19th Century British Library Newspapers], 2 February 1892, 7. 
21. See 'Egypt and its Explorers', Graphic [19th Century British Library Newspapers], 9 April $1892,470$.

22. Edwards, Pharaohs, 21-2.

23. Edwards, Pharaohs, 23-4.

24. On The RTS as a magazine publisher see Joseph McAleer, Popular Reading and Publishing in Britain, 1914-1950 (Oxford: The Clarendon Press, 1992), 205-43.

25. William M. F. Petrie, 'Rahotep and Nefert', Sunday at Home [British Periodicals] (1892), June 18: 526-7.

26. The Times, 'A New Race in Egypt', The Times Digital Archive, 18 April 1895, 9. See Challis, 2013: Ch. 8 for a discussion of Petrie's 'New Race' theory.

27. 'Chips', North-East Daily Gazette [19th Century British Library Newspapers], 20 April 1895.

28. Formally known as the British Association for the Advancement of Science, the British Association hosted annual meetings outside of London.

29. Debbie Challis, The Archaeology of Race: the eugenic ideas of Francis Galton and Flinders Petrie (London: Bloomsbury, 2013), 179-83.

30. As found in the 19th Century British Library database.

31. 'Mr Flinders Petrie's Egyptian Antiquities', The Times Digital Archive, 2 July 1888, 6. 'Egypt in Piccadilly', Daily News [19th Century British Library Newspapers], 23 June 1888, 3; 'Our London Correspondence', Glasgow Herald [19th Century British Library Periodicals], 13 July 1888, 7; 'Arrangements', Morning Post [19th Century British Library Newspapers], 28 June 1888, 5, 'Arrangements', Morning Post [19th Century British Library Newspapers], 2 July $1888,5$.

32. For a detailed history of the Egyptian Hall in the nineteenth century see Richard Altick, The Shows of London (Cambridge, MA: Belknap Press, 1978); see also Amara Thornton, 'The Egyptian Hall... Returns'. Last modified 1 December 2017: http://www.readingroomnotes. com/home/the-egyptian-hall-returns.

33. Petrie to Edwards, 28 June 1888, 3/1/PEN/35, Petrie Museum archives.

34. Petrie to Edwards, 1 August 1889, 3/1/PEN/45, Petrie Museum archives.

35. Petrie to Edwards, 1 August 1889, 3/1/PEN/45, Petrie Museum archives.

36. Petrie to Edwards, 14 October 1891, 3/1/PEN/61, Petrie Museum archives.

37. See Thornton, 'Exhibition Season'.

38. Charles Pascoe, London of To-Day (London: Simkin, Marshall, Hamilton, Kent \& Co Ltd, 1894), 268; Thornton, 'Exhibition Season'.

39. Petrie to Flaxman Spurrell, 29 March 1889, 2/1/SPU/168, Petrie Museum archives.

40. Petrie to Edwards, 26 September 1884: 3/1/PEN/11, Petrie Museum archives.

41. Petrie to Edwards, 26 September 1884: 3/1/PEN/11, Petrie Museum archives.

42. Petrie to Edwards, 7 October 1884: 3/1/PEN/13, Petrie Museum archives.

43. Petrie to Edwards, 28 June 1888: 3/1/PEN/15, Petrie Museum archives.

44. Petrie to Edwards, 12 July 1888: 3/1/PEN/35, Petrie Museum archives. Later on he was less concerned with the 'sort' of visitors who came to his displays; he recorded in Seventy Years in Archaeology that by the turn of the century workmen would visit his exhibitions during their lunch break (79). See also Challis, Race, 112-3.

45. Jonathan Silberstein Loeb, 'The Structure of the News Market in Britain, 1870-1914', Business History Review 83 (4) (2009).

46. Lee, Origins, 49.

47. Silberstein Loeb, 'Structure', 771-2.

48. Bob Nicholson, "'You Kick the Bucket; We Do the Rest!": Jokes and the Culture of Reprinting in the Transatlantic Press', Journal of Victorian Culture 17 (3) (2012), 274.

49. Donald Read, The Power of News: The History of Reuters (London: Oxford University Press, 1999), 1.

50. Read, News, 13, 24, 47, 62, 88, 97.

51. See John Garstang, Excavations at Meroe Sudan. Second Season, 1911. Guide to the Tenth Annual Exhibition of Antiquities Discovered (Liverpool: Institute of Archaeology, 1911), 8. In 2014 the British Museum produced a special 'Object in Focus' book on the Head of Augustus, briefly charting its history and legacy. See Thorsten Opper, The Meroe Head of Augustus (London: British Museum, 2014).

52. 'Excavation Work in the Sudan', The Times Digital Archive, 22 December 1910, 5.

53. 'Buried Nile City Unearthed', Gloucestershire Echo [British Newspaper Archive], 22 December 1910, 2; 'Discoveries in Egypt, Khartum', London Daily News [British Newspaper Archive], 
22 December 1910, 2; 'Exhuming a City', Dundee Courier [British Newspaper Archive], 24 December 1910, 6; 'Buried City of Meroe. Important Discoveries', Dublin Daily Express [British Newspaper Archive], 22 December 1910, 10.

54. Telegram ILN to Garstang, 22 December 1910, Meroe records, Garstang Museum archive, University of Liverpool. TGB3431 JG/7.

55. 'Professor John Garstang's Discoveries at Meroe', ILN Historical Archive, 10 June 1911, 892.

56. Artist A. Hugh Fisher's sketch of Salah was based on a painting by Garstang's artist-assistant Harold Jones. See 'Gifts from the Grave: Burial Relics Discovered in Upper Egypt', ILN Historical Archive, 16 July 1904, 89.

57. Ingram to Garstang [telegram], 27 June 1911, Meroe records, Garstang Museum archive, University of Liverpool.

58. 'At the Sign of St. Paul's', ILN Historical Archive, 12 August 1911, 272.

59. See Sidgwick to Garstang 12 June 1912, Meroe records, Garstang Museum archive, University of Liverpool; John Stobart, The Grandeur that was Rome (London: Sidgwick \& Jackson, 1912), plate 26.

60. Garstang to Editor of The Times, 15 May 1911; Article to The Times [draft], 22 May 1911, Meroe records, Garstang Museum archive, University of Liverpool; 'The Meroe Exhibition. Professor Garstang's Discoveries', The Times Digital Archive, 13 June 1911, 4.

61. Heslam to Garstang, 24 May 1911, Meroe records, Garstang Museum archive, University of Liverpool.

62. Garstang to the Editor, Evening Standard, 26 May 1911; Heslam to Garstang, 30 May 1911; undated Dictated MSS, Meroe records, Garstang Museum archive, University of Liverpool; 'A Buried City. Fascinating Story of the Soudan. Ancient Sacrificial Rites. (Special Interview)', Evening Standard \& St James's Gazette, 3 June 1911.

63. Editor of Nature to Garstang, 18 June 1911, Meroe records, Garstang Museum archive, University of Liverpool.

64. See, for example [Advertisement for Combined Circular Tours], The Scotsman [British Newspaper Archive], 13 October 1911, 10; Arthur Bull to Garstang, 1, 6, 9 June 1911; Garstang to Bull, 15, 25 May 1911; Arthur Bull to Garstang, 20 July 1911. A draft outline of the guidebook is included in Garstang's Meroe papers, Meroe records, Garstang Museum archive, University of Liverpool.

65. 'Queen Candace's Ancient Capital. The Royal City of Meroe to be Excavated', Nottingham Journal [British Newspaper Archive], 9 January 1914, 4; Weinthal, Fascinating, 246-7.

66. See Leo Weinthal, ed., 'Attractions for Tourists in the Sudan', in Egypt and Sudan Annual. Season 1922-1923 (London: African World, 1922), 121; Leo Weinthal, ed., 'Sudan of the Ancients', in Egypt and the Sudan Annual. Season 1923-1924 (London: African World, 1923), 122; Sudan Department of Railways and Steamers, Handbook of the Sudan Government Railways and Steamers (London: Office of the European Traffic Manager, 1924), 28.

67. Garstang, Excavations, 3.

68. Stevens, Sudan Year, 10. See also Thornton, 'Mills \& Boon....And Meroe'. Last modified 1 December 2017: https://www.readingroomnotes.com/home/mills-boon-and-mero.

69. Nettie F. Dietz, A White Woman in a Black Man's Country (Omaha, NE: privately printed, 1926), 47.

70. F. Sidgwick to Garstang, 12 June 1912, Meroe records, Garstang Museum archive, University of Liverpool.

71. Petrie to Spurrell, 21 February 1891, 2/1/SPU/176, Petrie Museum archive.

72. Former ILN archaeology editor Edward Bacon's 1976 book The Great Archaeologists and their discoveries as originally reported in the pages of the Illustrated London News (London: Secker \& Warburg, 1976) charts the history of ILN archaeology reporting. Austen Henry Layard's explorations in Mesopotamia were frequently reported in the ILN during the 1840s and 1850s, see Bacon, Great, 17. See also Challis, Harpy Tomb for analysis of the Illustrated London News' role in promoting archaeology in the mid-Victorian period.

73. Along with other Section Presidents of the 1907 British Association conference, Hogarth had first been profiled in the paper a few years before. See 'Portraits and the World's News', ILN Historical Archive, 3 August 1907, 157.

74. For details on portraiture and celebrity creation see Janet Browne's discussion of Elliot \& Fry's photographs of Charles Darwin: 'Looking at Darwin Portraits and the Making of an Icon', Isis 100 (3) (2009).

75. See, for example, Hogarth to Macmillan, 18 October 1911, Macmillan Archive, BL. 
76. David Hogarth, 'The Remodelling of History \& the Realisation of Legend IV: The Empire of the Hatti', ILN Historical Archive, 3 June 1911; Garstang to ILN Editor, 3 June 1911; Garstang to W. M. Meredith, 3 June 1911; Bruce Ingram, ILN to Garstang, 6 June 1911, Meroe records, Garstang Museum archive, University of Liverpool.

77. 'The Empire of the Hatti', ILN Historical Archive, 10 June 1911, 886.

78. "Men Who Perform the "Spade Work" of History: British Names Famous in the Field of Archaeology', ILN Historical Archive, 10 March 1923, 390-1.

79. Alan J. B. Wace, 'Twenty-Five Years of Archaeology', ILN Historical Archive, 17 April 1935, 558, Pl.XIII; 'Explanatory Index', ILN Historical Archive, 17 April 1935: v-vi.

80. Janet Hogarth and J. Malcolm Mitchell, 1911, 'Preface', in Encyclopaedia Britannica: a dictionary of arts, sciences, literature and general information (11th Edn), Vol. 29: Index, ed. Hugh Chisholm (Cambridge: Cambridge University Press, 1911), v; 'Encyclopaedia Britannica Eleventh Edition', Wikipedia [online]. Last modified 1 December 2017: https://en.wikipedia. org/wiki/Encyclop\%C3\%A6dia_Britannica_Eleventh_Edition. See also Bowler, Science, Ch. 8 for a discussion of $E B$ in relation to science.

81. Gillian Thomas, A Position to Command Respect: women and the eleventh Britannica (Metuchen, NJ: Scarecrow Press, 1992), 1.

82. Janet Hogarth and J. Malcolm Mitchell, 'Preface', EB11 Index, Vol. 29 (Cambridge: Cambridge University Press, 1911), v.

83. 'Prefatory Note', in Encyclopaedia Britannica: a dictionary of arts, sciences, literature and general information (11th Edn), Vol. 1: A to Androphagi, ed. Hugh Chisholm (Cambridge: Cambridge University Press, 1911): viii-x; see also Thomas, Position for a summary of the history of the EB 1911.

84. 'Prefatory Note' in Encyclopaedia Britannica: a dictionary of arts, sciences, literature and general information (11th Edn), Vol. 1: A to Androphagi, ed. Hugh Chisholm (Cambridge: Cambridge University Press, 1911), ix.

85. See Thomas, Position, 9-15; Gillian Thomas, 'Hogarth, Janet Elizabeth (1865-1954)', Oxford Dictionary of National Biography [online edn] (Oxford: Oxford University Press, 2004-16).

86. Chisholm, 'Prefatory Note', xv, xvi, xix.

87. Thomas, Position, 6-7; see 16-17 for a discussion of the difference in British and American expectations for the scholarship of the Encyclopedia.

88. 'List of Contributors' in EB11, Vol. 29. See also Thomas, Position for the role of women in the EB11. She notes that many more than were included in the List of Contributors wrote uncredited articles for the compendium and played a critical role in creating the index.

89. David G. Hogarth, 'Aegean Civilization', in Encyclopaedia Britannica: a dictionary of arts, sciences, literature and general information (11th Edn), Vol. 1: A to Androphagi, ed. Hugh Chisholm (Cambridge: Cambridge University Press, 1911): 245-51.

90. Percy Gardner, 'Greek Art', in Encyclopaedia Britannica: a dictionary of arts, sciences, literature and general information (11th Edn), Vol. 12: Gichtel to Harmonium, ed. Hugh Chisholm. (Cambridge: Cambridge University Press, 1911: 470-92).

91. 'Egypt: Ancient Egypt', in Encyclopaedia Britannica: a dictionary of arts, sciences, literature and general information (11th Edn), Vol. 9: Edwardes to Evangelical Association, ed. Hugh Chisholm. (Cambridge: Cambridge University Press, 1911): 39-90.

92. 'Initials and Headings. List of Contributors', in Encyclopaedia Britannica: a dictionary of arts, sciences, literature and general information (11th Edn), Vol. 8: Demijohn to Edward, ed. Hugh Chisholm (Cambridge: Cambridge University Press), viii. She is actually credited as co-author with D. G. Hogarth, who is listed first.

93. Chisholm, 'Prefatory Note', xxii-xxiii.

94. Thomas, Position.

95. Mitchell and Hogarth, 'Preface', 879-80.

96. Ramsay had recently collaborated with Gertrude Bell on the production of a book on early Christian sites, The Thousand and One Churches.

97. 'Petrie, William Matthew Flinders', in Encyclopaedia Britannica: a dictionary of arts, sciences, literature and general information (11th Edn), Vol. 21: Payn to Polka, ed. Hugh Chisholm (Cambridge: Cambridge University Press, 1911), 316.

98. 'The New Encyclopaedia Britannica. A Historic Compilation', Scotsman [British Newspaper Archive], 20 January 1911, 7; 'A Great Book. Wonders of the New Encyclopaedia. Simultaneous Issue. 29 Volumes: 27,000 Pages', London Daily News [British Newspaper Archive], 20 January $1911,5$. 
99. Thomas, Position, 11-12, 14-15.

100. [Advertisements], London Daily News [British Newspaper Archive], 25 April, 4 May 1911.

101. For example [Advertisements], London Daily News [British Newspaper Archive], 21 February 1912, 5 and 22 February 1912, 5.

102. Thomas, Position, 7.

103. [Advertisements], London Daily News, 1 February 1911, 7.

104. London Daily News, 21 and 22 February 1912.

105. See Bowler, Science, Ch. 8 for a discussion of science compendiums and serial publications.

106. Founder and editor of the Daily Mail and the Daily Mirror, later buying the Observer. See D. George Boyce, 'Harmsworth, Alfred Charles William, Lord Northcliffe (1865-1922)', Oxford Dictionary of National Biography (Oxford University Press, 2004-16). The house of Harmsworth has been credited with playing a major role in transforming 'popular journalism' through innovative approaches to advertising. See Peter Broks, Media Science Before the Great War (London: Macmillan Press, 1996), 15.

107. See Bowler, Science, Ch. 8 for a discussion of Harmsworth/Amalgamated Press in relation to science publishing.

108. See John Hammerton, 'From a "Fleetway" Window: Random Remarks by the Editor', Wonders of the Past, Part 5 (15 May 1923). This observation was later reprinted in a 1930s edition of Wonders. See John Hammerton, 'From the Editor's Desk: Chats about "Wonders of the Past", Wonders of the Past, Part 6 (7 December 1933).

109. The Harmsworth History of the World was revised just before the outbreak of war in 1914, in a new edition running to 15 volumes. See John Hammerton, Books and Myself: memoirs of an editor (Macdonald \& Co Ltd, 1944), 255. On Educational Book Co see 'News Notes', Bookman 38 (233) (April 1910), 5

110. Hammerton, Books, 194; [Advertisement for Harmsworth History of the World], The Leeds and Yorkshire Mercury [British Newspaper Archive], 9 October 1907, 6.

111. Hammerton, Books, 194.

112. Hammerton, Books, 195.

113. 'The Book of History', in The Book of History: A History of all Nations from the earliest times to the present, ed. John Hammerton et al. (London: Educational Book Company, 1915), 2.

114. See for example, 'A $£ 30,000$ History of the Nations. The Past as a Living Present. 2,500 Fine Pictures', Daily Mirror [British Newspaper Archive], 29 January 1914, 11.

115. Hutchinson, Walter, 'Introduction', in Hutchinson's History of the Nations: a popular, concise, pictorial and authoritative account of each nation from the earliest times to the present day, ed. Walter Hutchinson (London: Hutchinson \& Co, 1914), ii.

116. Harmsworth's History featured the work of French illustrator Andre Castaigne.

117. See for example ' $£ 30,000$ History'.

118. ' $£ 30,000$ History'; on Winifred Brunton see Alice Stevenson, 'Winifred Brunton: Hard Working Winnie!' Last modified 1 December 2017: http://trowelblazers.com/winifredbrunton./; Session Fees Book 1900-1, University College London Special Collections.

119. [Advertisement], Birmingham Mail [British Newspaper Archive], 17 February 1914, 2.

120. For example 'Reviews of New Books', Birmingham Daily Post [British Newspaper Archive], 18 February 1914, 4; [Advertisement for History of the Nations], Evening Dispatch [British Newspaper Archive], 10 March 1914, 3.

121. See Hammerton, Books, 278.

122. See, for example, 'Gallery of Contributors' and 'Editorial', Peoples of All Nations: Their Life Today and the Story of Their Past, Vol.1 (London: Amalgamated Press).

123. Hammerton, Books, 278.

124. Hammerton, Books, 273.

125. Hammerton, Books, 273.

126. Hammerton, Books, 272.

127. Hammerton, Books, 305-6.

128. Hammerton, Books, 306.

129. Hammerton, 'Wonders of the Past: The Endless Romance of Antiquity. How the Dead Past is Made to Live Again', in Wonders of the Past (New edition), Vol.1, edited by John Hammerton (London: Amalgamated Press (1923 [1933])), 1.

130. The original fortnightlies were bound and offered in three volumes in this first British edition and four volumes in the first US edition - which, according to Hammerton, was reprinted several times. The second edition of Wonders was serialised in the 1930s and eventually made into a two-volume work. See Hammerton, Books, 307. 
131. See for example Francis Ll. Griffith, 'Bibliography 1922-1923: Ancient Egypt', Journal of Egyptian Archaeology 9 (3/4) (1923), 202.

132. Hammerton, Wonders, Vol.1. Volume 2 features a portrait of A. H. Sayce in front of the Ishtar gate of Babylon, while Volume 3 begins with a portrait of William Mitchell Ramsay.

133. See Jessie Mothersole, 'Tomb Copying in Egypt', Sunday at Home (1908).

134. Jessie Mothersole, Hadrian's Wall (London: John Lane/Bodley Head, 1922); Mothersole, 'Hadrian's Wall: Relic of Roman Britain', in Wonders 1; Hammerton, Wonders 1, 2; Hammerton, Books, 306-7.

135. John Hammerton, 'From a "Fleetway" Window: Random Remarks by the Editor', Wonders of the Past, Part 18 (1923).

136. 'By Air to Le Touquet', The Times Digital Archive, 31 July 1933, 10.

137. See, for example, 'First Flight at Age of 80. Sir Flinders Petrie's Enthusiasm. Famous Archaeologist Going to Palestine By Air', Dundee Evening Telegraph [British Newspaper Archive], 17 July 1933, 7; 'Air-Minded, at 80. Famous Archaeologist's First Flight. The Gaza Excavations', Hartlepool Mail [British Newspaper Archive], 17 July 1933: 2; 'Off to Gaza by Air in August. Sir Flinders Petrie's Plans. The "Clapham Junction" of the Ancient World', Nottingham Evening Post [British Newspaper Archive], 17 July 1933, 3; 'Air-Minded' at 80. Sir Flinders Petrie's First Plane Trip. "Better Than A Camel”', Sunderland Daily Echo and Shipping Gazette [British Newspaper Archive], 17 July 1933, 5; 'Sir F. Petrie is Air-Minded Now. His First Flight at 80. Gaza - By Plane', Gloucester Citizen [British Newspaper Archive], 17 July 1933, 11.

\section{Chapter 5}

1. Petrie to Spurrell, 23 April 1890 2/1/SPU/173, Petrie Museum archives.

2. Petrie to Spurrell, 23 April 1890, 2/1/SPU/173, Petrie Museum archives.

3. Petrie to Spurrell, 23 April 1890, 2/1/SPU/173, Petrie Museum archives.

4. Petrie, Ten Years', 1.

5. Petrie to Spurrell, 23 April 1890, 2/1/SPU/173, Petrie Museum archives. On archaeologists and Arabic language see Rachel Mairs and Maya Muratov, Archaeologists, Tourists, Interpreters: Exploring Egypt and the Near East in the late 19th-early 20th centuries. (London: Bloomsbury, 2015)

6. Petrie, Ten Years', 167.

7. Petrie to Spurrell, 23 April 1890, 2/1/SPU/173, Petrie Museum archives. Petrie, Ten Years', 1.

8. Petrie to Spurrell, 28 March 1891, 2/1/SPU/178; Petrie to Spurrell, 23 September 1891, 2/ 1/SPU/273; Petrie to Spurrell, 19 December 1891, 2/1/SPU/179, Petrie Museum archives. See for example 'Religious Tract Society's List', The Times Digital Archive, 1 July 1892, 10.

9. Aileen Fyfe, 'Periodicals and Book Series: Complementary Aspects of a Publisher's Mission', in Culture and Science in the Nineteenth Century Media, ed. Louise Henson et al. (Aldershot: Ashgate, 2004), 72. For an overview of publishers' series related to popular science see Bowler, Science, Ch. 7.

10. Aileen Fyfe, Science and Salvation: evangelical popular science publishing in Victorian Britain (Chicago; London: University of Chicago Press, 2004), Ch. 1.

11. Ernest A. W. Budge, Cleopatra's Needles and other Egyptian Obelisks ... (London: Religious Tract Society, 1926): v; see also Fyfe, Science, 78-9.

12. See Religious Tract Society, 185-, 'The Monthly Volume' [advertisement], in Ancient Egypt: its monuments and history. Last modified 1 December 2017: https://babel.hathitrust. org/cgi/pt?id=hvd.ah4yut;view=1up;seq=6.

13. Fyfe, Science, Ch. 2. As Fyfe charts, the Monthly Series ceased publication in the 1850s, but was retained in the RTS catalogue until the 1880s. Science, 72-3; Budge, Cleopatra's, vi. The RTS eventually began to change this policy for some better-known writers. See Fyfe, Science, 170.

14. Budge, Cleopatra's, vi-ix.

15. See Religious Tract Society, 'By-Paths of Bible Knowledge', in James King, Cleopatra's Needle: A History of the London Obelisk, with an Exposition of the Hieroglyphs. Last modified 1 December 2017: https://archive.org/stream/cleopatrasneedle00king\#page/128/mode/2up.

16. Budge, Cleopatra's, vii.

17. Fyfe, Science, Ch. 4.

18. Executive Committee and Copyright Sub-Committee members appointed in May 1883, around the time of the publication of the first 'By-Paths' book, appear as readers listed in Copyright Committee reports in Executive Committee minutes. Executive Committee 
Minutes, 8 May 1883, USCL/RTS FBN 9, Religious Tract Society (RTS) archive, School of Oriental and African Studies (SOAS).

19. RTS 1883; See Executive Committee Minutes, 20 March 1883; 25 September 1883; 20 November 1883; 2 January 1884, USCL/RTS FBN9, RTS Archive, SOAS. On Margaret Harkness see Deborah Mutch and Terry Elkiss, 'Biography of Margaret Harkness', in A City Girl by John Law (Margaret Harkness), ed. Deborah Mutch (Brighton: Victorian Secrets, 2015). Thanks to Terry Elkiss for further evidence of Harkness's course of lectures on Assyrian antiquities and cuneiform. These were advertised in the Englishwoman's Review alongside Jane Harrison's Greek lectures. See 'Lectures by Ladies at the British Museum', Englishwoman's Review [19th Century British Periodicals], 14 October 1882, 464. Harkness joined the British Museum Reading Room in 1880 and began lecturing in 1882, continuing until 1884 (see A4788/3098, Readers Admission Book 1880-1888, British Museum Central Archive). A lengthy review of her first 'By-Paths' book appeared in the St James's Gazette. 'Assyrian Life and History', St James's Gazette [19th Century British Periodicals], 9 October 1883, 6-7.

20. Archibald H. Sayce, Fresh Light from the Ancient Monuments [By-Paths of Bible Knowledge II] (London: Religious Tract Society, 1900), 2.

21. Sayce, Reminiscences, 226. In his memoir Sayce also briefly discusses other books he published in the By-Paths series: Social Life of the Assyrians, The Hittites and Races of the Old Testament, see Reminiscences, 272-3. A 1900 edition of Fresh Light from the Ancient Monuments is in the Palestine Exploration Fund library.

22. Later advertisements renumbered the works, removing, among others, Harkness's volumes. See for example Religious Tract Society, 1905, 'By-Paths of Bible Knowledge', in The Bible and Babylon: Their Relationship in the History of Culture. Last modified 1 December 2017: https://archive.org/stream/thebibleandbabyl00koniuoft\#page/n145/mode/2up. Challis has analysed Sayce's 'By-Paths' book Races of the Old Testament and Sayce's racism as communicated to readers of the series. The legacy of racism in Sayce's work, she notes, continues today. The book, out of print for decades, is now available online. See Race, 138-44.

23. See Religious Tract Society, 'Present Day Primers', in Early Church History (London: Religious Tract Society, 1894). Last modified 1 December 2017: https://archive.org/stream/ earlychurchhisto00bart\#page/n1/mode/2up; Archibald H. Sayce, Primer of Assyriology (London: Religious Tract Society, 1894).

24. Society for Promoting Christian Knowledge. 'Ancient History from the Monuments' [Advertisement], in A History of Babylonia (London: Society for Promoting Christian Knowledge), 18-. Last modified 1 December 2017: https://archive.org/stream/historyof babylon00smitiala\#page/n199/mode/2up. 'The Reader', The Graphic [British Newspaper Archive], 29 May 1875, 13-14; 'The Society for Promotion of Christian Knowledge', Leamington Spa Courier [British Newspaper Archive], 28 August 1875, 9; Samuel Birch, Egypt from the earliest times to BC 300 (London: Society for Promoting Christian Knowledge, 1890).

25. The Egyptian and Assyrian Department's scholarly works, comprising transliteration, translation and analysis of ancient texts, appeared in the Semitic Series of Luzac \& Co, located close to the British Museum on Great Russell Street in Bloomsbury.

26. See Gillian Furlong, The archives of Routledge and Kegan Paul Ltd (1853-1973) (London: the Library, University College London, 1978), 5-7.

27. See, for example 'Publisher's Note', in Egyptian Ideas of the Future Life [Books on Egypt and Chaldea]. London: Kegan Paul, Trench, Trubner \& Co Ltd. Last modified 1 December 2017: https://archive.org/details/egyptianideasoffoobudguoft.

28. 'Forthcoming Books', London Daily News [British Newspaper Archive], 31 July 1901, 6. Budge and Charles Kegan Paul were acquainted through mutual membership of the Savile Club, see Ismail, Budge, 183-4. It is perhaps the reason why Kegan Paul published the series which featured Budge so prominently.

29. See Roger Luckhurst, The Mummy's Curse: The True History of a Dark Fantasy (Oxford: Oxford University Press 2012), 137-51 on Budge and his engagement with the magical and occult elements of ancient Egyptian culture within the context of Victorian interest in spiritualism, theosophy and the occult. Ismail (2011: Ch. 25) also discusses this topic. See Ernest A. Wallis Budge, 'Preface', in The Chapters Coming Forth By Day or The Theban Recension of the Book of the Dead (second edn) (London: Kegan Paul, Trench, Trubner \& Co, 1910).

30. Eugénie Strong, Roman Sculpture from Augustus to Constantine, 2 vols (London: Duckworth, 1907); Ernest Gardner, Six Greek Sculptors (London: Duckworth, 1910); 'Library of Art', 
in Pisanello (London: Duckworth) (Ch. 6). Last modified 1 December 2017: https://archive. org/stream/pisanellobygfhil00hill\#page/n467/mode/2up. See Steven Dyson, Eugénie Sellers Strong: Portrait of an Archaeologist (London: Duckworth, 2004) Ch. 3 on Sellers' London lectures and relationship with Jane Ellen Harrison, and Ch.7 for Sellers' work on the Library of Art. See Prefaces in Strong, Sculpture; Gardner, Sculptors.

31. See Ian Elfick and Paul Harris, T. N. Foulis, the history and biography of an Edinburgh publishing house (New Castle, Delaware; London: Oak Knoll Press \& Werner Shaw Ltd, 1998); William M. F. Petrie, The Arts and Crafts of Ancient Egypt (Edinburgh \& London: T. N. Foulis, 1909) [Advertisement], in Arts and Crafts of Ancient Egypt. Last modified 1 December 2017: https://archive.org/stream/artscraftsofanci1910petr\#page/n271/mode/2up. Foulis's London office was on Great Russell Street, near the British Museum's entrance.

32. William M. F. Petrie, The Arts and Crafts of Ancient Egypt (2nd edn) (Edinburgh \& London: T. N. Foulis, 1910), 156-7.

33. 'Obituary. Mr. P. H. Lee Warner', The Times Digital Archive, 30 January 1935, 7; Ernest A. W. Budge, Osiris and the Egyptian Resurrection (London: Lee Warner, 1911), The Papyrus of Ani. A Reproduction in Facsimile (London: Lee Warner, 1913), The Queen of Sheba and her only son Menyelck (London: Medici Society, 1922), Legends of Our Lady Mary the Perpetual Virgin... (London: Medici Society, 1922), One Hundred and Ten Miracles of Our Lady Mary... (London: Medici Society 1923). Budge discusses Philip Lee Warner in Rise, 176; Thomas A. Joyce, South American Archaeology: An Introduction ... (London: Medici Society Ltd., 1912), Mexican Archaeology: An Introduction... (London: Philip Lee Warner, 1914), Central American and West Indian Archaeology... (London: Philip Lee Warner, 1916); Percy Handcock, Mesopotamian Archaeology (London: Macmillan/Philip Lee Warner, 1912); Lionel Barnett, Antiquities of India... (London: Philip Lee Warner, 1914); Harry R. Hall, Aegean Archaeology: an Introduction... (London: Philip Lee Warner, 1915); Budge, Rise, 181-2; information on the Joyce, Handcock, Barnett and Hall positions at the British Museum is from Whitaker, Almanack 1911, 192.

34. Bryan W. Blouet, 'Mackinder, Sir Halford John (1861-1947)', Oxford Dictionary of National Biography [online edn] (Oxford University Press, 2004-16); David G. Hogarth, The Nearer East (London: William Heinemann, 1902); see for example 'The Nearer East. Creeds and the Iron Horse', Daily News [British Newspaper Archive], 14 March 1902, 8. On developments in geography and the Regions of the World series see 'The Regions of the World', Geographical Teacher 1 (3) (1 June 1902).

35. On Keltie see Michael J. Wise, 'The Scott Keltie Report 1885 and the Teaching of Geography in Great Britain', Geographical Journal 152 (3) (1986), 367-8. The series was later taken over by the publishers Alston Rivers Limited, who reissued the four original volumes and commissioned additional ones for the series. See Bookman, 'News Notes', Bookman [British Periodicals] 29 (169) (October 1905), 3. J. Scott Keltie, 'The Story of Exploration', in The Nile Quest: A Record of the Exploration of the Nile and its Basin (London: Lawrence and Bullen, 1903).

36. See [Advertisements], Academy [British Periodicals], 11 November 1905, 1163; David G. Hogarth, The Penetration of Arabia: a record of the development of western knowledge concerning the Arab peninsula (London: Alston Rivers Ltd, 1904). See also Priya Satia, Spies in Arabia: The Great War and the Cultural Foundations of Britain's Empire in the Middle East (Oxford: Oxford University Press, 2008) for an analysis of the importance of publishing on 'Arabia' for understanding the cultural background of intelligence work during the First World War; 'Science: The Penetration of Arabia', Athenaeum (4000) [British Periodicals], 25 June 1904, 822.

37. 'Dr S. A. Kapadia', The Times Digital Archive, 13 March 1941, 7; 'Mr. L. A. Cranmer-Byng', The Times Digital Archive, 22 January 1945, 6; 'New Editions', Graphic [British Newspaper Archive], 24 December 1904, 866; 'Library Table', Western Times [British Newspaper Archive], 7 February 1905, 3. See Cranmer-Byng and Kapadia's 'Series and Purpose' notice in Margaret A. Murray, Ancient Egyptian Legends (London: John Murray, 1920).

38. For the story of British Museum mummy no.22522, also known as the 'Unlucky Mummy', see Luckhurst, Mummy, Ch.2; Murray, Legends, 7-8.

39. See Luckhurst, Mummy, Ch.6. On Gunn, see Steve Vinson and Janet Gunn, 'Studies in Esoteric Syntax: the enigmatic friendship of Aleister Crowley and Battiscombe Gunn', in Histories of Egyptology: Interdisciplinary Measures, ed. William Carruthers (London: Routledge, 2015); Sheppard in Murray analyses Murray's Ancient Egyptian Legends and Ancient Egyptian Religious 
Poetry in detail (Ch 6). In 1926 Murray published Egyptian Poems, a slim volume of ancient Egyptian poetry translated into English, with the London publisher Arthur Stockwell.

40. 'Minor Books', Scotsman [British Newspaper Archive], 19 February 1906, 3. See, for example, William M. F. Petrie, The Religion of Ancient Egypt (London: Archibald Constable \& Co Ltd, 1906); Jane E. Harrison, The Religion of Ancient Greece (London: Archibald Constable \& Co, 1905). A list of the series can be found in 'Religions: Ancient and Modern', in The Religion of Ancient Greece. Last accessed 2 December 2017: https://archive.org/details/ religionofancien00harriala.

41. See 'Harper's Library of Living Thought', Athenaeum [British Periodicals], 23 January 1909, 91.

42. See series advertisements, 'Harper's Library of Living Thought', in Revolutions of Civilisation (3rd edn). Last modified 2 December 2017: https://archive.org/stream/revolutionsofciv 00petruoft\#page/n153/mode/2up; Christopher Hawes and Harriet B. Hawes, Crete, the Forerunner of Greece (London: Harper \& Brothers, 1909); Ernest Gardner, Religion and Art in Ancient Greece (London: Harper \& Brothers, 1910); Grafton Elliot Smith, The Ancient Egyptians and their Influence upon the civilization of Europe (London: Harper \& Brothers, 1911); William M. F. Petrie, Personal Religion in Egypt (London: Harper \& Brothers, 1909) and The Revolutions of Civilisation (London: Harper \& Brothers, 1911). See Gange, Dialogues and Challis, Race for a detailed analysis of Elliot Smith's and Petrie's texts. Other contributors to the series included the Russian novelist Leo Tolstoy and the English poet Algernon Charles Swinburne.

43. Adrian Room, 'Harrap, George Godfrey (1868-1938)', Oxford Dictionary of National Biography [online edn] (Oxford University Press, 2004-15); Mabel A. Brown, 'A Scheme of Correlated History and Literature', The Practical Teacher [British Periodicals] 31 (1) (1910), 68; Harry R. Hall, Threshold of History (London: Harrap, 1914), 5.

44. See Harry R. Hall, Days Before History (London: Harrap, 1927); see 'Fiction: Days Before History', Dundee Courier [British Newspaper Archive], 12 January 1907, 6. The first edition of Days was reprinted in 1907, 1909, 1911, 1912, 1913, 1914, 1915, 1917, 1919 and twice in 1920. It was enlarged and revised, first in 1908 and second in 1927; see Hall, Threshold (1918 edn), 6-7; Hall Threshold (1914 edn).

45. See Wheeler to O. G. S. Crawford, 10 June 1956. MS Crawford 57/156-7, Papers of O. G. S. Crawford, Bodleian Libraries, University of Oxford. I am grateful to Martyn Barber for alerting me to this valuable correspondence.

46. On archaeological television see Timothy Clack and Marcus Brittain, (eds) Archaeology and the Media (Walnut Creek, CA: Left Coast Press, 2007); Ray Sutcliffe (ed.), Chronicle: Essays from ten years of television archaeology (London: British Broadcasting Corporation, 1978). Sara Perry has recently charted the early history of archaeological television in the 1930s, and in particular the role of women in this history. See Sara Perry, 'Archaeology on Television, 1937', Public Archaeology (2017). Margaret Wheeler, Mortimer Wheeler and Kathleen Kenyon had appeared in a special episode of Buried Treasure on Jericho in 1956.

47. 'Cassell \& Company [Advertisement]', The Times Literary Supplement Historical Archive, 16 August 1957, 500.

48. Wheeler to Crawford, 14 June 1956, MS Crawford 57/165-6, Bodleian Libraries.

49. Wheeler to Crawford, 10 June 1956, MS Crawford 57: 156-7, Bodleian Libraries.

50. Wheeler to Crawford, 14 June 1956, MS Crawford 57/165-6; Wheeler to Crawford, 17 June 1956: MS Crawford 57/175, Bodleian Libraries.

51. Margaret C. Wheeler, A Book of Archaeology (London: Cassell, 1957). On Kenyon see Mariam Davis, Dame Kathleen Kenyon: digging up the Holy Land (Walnut Creek, CA: Left Coast Press, 2008). Kathleen Kenyon published her own book, Digging Up Jericho, with Ernest Benn in 1957. See also Margaret C. Wheeler, A Second Book of Archaeology (London: Cassell, 1959).

52. 'Mr Geoffrey Bles', The Times Digital Archive, 8 April 1957, 14.

53. See Amara Thornton, 'Archaeology for Children'. Last modified 2 December 2017: http:// www.readingroomnotes.com/home/archaeology-books-for-children; Jessica Mitford, 'Egyptomania', in Jessica Mitford, Poison Penmanship: the gentle art of muckraking (New York: New York Review of Books, 1979 [2010]), 247-8; the other two were a 1929 Baedeker and Agatha Christie's Death on the Nile. Mary Chubb, An Alphabet of Ancient Egypt (London: Geoffrey Bles, 1966), 16-17; 20-3; 36-7.

54. Mary Chubb, An Alphabet of Assyria and Babylonia (London: Geoffrey Bles, 1969), 20; Mary Chubb, Alphabet of Ancient Greece - Part 1 (London: Geoffrey Bles, 1967), 18-19, 30-1, 34-5, 46-9. 
55. See Eric Glasgow, 'The Origins of the Home University Library', Library Review 50 (2) (2001), 95.

56. 'Books for the People. A Great Experiment in Popular Education', London Daily News [British Newspaper Archive], 30 March 1911, 2; 'The World of Books. Speakers of the House of Commons. Home University Library etc.', Bath Chronicle and Weekly Gazette [British Newspaper Archive], 30 March 1911, 8.

57. Bowler, Science, 129, 134; 'Thornton Butterworth Limited', Aberdeen Journal [British Newspaper Archive], 12 January 1928, 3; 'Home University Library', Berwick Advertiser [British Newspaper Archive], 19 March 1936, 3.

58. John L. Myres, The Dawn of History (London: Williams \& Norgate, 1911); 'Home University Library of Modern Knowledge [Catalogue]', in The Negro (New York: Henry Holt \& Co). Last modified 2December 2017: https://archive.org/stream/negro00dubo\#page/n261/mode/2up; 'The Home University Library of Modern Knowledge', in The Dawn of History (London: Williams \& Norgate). Last modified 2 December 2017: https://archive.org/stream/dawnofhistory00myreuoft\#page/ 256/mode/2up; Home University Library of Modern Knowledge [Catalogue]', in Warfare in England (London: Thornton Butterworth). Last modified 2 December 2017: https://archive.org/ stream/warfareinengland00belluoft\#page/n259/mode/2up.

59. On Gowan's International Library see 'Recent Publications', Edinburgh Evening News [British Newspaper Archive], 30 June 1906, 4.

60. See Bowler, Science, 136-8.

61. Ruth Edwards, Victor Gollancz: a biography (London: Victor Gollancz, 1987), 144, 149.

62. See Folder of Agreements, ACB/B/5/1/4-6; Copy of Memorandum of Agreement between Edwyn Bevan and Victor Gollancz, 10 August 1926, ACB/B/5/1/4, A. \& C. Black archive, Reading University Publishing archive. A. \& C. Black acquired Benn in 1984.

63. Copy of Memorandum of Agreement between Professor J. A. K. Thomson and Ernest Benn, 27 January 1928; Copy of Memorandum of Agreement between Stanley Casson and Ernest Benn, 27 March 1930, ACB/B/5/1/4, A. \& C. Black archive: Reading University.

64. Benn Books, 1928 - ACB/B/5/4/1/5, A. \& C. Black archive, Reading University.

65. Casson, Archaeology.

66. See Desmond Flower, 'Paperbacks: A Revolution in Publishing', [Supplement], The Times Digital Archive, 19 May 1960, 29; John Benn, 'Paperbacks Pioneer', The Times Digital Archive, 25 May 1960, 13.

67. Through the Keystone Library, Thornton Butterworth offered readers reprinted books in a variety of genres: history, travel, 'belles lettres' and memoirs. These are listed on the dust jacket for the Keystone Library edition of Weigall's Glory of the Pharaohs (1936).

68. Hankey, Passion, 110-11.

69. See Arthur Weigall, Travels in the Upper Egyptian Deserts (London: William Blackwood \& Sons, 1909); Hankey, Passion, 98-9, 102.

70. Weigall, Treasury. The magazines were: Blackwood's, Putnam's, Pall Mall and Century. See 'By the Same Author [Advertisement]', in Arthur Weigall, The Life and Times of Akhnaton Pharaoh of Egypt. Last accessed 5 December 2017: https://archive.org/stream/ lifetimesofakhna00weig\#page/n5/mode/2up.

71. Arthur Weigall, The Life and Times of Akhnaton Pharaoh of Egypt (London: William Blackwood, 1911). See Weigall's 1922 Preface to the new edition for publishing history (Weigall, Akhnaton 1934); Hankey, Passion, 118, 139. Financed by American millionaire Theodore Davis, British archaeologist Edward Ayrton directed the excavation that uncovered a mummified body in Valley of the Kings tomb KV55; this was assumed at the time to be that of Akhenaten (Amenhotep IV).

72. Hankey, Passion, 139. The magazines were: Blackwood's, Century and Quarterly Review.

73. Arthur Weigall, The Life and Times of Cleopatra, Queen of Egypt (London: William Blackwood, 1914), xv.

74. Arthur Weigall, A History of Events in Egypt from 1798 to 1914 (London: William Blackwood, 1915); Hankey, Passion, 142-3, 149-51. Roosevelt's comments, originally published in the periodical The Outlook, were featured in a special 'Publisher's Foreword' on Weigall's popularity as a writer in The Glory of the Pharaohs. Arthur Weigall, The Glory of the Pharaohs (London: Thornton Butterworth, 1924 [1936]), 10. See Hankey, Passion, Chs 16-19; for Weigall as film critic and scriptwriter, see Laura Marcus, "Hieroglyphics in motion": representing ancient Egypt and the Middle East in film theory and criticism of the silent period', in The Ancient 
World in Silent Cinema, ed. Pantelis Michelakis and Maria Wyke (Cambridge: Cambridge University Press, 2013).

75. See Hankey, Passion, Chs 19-20 (especially 276-7); Weigall, Glory, Arthur Weigall, Tutankhamun and other Essays (London: Thornton Butterworth, 1923), 9. These British archaeology publications include Wanderings in Roman Britain (Thornton Butterworth, 1926), Wanderings in Anglo-Saxon Britain (Hodder \& Stoughton, 1927) and The Grand Tour of Norman England (Hodder \& Stoughton, 1927). See Hankey, Passion, 304-5.

76. McAleer, Popular, 14-15. McAleer notes that free library borrowers were generally not working class (Popular, 22). On commercial circulating libraries in the twentieth century, particularly Boots' and its impact on fiction publishing, see Nicola Wilson, 'Boots Book-lovers' Library and the Novel: The Impact of a Circulating Library Market on Twentieth-Century Fiction', Information \& Culture 49 (4) (2014); John Feather, A History of British Publishing (second edn) (London: Routledge, 2006), 123-5.

77. Emily Cook, Highways and Byways in London (London: Macmillan and Co Ltd, 1902), 305-7.

78. Simon Eliot, 'Fiction and Non-Fiction: One- and Three-Volume Novels in Some Mudie Catalogues, 1857-94', Publishing History 66 (2009), 32-3. Eliot has used Mudie's catalogues to investigate the relative importance of their fiction and nonfiction provision.

79. See Mudie's Select Library Ltd, Catalogue of the Principal Books in Circulation at Mudie's Select Library [January] (London: Mudie's Select Library Ltd, 1892) and Catalogues 1893, 1910, 1914.

80. “"The Times” and its Readers', Times Digital Archive, 9 September 1905, 9. The bookselling portion of the Book Club's remit eventually caused problems with the publishing world, who took action by restricting the supply of books. See Janet Courtney, Recollected in Tranquility (London: William Heinemann, 1926), 173-5.

81. Courtney, Recollected, 169.

82. Courtney, Recollected, 176.

83. The Times Book Club Ltd, A Catalogue of the Library of the Times Book Club (London: The Times, 1908).

84. The Times Book Club Ltd, A Catalogue of Books Added to the Library of The Times Book Club from 1st January 1915, to 30 October, 1936. (London: The Times Book Club Ltd, 1936).

85. Wilson, 'Boots'.

86. Boots, Catalogue of Modern English Literature in Circulation with Boots Book-lovers' Library... (London: Boots Head Department, 1912).

87. Simon Eliot, 'Public Libraries and Popular Authors, 1883-1912', The Library, S6 8 (4) (1986), 322.

88. See 'York Public Library', Yorkshire Gazette [British Newspaper Archive], 18 March 1899, 1; 'Beveridge Libraries', Fife Free Press \& Kirkaldy Guardian [British Newspaper Archive], 16 October 1926, 6; 'Library Additions', Sunderland Daily Echo and Shipping Gazette [British Newspaper Archive], 3 October 1939, 3.

89. 'The Honolulu Library', Pacific Commercial Advertiser [Library of Congress Chronicling America], 25 January 1894, 3.

90. Alison Adburgham, Yesterday's Shopping: the Army and Navy Stores catalogue, a facsimile of the Army \& Navy co-operative society's 1907 issue... (Newton Abbot: David \& Charles, 1969).

91. Sladen, Oriental Cairo: The City of the 'Arabian Nights' (London: Hurst \& Blackett, 1911), 13.

92. Annie Quibell, The Pyramids of Giza (Cairo: The C. M. S. Bookshop, 1910); Annie Quibell, The Tombs of Sakkara (second edn) (Cairo: Church Missionary Society, 1912 [1925]).

93. Petrie to Edwards, 7 July 1890, 3/1/PEN/52, Petrie Museum archive.

94. A new edition of Bell's Amurath to Amurath was stocked by 1928. See Government of Iraq, Maps of 'Iraq, with notes for visitors (Baghdad: Government of 'Iraq, 1928), 16. A number of memoirs have been produced highlighting the importance of Mackenzie's shop to people living in Baghdad from the 1920s on. See, for example, Richard Coke, 'The Baghdad Bookshop', Journal of the Royal Central Asian Society 13 (4) (1926); Nissim Rejwan, The Last Jews in Baghdad (Austin, TX: University of Texas Press, 2004); C. W. Richard Long, Bygone Heat: travels of an idealist in the Middle East (London: I. B. Tauris, 2004); Ida Staudt, Living in Romantic Baghdad: an American memoir of teaching and travel in Iraq (Syracuse, NY: Syracuse University Press, 2012), 51; Ghazi Karim, 'Suq al-Saray, Al-Mutannabi and the book trade of Baghdad in the 1940s: a personal narrative', International Journal of Contemporary Iraqi Studies 9 (3) (2015).

95. Gertrude Bell to Florence Bell, 7 November 1923. Gertrude Bell archive, Newcastle University [online]. 
96. See Mackay, Ancient.

97. See, for example, the Annotated Books Online project. Digitisation of these manuscripts has facilitated detailed study of these annotations.

98. Sarjeant to Near East Programme Organiser, 17 April 1942, Dr Margaret A. Murray, Speaker File 1 1942-62, BBC Written Archive Centre. Thanks are due to Debbie Challis for sharing her notes from the archive with me. For evidence of Murray on the radio see BBC Genome.

\section{Chapter 6}

1. George Paston, At John Murray's: records of a literary circle, 1843-1892 (London: John Murray, 1932), 73-4. On the early history of Murray's travel narrative publishing see Keighren et al. (2015).

2. See Malley, From archaeology to spectacle in Victorian Britain (Farnham: Ashgate, 2012) for an account of the reception in Britain of Layard's explorations. In 'Austen Henry Layard and the Periodical Press: Middle Eastern Archaeology and the Excavation of Cultural Identity in Mid-Nineteenth Century Britain', Victorian Review 22 (2) (1996). Shawn Malley also discusses Layard's publication history. See Paston, Murray, 76-8 on the initial publication of Nineveh and its remains. See also Larsen 'Nineveh', in Cities of God: the Bible and Archaeology in NineteenthCentury Britain, eds David Gange and Michael Ledger Lomas (Cambridge: Cambridge University Press, 2013). See Paston, Murray, 248-51 on the initial publication of Schliemann's work; on Schliemann creating his own identity partly as a result of his Murray books see Duesterberg, Popular, Ch.5.

3. On Murray brothers see William Zachs et al., 'Murray family (per. 1768-1967)', Oxford Dictionary of National Biography [online edn] (Oxford University Press, 2004-16). On Murray's publishing profile see Humphrey Carpenter, The Seven Lives of John Murray: the story of a publishing dynasty 1768-2002 (London: John Murray, 2008), 205.

4. Carpenter, Murray, 219; 'Sir John Murray', The Times Digital Archive, 1 December 1928, 14.

5. See Arthur Hughes rev. B. F. Cook, 'Murray, Alexander Stuart (1841-1904)', Oxford Dictionary of National Biography [online] (Oxford University Press, 2004).

6. Alexander S. Murray, 1892, Handbook of Greek Archaeology (London: John Murray, 1892): iii-v. A. S. Murray to Mr Murray, 4 March 1892, MS 40862, Incoming Correspondence, John Murray archive, National Library of Scotland (hereafter NLS).

7. A. S. Murray to Mr Murray, 23 January 1891, MS 40862, Incoming Correspondence, John Murray archive, NLS.

8. See A. S. Murray to Mr Murray, 23 January 1891, MS 40862, Incoming Correspondence, John Murray archive, NLS.

9. Brodrick to Murray, 21 October 1891, MS 40152, Incoming Correspondence, John Murray archive, NLS.

10. Brodrick to Murray, 7 October 1892, MS 40152, Incoming Correspondence, John Murray archive, NLS.

11. See, for example, Brodrick to Murray 7, 9 September 1893, Incoming Correspondence, John Murray archive, NLS.

12. Robinson, Egypt, xv

13. Advertisements for 'The Tourist' in the Egyptian Gazette show that the shop, established in 1869 , offered a number of items useful for tourists, from drawing equipment and stationery to Tauchniz editions of English literature (for example [Advertisements], Egyptian Gazette, 6 January 1900, 2). In his memoirs Ronald Storrs (Orientations, 131) discusses Livadas and other Cairo booksellers during the First World War.

14. Brodrick to Murray, 1 September 1893, MS 40152, Incoming Correspondence, John Murray archive, NLS.

15. Brodrick to Murray, 24 November 1894, MS 40152, Incoming Correspondence, John Murray archive, NLS. The New Hotel went through changes in this period - by 1900 it was put under new management and renamed the Grand Continental Hotel (Brodrick, Handbook to Egypt, 989).

16. Brodrick to Murray, 22 January 1896; 1 February 1896, MS 40152, Incoming Correspondence, John Murray archive, NLS.

17. Brodrick to Murray, 12 March 1896, MS 40152, Incoming Correspondence, John Murray archive, NLS. 
18. Brodrick to Murray, 16 December 1897, MS 40152, Incoming Correspondence, John Murray archive, NLS.

19. Brodrick to Murray [undated 1894], MS 40152, Incoming Correspondence, John Murray archive, NLS.

20. See Brodrick to Murray 26 July 1895, MS 40152, Incoming Correspondence, John Murray archive, NLS; Handbook to Egypt, MS 42734/329-30, Copies Ledger I, John Murray archive, NLS.

21. See Sayce, Reminiscences, Ch.15.

22. Brodrick to Murray, 21 and 23 August 1895, MS 40152, Incoming Correspondence, John Murray archive, NLS.

23. Brodrick to Murray, 15 November 1895, MS 40152, Incoming Correspondence, John Murray archive, NLS.

24. On Hotel d'Angleterre see Reynolds-Ball, Cairo 1898, 52; Brodrick, Handbook (ninth edn), 989.

25. Brodrick to Murray, 24-8 December 1895; Brodrick to Murray, 22 January 1896, MS 40152, Incoming Correspondence, John Murray archive, NLS; On the ubiquity and usefulness of dragomen for Western tourists to Egypt see Mairs and Muratov, Archaeologists.

26. Brodrick to Murray, 22 January 1896, MS 40152, Incoming Correspondence, John Murray archive, NLS.

27. Brodrick's short essay, 'An Experience on the Dahabiyeh', was posthumously published by her friend Eversley Robinson in Egypt, 118-23.

28. Handbook to Egypt (eighth edn) (London: John Murray, 1891), 388; Brodrick, Egypt (ninth edn), 635.

29. Brodrick to Murray, 1 February 1896, MS 40152, Incoming Correspondence, John Murray archive, NLS.

30. Brodrick, Egypt (ninth edn), 633.

31. Brodrick to Murray, 24-8 December 1895; 1 February 1896, MS 40152, Incoming Correspondence, John Murray archive, NLS.

32. Brodrick to Murray, 13 February 1896, MS 40152, Incoming Correspondence, John Murray archive, NLS.

33. See Frances Ll. Griffith, Beni Hasan Pt III (Fifth Memoir) (London: Egypt Exploration Society, 1896).

34. Brodrick to Murray, 12 March, 2 April 1896, MS 40152, Incoming Correspondence, John Murray archive, NLS.

35. Brodrick to Murray, 2 April 1896, MS 40152, Incoming Correspondence, John Murray archive, NLS.

36. Brodrick to Murray, 1, 13 February 1896, MS 40152, Incoming Correspondence, John Murray archive, NLS. See Henry Lyons, The Cadastral Survey of Egypt 1892-1907 (Cairo: Ministry of Finance, Survey Department, 1908) for the published account of the nineteenth-century surveys of Egypt.

37. Walter Wills and R. J. Barrett, The Anglo-African Who's Who (London: George Routledge \& Sons, Limited, 1905), 16.

38. Reid, Whose Pharaohs?, 149-67.

39. David G. Hogarth and Edward F. Benson, Report on the Prospects of Research in Alexandria (London: Macmillan \& Co, c.1895), 1-2. On Rosamond Blomfield's role in Alexandria's social life see, for example, 'The Day's News', Egyptian Gazette, 30 November 1895, 2.

40. Brodrick to Murray, 23 April 1896, MS 40152, Incoming Correspondence, John Murray archive, NLS.

41. Brodrick to Murray, 4 July 1896, MS 40152, Incoming Correspondence, John Murray archive, NLS; Handbook to Egypt, Copies Ledger I: 329-30, MS 43734, John Murray archive, NLS.

42. Brodrick to Murray, undated [Jan 1897?], MS 40152, Incoming Correspondence, John Murray archive, NLS; 'Books of the Week', The Times Digital Archive, 1 January 1897, 5.

43. See, for example, 'The ninth edition...', Morning Post [British Newspaper Archive], 18 February 1897, 3.

44. 'New Tourist Publications', The Times Digital Archive, 26 July 1897, 13. Brodrick to Murray, 5 August 1897, MS 40152, Incoming Correspondence, John Murray archive, NLS.

45. Brodrick to Murray, 14 September 1897, MS 40152, Incoming Correspondence, John Murray archive, NLS.

46. Handbook to Egypt, Copies Ledger I: 329-30, MS 43734, John Murray archive, NLS. 
47. Brodrick to Murray, 16 December 1897, MS 40152, Incoming Correspondence, John Murray archive, NLS; on Tanzim, see Mohamed G. Abdelmonem, The Architecture of home in Cairo: socio-spatial practice of the Hawari's everyday life (Burlington: Ashgate, 2015).

48. Brodrick to Murray, 28 January 1898, MS 40152, Incoming Correspondence, John Murray archive, NLS.

49. Brodrick to Murray, 16 December 1897, 28 January 1898, MS 40152, Incoming Correspondence, John Murray archive, NLS.

50. Brodrick to Murray, 24-8 December 1895, MS 40152, Incoming Correspondence, John Murray archive, NLS.

51. Brodrick to Murray, 28 January 1898, MS 40152, Incoming Correspondence, John Murray archive, NLS. Brodrick's views on Britain in Egypt were related in the British press as well. See, for example, 'London Correspondence', Monmouthshire Beacon [British Newspaper Archive], 16 December 1898, 7.

52. Brodrick to Murray, 28 January 1898, MS 40152, Incoming Correspondence, John Murray archive, NLS.

53. Brodrick to Murray, 28 January 1898, MS 40152, Incoming Correspondence, John Murray archive, NLS.

54. Brodrick to Murray, 26 February 1898, MS 40152, Incoming Correspondence, John Murray archive, NLS. The plans for the dam were approved, and building begun in 1898. The first phase of the project was completed in 1902.

55. Brodrick to Murray, 26 February 1898. The Museum moved to Kasr en-Nilin in central Cairo (near Tahrir Square) in 1902.

56. See Brodrick to Murray, 24 December 1895, MS 40152, Incoming Correspondence, John Murray archive, NLS.

57. Brodrick to Murray, 1 Feburary, 13 February 12 March, 2 April 1896, MS 40152, Incoming Correspondence, John Murray archive, NLS.

58. Brodrick to Murray, 16 December 1897, MS 40152, Incoming Correspondence, John Murray archive, NLS. On Cook's negative impact on Egyptian tourism see Waleed Hazbun, 'The East as Exhibit: Thomas Cook \& Son and the Origins of the International Tourism Industry in Egypt', in The Business of Tourism: Place, Faith, and History, eds Philip Scranton and Janet F. Davidson (Philadelphia, PA: University of Pennsylvania Press, 2007).

59. Brodrick to Murray, 13 February 1896, MS 40152, Incoming Correspondence, John Murray archive, NLS.

60. On Cook's difficulties see Brendon, Cook, 234-5; Brodrick to Murray, 28 January 1898, MS 40152, Incoming Correspondence, John Murray archive, NLS.

61. Brodrick to Murray, 26 February 1898, MS 40152, Incoming Correspondence, John Murray archive, NLS.

62. Brodrick to Murray, 17 November 1898; Brodrick to Murray, 14 July 1900, MS 40152 , Incoming Correspondence, John Murray archive, NLS.

63. Brodrick to Murray, 10 March 1898, MS 40152, Incoming Correspondence, John Murray archive, NLS.

64. Mary Brodrick, Handbook for Travellers in Syria and Palestine... (London: Edward Stanford, 1903), v-vi.

65. See Gretton, 'Introduction', xlii-xlv for the history of Murray's Handbooks after the sale in 1901. See also Charles Johnoth to John Murray, 19 April 1901, MS 42613, Papers concerning the sale by John Murray IV to Edward Stanford..., Murray archive, NLS.

66. Brodrick to Murray, 21 December 1903, MS 40152, Incoming Correspondence, John Murray archive, NLS.

67. Hall, Handbook, v-vii.

68. Brodrick to Murray, 23 December 1902, MS 40152, Incoming Correspondence, John Murray archive, NLS.

69. Brodrick to Murray, 23 December 1902, MS 40152, Incoming Correspondence, John Murray archive, NLS.

70. Brodrick to Murray, 3 May 1903; 26 June 1910, A. Llewellyn Roberts to Murray, 29 June 1910, MS 40152, Incoming Correspondence, John Murray archive, NLS.

71. Lock, 'Hogarth', 177; Janet Courtney, An Oxford Portrait Gallery (London: Chapman \& Hall, 1931), 8-17; Thornton, British Archaeologists.

72. David G. Hogarth, 'Inscriptions from Salonica', Journal of the Hellenic Society 8 (1887). William M. Ramsay and David G. Hogarth, 'Apollo Lermanus', Journal of the Hellenic Society 8 (1887). 
On the British School at Athens's engagements in Asia Minor see David Gill, 'The British School at Athens and Archaeological Research in the Late Ottoman Empire', in Archaeology, Anthropology.

73. On Cyprus Exploration Fund see Gill, Sifting; Thornton 'extricating'. On Gregori Antoniou see C. L. R. Fletcher, 'David George Hogarth, President R. G. S. 1925-27', Geographical Journal 71 (4) (1928); Lock, 'Hogarth'.

74. See Gill, Sifting, Ch.10; Hogarth, Wandering (second edition); Lock, 'Hogarth'.

75. Hogarth to John Murray, 13 November 1889, MS 40563, John Murray archive: National Library of Scotland. On John Murray IV at Magdalen see The Times, 'Sir John Murray'.

76. Hogarth's reference to a 'Levant guide-book' is the Handbook for Travellers in Turkey in Asia... See Lister, Guide, 17-18.

77. Hogarth to John Murray, 13 November 1889, MS 40563, John Murray archive, NLS.

78. See Charles Wilson, ed., Handbook for Travellers in Asia Minor, Transcaucasia, Persia etc (London: John Murray, 1895).

79. Hogarth to John Murray, 17 July 1895, MS 40563, Incoming Correspondence, John Murray archive, NLS.

80. Hogarth to John Murray, 4 August 1895, MS 40563, Incoming Correspondence, John Murray archive, NLS.

81. Hogarth to John Murray, 4 August 1895, MS 40563, Incoming Correspondence, John Murray archive, NLS. See, for example, 'Literary Notes and Gossip', Glasgow Herald [British Newspaper Archive], 17 August 1895, 10; 'Literature and Art', Nottinghamshire Guardian [British Newspaper Archive], 30 November 1895, 5.

82. Hogarth to John Murray, 17 July 1895, MS 40563, Incoming Correspondence, John Murray archive, NLS. The book eventually sold for 7 shillings and sixpence. Presumably the slightly higher price accounted for the added expense of illustrations.

83. Hogarth to John Murray, 24 July 1895, MS 40563, Incoming Correspondence, John Murray archive, NLS.

84. Hogarth to John Murray, 17 July 1895, MS 40563, Incoming Correspondence, John Murray archive, NLS.

85. Hogarth to John Murray, 4 August, 2 and 8 October 1895, MS 40563, Incoming Correspondence, John Murray archive, NLS.

86. Hogarth to John Murray, 5 November 1895, MS 40563, Incoming Correspondence, John Murray archive, NLS.

87. Hogarth, Wandering, 7. On Hogarth as generalist see Lock 'Hogarth', 178.

88. Hogarth, Wandering, 7. See also Satia, Spies, 35.

89. Lock, 'Hogarth', 178; Fletcher, 'Hogarth', 324-6; Courtney, Oxford, 19-37.

90. See Hogarth's Wandering Scholar in the Levant, Copies Ledger J: 4. MS 42735, John Murray archive, NLS.

91. Impressions of Turkey was published by Hodder \& Stoughton. Ramsay's wife Agnes Dick Ramsay also published books based on her experiences travelling with Ramsay. Her book Everyday life in Turkey appeared in the same year as Impressions in 1897. See Hogarth to Murray, 13 June 1897, MS 40563, Incoming Correspondence, John Murray archive, NLS.

92. Hogarth, Wandering (second edn): vii-ix.

93. See Hogarth's Wandering Scholar in the Levant, Copies Ledger J: 4, MS 42735, John Murray archive, NLS.

94. See, for example, 'Literary Notes', San Francisco Call [Library of Congress Chronicling America], 14 March 1897, 23.

95. Hogarth to John Murray, 5 April 1896, MS 40563, Incoming Correspondence, John Murray archive, NLS.

96. Hogarth to Murray, 30 April 1896, MS 40563, Incoming Correspondence, John Murray archive, NLS. On Newnes' Library see 'Literary Jottings', Whitstable Times and Herne Bay Herald [British Newspaper Archive], 8 December 1894, 2.

97. Hogarth to Murray, 30 April 1896, MS 40563, Incoming Correspondence, John Murray archive, NLS.

98. Hogarth to Murray, 30 April 1896, MS 40563, Incoming Correspondence, John Murray archive, NLS.

99. Hogarth to Murray, 2 September 1896, MS 40563, Incoming Correspondence, John Murray archive, NLS.

100. Hogarth to Murray, 2 September 1896, MS 40563, Incoming Correspondence, John Murray archive, NLS. 
101. Hogarth to Murray, 8 October 1896, MS 40563, Incoming Correspondence, John Murray archive, NLS.

102. Hogarth to Murray, 12 June 1897, MS 40563, Incoming Correspondence, John Murray archive, NLS.

103. Hogarth to Murray, 30 April and 11 October 1896, 20 June 1897, MS 40563, Incoming Correspondence, John Murray archive, NLS.

104. Hogarth to Murray, 27 June 1897, MS 40563, Incoming Correspondence, John Murray archive, NLS. Hogarth received 50 per cent profits from the sale. See MS 42735, Copies Ledger J: 290.

105. Hogarth to Murray, 27 June, 1 July 1897, MS 40563, Incoming Correspondence, John Murray archive, NLS.

106. Hogarth to Murray, c.October 1898, 23 August 1899, MS 40563, Incoming Correspondence, John Murray archive, NLS; Petrie's how-to manual is Methods and Aims in Archaeology.

107. Hogarth to Murray, 23 August 1899, MS 40563, Incoming Correspondence, John Murray archive, NLS. Hill was based on 'Sophocles Street' in Athens; he appears to be a major figure in the British seasonal and expat community there, offering banking services, photographic materials and acting as a forwarding agent - as well as being Treasurer of the British Relief Fund and churchwarden and Honorary Treasurer of the British Church in Athens. See Murray, Handbook Greece, xiii, 947-50.

108. See Fletcher, 'Hogarth', 328-9; Gill, 'Hogarth'.

109. Hogarth to Murray, 8, 16 October 1899, 22 September 1900, MS 40563, Incoming Correspondence, John Murray archive, NLS.

110. 'Miss Mary Hogarth: Architecture in Line and Wash', The Times Digital Archive, 26 February 1935, 19.

111. Hogarth to Murray, 19 July 1905, MS 40563, Incoming Correspondence, John Murray archive, NLS.

112. The Times, 'Mary Hogarth'.

113. Hogarth to Murray, 19 July, 14 November 1909, MS 40563, Incoming Correspondence, John Murray archive, NLS.

\section{Chapter 7}

1. Hogarth to G. A. Macmillan, 27 June 1895, Correspondence K: Archaeologists - D. G. Hogarth, Add MS 55133, Macmillan archive, British Library (hereafter BL).

2. For a general overview of Macmillan \& Co see Rosemary van Arsdel, 'Macmillan family (per. c.1840-1986)', Oxford Dictionary of National Biography [online edn] (Oxford: Oxford University Press, 2004-15); Charles Morgan, The House of Macmillan (1843-1943) (London: Macmillan, 1943); Elizabeth James, Macmillan: A Publishing Tradition (Basingstoke: Palgrave, 2002).

3. Leslie Howsam, Past, Ch.2 has discussed Alexander Macmillan's role in fostering popular history authors from the 1860s.

4. See James, Macmillan.

5. John Kajinski, 'Professionalism, Authority, and the Late-Victorian Man of Letters: A View from the Macmillan Archive', Victorian Literature and Culture 24 (1996), 236-7.

6. Morgan, Macmillan, 101.

7. Morgan, Macmillan; van Arsdel, 'Macmillan'.

8. Kajinski, 'Professionalism', 229.

9. For a discussion of the cataloguing of the Macmillan archive see Philip Blake-Hill, 'The Macmillan Archive', The British Museum Quarterly 36 (3/4) (1972). A recent analysis of Macmillan's publishing history - concentrating on fiction - can be found in James, Macmillan.

10. Including the American publishing houses Scribners and Putnams.

11. See Correspondence K: Archaeologists - Percy Gardner, Add MS 55128, Macmillan archive, British Library.

12. See University of Oxford/Ashmolean Museum, 'Maria Millington Lathbury (1856-1944). John Evans Centenary Project'. Last accessed 2 December 2017: http://johnevans.ashmolean.org/ evans/maria-lathbury.html. Her wedding announcement listed her as an 'archaeological lecturer'. 'Fashionable Weddings', Western Daily Press [British Newspaper Archive], 11 July 1892, 5. Joan Evans, Prelude \& Fugue: An Autobiography (London: Museum Press Limited, 1964), 23. 
13. 'Our Domestic Circle', Manchester Courier and Lancashire Advertiser [British Newspaper Archive], 3 October 1891: Supplement; 'Gossip of the Day', Inverness Courier [British Newspaper Archive], 13 October 1891, 6. Maria Millington Lathbury's daughter, Joan Evans, noted that Jane Harrison's support was crucial to Lathbury's success as a lecturer. Harrison even offered Lathbury the addresses of her regular audience members so that Lathbury could send her prospectuses to them (Evans, Prelude, 21-3).

14. Percy Gardner to George Macmillan, 25 March 1892. Correspondence K: Archaeologists Percy Gardner, Add MS 55128, Macmillan archive, BL. One of Leighton's best known paintings, Flaming June, showing a sleeping woman in a flowing Grecian dress, was finished in 1895. Mary Beard (Invention, Ch.4) chronicles Jane Harrison and Eugénie Sellers' participation in an 1883 'society theatrical', The Tale of Troy, which was held over two nights in London. Among the members of the play's large cast were Bram Stoker's wife Florence Balcombe and theatrical impresario Herbert Beerbohm Tree. Pat Easterling has chronicled the history of Cambridge's Greek plays, Pat Easterling, 'The Early Years of the Cambridge Greek Play: 1882-1912', in Stray, Classics... Cambridge. While at UCL Ernest and Mary Gardner also organised (and took part in) Greek plays from 1897.

15. Maria M. L. Evans, Chapters on Greek Dress (London: Macmillan \& Co, 1893). Through her marriage, Lathbury became stepmother to archaeologist Arthur Evans.

16. Evans, Chapters, xv.

17. Percy Gardner to [George?] Macmillan, 24 June 1892, 22 October 1894. Correspondence K: Archaeologists - Percy Gardner, Add MS 55128, Macmillan archive, BL.

18. Frederick Macmillan to George Brett, 2 January 1895, U: Letterbooks, Add MS 55285, Macmillan archive, BL.

19. Percy Gardner to [George?] Macmillan, 26 January 1895, Correspondence K: Archaeologists Percy Gardner, Add MS 55128, Macmillan archive, BL.

20. Frederick Macmillan to George Brett, 29 January, 21 Feburary 1895, Correspondence K: Archaeologists - Percy Gardner, Add MS 55128, Macmillan archive, BL.

21. Frederick Macmillan to George Brett, 21, 24 May 1895, U: Letterbooks, Add MS 55285, Macmillan archive, BL.

22. Percy Gardner to [George A?] Macmillan, 1 February, 17 May 1895, Correspondence K: Archaeologists - Percy Gardner, Add MS 55128, Macmillan archive, BL.

23. Percy Gardner to Macmillan \& Co, 22 August 1895, Correspondence K: Archaeologists - Percy Gardner, Add MS 55128, Macmillan archive, BL.

24. Percy Gardner to George Macmillan, 11 October 1895, Correspondence K: Archaeologists Percy Gardner, Add MS 55128, Macmillan archive, BL.

25. Frederick Macmillan to George Brett, 17 October 1895, U: Letterbooks, Add MS 55285, Macmillan archive, BL. This never materialised, but what came eventually in 1904 was Methods and Aims in Archaeology, published by Macmillan.

26. Frederick Macmillan to George Brett, 24 May, 24 August 1895, U: Letterbooks, Add MS 55285, Macmillan archive, BL.

27. Percy Gardner to George Macmillan, 11 October 1895, Correspondence K: Archaeologists Percy Gardner, Add MS 55128, Macmillan archive, BL.

28. Frederick Macmillan to George Brett, 17 October 1895, U: Letterbooks, Add MS 55285, Macmillan archive, BL.

29. 'Handbooks of Archaeology and Antiquities', in Handbook of Greek Sculpture Part 2. Last modified 3 December 2017: https://archive.org/stream/handbookofgreeks01garduoft\#page/ 552/mode/2up.

30. Frederick Macmillan to George Brett, 23 January 1896, U: Letterbooks, Add MS 55285, Macmillan archive, BL; see also Handbooks Advertisement.

31. Ernest Gardner to [George?] Macmillan, 30 October 1894, Correspondence K: Archaeologists Ernest Arthur Gardner, Mary Gardner, Add MS 55130, Macmillan archive, BL.

32. Ernest Gardner to [George?] Macmillan, 25 February, 18 March 1895, Correspondence K: Archaeologists - Ernest Arthur Gardner, Mary Gardner, Add MS 55130, Macmillan archive, BL.

33. Handbooks advertisement.

34. Ernest Gardner to [George?] Macmillan, 16 September 1896, Correspondence K: Archaeologists - Ernest Arthur Gardner, Mary Gardner, Add MS 55130, Macmillan archive, BL. Founded in the 1880s, the Teacher's Guild of Great Britain and Ireland provided a forum for teachers of all levels of education and all genders, whether from public or private schools, 
to discuss issues relevant to their profession. See 'Mr Mundella and the Teacher's Guild', Morning Post [British Newspaper Archive], 25 February 1884, 5.

35. Ernest Gardner, A Handbook of Greek Sculpture (London: Macmillan \& Co, 1897), ix-x.

36. Ernest Gardner to George Macmillan, 30 September 1904, Correspondence K: Archaeologists Ernest Arthur Gardner, Mary Gardner, Add MS 55130, Macmillan archive, BL. The first edition of Part 1 of the Handbook was reprinted eight times before the second edition was issued, although it was amended and corrected for a few of the reprintings. The first edition of Part 2 was reprinted seven times. See Ernest Gardner, Handbook, 1915 edn.

37. Gardner, Handbook (1915), vii-viii.

38. Percy Gardner to [George?] Macmillan, 2 November 1899, 28 October 1901. Correspondence K: Archaeologists - Percy Gardner, Add MS 55128, Macmillan archive, BL.

39. George Macmillan to H. P. Brett, 30 October 1902, U: Letterbooks, Add MS 55287, Macmillan archive, BL. Manuscript proposals were still coming in well into the first decade of the twentieth century. One of these was from Egyptologist Caroline Ransom, who proposed a book on 'Egyptian Art'. Her proposal was rejected, in part because Frederick Macmillan considered her to be a relatively invisible scholar despite her University of Chicago $\mathrm{PhD}$. A year after the rejection, Ransom was appointed Assistant Curator in the Egyptian Art Department at the Metropolitan Museum of Art (Frederick Macmillan to George Brett, 23 November 1909, Macmillan archive, Add MS 44289). For a brief biography of Ransom see Barbara Lesko, 'Caroline Louise Ransom Williams (1872-1952)', Breaking Ground: Women in Old World Archaeology. Last modified 3 December 2017: http://www.brown.edu/Research/Breaking Ground/search.php.

40. George Macmillan to George Brett, 16 June 1904, U: Letterbooks, Add MS 55287, Macmillan archive, BL.

41. Percy Gardner to George Macmillan, 3 June 1904, Correspondence K: Archaeologists - Percy Gardner, Add MS 55128, Macmillan archive, BL.

42. Gardner, Autobiographica, 66-7.

43. Percy Gardner to [George?] Macmillan, 17 January 1898, Correspondence K: Archaeologists Percy Gardner, Add MS 55128, Macmillan archive, BL.

44. 'Steam Cruise in the Aegean', The Times Digital Archive, 12 April 1892, 10.

45. 'Editorial', The Times Digital Archive, 13 April 1892, 9. At this time some of the Aegean islands (including Crete) were still under the jurisdiction of Ottoman Turkey; the 1892 cruise focused on the Cycladic islands, which were part of Greece. See Murray, Handbook of Greece, 948 for list of chief curriers/dragomen in Athens.

46. UCL, Calendar 1896, xliv; UCL, Calendar 1897, 52.

47. UCL, Calendar 1902, 118-9.

48. Bosanquet, Letters, 10-11.

49. The Times, 'E. A. Gardner', 29 November 1939, 4.

50. Ernest Gardner, Ancient Athens (London: Macmillan \& Co, 1902), vii.

51. 'Macmillan New York [Advertisement]', New York Tribune Illustrated Supplement [Library of Congress Chronicling America], 8 February 1903, 13.

52. 'Athens. A Survey of the Greek City in its Glory', New York Tribune Illustrated Supplement [Library of Congress Chronicling America], 21 December 1902, 10-11.

53. Macmillan \& Co, Guide to Greece, the Archipelago, Constantinople... (London: Macmillan \& Co, 1910).

54. Ernest Gardner to G. A. Macmillan, 30 January, 1 and 25 February 1908, Correspondence K: Archaeologists - Ernest Arthur Gardner and Mary Gardner, Add MS 11530, Macmillan archive, BL.

55. Ernest Gardner to G. A. Macmillan, 8 March 1908, Correspondence K: Archaeologists - Ernest Arthur Gardner and Mary Gardner, Add MS 11530, Macmillan archive, BL.

56. Ernest Gardner to G. A. Macmillan, 12 March 1908, Correspondence K: Archaeologists Ernest Arthur Gardner and Mary Gardner, Add MS 11530, Macmillan archive, BL.

57. Mary Gardner to Mr Macmillan, 1 January 1904, Records of Macmillan \& Co, fonds MAC, University of Reading.

58. For a discussion of this trip see Iain Ross, 'Oscar Wilde in Greece: Topography and the Hellenist Imagination', International Journal of the Classical Tradition 16 (2) (2009); see G. A. Macmillan to Malcolm Macmillan, 14 April 1877, George A. Macmillan's Personal Papers, Hellenic Society. For details of this archive see Richella Doyle, 'The Society for the Promotion of Hellenic Studies, Archive of George A. Macmillan's Personal Papers', Archaeological Reports 
56. See Christopher Stray, 'The Foundation and its Contexts', Greece \& Rome 50 (2003) for a brief history of the Hellenic Society. George Macmillan charted the Society's early years in 1929; see 'An Outline of the History of the Hellenic Society', Journal of Hellenic Studies 49 (1929). George Macmillan's lengthy obituary in The Times highlights the impact of his roles as Hon. Secretary of the Hellenic Society and the British School at Athens. 'Mr George Macmillan. Classical Studies in England', The Times Digital Archive, 4 March 1936, 16.

59. Hogarth to G. A. Macmillan, 4 September 1894, 31 May 1895. Correspondence K: Archaeologists - D. G. Hogarth, Add MS 55133, Macmillan archive, BL.

60. See Courtney, Oxford, 21 for a candid discussion of Hogarth's personal feelings towards Greeks; Hogarth to G. A. Macmillan, 27 June 1895, Correspondence K: Archaeologists D. G. Hogarth, Add MS 55133, Macmillan archive, BL; No.9616, Add MS 56018, Record of Manuscripts, Macmillan archive, BL.

61. Hogarth to G.A. Macmillan, 10 July 1895, Add MS 55133, Correspondence K: Archaeologists D. G. Hogarth, Add MS 55133, Macmillan archive, BL

62. By this point, beyond academic articles, Hogarth had only published a short book called Devia Cypria, an account of his travels and explorations in Cyprus as part of the Cyprus Exploration Fund, and the report on Alexandria mentioned in the previous chapter.

63. Hogarth to [George?] Macmillan, 15 July 1895, Correspondence K: Archaeologists - D. G. Hogarth, Add MS 55133, Macmillan archive, BL.

64. Hogarth to [George] Macmillan, 21 July 1895, Correspondence K: Archaeologists - D. G. Hogarth, Add MS 55133, Macmillan archive, BL.

65. See Thornton 'extricating' for details of Macmillan's funding calls; also Gill, Sifting, 194-200.

66. Royal Academy of Arts, Exhibition of Works by the Old Masters... Also of Drawings, Photographs, Plans and Casts showing the Results of Excavations at the Palace of Knossos in Crete. Winter Exhibition. Thirty-Fourth Year (London: Royal Academy, 1903), 45-50.

67. Hogarth to G.A. Macmillan, 11 October 1906, Correspondence K: Archaeologists - D. G. Hogarth, Add MS 55133, Macmillan archive, BL; David G. Hogarth, 'The Recent Wonderful Discoveries in Crete', Illustrated London News Historical Archive, 22 September 1906, 409-11.

68. Hogarth to G. A. Macmillan, 29 June 1907; Macmillan \& Co, Guide to Greece, the Archipelago, Constantinople... (London: Macmillan \& Co 1908), 179. See Whitaker, Almanack 1911, 655. Its population was among the largest in Ottoman Turkey-in-Asia. For further details on Smyrna as an international port see Giles Milton, Paradise Lost: Smyrna 1922, the destruction of Islam's City of Tolerance (London: Hodder \& Stoughton, 2009).

69. Macmillan, Greece 1908, 178. See Michael Ledger Lomas, 'Ephesus', in Cities of God: the Bible and Archaeology in Nineteenth-Century Britain, eds David Gange and Michael Ledger Lomas (Cambridge: Cambridge University Press, 2013), on the significance of Asia Minor to Protestant tourists desiring to visit early Christian churches.

70. Hogarth to G. A. Macmillan, 12 July 1907; 29 August 1907. Correspondence K: ArchaeologistsD. G. Hogarth, Add MS 55133, Macmillan archive, BL.

71. Macmillan, Greece 1908, 193. John Turtle Wood had excavated at Ephesus on behalf of the British Museum in the mid-nineteenth century. For further details on the history of excavation at the site see Challis, Harpy Tomb and Ledger Lomas, 'Ephesus'.

72. Archaeological Institute of America, 'Twenty-ninth Annual Report of the President, 1907-08', American Journal of Archaeology (1908), 5.

73. See, for example, 'Noted Lecturer to Speak Here', Evening Statesman [Library of Congress Chronicling America], 12 November 1907, 3; 'Prof. Hogarth Lectures', Washington Herald [Library of Congress Chronicling America], 5 January 1908, 11.

74. 'Scientist Lectures on Ancient Hittites. Archaeologist Hogarth Describes Interesting Prehistoric People', San Francisco Call [Library of Congress Chronicling America], 21 November 1907, 14. Phoebe Hearst, a prominent philanthropist and funder of archaeology, was among the guests listed at Hogarth's San Francisco lecture. See also Barbara Lesko, 'Phoebe Apperson Hearst', Women in Old World Archaeology. Last modified 3 December 2017: https://www.brown.edu/ Research/Breaking_Ground/results.php?d=1\&first=Phoebe\%20Appserson\&last=Hearst.

75. 'Eighth Anniversary. Classical Club to Meet in Celebration January 4', Evening Star [Library of Congress Chronicling America], 29 December 1907, 8.

76. 'Utah's Archaeological Fields are to be Further Explored', Salt Lake Herald [Library of Congress Chronicling America], 6 January 1908, 10.

77. Lock, 'Hogarth', 191, 196. 
78. This railway line, and the survey involved, was also an important intelligence gathering operation for Germany. The British archaeologists working at the site in the years that followed Hogarth's initial survey - Hogarth, T. E. Lawrence, Leonard Woolley and Reginald Campbell Thompson - were all involved in key roles in British intelligence during the First World War.

79. See David Fraser, The Short Cut to India: The Record of a Journey along the Route of the Baghdad Railway (William Blackwood \& Sons: Edinburgh and London, 1909); Morris Jastrow, The War and the Baghdad Railway: the story of Asia Minor and its relation to the present conflict (J. B. Lippincott \& Co, Philadelphia and London, 1918). The Baghdad Railway's history has been recently reassessed in Sean McMeekin, The Berlin-Baghdad Express: the Ottoman Empire and Germany's Bid for World Power, 1898-1918 (London: Allen Lane, 2010).

80. David G. Hogarth, 'West to East: The Baghdad Railway', Illustrated London News Historical Archive, 3 August 1912: 184.

81. Hogarth to G. A. Macmillan, 29 November 1908, Correspondence K: Archaeologists - D. G. Hogarth, Add MS 55133, Macmillan archive, BL.

82. Hogarth to G. A. Macmillan, 20 July 1909, Correspondence K: Archaeologists - D. G. Hogarth, Add MS 55133, Macmillan archive, BL.

83. David G. Hogarth, Accidents of an Antiquary's Life (London: Macmillan \& Co, 1910), 21. Janet Hogarth Courtney (Oxford, 35) quotes this sentence in her discussion of her brother's experiences in Crete.

84. Hogarth, Accidents, 69. The cave is called Psychro.

85. Hogarth, Accidents, 71-7.

86. Hogarth, Accidents, 147-51.

87. Hogarth, Accidents, 156-7.

88. Hogarth, Accidents, 165.

89. Hogarth, Accidents, 176.

90. Hogarth to G. A. Macmillan, 24 July 1909. Correspondence K: Archaeologists - D. G. Hogarth, Add MS 55133, Macmillan archive, BL.

91. Hogarth to G. A. Macmillan, 24 and 24 July 1909. Correspondence K: Archaeologists - D. G. Hogarth, Add MS 55133, Macmillan archive, BL.

92. Hogarth to G. A. Macmillan, 14 September 1909, Correspondence K: Archaeologists - D. G. Hogarth, Add MS 55133, Macmillan archive, BL.

93. See 'To Study Excavations Made in Palestine. Archaeological Society to Hear Report of Savant', San Francisco Call [Library of Congress Chronicling America], 9 November 1909, 3. Loeb endowed the AIA with the money in memory of his mentor Charles Elliot Norton, collector and curator at the Museum of Fine Art in Boston.

94. Hogarth's tour was announced in several papers across the United States. See for example [News], Dillon Herald [Library of Congress Chronicling America], 9 December 1909, 2.

95. G. A. Macmillan to G.P. Brett, 23 November 1909, U: Letterbooks, Add MS 55289, Macmillan archive, BL.

96. Hogarth to G. A. Macmillan, 18 November 1909, Correspondence K: Archaeologists - D. G. Hogarth, Add MS 55133, Macmillan archive, BL.

97. [News], New York Tribune [Library of Congress Chronicling America], 30 January 1910, 7.

98. 'Literary News and Criticism: The Enchantments of Digging in the Soil of Antiquity', New York Tribune [Library of Congress Chronicling America], 21 May 1910, 8.

99. Courtney, Oxford, 42.

100. See Satia, Spies.

101. D. G. Hogarth to Macmillan \& Co, 2, 4 October 1922, Correspondence K: Archaeologists D. G. Hogarth, Add MS 55133, Macmillan archive, BL.

\section{Chapter 8}

1. Jack Morpurgo, Allen Lane: King Penguin (London: Hutchinson of London, 1979), 115.

2. Steve Hare, ed., Penguin Portrait: Allen Lane and the Penguin Editors 1935-1970 (London: Penguin Books, 1995), 4-5; Mandira Sen, 'The Paperback Revolution', India International Centre Quarterly 10 (4) (1983); Morpurgo, Lane, 80.

3. Lane quoted in Hare, Penguin, 3. 
4. Penguin First Editions website is a valuable resource for understanding the evolution of Pelican books and contains a list of Pelican books released by number. See Penguin First Editions, 'Pelican Books'. Last modified 3 December 2017: http://www.penguinfirsteditions. com/index.php?cat=pelican001-099.

5. 'Books and writers: The Indian Civil Service - Penguins' Progress - Art Books from Vienna', Yorkshire Post and Leeds Intelligencer [British Newspaper Archive], 17 March 1937, 8; Bowler, Science, $140-2$.

6. Beyond publication and republication of her letters in the years following her death, Bell has been the subject of several biographies over the past 90 years. See for example M. R. Ridley, Gertrude Bell (London: Blackie \& Son, 1941); Anne Tibble, Gertrude Bell (London: A. \& C. Black, 1958); Hugo Winstone, Gertrude Bell (London: Constable, 1978); Georgina Howell, Daughter of the Desert: the remarkable life of Gertrude Bell (London: Pan Macmillan, 2006); Lisa Cooper, In Search of Kings and Conquerors: Gertrude Bell and the Archaeology of the Middle East (London: I. B. Tauris, 2016). Werner Herzog's feature film Queen of the Desert and a documentary, Letters from Baghdad, both chronicling Bell's experiences in the East, were released in 2016. Newcastle University, where Bell's archive is now located, has developed a comic book and teachers' resources for schools based on Bell's life and archive. See 'The extraordinary Gertrude Bell: Teaching Packs'. Last modified 3 December 2017: https://research. ncl.ac.uk/gertrudebell/schools/teachingpacks/; Newcastle University/Applied Comics etc, 2016, 'Gertrude Bell Comics: archaeologist, writer, explorer'. Last modified 3 November 2017: https://research.ncl.ac.uk/gertrudecomics/.

7. In 1928 Benn issued a "'gift" format' edition of Bell's Persian Pictures, with Bell publicly named as author and a new introduction by Sir Edward Denison Ross, then head of the School of Oriental Studies (now SOAS), as a companion to Bell's Letters (Benn, Autumn List, 10-11).

8. Ernest Benn, Happier Days: Recollections and Reflections (London: Ernest Benn, 1949), $156-8$.

9. See 'Benn's Sampler', Aberdeen Journal [British Newspaper Archive], 4 September 1930, 2; 'Benn's Sampler', Yorkshire Post and Leeds Intelligencer [British Newspaper Archive], 17 September 1930, 6 .

10. Benn Ltd, Benn's Sampler... (London: Ernest Benn Ltd, 1930), 5-6, voucher.

11. Benn Ltd, Sampler, 18, 210-2.

12. Benn Ltd, Being a list of books ... (London: Ernest Benn Ltd, 1931), 37.

13. Benn Ltd, Benn's Second Sampler ... (London: Ernest Benn Ltd, 1931), 191-4.

14. Hare, Penguin, 6; Sen, 'Paperback', 446.

15. Morpurgo, Lane, 99-100, 108-10.

16. See Penguins Progress, May 1937, DM 1294/4/1/4. With the Permission of the Penguin archive, University of Bristol Special Collections (hereafter UBSC).

17. Penguins Progress, May 1937: 4, DM 1294/4/1/4. With the Permission of the Penguin archive, UBSC.

18. Morpurgo, Lane, 117.

19. Penguins Progress, May 1937: 9, DM 1294/4/1/4. With the Permission of the Penguin archive, UBSC.

20. Penguins Progress, Spring 1939: 6, DM 1294/4/1/8. With the Permission of the Penguin archive, UBSC.

21. Sen, 'Paperbacks', 446; Morpurgo, Lane, 108.

22. Morpurgo, Lane, 127, 135.

23. Hare, Penguin, 50-6; Morpurgo, Lane, 119-26. Menon is credited with instigating Pelicans, providing valuable contacts in the intellectual world and recommending Williams and Beale as editors. Eventually Williams replaced Menon as head of Pelican editorial. The scientist Peter Chalmers-Mitchell also replaced Hogben.

24. National Life Story Collection (NLSC), Book Trade Lives, 2004, Tanya Schmoller (interviewer Sue Bradley), F14829, Tape 5 Side B, British Library Sound Archive.

25. Kenneth Day to Valerie Willey, 21 February 1967, Digging Up the Past (Leonard Woolley), Editorial File, DM1107/A02/0004. With the Permission of the Penguin archive, UBSC.

26. See Penguin First Editions; Woolley, Leonard. Digging Up the Past (Harmondsworth: Penguin Books, 1950).

27. Peter Gathercole, 'Childe Among the Penguins', Australian Archaeology 50 (2000), 8.

28. Hare, Penguin, 90-1; Morpurgo, Lane, 156-65. 
29. Morpurgo, Lane, 162-5; Hare, Penguin, 90, 104-14; Penguin First Editions, 'Penguin Forces Book Club'. Last modified 3 December 2017: http://www.penguinfirsteditions.com/index. php? cat $=$ mainFBC.

30. Frost to Woolley, 23 November 1942; Woolley to Frost, 24 November 1942, Digging Up the Past (Leonard Woolley), Editorial File DM1107/A02/0004. With the Permission of the Penguin Archive, UBSC.

31. See Penguin First Editions, 2013-17. On Childe's publication with Penguin see Gathercole 'Childe'.

32. On Glover, see Hare, Penguin, 120-33, also National Life Story Collection (NLSC) Book Trade Lives, 2004, Tanya Schmoller (interviewer Sue Bradley), F14829, Tape 5 Side B, British Library Sound Archive.

33. Frances Passmore to ASB Glover, 8 July 1955, Digging Up the Past (Leonard Woolley), Editorial File DM1107/A02/0004. With the Permission of the Penguin Archive, UBSC.

34. A.S.B. Glover to C. J. Hayes, 9 October 1956, Digging Up the Past (Leonard Woolley), Editorial File, DM1107/A02/0004. With the Permission of the Penguin Archive, UBSC.

35. Helen Macadam to Ernest Benn [copy], 9 April 1959, Digging Up the Past (Leonard Woolley) Editorial File, DM1107/A02/0004. With the Permission of the Penguin Archive, UBSC.

36. Penguin First Editions; Morpurgo, Lane, 144, 153-4.

37. Leonard Woolley, Ur: the first phases (London: Penguin Books, 1947).

38. Penguins Progress, 1947 [No 4 - Easter]: 58-9, DM1294/4/1. With the Permission of the Penguin archive, UBSC.

39. Penguins Progress, 1948 (No.6), 7, DM1294/4/1. With the Permission of the Penguin archive, UBSC.

40. Morpurgo, Lane, 213-15, 244, 248-51. Morpurgo notes that the expanding higher education system in the US also used Pelican books (sold through US branch Penguin Books Inc.) as college texts.

41. Penguins Progress, 1948 [No 6 - July], 5-6, DM1294/4/1. With the Permission of the Penguin archive, UBSC.

42. Allen Lane to Oliver Gurney, 26 November 1952, The Hittites (O. R. Gurney), Editorial File, DM1107/A259. With the Permission of the Penguin archive, UBSC.

43. See Penguin Books to Gurney, 7 August 1946, The Hittites (O. R. Gurney), Editorial File, DM1107/A259. With the Permission of the Penguin archive, UBSC.

44. National Life Story Collection (NLSC), Book Trade Lives, 2004, Tanya Schmoller (interviewer Sue Bradley), F14829, Tape 5 Side B, British Library Sound Archive. After leaving The Bodley Head Christie moved to publish with William Collins, where she remained for the rest of her life. See J. W. Lambert and Michael Ratcliffe, The Bodley Head 18871987 (London: The Bodley Head, 1987), 213-15; Mallowan, Memoirs, 288-9; Morpurgo, 1979: 59-60, 80.

45. Penguins Progress, 1948 [No 6 - July], 5-6, DM1294/4/1/1/17. Penguin archive, Bristol. With the Permission of the Penguin archive, UBSC. Mallowan's Asia volume never appeared.

46. Gurney to Penguin Books, 21 October 1950, The Hittites (O. R. Gurney), Editorial File, DM1107/A259. With the Permission of the Penguin archive, UBSC.

47. Gurney to Mallowan, 27 December 1950, The Hittites (O. R. Gurney), Editorial File, DM1107/ A259. With the Permission of the Penguin archive, UBSC.

48. Gurney to Mallowan, 27 December 1950; Glover to Gurney, 17 January 1951, The Hittites (O. R. Gurney), Editorial File, DM1107/A259. With the Permission of the Penguin archive, UBSC.

49. Gurney to Lane, 24 November 1952, DM1107/A259, The Hittites (O. R. Gurney), Editorial File, DM1107/A259. With the Permission of the Penguin archive, UBSC. By the 1950s most Pelican books were sold for between 1 shilling and 3 shillings and sixpence. Gurney's book was at the top end of the purchase price, partly because of the number of illustrations included. See Glover to Gurney, 1 October 1952, The Hittites (O. R. Gurney), Editorial File, DM1107/A259. With the Permission of the Penguin archive, UBSC.

50. See Michaels to Penguin, 30 December 1952; Glover to Bar David Literary Agency, 17 December 1953; Gurney to Penguin, 21 July 1955, Penguin archive, Bristol. With the Permission of the Penguin archive, UBSC.

51. Mallowan to Lane, 26 October 1948; Lane to Mallowan, 27 October 1948; Benn to Lane, 9 November 1948; Lane to Benn, 17 November 1948, DM1107/A46, Editorial File for Letters of Gertrude Bell (Elsa Richmond). With the Permission of the Penguin archive, UBSC. 
52. Allen Lane to Leonard Woolley [copy], 28 September 1951, A Forgotten Kingdom (Leonard Woolley), Editorial File DM1107/A261; [Pelican Books] to Gurney, 7 August 1946, The Hittites (O. R. Gurney), Editorial File DM1107/A259. With the Permission of the Penguin archive, UBSC.

53. Woolley to Lane, 1 October 1951, A Forgotten Kingdom (Leonard Woolley), Editorial File, DM1107/A261. With the Permission of the Penguin archive, UBSC.

54. Woolley to Lane, 1 October 1951. A Forgotten Kingdom (Leonard Woolley), Editorial File, DM1107/A261. With the Permission of the Penguin archive, UBSC.

55. Woolley to Lane, 10 October 1951, A Forgotten Kingdom (Leonard Woolley), Editorial File, DM1107/A261. With the Permission of the Penguin archive, UBSC.

56. Woolley to Lane, 12 October 1951, A Forgotten Kingdom (Leonard Woolley), Editorial File, DM1107/A261. With the Permission of the Penguin archive, UBSC.

57. Glover note [undated], A Forgotten Kingdom (Leonard Woolley), Editorial File, DM1107/ A261. With the Permission of the Penguin archive, UBSC.

58. Leonard Woolley, A Forgotten Kingdom (Harmondsworth: Penguin Books, 1953), 23.

59. Woolley, Forgotten, 14, 20.

60. Note [undated], A Forgotten Kingdom (Leonard Woolley), Editorial File, DM1107/A261. With the Permission of the Penguin archive, UBSC.

61. On AVM see Glyn Daniel, Some Small Harvest: the memoirs of Glyn Daniel (London: Thames \& Hudson, 1986), 247; for information on Rainey see John Bockstoce, 'Froelich Gladstone Rainey (1907-92)', Arctic 48 (1) (1993).

62. 'Six TV awards', Yorkshire Post and Leeds Intelligencer [British Newspaper Archive], 25 October 1954, 5. Wheeler's appearances are based on listings in the Radio Times via BBC Genome.

63. Wheeler to Frost, 2 July 1953; Bell to Wheeler, 7 August 1953, Rome Beyond Imperial Frontiers (R. E. M. Wheeler), Editorial File, DM1107/A335. With the Permission of the Penguin archive, UBSC.

64. Wheeler to Frost, 11 August 1953, Rome Beyond Imperial Frontiers (R. E. M. Wheeler), Editorial File, DM1107/A335. With the Permission of the Penguin archive, UBSC.

65. Frost, Internal Memo, 9 October 1953; Wheeler to Frost, 27 October 1953, Rome Beyond Imperial Frontiers (R. E. M. Wheeler), Editorial File, DM1107/A335. With the Permission of the Penguin archive, UBSC.

66. Glover to Wheeler, 16 March 1955, Rome Beyond Imperial Frontiers (R. E. M. Wheeler), Editorial File, DM1107/A335. With the Permission of the Penguin archive, UBSC. Pelican had already instigated the Penguin Classics series, republishing the work of several noted classical authors.

67. Peter Spicer to Allen Lane, 14 December 1954; Wheeler to Frost, 21 February 1955, Archaeology from the Earth (R. E. M. Wheeler), Editorial File, DM1107/A356. With the Permission of the Penguin archive, UBSC.

68. See Juliet O'Hea to Anthony Godwin, 11 October 1960, Rome Beyond Imperial Frontiers (R. E. M. Wheeler), Editorial File, DM1107/A335. With the Permission of the Penguin archive, UBSC.

69. See Tony Godwin to Juliet O'Hea, 24 January 1961, [undated card], Juliet O'Hea to A. Godwin, 11 October 1960, Rome Beyond Imperial Frontiers (R. E. M. Wheeler), Editorial File, DM1107/ A335. With the Permission of the Penguin archive, UBSC.

70. See correspondence in Rome Beyond Imperial Frontiers (R. E. M. Wheeler), Editorial File, DM1107/A335. With the Permission of the Penguin archive, UBSC.

71. See Lloyd's autobiography The Interval (Faringdon: Lloyd Collon, 1986) for his presentation of his own life and work.

72. Lloyd, Foundations, 9-10.

73. Woolley, L., 'Introduction', in Seton Lloyd, Foundations in the Dust: A Story of Mesopotamian Exploration (Oxford: Oxford University Press, 1947), vii-X.

74. Allen Lane to Seton Lloyd, 10 August 1953, Early Anatolia (Seton Lloyd), Editorial File, DM1107/A354. Glover to Geoffrey Cumberledge, 2 September 1953; Glover to Lloyd, 1 October 1953, Foundations in the Dust (Seton Lloyd), Editorial File, DM1107/A336. With the Permission of the Penguin archive, UBSC.

75. See Mallowan, Memoirs, 241-91.

76. Lloyd to Glover, 20 December 1953, Foundations in the Dust (Seton Lloyd), Editorial File, DM1107/A336. With the Permission of the Penguin archive, UBSC. See Lloyd, 1955.

77. Lloyd, Foundations. 
78. Mary Rich's journal is published as Appendix 1 in Narrative of a Residence in Koordistan... Vol. 1. Her introductory essay to Babylon's history appears in Narrative of a Journey to the Site of Babylon in $1811 \ldots$

79. When the book came up for reprinting in 1965, Lloyd asked whether the illustrations could be included in a revised edition. See Lloyd to James Cochrane, 3 October 1965, DM1107/A336. Foundations in the Dust (Seton Lloyd), Editorial File, DM1107/A336. With the Permission of the Penguin archive, UBSC.

80. See Drafts in Foundations in the Dust (Seton Lloyd), Editorial File, DM1107/A336. With the Permission of the Penguin archive, UBSC.

81. Letter from Allen Lane to Max Mallowan, 1 June 1953. Early Anatolia (Seton Lloyd), Editorial File, DM1107/A354. With the Permission of the Penguin archive, UBSC.

82. Memo from Glover to Allen Lane, 14 July 1953. Early Anatolia (Seton Lloyd), Editorial File, DM1107/A354. With the Permission of the Penguin archive, UBSC.

83. Memo from Glover to Allen Lane, 16 July 1953. Early Anatolia (Seton Lloyd), Editorial File, DM1107/A354. With the Permission of the Penguin archive, UBSC.

84. Daniel, Harvest, 224-5. Daniel was particularly displeased with the quality of some of the earlier Pelican archaeology books, namely amateur archaeologist S. E. Winbolt's Britain B. C. and anthropologist W. J. Perry's Growth of Civilisation. This attitude, however, implies Daniel's dismissal of earlier approaches to archaeology more generally.

85. Letter from Mallowan to Lloyd, 21 January 1954. Early Anatolia (Seton Lloyd), Editorial File, DM1107/A354. With the Permission of the Penguin archive, UBSC.

86. Letter from Lloyd to Glover, 24 March 1954. Early Anatolia (Seton Lloyd), Editorial File, DM1107/A354. With the Permission of the Penguin archive, UBSC. Gill, Sifting, 88.

87. Lloyd to Allen Lane, 7 February 1956; Lloyd to Glover, 27 August 1956. Early Anatolia (Seton Lloyd), Editorial File, DM1107/A354. With the Permission of the Penguin archive, UBSC.

88. The percentages are as follows: 64 per cent of fiction appearing as a Penguin paperback in 1957 sold below 750 copies per month on average, with the remaining 36 per cent selling above 751 copies per month. See [Draft figures on sales], Frost Papers, DM1843/36. With the Permission of the Penguin archive, UBSC.

89. [Draft figures on sales], Frost Papers, DM1843/36. With the Permission of the Penguin archive, UBSC.

90. [Draft figures on sales], Frost Papers, DM1843/36. With the Permission of the Penguin Archive, UBSC.

91. Penguins Progress, 6 July 1948, 3. Penguin archive, Bristol. With the Permission of the Penguin archive, University of Bristol Special Collections

92. See Janet Morgan, Agatha Christie: a Biography (Glasgow: William Collins \& Sons, 1985), 200-15.

93. Death average monthly rate listed as 2,500 per month; Murder as 3,000. [Draft figures on sales], Frost Papers, DM1843/36. With the Permission of the Penguin archive, UBSC.

94. See Daniel, Harvest, Ch.7.

95. Daniel to Godwin, 4 March 1964; 22 June 1964, Glyn Daniel, General File, DM1952/A02/ Archaeology. With the Permission of the Penguin archive, UBSC.

96. See Glyn Daniel General File, DM1952/614. With the Permission of the Penguin Archive, UBSC.

97. Memo from Penguin Books Ltd (Jim Cochrane), Glyn Daniel General File, DM1952/614. With the Permission of the Penguin archive, UBSC.

98. See Sen, 'Paperbacks'; Piet Schreuders, The Book of Paperbacks: A Visual History of the Paperback (London: Virgin Books, 1981); Dominic Strinati and Stephen Wagg, Come on Down? Popular Media Culture in Post War Britain. (London: Routledge, 1992).

99. See Sen, 'Paperbacks', 451. 'Obituary: Mr. Alan Bott', The Times Digital Archive, 19 September 1952, 8. Eventually a triumvirate composed of publishers William Heinemann, William Collins and Macmillan took over Pan publishing. A useful resource for Pan books can be found online at: http://www.tikit.net/.

100. R. E. Mortimer Wheeler, Still Digging (London: Michael Joseph, 1955); Wheeler, Still Digging: Adventures in Archaeology (London: Pan Books, 1958).

101. Sen, 'Paperbacks', 451; 'Hutchinson', TLS Historical Archive, 24 October 1958, 601; 'Grey Arrows', TLS Historical Archive, 29 May 1959, 313; Wheeler, Walls.

102. 'The Wonders of Ancient Egypt', Pan Record 20 (London: Pan Books, 1956). Last modified 3 December 2017: http://www.tikit.net/PAN\%20Record/Pan\%20Record\%2020/Default.html. 


\section{Chapter 9}

1. Reginald Campbell Thompson, Digger's Fancy: A Melodrama (London: Sidgwick \& Jackson, 1938), 12.

2. See David Anderson, 'Archaeology in Science Fiction and Mysteries', in Ancient Muses: Archaeology and the Arts, eds John H. Jameson, Jr, John E. Ehrenhard and Christine Finn (Tuscaloosa, AL: University of Alabama Press, 2003); Charles Thomas, 'The Archaeologist in Fiction', in To illustrate the monuments: essays on archaeology presented to Stuart Piggott, ed. J. V. S. Megaw (London: Thames \& Hudson, 1976) for overviews of archaeologists in fiction. Most concentrate on fiction produced in the later twentieth century.

3. Thompson, Digger's, 14, 22-3.

4. Thompson, Digger's, 22-3.

5. Thompson, Digger's, 25, 30-8.

6. For a discussion of these campaigns see Satia, Spies, Ch.7; Thompson, Digger's, 42.

7. Thompson, Digger's, 48.

8. See Agatha Christie, Lord Edgware Dies (London: Crime Club, 1933); Agatha Christie, An Autobiography (New York: Dodd Mead \& Co, 1977), 467.

9. Reginald Campbell Thompson, 'Ernest Alfred Wallis Budge, 1857-1934', Journal of Egyptian Archaeology 21 (1): 68-70 (1935): 68. On the sinister mummy see Luckhurst, Mummy, Ch. 2.

10. Ismail, Budge, Ch.22.

11. See Godfrey R. Driver, 'Reginald Campbell Thompson, 1876-1941', Proceedings of the British Academy 30 (1944).

12. Chronicled in his 1915 memoir, A Pilgrim's Scrip.

13. Driver, 'Thompson', 463.

14. 'List of New Books and Reprints. Travel', Times Literary Supplement Historical Archive, 28 January 1915, 30.

15. Thompson, Pilgrim's, 5.

16. Anon, 'Jottings from the Near East', Geographical Journal 46 (1) (1915).

17. Reginald Campbell Thompson, A List of Words and Phrases in the Basrah Dialect of Arabic (Simla: Government Central Branch, 1915); Florence Bell, ed., The Letters of Gertrude Bell, vol. 2 (Harmondsworth: Penguin Books, 1939): 353, 364, 371; Driver, 'Thompson', 463. Among the categories included in Thompson's Arabic grammar were transliterations of questions relevant to ascertaining troop movements from Arabic speakers, including 'Did you see any troops there?' (Thompson, List, 15).

18. Driver, 'Thompson', 464.

19. Thompson, Handbook; See 'List of New Books and Reprints. Travel', Times Literary Supplement Historical Archive, 16 January 1919, 34.

20. Driver, 'Thompson', 467.

21. Joseph McAleer, Passion's Fortune: the story of Mills and Boon (New York: Oxford University Press 1999), 3.

22. McAleer, Passion's, 14.

23. McAleer, Passion's, 29, 38-42, 46-52.

24. Mills \& Boon, 'Mills \& Boon's Autumn List', in By Chelsea Reach: Some Riverside Records (London: Mills \& Boon). Last accessed 4 December 2017: https://archive.org/stream/bychels eareachso00blunuoft\#page/278/mode/2up, 1921.

25. 'New Fiction', Scotsman [British Newspaper Archive], 20 October 1921, 2; 'A Song of Araby', Illustrated Sporting and Dramatic News [British Newspaper Archive], 8 October 1921, 175; Driver, 'Thompson', 466-7.

26. John Guisborough, A Song of Araby (London: Mills \& Boon, 1921), 24. See Satia Spies, 74 for a discussion of Arabia enabling freedom from government.

27. On the element of disguise in travel narratives see Keighren et al., Travels, 15; Satia, Spies, $77-8,112-15$.

28. The number of romance fiction novels published by Mills \& Boon increased in the 1920s. Popular and successful Mills \& Boon authors Louise Gerard and Joan Sutherland produced romance adventure fiction set in 'exotic' locations during the early to mid-1920s. McAleer notes that Charles Boon gave 1930 as the date at which Mills \& Boon began to specialise wholly in romance fiction (McAleer, Passion's, 6, 46-8).

29. Guisborough, Song, Ch.19. 
30. Guisborough, Song, 17. Jay Dixon has explored the feminist context for Mills \& Boon romances through the decades. However, Thompson/Guisborough's novels do not feature in her analysis. See The Romance Fiction of Mills \& Boon, 1909-90s (London: UCL Press, 1999).

31. Novelist 'Ouida' (real name Maria Louisa Ramé) was a popular novelist of the late nineteenth century. Her behaviour and writing scandalised many - see Eleanor Fitzsimons, Wilde's Women: How Oscar Wilde Was Shaped by the Women He Knew (London: Duckworth Outlook, 2015) Ch. 14; see Guisborough, Mirage, 96, 108-11.

32. Guisborough, Mirage, 274-5.

33. Henry W. Fowler and F. George Fowler, The Concise Oxford Dictionary: The 1911 First Edition (Oxford: Oxford University Press, 2011), 736.

34. Notable examples of these documentaries include the Egypt Exploration Society's film of John Pendlebury's excavations at Tell el Amarna, shown in conjunction with the EES's exhibitions, and the Wellcome Marston Archaeological Expedition to the Near East film of excavations at Tell ed Duweir (biblical Lachish) - see Thornton, 'Exhibition'. See also the website of the Filming Antiquity project: www.filmingantiquity.com.

35. See, for example, M. Isabel Santaula'ria i Capdevila, "'He comes back badder and bigger than ever!" Readapting the masculine and negotiating the feminine in treasure-hunting adventure fiction', Journal of Gender Studies 12 (3) (2010) for analysis of masculinity and femininity in adventure film and literature. Mark Hall also explores the idea of the archaeological romantic adventure specifically through popular films via themes - colonialism, treasure hunting, gender and sexuality and politics: see 'Romancing the Stones: Archaeology in Popular Cinema', European Journal of Archaeology 7 (2) (2004). See David Day, A Treasure Hard to Attain: Images of Archaeology in Popular Film, with a Filmography (Langham, MD: Scarecrow Press, 1997) for an overview of archaeology-based feature films.

36. Dorothy L. Sayers, Great Stories of Detection. Mystery and Horror (London: Victor Gollancz, 1928), 9.

37. Margaret Murray, My First Hundred Years (London: William Kimber, 1963), 175.

38. See Moshenska, 'M. R. James', 1199. See also Hall, 'Romancing'.

39. Holtorf, Archaeology, 84-91 documents late twentieth-century archaeologists' views on this aspect of archaeological work, in the context of the role of the archaeologist in 'making profound revelations'.

40. Christie, Autobiography, 386.

41. See Brian Stableford, Historical Dictionary of Fantasy Literature (Lanham, MD: The Scarecrow Press Inc, 2005), 79-80; 118-9; 292-4; 337; 406-7. For an overview of Murray's interest in and work on the occult see Sheppard, Murray, Ch.7.

42. An overview of the origins and definitions of fantasy as a fiction genre can be found in Stableford, Dictionary.

43. See Luckhurst, Mummy; Duesterberg, Popular. Relevant anthologies include Bill Pronzini, ed., Tales of the Dead (London: Book Club Associates, 1987); John Stephens, ed., Into the Mummy's Tomb (New York: Berkeley Books, 2001); Adam Smith, ed., Lost in a Pyramid \& Other Classic Mummy Stories (London: The British Library, 2016).

44. 'Lot No. 249' originally appeared in Conan Doyle's anthology of medical stories, Round the Red Lamp: being facts and fancies of medical life (Methuen, 1894); Arthur Conan Doyle, 'Burger's Secret', in The 'Sunlight' Yearbook for 1898 (Port Sunlight: Lever Brothers, Limited, 1898). This story was first brought to my attention in Ross McFarlane's blog post 'Burger's Secret: discover an unexpected Conan-Doyle story', Wellcome Library blog. Last modified 4 December 2017: http://blog.wellcomelibrary.org/2015/12/burgers-secret-discover-an-unexpectedconan-doyle-story/.

45. This story was first published in Blackwood's Incredible Adventures and subsequently republished in Strange Stories (1929); Algernon Blackwood, 'A Descent into Egypt', Strange Stories (London: Heinemann, 1929), see also Luckhurst, Mummy, 180-1.

46. For details on Margery Lawrence's life and writings see Richard Dalby 'Introduction', in Margery Lawrence, Nights of the Round Table [Kindle Edition], (Ashcroft, Canada: Ash-Tree Press, 1998 [2013]) and 'Introduction', in Margery Lawrence, Terraces of Night [Kindle Edition] (Ashcroft, Canada: Ash-Tree Press, 1999) [2013]).

47. Hall, 'Romancing', 170.

48. Katy Price, 'Gender and the Domestication of Wireless Telegraphy in 1920s pulp fiction', in Domesticity in the Making of Modern Science, ed. Donald Optiz et al. (London: Palgrave 
Macmillan, 2016), 132. See advertisement for the Mystery-Story Magazine in March 1925 issue of Hutchinson's Adventure Story Magazine.

49. Phil Stephensen-Payne, 'Galactic Central: Hutchinson's (Adventure \&) Mystery-Story Magazine'. Last modified 4 December 2017: http://www.philsp.com/mags/hutchinsons_ mys.html ; on Tutmania see, for example, Bob Brier, Egyptomania: Our Three Thousand Year Obsession with the Land of the Pharaohs (New York, NY: Palgrave Macmillan, 2013), Ch. 9.

50. See advertisement for the Mystery-Story Magazine in September 1923 issue of Hutchinson's Adventure Story Magazine.

51. Margery Lawrence, 'Curse of the Stillborn', Hutchinson's Mystery Magazine 5 (June 1925).

52. Margery Lawrence, Nights of the Round Table (London: Hutchinson, 1926).

53. See Margery Lawrence, Ferry Over Jordan (London: Robert Hale Limited, 1945). Richard Dalby draws on this for his introductions to Kindle editions of Lawrence's short story compilations Nights of the Round Table and Terraces of Night.

54. Lawrence, Ferry, 17-18.

55. See Frederick Bligh Bond, The Gate of Remembrance (third edn) (Boston: Marshall Jones Company, 1920). For modern reassessments of Bligh Bond and his work at Glastonbury see Tim Hopkinson-Ball, The Rediscovery of Glastonbury (Chalford: Sutton, 2007); Roberta Gilchrist and Cheryl Green, Glastonbury Abbey: Archaeological Excavations 1904 to 1979 (London: Society of Antiquaries of London, 2015).

56. For overviews see, for example, Walter Salter, The Society for Psychical Research: an outline of its history (London: Society for Psychical Research, 1948); Nicholas Lowe, 'Gilbert Murray and Psychic Research', in Gilbert Murray Reassessed: Hellenism, Theatre and International Politics, ed. Christopher Stray (Oxford: Oxford University Press, 2007); Roger Luckhurst, The Invention of Telepathy (Oxford: Oxford University Press, 2002); Alison Owen, The darkened room: women, power and spiritualism in late nineteenth century England (London: Virago Books, 1989).

57. Ivor Grattan-Guinness, Psychical Research: A Guide to its History, Principles and Practices - in celebration of 100 years of the Society for Psychical Research (Wellingborough: Aquarian Press, 1982), 16; Salter, Psychical, 8-9.

58. One of Conway's best friends from Newnham was the classical scholar and (later) Editor of the SPR's Journal and Proceedings and Honorary Research Officer Helen Verrall. Her mother, Margaret Merrifield, had been a lecturer in classics at Newnham and co-authored Mythology and Monuments with Harrison. Margaret Merrifield Verrall was considered one of the SPR's most talented mediums. Though there is no evidence that Conway was officially an SPR member, she attended SPR lectures and maintained her friendship with Helen Verrall. See Thornton, 'Allure'; see also Salter, Psychical.

59. A. Conway, 6 April 1929, Diary Entry, MSS Add 7676/Z31; A. Conway and G. Horsfield, Petra Excavation Fund Diary, p.25, Box 8, Horsfield Archive, UCL Special Collections.

60. See Cooper to Conway, 21 July 1929; L. M. Bazett, 'Psychometry of Petra Sand' 2/29, 'Business Papers to be Kept', Box 8, Horsfield Archive, UCL Special Collections. Margery Bazett later wrote about the experience of analysing the Petra sand in her 1946 memoir Beyond the Five Senses (Oxford: Basil Blackwell, 53-4).

61. See C. Drayton Thomas to Helen Salter, 7 January, 11 April 1924. Salter Papers, SPRMS 50/ B19, B22, SPR Archive, Cambridge University Library. From the date of the letters it is possible that the unnamed tomb was Tutankhamun's. In Drayton's interpretation of the sitting Leonard's spirits were able to access the tomb more readily because it was being actively excavated and there was a human presence in the space.

62. For a discussion of spiritualist fantasy fiction and 'timeslip' fiction see Stableford, Dictionary, 382-3; 406-7.

63. Margery Lawrence, The Rent in the Veil (London: Robert Hale Ltd, 1951), 132.

64. 'The Rent in the Veil', Dundee Courier [British Newspaper Archive], 5 August 1952, 4.

65. Lawrence, Rent, 271.

66. For an overview of the role of historical fiction in presenting hidden histories - and women's history in particular - in the twentieth century see Diana Wallace, The Women's Historical Novel: British Women Writers, 1900-2000 (Basingstoke: Palgrave Macmillan, 2005).

67. Margery Lawrence, Daughter of the Nile (London: Robert Hale Ltd., 1956).

68. See Vanessa Wagstaffe and Stephen Poole, Agatha Christie: A Reader's Companion (London: Aurum Press Ltd, 2006), 122-3.

69. Mallowan, Memoirs, 211. 
70. Christie's experiences in archaeology have been contextualised, and her archaeological novels, particularly Murder in Mesopotamia, evaluated in Charlotte Trümpler, ed., Agatha Christie and archaeology (London: British Museum, 2001). Christie recorded her own experiences in archaeology before the Second World War in her memoir Come Tell Me How You Live (1947).

71. For details of Agatha Christie's life see Mallowan, Memoirs; Christie, Autobiography; Morgan, Christie.

72. See Christie, Autobiography, Part VIII.

73. Christie, Autobiography, 383; Morgan, Christie, 172.

74. Morgan, Christie, 273.

75. For country house murder see, for example, James Bartell, 'The Bureaucrat as Reader: the detective novel in the context of middle class culture', in Theory and Practice of Classic Detective Fiction, ed. Jerome H. Delamater and Ruth Prigozy (Westport, CT: Greenwood Press, 1997).

76. Agatha Christie, Murder in Mesopotamia (London: Fontana Books, 1974 [1936]), 13.

77. The house is purportedly based on the Mallowans' house at Chagar Bazar in Syria. Christie and Mallowan collaborated with the Chagar Bazar architect, Robin Macartney, on the plans for the dig house at Chagar. Macartney designed the original dust jacket for Murder in Mesopotamia and three other Christie mysteries (see Mallowan, Memoirs); Morgan, Christie, 210.

78. Duesterberg, Popular. A plan of the Ur dighouse can be found in Robert Dyson, 'Archival Glimpses of the Ur Expedition in the Years 1920-1926', Expedition 20 (1) (1977).

79. Agatha Christie, They Came to Baghdad (London: Fontana Books, 1969 [1951]); Morgan, Christie, 206; for a brief discussion of publisher's responses to They Came to Baghdad see Morgan, Christie, 283-4.

80. See also Elizabeth Foxwell, 'A Scholarly Study of Amelia Peabody Emerson \& the Women's Movement', in Amelia Peabody's Egypt: A Compendium, ed. Elizabeth Peters and Karen Whitbread (New York, NY: MPM Inc, 2003).

81. See M. Isabel Santaula'ria i Capdevila, "'He comes back badder and bigger than ever!" Readapting the masculine and negotiating the feminine in treasure-hunting adventure fiction', Journal of Gender Studies 12 (3) (2010): 222-3 for 'New Woman' and Jacqueline TavernierCourbin, 'Sleuthing and Excavating in Egypt: Elizabeth Peters' Humor', Thalia: Studies in Literary Humor 20 (1) (2009).

82. See Elizabeth Peters and Kristen Whitbread, Amelia Peabody's Egypt: A Compendium (New York, NY: MPM Inc, 2003); Elizabeth Peters, Crocodile in the Sandbank [Kindle Edn] (London: Constable \& Robinson Ltd, 2006).

83. See Peters, Crocodile, 'Author's Note'.

84. See Elizabeth Peters, He Shall Thunder in the Sky (New York, NY: Avon Books, 2000, 2004).

85. Peters, Thunder. Having grown up in a remote Egyptian site before being adopted into the Emerson family, Nefret is an initiated priestess of an ancient temple and thus has her own Anglo-Egyptian identity.

86. On Muski, see Karl Baedeker, Egypt and the Sudan (Leipzig: Karl Baedeker, 1914), 53-4.

87. See Peters, Thunder, Ch.1.

88. Peters, Thunder, 6, 150, 199-204.

89. Peters and Whitbread, Compendium, 210.

90. Peters, Thunder, 199-200.

91. On digital see Amelia Peabody pages on the MPM website: http://mpmbooks.com/archive/ ameliapeabody/.

92. Mark Latham, The Journal of Reginald Campbell Thompson (Swindon: Cubicle 7 Entertainment Ltd, 2015). 'Cthuhlu' is the famed monster of H. P. Lovecraft, an early twentieth-century American horror writer. The creature is first featured in Lovecraft's short story Call of Cthuhlu (1928).

\section{Epilogue}

1. John L. Myres, 'Greek and Roman Archaeology', in Conference on the Future of Archaeology, University of London Institute of Archaeology, Occasional Paper No.5 (London, 1943), 26-8.

2. 'Archaeology and the State Overseas', in Conference, 72-6.

3. See Reid, Whose Pharaohs? and Contesting.

4. This exact chronology is different in various countries, but generally began before the Second World War. See Goode, Negotiating, Ch.1 for a brief overview. 
5. Hartmann, 'Tourism'; importantly Hartmann also notes that seasonality and tourism patterns are different in different countries.

6. Edward Bacon, Digging For History (London: A. \& C. Black), 3.

7. 'The "Illustrated London News" to be monthly', Times Digital Archive, 22 February 1971, 2.

8. Daniel, Harvest, 219.

9. On the birth of Romano-British archaeology see Freeman, Training; Myres, 'Archaeology'. Wartime damage also increased the visibility of British archaeological heritage in the public eye, and rebuilding efforts led to new discoveries. For a brief overview of the early history of the Council for British Archaeology and its efforts in engaging the public see Suzie Thomas, 'Brian Hope-Taylor, the Council for British Archaeology, and "the Need for Archaeological Propaganda"', Public Archaeology 12 (2) (2013): 101-16.

10. 'Archaeologists Whose Discoveries Have Made the Past Live Again in the Pages of the "Illustrated London News". Recent Contributors from Many Countries', Illustrated London News, 23 December 1953, 1052-3.

11. Fyfe et al., Untangling.

12. See, for example, the Academic Book of the Week project.

13. Paul Laity, 'Pelican books take flight again', The Guardian, 25 April 2014. Last accessed 6 December 2017: https://www.theguardian.com/books/2014/apr/25/ pelican-books-take-flight-relaunch.

\section{Appendix}

1. Morris Bierbrier, Who Was Who in Egyptology (fourth revised edn) (London: Egypt Exploration Society, 2012).

2. Cohen and Sharp-Joukowsky, Breaking Ground.

3. Robert Todd, ed., Dictionary Of British Classicists (Bristol: Thoemmes, 2004).

4. Linda Medwid, Makers of Classical Archaeology (Amherst, NY: Humanity Books, 2002).

5. Agnes Conway, Diary entry, 25 April 1907, Add 7676/Z09, Conway Papers, University of Cambridge. On steamboat ladies see Susan Parkes, 'Steamboat ladies (act. 1904-1909)', in Oxford Dictionary of National Biography [online edn] (Oxford: Oxford University Press, 2007-17).

6. Thanks to Samira Ahmed, Simon Guerrier and Michael McCluskey for a lively discussion on Twitter about radio terminology. 


\title{
Bibliography
}

\author{
Individual archive documents and historic newspaper articles are \\ referenced in the text.
}

\section{Archives}

Gardner Papers - UCL Special Collections

Gardner Papers - British Library

Macmillan \& Co archive - British Library

Macmillan \& Co archive; A. \& C. Black archive (for Ernest Benn) - Reading University Publishing Archive

Penguin archive - Bristol University Special Collections

Petrie Correspondence - Petrie Museum

Meroe archive - Garstang Museum, University of Liverpool

Agnes Conway Diaries - Cambridge University Library

Horsfield archive - UCL Special Collections/Institute of Archaeology

Religious Tract Society archive - SOAS

John Murray archive - National Library of Scotland

College Hall archive - University of London Special Collections

O. G. S. Crawford archive - Bodleian Libraries

Session Fees Books and UCL Calendars - UCL Records

\section{Digital Databases}

British Newspaper Archive: Aberdeen Journal, Aberdeen Press and Journal, Bath Chronicle and Weekly Gazette, Berwick Advertiser, Birmingham Daily Post, Britannia and Eve, Daily Mirror, Dublin Daily Express, Dundee Courier, Dundee Evening Telegraph, Edinburgh Evening News, Evening Dispatch, Fife Free Press and Kirkaldy Guardian, Glasgow Herald, Gloucestershire Citizen, Gloucestershire Echo, Graphic, Hartlepool Mail, Hartlepool Northern Daily Mail, Illustrated Sporting and Dramatic News, Inverness Courier, Leamington Spa Courier, Leeds Mercury, Liverpool Echo, London Daily News, Manchester Courier and Lancashire Advertiser, Monmouthshire Beacon, Morning Post, Newcastle Daily Journal, Nottingham Evening Post, Nottingham Journal, Nottinghamshire Guardian, Pall Mall Gazette, Scotsman, Sheffield Daily Telegraph, Sphere, Sunderland Daily Echo and Shipping Gazette, Wells Journal, Western Daily Press, Western Daily Times, Western Times, Whitstable Times and Herne Bay Herald, Yorkshire Gazette, Yorkshire Post and Leeds Intelligencer 
Times Digital Archive

Times Literary Supplement Historical Archive

19th Century British Library Newspapers: Berrow's Worcester Journal, Birmingham Gazette, Bristol Mercury and Daily Post, Daily News, Glasgow Herald, Leeds Mercury, Liverpool Mercury, Morning Post, North-East Daily Gazette

19th Century British Periodicals - New Readerships: Englishwoman's Review, Graphic, John Bull, Women's Herald, Women's Penny Post

British Periodicals: Academy, Athenaeum, Bookman, English Illustrated Magazine, Leisure Hour, Practical Teacher, Sunday at Home

Illustrated London News Historical Archive

Chronicling America, Library of Congress: Dillon Herald, Evening Statesman, New York Tribune, New York Tribune Illustrated Supplement, Pacific Commercial Advertiser, Salt Lake Herald, San Francisco Call, Washington Herald, Western Liberal

Newspapers.com: Jacksonville Daily Journal

Trove Australia: The Age

Internet Archive

Hathi Trust

Oxford Dictionary of National Biography

Who Was Who

JStor

Women in Old World Archaeology

Punch Historical Archive

Trowelblazers.com

BBC Genome

\section{Secondary Sources}

A. \& C. Black. Writers' and Artists' Year Book 1906. London: A. \& C. Black, 1906.

A. \& C. Black. Prospectus. Peeps at Ancient Civilisations. London: A. \& C. Black, 1927.

A. \& C. Black. Writers' and Artists' Year Book 1933. London: A. \& C. Black, 1933.

Abdelmonem, Mohamed G. The Architecture of home in Cairo: socio-spatial practice of the Hawari's everyday life. Burlington: Ashgate, 2015.

Adburgham, Alison. Yesterday's Shopping: the Army and Navy Stores catalogue, a facsimile of the Army \& Navy co-operative society's 1907 issue... Newton Abbot: David \& Charles, 1969.

Allcock, John B. and Young, Antonia (eds). Black Lambs \& Gray Falcons: Women Travellers in the Balkans (2nd edn). New York: Berghahn Books, 2000.

Altick, Richard. The Shows of London. Cambridge, MA: Belknap Press, 1978.

Anderson, David G. 'Archaeology in Science Fiction and Mysteries', in Ancient Muses: Archaeology and the Arts, edited by John H. Jameson, Jr, John E. Ehrenhard and Christine Finn. Tuscaloosa, AL: University of Alabama Press, 2003.

Anderson, Martin. 'The development of British tourism in Egypt, 1815-1850', Journal of Tourism History 4 (3): 259-79.

Anderson, Patricia and Rose, Jonathan (eds). British Literary Publishing Houses 1820-1880 [Dictionary of Literary Biography 106]. Detroit, MI: Gale Publishing, 1991.

Anon. 'Jottings from the Near East', Geographical Journal 46 (1) (1915): 56.

Archaeological Institute of America. 'Twenty-ninth Annual Report of the President, 1907-08', American Journal of Archaeology (1908): 5.

Ardis, Ann. New women, new novels: feminism and early modernism. New Brunswick, NJ: Rutgers University Press, 1990.

Ashley, Bob. The Study of Popular Fiction: A Sourcebook. London: Pinter Publishers, 1989.

Bacon, Edward. Digging For History. London: A. \& C. Black, 1960.

Bacon, Edward (ed.). The Great Archaeologists and their discoveries as originally reported in the pages of the Illustrated London News. London: Secker \& Warburg, 1976.

Baedeker, Karl. Egypt and the Sudan. Leipzig: Karl Baedeker, 1914. 
Bahrani, Zainab, Çelik, Zeynep and Eldem, Edhem. 'Introduction: Archaeology and Empire', in Scramble for the Past: A Story of Archaeology in the Ottoman Empire, 1753-1914, edited by Zainab Bahrani, Zeynep Çelik and Edhem Eldem, 15-42. Istanbul: SALT, 2011.

Baigent, Elizabeth. 'Poole, Sophia Lane (1804-1891)', in Oxford Dictionary of National Biography [online edn]. Oxford: Oxford University Press, 2004-2016.

Bar-Yosef, Eitan. The Holy Land in English culture 1799-1917: Palestine and the question of Orientalism. Oxford: The Clarendon Press, 2005.

Barker, Graeme, Roberts, Charlotte, Gosden, Christopher, Horning, Audrey and Welham, Kate. Reflections on Archaeology. London: British Academy, 2017.

Barnett, Lionel. Antiquities of India... London: Philip Lee Warner, 1914.

Bartell, James E. 'The Bureaucrat as Reader: the detective novel in the context of middle class culture', in Theory and Practice of Classic Detective Fiction, edited by Jerome H. Delamater and Ruth Prigozy, 177-92. Westport, CT: Greenwood Press, 1997.

Barton, Gregory. Informal Empire and the Rise of One World Culture. Basingstoke: Palgrave Macmillan, 2014.

Bassnett, Susan. 'Travel Writing and Gender', in The Cambridge Companion to Travel Writing, edited by Peter Hulme and Tim Youngs. Cambridge: Cambridge University Press, 2002.

Beard, Mary. 'Casts and Cast-Offs: the Origins of the Museum of Classical Archaeology', Proceedings of the Cambridge Philological Society 39 (1993): 1-29.

Beard, Mary. "The Invention and Reinvention of "Group D": An Archaeology of the Classical Tripos, 1870-1919', in Classics in 19th and 20th century Cambridge: Curriculum, Culture and Community, edited by Christopher Stray. Cambridge: Cambridge Philological Society, 1999, 95-134.

Beard, Mary. The Invention of Jane Harrison. Cambridge, MA: Harvard University Press, 2002.

Beckett, Lorna. The Second I Saw You: the true love story of Rupert Brooke and Phyllis Gardner. London: British Library Publishing, 2015.

Bell, Florence (ed.). The Letters of Gertrude Bell, Vol. 2. Harmondsworth: Penguin Books, 1939.

Bellot, Hugh Hale. University College London, 1826-1926. London: University of London Press, 1929.

Benn, Ernest Ltd. The Autumn List Being a Choice of Books to be Published During the Later Months of the Year 1928. London: Benn Books, 1928.

Benn, Ernest Ltd. Benn's Sampler: being a miscellany shewing forth the manifold devices of our literary craftsmen in sundry passages from the books put out at the sign of the Chinese Horse... London: Ernest Benn Ltd, 1930.

Benn, Ernest Ltd. Benn's Second Sampler wherein is set forth a further selection of pleasant and notable fragments of literature from the books put out at the sign of the Chinese Horse... London: Ernest Benn Ltd, 1931.

Benn, Ernest Ltd. Being a list of books to be published during the later months of 1931 from Bouverie House Fleet Street. London: Ernest Benn Ltd, 1931.

Benn, Ernest. Happier Days: Recollections and Reflections. London: Ernest Benn Ltd, 1949.

Benson, Arthur C. Life and Letters of Maggie Benson. London: John Murray, 1917.

Benson, Margaret and Gourlay, Janet. Temple of Mut in Asher; an account of the excavation of the temple and of the religious representations and objects found therein... London: John Murray, 1898.

Bernhardsson, Magnus. Reclaiming a Plundered Past: Archaeology and Nation Building in Modern Iraq. Austin, TX: University of Texas Press, 2005.

Bickers, Robert (ed.). Settlers and Expatriates: Britons over the Seas. Oxford: Oxford University Press, 2010.

Bierbrier, Morris (ed.). Who Was Who in Egyptology. London: Egypt Exploration Society, 2012.

Birch, Samuel. 'The Progress of Biblical Archaeology: An Address', Transactions of the Society of Biblical Archaeology 1 (1) (1872): 1-12.

Birch, Samuel. Egypt from the earliest times to BC 300. London: Society for Promoting Christian Knowledge, 1890.

Blackwood, Algernon. 'A Descent into Egypt', Strange Stories. London: Heinemann, 1929.

Blake, Peter and Onslow, Barbara. 'Temple Bar', in Dictionary of Nineteenth-Century Journalism in Great Britain and Ireland, edited by Laurel Brake and Marysa Demoor. London: Academia Press/British Library, 2007, 618-19. 
Blake-Hill, Philip V. 'The Macmillan Archive', The British Museum Quarterly 36 (3/4) (1972): 74-80. Bligh Bond, Frederick. The Gate of Remembrance (3rd edn). Boston: Marshall Jones Company, 1920. Blouet, Brian W. 'Mackinder, Sir Halford John (1861-1947)', Oxford Dictionary of National Biography [online edn]. Oxford: Oxford University Press, 2004-16.

Boardman, John. '100 Years of Classical Archaeology in Oxford', in Beazley and Oxford: lectures delivered in Wolfson College, Oxford, 28 June 1985, edited by Donna Kurtz. Oxford: Oxford University Committee for Archaeology, 1985.

Bockstoce, John. 'Froelich Gladstone Rainey (1907-92)', Arctic 48 (1) (1993): 88-9.

Bonser, Wilfred. 'A Bibliography of the Writings of Dr Murray', Folklore 72 (3) (1961), 560-6.

Boots, 1912. Catalogue of Modern English Literature in Circulation with Boots Book-lovers' Library... London: Boots Head Department.

Bowler, Peter J. Science for All: The Popularization of Science in Early Twentieth-Century Britain. Chicago; London: University of Chicago Press, 2009.

Bosanquet, Ellen S. Days in Attica. London: Methuen, 1914.

Bosanquet, Ellen S. The Tale of Athens. London: Methuen, 1932.

Bosanquet, Ellen S. (ed.). Robert Carr Bosanquet: Letters and Light Verse. Gloucester: John Bellows, 1938.

Bosanquet, Ellen S. Late harvest: memories, letters and poems. London: Chameleon Press, 1971.

Boyce, D. George. 'Harmsworth, Alfred Charles William, Lord Northcliffe (1865-1922)', Oxford Dictionary of National Biography [online edn]. Oxford: Oxford University Press, 2004-2016.

Breay, Claire. 'Women and the Classical Tripos 1869-1914', in Classics in 19th and 20th century Cambridge: Curriculum, Culture and Community. Supplementary Vol. 24, edited by Christopher Stray, 49-70. Cambridge: Cambridge Philological Society, 1999.

Brendon, Piers. Thomas Cook: 150 years of popular tourism. London: Secker \& Warburg, 1991.

Brier, Bob. Egyptomania: Our Three Thousand Year Obsession with the Land of the Pharaohs. New York, NY: Palgrave Macmillan, 2013.

Briggs, Asa. The history of broadcasting in the United Kingdom. Oxford: Oxford University Press, 1995.

British School at Athens. 'List of Directors, Honorary Students, Students and Associates', Annual of the British School at Athens 33 (1932/1933): 234-53.

Brodrick, Mary (ed.). Egypt under the pharaohs: a history derived entirely from the monuments. London: John Murray, 1891.

Brodrick, Mary (ed.). A Handbook for travellers in Lower and Upper Egypt (10th edn). London: John Murray, 1900.

Brodrick, Mary. Handbook for Travellers in Syria and Palestine... London: Edward Stanford, 1903.

Brodrick, Mary. 'Our Inheritance': University College London 1827-1927. An Address delivered by Mary Brodrick... London: University of London Press, 1926.

Brodrick, Mary and Morton, Anna A. A Concise Dictionary of Egyptian Archaeology: a handbook for students and travellers. London: Methuen \& Co, 1902.

Broks, Peter. Media Science Before the Great War. London: Macmillan Press, 1996.

Brown, Mabel A. 'A Scheme of Correlated History and Literature', The Practical Teacher [British Periodicals] 31 (1) (1910): 68-9.

Browne, Janet. 'Looking at Darwin Portraits and the Making of an Icon', Isis 100 (3) (2009): 542-70.

Budge, Ernest A. W. The Nile: Notes for Travellers in Egypt. London: Thos. Cook \& Son, 1890.

Budge, Ernest A. W. The Book of the Dead: Chapters Coming forth by Day [Books on Egypt and Chaldea]. London: Kegan Paul Trench Trubner \& Co Ltd, 1898.

Budge, Ernest A. W. The Nile: Notes for Travellers in Egypt. London: Thos. Cook \& Son, 1906.

Budge, Ernest A. W. Cook's Handbook for Egypt and the Sudan (2nd edn). London: Thos. Cook \& Son, 1906.

Budge, Ernest A. W. Osiris and the Egyptian Resurrection. London: Lee Warner, 1911.

Budge, Ernest A. W. The Papyrus of Ani. A Reproduction in Facsimile. London: Lee Warner, 1913.

Budge, Ernest A. W. By Nile and Tigris: A Narrative of Journeys in Egypt and Mesopotamia on Behalf of the British Museum between the years 1886 and 1913. Volume 1 of 2. London: John Murray, 1920.

Budge, Ernest A. W. The Queen of Sheba and her only son Menyelck. London: Medici Society, 1922.

Budge, Ernest A. W. Legends of Our Lady Mary the Perpetual Virgin... London: Medici Society, 1922.

Budge, Ernest A. W. One Hundred and Ten Miracles of Our Lady Mary... London: Medici Society, 1923.

Budge, Ernest A. W. The Rise and Progress of Archaeology. London: Martin Hopkinson, 1925. 
Budge, Ernest A. W. Cleopatra's Needles and other Egyptian Obelisks: a series of descriptions of all the important inscribed obelisks, with hieroglyphic texts... London: Religious Tract Society, 1926.

Burns, J. Help-Book for Travellers to the East, including Egypt, Palestine, Turkey, Greece and Italy. London: Cook's Tourist Office, 1870.

British Broadcasting Company. The British Broadcasting Corporation Third Annual Report 1929. London: HM Stationery Office, 1930.

Capart, Jean (ed.). Travels in Egypt (December 1880 to May 1891): letters of Charles Edwin Wilbour. Brooklyn: Brooklyn Museum, 1936.

Carpenter, Humphrey. The Seven Lives of John Murray: the story of a publishing dynasty 1768-2002. London: John Murray, 2008.

Carr, Lydia. Tessa Verney Wheeler: women and archaeology before World War Two. Oxford: Oxford University Press, 2012.

Carson, Blanche M. From Cairo to the Cataract. Boston: L. Page \& Co, 1909.

Casson, Stanley. 'The New York of the Ancient World', The Listener 1 (12) (1929): 427-8.

Casson, Stanley. Archaeology. London: Ernest Benn Ltd, 1930.

Ceram, C. W. Gods, Graves and Scholars: The Story of Archaeology (second revised and enlarged edition). New York, NY: Bantam Books, 1980.

Challis, Debbie. From the Harpy Tomb to the Wonders of Ephesus. London: Duckworth, 2008.

Challis, Debbie. The Archaeology of Race: the eugenic ideas of Francis Galton and Flinders Petrie. London: Bloomsbury, 2013.

Chisholm, Hugh. 'Prefatory Note', in Encyclopaedia Britannica: a dictionary of arts, sciences, literature and general information (11th edn). Vol. 1: A to Androphagi. ed. Hugh Chisholm (vii-ix). Cambridge: Cambridge University Press, 1911.

Christie, Agatha. Lord Edgware Dies. London: Crime Club, 1933.

Christie, Agatha. Murder in Mesopotamia [9th impression]. London: Fontana Books, 1974 [1936].

Christie, Agatha. They Came to Baghdad [9th impression]. London: Fontana Books, 1969 [1951].

Christie, Agatha. Come Tell Me How You Live. London: HarperCollins, 1999.

Christie, Agatha. An Autobiography. New York: Dodd Mead \& Co, 1977.

Chubb, Mary. Nefertiti Lived Here. London: Geoffrey Bles, 1954.

Chubb, Mary. An Alphabet of Ancient Egypt. London: Geoffrey Bles, 1966.

Chubb, Mary. An Alphabet of Ancient Greece - Part 1. London: Geoffrey Bles, 1967.

Chubb, Mary. An Alphabet of Assyria and Babylonia. London: Geoffrey Bles, 1969.

Clack, Timothy and Brittain, Marcus (eds). Archaeology and the Media. Walnut Creek, CA: Left Coast Press, 2007.

Clogg, Richard. 'Politics and the Academy: Arnold Toynbee and the Koraes Chair', Middle Eastern Studies 21 (4) (1985).

Cobbing, Felicity. 'Thomas Cook and the Palestine Exploration Fund', Public Archaeology 11 (4) (2012): 179-94.

Cohen, Getzel M. and Sharp-Joukowsky, Martha (eds). Breaking Ground: pioneering women archaeologists. Ann Arbor, MI: University of Michigan Press, 2004.

Coke, Richard. 'The Baghdad Bookshop', Journal of the Royal Central Asian Society 13 (4) (1926): 419-20.

Cook, Emily T. Highways and Byways in London. London: Macmillan and Co Ltd, 1902.

Cook, Thomas \& Son. Cook's Tourists' Handbook for Egypt, the Nile and the Desert. London: Thos. Cook \& Son, 1892.

Cool Root, Margaret. 'Introduction: Women of the Field: Defining the Gendered Experience', in Breaking Ground: pioneering women archaeologists, edited by Getzel M. Cohen and Martha Sharp-Joukowsky, 1-33. Ann Arbor, MI: University of Michigan Press, 2004.

Cooper, Lisa. In Search of Kings and Conquerors: Gertrude Bell and the Archaeology of the Middle East. London: I. B. Tauris, 2016.

Conan Doyle, Arthur. 'Burger's Secret', in The 'Sunlight' Yearbook for 1898. Port Sunlight: Lever Brothers, Limited, 1898, 438-56.

Conway, Agnes Ethel. A Ride Through the Balkans: On Classic Ground with a Camera. London: R. Scott, 1917.

Cottrell, Leonard. The Bull of Minos. London: Pan Books, 1953.

Cottrell, Leonard. The Lost Pharaohs. London: Pan Books, 1964.

Cottrell, Leonard. The Lion Gate. London: Pan Books, 1967.

Cottrell, Philip, Poehl Fraser, Monica and Fraser, Iain (eds). East Meets West: banking, commerce and investment in the Ottoman Empire. Aldershot: Ashgate, 2008. 
Courtney, Janet E. Recollected in Tranquility. London: William Heinemann, 1926.

Courtney, Janet E. An Oxford Portrait Gallery. London: Chapman \& Hall, 1931.

Crosbie, Barry and Hampton, Mark. 'Introduction: the cultural construction of the British world', in The Cultural Construction of the British World, edited by Barry Crosbie and Mark Hampton. Manchester: Manchester University Press, 2016, 1-15.

Dalby, Richard. 'Introduction', in Margery Lawrence, Nights of the Round Table [Kindle edn]. Ashcroft, Canada: Ash-Tree Press, 1998 [2013].

Daniel, Glyn. Some Small Harvest: the memoirs of Glyn Daniel. London: Thames \& Hudson, 1986.

Dalby, Richard. 'Introduction', in Margery Lawrence, Terraces of Night [Kindle edn]. Ashcroft, Canada: Ash-Tree Press, 1999 [2013].

Davis, Miriam. Dame Kathleen Kenyon: digging up the Holy Land. Walnut Creek, CA: Left Coast Press, 2008.

Davis, Thomas W. Shifting Sands: the rise and fall of Biblical archaeology. Oxford: Oxford University Press, 2004.

Day, David. A Treasure Hard to Attain: Images of Archaeology in Popular Film, with a Filmography. Langham, MD: Scarecrow Press, 1997.

Dever, Norma. 'They Also Dug! Archaeologist's Wives and Their Stories', Near Eastern Archaeology 67 (3) (2004): 162-73.

Dietz, Nettie F. A White Woman in a Black Man's Country. Omaha, NE: privately printed, 1926.

Dixon, Jay. The Romance Fiction of Mills \& Boon, 1909-90s. London: UCL Press, 1999.

Doyle, Richella. 'The Society for the Promotion of Hellenic Studies Archive of George A. Macmillan's Personal Papers', Archaeological Reports 56: 203-18.

Driver, Godfrey R. 'Reginald Campbell Thompson, 1876-1941', Proceedings of the British Academy 30 (1944): 1-39.

Drower, Margaret. Flinders Petrie: A Life in Archaeology. London: Victor Gollancz Ltd, 1985.

Drower, Margaret. Letters from the Desert: The Correspondence of Flinders and Hilda Petrie. Oxford: Aris \& Phillips, 2004.

Duesterberg, Susanne. Popular Receptions of Archaeology: Fictional and Factual Texts in 19th and Early 20th Century Britain. Austria: Transcript, 2015.

Duffy, Maureen. A Thousand Capricious Chances: A History of the Methuen List 1889-1989. London: Methuen, 1986.

Dyson, Robert H. 'Archival Glimpses of the Ur Expedition in the Years 1920-1926', Expedition 20 (1) (1977).

Dyson, Steven. Eugenie Sellers Strong: Portrait of an Archaeologist. London: Duckworth, 2004.

Easterling, Pat. 'The Early Years of the Cambridge Greek Play: 1882-1912', in Classics in 19th and 20th century Cambridge: Curriculum, Culture and Community, edited by Christopher Stray. Cambridge: Cambridge Philological Society, 1999, 24-47.

Eckenstein, Lina. A History of Sinai. London: Society for Promoting Christian Knowledge, 1921.

Eckenstein, Lina. Tutankh-aten: A Story of the Past. London: Jonathan Cape, 1924.

Edwards, Amelia. A Thousand Miles Up the Nile. New York: A. L. Burt, 1888.

Edwards, Amelia. Pharaohs, Fellahs and Explorers. London: Osgood McIlvaine, 1891.

Edwards, Ruth D. Victor Gollancz: a biography. London: Victor Gollancz, 1987.

Egypt Exploration Fund. Report of the Seventeenth Ordinary General Meeting, Subscription List and Balance Sheet. London: Kegan Paul, Trench, Trubner \& Co, 1902/1903.

Eldem, Edhem. 'An Ottoman Archaeologist Caught Between Two Worlds: Osman Hamdi Bey (18421910)', in Archaeology, Anthropology and Heritage in the Balkans and Anatolia: the Life and Times of F. W. Hasluck, 1870-1920, edited by David Shankland. Istanbul: Isis Press, 2004, 121-49.

Elfick, Ian and Harris, Paul. T. N. Foulis, the history and biography of an Edinburgh publishing house. New Castle, Delaware; London: Oak Knoll Press \& Werner Shaw Ltd, 1998.

Eliot, Simon. 'Public Libraries and Popular Authors, 1883-1912', The Library S68 (4) (1986):322-50.

Eliot, Simon. Some Patterns and Trends in British Publishing 1800-1919. London: Bibliographical Society, 1994.

Eliot, Simon. 'Fiction and Non-Fiction: One- and Three-Volume Novels in Some Mudie Catalogues, 1857-94', Publishing History 66 (2009): 31-47.

Ellegard, Henrik A. The Readership of the Periodical Press in Mid-Victorian Britain. Goteborg: Goteborgs Universitets arsskrift 63 (3), 1957.

Encyclopaedia Britannica. 'Egypt: Ancient Egypt', in Encyclopaedia Britannica: a dictionary of arts, sciences, literature and general information (11th edn), Vol. 9: Edwardes to Evangelical Association, edited by Hugh Chisholm. Cambridge: Cambridge University Press, 1911, 39-90. 
Encyclopaedia Britannica. 'Initials and Headings. List of Contributors', in Encyclopaedia Britannica: a dictionary of arts, sciences, literature and general information (11th edn), Vol. 8: Demijohn to Edward, edited by Hugh Chisholm. Cambridge: Cambridge University Press, 1911, v-xvi.

Encyclopaedia Britannica. 'Petrie, William Matthew Flinders', in Encyclopaedia Britannica: a dictionary of arts, sciences, literature and general information (11th edn). Vol. 21: Payn to Polka, edited by Hugh Chisholm. Cambridge: Cambridge University Press, 1911, 316.

Encyclopaedia Britannica. 'List of Contributors', in Encyclopaedia Britannica: a dictionary of arts, sciences, literature and general information (11th edn). Vol. 29: Index. Edited by Hugh Chisholm. Cambridge: Cambridge University Press, 1911.

Evans, Arthur. The Palace of Minos..., 6 Vols. London: Macmillan \& Co, 1921-36.

Evans, Joan. Time and Chance: The Story of Arthur Evans and his forebears. London: Longmans, Green, 1943.

Evans, Joan. Prelude \& Fugue: An Autobiography. London: Museum Press Limited, 1964.

Evans, John D. 'The First Half Century - And After', Bulletin of the Institute of Archaeology 24 (1987): 1-25.

Evans, Maria M. Chapters on Greek Dress. London: Macmillan \& Co, 1893.

Feather, John. A History of British Publishing (2nd ed.). London: Routledge, 2006.

Fedorowich, Kent and Thompson, Andrew S. 'Introduction: Mapping the contours of the British World: empire, migration and identity', in Empire, Migration and Identity in the British World, edited by K. Fedorowich and A. S. Thompson. Manchester: Manchester University Press, 2013, 1-41.

Fitzsimons, Eleanor. Wilde's Women: How Oscar Wilde Was Shaped by the Women He Knew. London: Duckworth Outlook, 2015.

Fletcher, C. R. L. 'David George Hogarth, President R. G. S. 1925-27', Geographical Journal 71 (4) (1928): 321-44.

Fowler, Henry W. and Fowler, F. George. The Concise Oxford Dictionary: The 1911 First Edition. Oxford: Oxford University Press, 2011.

Foxwell, Elizabeth. 'A Scholarly Study of Amelia Peabody Emerson \& the Women's Movement', in Amelia Peabody's Egypt: A Compendium, edited by Elizabeth Peters and Karen Whitbread. New York, NY: MPM Inc, 2003, 138-45.

Francis, Lesley L. Robert Frost: An Adventure in Poetry, 1900-1918. New Brunswick, NJ/ London: Transaction Publishers, 2004.

Fraser, David. The Short Cut to India: The Record of a Journey along the Route of the Baghdad Railway. William Blackwood \& Sons: Edinburgh and London, 1909.

Freeman, Philip. The Best Training Ground for Archaeologists: Francis Haverfield and the Invention of Romano-British Archaeology. Oxford: Oxbow, 2007.

Furlong, Gillian. The archives of Routledge and Kegan Paul Ltd (1853-1973). London: the Library, University College London, 1978.

Fyfe, Aileen. 'Periodicals and Book Series: Complementary Aspects of a Publisher's Mission', in Culture and Science in the Nineteenth Century Media, edited by Louise Henson, Geoffrey Cantor, Gowan Dawson, Richard Noakes, Sally Shuttleworth, Jonathan Topham. Aldershot: Ashgate, 2004, 71-82.

Fyfe, Aileen. Science and Salvation: evangelical popular science publishing in Victorian Britain. Chicago and London: University of Chicago Press, 2004.

Fyfe, Aileen, Coate, Kelly, Curry, Stephen, Lawson, Stuart, Moxham, Noah and Mørk Røstvik, Camila. Untangling Academic Publishing: a history of the relationship between commercial interests, academic prestige, and the circulation of research 2017. DOI: https://doi.org/ 10.5281/zenodo.546100.

Gange, David. Dialogues with the Dead: Egyptology in British Culture and Religion, 1822-1922. Oxford: Oxford University Press, 2013.

Gange, David and Ledger Lomas, Michael (eds). Cities of God: the Bible and Archaeology in Nineteenth-Century Britain. Cambridge: Cambridge University Press, 2013.

Gardner, Ernest. A Handbook of Greek Sculpture. London: Macmillan \& Co, 1897.

Gardner, Ernest. Ancient Athens. London: Macmillan \& Co, 1902.

Gardner, Ernest. Six Greek Sculptors [Library of Art]. London: Duckworth, 1910.

Gardner, Ernest. Religion and Art in Ancient Greece [Harper's Library of Living Thought series]. London: Harper \& Brothers, 1910.

Gardner, Ernest. A Handbook of Greek Sculpture. London: Macmillan \& Co, 1915.

Gardner, Ernest. 'Francis Llewellyn Griffith', Journal of Egyptian Archaeology 20 (1/2) (1934): 71-7. 
Gardner, Mary. 'Samian wine: some Greek sketches', Temple Bar: a monthly magazine for town and country readers [British Periodicals] 131 (530) (1905): 49-66.

Gardner, Mary. A Short and Easy Modern Greek Grammar with grammatical and conversational exercises, idiomatic, proverbial phrases, and full vocabulary. London: David Nutt, 1910.

Gardner, Percy. 'Greek Art', in Encyclopaedia Britannica: a dictionary of arts, sciences, literature and general information (11th edn). Vol. 12: Gichtel to Harmonium, edited by Hugh Chisholm. Cambridge: Cambridge University Press, 1911, 470-92.

Gardner, Percy. Autobiographica. Oxford: Basil Blackwell, 1933.

Garstang. John. Excavations at Meroe Sudan. Second Season, 1911. Guide to the Tenth Annual Exhibition of Antiquities Discovered. Liverpool: Institute of Archaeology, 1911.

Gathercole, Peter. 'Childe Among the Penguins', Australian Archaeology 50 (2000): 7-11.

Geographical Teacher. 'The Regions of the World', Geographical Teacher 1 (3), 1 June 1902, 119-22.

Gibson, Shimon. 'British archaeological institutions in Mandatory Palestine, 1917-1948', Palestine Exploration Quarterly 131 (2) (1999): 115-43.

Gilchrist, Roberta and Green, Cheryl. Glastonbury Abbey: Archaeological Excavations 1904 to 1979. London: Society of Antiquaries of London, 2015.

Gill, David W. J. "“The passion of hazard": Women at the British School at Athens before the First World War', Annual of the British School at Athens 97 (2002): 491-509.

Gill, David W. J. 'The British School at Athens and Archaeological Research in the Late Ottoman Empire', in Archaeology, Anthropology and Heritage in the Balkans and Anatolia: the Life and Times of F. W. Hasluck, 1870-1920. Istanbul: Isis Press, 223-55.

Gill, David W. J. 'Brodrick, Mary (1858-1933)', Oxford Dictionary of National Biography [online edn]. Oxford: Oxford University Press, 2004-2006.

Gill, David W. J. 'Hogarth, David George (1862-1927)', Oxford Dictionary of National Biography [online edn]. Oxford: Oxford University Press, 2004-2010.

Gill, David W. J. Students at the British School at Athens (1886-1914). Swansea: Ostraka Press, 2008.

Gill, David W. J. Sifting the Soil of Greece: the early years of the British School at Athens (18861919). London: Institute of Classical Studies, 2011.

Gill, David W. J. 'Harry Pirie-Gordon and the Palestine guide-books', Public Archaeology 11 (4) (2012): 169-78.

Gill, David W. J. 'The Collection of John Disney, Antiquarian and University Benefactor', The Museum Archaeologist 36 (2017): 68-79.

Glasgow, Eric. 'The Origins of the Home University Library', Library Review 50 (2) (2001): 95-9.

Goode, James. Negotiating for the past: archaeology, nationalism, and diplomacy in the Middle East, 1919-1941. Austin, TX: University of Texas Press. 2007.

Government of 'Iraq. Maps of 'Iraq, with notes for visitors. Baghdad: Government of 'Iraq, 1928.

Gratton-Guinness, Ivor. Psychical Research: A Guide to its History, Principles and Practices - in celebration of 100 years of the Society for Psychical Research. Wellingborough: Aquarian Press, 1982.

Graves, Carl. 2011. 'A Ready Intelligence: Emily Paterson, 1861-1947', Birmingham Egyptology [online]: http://birminghamegyptology.co.uk/virtual-museum/a-ready-intelligence/.

Gretton, John. 'Introduction', in W. B. C. Lister. A Guide to the Microfiche Edition of Murray's Handbooks for travelers [online]. University Publications of America, 1993.

Griffith, Francis Ll. Beni Hasan Pt III (fifth Memoir). London: Egypt Exploration Society, 1896.

Griffith, Francis Ll. 'Bibliography 1922-1923: Ancient Egypt', Journal of Egyptian Archaeology 9 (3/ 4) (1923): 201-25.

Guisborough, John. A Song of Araby. London: Mills \& Boon, 1921.

Guisborough, John. A Mirage of Sheba. London: Mills \& Boon, 1923.

Gunning, Lucia. The British Consular Service in the Aegean and the Collection of Antiquities for the British Museum. Farnham, Surrey: Ashgate, 2009.

Hall, Catherine. 'Introduction: thinking the postcolonial, thinking the empire', in Cultures of Empire: Colonizers in Britain and the Empire in the 19th and 20th Centuries: A Reader, edited by Catherine Hall. Manchester, Manchester University Press, 2000, 1-33.

Hall, Catherine and Rose, Sonya O. 'Introduction: Being at home with the empire', in At Home with the Empire: Metropolitan Culture and the Imperial World, edited by Catherine Hall and Sonya O. Rose. Cambridge: Cambridge University Press, 2006, 1-31.

Hall, Harry R. (ed.). Handbook to Egypt and the Sudan. (11th edn). London: Edward Stanford, 1907.

Hall, Harry R. Aegean Archaeology: an Introduction... London: Philip Lee Warner, 1915.

Hall, Harry R. The Threshold of History. London: George G. Harrap \& Co, 1918. 
Hall, Harry R. Days Before History (second revised and enlarged edition). London: George G. Harrap \& Co, 1927.

Hall, Mark A. 'Romancing the Stones: Archaeology in Popular Cinema', European Journal of Archaeology 7 (2) (2004): 159-76.

Hamilton, Norah R. Both Sides of the Jordan: A Woman's Adventures in the Near East. London: Jenkins, 1928.

Hammerton, John, Mee, Arthur and Innes, A. D. 'The Book of History', in The Book of History: A History of all Nations from the earliest times to the present, edited by John Hammerton, Arthur Mee and A. D. Innes. London: Educational Book Company, 1915, 1-2.

Hammerton, John (ed.). 'Gallery of Contributors', in Peoples of All Nations: Their Life Today and the Story of Their Past. Vol 1. London: Amalgamated Press, iii-v.

Hammerton, John. 'Wonders of the Past: The Endless Romance of Antiquity. How the Dead Past is Made to Live Again', in Wonders of the Past (new edition). Vol. 1, edited by John Hammerton. London: Amalgamated Press (1923 [1933]): 1-2.

Hammerton, John. 'From a "Fleetway" Window: Random Remarks by the Editor', Wonders of the Past, Part 18 (13 November 1923). London: Amalgamated Press.

Hammerton, John. 'From a "Fleetway" Window: Random Remarks by the Editor', Wonders of the Past, Part 5 (15 May 1923). London: Amalgamated Press.

Hammerton, John. 'From the Editor's Desk: Chats about "Wonders of the Past"', Wonders of the Past Part 6 (7 December 1933). London: Amalgamated Press.

Hammerton, John. 'From the Editor's Desk: Chats About "Wonders of the Past", Wonders of the Past Part 8 (21 December 1933). London: Amalgamated Press.

Hammerton, John. Books and Myself: memoirs of an editor. Macdonald \& Co Ltd, 1944.

Hammond, Andrew. 'Memoirs of conflict: British women travellers in the Balkans', Studies in Travel Writing 14 (1) (2010): 57-75.

Hanauer, James and Masterman, Ernest (eds). Cook's Handbook for Palestine and Syria (new edn). London: Thos. Cook \& Son, 1907.

Handcock, Percy. Mesopotamian Archaeology. London: Macmillan/Philip Lee Warner, 1912.

Hankey, Julie, A Passion for Egypt: Arthur Weigall, Tutankhamun and the Curse of the Pharaohs. London: Tauris Parke Paperbacks, 2001.

Hare, Steve (ed.). Penguin Portrait: Allen Lane and the Penguin Editors 1935-1970. London: Penguin Books, 1995.

Harlan, Deborah. 'Travel, Pictures, and Victorian gentlemen in Greece', Hesperia 78 (2009): 421-53.

Harrison, Jane E. Myths of the Odyssey in Art and Literature. London: Rivingtons, 1882.

Harrison, Jane E. Introductory Studies in Greek Art. London: T. Fisher Unwin, 1885.

Harrison, Jane E. The Religion of Ancient Greece. London: Archibald Constable \& Co, 1905.

Harrison, Jane E. Reminiscences of a Student's Life. London: Hogarth Press, 1925.

Harte, Negley. The University of London 1836-1986: an illustrated history. London: Athlone Press, 1986.

Hartmann, Rudi. 'Tourism, seasonality and social change', Leisure Studies 5 (1986): 25-33.

Hatem, Mervat. 'Through Each Other's Eyes: The Impact on the Colonial Encounter of the Images of Egyptian, Levantine-Egyptian, and European Women, 1862-1920', in Western Women and Imperialism: Complicity and Resistance, edited by Nupur Chaudhuri and Margaret Strobel. Bloomington, IN: Indiana University Press, 1992, 35-60.

Hawes, Christopher and Hawes, Harriet B. Crete, the Forerunner of Greece. London: Harper \& Brothers, 1909.

Hawkes, Jacquetta. Mortimer Wheeler: adventurer in archaeology. London: Weidenfeld and Nicolson, 1982.

Hazbun, Waleed. 'The East as Exhibit: Thomas Cook \& Son and the Origins of the International Tourism Industry in Egypt', in The Business of Tourism: Place, Faith, and History, edited by Philip Scranton and Janet F. Davidson. Philadelphia, PA: University of Pennsylvania Press, 2007, 3-33.

Hobbs, Andrew. 'When the Provincial Press was the National Press (c. 1830s-1900)', The International Journal of Regional and Local Studies 5 (1) (2009): 16-43.

Hodges, John. 'Edith Durham: Traveller and Publicist', in Black Lambs \& Gray Falcons: Women Travellers in the Balkans (2nd edn), edited by John B. Allcock and Antonia Young. New York: Berghahn Books, 2000, 9-31.

Hogarth, David. G. 'Inscriptions from Salonica', Journal of the Hellenic Society 8 (1887): 356-75. 
Hogarth, David. G. A Wandering Scholar in the Levant. London: John Murray, 1896.

Hogarth, David. G. A Wandering Scholar in the Levant (2nd edn). London: John Murray, 1896.

Hogarth, David. G. The Nearer East. [Regions of the World] London: William Heinemann, 1902.

Hogarth, David. G. The Penetration of Arabia: a record of the development of western knowledge concerning the Arab peninsula. [The Story of Exploration]. London: Alston Rivers Ltd, 1904.

Hogarth, David. G. Accidents of an Antiquary's Life. London: Macmillan \& Co, 1910.

Hogarth, David. G. 'Aegean Civilization', in Encyclopaedia Britannica: a dictionary of arts, sciences, literature and general information (11th edn), Vol. 1: A to Androphagi, edited by Hugh Chisholm. Cambridge: Cambridge University Press, 1911, 245-51.

Hogarth, David G. and Benson, Edward F. Report on the Prospects of Research in Alexandria. London: Macmillan \& Co, c.1895.

Hogarth, Janet and Mitchell, J. Malcolm. 'Preface', in Encyclopaedia Britannica: a dictionary of arts, sciences, literature and general information (11th edn), Vol. 29: Index, edited by Hugh Chisholm. Cambridge: Cambridge University Press, 1911, v-viii.

Hogarth, Janet and Mitchell, J. Malcolm. 'Classified Table of Contents', in Encyclopaedia Britannica: a dictionary of arts, sciences, literature and general information (11th edn), Vol. 29: Index, edited by Hugh Chisholm. Cambridge: Cambridge University Press. 1911, 879-80.

Holt, Peter M. and Daly, Martin W. A History of Sudan from the Coming of Islam to the Present Day (6th edn). London: Routledge, 2011.

Holtorf, Cornelius. Archaeology is a Brand! Walnut Creek, CA: Left Coast Press, 2007.

Hopkinson-Ball, Tim. The Rediscovery of Glastonbury. Chalford: Sutton, 2007.

Howell, Georgina. Daughter of the Desert: the remarkable life of Gertrude Bell. London: Pan Macmillan, 2006.

Howsam, Leslie. 'Academic Discipline or Literary Genre?: The Establishment of Boundaries in Historical Writing', Victorian Literature and Culture 32 (2) (2004), 525-45.

Howsam, Leslie. Past Into Print: The Publishing of History in Britain 1850-1950. London: British Library, 2009.

Hubbard, Louisa M. The Englishwoman's Year-Book and Directory for 1888. London: Hatchards, 1888.

Hughes, Arthur, rev. Cook, B. F. 'Murray, Alexander Stuart (1841-1904)', Oxford Dictionary of National Biography [online]. Oxford: Oxford University Press, 2004.

Hupchick, Dennis P. The Balkans: From Constantinople to Communism. New York: Palgrave Macmillan, 2002.

Hutchinson, Walter. 'Introduction', in Hutchinson's History of the Nations: a popular, concise, pictorial and authoritative account of each nation from the earliest times to the present day, edited by Walter Hutchinson. London: Hutchinson \& Co, 1914, i-xxiv.

Ismail, Matthew. Wallis Budge: Magic and Mummies in London and Cairo. Kilkerrin, Scotland: Harding Simpole Publishing, 2011.

Jackson, Ashley and Tomkins, David. 'Ephemera in the British Empire', in Exhibiting the Empire: cultures of display and the British Empire, edited by John MacAleer and John Mackenzie. Manchester: Manchester University Press, 2015, 143-4.

James, Elizabeth (ed.). Macmillan: A Publishing Tradition. Basingstoke: Palgrave, 2002.

Janes, Emily (ed.). The Englishwoman's Year-Book and Directory 1899. London: A. \& C. Black, 1899.

Janssen, Rosalind. The first hundred years: Egyptology at University College London. London: Petrie Museum, 1992.

Janssen, Rosalind and Janssen, Jacques. 'Excavating the Petrie Museum', in Anthony Leahy and John Tait (eds), Studies on ancient Egypt in honour of H. S. Smith. Occasional Papers 13. London: The Egypt Exploration Society, 1999, 153-6.

Jastrow, Morris. The War and the Baghdad Railway: the story of Asia Minor and its relation to the present conflict. Philadelphia and London: J. B. Lippincott \& Co, 1918.

Johnson, Marilyn. Lives in Ruins: Archaeologists and the Seductive Lure of Human Rubble. New York: HarperCollins, 2014.

Joyce, Thomas A. South American Archaeology: An Introduction... London: Medici Society Ltd, 1912.

Joyce, Thomas A. Mexican Archaeology: An Introduction... London: Philip Lee Warner, 1914.

Joyce, Thomas A. Central American and West Indian Archaeology... London: Philip Lee Warner, 1916.

Kajinski, John L. 'Professionalism, Authority, and the Late-Victorian Man of Letters: A View from the Macmillan Archive', Victorian Literature and Culture 24 (1996): 229-43.

Kakissis, Amelia. The Byzantine Research Fund Archive: encounters of Arts and Crafts architects in Byzantium. British School at Athens Studies 17 (2009): 125-44. 
Karim, Ghazi A. 'Suq al-Saray, Al-Mutannabi and the book trade of Baghdad in the 1940s: a personal narrative', International Journal of Contemporary Iraqi Studies 9 (3) (2015): 165-90.

Katz, Israel. Henry George Farmer and the First International Congress of Arab Music. Leiden, Netherlands: Brill, 2015.

Keighren, Innes M., Withers, Charles W. J., Bell, Bill. Travels into Print: Exploration, Writing and Publishing with John Murray, 1773-1859. Chicago, IL: University of Chicago Press, 2015.

Kenyon, Kathleen. Digging Up Jericho. London: Benn, 1957.

Kingsley Kent, Susan. Gender and Power in Britain, 1640-1990. London: Routledge, 1999.

Klironomos, Martha. 'Early Twentieth-Century British Women Travellers to Greece: Contextualizing the Example of Virginia Woolf', Literature Compass 4 (2) (2007): 473-85.

Laity, Paul. 'Pelican books take flight again', Guardian [online], 25 April 2014: https://www. theguardian.com/books/2014/apr/25/pelican-books-take-flight-relaunch.

Lambert, J. W. and Ratcliffe, Michael. The Bodley Head 1887-1987. London: The Bodley Head, 1987.

Larkin, Jamie. Trading on the Past: an examination of the cultural and economic roles of shops at museums and heritage sites in England. Unpublished $\mathrm{PhD}$ thesis, University College London, 2016.

Larsen, Timothy. 'Nineveh', in Cities of God: the Bible and archaeology in Nineteenth-Century Britain, edited by David Gange and Michael Ledger Lomas. Cambridge: Cambridge University Press, 2013, 111-35.

Latham, Mark. The Journal of Reginald Campbell Thompson. Swindon: Cubicle 7 Entertainment Ltd, 2015.

Lawrence, Margery. 'Curse of the Stillborn', Hutchinson's Mystery Magazine 5 (June 1925): 129-38.

Lawrence, Margery. Nights of the Round Table. London: Hutchinson, 1926.

Lawrence, Margery. Ferry Over Jordan. London: Robert Hale Limited, 1945.

Lawrence, Margery. The Rent in the Veil. London: Robert Hale Ltd, 1951.

Lawrence, Margery. Daughter of the Nile. London: Robert Hale Ltd, 1956.

Ledger Lomas, Michael. 'Ephesus', in Cities of God: the Bible and archaeology in Nineteenth-Century Britain, edited by David Gange and Michael Ledger Lomas. Cambridge: Cambridge University Press, 2013, 254-84.

Lee, Alan J. The Origins of the Popular Press in England 1855-1914. London: Croom Helm, 1976.

Lesko, Barbara. 'Caroline Louise Ransom Williams (1872-1952)', Breaking Ground: Women in Old World Archaeology. Last accessed 3 December 2017 https://www.brown.edu/Research/ Breaking_Ground/results.php?d=1\&first=Caroline\%20Louise\&last=Ransom\%20Williams.

Lesko, Barbara. 'Phoebe Apperson Hearst', Breaking Ground: Women in Old World Archaeology. Last accessed 3 December 2017. https://www.brown.edu/Research/Breaking_Ground/results. php?d=1\&first $=$ Phoebe\%20Appserson\&last $=$ Hearst.

Levine, Philippa. The Amateur and the Professional: antiquarians, historians and archaeologists in Victorian England 1838-1886. Cambridge: Cambridge University Press, 1986.

Lister, W. B. C. A Guide to the Microfiche Edition of Murray's Handbooks for travelers [online]. University Publications of America, 1993.

Lloyd, Seton. Foundations in the Dust. Oxford: Oxford University Press, 1947.

Lloyd, Seton. Foundations in the Dust. Harmondsworth: Penguin Books, 1955.

Lloyd, Seton. The Interval: a life in Near Eastern archaeology. Faringdon: Lloyd Collon, 1986.

Lock, Peter. 1990. 'D. G. Hogarth (1862-1927): “... A Specialist in the Science of Archaeology"', Annual of the British School at Athens 85: 175-200.

Long, C. W. Richard. Bygone Heat: travels of an idealist in the Middle East. London: I. B. Tauris, 2004.

Loughton, Tim. 'Future of A Level Archaeology [oral debate]', Parliament Live TV. Last modified 2 December 2017 http://www.parliamentlive.tv/Event/Index/ 4f5dba5e-4819-49d5-969f-9e4aec427ccd.

Lowe, Nicholas J. 'Gilbert Murray and Psychic Research', in Gilbert Murray Reassessed: Hellenism, Theatre and International Politics, edited by Christopher Stray. Oxford: Oxford University Press, 2007.

Luckhurst, Roger. The Invention of Telepathy. Oxford: Oxford University Press, 2002.

Luckhurst, Roger. The Mummy's Curse: The True History of a Dark Fantasy. Oxford: Oxford University Press, 2012.

Luke, Harry and Keith-Roach, Edward (eds). The Handbook of Palestine. London: Macmillan \& Co Ltd, 1922.

Luke, Harry and Keith-Roach, Edward (eds). The Handbook of Palestine and Transjordan. London: Macmillan \& Co Ltd, 1930. 
Lumby, C. Cook's Traveller's Handbook to Palestine, Syria \& 'Iraq. London: Simkin Marshall Limited, 1934.

Lyons, Henry G. The Cadastral Survey of Egypt 1892-1907. Cairo: Ministry of Finance, Survey Department, 1908.

Lyth, Peter. 'Carry on up the Nile: The Tourist Gaze and the British Experience of Egypt, 1818-1932', in Martin Farr and Xavier Guegan, The British Abroad Since the Eighteenth Century, Volume 1: Travellers and Tourists. Basingstoke: Palgrave Macmillan, 2013.

Macalister, Robert A. S. A Century of Excavations in Palestine. London: Religious Tract Society, 1929.

Mackay, Dorothy. The Ancient Cities of Iraq. Baghdad: Kenneth Mackenzie, 1926.

Mackay, Dorothy. Mohenjo-daro. Indian State Railways Publicity Department, 1929.

Mackenzie, John. 'Empires of Travel: British Guide Books and Cultural Imperialism in the 19th and 20th Centuries', in Histories of Tourism: Representation, Identity and Conflict, edited by John Walton. Clevedon: Channel View Publications, 2005, 19-38.

Macmillan, George. 'An Outline of the History of the Hellenic Society', Journal of Hellenic Studies 49 (1929): i-li.

Macmillan \& Co. Guide to the Eastern Mediterranean (2nd edn). London: Macmillan \& Co, 1904.

Macmillan \& Co. Guide to Greece, the Archipelago, Constantinople... London: Macmillan \& Co, 1908.

Macmillan \& Co. Guide to Greece, the Archipelago, Constantinople... London: Macmillan \& Co, 1910.

Mahn, Churnjeet. British women's travel to Greece, 1840-1914: travels in the Palimpsest. Farnham: Ashgate, 2012.

Mairs, Rachel. From Khartoum to Jerusalem: The Dragoman Solomon Negima and his Clients (18851933). London: Bloomsbury Academic, 2016.

Mairs, Rachel and Muratov, Maya. Archaeologists, Tourists, Interpreters: Exploring Egypt and the Near East in the late 19th-early 20th centuries. London: Bloomsbury, 2015.

Malley, Shawn. 'Austen Henry Layard and the Periodical Press: Middle Eastern Archaeology and the Excavation of Cultural Identity in Mid-Nineteenth Century Britain', Victorian Review 22 (2) (1996): 152-70.

Malley, Shawn. From archaeology to spectacle in Victorian Britain. Farnham: Ashgate, 2012.

Mallowan, Max E. L. Mallowan's Memoirs: Agatha and the Archaeologist. London: HarperCollins Publishers, 2010.

Marcus, Laura. "Hieroglyphics in motion": representing ancient Egypt and the Middle East in film theory and criticism of the silent period', in The Ancient World in Silent Cinema, edited by Pantelis Michelakis and Maria Wyke. Cambridge: Cambridge University Press, 2013, 74-90.

Mariette, August; Brodrick, Mary (ed., trans.). Outlines of Ancient Egyptian History. London: John Murray, 1892.

Matthews, Roger. The archaeology of Mesopotamia: theories and approaches. London: Routledge, 2003.

McAleer, Joseph. Popular Reading and Publishing in Britain, 1914-1950. Oxford: Clarendon, 1992.

McAleer, Joseph. Passion's Fortune: the story of Mills and Boon. New York: Oxford University Press, 1999.

McFarlane, Ross. 2015. 'Burger's Secret: discover an unexpected Conan-Doyle story', Wellcome Library blog, 26 December [online]: http://blog.wellcomelibrary.org/2015/12/burgerssecret-discover-an-unexpected-conan-doyle-story/.

McMeekin, Sean. The Berlin-Baghdad Express: the Ottoman Empire and Germany's Bid for World Power, 1898-1918. London: Allen Lane, 2010.

Medwid, Linda. Makers of Classical Archaeology. Amherst, NY: Humanity Books, 2002.

Melman, Billie. Women's Orients: English Women and the Middle East, 1718-1918 - Sexuality, Religion and Work. Ann Arbor, MI: University of Michigan Press, 1995.

Milton, Giles. Paradise Lost: Smyrna 1922, the destruction of Islam's City of Tolerance. London: Hodder \& Stoughton, 2009.

Mitford, Jessica. 'Egyptomania', in Jessica Mitford, Poison Penmanship: the gentle art of muckraking. New York: New York Review Books, 1979 [2010].

Mitton, Geraldine E. (ed.). The Englishwoman's Year-Book and Directory 1909. London: A. \& C. Black, 1909.

Moon, Barbara. More Usefully Employed: Amelia B. Edwards, writer, traveller and campaigner for ancient Egypt. London: Egypt Exploration Society, 2006.

Morgan, Charles. The House of Macmillan (1843-1943). London: Macmillan, 1943.

Morgan, Janet. Agatha Christie: a Biography. Glasgow: William Collins \& Sons, 1985. 
Morpurgo, Jack E. Allen Lane: King Penguin. London: Hutchinson of London, 1979.

Moscrop, John J. Measuring Jerusalem: the Palestine Exploration Fund and British interests in the Holy Land. London: Leicester University Press, 1999.

Moshenska, Gabriel. 'M. R. James and the archaeological uncanny', Antiquity 86 (334): 1192-1201, 2012.

Mothersole, Jessie. 'Tomb Copying in Egypt', Sunday at Home. London: Religious Tract Society (1908): 345-51.

Mothersole Jessie. Hadrian's Wall. London: John Lane/Bodley Head, 1922.

Mothersole, Jessie. 'Hadrian's Wall: Relic of Roman Britain', in Wonders of the Past (new edition). Vol. 2, edited by J. A. Hammerton. London: Amalgamated Press (1923 [1933]): 871-84.

Mudie's Select Library Limited. Catalogue of the Principal Books in Circulation at Mudie's Select Library [January]. London: Mudie's Select Library Ltd, 1892.

Mudie's Select Library Limited. Catalogue of the Principal Books in Circulation at Mudie's Select Library [January]. London: Mudie's Select Library Ltd, 1893.

Mudie's Select Library Limited. Catalogue of the Principal Books in Circulation at Mudie's Select Library [January]. London: Mudie's Select Library Ltd, 1910.

Mudie's Select Library Limited. Catalogue of the Principal Books in Circulation at Mudie's Select Library [January]. London: Mudie's Select Library Ltd, 1914.

Mullan, Richard and Munson, James. The Smell of the Continent: the British Discover Europe. London: Macmillan, 2009.

Murray, John. Handbook to Egypt (8th edn). London: John Murray, 1891.

Murray, John. Handbook for Travellers in Greece. ... (7th edn). London: John Murray, 1900.

Murray, Margaret A. Ancient Egyptian Legends [Wisdom of the East series]. London: John Murray, 1920.

Murray, Margaret A. Petra: the Rock City of Edom. London: Blackie \& Son Limited, 1939.

Murray, Margaret A. My First Hundred Years. London: William Kimber, 1963.

Mutch, Deborah and Elkiss, Terry. 'Biography of Margaret Harkness', in A City Girl by John Law (Margaret Harkness), edited by Deborah Mutch. Brighton: Victorian Secrets, 2015, 27-30.

Myres, John L. The Dawn of History [Home University Library]. London: Williams \& Norgate, 1911. Napier, Patricia. A Late Beginner. London: Slightly Foxed Ltd, 1966 [2013].

Naunton, Chris. 'The Film Record of the Egypt Exploration Society's Excavations at Tell el-Amarna', KMT 21 (2010): 45-53.

Naunton, Chris. 'How should we define “Egyptologist"?' Last modified 1 December 2017 https:// chrisnaunton.com/2017/05/25/how-should-we-define-egyptologist/.

Naville, Edouard. 'Introduction', in Helen M. Tirard. The Book of the Dead. London: Society for Promoting Christian Knowledge, 1910, 10-12.

Nelson, Claudia. 'The English Illustrated Magazine', in Dictionary of Nineteenth-Century Journalism in Great Britain and Ireland, edited by Laurel Brake and Marysa Demoor. London: Academia Press/British Library, 2007, 201-3.

Newcastle University. 2016. 'The extraordinary Gertrude Bell: Teaching Packs' [online], https:// research.ncl.ac.uk/gertrudebell/schools/teachingpacks/.

Newcastle University/Applied Comics Etc. 2016. 'Gertrude Bell Comics: archaeologist, writer, explorer' [online], https://research.ncl.ac.uk/gertrudecomics/.

Nicholson, Bob. “"You Kick the Bucket; We Do the Rest!": Jokes and the Culture of Reprinting in the Transatlantic Press', Journal of Victorian Culture 17 (3) (2012): 273-86.

O'Neill, Patricia and Edwards, Amelia B. 'The Social and Political Position of Women in Ancient Egypt', PMLA 120 (3) (2005): 843-57.

Opper, Thorsten. The Meroe Head of Augustus. London: British Museum, 2014.

Owen, Alison. The darkened room: women, power and spiritualism in late nineteenth century England. London: Virago Books, 1989.

Pan Books. 1956. 'The Wonders of Ancient Egypt', Pan Record 20. London: Pan Books [online], http://www.tikit.net/PAN\%20Record/Pan\%20Record\%2020/Default.html.

Parkes, Susan. 'Steamboat ladies (act. 1904-1909)', in Oxford Dictionary of National Biography [online edn]. Oxford: Oxford University Press, 2007-17.

Pascoe, Charles E. (ed.). London of To-Day. London: Simkin, Marshall, Hamilton, Kent \& Co Ltd, 1894.

Paston, George. At John Murray's: records of a literary circle, 1843-1892. London: John Murray, 1932. 
Peacock, Sandra J. Jane Ellen Harrison: the mask and the self. London: Yale University Press, 1988. Pemble, John. The Mediterranean Passion: Victorians and Edwardians in the South. London: Faber and Faber, 2009.

Pendlebury, John D. S. A Handbook to the Palace of Minos at Knossos and its Dependencies. London: Macmillan \& Co, 1933.

Penguin First Editions, 2013-17. Penguin Forces Book Club [online]: http://www. penguinfirsteditions.com/index.php?cat=mainFBC.

Penguin First Editions, 2013-17. Pelican Books [online]: http://www.penguinfirsteditions.com/ index.php?cat= pelican001-099.

Perry, Sara. 'Archaeology on Television, 1937', Public Archaeology (2017), 1-6.

Peters, Elizabeth. He Shall Thunder in the Sky. New York, NY: Avon Books, 2000.

Peters, Elizabeth and Whitbread, Kristen (eds). Amelia Peabody's Egypt: A Compendium. New York, NY: MPM Inc, 2003.

Peters, Elizabeth. Guardian of the Horizon. New York: William Morrow, 2004.

Peters, Elizabeth. Crocodile in the Sandbank [Kindle edn]. London: Constable \& Robinson Ltd, 2006

Peters, Elizabeth. A River in the Sky. New York: William Morrow, 2010.

Petrie, William M. F. 'A Digger's Life', English Illustrated Magazine 30 [British Periodicals] (March 1886): 440-8.

Petrie, William M. F. 'The Romance of Ancient Literature I', The Leisure Hour [British Periodicals] (November 1891): 12-13.

Petrie, William M. F. 'The Romance of Ancient Literature II', The Leisure Hour [British Periodicals] (December 1891): 96-8.

Petrie, William M. F. 'The Romance of Ancient Literature III', The Leisure Hour [British Periodicals] (January 1892): 165-167.

Petrie, William M. F. 'The Romance of Ancient Literature IV', The Leisure Hour [British Periodicals] (February 1892): 260-2.

Petrie, William M. F. 'Rahotep and Nefert', Sunday at Home [British Periodicals] (1892): 526-7.

Petrie, William M. F. Ten Years' Digging in Egypt, 1881-1891. London: Religious Tract Society, 1892.

Petrie, William M. F. Catalogue of Egyptian Antiquities found in the Peninsula of Sinai, and at Pithom, Oxyrhynkhos and Thebes; and Drawings of the Tombs at Saqqara; for the Egypt Exploration Fund and Egyptian Research Account, 1905. London: University College, 1905.

Petrie, William M. F. The Religion of Ancient Egypt [Religions Ancient and Modern Series]. London: Archibald Constable \& Co Ltd, 1906.

Petrie, William M. F. The Arts and Crafts of Ancient Egypt [World of Art/Arts and Crafts of the Nations series]. Edinburgh and London: T. N. Foulis, 1909.

Petrie, William M. F. Personal Religion in Egypt [Harper's Library of Living Thought]. London: Harper \& Brothers, 1909.

Petrie, William M. F. The Arts and Crafts of Ancient Egypt (2nd edn) [World of Art/Arts and Crafts of the Nations series]. Edinburgh and London: T. N. Foulis, 1910.

Petrie, William M. F. The Revolutions of Civilisation [Harper's Library of Living Thought series]. London: Harper \& Brothers, 1911.

Petrie, William M. F. Seventy Years in Archaeology [Cambridge Library Editions]. London: Sampson, Low, Marston \& Co Ltd, 1931.

Poole, Sophia Lane. The Englishwoman in Egypt: Letters from Cairo, written during a residence there in 1842, 3, \& 4... London: Charles Knight \& Co, 1844.

Poole, Sophia Lane and Poole, Reginald S. Cairo, Sinai, Jerusalem and the pyramids of Egypt. London: James Virtue, 1860/1861.

Possehl, Gregory L. 'Ernest J. H. Mackay and the Penn Museum', Expedition 52 (1) (2010): 40-3.

Price, Katy. 'Gender and the Domestication of Wireless Telegraphy in 1920s pulp fiction', in Domesticity in the Making of Modern Science, edited by Donald Optiz, Staffan Bergwik and Brigitte Van Tiggelen. London: Palgrave Macmillan, 2016, 129-50.

Pronzini, Bill (ed.). Tales of the Dead. London: Book Club Associates, 1987.

Pryce, Daisy Hugh. Love's Mirage. London: Greening \& Co Ltd, 1902.

Quibell, Annie. The Pyramids of Giza. Cairo: The C. M. S. Bookshop, 1910.

Quibell, Annie. The Tombs of Sakkara (2nd edn). Cairo: Church Missionary Society, 1912 [1925].

Quibell, Annie. Egyptian History and Art with reference to museum collections. London: Society for Promoting Christian Knowledge, 1923.

Quibell, Annie. A Wayfarer in Egypt. London: Methuen, 1925. 
Quirke, Stephen. Hidden Hands: Egyptian workforces in Petrie excavation archives, 1880-1924. London: Duckworth Egyptology, 2010.

Ramsay, William M. and Hogarth, David G. 'Apollo Lermanus', Journal of the Hellenic Society 8 (1887): 376-400.

Raphaely, Judith. 1999. "“Nothing but gibberish and shibboleths"?: The Compulsory Greek Debates, 1870-1919', Classics in 19th and 20th century Cambridge: Curriculum, Culture and Community, edited by Christopher Stray. Cambridge: Cambridge Philological Society, 71-94.

Raven, James. 'The Promotion and Constraints of Knowledge: The Changing Structure of Publishing in Victorian Britain', in The Organisation of Knowledge in Britain, edited by Martin Daunton. Oxford: Oxford University Press, 2005, 263-86.

Read, Donald. The Power of News: The History of Reuters. London: Oxford University Press, 1999.

Reid, Donald M. Whose Pharaohs?: archaeology, museums, and Egyptian national identity from Napoleon to World War I. Berkeley, CA: University of California Press, 2002.

Reid, Donald M. Contesting Antiquity in Egypt: Archaeologists, Museums and the Struggle for Identities from World War 1 to Nasser. Cairo: American University in Cairo Press, 2015.

Rejwan, Nissim. The Last Jews in Baghdad. Austin, TX: University of Texas Press, 2004.

Reynolds-Ball, Eustace. Cairo of To-Day. London: A. \& C. Black, 1898.

Reynolds-Ball, Eustace. Cairo of To-Day (5th edn). London: A. \& C. Black, 1907.

Reynolds-Ball, Eustace. Cairo of To-Day (6th edn). London: A. \& C. Black, 1912.

Rickards, Maurice and Twyman, Michael. The Encyclopedia of Ephemera: a guide to the fragmentary documents of everyday life for the collector, curator and historian. London: The British Library, 2000.

Ridley, M. R. Gertrude Bell. London: Blackie \& Son, 1941.

Riggs, Christina. 'Tutanhkamun goes to the fair', Photographing Tutankhamun. Last modified 29 November 2017, https://photographingtutankhamun.wordpress.com/2017/08/23/ tutankhamun-goes-to-the-fair/.

Robinson, Anne. The Life and Work of Jane Harrison. Oxford: Oxford University Press, 2002.

Robinson, Eversley (ed.). Egypt: Papers \& Lectures by the late May Brodrick. London: Alexander Moring Limited, 1937.

Room, Adrian. 'Harrap, George Godfrey (1868-1938)', Oxford Dictionary of National Biography [online edn]. Oxford: Oxford University Press, 2004-15.

Rose, Jonathan and Anderson, Patricia (eds). British Literary Publishing Houses 1881-1965. Detroit, MI: Gale Publishing, 1991.

Ross, Iain. 'Oscar Wilde in Greece: Topography and the Hellenist Imagination', International Journal of the Classical Tradition 16 (2) (2009): 176-96.

Rowlatt, Mary. A Family in Egypt. London: Robert Hale Ltd, 1956.

Royal Academy of Arts. Exhibition of Works by the Old Masters and Deceased Masters of the British School Including a collection of Paintings by Albert Cuyp and Works by Some English Landscape Painters, Also of Drawings, Photographs, Plans and Casts showing the Results of Excavations at the Palace of Knossos in Crete. Winter Exhibition. Thirty-Fourth Year. London: Royal Academy. 1903.

Royal Archaeological Institute. Report of the Council for the Year 1884-5. Archaeological Journal 44 (1887): 420-5.

Rubenstein, David. Before the Suffragettes: Women's Emancipation in the 1890s. Brighton: The Harvester Press, 1986.

Russell, R. B. n. d. Margery Lawrence. A Guide to Supernatural Fiction [online], http://tartaruspress. com/17.htm\#nights.

S, C. K. [Shorter, Clement King]. 'A Literary Letter: A Holiday in Greece', The Sphere [British Newspaper Archive], 8 August 1914: 164.

Salter, Walter H. The Society for Psychical Research: an outline of its history. London: Society for Psychical Research, 1948.

Santaula'ria i Capdevila, M. Isabel. "He comes back badder and bigger than ever!" Readapting the masculine and negotiating the feminine in treasure-hunting adventure fiction', Journal of Gender Studies 12 (3) (2010): 215-28.

Satia, Priya. Spies in Arabia: The Great War and the Cultural Foundations of Britain's Empire in the Middle East. Oxford: Oxford University Press, 2008.

Saturday Review, 'Unfolding the Past' [British Periodicals]. 1 December 1923: 136.

Sayce, Archibald H. Primer of Assyriology [Present Day Primers 5]. London: Religious Tract Society, 1894. 
Sayce, Archibald H. Fresh Light from the Ancient Monuments [By-Paths of Bible Knowledge II]. London: Religious Tract Society, 1900.

Sayce, Archibald H. Reminiscences. London: Macmillan, 1923.

Sayers, Dorothy L. (ed.). Great Stories of Detection. Mystery and Horror. London: Victor Gollancz, 1928.

Schlippenback, B. 'A Night with King Pharaoh', in Lost in a Pyramid \& Other Classic Mummy Stories, edited by Adam Smith. London: British Library, 2016, 28-58.

Schreuders, Piet. The Book of Paperbacks: A Visual History of the Paperback. London: Virgin Books, 1981.

Sèbe, Berny. 'Exhibiting the Empire in print: The press, the publishing world and the promotion of "Greater Britain"', in Exhibiting the Empire: cultures of display and the British Empire, edited by John McAleer and John Mackenzie. Manchester: Manchester University Press, 2015, 168-93.

Sen, Mandira. 'The Paperback Revolution', India International Centre Quarterly 10 (4) (1983): 443-65.

Shankland, David. 'The Life and Times of F. W. Hasluck (1878-1920)', in Archaeology, Anthropology and Heritage in the Balkans and Anatolia: the Life and Times of F. W. Hasluck, 1870-1920, edited by David Shankland. Istanbul: Isis Press, 2004, 15-67.

Sheehy, Donald, Richardson, Mark and Faggan, Robert (eds). The Letters of Robert Frost, Vol. 1. Cambridge, MA/London: Belknap Press, 2014.

Sheppard, Kate. The Life of Margaret Alice Murray. Lanham, MD: Lexington Books, 2013.

Sheppard, Kate. 'Margaret Alice Murray and Archaeological Training in the Classroom: Preparing "Petrie's Pups"', in Histories of Egyptology: interdisciplinary measures, edited by William Carruthers. New York: Routledge, 2015.

Short, Emma. 'Women Writing Travel 1890-1939', Journeys: The International Journal of Travel and Travel Writing 16 (1) (2015), 1-7.

Silberstein Loeb, Jonathan. 'The Structure of the News Market in Britain, 1870-1914', Business History Review 83 (4) (2009): 759-88.

Simpson, Robert S. 'Griffith, Francis Llewellyn (1862-1934)', Oxford Dictionary of National Biography [online edn]. Oxford: Oxford University Press, 2004-2008.

Slack, Nancy, Pycior, Helena M. and Abir-Am, Pnina. Creative Couples in the Sciences. New Brunswick, NJ: Rutgers University Press, 1996.

Sladen, Douglas. Queer things about Egypt. London: Hurst \& Blackett, 1910.

Sladen, Douglas. Oriental Cairo: The City of the 'Arabian Nights'. London: Hurst \& Blackett, 1911.

Smith, Adam (ed.). Lost in a Pyramid \& Other Classic Mummy Stories. London: The British Library, 2016.

Smith, Grafton Elliot. The Ancient Egyptians and their Influence upon the civilization of Europe [Harper Library of Living Thought series]. London: Harper \& Brothers, 1911.

Smith, Janet A. 'Putting Noah's Flood into a Glass Case', Aberdeen Journal [British Newspaper Archive]. 31 July 1930, 6.

Smith, Pamela Jane. A 'Splendid Idiosyncrasy': Prehistory at Cambridge 1915-50. Oxford: British Archaeology Reports: British Series 485, 2009.

Society of Biblical Archaeology. 'Introduction', Transactions of the Society of Biblical Archaeology 1 (1) (1872): i-V.

Sparks, Rachael. 'PUBLICISING PETRIE: Financing Fieldwork in British Mandate Palestine (1926-1938)', Present Pasts 5(1): 2 (2013). DOI: http://dx.doi.org/10.5334/pp.56.

Spiro, L. 'Leading Nineteenth Century Publishers of Travel Guidebooks to Egypt', Openstax CNX. Last modified 2 December 2017, http://cnx.org/contents/Pb1T261b@3/ Leading-Nineteenth-Century-Pub.

Stableford, Brian. Historical Dictionary of Fantasy Literature. Lanham, MD: The Scarecrow Press, Inc, 2005.

Staudt, Ida D. Living in Romantic Baghdad: an American memoir of teaching and travel in Iraq. Syracuse, NY: Syracuse University Press, 2012.

Stephens, John R. (ed.). Into the Mummy's Tomb. New York: Berkeley Books, 2001.

Stevens, Ethel S. My Sudan Year. London: Mills \& Boon Limited, 1912.

Stephensen-Payne, Phil. 'Galactic Central: Hutchinson's (Adventure \&) Mystery-Story Magazine' [online], http://www.philsp.com/mags/hutchinsons_mys.html. 
Stevenson, Alice. 'Winifred Brunton: Hard Working Winnie!' Trowelblazers [online], 2015. Last modified 2 December 2017 http://trowelblazers.com/winifred-brunton/.

Stevenson, Alice. 'The Object of Study: Egyptology, Archaeology, and Anthropology at Oxford, 1860-1960', in Histories of Egyptology: Interdisciplinary Measures, edited by William Carruthers. London: Routledge, 2015, 19-33.

Stevenson, Alice, Libonati, Emma and Williams, Alice. “"A selection of minor antiquities": a multisited view on collections from excavations in Egypt', World Archaeology 48(2) (2016).

Stewart, Jessie. Jane Harrison: a portrait from letters. London: The Merlin Press, 1959.

Stig Sørenson, Mary Louise. 'Rescue and Recovery: on historiographies of female archaeologists', in Excavating Women: A History of Women in European Archaeology, edited by Margarita DiazAndreu and Mary Louise Stig Sørenson. London: Routledge, 1998, 31-60.

Storrs, Ronald. Orientations (definitive edition). London: Nicholson \& Watson, 1949.

Stray, Christopher. Classics Transformed: schools, universities and society in England, 1830-1960. Oxford: The Clarendon Press, 1998.

Stray, Christopher. 'The First Century of the Classical Tripos (1822-1922): High Culture and the Politics of Curriculum', in Classics in 19th and 20th century Cambridge: Curriculum, Culture and Community, edited by Christopher Stray. Cambridge: Cambridge Philological Society, 1999, 1-14.

Stray, Christopher. 'The Foundation and its Contexts', Greece \& Rome 50 (2003): 3-22.

Strinati, Dominic and Wagg, Stephen. Come on Down? Popular Media Culture in Post War Britain. London: Routledge, 1992.

Strong, Eugénie. Roman Sculpture from Augustus to Constantine, 2 vols. London: Duckworth, 1907.

Sudan Department of Railways and Steamers. Handbook of the Sudan Government Railways and Steamers. London: Office of the European Traffic Manager, 1924.

Sutcliffe, Ray (ed.). Chronicle: Essays from ten years of television archaeology. London: British Broadcasting Corporation, 1978.

Tavernier-Courbin, Jacqueline. 'Sleuthing and Excavating in Egypt: Elizabeth Peters' Humor', Thalia: Studies in Literary Humor 20 (1) (2009), 24-54.

Theakstone, John. 'An alphabetical bibliography of books by Victorian and Edwardian women travellers published between 1837 and 1910' (2003) [online]. www.victorianresearch.org/ wtravelbib2003.pdf.

Thomas, Charles. 'The Archaeologist in Fiction', in To illustrate the monuments: essays on archaeology presented to Stuart Piggott, edited by J. V. S. Megaw. London: Thames \& Hudson, 1976, 310-19.

Thomas, Gillian. A Position to Command Respect: women and the eleventh Britannica. Metuchen, NJ: Scarecrow Press, 1992.

Thomas, Gillian. 'Hogarth, Janet Elizabeth (1865-1954)', Oxford Dictionary of National Biography [online edn]. Oxford: Oxford University Press, 2004-2015.

Thomas, Suzie. 'Brian Hope-Taylor, the Council for British Archaeology, and "the Need for Archaeological Propaganda"', Public Archaeology 12 (2) (2013): 101-16.

Thompson, Reginald Campbell. A Pilgrim's Scrip. London: John Lane/Bodley Head, 1915.

Thompson, Reginald Campbell. A List of Words and Phrases in the Basrah Dialect of Arabic. Simla: Government Central Branch, 1915.

Thompson, Reginald Campbell. A Small Handbook to the History and Antiquities of Mesopotamia... Bombay: Times Press, 1918.

Thompson, Reginald Campbell. 'Ernest Alfred Wallis Budge. 1857-1934', Journal of Egyptian Archaeology 21 (1) (1935): 68-70.

Thompson, Reginald Campbell. Digger's Fancy: A Melodrama. London: Sidgwick \& Jackson, 1938.

Thompson, Reginald Campbell and Hamilton, Robert W. 'The British Museum Excavations on the Temple of Ishtar at Nineveh, 1930-31', Liverpool Annals of Archaeology and Anthropology 19 (1932).

Thompson, Reginald Campbell and Hutchinson, Richard. A Century of Exploration at Nineveh. London: Luzac \& Co, 1929.

Thornton, Amara. British Archaeologists, Social Networks and the Emergence of a Profession: the social history of British archaeology in the Eastern Mediterranean and Middle East 1870-1939. Unpublished PhD thesis. University College London, 2011.

Thornton, Amara. 'The Allure of Archaeology: Agnes Conway and Jane Harrison at Newnham College, 1903-1907', Bulletin for the History of Archaeology 21 (1) (2011): 37-56. DOI: http:// dx.doi.org/10.5334/bha.2114. 
Thornton, Amara. 'Archaeologists-in-Training: Students of the British School of Archaeology in Jerusalem, 1920-1936', Journal of Open Archaeology Data, 1:1 (2012). DOI: http://dx.doi. org/10.5334/4f293686e4d62.

Thornton, Amara. 'Tents, Tours and Treks: Archaeologists, Antiquities Services and Tourism in British Mandate Palestine and Transjordan', Public Archaeology 11 (4) (2012), 195-216. DOI: 10.1179/1465518713Z.00000000020.

Thornton, Amara. “"... a certain faculty for extricating cash”: Collective Sponsorship in late 19th and early 20th century archaeology', Present Pasts 5 (1), 1 (2013): 1-12. DOI: $10.5334 / \mathrm{pp} .55$.

Thornton, Amara. 'Mills \& Boon... And Meroe', Reading Room Notes [Blog], 1 December 2013. https://www.readingroomnotes.com/home/mills-boon-and-mero.

Thornton, Amara. 'Margaret Murray’s Meat Curry', Present Pasts 6 (1), 3 (2014): 1-7. DOI: 10.5334/ pp.59.

Thornton, Amara. 'The Nobody: Exploring Archaeological Identity with George Horsfield (18821956)', Archaeology International 17 (2014), 137-56. DOI: 10.5334/ai.1720.

Thornton, Amara. 'The Wayfarer: Annie Pirie Quibell', Reading Room Notes [blog], 24 May 2014 [online], http://www.readingroomnotes.com/home/the-wayfarer-annie-pirie-quibell

Thornton, Amara. 'I'll Meet You in St. Louis', Reading Room Notes [blog], 15 October 2014 http:// www.readingroomnotes.com/home/ill-meet-you-in-st-louis.

Thornton, Amara. 'A Balkan Adventure', Reading Room Notes [blog], 21 November 2014 [online], http://www.readingroomnotes.com/home/a-balkan-adventure.

Thornton, Amara. 'Howard Carter Lights UpTheAncients',Reading Room Notes [blog], 23 March 2015 [online]. http://www.readingroomnotes.com/home/howard-carter-lights-up-the-ancients.

Thornton, Amara. 'A Book, A Pudding and A Party', Reading Room Notes [blog]. 30 June 2015 [online], http://www.readingroomnotes.com/home/a-book-a-pudding-and-a-party.

Thornton, Amara. 'Exhibition Season: Annual Archaeological Exhibitions in London, 1880s1930s', Bulletin of the History of Archaeology 25 (2) (2015): 1-18; Appendices 1 (1-5) and 2 (1-44). DOI: 10.5334/bha.252.

Thornton, Amara. 'An Unusual Archaeological Memoir', Reading Room Notes [blog], 29 September 2015 [online], http://www.readingroomnotes.com/home/an-unusual-archaeologicalmemoir.

Thornton, Amara. 'Social Networks in the History of Archaeology: Placing Archaeology in its Context', in Historiographical Approaches to past archaeological research (Berlin Studies of the Ancient World 32), edited by G. Eberhardt and F. Links. Berlin: Edition Topoi, 2015, 69-94.

Thornton, Amara. 'Archaeology for Children', Reading Room Notes [blog]. 27 January 2016, http:// www.readingroomnotes.com/home/archaeology-books-for-children.

Thornton, Amara. 'Agnes Conway's Rome', Reading Room Notes [blog]. 26 October 2016 [online], http://www.readingroomnotes.com/home/agnes-conways-rome.

Tibble, Anne. Gertrude Bell. London: A. \& C. Black, 1958.

Times Book Club. A Catalogue of the Library of the Times Book Club. London: The Times, 1908.

Times Book Club. A Catalogue of Books Added to the Library of the Times Book Club from $1^{\text {st }}$ January 1915, to 30 October, 1936. London: Times Book Club Ltd, 1936.

Tirard, Helen M. The Book of the Dead. London: Society for Promoting Christian Knowledge, 1910.

Tirard, Helen M. and Tirard, Nestor. Sketches from a Nile Steamer. London: Kegan Paul, Trench, Trubner \& Co, 1891.

Todd, Robert (ed.). Dictionary Of British Classicists. Bristol: Thoemmes, 2004.

Toynbee, Jocelyn Mary C. and Major, Henry D. A., rev. Gill, David. 'Gardner, Ernest Arthur (1862-1939)', in Oxford Dictionary of National Biography [online edn]. Oxford: Oxford University Press, 2004.

Trümpler, Charlotte (ed.). Agatha Christie and archaeology. London: British Museum, 2001.

Turner, Graeme. 'Approaching Celebrity Studies', Celebrity Studies 1 (1) (2010), 11-20.

Tusan, Michelle. 'At Home in the Ottoman Empire: humanitarianism and the Victorian diplomat', in The Cultural Construction of the British World, edited by Barry Crosbie and Mark Hampton. Manchester: Manchester University Press, 2016, 77-94.

Two Temple Place. Beyond Beauty: Transforming the Body in Ancient Egypt. London: Two Temple Place, 2016.

University of Liverpool. Redbrick University: A Portrait of University College, Liverpool and the University of Liverpool 1881-1981. Liverpool: University of Liverpool, 1981. 
University of Oxford/Ashmolean Museum. 'Maria Millington Lathbury (1856-1944). John Evans Centenary Project.' Last accessed 2 December 2017, http://johnevans.ashmolean.org/evans/ maria-lathbury.html.

Uphill, Eric. 'A Bibliography of Sir William Matthew Flinders Petrie (1853-1942)', Journal of Near Eastern Studies 31 (4) (1972): 356-79.

Van Arsdel, Rosemary T. 'Macmillan family (per. c. 1840-1986)', Oxford Dictionary of National Biography [online edn]. Oxford: Oxford University Press, 2004-15.

Vicinus, Martha. Independent women: work and community for single women 1850-1920. London: Virago, 1985.

Vinson, Steve and Gunn, Janet. 'Studies in Esoteric Syntax: the enigmatic friendship of Aleister Crowley and Battiscombe Gunn', in Histories of Egyptology: Interdisciplinary Measures, edited by William Carruthers. London: Routledge, 2015, 96-112.

Wagstaffe, Vanessa and Poole, Stephen. Agatha Christie: A Reader's Companion. London: Aurum Press Ltd, 2006.

Walkowitz, Judith. City of Dreadful Delight: Narratives of Sexual Danger in Late-Victorian London. Chicago: University of Chicago Press, 1992.

Wallace, Diana. The Women's Historical Novel: British Women Writers, 1900-2000. Basingstoke: Palgrave Macmillan, 2005.

Wallace-Hadrill, Andrew. The British School at Rome: One Hundred Years. Rome: British School at Rome, 2001.

Weigall, Arthur E. P. Travels in the Upper Egyptian Deserts. London: William Blackwood \& Sons, 1909.

Weigall, Arthur E. P. The Life and Times of Akhnaton Pharaoh of Egypt (2nd impression). London: William Blackwood, [1910] 1911.

Weigall, Arthur E. P. The Treasury of Ancient Egypt: Miscellaneous Chapters on Ancient Egyptian History and Archaeology. London: William Blackwood \& Sons, 1911.

Weigall, Arthur E. P. The Life and Times of Cleopatra, Queen of Egypt: a study of the origin of the Roman Empire. London: William Blackwood, 1914.

Weigall, Arthur E. P. A History of Events in Egypt from 1798 to 1914. London: William Blackwood \& Sons, 1915.

Weigall, Arthur E. P. Tutankhamun and other Essays. London: Thornton Butterworth, 1923.

Weigall, Arthur E. P. The Glory of the Pharaohs. London: Thornton Butterworth, 1924 [1936].

Weigall, Arthur E. P. Flights into Antiquity. London: Hutchinson \& Co, 1928.

Weigall, Arthur E. P. The Life and Times of Akhnaton Pharaoh of Egypt. London: Thornton Butterworth Ltd, 1934.

Weigall, Arthur E. P. Laura Was My Camel. London: Eyre \& Spottiswoode, 1941.

Weinthal, Leo (ed.). Fascinating Egypt and Sudan Guide 1913-1914. London: African World, 1913.

Weinthal, Leo (ed.). Egypt and Sudan Annual. Season 1922-1923. London: African World, 1922.

Weinthal, Leo (ed.). Egypt and the Sudan Annual. Season 1923-1924. London: African World, 1923.

Wheeler, R. E. Mortimer. Maiden Castle, Dorset: Oxford: University Press for Society of Antiquaries of London, 1943.

Wheeler, R. E. Mortimer. Still Digging. London: Michael Joseph, 1955.

Wheeler, R. E. Mortimer. Still Digging: Adventures in Archaeology. London: Pan Books, 1958.

Wheeler, R. E. Mortimer. The British Academy 1949-1968. London: The British Academy, 1970.

Wheeler, Margaret C. A Book of Archaeology. London: Cassell, 1957.

Wheeler, Margaret C. A Second Book of Archaeology. London: Cassell, 1959.

Wheeler, Margaret C. Walls of Jericho. London: Arrow Books Ltd, 1959.

Whidden, James. 'Expatriates in Cosmopolitan Egypt: 1864-1956', in Robert Bickers, Settlers and Expatriates: Britons over the Seas. Oxford: Oxford University Press, 2010, 45-72.

Whitaker, John. Whitaker's Almanack 1900 [facsimile edition]. London: The Stationery Office, 1900.

Whitaker, John. An Almanack for the year of our Lord 1911. London: Whitaker, 1911.

Whitaker, John. An Almanack for the year of our Lord 1927. London: Whitaker, 1927.

Wikipedia. 'Encyclopaedia Britannica, Eleventh Edition', Wikipedia [online]. Last modified 1 December 2017. https://en.wikipedia.org/wiki/Encyclop\%C3\%A6dia_Britannica_Eleventh_ Edition.

Wills, Walter and Barrett, R. J. The Anglo-African Who's Who. London: George Routledge \& Sons, Limited, 1905. 
Wilson, Charles (ed.). Handbookfor Travellers in Asia Minor, Transcaucasia, Persia etc. London: John Murray, 1895.

Wilson, David. The British Museum: a history. London: British Museum Press, 2002.

Wilson, Nicola. 'Boots Book-lovers' Library and the Novel: The Impact of a Circulating Library Market on Twentieth-Century Fiction', Information \& Culture 49 (4) (2014): 427-49.

Wilson, Nicola. 'Archive fever: the publishers' archive and the history of the novel', in New Directions in the History of the Novel, edited by Patrick Parrinder, Andrew Nash and Nicola Wilson. Houndmills: Palgrave Macmillan, 2014, 76-87.

Winstone, Hugo V. F. Gertrude Bell. London: Constable, 1978.

Wise, Michael J. 'The Scott Keltie Report 1885 and the Teaching of Geography in Great Britain', Geographical Journal 152 (3) (1986): 367-82.

Withey, Lynn. Grand tours and Cook's tours: a history of leisure travel, 1750-1915. London: Aurum, 1997.

Woolley, Leonard. 'Why Dig Up The Past?', The Listener 3 (75) (1930): 1061-2.

Woolley, Leonard. 'The Archaeologist at Work', The Listener 3 (76) (1930): 1104-6.

Woolley, Leonard. 'Building up the Past', The Listener 3 (77) (1930): 9-10.

Woolley, Leonard. 'The Witness of Bricks and Mortar', The Listener 3 (78) (1930): 50-1.

Woolley, Leonard. 'Treasures of the Grave', The Listener 4 (79) (1930): 89.

Woolley, Leonard. Antiquities of Ur. London: Hazell, Watson \& Viney, 1930.

Woolley, Leonard. Digging Up The Past. London: Ernest Benn, 1930.

Woolley, Leonard. Ur: the first phases. London: Penguin Books, 1947.

Woolley, Leonard. Digging Up the Past. Harmondsworth: Penguin Books, 1950.

Woolley, Leonard. A Forgotten Kingdom. Harmondsworth: Penguin Books, 1953.

Woolley, Leonard. Spadework: Adventures in Archaeology. London: Lutterworth Press, 1953.

Wrigley, Amanda. Greece on Air: Engagements with Ancient Greece on BBC Radio, 1920s-1960s. Oxford: Oxford University Press, 2015.

Young, Lee. 'Annie Abernethie Quibell', Ancient Egypt 14 (4) (2014): 16-23.

Zachs, William, rev. Isaac, Peter, Fraser, Angus and Lister, William. 'Murray family (per. 17681967)', Oxford Dictionary of National Biography [online edn]. Oxford: Oxford University Press, 2004-16. 


\section{Index}

Adams, Mary, 179

African World, 15, 36, 88

Fascinating Egypt and Sudan, 36, 88

Egypt and Sudan Annual, 88

Albania, 62, 63

Amalgamated Press, 3, 17, 95, 99, 101

Amos, Sarah Maclardie, 39

Amos, Sheldon, 39

Antiquities,

Departments/Services, 6, 30, 35, 41, 170, 180, 215, 217, 220

Inspectors, 17, 18, 30, 40, 45, 46, 65, 66, $67,99,120,195,208,215,220$

Legislation, 15, 211

Antoniou, Gregori, 142

Archaeological Institute of America, 163, 167

Artists, 6, 7, 31, 45, 65, 66, 70, 73, 98, 101, 113, 129, 148, 152, 181, 202, 205, 208, 215, 219

Asia Minor 13, 30, 36, 39, 62, 89, 90, 142, $214,217,220,221$

guidebooks to, 34, 38, 143, 158-9, 162-3

D. G. Hogarth and, 142-3, 144, 162-4, 165,218

Baedeker guides, 34, 35, 59, 125, 130, 131, 134, 135, 136, 137

Baedeker, Karl, 32

Baikie, Rev. James, 3, 4, 6

Balkans, 13, 14, 28, 62, 63, 64, 110, 216

Balkan Wars, 14, 61, 63

Basil Blackwell (firm), 45, 217

Bell, Gertrude, 4, 10, 91, 92, 93, 126, $167,170,176,177,181,184$, 191, 208, 214

Benn, Ernest, 118-19, 169-70, 177

Benson, Edward Frederic, 28, 57, 59, 135, 192, 197

Benson, Margaret, 69-70, 215, 21

Bey, Osman Hamdi, 16

Bingham, Hiram, 1

Birch, Samuel, 21, 22, 49, 106, 107

Blackie \& Son (firm), 70, 219

Blackwood, Algernon, 111, 197

Bligh Bond, Frederick, 200

Blomfield, Richard, 135, 136

Blomfield, Rosamond, 135

Bosanquet, Ellen Sophia, 6, 9, 40, 59, 60-62, $66,67,124,211,215$

Breasted, James Henry, 3, 203

Brett, George, 149, 152, 153, 156, 167
British Archaeological Association, 20

British Broadcasting Corporation (BBC), 4, 42, 44, 119, 126, 169, 179, 185, 186, 215, 216, 217, 218, 219, 220, 221

British Empire Exhibitions, 40

British Museum see Museums

British Institute of Archaeology in Ankara, 217, 218

British School at Athens, 27, 30, 38, 143, 146, 147, 150, 182

students at, 28, 56, 57, 62, 72, 93, 142, 215, 216-7, 218, 220

and Ernest and Mary Gardner, 56-7, 155, 157 and Robert Carr and Ellen Sophia Bosanquet, 59-61, 157

and David George Hogarth, 146-7, 162, 165 and George Macmillan, 150, 160

British School at Rome, 27, 62, 216, 220

British School of Archaeology in Egypt, 24, 93, 94, 219

British School of Archaeology in Iraq, 175, 181, 218-19

British School of Archaeology in Jerusalem, 27, 41, 217

Brodrick, Mary, 6, 7, 9, 34, 48, 50-1, 52-5, 56, $60,69,124,128-41,146,206,215$

Brugsch, Heinrich, 52, 53, 54, 129, 130, 131

Budge, E. A. Wallis, 7, 8, 9, 11, 22, 29, 36-7, 41, 45, 52, 96, 106, 107, 108, 109, 110, $117,118,123,124,126,189,215$

Cairo see Egypt

Cambridge, University of, 6, 22, 23, 24, 27, 28, $29,56,92,94,106,149,185,189,193$, 194, 200, 202, 214, 215, 216, 217, 218, 220

Cambridge University Press, 92, 94

Carter, Howard, 1, 4, 5, 6, 11, 90, 91, 122, 198, 203, 215

Casson, Stanley, 20, 42, 43, 118, 119, 124, 173, 215

Ceram, C. W. (Kurt Marek), 4, 6

Chatto \& Windus (firm), 9, 73, 186, 221

Childe, Gordon, 173

Children's books, 112-16

Christie, Agatha, 175, 176, 184, 186, 189 , 196, 203-205, 216

Church Missionary Society (CMS) Bookshop, 125

Chubb, Mary, 6, 9, 71-3, 115-16, 216

Cochrane, Jim, 185

College Hall, 51, 129 
compendiums, $18,75,91-102$

Constable \& Co (firm), 90, 112, 169, 217, 219, 220

'Religions Ancient and Modern' series, 112

Conway Horsfield, Agnes, 6, 9, 28, 62-5, 200, 201, 214, 216

Conway, Martin, 62

Cook, Thomas, 36

Cook, John, 37, 38, 139

Cottrell, Leonard, 4, 6, 185, 186, 187, 211

Cranmer-Byng, Launcelot, 111

Crawford, O. G. S., 115, 182

Crete, 3, 14, 59, 60, 112, 116, 147, 162, 163, $165,216,218$

Cyprus, 14, 142, 144, 217

Daniel, Glyn, 183, 184, 185, 211

Devonshire, Henriette Caroline, 68

Doyle, Arthur Conan, 4, 197, 200

Duckworth (firm), 108

'Library of Art' series, 108-9

East India Company, 12, 15

Eckenstein, Lina, 11, 31, 70, 125, 216

Egypt

Abydos, 31, 70

Alexandria, 15, 37, 40, 49, 85, 121, 131 , $132,135,136,142,160,162,197$

Aswan, 36, 53, 131, 132, 133, 137, 138

Ballas, 82

Cairo, 13, 35, 36, 38, 39, 40, 49, 65, 85, 88, $99,125,130,131,132,133,134,135$, 136, 167, 191, 206, 207, 208, 219

Deir el Bahri, 52, 142

Fayum, 83, 135

Hawara, 83

Hierakonpolis/El Kab, 65, 138

Luxor/Thebes, 35, 40, 69, 70, 72, 82, 125, $131,137,215,217$

Naqada, 82

Saqqara, 40, 65, 70, 101, 126

Suez, 13, 38, 79, 111

Tell el-Amarna, 71, 72, 82, 116, 121, 180 , 206, 207, 216

tourism to, 15, 16, 34-40, 52, 54-5, 88-9, 103, 125, 129-41, 146, 206, 215

Egypt Exploration Fund (also Egypt Exploration Society, EEF), 6, 24, 28, 30 , $31,36,49,50,53,54,71,76,81,83,93$, $121,134,135,142,180,215,216,217$, $218,219,220$

Egyptian Gazette, 39

Egyptian Hall, 83, 84

Egyptian Research Account, 24, 27, 65, 93, 94, 217,219

Englishwoman's Year Book and Directory, 7, 48, 54

Encyclopedia Britannica (11 ${ }^{\text {th }}$ edition), 91-95

Ephemera, 12, 88, 89

Ernest Benn Ltd (firm), 10, 43, 44, 118-120, $169,170,171,172,173,174,176,186$, $215,218,220,221$

Sixpenny Library, 20, 118-120, 169

Evans, Arthur John, 3, 4, 5, 10, 11, 29, 38, 60, $91,116,147,159,162,164,165,186,216$
Exhibition, 2, 7, 31, 40, 41, 43, 44, 47, 75, 79, $80,82,83,84,86,87,88,89,162$

Film, 42, 195

Fortnightlies, 95

Frith, Francis, 49

Frost, Eunice, 173, 174, 179, 180, 183, 184

Gardner, Alice, 62

Gardner, Ernest, 24, 28, 30, 38, 92, 93, 94, 95, $109,112,124,142,151,155-9,216-7$

Gardner, Mary Wilson, 6, 38, 56-59, 150, 151, 159, 217

Gardner, Percy, 22, 23, 28, 29, 45, 92, 94, 95, $123,124,150,151-6,160,167,217$

Gaze, Henry, 53

Geoffrey Bles (firm), 9, 115, 216

George Bell \& Sons (firm), 179

George G. Harrap \& Co (firm), 112

'Books on Primitive Times' series, 112-13

Glover, Alan Samuel Boots, 174, 176, 178, 179,182

Gollancz, Victor, 119

Gourlay, Janet, 69, 70, 217

Gowans \& Gray (firm), 9, 117, 215 'Gowan's International Library', 117-18

Grant (Bey), James, 39

Grant, Florence Sabina Gibson, 39

Greece, 14, 18, 23, 30, 31, 89, 124, 146, 150, 156, 160, 161, 186, 215, 216, 217, 218

Athens, 36, 56, 57, 58, 59, 60-2, 147, 148, $157-8,182,215$

guidebooks, 34, 38, 39, 58, 150, 162

tourism to, 24, 28, 36, 39, 55, 57, 61-3, 157-9

Grey Arrow books, 186

Gurney, Oliver, 176, 177, 217

Hall, Harry, 9, 96, 97, 109, 110, 112-13, 123, 126, 140, 189, 190, 217

Hamilton, Norah Rowan, 40

Hammerton, John Alexander, 3, 95, 96, 99. $100,101,102$

Harmsworth, Alfred, 95

Harmsworth (firm)

History of the World, 96-9, 218, 219, 22

Peoples of all Nations, 99, 219

Universal History of the World, 99-100, 216, 217, 218, 219, 220

Wonders of the Past, 100-101, 217, 218 , 219, 220, 221

Harper \& Brothers (firm), 112, 217, 219

'Library of Living Thought' series, 112

Hamoudi (Mohammed ibn Sheikh Ibrahim), 2, 16

Hansard, Winifred 'Freda', 31, 70

Harrap, George, 112

Harrison, Jane Ellen, 6, 7, 23, 28, 52, 55-6, $62,64,112,117,118,119,123,124$, 201, 218

Hatshepsut, 52, 202

Hawes, Charles, 112

Hawes, Harriet Boyd, 112

Hazzidakis, Joseph, 60

Hodder \& Stoughton (firm), 9, 215, 217, 220 
Hogarth, David George, 4, 5, 10, 17, 28, 29, 30, $31,38,39,60,89,90,91,92,93,95,97$, $99,110,111,117,123,124,126,128,135$, 136, 170, 190, 191, 194, 197, 208, 218

as Murray author 9, 31, 141-8

as Macmillan author 9, 17, 31, 38, 150-1, $159,160-8$

and Illustrated London News, 89-91

Hogarth, Janet, 92, 93, 123, 142, 167

Hogarth, Mary, 148

Home University Library see Williams \& Norgate

Hooper, Horace, 91, 92, 94, 123

Hornstein, Charles, 131

Horsfield, George, 18

Hutchinson \& Co. (firm), 9, 97-8, 186, 198, 199, 219, 220

Hutchinson, Richard, 46

Hutchinson, Walter, 97

Illustrated London News, 83, 86, 89, 90, 162, $164,211,212,216,217,218,219,220$

Illustrations, 3, 42, 53, 86, 90, 92, 96, 99, 100, 104, 109, 113, 116, 144, 148, 153, 155, 156, 158, 166, 174, 181, 182, 203, 208

Imperial Airways, 49, 102

India

Antiquities Service, 73

Indus Valley, 69

Mohenjo-daro, 69

Intelligence (archaeologists in), 4, 14, 38, 58, 99, 167, 170, 190, 191, 193, 207, 208, 215, $217,218,220,221$

Iraq

Babylon, 41, 182

Baghdad, 15, 41, 43, 68, 125, 126, 164, 170, 204, 205, 215, 218

Eshnunna, 71, 116

Iraq Railways, 69, 164

Kish, 41, 68

Nineveh, 16, 128, 189, 190, 193, 194

Ur, 8, 43, 170, 175, 194, 196, 204, 221

J. M. Dent \& Co (firm), 9

James, Montague Rhodes, 4, 28, 59, 197, 198

Jerrold, Douglas, 119

John Murray (firm), 9, 19, 45, 52, 53, 54, $64,69,111$, Ch 6, 160, 163, 215, 217, 218, 219

Handbooks, 34, 35, 53, 54, 57, 125, 131 , $135,137,139,140,143,146,158$, 215, 218

'Wisdom of the East' series, 111-12

Kapadia, Shaporji, 111

Karo, Georg, 62

Kegan Paul (firm), 8, 9, 11, 51, 108, 215, 220

'Books on Egypt and Chaldea' series, 108

Kelsey, Francis, 151, 152, 153, 154, 167

Kenyon, Kathleen, 73, 115

Keystone Library see Thornton Butterworth

King, Leonard William, 9, 96, 189, 190

King's College Ladies Department (King's

College Women's Department), 51, 52, 217, 220
Kingsford, (Florence) Kate, 70

Kitchener, Horatio Herbert, 86, 87, 117

Lane, Allan, 118, 169-79, 181-4

Lathbury Evans, Maria Millington, 7, 55, 56, $151,152,216$

Lavers, Ralph, 72

Lawrence \& Bullen (firm), 9, 110

'Story of Exploration' series, 110-11

Lawrence, Margery, 198-203

Lawrence, Thomas Edward, 4, 99, 167, 190, 191, 208

Layard, Austen Henry, 15, 105, 115, 128, 180, 182

Le Brun, Eugenie, 68

League of Nations, 14, 40

Lectures (lecturing), 2, 6, 7, 22, 31, 41, 42, 47, $82,83,103,106,109,129,157,163,167$, 215, 216, 219

at British Museum, 50-2, 55, 151-2

and women, 7, 48-56, 60, 70, 109, 140, $141,151-2,193,215,216,217,218,220$

Leighton, Frederick, 129, 152

Levant Company, 14, 15

Libraries, 104, 122

Boots' Book Lovers Library, 124

Mudie's Circulating Library, 122-3

Times Book Club, 123-4

Listener, The , 42-4, 119, 169, 215, 221

Livadas, Charles, 131

Liverpool, University of, 6, 27, 86, 217

Lloyd, Seton, 180-4, 211, 218

Lloyd, Ulrica Hyde, 181

Macalister, Robert A. S., 45, 95

Mackay, Dorothy Simmons, 41, 68-9, 126, 210, 218

Mackay, Ernest, 68, 210

Mackenzie Book Shop, 125-6

Mackenzie, Kenneth, 125, 126

Macmillan \& Co (firm), 9, 11, 17, 19, 28, $38,45,57,59,143,148,216,217,218$, 219, 220

Guides, 38, 125, 154-9, 162-3

'Handbooks on Archaeology and Antiquities' series, 151-6

Macmillan, Alexander, 149, 160

Macmillan, Daniel, 149

Macmillan, Frederick, 152, 153, 154

Macmillan, George, 38, 143, 150, 154, 156, $158,160,162,167$

Magazines, 10, 12, 42, 57, 70, 78, 111, 120, $121,145,146,149,161,165,170,186$, 198, 199

Mallowan, Max, 23, 175-8, 181-4, 189, 203, 204, 216, 218

Mariette, Auguste, 53, 54, 129, 131

Mariette, Sophie, 54

Marshall, Sir John, 69

Martin Hopkinson (firm), 9, 45

Maspero, Gaston, 3, 51, 54, 202, 207

Masterman, Ernest, 38

Medici Society (firm), 9, 109, 215, 218

'Handbooks to Ancient Civilisations' series 109-10 
Menon, Krishna, 172

Methuen \& Co (firm), 8, 9, 55, 59, 65-6, 108, 141, 192, 215, 218, 219

'Wayfarer' series, 65-6

Montenegro, 62

Morton, Anna Anderson, 54, 55, 124, 132, $133,134,136,137,141$

Murray, A. H. Hallam, 128, 129, 130, 133, $134,141,148$

Murray, Alexander Stuart, 129

Murray III, John, 34, 128, 129

Murray IV, John, 53-4, 129, 130, 139, 142

Murray, Margaret, 70-1, 101, 111, 124, 125, $126,196,219$

Museums, 5, 16, 29, 30, 32, 35, 40, 46, 56, 74, 97, 100, 116, 141, 155, 159, 180, 189

Amman Museum, 73

Ashmolean Museum, 29, 151, 164, 216, 217, 218, 221

Baghdad Museum, 12, 6, 170

British Museum, 6, 8, 16, 22, 23, 29, 36, 43, $45,48,50,51,52,55,86,89,96,106$, $107,108,109,113,118,129,140,142$, $151,162,164,181,189,190,202,215$, $216,217,218,220,221$

Candia Museum, 60

Egyptian Museum (Cairo) (also Cairo Museum, Boulaq Museum, National Museum of Egyptian Antiquities), 65, 67, 126, 138, 206, 219

Fitzwilliam Museum, 29, 183

Greco-Roman Museum (Alexandria), 135

Petrie Museum, 101

South Kensington (Victoria \& Albert), 55, 84, 215, 218

Myres, John Linton, 11, 28, 117, 156, 186, 210

Naville, Edouard, 52

Nefertiti, 67, 189

New Woman, 48, 207

Newnham College, 23, 29, 62, 72, 200, 218

News(paper), 2, 10, 11, 12, 31, 39, 42, 44, 50, 59, 68, 75-91, 92, 94, 95, 102, 117, 125, $144,167,171,198,209,211,212$

Newton, Charles Thomas, 15, 23

Orient Press (firm), 111

Oxford, University of, 6, 22, 24, 27, 28, 29, 59, $69,107,119,142,143,146,151,152$, $156,167,176,195,197$

Oxford University Press, 168, 180

Palestine, 3, 12, 14, 18, 21, 30, 32, 45, 49, 68, $69,103,106,123,176,178,211,215$, 216, 217, 219

Beth-Shan (Beisan), 68

Jerusalem, 3, 30, 41, 103, 105

Jericho, 73, 115

tourism to, 36, 37-40, 139

guidebooks, 34, 37-8, 40-1, 139, 215

Palestine Exploration Fund, 21, 30, 33, 34, 38, 41, 45, 95, 103, 106, 143

Pan Books Ltd (firm), 4, 185-7

Paterson, Emily, 50

Pendlebury, John, 11, 72
Pendlebury, Hilda, 72

Penguin (firm), 10, 19, 120, Ch 8, 211, 212, 215, 217, 221

Pelican, 118, 120, 169, 170, 170-187, 212, 219

Periodicals, 10, 41, 48, 50, 62, 75, 76, 91, 149

Peters, Elizabeth (Barbara Mertz), 5, 205-9, 219

Petrie, Hilda, 70

Petrie, W. M. Flinders, 3, 5-8, 16, 23, 30-1, $36,38,42,45-6,50,89,90-104,108$, 109-112, 116, 123, 124, 125, 132, 138, $147,154,202,207,219$

and students, 6, 24, 27, 34, 46, 65, 68, 70

and in the news, 7, 74-85

Poole, Reginald Stuart, 23, 24, 28, 49, 50, 106

Poole, Sophia Lane, 49, 219

Pricing, 9, 138

Pryce, Daisy Hugh, 35

Quibell, Annie A. Pirie, 6, 8, 11, 32, 45, 65-8, 125, 126, 208, 219

Quibell, James Edward, 65, 138, 208

Quibell, Kate, 138

Radford, Evelyn, 62-5

Radio, 2, 8, 42, 43, 47, 113, 119, 127, 169, 215, 216, 217, 218, 219, 220, 221

Railways, 14, 32, 69, 88, 131, 134, 139, 218

Ramsay, William Mitchell, 28, 94, 100, 142, 143,145

Rational Dress, 207

Readership, 10, 12, 18, 28, 47, 57, 60, 76, 95, 98, 99, 104, 107, 108, 111, 120-6, 150, 158, 172, 174, 176, 183, 194, 203

Religious Tract Society (RTS) (firm), 8, 9, 45, 80, 81, 82, 104, 105-107, 108, 215, 219

Monthly Series', 105

'By-Paths of Bible Knowledge' series, 106, 107, 123

'Present Day Primers', 107

Leisure Hour, 80, 81

Sunday at Home, 81, 82

Renshaw, Lucy, 49

Reynolds-Ball, Eustace, 36, 38

Rich, Claudius James, 181-2

Rich, Mary, 181-2

Robert Scott (firm), 64, 65, 216

Robert Hale (firm), 186, 202

Royal Archaeological Institute, 20, 79

Royal Asiatic Society, 21

Sampson Low, Marston \& Co. (firm), 219

Sayce, Archibald Henry, 22, 28, 45, 90, 91, 96, 97, 100, 106, 107, 123, 124, 126, 132, 133, 134, 136, 219

Schliemann, Heinrich, 3, 116, 128, 186

Schmoller, Tatiana Kent, 172, 175

Sellers Strong, Eugénie, 28, 55, 62, 101, 108-109, 220

Strong, Arthur, 108

Serial, 12, 17, 18, 75, 89, 91-102

Shaiya, Mejid, 16

Sixpenny Library see Ernest Benn 
Smith, Grafton Eliott, 11, 112, 200

Society for the Promotion of Christian

Knowledge (SPCK), 8, 11, 70, 107, 216, 218, 219, 220

'Ancient History from the Monuments' series, 107

Society of Antiquaries of London, 1, 20, 87

Society of Antiquaries of Scotland, 129

Society of Psychical Research (SPR), 200, 201

Society of Biblical Archaeology (SBA), 21, 22,107

Sorbonne, 51, 215

Steamship (steamer), 14, 32, 35, 36, 37, 39, 52, 58, 133, 137, 139, 157, 159

Stewart, Jessie , 52

Storrs, Ronald, 40

Sudan, 12, 13, 15, 16, 18, 30, 34, 35, 36, 37 , $38,85,86,88,89,137,138,139,146$, $190,215,17,218,219,221$

Meroe, 85-9

Khartoum, 13, 37, 49, 85, 99, 89, 137, 138, 139

Sudan Government Railways and Steamers Circular Tours, 88

Suffrage, 7, 46, 61

Syria, 14, 34, 38, 40, 41, 126, 139, 164, 178, 190, 215, 216, 218

T. Fisher Unwin (firm), 9, 218

T. N. Foulis (firm), 109

'Arts and Crafts of the Nations' series 109

Television, 113, 114, 175, 179, 211, 219, 221

Thomas Cook \& Son (firm), 9, 33, 36, 53, 40, 131, 133, 137-9

And guidebooks 9, 33-8, 39, 41, 59, 130, 215

And tours 36-40, 52

Thompson, Barbara Brodrick Campbell, 189, 190, 194

Thompson, Reginald Campbell, 4, 16, 17, 41, 46, 117, 188, 189, 190-5, 206, 209, 220

Thornton Butterworth (firm), 9, 19, 117, 120, 122,220

'Keystone Library', 120

Tirard, Helen Beloe, 50-2, 55, 56, 123, 220

Tourism, 14, 15, 16, 18, 21, 24, 27, 32, 34, 35, $38,39,40,41,61,74,75,88,116,130$, 131, 137, 138, 139, 146, 157, 159, 208, 211

Tours, 6, 12, 31, 32, 34, 36, 37, 39, 40, 50, $51,54,55,58,62,63,66,81,86,88$,
133, 136, 157, 163, 166, 196, 205, 206, 215, 219

Transjordan, 12, 14, 18, 30, 40, 41, 211 , 216, 219

Turkey in Europe, 13

Tut(ankhamun), 3, 4, 11, 12, 40, 45, 46, 90, $100,121,122,198,203,215$

United States, 14, 17, 49, 81, 101, 119, 145, $149,155,156,218,220$

University College London, (UCL), 6, 23, 24, $25,26,27,28,34,48,49,50,51,55,58$, $65,69,70,82,101,132,155,156,157$, 214, 215, 216, 217, 219, 220, 221

University Extension, 7, 70, 110, 218, 219,220

Waddington, Hilary, 72

Walker, Alice, 63

Warner, Philip Lee see Medici Society

Watts, Jill, 116

Weigall, Arthur, 8, 9, 10, 11, 17, 42, 45, 46, 99, 101, 119-124, 220

Wells, H. G. 57

Wheeler, Margaret Collingridge, 73, 113, 114, $115,186,220$

Wheeler, Mortimer, 27, 175, 179, 180, 182, 183, 184, 186, 211, 221

Wilhelm, Kaiser, 38, 63

Willberg, Wilhelm, 62

William Blackwood \& Sons (firm), 9, 10, 121

William Heinemann, 9, 110, 170, 215, 220

'Regions of the World', series 110

Williams \& Norgate (firm), 9, 214, 215, 217,218

'Home University Library', 117, 215, 218

Williams, William (Bill) 172, 173, 175

Wilson, Charles 34, 143

Women 6, 7, 18, 21, 23, 24, 25, 26, 28, 29, 31, $32,39,47,48-74,76,93,94,101,113$, $115,122,125,133,165,166,194,195$, 202, 204, 205, 206, 212

Woolley, (Charles) Leonard, 1, 2, 4, 5, 7, 8, 10, $29,42,43,44,46,90,91,101,124,169$, $170,171,172,173,174,177,178,180$, $181,184,191,196,208,210,221$

Woolley, Katherine, 16, 204

World War 1, 4, 9, 10, 30, 39, 40, 58, 62, 68, 90, 99, 107, 109, 110, 167, 170, 208, 214. $218,220,221$ 

'Deftly written and drawing on a wide range of material, Amara Thornton demonstrates how archaeology and how writing about the ancient past has captured the imagination since the late nineteenth century... Truly interdisciplinary in scope, Archaeologists in Print is a must read for anyone interested in the history of archaeology, the role of women in archaeology and publishing, and how history has been told through print and broadcast media. A timely study!' -Debbie Challis, Education and Outreach Officer at LSE Library

Archaeologists in Print is a history of popular publishing in archaeology in the nineteenth and twentieth centuries, a pivotal period of expansion and development in both archaeology and publishing. It examines how British archaeologists produced books and popular periodical articles for a non-scholarly audience, and explores the rise in archaeologists' public visibility. Notably, it analyses women's experiences in archaeology alongside better known male contemporaries as shown in their books and archives. In the background of this narrative is the history of Britain's imperial expansion and contraction, and the evolution of modern tourism in the Eastern Mediterranean and Middle East. Archaeologists exploited these factors to gain public and financial support and interest, and build and maintain a reading public for their work, supported by the seasonal nature of excavation and tourism. Reinforcing these publishing activities through personal appearances in the lecture hall, exhibition space and site tour, and in new media - film, radio and television - archaeologists shaped public understanding of archaeology. It was spadework, scripted. The image of the archaeologist as adventurous explorer of foreign lands, part spy, part foreigner, eternally alluring, solidified during this period. That legacy continues, undimmed, today.

Amara Thornton is a historian of archaeology. Her PhD explored the social history of British archaeologists working in the Eastern Mediterranean and Middle East between 1870 and 1939. Amara held a British Academy Postdoctoral Fellowship from 2013 to 2016, has been Coordinator of the UCL Institute of Archaeology's History of Archaeology Network since 2010, and is Principal Investigator of Filming Antiquity, a digitisation and research project for historic archaeology footage from the 1930s-1950s.

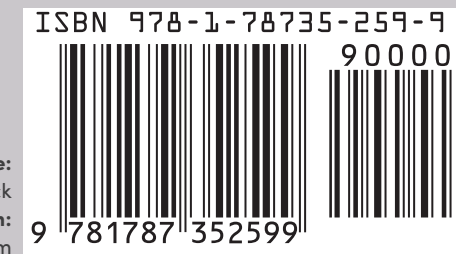

